\title{
EXPERIENCIAS EN COMÚN
}

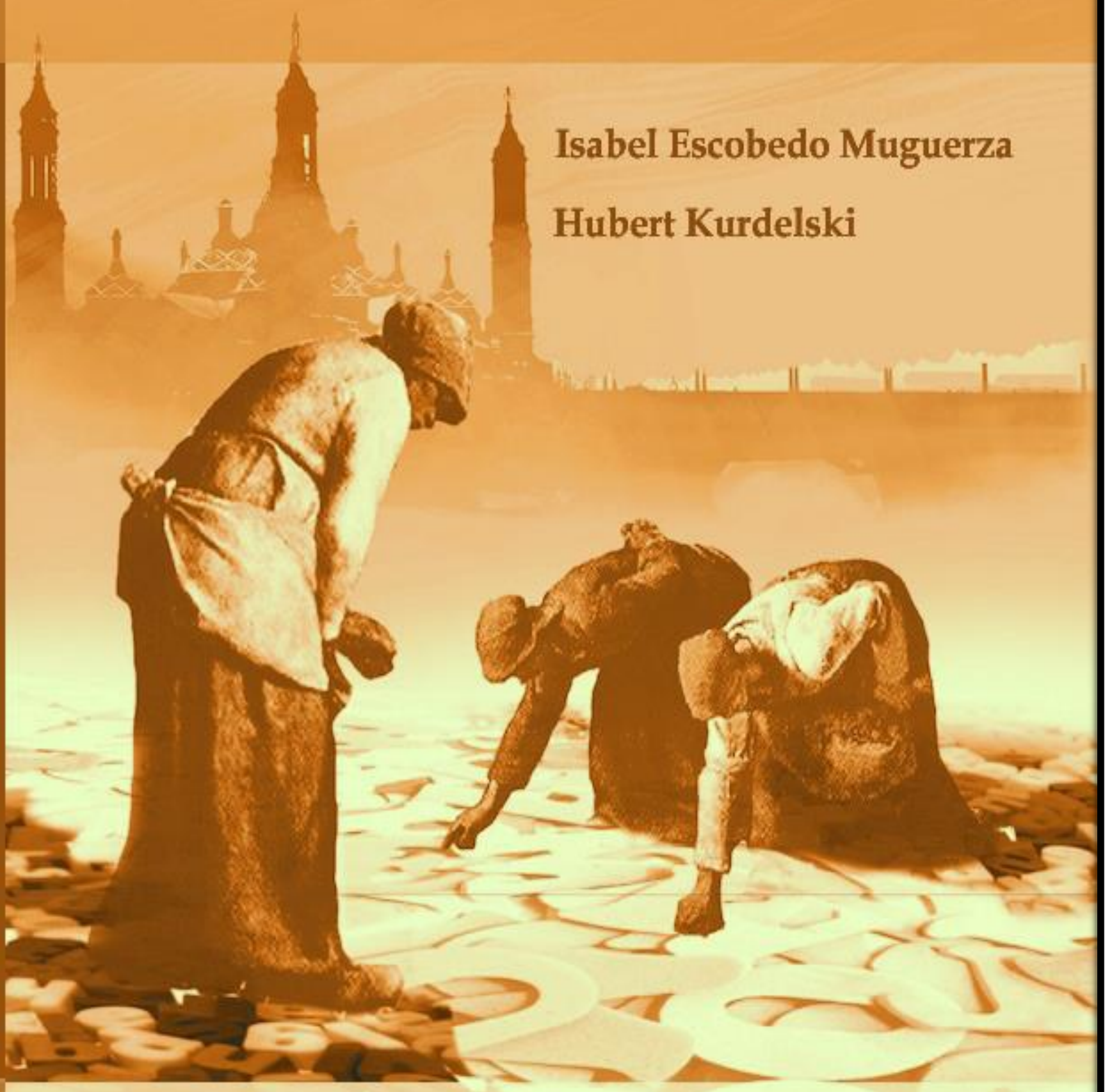

\section{Colección Jóvenes por la Historia}



EXPERIENCIAS EN COMÚN 


\section{EXPERIENCIAS EN COMÚN}

ISABEL ESCOBEDO MUGUERZA

HUBERT KURDELSKI

(Editores)

\section{COLECCIÓN JÓVENES POR LA HISTORIA \\ TENDENCIAS ACTUALES DE LA INVESTIGACIÓN HISTÓRICA}

ZARAGOZA, 2019 


\section{COLECCIÓN JÓVENES POR LA HISTORIA}

\section{VOLUMEN III}

(c) ISABEL ESCOBEDO MuguERZA

(c) HUBERT KURDELSKI

$1^{\circ}$ Edición, Zaragoza 2019

ISBN: 978-84-16723-76-8

ISBN O.C: 978-84-16723-73-7

No se permite un uso comercial de la obra original ni de las posibles obras derivadas, la distribución de las cuales se debe hacer con una licencia igual a la que regula la obra original. En cualquier explotación de la obra autorizada por la licencia hará falta reconocer la autoría.

Diseño de portada: RoBERTO MOROTE

Con la colaboración de:

UNIVERSIDAD DE ZARAGOZA

Calle de Pedro Cerbuna, 12

50009 Zaragoza

ASOCIACIÓN DE HISTORIA CONTEMPORÁNEA

Universidad Complutense de Madrid

Departamento de Historia Contemporánea, 8 a Planta, despacho 33

Profesor Aranguren, s/n

28040 Madrid

INSTITUCIÓN FERNANDO EL CATÓLICO

Plaza de España, 2

50004 Zaragoza 
"Si yo fuera anticuario sólo me gustaría ver las cosas viejas. Pero soy historiador y por eso amo la vida”

Marc Bloch, Introducción a la Historia 



\section{ÍNDICE}

INTRODUCCIÓN 14

\section{CAPÍTULO I}

MEDIOS DE COMUNICACIÓN SOCIAL Y LITERATURA. UNA APROXIMACIÓN INTERDISCIPLINAR. 20

SOPHIE Bustos

RUBÉN CABAL TEJADA

ALEJANDRO GutiÉRREZ TAENGUA

GABRIELA DE LIMA GRECCO

ÁlVARO LÓPEZ FrANCO

SARA MARTÍN GUTIÉRREZ

1. Las estrellas cinematográficas durante el primer franquismo desde una

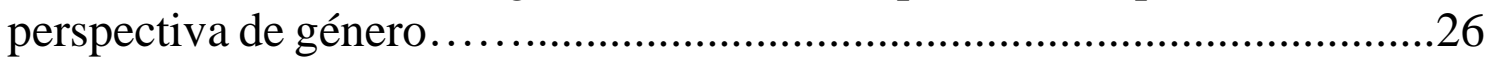

ÁlVARO ÁlVAREZ RODRIGO

2. El anime como fenómeno de masas global: fantasía, censura y

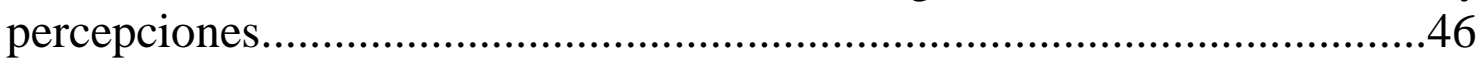

ANTONIO BLAT MARTÍNEZ

Miguel Blanco HerReros

3. La política y su representación. Caciquismo español y clientelismo italiano en la literatura: el caso de Procopio Atúnez /Abilio Calderón Rojo y Arcangelo Cozzi/Michele Capozzi..............................................................68

VINCENZO BARRA 


\section{CAPÍTULO II}

LOS OFICIOS DE LA HISTORIA EN LA EUROPA CONTEMPORÁNEA (SS. XIX Y XX) .89

GuSTAVo ALARES LÓPEZ

MARÍA JosÉ SOLANAS BAGÜÉS

JOSÉ LUIS FLORES POMAR

2. Al-Ándalus como preocupación de la historiografía nacionalista y la formación de la escuela arabista aragonesa

PABLO BORNSTEIN

3. ¿Por qué se olvidó el final de la guerra del Rif?

ALEJANDRo Rey MiLláN

4. Las grandes narrativas de la Historia del Arte en la España de la Transición: el caso de la Nueva Figuración Madrileña. 135

BEATRIZ GARCÍA PÉREZ

5. Las prácticas de un historiador: Carlos E. Corona Baratech

EDUARDO ACERETE DE LA CORTE

\section{CAPÍTULO III}

¿Cómo PenSAR los PROBlemas históRicos CONCRETOS? Historia Y CAMBIO SOCIAL 174

JULIO LISANDRO CAÑóN VOIRIN

Alba DíAz GEADA

DAVID VALE DíAZ 
2. De micro a macro: propuesta metodológica para el estudio de las actitudes sociales ante contextos de violencia estatal masiva....

CONCEPCIÓN LÓPEZ SÁNCHEZ

3. El anarquismo insurreccionalista en el siglo XXI: un fenómeno internacional. 198

\section{Miguel MoRÁn PALlaRÉS}

4. ¿Historia de las mujeres y/o Historia de(1) género? La mujer como sujeto histórico

\section{UXÍA OTERO-GONZÁLEZ}

5. El Mercado de la democracia: Una propuesta analítica del clientelismo político en perspectiva microhistórica

DANIELA FERRÁNDEZ PÉREZ

\section{CAPÍtUlo IV}

HISTORIA ORAL Y FUENTES DOCUMENTALES

GABRIEL BENAVIDES ESCRIVÁ

2. El archivo Ricardo Sanz, documentos para la historia

VÍCTOR BENAVIDES ESCRIVÁ

3. El Archivo de la Escuela de Artes y Oficios de Valencia y su taller de cerámica. 291

MARTA VICENTE CARRASCO

4. ¿Pueden ser útiles los cuentos populares y la tradición oral africana para deconstruir estereotipos de raíz colonial?

José MANUEl MAROTO BlanCO

ROSALÍA LÓPEZ FERNÁNDEZ 
5. Memoria familiar, historia de todos: el caso de Francisco Escáneo Franco.

\title{
ALDARA CIDRÁs
}

6. ¿Puerta de la agricultura o refugio de mocambeiros? las fuentes y las caracterizaciones de la frontera entre Pará y Maranhão (1790-1818)

\section{SuENy Diana OliveIRA DE SOUZA}

7. Testigos y protagonistas de la política exterior española: una reflexión metodológica sobre el uso de las fuentes orales y el acceso a las fuentes documentales en historia del tiempo presente

JoSÉ CARLOS ARÁNGUEZ

FERRAN MARTÍNEZ LLISO

\section{CAPÍTULO V}

\section{¿EL CORTO Siglo XX? EXPERIENCIAS DE JÓVENES INVESTIGADORES DESDE (Y HACIA) UN NUEVO SIGLO 396}

\author{
ALBA FERNÁNDEZ GALLEGO \\ ALEJANDRO PÉREZ-OLIVARES \\ CARLOS PíRIZ
}

2. El espacio como forma de hacer historia. Del giro espacial a la narrativa de la simultaneidad. 407

JOAN MUÑOZ GONZÁLEZ

3. Seminario de Historia y Teoría de la Cultura. Una propuesta de generación de conocimiento colectivo .426

FERNANDO GARCÍA NAHARRO

CARlos NavarRo GonzÁleZ 
Federico PeÑAte DomíngueZ

José EMILIo PÉREZ MARTÍNEZ

4. La espiral dialéctica de la historiografía: pasado y presente de los marxistas británicos...............................................................................450

RAFAEL BUHIGAS JIMÉNEZ

\section{SCRIPTORIA III}

MEMORIAS E IDENTIDADES. SOBRE POSICIONAMIENTOS COMPROMETIDOS EN INVESTIGACIÓN CON FUENTES ORALES PARA LA (RE)ELABORACIÓN DE LA HISTORIA RECIENTE ..........................................473

VICENT BELLVER I LOIZAGA

SORAYA GAHETE MUÑOZ

SARA MARTÍN GUTIÉRREZ

PAU LÓPEZ-ClAVEL

\section{EPÍLOGO}

El Caudal Que nos arrastra. 488

GUSTAVO ALARÉS LÓPEZ 


\section{EXPERIENCIAS EN COMÚN}

\section{INTRODUCCIÓN}

Isabel Escobedo Muguerza

Hubert Kurdelski

Sin duda, no son los mejores tiempos para que los jóvenes decididos den sus primeros pasos por los senderos de la Academia. Los que dedican sus esfuerzos a formarse como especialistas en historia contemporánea no suponen ninguna excepción entre los investigadores doctorales y postdoctorales. Así pues, la falta de financiación o el rígido sistema de evaluación y reconocimiento profesional basado en la estandarización cuantitativa, y su influencia en la vida privada y provisional de dichos jóvenes serán temas abordados a lo largo de esta publicación. No obstante, a pesar de dichos problemas, los jóvenes mantienen su actividad investigadora, tratando de seguir nadando en medio de su situación de precariedad. Una de las mejores muestras de esta persistencia es el ciclo de congresos bianuales de jóvenes investigadores e investigadoras. En el marco de dichos encuentros, y en concreto del VI Encuentro Internacional de Jóvenes Investigadores e Investigadoras en Historia Contemporánea, del cual ha surgido la idea de superar el límite que imponían la publicación de las tradicionales actas y apostar por un proyecto editorial más ambicioso, la colección Jóvenes por la Historia. El objetivo principal de la colección consiste en proporcionar un espacio más amplio y mejor organizado para la publicación de textos más completos, frutos tanto de las dinámicas de los congresos, como de su reinterpretación critica en los meses posteriores. Por tanto, la serie brinda la posibilidad de un debate profundizado y constituye una lectura más atractiva para el lector interesado en nuevas ópticas en la historiografía contemporánea.

Como han demostrado los dos libros anteriores, la nueva generación de investigadores no ha perdido el interés por los temas centrales para la historiografía del 
siglo XIX y XX como: el fascismo, la violencia política, la conflictividad campesina o urbana; intentando abordarlos de manera innovadora. Tampoco han faltado temáticas y enfoques como el feminismo o el análisis de las culturas políticas introducidas en su tiempo por nuestros predecesores en los primeros pasos de sus carreras investigadoras. ${ }^{1}$ A pesar de una trayectoria incipiente y el trabajo diario concentrado en los temas concretos de sus proyectos doctorales y postdoctorales, los participantes del proyecto no eluden los problemas más amplios y cruciales para el desarrollo de su oficio. Por tanto, el tercer volumen de la colección está dedicado al debate metodológico y el legado historiográfico.

Como sus antecesores, este libro también está ordenado según los ejes de interés surgidos de los debates generados tanto en el periodo anterior, como posterior al congreso. El primero de los capítulos constituye una aproximación a problemática de las fuentes culturales. El abanico de los casos analizados por sus autores abarca las fuentes literarias, cinematográficas, la prensa e incluso el anime. A pesar de la diversidad del material en cuestión, los escritos de esta parte comparten una preocupación común. El problema surge de la tensión entre la función relatora de las fuentes culturales y su potencial de la creación de una realidad cultural y social nuevas. Dicha dificultad, por un lado, obliga a un trato mucho más crítico que incluya el contexto, las posibles manipulaciones y censuras. Po otro, la función creadora permite analizar de qué manera los medios culturales y de comunicación contribuyen a cambiar la sociedad en la época contemporánea.

La temática vinculada al cambio social sigue presente en el segundo capítulo, del cual forma la parte troncal. A través de análisis de procesos componentes de esta evolución y de los movimientos sociales que formaron parte intrínseca de ella, los autores que cooperaron en la creación de este capítulo buscan nuevas ópticas y averiguan su compatibilidad con los hilos ya asentados en la historiografía. En este contexto, los investigadores trabajan problemas muy diferenciados como: la respuesta social a la represión, el anarquismo insurreccional, las redes clientales o las relaciones de género. No obstante, estos campos limitados permiten: buscar las relaciones entre la escala micro

\footnotetext{
${ }^{1}$ Un ejemplo de las aportaciones al desarrollo de nuevos enfoques interpretativos en la historiografía española por parte de los cofundadores de los Encuentros de Investigadores Jóvenes: José L. LEDESMA, MUÑOZ SORO JAVIER e JAVIER RODRIGO (eds.): Culturas y políticas de la violencia. España siglo XX., Madrid, 2005.
} 
y macro, los análisis cualitativos y cuantitativos, y el peso de redes sociales y relaciones no oficiales en los procesos del cambio histórico.

La siguiente parte del libro está dedicada a las consideraciones sobre la figura del historiador europeo y su oficio en los siglos XIX y XX. Desde una postura crítica con la visión postmoderna, sus autores defienden el carácter científico y el peso social de la figura de historiador atreves del análisis historiográfico. No obstante, dicha defensa no carece de una visión crítica. Aunque enmarcados en contextos históricos tan diferentes como: la creación de una identidad nacional española en el siglo XIX, el franquismo o la transición hacia la democracia, los textos delatan un interés general compartido. A través de análisis de biografías de historiadores y trayectorias del desarrollo de instituciones científicas y culturales, las aportaciones buscan los mecanismos que por un lado condicionaron su trabajo y por otro lado posibilitaron su proyección social y cultural.

El cuarto apartado recoge las experiencias y consideraciones vinculadas al tema crucial para cualquier investigación histórica - las fuentes. Partiendo desde intereses dispersos, los investigadores unen sus experiencias meditando las posibilidades de sortear las dificultades derivadas de la dificultad o la imposibilidad de acceso a las fuentes tradicionales. Como respuesta a dicho inconveniente, la mayoría de los ponentes destaca la utilidad de un amplio abanico de fuentes menos tradicionales como: recuerdos familiares, colecciones y archivos personales, las entrevistas y el patrimonio cultural. Abordando la problemática derivada de un uso critico de dichas fuentes, los autores buscan las posibilidades de llenar los vacíos historiográficos en la historiografía contemporánea y reciente através de análisis cruzado del material tradicional e innovador.

El penúltimo capítulo de la publicación gira en torno al clásico concepto del Corto Siglo XX desarrollado por Eric Hobsbawm a mediados de los años $90^{\prime} .^{2}$ No obstante, la centuria y el concepto en cuestión forman solamente un telón de fondo propició para la reflexión sobre el investigador del siglo XX, la academia y los retos que ante ellos plantea la realidad social del siglo actual. Las aportaciones y una introducción extensa, que refleja fielmente las dinámicas del encuentro, plantean el rol de la herencia ideológica y conceptual del siglo pasado en el proceso de renovación y adaptación del taller del historiador a las realidades de la época actual. Otra de las preocupaciones tangibles entre

\footnotetext{
${ }^{2}$ Eric Hobsbawm, Historia del Siglo XX: 1914-1991, Critica, Barcelona, 2000.
} 
los autores de esta parte del libro es la necesidad de que dicho proceso de renovación y adaptación no se produzca en un contexto aislado de la calle, con sus inquietudes sociales y el potencial de sus ópticas. En este contexto cabe destacar la aportación que presenta y analiza el desarrollo del Seminario de Historia y Teoría de la Cultura, un intento práctico de entablar un debate teórico con otros sectores sociales no vinculados directamente con el mundo universitario.

El volumen termina con una aportación atípica - el scriptoria. El texto titulado: "Memorias e identidades. Sobre posicionamientos comprometidos en investigación con fuentes orales para la (re)elaboración de la historia reciente." constituye la mejor muestra del ambiente intelectual de los Encuentros de Jóvenes Investigadores. Nacido por la iniciativa de las y los miembros de los proyectos Compromiso y militancia femenina en la Transición en España y Trayectorias e historias de vida desde los movimientos sociales valencianos, el escrito es fruto de un trabajo conjunto realizado antes del congreso, un debate animado durante el encuentro y la continuidad de la experiencia en contactos posteriores. Gracias a las aportaciones surgidas en cada de las etapas del trabajo, el texto no limita su interés a las cuestiones puramente técnicas y metodológicas. Resultado de un encuentro de alrededor de tres decenas de investigadores enfrentados por primera vez con el reto de tratar las fuentes orales, el escrito versa sobre problemas como: la soledad del investigador, el peso de la identidad de éste y de sus interlocutores, o la deuda contraída con las personas entrevistadas y las posibilidades de pagarla en el marco de la divulgación social.

Terminando esta breve introducción cabe señalar que no consideramos este volumen como el final de la serie. Esperemos que su publicación no solamente anime el debate de cara a los próximos encuentros, sino también encuentre continuidad convirtiéndose, tanto en fuente de información, como en estimulo de participación para las nuevas generaciones de historiadores. 


\title{
CAPÍTULO I
}

\section{Medios de CoMunicación Social Y Literatura. UNA APROXIMACIÓN INTERDISCIPLINAR}

\author{
Sophie Bustos (Universidad Autónoma de Madrid) \\ Rubén Cabal Tejada (Universidad de Oviedo / Sorbonne Nouvelle-Paris 3) \\ Alejandro Gutiérrez Taengua (Universidad de València) \\ Gabriela de Lima Grecco (Universidad Autónoma de Madrid) \\ Álvaro López Franco (Universidad de Málaga) \\ Sara Martín Gutiérrez (Universidad Complutense de Madrid)
}

Esta mesa se interesó inicialmente por las reflexiones que brindan a la historiografía aquellas investigaciones sobre medios de comunicación social y publicaciones literarias que tienen en cuenta, entre otras cuestiones, su evolutivo con-texto 
histórico y editorial, sus diferentes formas de recepción y el desigual efecto que sobre estos mantiene la labor censora. Consecuentemente, como elemento problematizador para fomentar el debate académico, se consideró pertinente centrar la discusión en la cuestión de la construcción de discursos hegemónicos, en relación al impacto político, cultural y social de los medios de comunicación (en su forma impresa o audiovisual) y de las obras literarias, a lo largo del tiem-po. También se puso el acento en las formas de restricción ejercidas sobre éstas históricamente desde el Estado u otras instituciones (como la Iglesia Católica), sin olvidar, por último, la cuestión de la efectiva recepción de sus mensajes, expresa-da en un particular universo de prácticas y representaciones sociales.

A efectos de presentación y organización, los ejes centrales que se aborda-ron en esta mesa, clasificados y agrupados según las temáticas específicas de los textos aceptados, fueron los siguientes:

1) Texto/contexto: ¿reflejando o creando la realidad?

2) Las obras literarias como fuente primaria para la Historia

3) Formas de control y censura de los medios de comunicación social.

Cabe apuntar, por último, que si bien nuestra convocatoria no se acotó inicialmente a un espacio geo-temporal preferente, la mayoría de exposiciones ver-saron sobre estudios de caso y problemáticas que se enmarcan en la cronología del siglo XX, siendo minoría las aportaciones referidas, por su parte, al siglo XIX.

\section{Texto/contexto: ¿reflejando o creando la realidad?}

En este primer eje temático, se han recogido los trabajos de Emiliano Abad García, Micaela Pattison y Álvaro Álvarez Rodrigo. La propuesta de Abad García, titulada « ${ }^{` C e}$ n'est pas ça': Musée du quai Branly, 10 años de historia» aporta un nuevo análisis sobre el pasado colonialista francés y el estudio de la violencia es-tatal desde el punto de una perspectiva humanista y universalista. En especial, este trabajo se interesa en la relación entre los discursos expositivos y «científi-cos» que muestran ciertos museos y las representaciones que sobre algunos pueblos o culturas se construyen por esta vía, asumiendo para ello el autor desde la crítica foucoultiana al binomio poder/saber hasta las teorías postcoloniales. 
Pattison, por su parte, en su artículo «La creación de la Muchacha Moderna: consumo, modernidad y género en la revista gráfica española (1928-1933)», aborda una de las dimensiones de los medios más llamativas: su capacidad no sólo de reflejar la realidad, sino, incluso, de crearla. En este caso, concretamente, la autora analiza las imágenes de feminidad que globalmente se configuran en los años veinte y treinta en relación a la modernidad expresada por las revistas Es-tampa y Crónica. Este trabajo nos permite, entre otras cosas, ampliar el debate sobre el papel de los medios en la configuración de imaginarios y categorías esté-ticas definidas para las mujeres y en el papel que históricamente ejercieron los medios a través de la caracterización y potenciación de un determinado modelo de consumo (o a través de él).

Un enfoque parecido utiliza Álvaro Álvarez en su artículo «Las estrellas cinematográficas durante el primer franquismo desde una perspectiva de género». Centrándose principalmente en las figuras de Amparo Rivelles, Conchita Montes y Sara Montiel, el autor utiliza el contraste entre la imagen cinematográfica de los personajes de estas artistas y su representación en la prensa generalista para analizar y remarcar una de las contradicciones culturales del régimen: la no co-rrelación entre los discursos de los personajes interpretados con los valores y la moral del modelo de género franquista. Un desfase que genera, por otro lado, el inicio de un proceso de construcción de identidades de género entre los públicos del primer franquismo a través del cine.

El primero de los trabajos interesa, a nuestro juicio, por referirse a formas narrativas (como la museística) que se asemejan al relato histórico pero que, al mismo tiempo, suponen una forma de negación de la historia al perseguir cons-truir consensos en base a relatos alternativos sobre el pasado. Por su parte, el segundo y el tercero de los artículos se refieren a los estudios de género y a su interrelación con los medios de comunicación. Todos ellos ofrecen nuevos enfo-ques de estudio sobre la capacidad de ciertas obras o dispositivos culturales de «configurar»o «subvertir» la realidad. Los tres trabajos fueron debatidos y ex-puestos en este eje, que se estructura en torno a la relación entre texto y contex-to, es decir, que se interesa por la dialéctica entre realidad y ficción.

A este respecto, los trabajos de Álvaro Álvarez y de Micaela Pattison, especialmente, abordan desde una perspectiva que asume la categoría de género, có-mo los modelos tradicionales difundidos por un régimen a veces pueden ser cuestionados y 
desmentidos por una batería de imágenes y representaciones al-ternativas, vertidas desde diferentes plataformas, cuyo poder de influencia resul-ta completamente efectivo a la hora de difundir patrones y modelos de conducta. Se plantean, por último, entonces una serie de preguntas, a nuestro juicio, funda-mentales: ¿Desde qué contexto irrumpen estos cambios? ¿Cómo se proyectan de cara a la sociedad algunos de sus efectos? ¿Cómo se puede analizar este proceso? Y, en definitiva: ¿Cómo construyen los medios de comunicación una parte de nuestra realidad?

\section{Las obras literarias como fuente primaria para la Historia}

En este segundo eje se propuso el uso de la prensa y de la literatura como fuentes primarias de gran valor para la construcción del relato de la historia. Se consideraron muy apropiados como ejemplos de estudio los trabajos de los co-municantes Vincenzo Barra, titulado «La política y su representación. Caciquismo español y clientelismo italiano en la literatura: el caso de Procopio Atúnez /Abilio Calderón Rojo y Arcangelo Cozzi/Michele Capozzi», el de Juan Andrés García Mar-tín «Doblón: ¿un semanario económico con mentalidad política?», y el elaborado por Marta García Cabrera, «Neutralidad, resistencia y benevolencia: propaganda británica en España durante la Segunda Guerra Mundial, (1939-1945)».

El primero de ellos se basa en el análisis comparado de dos protagonistas de una novela española (Caciquismo y Caciques, de Genaro González Carreño, pu-blicada en 1917) y otra italiana (Eredità illegittime, de Carlo del Balzo, publicada en 1889). Barra pone de relieve cómo la literatura fue una plataforma para de-nunciar uno de los problemas estructurales de la historia de finales del siglo XIX y principios del siglo XX en España e Italia: el caciquismo. Por su parte Juan Andrés García Martín realiza un estudio muy preciso sobre el semanario económico Do-blón, que vio la luz en la España de la pre-transición democrática, empleando la propia colección de la publicación como fuente combinada con entrevistas a sus protagonistas. Finalmente, la comunicación de García Cabrera incide en cómo se organizó la propaganda en España y cómo evolucionó a lo largo de la guerra, así como los objetivos conseguidos y su relación con la política exterior británica.

A pesar de tratarse de trabajos referidos a periodos geográficos y espacia-les diversos, los tres estudios resultan coherentes por poner en cuestión el papel del 
historiador en relación a su aproximación a los textos literarios como fuentes primarias. Asimismo, estos artículos se interesan, de una forma u otra, por las dificultades que conlleva y el potencial que mantiene el uso de prensa y de obras literarias en el quehacer historiográfico, desdibujando, para ello, la aparentemen-te rígida frontera entre realidad y narrativa en relación a nuestra capacidad como investigadores para generar conocimiento científico.

\section{Formas de control y censura de los medios de comunicación social}

En este último eje se buscaba abordar el control y la censura ejercidas des-de los Estados y regímenes autoritarios, así como la influencia que desarrollaron éstos, a su vez, sobre los medios de comunicación, el cine o las publicaciones lite-rarias. Para encarar este debate se seleccionaron los textos de Antonio Blat y Mi-guel Blanco, «El anime como fenómeno de masa global: fantasía, censura y per-cepciones», la investigación de María López de Ramón, titulada «La prensa bajo el régimen canovista: el silencio de las masas» y el estudio de José Luis Agudín, «¿Una libertad para todos? El Siglo Futuro, La Constancia, Tradición y Pensamiento Alavés tras la Sanjurjada». Todos ellos abordaron diferentes formas de censura en distintos periodos de la etapa contemporánea. Para Agudín, el intento de golpe de Estado contra la II República en 1932 y la posterior persecución de la prensa tradicionalista y alfonsina sirve de telón para realizar un análisis del discurso pe-riodístico en la prensa El Siglo Futuro, La Constancia, Tradición y Pensamiento Ala-vés para discrepar las simpatías de la prensa tradicionalista con los golpistas.

López de Ramón elabora, por su parte, un análisis de la realidad de la res-tauración canovista de los instrumentos creados por Cánovas del Castillo para controlar la prensa, como la censura previa o el depósito de publicaciones, así como disposiciones legislativas que impedían, directamente, que la prensa criti-que de manera directa o indirecta el sistema monárquico o la familia real. López de Ramón pone en relevancia la hipótesis de que a pesar de que la Constitución contempla la Libertad de Prensa, en la práctica, ésta no existe, una circunstancia que impidió la proliferación de periódicos de líneas distintas al régimen.

Finalmente, Antonio Blat y Miguel Blanco Con una amplia base bibliográfica (que abarca desde la historiografía hasta los estudios culturales o la sociología) y cronológica 
(desde la ocupación norteamericana de las islas niponas hasta la primera década del siglo $\mathrm{XXI}$ ), presentan a través del anime un doble proceso: el que permitió a la cultura popular japonesa tomar una fuerte presencia en el mundo occidental a través del contacto con la norteamericana, por un lado, y el que explica cómo aquella misma cultura se ve influida por el contexto político y cultural occidental. Para ello, recurren a cuatro conceptos que sirven, al mismo tiempo, para periodizar su estudio: censura, globalización/localización, domestica-ción de referencias culturales y (auténtica) traducción. En este estudio, de fondo y a gran escala, se hace referencia al circuito de emisión y recepción de productos culturales, a cómo una obra (de arte o no) es percibida y procesada de distinta manera según quién o quiénes la consumen y a la multiplicidad y complejidad de los elementos que pueden interferir en el trayecto entre unos y otros.

\section{A modo de conclusión}

En esta mesa se han presentado una amplia variedad de propuestas que nos permiten en primer lugar valorar el poder de la prensa en la historia y compren-der la manera en que ésta ayuda a conformar identidades; a difundir patrones de pensamiento y modelos de género; a crear opinión; y a expresar las distintas in-quietudes culturales existentes. La pregunta fundamental que se deriva de las investigaciones recogidas en este apartado, consecuentemente, se puede formular de la siguiente manera: ¿Cómo contribuye la prensa, o cualquier medio de comu-nicación, a cambiar la realidad de una sociedad en su tiempo?

En segundo lugar, se ha comprobado también la problemática de la censura en distintos contextos históricos. Si bien en cada espacio y tiempo los censores han encontrado la manera de silenciar aquellas opiniones disidentes de una ma-nera distinta, sus fines y objetivos se mantienen inmunes al paso del tiempo, al avance y globalización de los medios de comunicación. Cabría así ampliar en el futuro estas consideraciones, en otros congresos o jornadas, interesándonos no sólo sobre la importancia de la censura, la forma final que acoge, o las normas que la amparan, sino ahondando en la cuestión de si su mera existencia, es lo que permite, sin importar la particularidad de cada contexto histórico, la aparición de formas alternativas de resistencia discursiva. 


\title{
Las estrellas cinematográficas durante el primer franquismo desde una perspectiva de género*
}

The movie stars during the first Francoism from a gender perspective

\author{
Álvaro Álvarez Rodrigo \\ Universidad de Valencia
}

\section{Resumen}

Las estrellas femeninas de cine gozaron durante los años cuarenta y cincuenta de una gran popularidad y carisma, que las convirtieron en elementos de creación de identi-dades colectivas. Pero en la precaria y moralmente estrecha España de posguerra, estos modelos a menudo no se correspondían con los ideales de feminidad franquista y encarnaron contradicciones respecto al discurso oficial de género. La presente comu-nicación propone un análisis de la construcción de la imagen de las estrellas cinema-tográficas de la época y de su recepción por parte de las españolas, así como del modo en que el régimen trató de instrumentalizarlas.

\section{Palabras clave}

Estrellas cinematográficas, género, primer franquismo, medios de comunicación.

\begin{abstract}
Female movie stars enjoyed a great popularity and charisma during the forties and fifties, and became elements of creation of collective identities. But in the precar-ious and morally close post-war Spain, these models often did not correspond with the ideals of femininity of Francoism and embodied contradictions with respect to the offi-cial discourse of gender. This paper proposes an analysis of the construction of the image of

\footnotetext{
* El autor participa en el proyecto de investigación I+D+i HAR2014-57392-P (“Transiciones, movimientos sociales y democracia en el siglo XX. España en perspectiva comparada"), financiado por el Ministerio de Economía y Competitividad y por el Fondo Social Europeo.
} 
movie stars in that period and its reception by Spanish women, as well as the way in which the regime tried to exploit them.

\section{Palabras clave}

Movie stars, gender, first Francoism, mass media.

\section{Introducción}

En los años cuarenta y cincuenta el cine fue un gran medio de entretenimiento de masas y sus principales artistas, figuras populares y carismáticas. Las estrellas cinematográficas se convirtieron así en elementos de identificación y de creación de identidades colectivas, y el régimen franquista trató de instrumentalizarlas como modelos de comportamiento, especialmente dirigidos a las mujeres, que, en España como en otros países, eran el público mayoritario que acudía a las salas. ${ }^{1}$

Las estrellas femeninas gozaron de un protagonismo público que no se correspondía en absoluto con los ideales de domesticidad y de reclusión en la esfera privada que el régimen atribuía a las mujeres, y encarnaron como pocas las tensiones y contradicciones del discurso oficial sobre género.

Mientras que las películas y el resto de medios de comunicación trataban modelar una imagen de las actrices acorde con sus principios, su misma condición de estrellas les otorgaba un poder y una autonomía personal que les permitía zafarse, hasta cierto punto, de los estrechos márgenes de actuación que el régimen imponía al resto de mujeres. Unos comportamientos que el régimen tal vez pudiera tolerar, pero en absoluto aprobar públicamente, y que por tanto trató de silenciar, modular o resignificar.

Este el planteamiento general de la investigación que se está desarrollando sobre la construcción de las estrellas cinematográficas durante el primer franquismo, y que la

\footnotetext{
1 Jo LABANYI: "Historia y mujer en el cine del primer franquismo", en Laura GÓMEZ VAQUERO y Daniel SÁNCHEZ SALAS: El espíritu del caos: Representación y recepción de las imágenes durante el franquismo, Madrid, Ocho y Medio, 2009, pp. 85-112.
} 
presente comunicación tiene como objeto presentar. A lo largo de las siguientes páginas, se expondrá el marco teórico y metodológico en el que se sitúa, las principales hipótesis de trabajo y los objetivos principales del proyecto.

No se trata en cualquier caso de un trabajo de carácter biográfico sobre las principales estrellas ni sobre el star-system español en su conjunto, puesto que no se sitúa en el marco de los estudios de cine sino en el de una investigación de historia. Se intentará relacionar la proyección pública de unos sujetos históricos particulares con un contexto histórico determinado. El objeto es comprender el significado social y cultural de las estrellas e inscribirlo en un proceso de cambio, puesto las estrellas no ha de ser entendidas como una imagen estática sino en continua evolución.

El marco cronológico es el del primer franquismo. Como punto de partida se ha tomado el momento en que el régimen comienza a reordenar la industria cinematográfica tras el final del conflicto bélico, sin ignorar que, a pesar de la ruptura que supuso la Guerra Civil, existen ciertas continuidades respecto a la etapa republicana ni que ya durante la contienda desde el bando franquista se promovieron coproducciones con Alemania e Italia. Como fecha de cierre del período se ha optado por una referencia interna del objeto de estudio: El estreno de El último cuplé (1957), uno de los grandes éxitos cinematográficos bajo el franquismo, con el regreso de Sara Montiel a España.

\section{Marco teórico y metodológico}

En primer lugar, indicar que se parte de la conceptualización de las estrellas cinematográficas como una representación cultural. Una imagen construida sobre la dialéctica entre la personalidad del artista y los personajes que interpreta, que para el espectador presenta un componente extraordinario, que es motivo de fascinación, y otro ordinario, que le aproxima a su propia vida cotidiana y que permite los fenómenos de identificación con la estrella. ${ }^{2}$

A partir de esta propuesta pionera de Edgar Morin, los star studies se han desarrollado en las últimas décadas desde tres perspectivas de análisis: como fenómeno de producción, de recepción o de la industria. Mi proyecto se sitúa en la primera de ellas, en el análisis intertextual de las estrellas, consideradas como una representación que

\footnotetext{
${ }^{2}$ Edgar MORIN: Las estrellas del cine, Buenos Aires, Eudeba, 1964.
} 
puede ser descifrada a partir de atributos de clase, género, raza, nación... Pero sin perder tampoco de vista las propuestas que se fijan en cómo esas representaciones eran consumidas en un contexto de recepción determinado, a partir del cual podían ser reinterpretadas, y que no entienden al espectador como un simple receptor o descodificador de mensajes preconstituidos, sino como un sujeto que activamente construye significados. ${ }^{3}$

Nos encontramos ante una imagen compleja, intertextual y polisémica, que no solo está construida desde diferentes fuentes, sino que tiene una fuerte carga de subjetividad también por parte de cada receptor, que rellena el hueco entre la persona real y la imagen, asignándoles significados que pueden diferentes entre el conjunto de la audiencia o incluso contradictorios. Sin embargo, se trata de una polisemia estructurada, de interpretaciones múltiples pero finitas, y que a su vez posee una dimensión temporal, ya que las imágenes se desarrollan y cambian con el paso del tiempo. ${ }^{4}$ Una dimensión cronológica e histórica, ya que la creación de estas identidades tiene lugar en un contexto cultural concreto que permite hacer esta imagen inteligible y analizarla como representativa de las preocupaciones sociales. ${ }^{5}$

Esta dialéctica entre la persona y personaje, de la que surge la imagen de la estrella cinematográfica, es asimismo el resultado de la tensión entre el discurso sobre la estrella y sus prácticas como sujeto histórico. No se trata de establecer una falsa dicotomía entre ambas, sino de comprender que discursos y prácticas se retroalimentan y se desarrollan en un contexto histórico determinado. Esta constatación nos permite ser precavidos en el análisis de las estrellas como imágenes, que, según han llegado a afirmar algunos autores, no existen fuera del texto, de manera que no se tenga en cuenta ni la experiencia ni la agencia de los individuos. Del mismo modo, tampoco pensar que la identidad es una atribución que los personas poseen ni meras manifestaciones autoconscientes, sino que se articulan en el lenguaje que adjudica significados y forja la autopercepción de los

\footnotetext{
${ }^{3}$ Annette KUHN: Dreaming of Fred and Ginger: Cinema and cultural memory, New York, New York University Press, 2002; ÍD: "Géneros de mujeres: teoría sobre el melodrama y el culebrón”, Secuencias: Revista de historia del cine, 15 (2002), pp. 7-17.

${ }^{4}$ Richard DYER: Las estrellas cinematográficas, Barcelona, Paidós, 2001, pp. 89-90.

5 Paul MCDONALD: "Volver a conceptualizar el estrellato", en Richard DYER: Las estrellas cinematográficas..., pp. 221-222.
} 
individuos a partir del imaginario social vigente en cada contexto histórico. Una identidad que, como el propio sujeto, no es estable y está en proceso de permanente construcción. ${ }^{6}$

Asimismo, se considera fundamental inscribir el análisis sobre la construcción de las estrellas cinematográficas en el seno de las culturas políticas en que se insertan, para el que se parte de una definición amplia de culturas políticas, que resulta aquí de utilidad: "conjuntos de discursos y prácticas, como códigos o conjuntos de valores y representaciones, específicos, plurales y conflictivos. Las culturas políticas están sujetas a cambios y permutaciones; experimentan procesos de auge y declive; se definen en un proceso de interacción entre ellas y los planos de la vida cotidiana: generan, por la vía de la hegemonía de alguna de ellas o por elementos fuertes de transversalidad, marcos culturales compartidos, que podrán constituirse a su vez en territorios en disputa."7

En el caso del franquismo, como es bien sabido, coexistieron dos culturas políticas hegemónicas en disputa a lo largo de toda la dictadura, la falangista y la nacionalista reaccionaria o nacionalcatólica. A pesar de que hubo un proceso de fascistización más intenso hasta 1945 y de catolización a partir de esa fecha, el juego de colaboraciónrivalidad se mantuvo y sirvió de base de la cultura franquista a lo largo de todo el período. ${ }^{8}$

Por último, el concepto de género, entendido como construcción cultural de la diferencia sexual, a la vez que las relaciones de género como relaciones sociales cambiantes históricamente, y sobre las que se libran relaciones de poder ${ }^{9}$, es la clave que vertebra toda la investigación y que conecta las propuestas teórico-metodológicas señaladas. En tanto que las culturas políticas en las que se insertan los sujetos les facilitan el lenguaje político y los significados discursivos para redefinir su marco simbólico, autorreferencial, entre las que se encuentra su identidad de género. ${ }^{10} \mathrm{Y}$ precisamente el cine en general, y sus estrellas en particular, fueron un instrumento del cual el régimen

\footnotetext{
${ }^{6}$ Miguel Ángel CABRERA: Historia, lenguaje y teoría de la sociedad, Madrid, Cátedra, 2001. pp. 101126.

${ }^{7}$ Manuel PÉREZ LEDESMA e Ismael SAZ CAMPOS: Del franquismo a la democracia: 1936-2013, Madrid, Marcial Pons, 2015, pp. 11-12.

${ }^{8}$ Ismael SAZ CAMPOS: España contra España: Los nacionalismos franquistas, Madrid, Marcial Pons, 2003.

9 Joan W. SCOTT: "El género: una categoría útil para el análisis histórico", en James AMELANG y Mary NASH (ed.): Historia y género: Las mujeres en la Europa moderna y contemporánea, Valencia, Institució Alfons el Magnànim, 1990, pp. 23-56; y Arlette FARGE: "La historia de las mujeres. Cultura y poder de las mujeres: ensayo de historiografía", Historia social, 9 (1991), pp. 79-101.

${ }^{10}$ Ana AGUADO: “Culturas políticas y feminismo", Historia social, 67 (2010), pp. 69-73.
} 
franquista se valió para presentar modelos de feminidad y masculinidad. Puesto que mediante el discurso sobre las estrellas se crea identidades individuales carismáticas, que ejercen un gran atractivo y sirven de agentes de construcción de identidades colectivas. ${ }^{11}$

El presente trabajo se centra en las estrellas femeninas, pero sin perder de vista que el género es un concepto relacional, de manera que los ideales de masculinidad resultan imprescindibles para entender los modelos de feminidad. Al mismo tiempo, ser conscientes de que también los hombres son seres sexuados, y no son solo individuos que, a diferencia de las mujeres, no están definidos por su sexo; lo que ha motivado que se preste una escasa atención a la masculinidad, respecto a la feminidad. ${ }^{12}$

\section{Fuentes para un análisis intertextual}

La composición intertextual de la imagen de las estrellas nos obliga a escoger, de entre un conjunto amplísimo y variado, las fuentes pertinentes para los propósitos de la investigación. Se trata de no pensar en los textos ni como una combinación acumulativa ni como momentos aislados en la carrera de la estrella. El concepto de polisemia estructurada nos debe permitir entender la imagen como una totalidad compleja con una dimensión temporal. ${ }^{13}$ Siempre sin perder de vista que tratar de restaurar todos los significados posibles de una estrella es una tarea inabarcable.

En cualquier caso, se debe tener en cuenta algunos elementos específicos en su análisis. Por un lado, para la mayoría de artistas la carrera profesional y su reconocimiento público como estrella no se limitaba al ámbito cinematográfico, sino que se desarrollaba en otros como el teatro, los espectáculos musicales o la industria discográfica. Y, por otro lado, aunque la imagen de las estrellas, como producto intertextual construido a partir de una serie de relatos, adopta una forma narrativa, hay que valorar también la elaboración imaginaria ligada a los efectos iconográficos que se relacionan con el cuerpo y su uso espectacular. $^{14}$

\footnotetext{
${ }^{11}$ Vicente SÁNCHEZ-BIOSCA y Vicente J. BENET: "Las estrellas: un mito en la era de la razón", Archivos de la Filmoteca, 18 (1994), pp. 5-10.

${ }^{12}$ Mary VINCENT: "La reafirmación de la masculinidad en la cruzada franquista", Cuadernos de Historia Contemporánea, 28 (2006), pp. 135-151.

${ }^{13}$ Richard DYER: Las estrellas cinematográficas ..., pp. 85-91.

${ }^{14}$ Vicente SÁNCHEZ-BIOSCA y Vicente J. BENET: "Las estrellas: Un mito en la era de...".
} 
El primer texto a analizar son las películas, ya que "poseen un lugar distintivo y privilegiado en la imagen de una estrella", al tiempo que estas "se acostumbraban a construir alrededor de las imágenes de las estrellas". ${ }^{15}$ No se trata de un análisis extensivo de la filmografía española de los años cuarenta y cincuenta, sino de una selección de títulos en razón de su éxito de público y particularmente de la participación de las estrellas tomadas como casos de estudio, a las que luego nos referiremos. En cada película interesa observar una cierta tipología del personaje, directamente relacionada con el género cinematográfico, el tono y el mensaje del film, y qué valores de género, morales, políticos y religiosos encarnan los personajes.

El cine ofrecía discursos descriptivos sobre cómo debían ser las mujeres, que eran las principales consumidoras de este medio de entretenimiento, a través de la repetición de estereotipos y del control de la censura ${ }^{16}$. Pero al mismo tiempo, ese mismo hecho de que el público mayoritario durante la posguerra fueran mujeres y clases bajas, hace suponer que los espectadores pudieran realizar interpretaciones alternativas y no ortodoxas de los relatos y personajes cinematográficos, alejadas del mensaje y de las intenciones originales del film ${ }^{17}$.

Las cuestiones a analizar desde la categoría de género son diversas: Modelos de feminidad y masculinidad; la sexualidad de los personajes (hetero/homo, atractivo, sensualidad, asexualidad, alcanzable o inalcanzable debido a barreras físicas, psíquicas o morales...); el vestuario; la interpretación y la puesta en escena; etc. La estrella tiene que ser interpretada dentro del relato y de su relación con resto de personajes, que a menudo refuerzan o complementan su imagen. Por ejemplo, la virilidad del protagonista puede ser realzada por la presencia de personajes afeminados, o el valor de la mujer virtuosa frente a la pecadora.

En segundo lugar, de la pluralidad de medios de comunicación que proyectan la imagen de las estrellas fuera de la pantalla, se ha tomado como fuente principal el semanario cinematográfico Primer Plano, por diversos motivos. Para comenzar, es la

\footnotetext{
${ }^{15}$ Richard DYER: Las estrellas cinematográficas..., p. 87.

${ }^{16}$ Fátima GIL GASCÓN: Españolas en un país de ficción: La mujer en el cine franquista (1939-1963), Sevilla, Comunicación Social, 2011, p. 14.

${ }^{17}$ Jo LABANYI: "Historia y mujer..., pp. 85-112; Aintzane RINCÓN DÍEZ: Representaciones de género en el cine español (1936-1982): Figuras y fisuras, Madrid, Centro de Estudios Políticos y Constitucionales, 2014.
} 
única publicación especializada que recorre todo el período (estuvo en los quioscos ininterrumpidamente entre 1940 y 1963), y, al ser de carácter semanal, ofrece una gran cantidad de información y permite un seguimiento exhaustivo de la actualidad cinematográfica. Editado por la Cadena de Prensa del Movimiento, era la voz oficiosa del régimen en asuntos de cinematografía, y nos permite analizar el discurso de género desde la perspectiva de una cultura política concreta, la falangista. Pertenece al mundo del cine, y es, por tanto, una mirada desde dentro, sin los prejuicios y prevenciones que podríamos encontrar, por ejemplo, en sectores eclesiásticos. Así, se observa una complicidad de los periodistas del medio con las estrellas, ya que en cierta manera, forman parte de un mismo ambiente.

Si bien hay que tomar estas cifras con extrema cautela, según las primeras estadísticas consultadas ${ }^{18}$, Primer Plano tiene una importante tirada de más de 60.000 ejemplares en la primera mitad de la década de los cuarenta, con un precio de venta popular. A título comparativo, indicar que entre las publicaciones de Prensa del Movimiento era solo superada por algunos diarios (Arriba llegaba a los 90.000 ejemplares) y por las publicaciones de las organizaciones de Falange. Otras revistas de fans como Cámara o Radiocinema se quedaban en los 10.000 .

Desde sus orígenes, conjuga en sus páginas la reflexión teórica con la información de carácter comercial, de las que las estrellas son su máxima expresión. Adopta, por tanto, el modelo híbrido que caracteriza mayoritariamente a las revistas cinematográficas de la época ${ }^{19}$. Sin embargo, a menudo los estudios académicos tienden a ignorar este tipo de informaciones por entender que se ocupan de una actividad eminentemente frívola ${ }^{20}$. En cierta manera, sería la repetición de una concepción de preeminencia de la alta cultura sobre la cultura popular, que a menudo tiene también una derivada de género ${ }^{21}$.

Contrariamente, los estudios actuales están poniendo en valor el cine popular bajo el franquismo, puesto que muchos de estos títulos fueron los de mayor difusión. Algunas

\footnotetext{
${ }^{18}$ s.a., Anuario de la prensa española. Madrid, Ministerio de Información y Turismo, 1943.

19 Jorge NIETO FERRANDO: Cine en papel: Cultura y crítica cinematográfica en España: (1939-1962), Valencia, Filmoteca Valenciana, 2009.

${ }^{20}$ Virginia LUZÓN AGUADO: "Star studies today: From the picture personality to the media celebrity", BELLS: Barcelona English language and literature studies, 17 (2008), pp. 11-21.

${ }^{21}$ Isabel CLÚA GINÉS: "Género y cultura popular", Lectora: revista de dones i textualitat, 11 (2005), pp. 9-14.
} 
investigaciones, desde una perspectiva gramsciana, ponen el foco en la comedia popular como expresión de una cultura subalterna, en ocasiones resistente o alternativa, pero que no puede ser encapsulada, ya que alta y baja cultura se alimentan mutuamente ${ }^{22}$. Y en el caso de Primer plano, incluso conviven en apariencia armónica.

Esa misma ambivalencia de Primer plano en su definición como revista culta o popular se repite a la hora de determinar quién es el público potencial al que se dirige. Parece que, apuesta por abarcar todo el espectro de lectores potenciales, bajo la única condición de que sean aficionados al cine. Como ya se ha señalado, igual publica un artículo de debate intelectual como un mero cotilleo sobre Hollywood. Pero la misma indefinición o cohabitación la encontramos respecto al género de los lectores a quien se dirige. Por sus contenidos y por el modo de apelación se diría que a hombres y mujeres, según el modelo general de las revistas cinematográficas de la época, que implícitamente proyectaban la idea de que la alta cultura correspondía a los hombres y la baja a las mujeres $^{23}$. Pero, ¿podemos afirmar que las informaciones sobre las estrellas no interesaban a los hombres ni que las mujeres no leían los artículos de mayor profundidad? Sin contar que algunos textos como las críticas de películas o las noticias sobre rodajes resultan de difícil clasificación. Por tanto, es una asunción acrítica pensar que la información trivial era leída exclusivamente por mujeres. No obstante, vale la pena apuntar que la publicidad está dirigida de manera clara hacia productos considerados de consumo femenino.

Cabe recordar que nos encontramos ante una publicación bajo control de Falange pero que se dirige al público en general y no a sus asociados o simpatizantes. En las publicaciones de Falange, salvo las específicamente femeninas como $Y$, Medina y Teresa, se da por supuesto que van dirigidas a un lector masculino. Las mujeres suelen estar ausentes en sus páginas y cuando aparecen referencias a ellas son muy esquemáticas, responden a estereotipos y no se recoge sus experiencias. ${ }^{24}$ Esto sitúa Primer plano en una posición muy interesante, ya que combina ambos tipos de lectores... y de autores.

\footnotetext{
22 Steven MARSH: Popular Spanish film under Franco: Comedy and the weakening of the state, Basingstoke, Palgrave Macmillan, 2006.

23 Antje ASCHEID: Hitler's heroines: Stardom and womanhood in nazi cinema, Philadelphia, Temple University Press, 2004, pp. 5-6.

${ }^{24}$ Inbal OFER: "A "new" woman for a "new" Spain: The Sección Femenina de la Falange and the image of the national syndicalist woman", European History Quarterly, 4 (2009), pp. 583-605.
} 
Porque, aunque son una minoría, la revista cuenta con algunas periodistas en su plantilla, bajo dirección masculina, cuyos artículos resultan interesantes comparar con los de firma masculina.

Junto a las películas y Primer plano, otras fuentes primarias servirán para perfilar una imagen más completa de las estrellas y ofrecerán elementos de comparación respecto al tratamiento de la información, incluidos los silencios, del semanario falangista. Sería interesante contrastarlo con una publicación equivalente nacionalcatólica, pero hasta el momento no se ha localizado alguna realmente equiparable. La Iglesia hizo correr ríos de tinta sobre el cine, ya sea en las publicaciones de Acción Católica o de otras entidades como el SIPE desde los años 40 o en revistas especializadas como Film ideal en los 50. Pero rechazaba la excesiva atención que, a su juicio, se prestaba el mundo de las estrellas, como un efecto adverso del cine, que arrastraba a los espectadores hacia modelos de comportamiento a menudo alejados de las virtudes cristianas. ${ }^{25}$ Fuera de la prensa especializada, el diario $A B C$ resulta útil en cuanto que es un medio de ideología reaccionaria que sí presta atención a las estrellas, pero de manera episódica dentro de un contexto más amplio dedicado a la cultura y los espectáculos.

Por último, mediante el recurso a otras fuentes se concretará la imagen polisémica e intertextual de las estrellas. Entre ellas, destacar otras revistas de fans (Radiocinema, Cámara, Fotogramas e Imágenes), la publicación promocional Noticiario Cifesa o el NoDo, que tiene el valor añadido que precedía las proyecciones de las películas que protagonizaban las estrellas.

\section{Contexto histórico del estrellato español}

Si bien el star system había nacido en Hollywood como un reclamo para atraer espectadores a las salas de cine, ya en los años 30 las estrellas eran mucho más que un simple gancho comercial para las películas. Tanto o más que los films en sí mismos, se convirtieron en referentes de hábitos de consumo o de actitudes sociales, morales o políticas. $^{26}$

\footnotetext{
${ }^{25}$ Fernando SANZ FERRERUELA: Catolicismo y cine en España (1936-1945), Zaragoza, Institución Fernando el Católico, 2013, p. 243.

26 Paul MCDONALD: The star system: Hollywood's production of popular identities, New York, Wallflower, 2000.
} 
El franquismo no rechazó el modelo de estrellato de Hollywood si no que lo adaptó a sus necesidades y propósitos, al tiempo que se inspiró en el uso instrumental que los regímenes fascistas alemán e italiano hicieron del cine para la transmisión de sus valores y mitos. ${ }^{27}$ Pero que las grandes productoras españolas como Cifesa o Suevia miraran hacia la industria de Hollywood, no salvaba la enorme distancia que las separaba de su sistema de estudios. ${ }^{28}$

Para comenzar porque Hollywood se insertaba en un sistema democrático y de libre mercado, y la España de la posguerra era una dictadura con una economía inspirada en la autarquía. Ello no significa en absoluto que en Hollywood las estrellas no estuvieran sometidas a una disciplina incluso mayor por parte de los estudios, ni que su imagen quedara fuera de control ideológico ni de la presión de los medios. De modo que si en España la Iglesia católica tuvo un papel preponderante en la censura moral del cine, otro tanto sucedió con el lobby católico en Estados Unidos ${ }^{29}$.

En cualquier caso, no se trata aquí de establecer una comparación entre el star system de Hollywood, o el de otras cinematografías, y el español. Ni siquiera centrarme en determinar si bajo el primer franquismo este existió realmente. De todos modos, plantear si existe un sistema de estrellas, es decir, una interrelación organizada de elementos o rasgos y unos mecanismos estandarizados para la promoción de las imágenes de las estrellas, no significa que haya una categoría uniforme de estrella, ya que las estrellas son representadas de manera individualizada ${ }^{30}$.

Como ya se ha comentado, existe una fuerte carga de subjetividad por parte del receptor en la creación de la imagen de la estrella, imprescindible para cubrir ese espacio vacío que existe entre la persona y el personaje. En este sentido, cobra relevancia el cotilleo, como una vía por la que, a través de charlas informales, las estrellas participan en la cultura popular y la vida cotidiana. Frecuentemente estos comentarios están basados en rumores infundados inspirados, en mayor o menor medida, en la vida real de las

\footnotetext{
${ }^{27}$ Kathleen M. VERNON y Eva WOODS PEIRÓ: “The construction of the star system”, en Jo LABANYI y Tatjana PAVLOVIĆ: A companion Spanish cinema, Malden, Wiley-Blackwell, 2013, pp. 293-318, esp. p. 304.

${ }^{28}$ Véase: Félix FANÉS: Cifesa: La antorcha de los éxitos, Valencia, Institució Alfons el Magnànim, 1982; José Luis CASTRO DE PAZ y Josetxo CERDÁN: Suevia films-Cesáreo González. Treinta años de cine español, Santiago de Compostela, Xunta de Galicia, 2005.

${ }^{29}$ Gregory D. BLACK: Hollywood censurado, Cambridge, Cambridge University Press, 1998.

${ }^{30}$ Paul MCDONALD: The star system..., p. 1.
} 
estrellas; pero que no pueden ser subestimados simplemente como falsedades, porque esa misma mentira repetida regularmente se convierte para mucha gente en una "verdad" que se adhiere a la imagen de las estrellas. ${ }^{31}$ Un fenómeno difícil de calibrar, pero del que cabe suponer que en la España de posguerra cobraría una mayor relevancia, ya que la población era perfectamente consciente de la censura y el control de los medios de comunicación por parte del régimen.

En Hollywood el rumor fue un mecanismo de promoción en manos de los estudios, que a menudo aireaban romances ficticios entre estrellas para avivar el interés del público. Sin embargo, el estricto discurso moral que se elabora sobre las estrellas españolas dejaba un campo corto para la utilización de este recurso promocional, si bien Cifesa, por ejemplo, no desaprovechó el gancho para el público que podía significar el romance entre sus estrellas Amparo Rivelles y Alfredo Mayo a principios de los años cuarenta.

Como han puesto de manifiesto diferentes investigaciones, el régimen franquista no buscó únicamente legitimarse mediante la represión, sino que también buscó granjearse apoyos sociales más allá de los sectores que se identificaban con los vencedores de la Guerra Civil (otra cuestión es valorar sus logros, en los que parece ser que fue muy limitado en la consecución de apoyos positivos y activos, pero que sí fue efectivo en un consentimiento pasivo). ${ }^{32}$ Las estrellas pudieron servir en este sentido como instrumentos para articular este consenso, ya que eran figuras "amables" y atractivas, que representaban aspiraciones para un amplio sector de la población.

Por otra parte, sin negar que las estrellas encarnan determinados tipos sociales que son presentados como modelos o contramodelos (el buen Joe, el tipo duro, la Pin-up, el rebelde, la mujer independiente, etc. $)^{33}$, que pueden incluso tener su adaptación a estereotipos autóctonos ${ }^{34}$, a efectos de este proyecto, establecer una clasificación tipológica no resulta demasiado útil.

\footnotetext{
${ }^{31}$ Ibid., p. 6.

${ }^{32}$ Carlos FUERTES MUÑOZ: "Vida cotidiana, educación y aprendizajes políticos de la sociedad española durante el franquismo", en Manuel PÉREZ LEDESMA e Ismael SAZ CAMPOS: Del franquismo a la democracia..., pp. 53-79.

${ }^{33}$ Richard DYER: Las estrellas cinematográficas..., p. 69-84.

${ }^{34}$ Ángel COMAS: El star system del cine español de posguerra (1939-1945), Madrid, T\&B Editores, 2004, pp. 80-88.
} 


\section{Las estrellas españolas}

La presente investigación se centra en las actrices españolas, y se mueve en un equilibrio entre un marco general y los estudios de casos. Se han seleccionado tres nombres del firmamento cinematográfico de la época, de las que, siendo conscientes de la carga subjetiva que hay en toda selección de este tipo, se ha valorado no solo su enorme popularidad en la época, sino también que encarnan de manera relevante algunas de las tensiones y contradicciones más significativas con el discurso de género oficial franquista.

Estas actrices son Amparo Rivelles, Conchita Montes y Sara Montiel. Las tres comienzan su carrera tras la guerra, aunque su vía de acceso es absolutamente distinta, y la desarrollan a lo largo todo el periodo. Se trata de ver cómo se construye esa imagen y cómo evoluciona a lo largo del tiempo. Al resto de estrellas femeninas, también se le presta atención; pero fundamentalmente sobre aspectos parciales, que sirven como puntos de comparación, que ayuden a reveladoras diferencias o similitudes entre ellas.

Algunas de esas contradicciones que aparecen en el discurso sobre las estrellas femeninas son fáciles de vislumbrar. Por ejemplo, su inserción en el mundo de trabajo en aparente pie de igualdad respecto a sus compañeros y su presencia en la esfera social pública; las apelaciones a la belleza femenina o el culto al cuerpo (deporte y ejercicio físico), relacionadas con la profesión de actriz; las aspiraciones de realización personal a través del trabajo en lugar de en la maternidad y la familia; o la escasa importancia que se concede a las prácticas religiosas. Motivos, a su vez, de posibles divergencias entre los discursos falangista y nacionalcatólico, que proponían modelos no siempre coincidentes a sus asociadas. ${ }^{35}$

Las estrellas, como figuras carismáticas, brindaban la oportunidad de complementar estos modelos ideales (vírgenes, santas o reinas, entre otros) con personajes que

\footnotetext{
35 Sobre modelos feminidad, véase, entre otros: Rebeca ARCE PINEDO: Dios, patria y hogar: La construcción social de la mujer española por el catolicismo y las derechas en el primer tercio del siglo XX, Santander, Universidad de Cantabria, 2008; Giuliana DI FEBO: "La cuna, la cruz y la bandera. Primer franquismo y modelos de género", en Isabel MORANT: Historia de las mujeres en España y América Latina, vol. IV, Madrid, Cátedra, 2005, pp. 217-237; Inbal OFER: Señoritas in blue: The making of a female political elite in Franco's Spain (1936-1977), Brighton, Sussex Academic Press, 2009; Jordi ROCA i GIRONA: De la pureza a la maternidad: La construcción del género femenino en la postguerra española, Madrid, Ministerio de Educación y Cultura, 1996.
} 
resultarían más próximos al conjunto de las mujeres españolas. Las fronteras entre lo público y lo privado se distorsionan, y la vida de la estrella "sus convicciones morales y políticas y su propia cotidianidad pasan a ser objetos de dominio público a través de los medios de comunicación" 36 . Pero en la creación de esa imagen participa asimismo un sujeto histórico, que tiene agencia, y cuyo comportamiento no tiene porqué ajustarse al modelo oficial.

Estas mujeres gozaban de autonomía personal y económica, trabajaban fuera de casa y viajaban libremente, aspiraban a una realización personal, tenían una proyección pública, etc. En definitiva, rompían con el estereotipo que el régimen les atribuía por su condición de mujeres, tanto en la vida real como en las películas. De hecho, disfrutaban de una autonomía y un poder personal superior al común de las españolas, que les permitía, a pesar de su relevancia pública o tal vez gracias a ella, que se admitiera, mediante esa doble moral tan característica de la sociedad franquista, que protagonizaran en la vida real situaciones que en sus películas serían motivo de escándalo o de conflicto dramático. Solo a título ilustrativo, se puede anotar que Amparo Rivelles fue madre soltera, que Conchita Montes vivía amancebada con Edgar Neville y participaba en círculos intelectuales, o que la sensualidad de Sarita Montiel ponía en evidencia a una sociedad sexualmente reprimida...

Aunque la investigación esté centrada en las estrellas femeninas, no se puede perder de vista el carácter relacional del concepto de género, de manera que los modelos de masculinidad complementan y ayudan a comprender los de feminidad. Al igual que en el caso de las mujeres, coexisten diversos discursos sobre el varón, incluso dentro del campo de las derechas, que a su vez se pueden relacionar con las diferentes culturas políticas. Se trata de identificar estos modelos, que de una manera reduccionista sintetizaría en un discurso que enfatiza la virilidad, más próximo al falangismo, y otro que destaca el papel del hombre como padre de familia católico. Distintos modelos de masculinidad que pueden coexistir, evolucionar en el tiempo e influirse mutuamente. Puesto que ello no significa que existiera un único modelo de género, ni que no se plantearan conflictos ni contradicciones entre las distintas culturas políticas ni incluso dentro de estas. Puesto que

\footnotetext{
${ }^{36}$ Vicente SÁNCHEZ-BIOSCA y Vicente J. BENET: “Las estrellas: Un mito en la era de...”, p. 8.
} 
la pluralidad de modelos tampoco significa que estos ideales convivan de una manera armónica, sino que se establece "una articulación conflictiva y jerárquica”. 37

Asimismo, son un reflejo de una doble moral, que afectaba de manera diferente a hombres y mujeres, y también a diferentes clases sociales, al tiempo que funcionan como arquetipos de masculinidad no solo respecto a las mujeres, sino también respecto a conductas masculinas no aprobadas, como la homosexualidad y el amaneramiento. Actores como Alfredo Mayo, Jorge Mistral, Rafael Durán o Fernando Fernán-Gómez, se convierten dentro y fuera de la pantalla en figuras que discuten y complementan los modelos femeninos.

\section{El reflejo de las estrellas internacionales}

Aunque el tema de investigación es la construcción de la imagen de las estrellas españolas, no se puede perder de vista que se establece un juego de espejos con las estrellas internacionales, especialmente de Hollywood, que resulta muy revelador. El propósito es observar el tratamiento diferenciado que los medios dispensan a determinadas situaciones y sobre todo compararlas con el modo en que esos mismos criterios informativos se aplican a las estrellas españolas en la construcción de las imágenes de unas y otras.

En los primeros años, la cartelera española tiene un déficit de oferta, en buena medida motivado por la guerra mundial y por las propias condiciones de la industria española. Hasta 1942 las películas alemanas fueron las que tuvieron una mayor proyección en las pantallas españolas. Los espectadores españoles también conocían a los actores y actrices alemanes además de los nacionales y norteamericanos. ${ }^{38}$ Pero a partir de estos momentos las estrellas de Hollywood acaparan la atención de los medios. Una situación que hay también que relacionar con los sucesivos acuerdos cinematográficos que el régimen franquista estableció en los años cuarenta con Alemania y Estados Unidos. ${ }^{39}$ Las europeas quedan en un segundo plano, si bien en los cincuenta asistimos a la irrupción de un nuevo modelo de actrices que triunfan en Italia. Con Latinoamérica

\footnotetext{
${ }^{37}$ Nerea ARESTI: Masculinidades en tela de juicio: Hombres y género en el primer tercio del siglo XX, Madrid, Cátedra, 2010.

${ }^{38}$ Fátima GIL GASCÓN: Españolas en un país de ficción ..., pp. 24-25

${ }^{39}$ Emeterio DÍEZ PUERTAS: Historia social del cine en España, Madrid, Fundamentos, 2003.
} 
hubo un constante ir y venir de estrellas hacia uno y otro lado del Atlántico, e incluso en coproducciones como las protagonizadas por María Félix y Jorge Negrete.

El doblaje facilitó que las audiencias extranjeras coexistieran y entraran en competencia con las españolas ${ }^{40}$ y los medios españoles reconstruyen su imagen. Podríamos hablar de una doble mediación, puesto que son receptores de una imagen elaborada desde Hollywood que adaptan para su audiencia española. También los periodistas españoles se sienten atraídos por el carácter extraordinario de las estrellas de Hollywood, que les resultan fascinantes e inalcanzables, frente a unas artistas españolas con quienes mantienen una relación personal más próxima.

Una doble mediación que en ese contexto histórico suponía también una doble censura. Como ya se ha señalado, sería una falacia creer que las estrellas de Hollywood se construían en un marco idílico de libertad de prensa frente al control estatal español. También padecieron una intensa censura, aunque fuera a través de mecanismos informales como la poderosa Legión de la decencia ${ }^{41}$. Pero la Iglesia española, principal árbitro moral, era todavía más intransigente y aplicaba filtros más estrechos, y a través de las calificaciones morales de películas llegaban a recomendar a los feligreses no asistir a la proyección de películas que las autoridades franquistas habían dado por moralmente aceptables $^{42}$.

En concreto, hay tres aspectos, a su vez estrechamente interrelacionados, que resultan interesantes analizar.

\section{Modernidad vs. tradición en clave nacionalista}

El tratamiento que se dispensa a las estrellas de Hollywood es complejo. Por un lado, hay una fascinación por las estrellas y por otro una mirada de superioridad moral respecto a ellas. Hay una reafirmación nacionalista que se muestra cuando se compara la virtud y la "normalidad" de las estrellas españolas con la extravagancia y la falta de consistencia moral de las americanas. Un fenómeno que hay que relacionar como una

\footnotetext{
40 Ángel COMAS: El star system del cine español..., pp. 134.

${ }^{41}$ BLACK, Gregory D. La cruzada contra el cine (1940-1975).

${ }^{42}$ Fernando SANZ FERRERUELA: Catolicismo y cine en España...
} 
reacción contra la modernidad y en favor del discurso de defensa de los valores tradicionales que propugnaba el franquismo. ${ }^{43}$

Pero esta comparación maniquea provoca dos efectos no deseados. Por un lado, ese mundo que se presentaba como la gran bestia negra tenía un gran atractivo para buena parte de la juventud. ${ }^{44}$ Por otra parte, se tomaba como elemento de comparación por parte española a un grupo de mujeres, las estrellas 'patrias', con una identidad más moderna y emancipada que el modelo ideal.

La imagen de las actrices internacionales era sometida a un proceso de depuración de igual o mayor intensidad que las estrellas españolas. Su capacidad de atracción tiene que ser reconducida, explicada, sancionada moralmente o incluso ridiculizada. Y por supuesto, se silencia aquello que chirría

\section{El cuerpo femenino y el deseo}

La belleza, el culto al cuerpo y la fragmentación del físico femenino son elementos primordiales en la construcción de la estrella. A mediados de los setenta, el ensayo de Laura Mulvey "Placer visual y cine narrativo"45 abrió un debate fundamental sobre la teoría del espectador, al afirmar, desde planteamientos psicoanalíticos, que el cine clásico estaba organizado desde el punto de vista de los placeres y deseos del hombre heterosexual. Una propuesta que desde entonces ha generado muchas respuestas, críticas y reflexiones.

Así, la feminidad se construye como objeto de deseo masculino. El cuerpo femenino se muestra y es aprobado por la supervisión masculina. En el mundo del espectáculo, la mujer se convierte en un placer para la mirada masculina y como sujetos sexuales no puede existir sin la consciencia de sí mismas como objetos sexuales. ${ }^{46}$ Sin embargo, esto no implica que la imagen de la mujer no sea también objeto de observación por las mujeres espectadoras. No solo como satisfacción de un deseo homoerótico,

\footnotetext{
${ }^{43}$ Kathleen M. VERNON y Eva WOODS PEIRÓ: The construction of the star system.., pp. 304-315.

${ }^{44}$ Carmen MARTÍN GAITE: Usos amorosos de la postguerra española, Barcelona, Anagrama, 2002, pp. 28-31.

${ }^{45}$ Laura MULVEY: "Placer visual y cine narrativo", en Brian WALLIS: Arte después de la modernidad: Nuevos planteamientos en torno a la representación, Madrid, Akal, 2001, pp. 365-377.

46 Jackie STACEY: Star gazing: Hollywood cinema and female spectatorship, London, Routledge, 1994, p. 8 .
} 
evocado en dicha fascinación en un nivel tanto consciente como inconsciente, sino también que esta fascinación por otra mujer, por la estrella de la pantalla, puede ser un deseo de identificación. Las estrellas de Hollywood podían ser vistas como modelos de atractivo sexual y como una fuente de poder y confianza en sí mismo. ${ }^{47}$

Este planteamiento es válido también para las actrices españolas. Sin embargo, aquí la voluntad de atribuir una rectitud moral superior a las estrellas nacionales que a las extranjeras dificulta estas implicaciones de la fascinación por la estrella. Esto conlleva un diferente tratamiento diferenciado entre ambas, cuya expresión más clara se encuentra en un vestuario más atrevido y actitudes más sensuales. También los nazis eliminaron el componente sexual de las estrellas cuando son retratadas fuera de las pantalla, en tanto que lo sienten como una amenaza, ya sea para la camaradería o la maternidad, a pesar de que en las películas aparezcan como objetos sexuales. ${ }^{48}$

Esta cosificación y fragmentación del cuerpo femenino que se representa en el uso cinematográfico y fotográfico del primer plano ha sido señalada como una forma de alienación, opresión y objetivación, pero desde la perspectiva de la espectadora, puede ser también una forma de fascinación y de crear intimidad respecto a la estrella. ${ }^{49} \mathrm{La}$ adopción de un nuevo culto al cuerpo por imitación, en primer lugar, de las estrellas de Hollywood que ofrecían una imagen femenina inédita y sofisticada, contribuirá a que las mujeres españolas comiencen a rehacer su identidad tomando el cuerpo femenino como un arma ideológica contra la política moral y sexual del régimen, basado en valores católicos. ${ }^{50}$

En definitiva, se trata de analizar el cuerpo de las mujeres tanto desde la perspectiva de su significado, como de objeto del proceso de disciplina social (y también de

\footnotetext{
${ }^{47}$ Ibid., pp. 27-29.

${ }^{48}$ Antje ASCHEID: Hitler's heroines..., pp. 215-217.

${ }^{49}$ Jackie STACEY: Star gazing: Hollywood cinema ..., pp. 206-212

${ }^{50}$ Aurora MORCILLO GÓMEZ: En cuerpo y alma: Ser mujer en tiempos de Franco, Madrid, Siglo XXI, 2015, p. 285.
} 
resistencia) ${ }^{51}$ y de "incorporar" los conceptos de emoción y cuerpo a los discursos sobre género. $^{52}$

\section{Modelos de consumo}

El estilo de vida de las estrellas era uno de los elementos de la grandeza de Hollywood, hasta el punto que funcionaban, especialmente las actrices, como ídolos de consumo. ${ }^{53}$ La fetichización del cuerpo y el culto a la belleza de la mujer convierten a la estrella en un producto, de manera que funciona tanto como un instrumento para modelar ideológicamente a las mujeres como para fomentar entre ellas el consumo. Las mujeres son pues a la vez productos y consumidores en un intercambio de bienes, en el que cabe preguntarse qué implicaciones tienen estos cambios en una cultura patriarcal. Una interpretación señala que es una intensificación de las formas de objetivación femenina. Se anima las mujeres a mejorar su cuerpo como objetos de deseo para los hombres. Pero como vimos, también se puede interpretar como una vía de escape de la domesticidad, de la imagen de respetabilidad y asexualidad. ${ }^{54}$

En España, esta situación entraba en conflicto con los discursos oficiales que mantenían una actitud precavida e incluso condenatoria hacia el consumo como un factor de penetración de la modernidad. En el caso de la Iglesia católica, la apuesta por la modestia, el recato y un consumo austero era absoluta, mientras que la Sección Femenina mantuvo una actitud más ambivalente hacia el culto al cuerpo. En la práctica, el régimen adoptó una posición intermedia, tratando de encajar los elementos de modernidad en los modelos tradicionales. Las españolas respondieron de forma variada a estos discursos y dieron lugar a una heterogeneidad de prácticas. ${ }^{55}$ Pero el consumismo y la imagen física

\footnotetext{
${ }^{51}$ Miren LLONA GONZÁLEZ: "Los otros cuerpos disciplinados: Relaciones de género y estrategias de autocontrol del cuerpo femenino (primer tercio del siglo XX)", Arenal: Revista de historia de mujeres, 14 (2007), pp. 79-108.

${ }^{52}$ José Javier DÍAZ FREIRE: "Cuerpos en conflicto: La construcción de la identidad y la diferencias en el País Vasco a finales del siglo XIX", en Mary NASH y Diana MARRE (ed.): El desafío de la diferencia: Representaciones culturales e identidades de género, raza y clase, Bilbao, Universidad del País Vasco, 2003, pp. 61-94; ÍD: “Cuerpo a cuerpo con el giro lingüístico", Arenal: Revista de historia de mujeres, 14 (2007), pp. 5-29.

${ }^{53}$ Richard DYER: Las estrellas cinematográficas..., pp. 56-61.

${ }^{54}$ Jackie STACEY: Star gazing: Hollywood cinema ..., pp. 225-238.

${ }^{55}$ Inmaculada BLASCO HERRANZ: "Moda e imágenes femeninas durante el primer franquismo: Entre la moralidad católica y las nuevas identidades de mujer", en Emilio J. GARCÍA WIEDEMANN y María Isabel MONTOYA RAMÍREZ: Moda y sociedad: Estudios sobre educación, lenguaje e historia del vestido, Granada, Universidad de Granada, 1998, pp. 135-146.
} 
que representaban las estrellas ayudó con el paso del tiempo a cambiar su autopercepción y la configuración de una nueva identidad que les animaba a disponer de su propio cuerpo, a remodelarse tanto por dentro como por fuera. ${ }^{56}$

De todos modos, el retraso de España en la incorporación al consumo de masas provocaba que las estrellas, junto a la publicidad, anunciaran un mundo de sofisticación que no estaba al alcance del común de las españolas. En este sentido, las estrellas, como el cine, podían funcionar como formas de escapismo y también como expresión de un deseo de movilidad social. Conviene no caer en el error que, en este, como en otros aspectos abordados en la investigación, España representaba un caso excepcional. Así, por ejemplo, algo similar sucedía en la sociedad británica de posguerra. ${ }^{57}$ En cualquier caso, esas tensiones entre realidad y expectativas convirtieron los cincuenta en una etapa interesante de transición y contradicciones.

\footnotetext{
${ }^{56}$ Aurora MORCILLO GÓMEZ: En cuerpo y alma..., pp. 143-144.

${ }^{57}$ Jackie STACEY: Star gazing: Hollywood cinema ..., pp. 81-115.
} 


\section{El anime como fenómeno de masas global: fantasía, censura y percepciones}

Anime as global mass phenomenon: fantasy, censorship and perceptions

Antonio Blat Martínez

Universidad de Valencia

Miguel Blanco Herreros

Universidad Complutense de Madrid

\section{Resumen}

Este estudio ofrece una perspectiva histórica del fenómeno del anime, atendiendo a la censura y adaptación a la que es sometido este producto en EEUU. A lo largo de estas páginas, la censura se vincula con las diferentes percepciones de la cultura receptora, que mediante el proceso de censura globaliza el producto, adaptándolo al entorno local en que se comercializa. Para ello se analizan, no sólo determinadas obras afectadas por esos procesos, sino también la importancia de la evolución de las percepciones mutuas; su formación desde el trabajo académico, el arte y la cultura popular.

\section{Palabras clave}

anime, censura, Japón, Estados Unidos, percepciones.

\section{Abstract}

This essay aims to provide a historical perspective on the phenomenon of anime, focusing on the censorship it often experiences when released in the US. Throughout these pages, 
a strong relation between censorship and the perceptions of the receiving culture - the product is globalized and adapted to the local environment to which it is marketed - is going to be shown. To this end, not only some works affected by these processes are analyzed, but also the evolution of mutual perceptions; their formation from academic work, art and popular culture.

\section{Palabras clave}

anime, censorship, Japan, United States, perceptions.

\section{Introducción}

Este estudio analiza los vínculos entre la censura, la creación de productos glocales y las percepciones creadas como resultado de estos procesos de intercambio y transformación mutuos en el anime (animación japonesa). ${ }^{1} \mathrm{Su}$ exportación se vincula con la censura en mayor o menor medida, pues el objetivo es adaptar el producto cultural a las sensibilidades autóctonas, con tal que no resulten extrañas a los espectadores/consumidores del país receptor. Por norma general, el objetivo de esta alteración es conseguir un mayor éxito comercial. Sin embargo, son varios los factores que afectan a la edición de dichos productos. En este caso, dado el matiz cultural que tiene el trabajo, se ha optado por diferenciar cuatro tipos de censura dependiendo el grado de edición:

1) Censura: alteración realizada por un régimen autoritario con un objetivo político. En este caso, vinculado con la ocupación aliada de Japón (1945-1950).

\footnotetext{
${ }^{1}$ Para los objetivos del trabajo será suficiente con esa definición, aunque se debe ser consciente de que su definición es más compleja. Para más información sobre la cuestión ver: Luis PÉREZ GONZÁLEZ: "Fansubbing anime: insights into the 'butterfly effect' of globalization on audiovisual translation", Perspectives: studies in translation theory and practice, 14:4 (2006), p. 261; Joshua M. DRAPER: The Cool Japan Project and the globalization of anime and Manga in the United States, 2015, pp. 7-8; ADACHI: A study of Japanese animation as translation: a descriptive analysis of Hayao Miyazaki and other anime dubbed into English, Florida, Boca Raton, 2012, p. 35.
} 
2) Glocalización/Localización: ${ }^{2}$ término vinculado con la praxis económico/comercial, por el que un producto se adapta a los gustos o preferencias locales. Se usa para los casos de fuertes ediciones (con eliminación y/o adición de contenido, alteración del orden de narración de la historia, etc.) de los productos exportados a Estados Unidos desde el final de la ocupación hasta mediados de los noventa aproximadamente.

3) Domesticación de referencias culturales: un tipo de censura, aludida por Illaria Parini, ${ }^{3}$ que según Reito Adachi facilita el doblaje al que es sometida la animación. ${ }^{4}$ El término se encuentra en la línea propuesta por Fawcett de entender las traducciones y subtitulados como adaptaciones, es decir, como una mediación intercultural e interlingual, deliberada y arbitraria. ${ }^{5}$ Un concepto muy apropiado para las ediciones efectuadas desde mediados de los noventa.

4) (Auténtica) Traducción: vinculada al fansubbing (subtitulación amateur realizada por los propios aficionados), que tiene como objetivo ser lo más fiel posible al producto original, manteniendo palabras y expresiones propias de la cultura japonesa y añadiendo notas explicativas sobre el significado. Se podrían considerar adaptaciones, sin embargo, dado el carácter particular de estas traducciones y el afán de los aficionados por respetar el acervo cultural original, se ha optado por resaltar la diferencia a través de este término.

El ámbito geográfico se ha delimitado en torno a la adaptación de estos productos en Estados Unidos, un país muy vinculado con Japón desde el fin de la Segunda Guerra Mundial. A través del estudio de los elementos eliminados, se pretende entender hasta qué punto se vinculan con el "otro" y si han sido sustituidos por elementos que se identifiquen en mayor medida con la identidad cultural del país receptor.

La idea del "otro" y su representación mental es uno de los elementos cruciales a la hora de entender por qué y cómo se produce ese proceso de adaptación local/glocal.

\footnotetext{
${ }^{2}$ Más sobre este término en Peter BURKE: Hibridismo Cultural, Madrid, Akal, 2013, p. 114.

${ }^{3}$ Ilaria PARINI: "Censorship of Anime in Italian distribution", Meta: translators' journal, 57: 2 (2012), p. 329.

${ }^{4}$ Reito ADACHI: A study of..., p. 54.

${ }^{5}$ Luis PÉREZ GONZÁLEZ: "Fansubbing anime: insights into the 'butterfly effect' of globalization on audiovisual translation", Perspectives: studies in translation theory and practice, 14:4 (2006), p. 260.
} 
Durante casi medio siglo la relación Occidente/Japón se entendió como una transculturación en donde Occidente tenía garantizada su hegemonía sobre un país más débil militar y políticamente. ${ }^{6}$ La imagen del japonés, rodeada de exotismo, se empezó a valorar en función de su grado de occidentalización, entendiendo que renunciar a sus esencias culturales y estéticas era el único camino para salir de su posición subalterna. ${ }^{7}$ Más adelante se debatirá sobre si la adopción de elementos culturales occidentales se produce en un proceso de destrucción o de simple fagocitación por parte de los japoneses.

Los conceptos de "orientalismo" y "occidentalismo" son importantes a la hora de analizar las percepciones que se producen entre Japón y Occidente. Cuando se habla de “orientalismo" todo el mundo recuerda la definición de Edward Said. Es decir, la historia de cómo Occidente ha definido, representado y esquematizado Oriente, creándolo -para él "Oriente" no es una realidad pre-existente- y definiéndose así a sí mismo, ya sea geográfica, cultural o moralmente. ${ }^{8}$ Según él, para poder hacer algo así - crear una geografía imaginada y ser capaz de convencer a los pueblos afectados de que aceptasen ese nuevo concepto como si fuera natural- Occidente ha utilizado la hegemonía, entendiendo ésta como una mezcla de conceptos gramscianos y foucaultianos, es decir: el ejercicio de las funciones de dirección intelectual y moral que acompañan a la dominación política, gracias a un consenso entre el actor político y sus subordinados, ${ }^{9}$ dentro del contexto competitivo del poder, en el cual el saber no sólo se convierte en el objeto del mismo, sino también en su instrumento, pues es capaz de crear verdades, no científicas sino culturales. ${ }^{10}$

"Occidentalismo" es un término que es difícil de definir. Por un lado, tenemos la idea de Ian Buruma, un tanto simplista, de que sencillamente es la imagen negativa y hostil que se ha creado de Occidente en aquellos pueblos que se consideran - o se han considerado - sometidos o perjudicados por las acciones de los occidentales. ${ }^{11}$ Couze

\footnotetext{
${ }^{6}$ T. KOZAKI: Les Japonais Sont-Ils Occidentaux?, París, L’Harmattan, 1991, pp. 73-74.

${ }^{7}$ Renato ORTIZ: Lo próximo y lo distante. Japón y la modernidad-mundo, Buenos Aires, Interzona, 2003, p. 222.

${ }^{8}$ Edward SAID: Orientalism, Nueva York, Knopf Doubleday, 2014, pp. 1-18.

${ }^{9}$ Luciano GRUPPI: El concepto de Hegemonía en Gramsci, México, Ediciones de Cultura Popular, 1978, pp. 7-24 y 89-111.

${ }^{10}$ DELGADILLO, Juan Fernando: "Foucault y el análisis del poder", en Revista Educación y Pensamiento, vol. 19, Santiago de Cali, Colegio Hispanoamericano, 2012, pp. 160-170.

${ }^{11}$ Ian BURUMA y Avishai MARGALIT: Occidentalism. The West in the eyes of its enemies, Nueva York, Penguin Books, 2004, pp. 5-12.
} 
Venn, sin embargo, lo define como el espacio conceptual e histórico en el que se constituye una particular narrativa del sujeto y del espacio histórico; se convierten en hegemónicos gracias a la modernidad; y tienen efectos globales gracias al enfoque universalista de esa misma modernidad y a la realidad del colonialismo europeo. ${ }^{12}$ Es decir, "occidentalismo" como la hegemonía de la modernidad occidental sobre el resto del mundo, al principio basada en la dominación colonial y ahora en el establecimiento de formas globales de regulación y ejercicio económico, político, cultural y militar, frente a las cuales las narrativas no-occidentales sólo pueden quedar en un agónico segundo plano. ${ }^{13}$ Otras interpretaciones simplemente lo consideran el reflejo equivalente del orientalismo, renunciando al discurso de la hegemonía, que no podría funcionar.

Sin embargo, estas conceptualizaciones de "orientalismo" y "occidentalismo" son difícilmente aplicables a los temas que se exploran. Es necesario abrirse a explicaciones más modernas, como la de Patrick Porter, que entiende el orientalismo no como algo monolítico y dependiente de la hegemonía, sino como un conjunto plural y dinámico de ideas epistemológicas, actitudes y prácticas culturales, entendiendo la cultura como un "ambiguo repertorio de ideas en competencia que pueden ser seleccionadas, instrumentalizadas, y manipuladas, y no tanto un guion claro para la acción". ${ }^{14}$ Es decir, el orientalismo -y el occidentalismo, pues desde esta visión, ambos pueden ser definidos análogamente- no es más que un conjunto de ideas, su uso y manipulación, con el fín de obtener una imagen del "otro". Ideas mutables, seleccionables, manipulables, tergiversables, y en última instancia desechables.

Los procesos de adaptación y censura del anime y cultura popular japonesa, pueden ser comprendidos como un acto de orientalismo, si bien no desde una perspectiva plenamente saidiana, pero sí utilizando una aproximación más flexible y científica -por tanto, menos ideológica- de sus ideas. En el caso estudiado, la censura tiene una doble motivación cultural-comercial. Es decir: se elimina lo culturalmente ajeno, con el objetivo de acercar culturalmente el producto a un espectador externo a la cultura en la que se ha originado.

\footnotetext{
${ }^{12}$ Couze VENN: Orientalism. Modernity \& Subjectivity, Wiltshire, Sage, 2000, p. 2.

${ }^{13}$ Ibid., p. 19.

${ }^{14}$ Patrick PORTER: Military Orientalism. Eastern war through Western eyes, Londres, Hurst \& Co., 2009, pp.14-15.
} 
Pese a todo, se observa un aumento del consumo de aquellos productos culturales ajenos y exóticos. Desde la década de los 90 crece la fascinación por la cultura contemporánea asiática y desde el fin del siglo XXI “el Oriente” está una vez más en el foco del deseo y la fantasía europea. ${ }^{15}$ Especialmente durante este último periodo, el interés de los fans ha ido en aumento, paralelamente al crecimiento del soft power japonés (gross national cool, como lo define McGray), con el apoyo económico del gobierno japonés desde 2013. Aquí se defiende que el aumento de público (incluyendo público casual), pueda provocar que se atribuya las referencias culturales ajenas al mundo de la fantasía (no deja de ser una apreciación inconsciente del exotismo), atemperado así la censura cultural del otro.

El producto cultural elegido es el anime y por extensión la cultura popular japonesa. Las razones por las que se elige el anime para el estudio de la censura desde un punto de vista cultural y global son varias. En primer lugar, el éxito de la cultura popular japonesa que hace frente al imperialismo cultural estadounidense, incluso en su propio territorio. De hecho, es la principal exportación cultural japonesa. ${ }^{16}$ Un fenómeno, que ha atraído la atención de académicos alrededor de todo el mundo, ${ }^{17}$ provocando la aparición de una revista dedicada al tema: Mechademia. También se atiende al papel de los aficionados como tribu cultural, con un papel muy importante en la distribución del anime y la difusión de la cultura popular japonesa, escapando de los canales tradicionales de difusión y creando redes internacionales de aficionados.

Centrarse en la censura que ha sufrido el anime desde su aparición en todo Occidente escapa a los objetivos de este trabajo, por lo que se ha optado por estudiar la distribución y edición del anime en Estados Unidos por las razones siguientes:

En primer lugar, la información disponible al respecto es muy alta y accesible. En segundo lugar, por el ya mencionado carácter particular de la relación entre Estados Unidos y Japón. En tercer lugar, EEUU es el mayor mercado de anime después del propio Japón. Además, es el lugar de origen del fenómeno fansubbing, y distribuye una parte

\footnotetext{
15 Sharon KINSELLA: Adult manga. Culture and power in contemporary Japanese society, Londres, Curzon, p. 12-13.

${ }^{16}$ Annale NEWITZ: “Anime otaku: Japanese animation fans outside Japan”, Bad subjects, 13 (1994), p. 11.

${ }^{17}$ Sharon KINSELLA: Adult manga..., p. 12.
} 
importante de la cultura popular japonesa al resto del mundo. De hecho, en base al acuerdo Disney/Tokuma, es el distribuidor de Ghibli para todo el mundo, incluido Japón, con la excepción del resto de Asia. ${ }^{18}$

\title{
Influencia estadounidense: ocupación, censura e hibridación
}

\author{
Estados Unidos, (...), sería el modelo, el único modelo ${ }^{19}$ \\ I believe that the American occupation contributed to Japanese culture
}

more than it constricted $i t^{20}$

El objeto principal es el estudio del anime como fenómeno global de masas, especialmente sus características transculturales y/o transnacionales. Por ello, el grado de censura (localización en este apartado) al que es sometido es de vital importancia. Si la censura y/o localización se coloca en el foco de estudio, la influencia de Estados Unidos en Japón, especialmente después de la II Guerra Mundial, no se puede desatender, especialmente durante los siete años de ocupación del archipiélago.

La ocupación estadounidense (1945-1952) y la inmediata posguerra forman parte de la historia de la animación japonesa. El éxito global de la cultura popular japonesa, asienta sus raíces en la posguerra temprana, cuando el manga triunfó como entretenimiento barato en un empobrecido Japón. ${ }^{21}$ De hecho, el vínculo entre la posguerra y el manga-anime afecta también a su temática, destacando las apocalípticas, vinculadas con los bombardeos de la Guerra del Pacífico y las bombas atómicas. "Manga and anime emerged as underground expressions of trauma in Japan". ${ }^{22}$ No obstante, en esta época, el alcance del fenómeno fue local, tanto en lo que se refiere a producción y consumo, como a las temáticas tratadas.

Pese a todo, se aprecia la influencia estadounidense que, a través de las fuerzas de ocupación, difunden la cultura popular norteamericana por Tokio, que se convierte, en

\footnotetext{
${ }^{18}$ De hecho, una propuesta interesante para un futuro estudio, sería la de verificar hasta que punto, son las versiones estadounidenses las que llegan a Europa y en caso afirmativo, comprobar si se sigue dando, o ha habido un cambio en el futuro reciente con el aumento del soft power japonés en el siglo XXI.

${ }^{19}$ Ian BURUMA: La creación de Japón, 1868-1964, Barcelona, Mondadori, 2003, p.145.

${ }^{20}$ Kyoko HIRANO: Japan society Newsletter, octubre, 1993, p. 4.

${ }^{21}$ Craig NORRIS: "Manga, anime and visual art culture", en Yoshio SUGIMOTO (ed.): The Cambridge Companion to Modern Japanese culture, Cambridge, Cambridge University Press, 2009, p. 241.

${ }^{22}$ Roland KELTS: Japanamerica. How Japanese Pop culture has invaded the U. S., Nueva York, Palgrave Macmillan, 2007, p. 37.
} 
terminología de Mary L. Pratt, en zona de contacto. ${ }^{23}$ Por ejemplo, los comics estadounidenses tuvieron gran influencia en el manga. ${ }^{24}$ Incluso el propio Osamu Tezuka ("the postwar comics and animation culture of Japan would never happened without him"), ${ }^{25}$ estuvo muy influenciado por el estilo de Disney. ${ }^{26}$

El objetivo de la ocupación era curar del militarismo a los japoneses, ${ }^{27}$ "liberarles" del "medievalismo político" en el que se encontraba anclada la nación japonesa, y que tras su derrota entraba en la "adolescencia política". ${ }^{28}$ Un discurso muy presente en el general Douglas MacArthur, Supreme Comander for the Allied Powers (SCAP) en Japón, quien comparaba al pueblo japonés con un chico de doce años. ${ }^{29}$ En esa misma línea se mueve John M. Maki, aunque enfocándose más en la ideología que en la cultura, como hacía Ruth Benedict. Ante la certeza de que EEUU no tenían la capacidad de eliminar a todos los japoneses, debía optar por la reeducación de ese país feudal y de guerreros. Precisamente, el militarismo (asociado al "yellow peril") fue una de las características con las que se asoció lo japonés durante la Segunda Guerra Mundial: la admiración por la rápida modernización había quedado atrás y solo quedaba la imagen del enemigo definitivo.

La concepción de Japón como un país feudal de guerreros, hizo que cualquier referencia al feudalismo fuera susceptible de ser censurada. Por el contrario, se debían promover "las virtudes de la demokurashii" 30 y en general el American way of life. Por ejemplo, la lealtad feudal se contraponía al espíritu del individualismo americano. Tal vez por eso, las primeras exportaciones culturales japonesas a Estados Unidos se vinculen más con la posmodernidad que con la tradición japonesa de la época Edo. Godzilla (1952) y Astro Boy (1963) son criaturas postmodernas, híbridas, vinculadas más al futuro de la

\footnotetext{
${ }^{23}$ Mary Louise PRATT: Imperial Eyes: travel writing and transculturation, Nueva York, Routledge, 2007.

${ }^{24}$ Craig NORRIS: "Manga ..."

${ }^{25}$ Frederik L. SCHODT: The astro boy essays, Stone Bridge Press, Berkeley, 2007, pp. vii-viii.

${ }^{26}$ Roland KELTS: Japanamerica...

${ }^{27}$ John M. MAKI: Japanese Militarism: Its Cause and Cure, Nueva York, Alfred A. Knopf, 1945, pp. 182, 189, 190-191, 226, 232.

${ }^{28}$ Ibid., pp. 233, 240, 249, 250.

${ }^{29}$ Ian BURUMA: La creación..., p. 147.

${ }^{30}$ Ibid., p. 150.
} 
postguerra que al pasado japonés y por tanto alejadas de la tradición feudal. "Cartoons arrived as part of the cultural effort to defeudalized Japan". 31

En la tónica habitual de los discursos sobre "el otro", a quien se le atribuyen cualidades antagónicas y negativas, Edwin O. Reischauer, consideraba al Japón como la némesis definitiva del sistema de vida americano. ${ }^{32}$ Para él, la única posibilidad para que Japón alcanzase los estándares democráticos apropiados era la ocupación. ${ }^{33}$ No es de extrañar, pues, el rumbo que tomó la ocupación, en cuanto a difusión del estilo de vida americano y la eliminación de la supuesta tradición feudal japonesa, que en términos de Reischauer, era lo opuesto a la libertad estadounidense. Existía una sincera creencia en que Estados Unidos representaba la democracia y la libertad, ${ }^{34}$ por lo que su antagonista, Japón, era un país patológicamente agresivo, que no había conseguido alcanzar la modernidad de forma adecuada; tendente a la explosión debido a la supresión constante de sus emociones; y que necesitaba de la ocupación para lograr encauzarse hacia un verdadero futuro de paz y democracia. ${ }^{35}$

Durante esta época la industria del cine estuvo bajo el control de Estados Unidos, ${ }^{36}$ que no dudó en usar la censura como medio de alcanzar los objetivos antes citados. Sin embargo, el control de las imágenes y la aplicación de la censura, llevaba implícita la paradoja de estar en contra de los ideales democráticos. De hecho, se censuraba todo lo relacionado con el reciente conflicto, como la destrucción efectuada por los bombardeos aliados, ${ }^{37}$ la propia ocupación ${ }^{38} \mathrm{o}$ incluso la censura ejercida por las fuerzas de ocupación.

Destaca la censura sobre las bombas atómicas 39 ("The treatment of the Hiroshima bombing was critically important to the American government"). ${ }^{40}$ Alicia Gibson recalca

\footnotetext{
${ }^{31}$ Antonia LEVI: "The sweet smell of Japan. Anime, manga and Japan in North America", Journal of Asian Pacific Comunication, 23:1 (2013), pp. 3-18.

${ }^{32}$ Edwin O. REISCHAUER: Japan: Past \& Present, Nueva York, Alfred A. Knopf, 1946, p. 3.

${ }^{33}$ Ibid, p. 40.

${ }^{34}$ Ruth BENEDICT: The Chrysanthemum and the Sword. Patterns of Japanese Culture, Boston \& Nueva York, Houghton Mifflin Co., 2005, pp. 294, 314.

${ }^{35}$ Ibid, pp. 165, 169, 296, 300, 315.

${ }^{36}$ Kyoko HIRANO: Mr. Smith goes to Tokyo: the Japanese cinema under the American occupation, $1945-$ 1952, Smithsonian Institution Press, Washington, 1992, p. 9.

${ }^{37}$ Ibid., pp. 54-59.

${ }^{38}$ Algo que era extremadamente difícil, pues los signos de la ocupación se encontraban por todos lados, como se describe en Kyoko HIRANO: Mr. Smith ..., p. 56.

${ }^{39}$ Ibid., pp. 59-66.

${ }^{40}$ Ibid., p. 62.
} 
que incluso se prohibió expresar públicamente las experiencias de las víctimas. ${ }^{41}$ Estas cuestiones son las que tienen más relevancia para el presente estudio, ya que esta censura se puede rastrear en la localización de los productos japoneses que llegaron a Estados Unidos tras la ocupación.

En respuesta al ejercicio de esta censura, contraria a los ideales democráticos y a la concepción de Japón como una nación feudal y militarista, se alzaron algunas voces críticas en Estados Unidos, intentando un análisis objetivo y científico de Japón. Charles Burton Fahs y John Fee Embree son los más destacados. El primero consideraba que las acusaciones que sus colegas habían vertido sobre Japón eran propias de la ceguera que provocaba el enfrentamiento bélico, y que América estaba muy lejos de ser ese imperio de la paz y la libertad que pregonaban. ${ }^{42}$ El segundo criticó el trato a los nipo-americanos y afirmó que toda ocupación era por definición autoritaria, por lo que difícilmente se podría desarrollar una democracia sobre esa base. Ambos defendían que Japón no era agresivo y militarista por naturaleza, sino que había llegado a ese punto debido a las circunstancias políticas, diplomáticas y económicas en las que se había desarrollado su modernidad. ${ }^{43}$

Fuera del mundo académico hay mayor diversidad de enfoques, demostrando que la opinión pública norteamericana no tenía una única visión de los japoneses, sino que era como un caleidoscopio. ${ }^{44}$ John Hersey y Helen Mears escribieron notables trabajos en donde se planteaban cuestiones éticas -en especial Hersey, sobre las bombas atómicase intentaban hacer un acercamiento más empático a los que habían sido sus enemigos, entendiendo, como Fahs y Embree, que Japón no se podía analizar como un ente independiente de su contexto geopolítico. ${ }^{45}$

Con la firma del Tratado de Paz de San Francisco los japoneses recuperan la soberanía sobre su territorio, liberándose así de la censura impuesta por el CDD. Se

\footnotetext{
${ }^{41}$ Alicia GIBSON: "Atomic Pop! Astro Boy, the dialectic of enlightenment, and machinic modes of being", Cultural Critique (2012) 80, p. 186.

${ }^{42}$ Charles Burton FAHS: Government in Japan: recent trends in its scope and operation, Nueva York, Institute of Pacific Relations, 1940, pp. xi, 88-89.

${ }^{43}$ John Fee EMBREE: The Japanese nation: a social survey, Nueva York, Farrar \& Rinehart, 1945, p. 51.

${ }^{44}$ Susan J. NAPIER: From impressionism to anime: Japan as Fantasy cult in the mind of the West, Nueva York, Palgrave Macmillan, 2007.

${ }^{45}$ Richard H. MINEAR: "Cross-Cultural Perception and World War II: American Japanist of the 1940s and Their Images of Japan”, International Studies Quarterly, vol. 24, 4 (dic. 1980), pp. 571, 576.
} 
produce entonces un viraje en las percepciones de EEUU con respecto a Asia, en lo que respecta a la forma en la que se producen las imágenes culturales. Como señala Christina Klein, durante la guerra fría nos encontramos con un conocimiento poco intelectual de Asia, ${ }^{46}$ cada vez más apoyado en los medios de masas y en las artes audiovisuales y menos en análisis académicos, como había sucedido en las tres décadas anteriores -pese a la falta de objetividad ya señalada. En definitiva, se trata de un conocimiento cada vez más popular y comercial. Durante la primera década de la post-ocupación existe un intenso interés por lo asiático en América. ${ }^{47}$

Al mismo tiempo, la censura directa de EEUU sobre el Japón ocupado ya desaparece y únicamente controlará las producciones culturales japonesas exportadas a su territorio. Precisamente el tipo de censura analizada en este estudio, es decir: la localización o la censura de productos culturales foráneos en los lugares de recepción.

El ejemplo paradigmático es la glocalizacion de Gojira (1954), en Godzilla, King of the Monsters! (1956). Es el primer evento mediático internacional de la posguerra japonesa, ${ }^{48}$ pionero en llevar la cultura japonesa a los mercados internacionales ${ }^{49}$ y sufrir la censura y/o glocalización del país receptor. En esta línea glocalizadora, aunque con una cronología ligeramente posterior, se ubica Tetsuwan Atomu (Mighty Atom, 1963), glocalizado como AstroBoy (1963), la primera serie de televisión japonesa emitida en Estados Unidos. ${ }^{50}$ En este caso se hace referencia a la serie de animación: el inicio del personaje data de 1952, pero el interés del estudio es la exportación de la serie de animación.

Además, existen toda una serie de paralelismos entre ambos como objetos culturales transpacíficos ${ }^{51}$ ligados a lo atómico. Personifican tanto el trauma y la ansiedad

\footnotetext{
${ }^{46}$ Anne L. FOSTER: "Cold War Orientalism: Asia in the Middlebrow Imagination, 1945-1961 by Christina Klein" (Review), The Journal of Asian Studies, vol. 63, 1 (feb. 2004), pp. 136-138.

${ }^{47}$ Christina KLEIN: Cold War Orientalism: Asia in the Middlebrow Imagination, 1945-1961, University of California Press, Berkeley \& Los Angeles, 2003, pp. 2-4.

${ }^{48}$ B. KUSHNER: "Gojira as Japan's first postwar media event" en William TSUTSUI y M. ITO (eds.): In Godzilla footsteps. Japanese pop culture icons on the global stage, Nueva York, Palgrave Macmillan, 2006, p.41.

${ }^{49}$ William TSUTSUI: Godzilla on my mind. Fifty years of the king of the monsters, Nueva York, Palgrave Macmillan, 2004, p. 2.

${ }^{50}$ Alicia GIBSON: “Atomic Pop!..., p. 183.

${ }^{51}$ Ibid., p. 184.
} 
de las bombas atómicas, ${ }^{52}$ como el extraordinario poder que es posible alcanzar a través de la ciencia y la tecnología. ${ }^{53}$ No es extraño que tengan estas similitudes, pues la fecha de creación, 1952, los vincula con el Japón post-atómico y la reciente desocupación que permitía, finalmente, exteriorizar los traumas de la guerra. A lo que se sumaban las ansiedades del presente (pruebas nucleares en las islas Marshall) y del futuro (Guerra Fría) donde lo atómico continuaba jugando un componente esencial. Ambas son figuras modernas posmodernas/post-atómicas, que se alejan de la tradición histórica de Japón. Como ya hemos señalado, había poco conocimiento académico de Asia en este periodo, por ello, el papel de la cultura popular será muy importante.

En esta época, la glocalización de los productos importados desde Japón, además de adaptar el contenido a la cultura de destino (domesticación de referencias culturales) censura todo aquello relacionado con la Guerra del Pacífico. En la línea de esa domesticación, Godzilla pasa de ser un producto serio, un género casi de terror, a incorporarse al género norteamericano, muy de moda en la época, del monster in the loose. ${ }^{54}$ Godzilla tiene el honor de ser el primer lanzamiento transnacional de la cultura popular japonesa, ${ }^{55}$ que comienza la metamorfosis histórica de Gojira en Godzilla, the King of the Monsters $!{ }^{56}$ Godzilla se internacionaliza a partir de la versión americana. ${ }^{57}$ Es la adaptación glocalizada norteamericana la que se conoce, no la japonesa original.

La edición norteamericana de Gojira sufre una serie de modificaciones con tal de que se adapte al público estadounidense. Se incluye un narrador norteamericano mediante la adición de metraje nuevo. Un personaje que hace las veces de "traductor cultural", y cuenta la historia en un idioma comprensible para los Estados Unidos. Destaca la eliminación de una escena donde se comentan cuestiones vinculadas con los bombardeos, la contaminación atómica del mar y la lluvia ácida. ${ }^{58}$ A continuación, se reproduce parte de diálogo de la misma, en original japonés:

\footnotetext{
52 Ibid., p. 184.

${ }^{53}$ Ibid., p. 183.

${ }^{54}$ Sayurie GUTRHIE-SHIMIZU: "Lost in Translation and morphed in transit: Godzilla in cold war America” en William TSUTSUI y M. ITO (eds.): In Godzilla..., pp. 51-62.

55 Ishiro HONDA y Terry O. MORSE: Godzilla, King of the Monsters!, Toho Film y Jewell Enterprise, 1956, 00:00:42.

${ }^{56}$ Sayurie GUTRHIE-SHIMIZU: "Lost...”, p. 54.

${ }^{57}$ Barak KUSHNER: “Gojira as Japan's first postwar media event” William TSUTSUI y M. ITO (eds.): In Godzilla..., p. 46.

${ }^{58}$ Ishiro HONDA: Gojira, Toho Films, 1954, 00:28:16-00:28:54.
} 
「嫌ね、原子マグロだ放射能雨だ、この上今度はゴジラと来たわ。」 59

\section{「あ一あまた疎開か。嫌だなあ。」60}

Por su parte, la primera censura que sufre Tesuwan Atomu, es el nombre: se elimina la referencia a lo atómico y pasa a denominarse AstroBoy. ${ }^{61} \mathrm{El}$ episodio número siete es eliminado en su totalidad, donde aparecen misiles y violencia asociada a investigación en tecnología militar ${ }^{62}$ (similar a la situación de la Guerra Fría). Finalmente, se cancela después de dos temporadas y 104 episodios, por considerarse que había demasiadas batallas para la programación infantil. ${ }^{63}$ La censura hereda las percepciones de la época de la ocupación, como se ha señalado, predomina lo moderno y se evita lo feudal.

En el periodo correspondiente a la guerra y la ocupación, los estadounidenses hicieron un esfuerzo por comprender Japón, aunque las circunstancias hicieron que la objetividad se esfumara en la mayoría de los casos - con numerosas aunque menos populares excepciones- dejando paso a una interpretación más pasional y romántica de un Japón exótico, militarista y violento, que sólo se empezaría a romper a partir de los años cincuenta, gracias a la nueva imagen de modernidad y dinamismo económico que el país nipón desplegará hasta finales de los ochenta, gracias en gran medida al cine, el anime y su exitosa internacionalización.

A partir de 1964, debido a la guerra en Vietnam, la atención norteamericana se focalizó en dicha zona, relegando al resto de Asia a un segundo plano a nivel político y cultural. Sin embargo, para Japón esta "desatención" de los EEUU supuso que su propia fuerza cultural, de forma voluntaria o no, empezase a ocupar un espacio en el imaginario norteamericano. Aunque ya había empezado a penetrar con "Godzilla" en la década anterior, será a partir de los años sesenta cuando podamos hablar realmente de una constante -aunque poco organizada- penetración cultural japonesa en Occidente, saltando así mediante la cultura popular el espacio que había creado la realidad política

\footnotetext{
${ }^{59}$ Iya ne, genshi maguro to hōsha no ame da. Sono ue kondo gojira to kita wa. Atún atómico/radiactivo, lluvia acida y ahora Godzilla. Ishiro HONDA: Gojira ..., (00:28:30)

${ }^{60} \mathrm{Ahh}$, mata sokai ka. Iya dana. ¿Evacuaciones otra vez? Eso apesta. Ishiro HONDA: Gojira ..., (00:28:52).

${ }^{61}$ En este caso no ha sido posible comparar la versión japonesa y la norteamericana, por lo que se usa bibliografía secundaria sobre esta censura.

${ }^{62}$ Alicia GIBSON: “Atomic Pop!...”, p. 185.

${ }^{63}$ Anne ALLISON: Millenial Monsters. Japanese Toys and the Global Imagination, University of California Press, Berkeley, 2006, p. 60.
} 
de la Guerra Fría. Ya no eran los EEUU los que creaban de forma absoluta e independiente las imágenes de Japón, sino que Japón desplegaba su propia imagen a través de la fantasía. Al no poder censurar en origen, los estadounidenses tendrán que empezar a actuar en el destino, adaptando y moldeando esas creaciones a sus gustos e intereses culturales y políticos. ${ }^{64}$

\title{
El anime fandom y el éxito del anime
}

\author{
Americans are (...) studying the Japanese language, \\ enjoying Japanese food, and even seeing Japanese films \\ more than ever before ${ }^{65}$ \\ Japan figured little in the landscape of American \\ mass culture prior to the $1990^{66}$
}

Como ya señalamos, los años sesenta llevaron aparejados un progresivo alejamiento cultural y político - no tanto a nivel diplomático, pues seguía siendo una punta de lanza para los americanos en Asia- de EEUU con respecto a Japón. Esto permitió que por primera vez la cultura popular japonesa entrase en América de manera más o menos directa, aprovechando su situación como aliado tranquilo y privilegiado de EEUU en el Pacífico. ${ }^{67}$ Especialmente, a medida que la guerra en Vietnam se recrudecía y otros conflictos se abrían a lo largo y ancho del mundo, los norteamericanos empezaron a ver a Japón como un país fiable, capaz de cuidar de sí mismo, y que no iba a causarles problemas como otros aliados suyos. ${ }^{68}$ En definitiva, esta década abrirá una imagen más positiva e igualitaria de Japón.

La cultura popular siguió introduciéndose, con diferentes niveles de edición, a lo largo de la década. A esto se sumará una “invasión” económica de Japón a EEUU: el país

\footnotetext{
${ }^{64}$ August RAGONE: Eiji Tsuburaya: Master of Monsters: Defending the Earth with Ultraman, Godzilla, and Friends in the Golden Age of Japanese Science Fiction Film, San Francisco, Chronicle Books, 2014, pp. 46-47.

${ }^{65}$ Kyoko HIRANO: Mr. Smith..., p. 2.

${ }^{66}$ Anne ALLISON: Millenial..., p. 115.

${ }^{67}$ Richard H. MINEAR: Through Japanese Eyes, Lanham (Maryland), APEX Press, 2008, p. 153.

${ }^{68}$ Nathan GLAZER: "From Ruth Benedict to Herman Kahn: The Postwar Japanese Image in the American Mind" en Akira IRIYE: Mutual Images: Essays in American-Japanese Relations, Cambridge, Harvard University Press, 1975, pp. 141.
} 
nipón conseguiría salir airoso de la crisis del petróleo de 1973, mientras que la economía norteamericana retrocedía. ${ }^{69}$

Por ello, se llega a los años ochenta con un Japón muy dinámico, que era percibido en EEUU como su principal competidor (amistoso) comercial, y que se había convertido en una nación prototípicamente capitalista, con una sociedad basada en los mass media, en la cultura popular posmoderna y apoyada en la información. ${ }^{70}$ De hecho, existe la idea que Japón era posmoderno, antes incluso que se acuñará el término. ${ }^{71}$ La idea de Japón como un país capaz de alcanzar utopías ultra-tecnológicas se hacía palpable tanto en las producciones americanas (Blade Runner) como en las japonesas (Akira), y por primera vez no sólo se estudia su cultura por un mero interés académico, sino porque se considera que ciertos métodos y actitudes culturales japonesas eran las que les estaban dando la ventaja económica internacional.

La efeméride por antonomasia para el inicio del éxito internacional del anime es, precisamente, el estreno de Akira (Katsuhiro Otomo, 1988). Efectivamente, como evento implica un antes y un después en el anime. No obstante, su éxito es una cuestión compleja que no responde únicamente al éxito o la calidad del estreno del largometraje, sino que existen multitud de factores que lo explican. Entre los 70 y los 80 se tiende a hacer un anime orientado a adultos, ${ }^{72}$ un dato interesante teniendo en cuenta que la animación en Estados Unidos se había dirigido tradicionalmente a un público infantil. De hecho, se continúa teniendo esa concepción, ${ }^{73}$ siendo uno de los motivos por los que la censura en el anime es tan pronunciada.

Pese a la temprana emisión en Estados Unidos de Godzilla (1954) o Astro Boy (1963), las compañías de animación japonesas todavía no se habían introducido en el mercado norteamericano de forma permanente. Es por eso que entre 1976 y 1993 son los propios fans quienes distribuyen el anime de forma extraoficial. ${ }^{74}$ En esta época recurrían

\footnotetext{
${ }^{69}$ David FRUM: How We Got Here: The '70s. New York, Basic Books, 2000, p. 321.

${ }^{70}$ Joseph J. TOBIN: Re-made in Japan: Everyday Life and Consumer Taste in a Changing Society, New Haven \& London, Yale University Press, 1992, p. 6.

${ }^{71}$ Roland KELTS: Japanamerica ..., p. 25.

72 Luis PEREZ GONZÁLEZ: "Fansubbing anime: insights into the 'butterfly effect' of globalization on audiovisual translation", Perspectives: studies in translation theory and practice, 14:4 (2006), p. 262.

73 Ilaria PARINI: "Censorship..."

${ }^{74}$ Sean LEONARD: "Progress against the law. Anime and fandom, with the key to the globalization of culture", International Journal of cultural studies, 8:3, p. 282.
} 
al intercambio de cintas VHS. Por ejemplo, en la línea de la transculturación bidireccional, destaca el caso de un estadounidense que durante su infancia (décadas de 1960 y 1970) vivió en una base norteamericana en Japón, lo que le permitió intercambiar videos de programas norteamericanos por japoneses. ${ }^{75}$

La aparición del fansubbing se vincula con el creciente interés de los aficionados y el avance tecnológico que facilita la producción de material subtitulado. La década de los noventa cumple ambos requisitos, pues por un lado el anime disfruta de un éxito sin precedentes hasta la fecha mientras que por otro es posible producir subtítulos sin grandes inversiones. De hecho, el primer fansub conocido fue realizado para Lupin III, pero en 1986 costaba alrededor de 4000 dólares y unas 100 horas de trabajo subtitular, por lo que no hubo continuidad. ${ }^{76}$ Existe una clara correspondencia entre el aumento del fansubbing digital y el crecimiento de la industria del anime en Estados Unidos. ${ }^{77}$

Como contrapartida al fansubbing, resaltan las ediciones censuradas de los productos japoneses glocalizados por empresas comerciales en Estados Unidos. El ejemplo paradigmático de esta "censura aberrante"78 es la glocalización estadounidense de Kaze no Tani no Naushika (1984), convertida en Warriors of the Wind (1985). Reito Adachi llama la atención sobre la influencia que tiene el contexto norteamericano en la producción de Warriors of the Wind en plena era Reagan. Una época donde las batallas por la justicia entre el bien y el mal eran representadas de una forma plana. ${ }^{79}$ Efectivamente, en la versión norteamericana los personajes son planos: Kushana (princesa del reino de Tomerkia) carece de la profundidad que muestra en la versión japonesa, como consecuencia de la fuerte edición de las diferentes escenas en que aparece. Además, el rol que tiene la jungla tóxica en el conjunto del planeta y la labor de los insectos no se desarrolla. En esta línea se puede apreciar el cambio del nombre del insecto más grande y poderoso de la jungla tóxica: en la versión japonesa recibe el nombre de 大 虫 ( $\bar{m} m u[\mathrm{shi}]$, gran insecto), una denominación descriptiva y aséptica. Sin embargo, en la

\footnotetext{
${ }^{75}$ Ibid., pp. 289-290.

${ }^{76}$ Ibid., p. 291.

${ }^{77}$ Hye-Kyung LEE: "Cultural consumer and copyright: A case study of anime fansubbing", Creative Industries Journal, 3:3 (2011), p. 241.

${ }^{78}$ Entrevista a Isahao Takahara, productor de Naushika, las palabras exactas son: "an enormous and aberrant censorship", en Reito ADACHI: A study of..., p. 146.

${ }^{79}$ Reito ADACHI: A study of..., p. 147.
} 
versión norteamericana recibe el nombre de Gorgon. Según Adachi por el nombre de la criatura de tres cabezas de la mitología griega, ${ }^{80}$ aunque también es posible relacionarlo con el nombre de una de las criaturas más poderosas del universo de Dungeons \& Dragons, el demogorgon, que aparece en la década de 1970.

El gran momento de Japón, desde el punto de vista de la internacionalización cultural, se da entre finales de los ochenta y los años 2000. Aunque el país nipón desarrolló su propia crisis económica, de la que todavía lucha por salir, su prestigio tecnológico y cultural le llevaron a tener más presencia internacional que nunca. Desde la década anterior, en el mundo del manga y el anime (y casi al mismo tiempo, el de los videojuegos) existe una mayor inclusión de elementos "Nihonjin-banare", es decir, elementos culturalmente no-japoneses, en sus producciones. ${ }^{81}$ Ejemplos clásicos podrían ser La rosa de Versalles (1979-1980) o Cipher (1989), con ambientación en Francia y Nueva York respectivamente, pero también en la década posterior podemos observar la tendencia, con adaptaciones literarias occidentales; uso de la mitología occidental (Caballeros del Zodíaco (1986-1989; 2002-2005); o la introducción de personajes con características claramente no asiáticas - justificadas o no - como ocurre en Sailor Moon (1992-1993), Neo Genesis Evangelion (1995-1996), Rurouni Kenshin (1996-1998), etc. ${ }^{82}$

Sato señala que esta “des-japonización” del anime y el manga, es producto y a la vez consecuencia de los propios prejuicios que la sociedad japonesa tiene con respecto a la fotogenia de ellos frente a los caucásicos. ${ }^{83}$ Algo debatible, no debemos olvidar que los orígenes estéticos del anime se encuentran en la animación occidental, como ya se ha señalado en este texto.

En la década de 1990 se populariza el estudio de la ocupación aliada ${ }^{84}$ y comienza, ya de forma ininterrumpida, el fenómeno del fansubbing en Estados Unidos, apoyado en

\footnotetext{
${ }^{80}$ Ibid., p. 145.

${ }^{81}$ Kenji SATO: "More animated than life", Kyoto Journal: Insights from Kyoto-Japan-Asia, vol. 46, 21, (febrero, 2008), pp. 1-10.

82 Amy Shirong LU: "The Many Faces of Internationalization in Japanese Anime" en Animation: An Interdisciplinary Journal, vol. 3, 2, pp. 171-172.

${ }^{83}$ Keiji SATO: "More animated...", pp. 2-5.

${ }^{84}$ Kyoko HIRANO: Mr. Smith..., p. 7.
} 
la circulación mano a mano o por correo de cintas VHS, ${ }^{85}$ y la posibilidad de visionar el anime en versión original. ${ }^{86}$ Por lo tanto, el comienzo del fansubbing y el éxito del anime se solapan. De hecho, para Leonard, sin el interés de los fans el anime no habría tenido el éxito que disfruta en la actualidad, pues la difusión de estos alcanza niveles internacionales. ${ }^{87}$ Los aficionados que viajaban a Japón y traían consigo el material original japonés comenzaron a darse cuenta de los cambios que sufrían bajo la edición norteamericana. El fansubbing surge de la mano de la globalización de la animación japonesa nacido para dar una experiencia más auténtica del anime y de la cultura japonesa en la que se encuentra incrustada. ${ }^{88}$ Ambos elementos contribuyen en gran medida a la internacionalización definitiva de un fenómeno que había comenzado siendo local después de la guerra y con influencia cultural de EEUU.

La década de los noventa marca el inicio del éxito mundial. Los mayores éxitos indiscutibles del anime se dieron precisamente en aquellos momentos, como Dragon Ball/Dragon Ball Z (1986-1996), Sailor Moon (1992-1993), Ranma 1/2 (1989-1992), o más tarde Pokémon (1997-act) y Digimon (1997-act). Sin embargo, puesto que el éxito adquirido estuvo en gran medida influenciado por los fans, que disfrutaban con el anime original, pensado para una audiencia japonesa, no dejan de ser productos locales que eran glocalizados por las distribuidoras.

En esta línea de glocalización, ya en la década de los noventa, se da el caso, ilustrado por Anne Allison, de Mighty Morphin Power Rangers (1993). Su emisión en Estados Unidos usaba el metraje de la acción de la versión japonesa y añadía escenas con actores norteamericanos. ${ }^{89}$ Haim Saban, "creador" de la misma, vio algunos capítulos de Kyoryu Sentai Zyuranger, nombre que recibía la temporada de ese año de las famosas Super Sentai Series, programa de televisión del género tokusatsu, y que caracteriza por el uso intensivo de efectos especiales. Saban grabó el programa y se lo llevó a EEUU -todo ello vulnerando la ley japonesa- donde lo sometió a un proceso de doblaje y adaptación, eliminando las escenas en donde los protagonistas salían sin máscara por otras nuevas

\footnotetext{
${ }^{85} \mathrm{M}^{\mathrm{a}}$ Rosario FERRER SIMÓ: "Fansubs y scanlations: la influencia del aficionado en los criterios profesionales", Puentes, 6 (2005), p. 27.

${ }^{86}$ Sean LEONARD: "Progress...", p. 282.

${ }^{87}$ Ibid., p. 282.

${ }^{88}$ Luis PEREZ GONZÁLEZ: "Fansubbing..”, p. 260.

${ }^{89}$ Anne ALLISON: Millenial..., p. 114.
} 
grabadas con actores norteamericanos. Igualmente, dejaron de localizarse en Tokio para hacerlo en Angel Grove, una ciudad americana ficticia basada en Los Ángeles. Los enemigos mantuvieron su metraje y no fueron sustituidos al principio, pero sí vieron sus nombres cambiados para hacerlos más amigables al oído de los niños estadounidenses. Esto se debió a que, de no hacerlo así, se tendrían que volver a grabar las escenas de lucha. Todo ello demuestra cómo incluso en los años noventa, nadie concebía estrenar una serie protagonizada por japoneses y ambientada en Japón, que no fuera de dibujos animados. ${ }^{90}$

Pese a todo, la década de los noventa supone un cambio de paradigma, el paso de la glocalización a la mera domesticación de referencias culturales. Un ejemplo de esta dinámica es la firma del Disney/Tokuma deal ${ }^{91}$ (1996), ya mencionado, en virtud del cual Disney adquiría los derechos de distribución de las películas (homevideo) de Ghibli a nivel mundial, incluso en Japón, aunque exceptuando el resto de Asia. Después de la "censura aberrante"92 que había sufrido Kaze no Tani no Naushika, Ghibli no estaba dispuesta a que se editará/censurara el contenido de sus largometrajes. ${ }^{93}$ Precisamente es Disney la que comercializa la nueva versión de Nausicaä, sin cortes, en 2005.

El cambio de siglo supone el momento de mayor popularidad y prestigio cultural del anime. Adachi identifica tres producciones japonesas como puntos de inflexión que llevan a esa situación: Atamayama (2002), El viaje de Chihiro (2001) y Pokémon (1998), ${ }^{94}$ todas ellas pertenecientes al periodo finisecular. Además, Leonard habla del aumento exponencial de la animación japonesa a lo largo del mundo entre 1995 y $2005 .{ }^{95}$ Un momento de cambio en lo que a censura se refiere: de una edición severa de contenido (glocalización), se pasa a una domesticación de referencias culturales, manteniendo el acervo cultural japonés, aunque todavía con algunas licencias en un intento por adaptar los productos foráneos a la cultura receptora. Un cambio que no se podría haber realizado sin el trabajo de los aficionados, en cuanto a difusión y traducción del anime.

\footnotetext{
${ }^{90}$ Sam WILLIGAR: Kamen Rider Shin: Left Behind and Other Heroic Tales, Nueva York, Pronoun, 2016, cap. 36.

${ }^{91}$ Para más información sobre el particular: Daniel CAVALLARO: The Anime art of Hayao Miyazaki, Carolina del Norte, MacFarland \& Company, 2006., p. 43.

92 Entrevista a Isahao Takahara, productor de Naushika, las palabras exactas son: "an enormous and aberrant censorship", en Reito ADACHI: A study of..., p. 146.

${ }^{93}$ Ibid.

${ }^{94}$ Reito ADACHI: A study of ..., p. 2.

95 Sean LEONARD: "Progress...", p. 281.
} 


\section{Censura en el siglo XXI}

If manga and anime emerged as underground expressions of trauma in Japan, then their sudden popularity in the United States today means that we are finally hearing another voice in our conversations about atomic bombs, Vietnam, the cultural upheavals of the 1960s and 1970s, and the violence, uncertainties, and fears of the twenty-first century $^{96}$

Efectivamente, la popularidad del manga y el anime, no sólo en Estados Unidos, sino en todo el mundo, permite atender a otro tipo de discurso diferente al estadounidense. El imperialismo cultural norteamericano parece haber sido claramente contestado definitivamente por Japón, lo que no excluye que existan otras voces en el panorama internacional de la cultura popular.

En el siglo XXI la distribución del anime a través de Internet ha posibilitado que el número de espectadores de anime crezca exponencialmente, pues ya no existen las limitaciones del formato VHS o del DVD. Además, desde el año 2013, el gobierno japonés finalmente ha decidido respaldar el fomento de la cultura popular japonesa, entre la que indiscutiblemente se encuentra el manga y el anime, mediante el proyecto Cool Japan. Es sin duda un nuevo cambio de paradigma, no sólo por el aumento en el consumo, sino por toda una serie de reediciones que sustituyen las versiones glocalizadas anteriores por las originales. Así por ejemplo, en 2004, coincidiendo con el 50 aniversario del lanzamiento de Gojira (1954) se estrena por primera vez en Estados Unidos la versión original. Bernardi afirma que los norteamericanos se extrañaron de no ver a Richard Buhr en escena. ${ }^{97}$ En 2005, Disney lanza Nausicä̈ of the Valley of the Wind en DVD, ya citada, en este caso con una domesticación de referencias culturales (como la supresión de silencios demasiados largos) pero ya muy alejadas de la glocalización de los ochenta. Por lo tanto, el auge de la cultura popular japonesa, supone una revisión de la censura del pasado.

Aunque todavía existe cierta censura/edición por parte de Estados Unidos, es innegable que mengua. Esto puede relacionarse con 1) los fansubbings, 2) el incremento

\footnotetext{
${ }^{96}$ Roland KELTS: Japanamerica..., p. 37.

97 Joanne BERNARDI: "Teaching Godzilla: Classroom encounters with a cultural icon" en William TSUTSUI y M. ITO (eds.): In Godzilla..., p. 111.
} 
del soft power japonés y 3) la característica fantástica del anime que permite que se pueda atribuir los elementos de la cultura japonesa al mundo de la imaginación y lo fantástico. Hasta ahora no se ha comentado una de las características con las que se suele vincular al anime en el mundo académico, asociable también a su trayectoria exitosa: el carácter mukokuseki (lit. Sin nacionalidad) de la cultura popular japonesa, especialmente en lo referido a la estética. Sin embargo, no se debe pasar por alto, que se trata de un producto local: al fin y al cabo, durante el proceso de creación se tiene muy en cuenta el gusto del público japonés. ${ }^{98}$ De ahí la gran cantidad de referencias culturales japonesas en la mayoría de ellos. Sin embargo, es cierto que la estética de los personajes manga, así como ciertos clichés, son indistinguibles a nivel cultural.

Lo "mukokuseki" del anime puede ser atribuido a varias cuestiones. Por un lado, a lo que el propio término se refiere (el dibujar personajes no asiáticos, neutros, etc.). En este caso, se resalta la capacidad del propio espectador no especializado de realizar un vaciado -“mukokuseki"-, atribuyendo todo aquello que no entiende al mundo de la fantasía, en lugar de al acervo cultural japonés. Al fin y al cabo, el anime es otro mundo, un lugar fantástico que no se corresponde con Japón. ${ }^{99}$ He aquí la paradoja: unos atribuyen a Japón estas características creando un Japón fantástico que no se corresponde con el Japón auténtico y otros únicamente lo vinculan con lo fantástico, sin atribución a un lugar real. Los primeros, al visitar Japón superponen la imagen del Japón plasmado en la cultura y la correspondencia es absoluta, pues únicamente buscan la confirmación de una idea preconcebida.

Bellah utiliza conceptos parecidos al explicar la introducción de lo occidental en Japón, definiendo a la cultura japonesa como una forma que no tiene forma (katachi ga nai katachi), tal y como la concibe Nishida Kitarō. Maruyama Masao también plantea una definición similar, al llamar a la cultura japonesa como "bolsa vacía" o "tradición no estructurada". Con ello quieren decir que, independientemente de la cantidad de elementos foráneos que se puedan introducir en la "bolsa", esta no cambia, pues por sí misma no es más que un recipiente de elementos externos (primero de China y Corea,

\footnotetext{
${ }^{98}$ Ver Roland KELTS: Japanamerica ... y Luis PEREZ GONZÁLEZ: "Fansubbing..”, p. 262 para el anime en general y Reito ADACHI: A study..., para el caso de Ghibli.

${ }^{99}$ Susan J. NAPIER: From Akira to Princess Mononoke, Nueva York, Palgrave Macmillan, 2000, pp. 2426.
} 
después de Occidente). ${ }^{100}$ Maruyama llega incluso más allá al afirmar que, más que poderse hablar de una historia del pensamiento japonés, estaríamos hablando de una historia de la recepción de todos esos sistemas externos que se han ido introduciendo en la "bolsa" de la cultura nipona, que se ha ido adaptando a ese fenómeno sin que por ello se vea afectada porque no es más que un recipiente. ${ }^{101}$

Todo se encuadra dentro del concepto de "domesticación cultural", tal y como lo entendía Joseph Tobin, ${ }^{102}$ frente al tradicional de "occidentalización”. La tendencia a la "japonización” de los elementos foráneos predominaría sobre la dimensión occidentalizante. ${ }^{103} \mathrm{El}$ anime precisamente es una muestra posible de esto, al mostrar cómo, independientemente de su carácter cultural netamente japonés, lo que se está creando es un mundo nuevo - una fantasía- en la que el acervo cultural japonés no es más que un soporte (una "bolsa") en la que se introducen otros elementos externos, sean estos fantasías o realidades ajenas. Por ello, lo japonés, la cultura japonesa, no se convierte en el elemento definitorio, sino en un mero soporte que se puede volver invisible -una fantasía- a ojos del espectador extranjero y profano en la materia.

\footnotetext{
${ }^{100}$ Robert N. BELLAH: Imagining Japan: The Japanese Tradition and Its Modern Interpretation, Berkeley \& Los Angeles, University of California Press, 2003, p. 189.

${ }^{101}$ Ibid.

102 Joseph J. TOBIN: Re-made..., p. 4.

${ }^{103}$ Renato ORTIZ: Lo próximo..., p. 225.
} 


\section{La política y su representación. Caciquismo español y clientelismo italiano en la literatura: el caso de Procopio Atúnez /Abilio Calderón Rojo y Arcangelo Cozzi/Michele Capozzi}

Policy representation in literature: Spanish caciquism and Italian patronage system. The case of Procopio Atúnez /Abilio Calderón Rojo and Arcangelo Cozzi/Michele Capozzi

Vincenzo Barra

Universidad de Santiago de Compostela

\section{Resumen}

Mediante la comparación de dos obras literarias emblemáticas, la novela de Carlo del Balzo Eredità illegittime (1889) y Caciquismo y Caciques (1917) por Genaro González Carreño, se quiere poner de relieve, desde una óptica comparada, las similitudes y diferencias entre el sistema clientelar español de la Restauración y el caso italiano, en la cultura política liberal de la transición del siglo XIX al XX. Con la comparación de los dos protagonistas, "Procopio Atúnez" alter ego de Abilio Calderón Rojo, y de "Arcangelo Cozzi”, alter ego de Michele Capozzi se evidencia como el caciquismo de la Restauración va más allá del clientelismo político puro, es decir, del intercambio de favores en el momento electoral: son el miedo, la prevaricación física y psicológica y los métodos electorales fraudulentos a prevalece, incluso sobre los vínculos clientelares.

\section{Palabras clave}

Restauración Borbónica, Italia liberal, Caciquismo, Elite, Clientelismo. 


\begin{abstract}
Through the comparison of two emblematic literary works, the novel by Carlo del Balzo Eredità illegittime (1889) and Caciquismo y Caciques (1917) by Genaro González Carreño, the article aims to highlight, from a comparative perspective, similarities and differences between the system of patronage in the Spanish Restoration and the Italian case, in the transition from the 19th to the 20th century. The comparison of the two characters, "Procopio Atúnez" alter ego of Abilio Calderón Rojo, and “Arcangelo Cozzi”, alter ego of Michele Capozzi, makes evident that the caciquism goes beyond the pure political patronage as the exchange of favours in the electoral moment: on the contrary, fear, physical and psychological intimidation and electoral fraud prevail even on the clientelism.
\end{abstract}

\title{
Palabras clave
}

Spanish Restoration, Liberal Italy, Caciquism, Elite, Clientelism.

\section{Introducción}

Este paper es parte de una investigación doctoral en desarrollo que se propone hacer luz, desde una perspectiva comparada, sobre semejanzas y diferencias entre el caciquismo español durante la Restauración Borbónica (1876-1923) y el sistema de patronage en el caso italiano a partir de la caída de la "Destra Storica" (1876-1922)1.

\footnotetext{
${ }^{1}$ La literatura sobre el tema es muy amplia. Para un balance comparativo véanse Gabriele RANZATO: "La forja de la soberanía nacional: las elecciones en los sistemas liberales italiano y español", Ayer, 3 (1991), 115-138; ÍD: "Natura e funzionamento di un sistema pseudo-rappresentativo: la Spagna «liberaldemocratica» (1875-1923)", en Claudio PAVONE y Mariuccia SALVATI (eds.): Suffragio, rappresentanza, interessi, Milano, Franco Angeli, 1991, pp. 167-253; Maria Serena PIRETTI (ed.): I sistemi elettorali in Europa tra Otto e Novecento, Bari, Laterza, 1997; Silvana CASMIRRI y Manuel SUÁREZ CORTINA (eds.): La Europa del Sur en la época liberal: España, Italia y Portugal: una perspectiva comparada, Santander, Universidad de Cantabria, 1998, pp. 251-272; Raffaele ROMANELLI (ed.): How Did They Become Voters? The History of Franchise in Modern European Representation, The Hague, Kluwer Law International, 1998; Renato CAMURRI: "La Italia liberal y la Espana de la Restauracion: una perspectiva comparada" en Rosa Ana GUTIERREZ et al. (eds.): Elecciones y cultura política en Espana e Italia (1890-1923), Valencia: Universitat de Valencia, 2003; Rafael ZURITA y
} 
Un instrumento privilegiado en la comparación de los sistemas políticos indicados puede resultar también la comparación entre sus respectivas representaciones en la literatura. A este fin aquí han sido comparadas las representaciones literarias de dos hombres políticos en España e Italia: Abilio Calderón Rojo ${ }^{2}$ (1867-1939), diputado por Palencia desde 1898 al 1923, miembro del Partido Conservador y varias veces ministro; y Michele Capozzi ${ }^{3}$ (1836-1917), uno de los líderes de la escena política en Irpinia (Avellino) diputado desde 1867 al 1904 y presidente del Consejo Provincial para casi cuarenta años.

A sabiendas de que las historias no son narradas mejor sólo porque narradas juntos ${ }^{4}$, y que la misma comparación es difícilmente un resultado en sí misma ${ }^{5}$, lo que aquí nos proponemos es la utilización de la comparación de la literatura como instrumento heurístico, a fin de poner de relieve algunas afinidades y diferencias de las experiencias liberales nacionales, italiana y española.

\section{Michele Capozzi, Abilio Calderón Rojo y sus alter ego literarios}

El diputado Cozzi hablaba bastante bien, y astutamente, pero a veces tartamudeaba. La lengua se rebelaba al pensamiento, y, antes de proceder, se obstinaba a repetir, dos o tres veces, la misma sílaba, por lo que, si era locuaz y contundente en el seno del Consejo provincial, nunca había osado abrir boca en Montecitorio. Pero esto no le importaba nada, porque él no era un hombre político en el sentido amplio de la palabra, su campo no era

Renato CAMURRI (eds.): Las elites en Italia y en España (1850-1922), Valencia, Universitat de Valencia, 2008, pp. 245-256; Manuel SUÁREZ CORTINA (ed.): "Estado y nación en la Europa del Sur en la época liberal", Alcores: revista de historia contemporáneas, 8 (2009), pp. 15-53.

${ }^{2}$ Sobre Abilio Calderón Rojo véanse Pedro Miguel BARREDA MARCOS: Buenas tardes, Palencia. Las calles, las gentes, la historia, Palencia, Caja de Ahorros y Monte de Piedad de Palencia, 1987; ÍD.: Don Abilio Calderón Rojo. Palencia, paso a paso, Palencia, Caja España Palencia, 1991; Esther CALZADA DEL AMO: Poder politico y partido conservador en Palencia: Abilio Calderón Rojo (1890-1939), Palencia, Ayuntamiento, 1996; Esther CALZADA DEL AMO, José-Vidal PELAZ LOPEZ y JuanVILLA ARRANZ: La élite parlamentaria palentina: de la sombra de Gamazo al "triunfo" del caciquismo (18761923), en Pedro CARASA (ed.): Elites castellanas de la Restauración, II, Salamanca, Junta de Castilla y Leon, 1997, pp. 285-210; ÍD.: Castilla y León, en José VARELA ORTEGA (ed.): El poder de la influencia. Geografía del caciquismo en España (1875-1923), Madrid, Marcial Pons, 2001, pp.175-233.

${ }^{3}$ Sobre Michele Capozzi consultar Francesco DE SANCTIS: Un viaggio elettorale, Napoli, Morano, 1876; Francesco BARRA y Annibale COGLIANO: Il ceto politico irpino dai Borboni a Giolitti, Atripalda, Quaderni Irpini, 1990.

${ }^{4}$ Frederik COOPER: "Race, Ideology, and the Perils of Comparative History", American Historical Review, 101: 4 (1996), p. 1134.

5 Deborah CHOEN y Maura O'CONNOR (eds.): Comparision and history. Europe in cross-national perspective, New York, Routledge, 2004, p. XV 
Montecitorio. Don Arcangelo era diputado para gobernar la provincia. Su horizonte era provincial, no nacional. No había tenido tradiciones políticas en la familia, ni había mostrado de tener fuertes convicciones. Había debutado en el partido de izquierda, y luego, había pasado a la derecha, para ganar el puntillo de deshacerse de un prefecto, que no había querido ser simplemente su secretario. La mayor satisfacción de don Arcangelo era tener la conciencia de decir a sí mismo, acostándose: - El prefecto soy yo! ${ }^{6}$

El diputado "Arcángelo Cozzi” aquí retrato es el alter ego literario del diputado Michele Capozzi (1836-1917), entre los protagonistas de la novela de Carlos del Balzo Eredità illegittime, publicada en 1889. El sujeto principal de la novela, por primera vez en Italia, eran las elecciones políticas, y en la novela se indicaban tejemaneje y maquinaciones de la campaña electoral en Irpinia, una provincia del sur de Italia.

Michele Capozzi fue protagonista de una auténtica "leyenda negra" creada por sus adversarios políticos, su poder polarizó durante muchas décadas la vida política de la provincia de Avellino, que se dividió en “capozziani” y “anti-capozziani”. Perteneciente a una vieja familia provincial, fue heredero de grandes propiedades y de relaciones y amistades con la clase dirigente del reino de Italia. Licenciado en jurisprudencia, no ejerció nunca la profesión, pero se dedicó a la gestión del patrimonio familiar.

Diputado desde el 1867, el sistema de poder de lo que era llamado por sus opositores el "Rey Michele", el "soberano", el "sultán” fue así saldo por durar cuarenta años. Su participación en los trabajos de la Camera, sin embargo, fue siempre escasa porque su horizonte era la política provincial. El mismo mandato parlamentario estaba destinado precisamente a la conservación de la hegemonía política y administrativa en Irpinia. Como eficazmente señaló Carlo del Balzo en el retrato hecho de él en su novela, Capozzi «era diputado para gobernar la provincia». Sin embargo, su actividad de intermediación nunca fue exclusivamente local, pero logró tender una red clientelar con una trascendencia nacional, así que su radio de acción podía llegar a todos los niveles centrales del poder político y administrativo.

\footnotetext{
${ }^{6}$ Carlo DEL BALZO: Eredità illegittime, Milano, Libreria Editrice Galli, 1889, p. 30.
} 
Venimos a la España de la Restauración borbónica y al segundo retrato literario, el del personaje de "Procopio Atúnez", símbolo del peor caciquismo español:

De humilde origen y linaje obscuro [...] instintivo y pasional $[\ldots]$ ni la educación ni el medio hubieron de mostrarse propicios para desarrollar las mas nobles facultades del alma, y atenuar o corregir los defectos nativos [...]: las abyecciones y vilezas; la nula o escasa estimación del honor; la falta de respeto a la fe jurada; la sordidez y avaricia, la ruindad en el pensar, la bajeza en el sentir, la tosquedad en el hablar. [...] En semejantes sujetos la humildad es, de ordinario, rebajamiento; bajo tremor, el respeto; la altivez, soberbia; mascara hipócrita, la bondadosa sonrisa; celada traicionera, la promesa o el don; obligada restitución, la generosidad; la demanda de perdón, insuperable miedo; alevosa zancadilla, la aparente sumisión; y, en fin, el propósito de enmienda, forzoso compás de espera para nuevas tropelías?.

Procopio Atúnez, deforme y inmoral cacique, es el alter ego literario de Abilio Calderón Rojo en la obra sobre el caciquismo de Genaro González Carreño titulada Caciquismo y Caciques, publicada en Palencia en 1917.

Abilio Calderón Rojo nació en 1867 en Grijota (Palencia). De humildes orígenes, el padre supo introducirse en la industria molinera, que se convirtió en la base económica del poder de la familia, ampliada con una prudente política matrimonial hasta la creación de un banco. Licenciado en derecho en Madrid, no ejerció nunca la profesión de abogado y comenzó una brillante carrera política como diputado provincial desde 1892 al 1898 mientras, bajo la guía de Germán Gamazo, se convirtió en diputado de Palencia en el Partido Liberal. Pasado luego al Partido Conservador con Antonio Maura, y posteriormente con Eduardo Dato a partir del 1914, tuvo cargos de nivel nacional: fue Director General de Administración Local desde 1903 al 1904 y luego el 1908 al 1909; Director General de Obras Públicas en 1907 y desde 1913 al 1914; gobernador Civil de Madrid en 1917, Ministro de Fomento en 1919 y de Trabajo en 1922. Hasta el 1936, salvo que, en el paréntesis de la dictadura de primera de Rivera, siempre fue elegido diputado de Palencia.

\footnotetext{
${ }^{7}$ Genaro GONZÁLEZ CARREÑO: Contribución a una Ética hispana en el siglo XX. Caciquismo y Caciques, Palencia, Imp. y Lib. de Abundioz Menéndez, pp. 24 e 25.
} 
Emblema del caciquismo y símbolo de toda una época histórica española, Calderón fue glorificado por sus amigos y denostado por sus adversarios políticos con un amor o un odio ambos absolutos. Mediante el favor público, las clientelas privadas, el uso de la prensa diaria y el manejo del sistema electoral, Calderón se identificó indiscutiblemente con los intereses de su distrito como "buen cacique".

\section{Carlo del Balzo y Eredità illegittime}

Mas allá de ser un intelectual, y un novelista verista ligado a Capuana y Verga, Carlo del Balzo $^{8}$ (1853-1908) fue también un protagonista de la vida política italiana de finales de ' 800 . De noble y patriótica familia de S. Martino Valle Caudina (Avellino), hermano del diputado ministerial Girolamo, fue gran figura de novelista verista, de publicista, de orador y hombre político de fe radical y luego decididamente republicana. Elegido diputado al Parlamento en 1896 como diputado de Mirabella Eclano, salió a la luz especialmente en la batalla de la obstrucción parlamentaria contra el cambio reaccionario del Gobierno Pelloux (1899-1900).

Antes de entrar en el Parlamento, Carlo del Balzo apoyó eficazmente en primera persona el hermano Girolamo en las campañas electorales del 1882-83 y del 1886. Esta última describió vívidamente y con fuertes colores en la novela Eredità illegittime que publicó en Milán en 1889. Se trata de una narración de enfoque típicamente naturalista y verista, aplicada al mundo político provincial, aprovechado en el momento revelador de la campaña electoral. En forma despiadada, y "objetiva", se trazan las figuras de todos los hombres políticos provinciales, apenas cubiertas por transparentes seudónimos.

Del Balzo, influido profundamente por el naturalismo francés, pretendía escribir un ciclo de novelas en que observar y criticar desde el interior el mundo burgués. El título del ciclo era Deviati (“desviados”), y las novelas de carácter social estudiaban los desviados en el amor, en la política, en la religión, en la literatura, en el periodismo, en el teatro, en el matrimonio. Del Balzo, pero nunca aceptó completamente los cánones del naturalismo: impersonalidad, abolición del juicio subjetivo, objetividad de la obra. Al

\footnotetext{
${ }^{8}$ Para profundizar consultar Paola VILLANI: Carlo Del Balzo tra letteratura e politica, Napoli, Edizioni Scientifiche Italiana, 2001; Giovanna CALTAGIRONE: Dietroscena. L'Italia post-unitaria nei romanzi di ambiente parlamentare (1870-1900), Roma, Bulzoni Editore, 1983; Raffaele DELLA FERA et al. (eds.): Carlo Del Balzo, un intellettuale moderno, Avellino, Edizioni del Centro Dorso, 2010.
} 
contrario, la figura del escritor surge con prepotencia detrás de las vicisitudes y los personajes.

Eredità illegittime era la segunda novela del ciclo de los Deviati, y el título quería expresar como la actividad política y las cargas públicas no eran herencia que legítimamente podían ser transmitidas de padre a hijo. El sujeto principal de la novela son precisamente las elecciones políticas del 1886 en la provincia de Avellino, representadas como en una gran pintura de la verdad. Alrededor de las elecciones se articulan luego las vicisitudes de la historia de amor contrastada de Elisa y Andrea, pero sobre todo se destacan las intrigas y las miserias de toda una clase política provincial.

La figura central es la del diputado "Arcangelo Cozzi” (Michele Capozzi), pero junto a ella dominan, muy reconocibles por todos, los hombres políticos provinciales y los diputados. Figura grotesca y trágica, por ejemplo, es la del "Marqués Bellina" (Camillo Caracciolo di Bella), que en su paterna obstinación pretende la elección de su inepto hijo, casi que la diputación política fuera una herencia de transmitir:

Aquel Marqués Bellina era un pez gordo; docto y amable, pero terco y desconocedor de las verdaderas condiciones de la provincia. [...] luchaba como un león. Su hijo, Gasparino, debía ser electo a toda costa, la provincia, donde poseía tan amplias posesiones, tenía el deber de darle un puesto en el Parlamento 9.

El "Consigliere Dentice", a la cabeza de la prefectura de Avellino, es Antonio La Mola, que aspira a obtener los favores del gobierno, sino que no se encuentra eficazmente ayudado por Capozzi, que persigue sus fines personales y particulares. Otras figuras de marco son el "abogado Angelico" (Serafino Soldi), histórico adversario de Capozzi, descrito como «personaje influyente, que se había retirado de la lucha, instruido por derrotas anteriores, flexible de espalda y de inteligencia»; el "consiglier Grilluccio" (Luigi Gaeta), «el estúpido de la compañía» convencido de ser elegido con el apoyo de Capozzi; "Felice Diotaiuti" (el diputado Donato di Marzo); el diputado nicoterino "Pietro Napo" (Luigi Napodano); “Geremia Allucca” (Paolo Anania De Luca), descrito como un imbécil con la fiebre de la candidatura, y muchos otros.

\footnotetext{
${ }^{9}$ Carlo DEL BALZO: Eredità illegittime..., p. 111.
} 


\section{“Arcangelo Cozzi" y Michele Capozzi}

La figura de Capozzi, viene con insistencia en la novela despojada de la aureola de sacralidad de que el poder le había rodeado, a través de la descripción de una serie de tonterias, de manías, de defectos físicos y morales que hacen de Arcangelo Cozzi un omito vanidoso aunque inteligente, que siempre tiene éxito al final fingiendo complacer a todos, y logra imponerse como árbitro de la provincia: «Los votos les ganaba por todos; les prometía a todos, y, en el fondo, dejaba que quien quería llevar el agua a su molino si la llevara por sí mismo» ${ }^{10}$. Su «enorme cabeza», las «grandes labios», su misma tartamudez, esconden un oportunismo político y un utilitarismo que hacen del Cozzi un ser esencialmente astuto pero engañoso y desleal.

Las descripciones físicas de Cozzi, como de los otros personajes de la novela, son esencialmente despiadadas fotografías, donde cada detalle corresponde a la realidad, y el lector puede por lo tanto fácilmente identificar Capozzi y también los demás hombres políticos reales que Del Balzo ha sólo ligeramente disfrazado con nombres apenas modificados con juegos de palabras. Pero más allá de los defectos físicos, el verdadero punto débil de Cozzi/Capozzi parece ser la vanidad:

Don Arcangelo [... p preveía una gran velada; no se mostraba ni torpe ni preocupado, incluso regocijaba en su sillón, siendo estimado el árbitro de su provincia ${ }^{11}$.

El Cozzi no se contentaba de ser, de hecho, el verdadero prefecto de la provincia de Avellino, con el poder de establecer candidaturas y beneficios para los amigos; Cozzi quería ser considerado "el rey" de la provincia de Avellino. E incluso los más grandes personajes como el Marqués Bellina, si quería hacer elegir a su hijo al Parlamento, debía tener su consentimiento y su apoyo.

En todas las situaciones en que Del Balzo retrata Capozzi a través de su alter ego literario, por tanto, emerge como preponderante el cinismo y la vanidad del hombre, esencialmente un pequeño provincial de mentalidad y de horizonte político que, pero quiere presentarse a los demás como un gigante y un nuevo Machiavelli:

\footnotetext{
${ }^{10}$ Ibid., p. 258.

${ }^{11}$ Ibid., p. 29.
} 
Al paso del Cozzi, [en el interior del Palacio de la Prefectura], todos se levantaban. En esencia el comendador [Cozzi] era el prefecto. Y el Cozzi, dando saltos de gusto, aclamaba todos cuantos, recibiendo los homenajes con desenvoltura, haciendo el humilde, exagerando en familiaridad con todos. Se sentía el rey de la provincia, y habría besado los que se postraban para mantenerle en el pedestal ${ }^{12}$.

Del Balzo, por tanto, expresa el desencanto y el malestar por el progresivo deterioro de la vida político-administrativa del sur de Italia y de la provincia de Avellino, cuyos hombres políticos, guiados por Capozzi, habían pervertido el sentido de la honestidad, de la rectitud, de la cosa pública: hombres políticos sin ningún valor personal que representan al pueblo de que han sido elegidos persiguiendo únicamente fines egoístas. Pero también a nivel personal, las relaciones humanas son corruptas y guiadas sólo por el egoísmo y el clientelismo. El momento electoral, el verdadero protagonista de la novela, se convierte así en la piedra de toque de todo un sistema político y social provincial: la Irpinia parecía, en este contexto desolador, el paradigma emblemático de la crisis del Mezzogiorno, cuyas causas iban en buena medida atribuidas a la política de clientelismo y "trasformismo", personificada en Avellino en la figura de Michele Capozzi ${ }^{13}$.

También un sistema de poder en apariencia tan monolítico y sólido, sin embargo, podía ser puesto a la berlina con humor y ridículo, desvelando la trivialidad y banalidad de Arcangelo Cozzi. La liturgia del poder que sucedía en la casa de Cozzi para uso de los visitantes, importantes o menos que fueran y que servía a sacralizar la figura de Capozzi a los ojos de sus electores, estaba revelada por Del Balzo para poner de relieve como esa cubría una realidad sin sustancia, en buena medida el vacío, la ausencia y la negación de la verdadera política: era una ficción puesta en escena para dar la idea de grandeza. Como una especie de "epifanía del vacío" Del Balzo describe irónicamente, en efecto, el encuentro del marqués Bellina con Cozzi, en su casa de Nápoles:

Luego, las costumbres de aquella casa le molestaban; cuando se pasaba aquella entrada, parecía entrar en un lugar misterioso. Quién abría la puerta, no sabía nunca si don Arcangelo estaba en casa. Mientras que el siervo fingía de correr a informarse, en las

\footnotetext{
${ }^{12}$ Ibid., p. 18.

${ }^{13}$ BISTURY [seud. Vincenzo PenNetTI]: "Il Paese di cuccagna", La Provincia, 22 de julio-7 octubre de 1892.
} 
habitaciones interiores se veían, en recta y a la izquierda, a lo largo de dos pasillos, pasar, fugazmente, las sombras de personas que se escondían. Después, cuando eran introducidos en el salón, se oía el ruido de puertas abiertas y cerradas. Cuando don Arcangelo, bajo y fornido, comparecía, parecía como haber tenido una especie de visión $^{14}$.

\section{Genaro González Carreño y Caciquismo y caciques}

Genaro González Carreño nació en Valladolid en torno al 1870, estudió derecho en Madrid para luego ganar el concurso para profesor de psicología, lógica, ética y derecho en los institutos secundarios, enseñando en Andalucía, a Figueres (1902), a Pontevedra (1907) hasta llegar a Palencia. Políticamente cercano al Carlismo y filosóficamente al neotomismo, fue redactor del periódico tradicionalista El Correo Espanol y autor de algunas obras de carácter psicológico, moral y pedagógico, como La educación sexual ${ }^{15}$, sino también de una novela, Siete meses de amor ${ }^{16}$. Sobre todo fue el traductor de una serie de obras de filósofos franceses, especialmente del sociólogo y filósofo Alfred Fouillée $^{17}$. En 1942 fue secretario del Instituto Luis Vives de filosofía del Consejo Superior de Investigaciones Científica.

En Palencia Carreño se dio también a la política activa poniéndose abiertamente contra Abilio Calderón y presentándose en las elecciones municipales de noviembre de 1915. Fue elegido, único concejal jaimista, con 262 votos. Enseguida se hizo portavoz y promotor de una campaña moralizadora dentro del Municipio, oponiéndose con firmeza y también descaro a los abusos y las transgresiones cometidas por los amigos de Calderón en la administración.

La que podía ser una situación fastidiosa para Calderón, pero básicamente inofensiva, se reveló un peligro porque la actividad política de González Carreño iba a insertarse en un marco más amplio de desestabilización del sistema calderoniano: en el transcurso del 1915, en efecto, ocurrió la clamorosa disidencia de Jerónimo Arroyo, brazo

\footnotetext{
${ }^{14}$ Carlo DEL BALZO: Eredità illegittime..., p. 28.

${ }^{15}$ Genaro GONZÁLEZ CARREÑO: La educación sexual, Madrid, Sáenz De Jubera, 1910.

${ }^{16}$ Genaro GONZÁLEZ CARREÑO: Siete meses de amor, Oñate, M. Raldúa, 1900.

17 Alfred FOUILLIÉE: El moralismo de Kant y el amoralismo contemporáneo, trad. Genaro González Carreño, Madrid, Ricardo Rojas, 1908; ÍD.: Elementos sociológicos de la Moral, Madrid, Sáenz de Jubera Hermanos, 1908; ÍD.: La Moral de las ideas-fuerzas, Madrid, Sáenz de Jubera Hermanos, 1908.
} 
derecho de Calderón y además su cuñado. A partir de marzo de aquel año, y progresivamente durante todo el verano, los dos se intercambiaron públicamente sobre los periódicos acusaciones mutuas, incluso sobre hechos absolutamente privados, como la herencia de Doña Arsenia Arroyo, esposa difunta de Calderón, creando una situación potencialmente explosiva. Arroyo, en efecto, no sólo había decidido abandonar el partido conservador de Palencia, cuyo líder indiscutible era Calderón, pero aun más clamorosamente había pasado en el Partido Liberal, bajo la égida de Santiago Alba y del Conde de Garay. Además había recibido el encargo por el Conde de Romanones de guiar a los liberales a Palencia, con la intención de socavar el prestigio del omnipotente Calderón mientras estaba en el ápice de su poder ${ }^{18}$.

Las elecciones municipales del 14 de noviembre de 1915 fueron por eso el primer banco de pruebas de estabilidad del sistema de poder de Calderón, que fue apenas vulnerado en prestigio, pero no en la sustancia: los Conservadores obtuvieron seis concejales y los liberales de Jerónimo Arroyo solamente dos. Fue elegido, como dicho, también Carreño, jaimista, pero empujado cada vez más en una asociación con Arroyo, en función anti-calderoniana ${ }^{19}$.

La situación era todavía más confusa y paradójica porque en ese mismo período, al principio del 1916, los periódicos de Palencia mudaron su tradicional posición política, convirtiéndose El Diario Palentino en partidario de Calderón y El Día de Palencia en su decidido opositor ${ }^{20}$. El prestigio de los dos diarias, así como de los dos hombres políticos que se enfrentaban tan duramente, resultó afectado.

La génesis de la obra de Carreño, Caciquismo y Caciques se inscribe así en buena parte en el contexto de la lucha que oponía Calderón a Arroyo. De aquel enfrentamiento aprovechó abiertamente Carreño.

No por casualidad, precisamente a finales de marzo de 1917 figuraba en El Día de Palencia el primer anuncio de la salida de un nuevo libro de González Carreño, Caciquismo y caciques, presentado como una obra científica que retrata la verdad «como

\footnotetext{
${ }^{18}$ Pedro Miguel BARREDA MARCOS: Don Abilio Calderón Rojo..., pp. 154-158.

${ }^{19}$ González Carreño figura entre los organizadores del homenaje a Jerónimo Arroyo en "El banquete a don Jerónimo Arroyo", El Día de Palencia, 17 de octubre de 1916, p. 2.

${ }^{20}$ Pedro CARASA SOTO (ed.): El poder local en Castilla, Valladolid, Universidad de Valladolid, 2003, pp. 95-99.
} 
una cámara fotográfica» ${ }^{21}$, aunque con un lenguaje humorístico la figura de un cacique de fantasía: Procopio Atúnez, individuo feo y odioso, inmoral e ignorante que se considera dueño absoluto de una no mejor identificada provincia. La identificación del cacique en cuestión con Calderón no era difícil para nadie, de todos modos el libro de González Carreño fue presentado no como «obra de la pasión, sino mandato imperativo del deber» ${ }^{22}$.

Ofensa aún más grave era para Calderón que el libro de González Carreño fue publicado precisamente por Abundio Zurita Menéndez, director propietario del Día de Palencia con el que había compartido décadas de amistad ${ }^{23}$.

\section{“Procopio Atúnez" y Abilio Calderón Rojo}

La obra de González Carreño se inscribe claramente en la línea de la literatura contra el caciquismo, que tuvo desarrollo tras el 1898 y la pérdida de las últimas colonias y la desastrosa guerra con los Estados Unidos. La pérdida definitiva del imperio colonial, en efecto, marcó un momento de crisis para España y el comienzo de un movimiento decidido a realizar un verdadero cambio político y social. El caciquismo estuvo en el centro de atención, fue analizado en todo su aspecto e identificado como el más grande problema de España ${ }^{24}$.

Caciquismo y caciques tiene, por tanto, una pretensión de carácter científico, y se propone como estudio objetivo y general sobre el caciquismo, que intenta analizar las causas, los efectos más negativos sobre la sociedad, y por último indica algunas soluciones para poner fin al fenómeno. Pero la obra tiene en realidad dos planos paralelos, porque a cada uno de los ocho capítulos en los que se divide ("Principios generales", "Factores del cacique", "Mentalidad y cultura", "Moralidad", tratada en 4 capítulos, "Daños mayores del caciquismo", "Remedios"), hacen de complementario los hechos de Procopio Atúnez, personificación literaria y simbólica del cacique. Y es precisamente con

\footnotetext{
21 “Caciquismo y caciques”, El Día de Palencia, 28 de marzo de 1917, p. 2.

22 "Libro interesantísimo", El Día de Palencia, 3 de abril de 1917, p. 1.

23 José-Vidal PELAZ LOPEZ: Caciques, apóstoles y periodistas. Medios de comunicación, poder y sociedad en Palencia (1898-1939), Salamanca, Universidad de Valladolid, 2000, pp. 118-146.

${ }^{24}$ Las principales líneas de interpretación de la época son la de Joaquín COSTA: Oligarquía y caciquismo como la forma actual de gobierno en España: urgencia y modo de cambiarla, Madrid, Los hijos de M.G. Hernández, 1902; y la de José ORTEGA Y GASSET: "Sobre la vieja política", El Sol, 27 de noviembre de 1923 , p. 1.
} 
este artificio literario y el uso de dos planos paralelos que González Carreño desarrolla un ataque personal y político, aunque en forma indirecta, a Calderón Rojo. El artificio literario de la utilización de un personaje inventado, en efecto, le permite crear un espacio que escapa del carácter pseudo-científico del libro, donde poder expresarse con mayor libertad e ironía. El título de la obra era - explicaba El Día de Palencia - «Caciquismo: es decir, estudio impersonal y abstracto de ese harto deplorable fenómeno social en su esencia y en sus causas y efectos...; Caciques: esto es análisis, sereno y pormenorizado de los personajes en que el caciquismo encarna y vive hoy; lo que soy, lo que quieren y a lo que aspiran; y medios prácticos para acabar con su ilegitima y funesta dominación» ${ }^{25}$. Se narra por eso al final del segundo capítulo de «Quien fue Procopio, su retrato, su origen y educación»; al final del tercer capítulo «Necedad e ignorancia de Procopio»; en los cuatro capítulos siguientes sobre la moralidad: «Lealtad de Procopio», «Proezas de Procopio», «Soberbia y egolatría de Procopio», «Doble farsa de Procopio y medios para mantenerla»; al final del capítulo octavo se relata la «Muerte de Procopio», y al final del último «Necesidad de combatir a los amigos de Procopio».

La personificación del cacique, Procopio Atúnez, es una figura odiosa moralmente y repelente físicamente, casi que su fealdad interior sea una manifestación visible de sus características exteriores:

Algo cuellicorto, la anchura de sus hombros, la aparente solidez de sus espaldas robustas y las manazas musculosas, - dones con que la generosa Natura suplir quiso lo desmedrado de su talla - no dudo os dieran la impresión de hallaros ante un ariscado mozo de mulas; con su amplio y prominente abdomen, os harían pensar en el endomingado tenderos de embutidos y tocino. Los pies, a que creyéramos hacer agravio llamándoles sólo grandes, apóyense con firmeza y seguridad, como en muestra de posesión y dominio; y tal parecen querer hundirse en el suelo, que, sin ser poderosos a evitarlo, la imaginación (misteriosos lazos asociativos) evocaba el caballo de Atila, que donde ponía los cascos, nunca más brotaba la hierba.

Si en los ojos de torvo y avieso mirar - estrabismo ingénito o inveterado hábito de solapada truhanería - se delatan la sordidez y artera astucia del rústico desconfiado; la

25 “Caciquismo y Caciques”, El Día de Palencia, 11 de abril de 1917, p.1. 
premiosidad de la palabra, con lo asaz sobrio e inexpresivo del gesto, decían de pobreza de léxico, fruto de la inopia de ideas ${ }^{26}$.

Precisamente la insistencia en la fealdad de Procopio ofreció la oportunidad a la réplica irónica del Diario Palentino contra el «libelo Caciquismo y caciques», porque «en él se combate a un político palentino cuya cara se cubre levemente con nombre supuesto. Y se le combate porque tiene los pies grandes y el cuello corto, y la estatura baja, y las espaldas desmesuradamente anchas... En suma, se le combate por feo» ${ }^{27}$.

En efecto, sólo vagamente unos rasgos físicos de Procopio Atúnez encajaban con Abilio Calderón, como trataba de demostrar el mismo González Carreño en el cuadro siguiente ${ }^{28}$ :

\section{Procopio Atúnez}

Comenzaba a pasarse y reblandecerse

Desmedrado de talla

Amplio y prominente abdomen

Manazas musculosas y pies desmesurados, enormes

Torvo y avieso a mirar; estrabismo

Premioso de palabra y asaz, sobrio e inexpresivo en el gesto

\section{Abilio Calderón}

No contaba cincuenta anos y gozó siempre de salud y vigor envidiables

No conviene; $d a$ y pasa la talla

Jamás pudo este rasgo atribuírsele

Distinguiese precisamente por todo lo contrario

Nunca fue bizco

Podrán tal vez asignarse otras características a su palabra y expresión; jamás la premiosidad y sobriedad

\footnotetext{
${ }^{26}$ Genaro GONZÁLEZ CARREÑO: Contribución a una Ética ..., pp. 3-4.

${ }^{27}$ UN GUAPO [seud.]: "La Chelito a Palencia", El Diario Palentino, 7 de abril de 1917, p. 2.

${ }^{28}$ Genaro GONZÁLEZ CARREÑO: Los puntales de los Viejos partidos, Madrid, Juan Pérez Torres, 1919, pp. 28-29.
} 
Calderón, pero reaccionó de manera inmediata denunciando por injurias graves, después de algunos inútiles intentos de conciliación, tanto el autor, Genaro González Carreño, tanto el editor, Zurita Menèndez, propietario y director del Día de Palencia.

A pesar de que tanto durante como después del proceso González Carreño siempre se esforzó de negar la identificación de Procopio con Calderón Rojo, basándose también en estas diferencias físicas, el proceso concluyó que los rasgos físicos se solapaban «por la forma exageradamente grotesca con que sus enemigos les indican».

Pero los mayores elementos de coincidencia estaban en el ámbito político: Procopio Atúnez es un oportunista, un egoísta y un soberbio fanfarrón que «nada absolutamente ha producido en ninguno de los ordenes de la actividad mental» ${ }^{29}$. Su política está dominada exclusivamente del interés personal del momento y no de los ideales: «Nunca apreció Procopio de cuestiones doctrinales y de principios; $[\ldots]$ ¿Proteccionismo? ... ¿Salario mínimo?... ¿Libertad docente? [...] [era] de una gran transigencia con toda las ideas: derechas o izquierdas, eso le daba a él como de las miserias de antaño...» ${ }^{30}$. González Carreño hacía así la imitación de la falta de coherencia política de Calderón Rojo, liberal con Gamazo, conservador con Maura y luego “idóneo” con Dato.

El lema preferido de Procopio Atúnez era no por casualidad «Todo por mi pueblo y para mi pueblo», que sonaba literalmente como el de Calderón Rojo: «Todo por Palencia y para Palencia», que de hecho se traducía por Procopio en un único sentido: «favor para el amigo; justicia para el adversario».

Calderón Rojo quedó mortalmente ofendido también por el hecho de calificar la familia de Procopio como de «humildes orígenes y linaje oscuro» ${ }^{31}$, clara alusión al padre de Calderón Rojo.

El objetivo de la crítica política y moral de González Carreño resultaba evidente y notoria: la intención era sacudir el prestigio de Calderón denunciando sus defectos y miserias personales y familiares, sobre todo el egoísmo, la cobardía y la violencia opresora y corrompedora. González Carreño pretendía demostrar a todos como el poder

\footnotetext{
${ }^{29}$ Genaro GONZÁLEZ CARREÑO: Contribución a una Ética ..., p. 34.

${ }^{30}$ Ibid., pp. 101-102.

${ }^{31}$ Ibid., p. 24.
} 
de Calderón Rojo era una ficción y se basara en una doble mentira, mediante el análisis del caciquismo de Procopio:

Táctica fue siempre de Procopio y finalidad suprema de sus procedimientos políticos, el hacer creer en la corte que la provincia era feudo suyo indiscutido y que en ella ejercitar a su sabor podía los privilegios señoriales; y hacer por otra parte creer en la provincia que en la corte se le había hecho colación del feudo con toda suerte de solemnidades de fondo y forma; no pudiendo por tanto adoptarse medidas con la provincia relacionadas, de cualquier manera, sin su placet, aquiescencia o intervención. Dos engaños que mutuamente se apoyaban y sostenían ${ }^{32}$.

Los medios para ese engaño con la Corte de Madrid y con la provincia de Palencia eran los clásicos:

las vilezas, [...] las felonías, los atropellos, injusticias y ruindades que pondría en juego quien nunca escrupulizó ni seleccionó los medios para conseguir sus fines y nunca se propuso fines que no fueran bajos, egoístas y rastreros. El acertó a desprestigiar con calumnias, desfigurando hechos o fingiendo acciones, a las personas que podían hacerle sombra y estorbarle en la provincia; él supo arrebatarle al uno, - honrado y noble, - el acta y con el acta la posición política, fingiéndose adepto suyo, para mejor traicionarle; insinuarse hipócrita en el ánimo de otro, hasta conseguir suplantarle; manchar la limpia fama de éste, despojar al otro de todo su crédito; someter a unos, anular o dejar aislados a otros; engañando y vendiendo a todos... ${ }^{33}$

Mientras que el proceso seguía con el desfile de los testigos, la batalla de Carreño proseguía sin parada también en el Ayuntamiento, donde se hizo promotor de una propuesta en favor de los empleados municipales en nombre del "bloque anticaciquil" que encabezaba ${ }^{34}$. Se pedía en efecto, desafiando abiertamente Calderón Rojo, que Ayuntamiento y alcalde renunciaran espontáneamente a la facultad que la ley les confería de nombrar y cesar a los empleados, solicitando que el procedimiento de contratación y remoción fuera formalizado con protocolos y regulados, así como las promociones y los

\footnotetext{
${ }^{32}$ Ibid., p. 96.

${ }^{33}$ Ibid., p. 97

34 “Proposición justa. Los empleados municipales", El Día de Palencia, 10 de noviembre de 1917, p. 2.
} 
castigos. El objetivo era sustraer la administración pública al arbitrio del caciquismo calderoniano.

Resultaron al final inútiles las precauciones que González Carreño había tomado en el prólogo y epílogo de la obra (como también en las paginas 22, 80, 81, 91, 92, 100, 101, $104,111,112,113,114,118,139)$, donde se afirmaba en varias ocasiones que Procopio Atúnez era sólo una pura creación de imaginación con que no se aludía a ninguna persona en particular (pp. 7 y 8). Expresamente casi dondequiera en el libro se hablaba de Procopio como de un ejemplo, tanto que su nombre era declinado en diverso modo siempre como símbolo del caciquismo: "Los Procopios", el "tipo procopiesco", los "procopiofilos, el "procopismo" 35 .

Como ya se ha mencionado, nada se pudo para González Carreño, que fue condenado clamorosamente a la pena «de tres anos, seis meses y veintiún días de destierro a 25 kilómetros de esta capital» de Palencia, a una multa y al pago de las costas procesales. Del libro en cuestión, ya varias veces secuestrado, fue prohibida definitivamente la venta $^{36}$.

\section{Conclusiones}

Resulta claro cómo tanto Capozzi/Cozzi que Calderón/Atúnez, se mueven dentro del mismo cuadro sociopolítico marcado por el clientelismo político, la corrupción electoral y el poder de las oligarquías locales. Aunque desde el punto de vista de los géneros literarios, por lo tanto, Atúnez y Cozzi proceden de dos mundos totalmente diferentes, la novela naturalista uno y la literatura "científica" sobre el caciquismo el otro, pero ellos viven en dos realidades que tienen muchas similitudes y de que al mismo tiempo son el símbolo y la personificación.

Un anónimo palentino así escribía a Antonio Maura de Calderón:

Hizo de esta región su feudo, persiguiendo y dañando a todos los hombres honrados y monopolizando para sí y para los suyos la industria, el comercio, los cargos públicos, suyo tiene que ser el obispo, el Gobernador, el Alcalde, diputados, concejales, jueces y

\footnotetext{
${ }^{35}$ Genaro GONZÁLEZ CARREÑO: Los puntales..., pp. 30-31.

36 “En la Audiencia”, El Diario Palentino, 16 de diciembre de 1918, p. 2.
} 
alcaldes de toda la provincia... para quien no está a su lado, la injusticia, el atropello, la saña ${ }^{37}$.

Por contra, el periódico La Gazzetta del Principato Ulteriore con estas palabras acusaba Capozzi de haber construido en torno a sí mismo un sistema de poder opresor y corrupto, gracias al uso de los recursos del presupuesto provincial:

Desde 1866 [...] Capozzi ha mantenido la administración de la provincia, como administración propia y de que podía hacer y deshacer a su manera; sin control de especie, porque había sabido hacerse un Consejo de satisfechos, y cerró la boca a los críticos tirando en su garganta un subsidio más o menos pingue; él en definitiva ya se estaba deificado, habiéndose hecho por la gracia de Dios y para la estupidez de Irpinia el nuevo feudatario del Principato Ulteriore ${ }^{38}$.

"Feudo" y "feudatario" son las dos palabras que se repiten constantemente para ambos hombres políticos, cada uno en el centro de los sistemas político-clientelares que habían sabido construirse. Pero, más allá del común denominador del clientelismo político, la comparación entre las representaciones literarias de Calderón Rojo y Capozzi parece indicar una no desdeñable diferencia "cultural" entre caciquismo español y notables italianos, reflejo probablemente de importantes diferencias estructurales.

No es irrelevante, en efecto, que una descripción realista hasta los mínimos detalles de Capozzi, como la que Del Balzo hizo en Eredità illegittime, no ha tenido la más mínima consecuencia en el plano personal, político y tampoco ningún eco pertinente en la prensa; y que, al contrario, una descripción claramente exagerada de Calderón Rojo y sin precisa correspondencia en los atributos físicos, como la que hizo González Carreño, ha suscitado no sólo sus enojos sino también ha tenido consecuencias judiciales para el temerario autor.

Cierto es paradójico que Calderón Rojo no ha temido el ridículo denunciando González Carreño y pretendiendo que la autoridad judicial lo quedaran protegido por las «graves injurias» sufridas, casi "certificando" en este modo su papel de cacique de

\footnotetext{
${ }^{37}$ Carta a Antonio Maura, Fundación Antonio Maura Montaner, leg. 435/10.

38 "Il Consiglio Provinciale", La Gazzetta del Principato Ulteriore, 4 de octubre de 1873.
} 
Palencia y su coincidencia con el "monstruo" Procopio Atúnez. Como el mismo González Carreño escribía algún año después de los acontecimientos:

¿Como es posible, me planteé yo, que exista un ciudadano, no designado de modo alguno en mi libro, que se sienta aludido, lo proclame, recabe para sí el alto honor de encarnar a Procopio Atúnez (tipo de los caiques perversos sobre el que yo acumulé toda clase de hediondeces morales) y solicite ahincadamente de los Tribunales que así lo reconozcan y declaren?... ${ }^{39}$

El periódico madrileño España comentó que se trataba de «un caso clínico de lo mas curioso que puede presentarse en materia de política genuinamente oligárquica e ilimitadamente caciquista» ${ }^{40}$. El proceso debió de ser en muchos aspectos realmente surrealista, con: «el ameno y regocijante espectáculo de unos cuantos señores, sedicentes amigos desfilando ante el Tribunal para decir: "Es tan monstruoso, tan vil, tan hediondo y repugnante el tipo de Procopio Atúnez, que nosotros tenemos conciencia cierta de que conviene, y solamente conviene a nuestro querido amigo" $\gg{ }^{41}$.

El "caso clínico", en realidad es sin duda indicativo del hecho de que el caciquismo calderoniano es efectivamente "absorbente", es decir, tiende a monopolizar no sólo las manifestaciones directamente políticas o sociales y económicas, sino incluso las recreativas, literarias y culturales. Además, es la señal de que el caciquismo tiene un nivel de tolerancia más bajo hacia manifestaciones que pongan en entredicho su autoridad consolidada y constituida, y de modo especial hacia lo que mediante el ridículo intenta romper el respeto que se origina con el miedo. Al contrario, el notable italiano tiene un nivel de mayor tolerancia hacia la crítica intelectual, incluso cuando es objeto de sátira y escarnecido, porque el sistema de la influenza de los notables no tiene como eje central el miedo. El poder del notable italiano está por el contrario en mesura mayor en el poder de la influencia, en la clientela y en el intercambio de favores a cambio de votos, y por eso hay un espacio más amplio para el desacuerdo, porque más es la articulación, la complejidad, y la dialéctica interna al propio sistema. De hecho, el caciquismo de la Restauración aparece ir más allá del clientelismo político puro, es decir, del intercambio

\footnotetext{
${ }^{39}$ Genaro GONZÁLEZ CARREÑO: Los puntales..., p. 33.

${ }^{40}$ Matías PEÑALVA en Genaro GONZÁLEZ CARREÑO: Los puntales, p. 39.

${ }^{41}$ Genaro GONZÁLEZ CARREÑO: Los puntales..., p. 41.
} 
de favores en el momento electoral: son el miedo, la prevaricación física y psicológica, los métodos electorales fraudulentos a prevalecer incluso sobre los vínculos clientelares ${ }^{42}$. El caciquismo en este sentido se configura como un sistema de poder que o es realmente totalizador y "absorbente" o no existe, y por ello difícilmente puede tolerar "grietas". El espacio para la dialéctica es mínimo y en el mejor caso reservado a los niveles más altos de la política. El cacique español, oficializado y oficial, arrogante en sus pretensiones, vanaglorioso en la defensa de su honor y de un malentendido sentido de la hidalguía, aparece en el caso en cuestión implacable contra cualesquiera posible voce en protesta, sin ninguna duda ni temor, ni siquiera el de caer en el ridículo.

\footnotetext{
${ }^{42}$ En la misma línea historiográfica véase Gabriele RANZATO: "Natura e funzionamento di un sistema...", en Claudio PAVONE y Mariuccia SALVATI (eds.): Suffragio..., pp. 242-243; ÍD: La difficile modernità, Torino, Edizioni dell'orso, 1997, p. 107.
} 


\section{CAPÍTULO II}

\section{LOS Oficios de la Historia EN la EUROPA CONTEMPORÁNEA (SS. XIX Y XX)}

Gustavo Alares López (Universidad de Zaragoza)

María José Solanas Bagüés (Universidad de Zaragoza)

José Luis Flores Pomar (Universidad de Zaragoza)

Pese a las sucesivas crisis de la historia y el cuestionamiento de la capacidad representativa de los discursos históricos - con la consiguiente devaluación de la figura de historiador profesional como interlocutor con el pasado- desde nuestra perspectiva entendemos la disciplina histórica - con todas sus particularidades- dentro del ámbito de la ciencia. Desde este enfoque, los relatos históricos serían algo más que meros "actos poéticos"-entendidos dentro del paradigma White-, situándose en los dominios de una disciplina científica radicada en el ámbito de la Wissenschaft, y evitando los excesos del relativismo cultural y la inoperancia derivada de los mismos. ${ }^{1}$ Así, desde esta perspectiva,

${ }^{1}$ Jörn RÜSEN: History. Narration, Interpretation, Orientation, Oxford, Nueva York, Berghahn Books, 2005. 
la historia de la historiografía albergaría unos objetivos explícitos que deberían superar el mero análisis de los discursos históricos para referirse de manera integral a los procesos de construcción de la profesión. En palabras del historiador alemán Lutz Raphael:

[...] una historia de la historiografía supone [...], una contribución fundamental a la historización y problematización autocrítica de conceptos e hipótesis de investigación actuales. Los historiadores se interesan por antiguas controversias de su disciplina, verifican viejos argumentos y actualizan formas olvidadas de enfrentarse a un problema. Sin embargo, en tanto que historia de una ciencia, la historia de la historiografía ofrece algo más: con ayuda de métodos de la historia social y cultural intenta analizar las instituciones de la disciplina así como las precondiciones políticas, sociales y culturales de los inicios de la práctica profesional de los historiadores. ${ }^{2}$

Fueron sobre estas premisas teóricas bajo las en líneas generales se estableció el taller Los oficios de la historia en la Europa contemporánea (siglos XIX-XX). En última instancia, la mesa-taller propuesta tuvo como objetivo el ofrecer un espacio para la reflexión sobre los modos y agentes implicados en el análisis y representación del pasado en la Europa contemporánea. De esta manera, el llamamiento inicial pretendía convocar a los jóvenes especialistas para, a través de un enfoque amplio y abierto, poder incluir aportaciones relativas tanto al quehacer profesional del historiador y a las múltiples representaciones del pasado, como a los usos públicos de esos relatos.

De esta manera, los ámbitos propuestos se vincularon por un lado a la propia construcción histórica del oficio de la historia, contemplado este de una manera amplia e integradora que incluyera la institucionalización profesional y académica, la conformación de una identidad gremial, la adquisición de un estatus social y las variaciones en los valores éticos y profesionales asociados a la figura del historiador. Y por otro, a los usos públicos de la historia a través de algunos conceptos clave como cultura histórica y políticas del pasado, permitiendo a través de este último aludir a las representaciones del pasado en sus múltiples formatos (historiografía profesional, literatura, museografía, medios audiovisuales y medios digitales). ${ }^{3}$

\footnotetext{
${ }^{2}$ Lutz RAPHAEL: La ciencia histórica en la era de los extremos. Teorías, métodos y tendencias desde 1900 hasta la actualidad, Zaragoza, Institución Fernando el Católico, 2012.

${ }^{3}$ Respecto a la noción de cultura histórica, Jörn RÜSEN: "Was ist Geschichtskultur? Überlegungen zu einer Art, über Geschichte nachzudenken”, en H.T. K. FÜSSMANN y J. Rüsen GRÜTTER (eds.):
} 
Del mismo modo, y teniendo en cuenta el carácter transnacional de la construcción de las diferentes comunidades historiográficas, el taller ofreció la posibilidad de incorporar trabajos vinculados a un concepto particularmente útil a este respecto como el de las transferencias culturales. ${ }^{4}$ Asumiendo esta dimensión transnacional -ese "entorno ecuménico de la historiografía" al que aludiera Juan José Carreras-, podemos trazar una arqueología internacional del oficio de los historiadores -con sus préstamos y reapropiaciones, pero también con sus rechazos- para reconstruir una especie de atlas de la profesión y sus distintas comunidades historiográficas. ${ }^{5}$

A la mesa-taller concurrieron un total de cinco comunicaciones. Un conjunto de textos interesantes y por lo general bien trabajados, que a su vez reflejan la diversidad de enfoques propios de una subdisciplina como la historia de la historiografía, cuyos objetivos, objetos y métodos todavía no se encuentran definidos con el rigor suficiente, al menos en el ámbito historiográfico español. ${ }^{6}$ Como señaló hace unos años Miquel À. Marín en relación a la historia de la historiografía, "su estatus como disciplina se halla a gran distancia del de otros territorios de la investigación especializada, una circunstancia que en España es algo más acusada". ${ }^{7}$ Unos problemas e indefiniciones que persisten en la actualidad y que han tenido cumplido reflejo en el taller.

De hecho, las comunicaciones presentadas destacan por su heterogeneidad y

Historische Faszination. Geschichtskultur heute, Keulen, Weimar and Wenen, Böhlau, 1994, estando disponible una traducción española en http://www.culturahistorica.es/ruesen.Castellanohtml De acuerdo con Maria Grever, el análisis de una determinada cultura histórica implicaría el estudio de "the production and reproduction of historical knowledge and understanding as Well as the social infrastructure of the field of history (such as museums, history curricula, national holidays and other memorial observances) -all of which provide the conditions that are necessary for people to deal with the past". Maria GREVER: "Fear of Plurality: Historical Culture and Historiographical Canonization in Western Europe”, en Angelika EPPLE y Angelika SCHASER (eds.): Gendering Historiography: Beyond National Canons, Frankfurt, Nueva York, Campus Verlag, 2009, pp. 45-62, esp. p. 54. Una aplicación práctica de ambos conceptos en Ignacio PEIRÓ: En los altares de la patria. La construcción de la cultura nacional española, Madrid, Akal, 2017 y Gustavo ALARES: Políticas del pasado en la España franquista (1939-1964). Historia, nacionalismo y dictadura, Madrid, Marcial Pons, 2017.

${ }^{4}$ Una aproximación al concepto en María José SOLANAS: "Transferencias culturales: origen, desarrollo y aplicación al estudio de la historia de la historiografía española”, en Pedro RÚJULA e Ignacio PEIRÓ (eds.): La historia en el presente, Teruel, Instituto de Estudios Turolenses, 2007, pp. 379-392.

5 Juan José CARRERAS: "El entorno ecuménico de la historiografía", en Carlos FORCADELL e Ignacio PEIRÓ (coords.): Lecturas de la historia: nueve reflexiones sobre historia de la historiografía, Zaragoza, Institución Fernando el Católico, 2002, pp. 11-22.

${ }^{6}$ Miquel À. MARÍN: “La historia de la historiografía en España: recepción y crisis de una disciplina, 1976207”, en Teresa María ORTEGA (coord.): Por una historia global: El debate historiográfico en los últimos tiempos, Granada, Universidad de Granada, Universidad de Zaragoza, 2007, pp. 391-437.

7 Miquel À. MARÍN: "La historia de la historiografía en España...”, p. 391. 
multiplicidad de perspectivas: desde los intentos de abordar la construcción intelectual y profesional de diversos historiadores - presentes en los trabajos de Eduardo Acerete y Pablo Bornstien-, hasta el análisis de diversos discursos historiográficos y sus condicionantes académicos y políticos -en la comunicación de Beatriz García Pérez sobre la Nueva Figuración Madrileña-, o el texto presentado por Alejandro Rey Millán, en el que se reflexiona sobre el silencio historiográfico sobrevenido a los diversos episodios ocurridos en el Rif entre los años 1924-1926. Y siendo esta variedad un elemento inicialmente provechoso, no pasan desapercibidas las consiguientes dificultades a la hora de establecer acuerdos sobre el uso de categorías comunes y asentar marcos conceptuales amplios que permitan un fructífero diálogo historiográfico.

Bajo el título "Ándalus como preocupación de la historiografía nacionalista y la formación de la escuela arabista aragonesa", el investigador Pablo Bornstein de la Universidad de Tel Aviv analiza el proceso de institucionalización de los estudios de lengua e historia árabe en el siglo XIX. Una institucionalización disciplinar que vino a producirse en un momento en el que se estaba construyendo la nación liberal española, con la importancia clave de la historia nacional como herramienta en la configuración de los estados-nación decimonónicos.

El análisis de Pablo Bornstein se articula fundamentalmente a través de dos figuras: por un lado, la de Pascual Gayangos y Arce, considerado como el artífice de la creación de los estudios árabes en España; y por otro Francisco Codera, su más prominente discípulo. Pascual Gayangos, nombrado catedrático de Árabe en la Universidad Central de Madrid en 1843, y miembro de la Real Academia de la Historia, fue el principal introductor del arabismo en la academia española. Por su parte, Francisco Codera, catedrático de Griego y Árabe en la Universidad de Granada (1866-1868), Zaragoza (1869-1873) y finalmente la Universidad Central de Madrid (1874-1902), estableció en la institución aragonesa una escuela que germinaría a principios del siglo XX con figuras tan destacadas como Miguel Asín y Palacios o Andrés Giménez Soler.

Como señala Bornstein, los estudios árabes vinieron a incardinarse como un elemento más en la búsqueda de las esencias históricas de la nación española. Un debate mediatizado por la larga presencia musulmana y la existencia de Al-Andalus, circunstancia que reforzaba aquélla recurrente visión orientalista de la nación española 
dentro del conjunto de naciones europeas. ${ }^{8}$ Así que, con especial interés desde el siglo XIX -y en gran medida a través de la institucionalización del arabismo-, intelectuales, historiadores y políticos reflexionaron y polemizaron sobre la importancia del pasado islámico -y oriental/orientalista- en la conformación histórica de España. En esa secular búsqueda esencialista de las raíces culturales de la nación española y en ese largo proceso de configuración de la cultura nacional española, los arabistas fueron un elemento fundamental a la hora de determinar qué elementos del pasado islámico debían integrarse o excluirse en el relato decimonónico de la nación española.

"Las prácticas de un historiador: Carlos Corona Baratech" es el título del trabajo presentado por Eduardo Acerete, investigador especialista en la historiografía modernista formado en la Universidad de Zaragoza. A través del análisis de la figura del historiador -y catedrático- Carlos Corona Baratech (1917-1987), la comunicación pretende abordar diversas cuestiones vinculadas a la historiografía durante el franquismo. El texto analiza el itinerario formativo del historiador jacetano hasta la obtención en 1953 de la cátedra de Historia Universal Moderna y Contemporánea de la Universidad de Zaragoza.

Pero no sólo eso. El análisis de la trayectoria de este historiador, su formación y anclaje académico y profesional, permite a Eduardo Acerete avanzar una reconstrucción del ecosistema institucional de la universidad franquista, de las prácticas historiográficas de posguerra, de los procesos de institucionalización del modernismo en toda su extensión (dotación de cátedras y promoción profesional, revistas, etc...), y, en definitiva, ofrecer una panorámica -necesariamente breve pero significativa- sobre la conformación del habitus del historiador bajo el franquismo. Al mismo tiempo, el texto aborda la producción historiográfica de Corona no solo desde el punto de vista historiográfico, sino también como un elemento relevante en sus estrategias de promoción profesional, concluyendo con la obtención de la cátedra en 1953 como punto de llegada a la anhelada consolidación académica. Un texto que, en su necesaria brevedad, constituye un modelo válido para el análisis de la formación y de las prácticas de los historiadores franquistas.

Por su parte, Alejandro Rey Millán hace un exhaustivo repaso de uno de los episodios, por el que, a su juicio, la historiografía hispana ha pasado "de puntillas": los

\footnotetext{
${ }^{8} \mathrm{Al}$ respecto, resulta indispensable Xavier ANDREU: El descubrimiento de España: mito romántico e identidad nacional, Madrid, Taurus, 2016.
} 
acontecimientos acaecidos entre los años 1924 y 1926 en el Protectorado español en el norte de África, cuando una gran cantidad de soldados españoles quedaron desabastecidos debido a una retirada planteada por el general Miguel Primo de Rivera, ya como jefe de gobierno en España tras protagonizar un golpe de estado en 1923.

A través del estudio de las memorias escritas por un soldado de reemplazo, el extremeño José Caballero Reyes -verdadero hallazgo documental que articula el texto-, Alejandro Rey establece un repaso a este periodo de la historia de España estableciendo una dualidad de planteamientos: por un lado, intenta poner en valor un episodio trascendental en la historia militar española; y por otro, pretende buscar una serie de respuestas al silencio historiográfico relativo a este periodo histórico.

El trabajo de Rey Millán alude implícitamente al conjunto de ausencias que persisten en el estudio del pasado colonial español. Una cuestión que solo en fechas recientes ha empezado a integrar la agenda investigadora de los historiadores españoles. De hecho, y a diferencia de otras historiografías nacionales -particularmente Gran Bretaña, Francia, Portugal, pero también los Países Bajos, por ejemplo-, el pasado colonial español se encuentra todavía pendiente de un estudio en profundidad. Al margen de meritorias excepciones, la producción relativa al tema resulta fundamentalmente descriptiva, cuando no sujeta a la nostalgia patriótica. Muestra, en ambos casos, de una evidente inmadurez. Cuestiones como la etnicidad, la idea de España como potencia "civilizadora" (con todo el conjunto de valores asociados), o las transferencias ideológicas entre los diferentes discursos coloniales constituyen todavía un campo en gran medida expedito.

Como cierre del conjunto de textos aportados a la mesa se encuentra la aportación de Beatriz García, de la Universidad Autónoma de Madrid. La autora analiza la emergencia de los artistas congregados en torno al movimiento Nueva Figuración Madrileña $[\mathrm{NFM}]$ y conocidos en gran medida bajo la etiqueta de "los esquizos de Madrid”. Un grupo que surgió a finales de los setenta y principios de la década siguiente, y que tuvo expresión a través de varias exposiciones colectivas como 1980, Madrid D.F. y Otras figuraciones.

El texto aborda el papel de la crítica como productora de relato (en este caso artístico), permitiendo de esta manera aludir al carácter performativo de los discursos 
artísticos y su capacidad para establecer marcos teóricos y contextos interpretativos. A través de este análisis, la autora alude a las interferencias del sistema del arte y del emergente Estado cultural que se consolidaría en la década de los ochenta, en la etapa de desmontaje de la cultura oficial heredada del franquismo.

La NFM, tal y como fue caracterizada -y promocionada- pretendía reaccionar frente a la politización del arte y, al mismo tiempo, recuperar la figuración frente a la abstracción y el abuso del arte conceptual. Pero más allá de este escenario interpretativo fraguado sobre posiciones antagónicas y construido por críticos y galeristas afectos a la NFM, Beatriz García plantea la necesidad de iniciar una nueva valoración historiográfica de la NFM ajena de estas premisas y valoraciones. Así, a lo largo del texto se plantea la necesidad de llevar a cabo un proceso de decapado -quizá fuera arriesgado aludir a la deconstrucción- de los argumentos establecidos por los críticos afines a la NFM. A este respecto, la autora señala la debilidad de la "retórica del antagonismo" y critica su intención de "escenificar una batalla que no existía". La comunicación alude a la inexistencia en la NFM de una oposición binaria tan clara como la esgrimida por la crítica, y señala la existencia de realidades más eclécticas. A juicio de la autora, esta construcción de un marco teórico para el encaje y desarrollo de la NFM se produjo en gran medida al margen del propio hecho artístico, vinculándose a estrategias de promoción y búsqueda de escenarios propios.

La autora abre interesantes vías de análisis vinculadas a los (re)posicionamientos protagonizados por el mundo cultural en el contexto de la Transición, a la búsqueda de narrativas (auto)justificatorias tendentes a asegurar una posición en el nuevo contexto cultural, o el valor de cambio del concepto ruptura dentro del sistema del arte y del emergente Estado cultural de los años ochenta. Todos los anteriores podrían ser contemplados como condicionantes institucionales -en el amplio sentido del términoque tuvieron una destacada influencia en los artistas -pero también en críticos y galeristas- a la hora de establecer unos marcos conceptuales y unas estrategias de inserción en el sistema del arte.

Desde esta multiplicidad de perspectivas, enfoques diferentes, usos conceptuales e intereses historiográficos diversos detectados en los textos, su análisis evidencia tanto un elevado conjunto de posibilidades analíticas en el marco de la denominada historia de la 
historiografía, como la percepción de encontrarnos ante una disciplina todavía en construcción que adolece en ocasiones de debilidad conceptual y de la falta de un marco común aceptado, así como de herramientas comunes para abordar su desarrollo. Sin embargo, la solidez de los argumentos presentados por los comunicantes augura un interesante desafío para integrar en parámetros propios de la historia de la historiografía todas las propuestas abordadas desde tan diferentes, estudiados y justificados intereses historiográficos. Una tarea que esperamos poder continuar en los próximos Congresos de Jóvenes Investigadores de la AHC. ${ }^{9}$ 


\title{
Al-Ándalus como preocupación de la historiografía nacionalista y la formación de la escuela arabista aragonesa
}

\author{
Al-Andalus problematized: The Concerns on Islam of Spanish Nationalist \\ Historiography and the Formation of the Aragonese Arabist School
}

Pablo Bornstein

Universidad de Tel Aviv

\begin{abstract}
Resumen
El texto hace una breve descripción del cómo los estudios arabistas proyectaron en las décadas centrales del siglo XIX una serie de interrogantes sobre el peso que la historia andalusí había tenido en la construcción de una identidad histórica española. Así mismo se rastrea como estos interrogantes irán recibiendo cada vez una mayor atención en el marco de la historiografía española, tanto en instituciones como la Real Academia de la Historia como en la Universidad.
\end{abstract}

\section{Palabras clave}

Arabismo, Historiografía, Nacionalismo, Al-Ándalus, Aragón.

\begin{abstract}
The present text describes briefly how, during the mid-decades of the 19th century, arabist studies problematized the question of the weight that Andalusi history had in the construction of a Spanish historical identity. It also traces how these queries came gradually to receive more and more attention within the general framework of Spanish historiography, both in cultural institutions such as the Royal Academy of History and in the Spanish University.
\end{abstract}




\section{Palabras clave}

Arabism, Historiography, Nationalism, Al-Andalus, Aragon.

\section{Un pasado lleno de sombras}

A lo largo de la historia moderna española, la visión historiográfica sobre la presencia islámica medieval en la Península Ibérica, y las imágenes que de ella derivaban sobre lo musulmán, quedaron por lo general estructuradas bajo el telón de fondo del esquema de la Restauración cristiana de España. Esta interpretación, apuntalada por cronistas tan influyentes como Juan de Mariana, estaba presidida por un providencialismo por el cual la invasión islámica de 711 aparecía como un castigo divino a los vicios de los últimos reinos visigodos, que abría paso posteriormente a un periodo en el que los verdaderos españoles, cristianos, iban a luchar por restablecer la verdadera fe y expulsar a quienes no eran sino elementos extraños al país. Si bien siempre existieron voces discrepantes que ofrecían interpretaciones alternativas sobre ese pasado ${ }^{1}$ el triunfo en España del catolicismo contrarreformista y el celo guardián de la Inquisición mantuvieron a buen recaudo la identificación colectiva con la visión teologal y providencialista.

Sin embargo la creciente atención concedida durante el siglo XVIII a los fenómenos culturales y la cristalización de una idea de patria articulada cada vez más sobre los rasgos étnicos del sujeto colectivo, permitirían que se abriera la puerta en España a la posibilidad de revaloraciones interpretativas sobre el pasado andalusí. ${ }^{2}$ Estos caminos convergirían durante el XIX en la construcción de un pensamiento nacionalista español que iba a cimentarse sobre visiones históricas que buscaban elucidar, mirando hacia el pasado, cuáles eran los rasgos característicos de la nación española.

\footnotetext{
${ }^{1}$ Ver Mercedes GARCÍA-ARENAL y Fernando RODRÍGUEZ MEDIANO: Un oriente español: Los moriscos y el Sacromonte en tiempos de Contrarreforma, Madrid, Marcial Pons Historia, 2010.

${ }^{2}$ Sobre el nuevo enfoque hacia lo cultural durante el XVIII, Inman Fox ha señalado, siguiendo a Benedict Anderson, que uno de los fenómenos intelectuales cruciales del siglo de la Ilustración y que a la larga contribuiría de forma crítica al surgimiento del nacionalismo moderno, fue la sustitución de las visiones religiosas por el concepto de civilización -como conjunto de elementos culturales-a la hora de explicar la continuidad histórica de los grupos sociales. Ver Inman FOX: La invención de España, Madrid, Cátedra, 1997. El surgimiento de un etno-patriotismo español en el XVIII es analizado en José ÁLVAREZ JUNCO: Mater Dolorosa: La idea de España en el siglo XIX, Madrid, Taurus, 2015.
} 
Un postulado historiográfico fundamental en la elaboración del presente texto es que el desarrollo de la erudición arabista decimonónica española estuvo estrechamente vinculado a la construcción historiográfica que iba construyéndose a medida que el país penetraba por la senda de la modernidad y el nacionalismo. En tal sentido, toda la producción arabista debe ser entendida en interrelación con las visiones históricas que buscaban en el pasado peninsular los elementos que permitieran afirmar la existencia de un secular ser nacional. Por tanto, lo que aquí se pretende demostrar es que los arabistas participaron de forma importante en la construcción de una identidad nacional historiada, esforzándose por dotar de sentido histórico a aquella parte del pasado peninsular -AlÁndalus- que resultaba más controvertida en aquello que concierne a la definición nacionalista de una identidad colectiva que, fundamentalmente, gravitaba sobre imágenes católicas. En las décadas centrales del XIX, la figura más representativa de la contribución arabista a la historiografía nacionalista a la hora de plantear la incorporación del legado andalusí fue sin duda la de Pascual de Gayangos y Arce.

\section{La inclusión del arabismo en la Universidad}

La trayectoria profesional de Pascual de Gayangos encarna a la perfección la transformación de los estudios arabistas en España, transitando de la dimensión teológica con que habían sido tradicionalmente abordados para conformarse como una disciplina moderna y metódica de análisis histórico-cultural, que será incorporada a los planes de humanidades de algunas universidades con la llegada del estado liberal isabelino. Esa transformación implicaba un giro -extensivo a todas las humanidades- hacia una valoración cada vez mayor de los fenómenos culturales, que se distanciaba del tipo de erudición que se practicaba en las instituciones educativas del Antiguo Régimen. Así, los hombres de letras de este periodo de transición sentarían las bases del gradual giro metodológico que a la larga permitiría la profesionalización de la historia y que quedaría consolidado hacia finales de siglo. ${ }^{3}$

Gayangos, quien había recibido gran parte de su formación en Francia, donde aprendió árabe bajo la tutela del renombrado orientalista Silvestre de Sacy en L'École

\footnotetext{
${ }^{3}$ Para el proceso de profesionalización de la actividad histórica ver Ignacio PEIRÓ MARTÍN: Los guardianes de la historia: La historiografía académica de la Restauración, Zaragoza, Institución Fernando el Católico, 1995.
} 
Spéciale des Langues Orientales, haría gala de una empatía hacia los musulmanes que habían poblado un día la península poco corriente en la cultura literaria española y que solo en el XIX iba abriéndose paso entre algunos eruditos. ${ }^{4}$ En una carta enviada a un amigo Gayangos daba cuenta con evidente emoción de los hallazgos que había realizado de inscripciones árabes locales en la provincia de Málaga, "únicos restos de un pueblo noble, valiente e industrioso que nuestra bárbara ignorancia arrojó con el cuchillo en la mano fuera de sus hogares". ${ }^{5}$ El compromiso de Gayangos con la construcción del nuevo estado liberal quedará evidenciado desde el mismo año 1833 en el que moría Fernando VII. En tal fecha entraba en el Ministerio de Estado en calidad de intérprete de lenguas orientales. Desde ese momento, una parte importante de su carrera profesional estará guiada por el objetivo de alumbrar la capital importancia que el estudio de las fuentes históricas árabes tenía para la propia historia de España. El hecho de que a partir de 1836 impartiera clases de árabe en el Ateneo de Madrid sin recibir ninguna contraprestación económica demuestra que Gayagos consideraba esa función como un servicio público prestado a la nación, un acto patriótico. ${ }^{6}$

Sin embargo, el estado español era un estado débil y el control del gobierno liberal sobre algunas de las instituciones culturales del país era frágil. Tras serle repetidamente denegado el acceso a los manuscritos árabes de El Escorial por parte de las autoridades eclesiásticas del monasterio, y frustrado con la renuencia del gobierno hacia su petición de crear una cátedra de Árabe en Madrid, Gayangos decidió en 1837 mudarse a Londres para proseguir allí sus investigaciones sobre el pasado andalusí. En Gran Bretaña Gayangos disfrutó de una corta pero exitosa estancia, alcanzado un amplio reconocimiento profesional por la publicación, entre 1840 y 1843 de The History of the Mohammedan Dynasties in Spain, la edición traducida de una obra del historiador

\footnotetext{
${ }^{4}$ Para una semblanza biográfica de Gayangos: Gonzalo ANES (Ed.): Pascual de Gayangos: En el bicentenario de su nacimiento, Madrid, Real Academia de la Historia, 2010.

${ }^{5}$ La cita está tomada de Gonzalo ANES: Pascual de Gayangos..., p. 12. A pesar de la obvia empatía que Gayangos muestra hacia la población andalusí, la transposición hacia el pasado de marcadores identitarios, como los que aparecen en el texto citado en la oposición binaria entre "nuestra bárbara ignorancia" y aquel "pueblo noble, valiente e industrioso", evidencian la auto-identificación histórica con la población cristiana del medievo peninsular, extensible a todos los pensadores e intelectuales nacionalistas, incluyendo los más liberales. A pesar de los esfuerzos que arabistas como Gayangos harán por poner en evidencia la influencia andalusí sobre la cultura nacional... la dicotomía identitaria nunca quedaría del todo suprimida.

${ }^{6}$ El Ateneo de Madrid fue fundado en 1835 durante la regencia de Francisco Martínez de la Rosa en medio de un clima de grandes expectativas políticas entre los liberales españoles. Francisco VILLACORTA BAÑOS: El Ateneo Científico, Literario y Artístico de Madrid (1885-1912), Madrid, CSIC, 1985.
} 
argelino del siglo XVII Al-Maqqari, que incluía una vasta colección de notas eruditas sobre diversos temas de la historia andalusí y el islam. La decisión de traducir el texto de Al-Maqqari partía del deseo de Gayangos de hacer accesible al público una visión general sobre la historia árabe de la Península.

Gayangos creía firmemente, como así se lo confesaba de forma epistolar a su amigo y director por entonces de la Real Academia de la Historia, Martín Fernández de Navarrete, que la historia de España estaba "aún por escribir". ${ }^{7}$ Contrastando con lo que él percibía como una negligencia española, Gayangos aludía a la actitud contrapuesta que existía en Gran Bretaña, donde afloraba un genuino interés hacia la cultura andalusí y se consideraban a sus escritores y filósofos como intermediarios directos en la recuperación europea de la ciencia griega. De tal modo que -siempre siguiendo a Gayangos- Europa consideraba a la España musulmana como "la piedra angular" sobre la que descansaba la construcción de la civilización medieval europea. Por tanto, reclamar esa herencia cultural andalusí como perteneciente al propio patrimonio nacional era para Gayangos una obligación patriótica, y a ello dedicó buena parte de su carrera. Como se puede ver, en el fondo de las preocupaciones eruditas de Gayangos se alojaba un claro y coetáneo deseo de afirmar la importancia cultural española, en un momento en el que el país atravesaba grandes inseguridades sobre su estatus internacional.

Independientemente de cuál fuera el verdadero estado de negligencia de los estudios acerca del pasado islámico peninsular en España, lo cierto es que gracias al reconocimiento internacional alcanzado por Gayangos debido a su edición de la obra de Al-Maqqari, el estado decidió atender a la antigua petición del arabista y en 1843 se creaba una cátedra de árabe erudito en la Universidad Central. La vuelta de Gayangos al país marcaría un punto de inflexión en el desarrollo de la erudición arabista, al quedar los avances en ese campo finalmente integrados dentro de un currículo universitario. Desde su cátedra madrileña, el arabista sevillano fue capaz de inculcar a una generación de estudiantes su proyecto de incorporar el empleo de fuentes árabes originales al estudio de la historia española. Gayangos entrenaría académica a sus discípulos "para resolver el interesante problema de cuánto y de qué modo contribuyó el establecimiento de los árabes

\footnotetext{
7 Referencias a las cartas de Gayangos a Fernández de Navarrete en Gonzalo ANES: Pascual de Gayangos..., pp. 15-17.
} 
en nuestra península a la civilización de la Europa moderna". ${ }^{8}$ Esta problemática historiográfica -relacionada con una historia sentida como propia- sería la que conformaría el carácter del arabismo español por encima de cualquier otra posible consideración de tipo más filológico, y lo que a su vez marcaría de forma más pronunciada el distanciamiento del mismo respecto al resto del orientalismo europeo. ${ }^{9}$

El mismo año en que Gayangos había regresado a España, 1843, era también el año que marcaría el inicio de un largo periodo de hegemonía política moderada en el país, tras varios años de predominancia de los progresistas. En ese periodo, que se extendiera casi dos décadas, el partido Moderado ejercería una férrea supervisión de la producción cultural. Bajo ese nuevo clima intelectual, el discurso nacionalista, que desde inicios de siglo había estado marcadamente alineado con sectores liberales progresistas, experimentaría una reconfiguración hacia posiciones más conservadoras.

\section{¿Una nación semítica?}

Cuando se trataba de vindicar la inmaculada catolicidad de la nación, la ubicua e incontestable presencia de remanentes del pasado tanto árabe como judío en la península se antojaba como un obstáculo que, en el lenguaje "culturocéntrico" del nacionalismo, aparecía más difícil de superar que en los esquemas providencialistas de la era prenacional. En ese marco, como ha demostrado Aurora Rivière, el orientalista emergía como juez, en virtud de su autoridad erudita, a la hora de ponderar si los elementos orientales del pasado ibérico formaban parte intrínseca del sustrato nacional, o si por el contrario se trataba de influencias externas que no debían verse como elementos constitutivos de "lo español". ${ }^{10}$ En la edad dorada del nacionalismo, el orientalismo

\footnotetext{
${ }^{8}$ El pasaje citado corresponde al plan de estudios del primer curso impartido por Gayangos en la Central en 1844, y aparece citado en Bernabé LÓPEZ GARCÍA: "Enigmas de al-Andalus: una polémica", Revista de Occidente, 224 (enero 2000), pp. 31-50.

${ }^{9}$ Este distanciamiento del resto del orientalismo europeo, articulado sobre una visión introspectiva de un pasado percibido como problemático, ha sido argumentado entre otros por Eduardo Manzano Moreno, quien destaca que el arabismo español no produjo en el XIX ningún filólogo del tipo del británico Stanley Lane-Poole o del holandés Reinhart Dozy. Ver Eduardo MANZANO MORENO: "La creación de un esencialismo: la historia de al-Andalus en la visión del arabismo español”, en Gonzalo FERNÁNDEZ PARRILLA y Manuel C. FERIA GARCÍA (eds.): Orientalismo, exotismo y traducción, Cuenca, Ediciones de la Universidad de Castilla-La Mancha, 2000, pp. 23-37.

${ }^{10}$ Aurora RIVIÈRE GÓMEZ: Orientalismo y nacionalismo español. Estudios árabes y hebreos en la Universidad de Madrid (1843-1868), Madrid, Dykinson, 2000.
} 
Al-Ándalus como preocupación de la historiografía nacionalista y la formación de la escuela arabista aragonesa

español -en contraste con el resto del orientalismo europeo-quedaba determinado por el papel que podía jugar en la construcción de una narrativa histórica nacional.

El que los interrogantes que planteaba este introspectivo orientalismo -de hebraístas y arabistas por igual- iban quedando imbricados en algunos de los debates historiográficos más apremiantes del momento queda demostrado por la atención dada al pasado árabe y judío de la península en los últimos años de la década de 1840 por dos historiadores que difícilmente pueden ser considerados como orientalistas: hablamos de José Amador de los Ríos y de Adolfo de Castro y Rossi. En el contexto de la pugna por apuntalar la catolicidad inherente de la nación, Amador de los Ríos y de Castro pasarían a representar posiciones contrapuestas, ambos gozando de impecables credenciales nacionalistas, sobre la religiosidad de espíritu patrio.

La polémica quedaría abierta tras la publicación en 1847 por de Castro y Rossi de la primera de una serie de obras que el autor dedicaría a la reflexión nacional por excelencia, la preocupación por la decadencia española. El tema de esta primera obra versaba sobre la historia de los judíos en España, y el diagnóstico que se podía obtener de su lectura era que la principal causa de la decadencia había radicado en la intolerancia que a lo largo de los siglos había instalado la Iglesia, con la connivencia de la monarquía, en la mente de los españoles. La actitud mostrada hacia los judíos aparecía entonces como indicador clave del desvío que la nación había realizado del curso correcto por el que debía haber transitado su historia. No habiendo aprendido del ejemplo dado por los árabes andalusíes, bajo cuya tolerancia había florecido una cultura judía que había contribuido de forma sustancial a la grandeza del Califato, los reinos cristianos no habían sino perseguido injustamente a los judíos bajo falsos libelos hasta llegar a la definitiva expulsión de 1492 y al posterior hostigamiento inquisitorial sobre los conversos. Se había dado entonces el caso de "españoles" que habían sido expulsados de su patria por sus creencias religiosas. ${ }^{11}$

\footnotetext{
${ }^{11}$ Sobre la obra de Castro ver José ÁLVAREZ JUNCO: Mater Dolorosa..., pp. 402-405. En de Castro y Rossi quizá vemos la más resuelta reivindicación de la "españolidad" de los antiguos habitantes nocristianos de la Península. Esa actitud sin embargo se fue volviendo cada vez más común a mediados del XIX, y es frecuente ver hablar a las fuentes del periodo de "musulmanes españoles" o del "Islam español". Sin embargo, tales ejercicios taxonómicos eran empleados invariablemente con un alto nivel de ambigüedad, y si no cabe duda de que evidencian un creciente reconocimiento de la contribución hecha por musulmanes y judíos a la cultura nacional, en el mejor de los casos a estos musulmanes y judíos "españoles"
} 
La asunción en aquellos años por parte de autores liberales como de Castro de una visión negativa del pasado propio en clave de lo que más adelante sería conocido como la "Leyenda Negra" española provocó la reacción de los católicos con una contranarrativa, en la que Amador de los Ríos ponía el contrapunto a la visión de de Castro. En su historia sobre los judíos peninsulares, Amador de los Ríos eximía a los Reyes Católicos del fanatismo religioso que les atribuía de Castro. Para Amador, Isabel y Fernando se habían visto obligados a promulgar el edicto de expulsión en aras de la unidad nacional y en virtud de la desconfianza popular hacia los judíos. Era el pueblo el que se había expresado su propia esencia católica, y si los judíos habían tenido que pagar el precio de la unificación, en buena medida se lo habían ganado a pulso tras haber vendido el país a los invasores musulmanes en el año 711. ${ }^{12}$ Pero si en los argumentos de Amador de los Ríos se escuchaban claros ecos de un tradicional antisemitismo cristiano, lo novedoso de su obra residía en el profundo análisis que hacía de la literatura judía medieval y en su llamamiento a incorporar dicha literatura al patrimonio cultural de la nación. Su actitud se convertiría en paradigmática de un liberalismo de talante conservador en el que si bien la catolicidad de la nación se mantenía incontestable, cada vez había un mayor espacio de reconocimiento - ciertamente ambiguo- de contribuciones culturales semíticas. El mismo año que publicaba su obra sobre los judíos, Amador dedicaba el discurso de ingreso en la Real Academia de la Historia a considerar la influencia árabe en la literatura española, lo que permite valorar el grado en que este tipo de planteamientos iban encumbrándose hacia el centro del debate historiográfico. ${ }^{13}$

De hecho, la Academia de la Historia, por entonces sin duda el principal foco de la producción historiográfica nacional, se iba a constituir como uno de los foros centrales en los que dirimir las preocupaciones orientalistas sobre el pasado nacional. Así, Modesto Lafuente, sobre cuya contribución en la elaboración de una visión canónica del pasado nacional poco cabe añadir, dedicaba en 1853 su discurso de recepción en la Academia a la historia del Califato de Córdoba. Podemos hablar casi de una moda orientalista, que Lafuente justificaba al tratarse la invasión islámica de "un acontecimiento de los que

se les colocaba en una posición liminal en la que siempre perduraba un elemento de otredad. Ver por ejemplo el caso citado anteriormente de Gayangos en nota 5.

${ }^{12}$ Ibid., pp. 408-412.

${ }^{13}$ Aurora RIVIÈRE GÓMEZ: Orientalismo y nacionalismo español..., p. 65. 
influyeron más en la condición y en la vida social de España”. ${ }^{14}$ El relato de Lafuente, a pesar de presentar una completa identificación de la nación española con los reinos cristianos medievales, no escatima de palabras de elogio hacia los logros culturales alcanzados en el Califato. Las alabanzas se centran en el elemento árabe, raza "pura, noble, ardiente, voluptuosa y galante", que consigue imponerse al resto de grupos étnicos invasores -entre los que Lafuente lista a bereberes, persas, egipcios e, interesantemente, también a los israelitas-, y es precisamente a través de los árabes que "las artes de Oriente [...] vienen a aclimatarse en el suelo español". A pesar de la constante vaguedad de las referencias a esa "aclimatación" de lo oriental en lo español, lo cierto es que veladamente existe ya un reconocimiento - nada menos que por parte del autor de la obra de conjunto sobre la historia de España más influyente desde la obra de Juan de Mariana en el siglo XVI- del peso de ese pasado en las manifestaciones culturales de lo que en este periodo se está definiendo como lo “español”. Sin embargo, lo que prima en la mirada de Lafuente hacia lo andalusí es lo que esta historia puede alumbrar sobre quienes estaban por entonces construyendo "España", es decir -ahí sí que no cabe ambigüedad- los reinos cristianos. La Reconquista es por tanto piedra angular en la forja de lo español. ${ }^{15}$ Tras referirse a la caída del Califato y al giro que se produce en el equilibrio de poder en la Península en favor de las armas cristianas, Lafuente concluye: "Hasta ahora el pueblo español ha pugnado por vivir; desde ahora empieza a pensar en organizarse; cuenta ya con la existencia material, y comienza su vida política y civil". ${ }^{16}$

\section{Los años de consolidación del arabismo}

De la misma forma que la mirada orientalista sobre el pasado nacional había entrado en el seno de la Academia de la Historia también lo haría en el ámbito de la Universidad. Si historiadores como Amador de los Ríos o Lafuente habían consagrado ocasiones tan

\footnotetext{
${ }^{14}$ Discursos leídos en sesión pública de la Real Academia de la Historia en la recepción de don Modesto Lafuente, el 23 de enero de 1853.

${ }^{15}$ En este sentido, Martín Ríos Saloma ha demostrado la importancia de la obra de Lafuente a la hora de consolidar el empleo historiográfico del mismo vocablo "Reconquista", frente al uso tradicional de "Restauración”, y que va íntimamente ligado a cambios en la concepción de la identidad nacional por las que el elemento étnico-patriótico, y su apego al territorio, se convierten, por encima de nociones religiosas, en los nexos fundamentales para entender la continuidad histórica de la comunidad nacional. Ver Martín RÍOS SALOMA: La Reconquista. Una construcción historiográfica (siglos XVI-XIX), México D.F., Universidad Nacional Autónoma de México, 2011.

${ }^{16}$ Discursos leídos en sesión pública de la Real Academia de la Historia en la recepción de don Modesto Lafuente, el 23 de enero de 1853.
} 
solemnes como la acogida en la Academia a este tipo de disquisiciones, el historiador Remigio Ramírez dedicaba su discurso de investidura como doctor en Historia en la Universidad Central, en 1861, a las descripciones geográficas de "España" hechas por historiadores árabes. Su discurso comenzaba de la siguiente manera: "Necesario es ser enteramente profano en la historia de nuestro país, y en la de nuestros usos y costumbres, para no ver por todas partes la influencia que en España ejerció la dominación de los árabes, sus dueños y poseedores por espacio de siete siglos". ${ }^{17}$

En la década de 1860 los estudios arabistas continuaron ganando peso en los programas de estudio de algunas universidades españolas a medida que iban dando frutos los esfuerzos de Gayangos y de José Moreno Nieto, quien había recibido la cátedra de árabe que se abrió en Granada en 1847. La ciudad andaluza iría consolidando su posición como uno de los puntos focales en la producción arabista, primero con la llegada a su universidad como profesor de literatura en 1856 de Francisco Fernández y González, uno de los discípulos de Gayangos en Madrid, y posteriormente con la incorporación de Francisco Javier Simonet, quien en 1862 tomaba posición de la cátedra que había quedado vacante unos años antes tras la elección de Moreno Nieto como miembro de las Cortes.

En Granada Fernández y González concebiría la idea de publicar una colección de obras traducidas de la "España árabe". Esta sería la primera de una serie de iniciativas similares que tendrán lugar en el marco del arabismo español para publicar obras de autores andalusíes con una especial relevancia para la historia de España. Todas estas iniciativas, como sería el caso de la colección del profesor de la Universidad de Granada, estarían sin embargo destinadas al fracaso editorial. En 1861 Fernández y González publicaba en Revista Ibérica un esbozo de su plan editorial, que perseguía poner de relevancia la otrora superioridad cultural "española" en un tiempo en que "franceses e italianos acudían a beber ilustración y ciencia en las escuelas de Andalucía". ${ }^{18}$ Como Gayangos anteriormente, Fernández y González reivindicaba la pertenencia de la producción cultural andalusí al común acervo de los españoles y buscaba, a través de la publicación de dicha colección, concienciar al público español de la riqueza de ese

\footnotetext{
17 “España cristiana y mahometana: breve descripción geográfica según los historiadores árabes", Discurso leído por el Dr. D. Remigio Ramírez González en el acto solemne de recibir la investidura de doctor en la facultad de filosofía y letras, Madrid, 1861.

${ }^{18}$ Citado en Aurora RIVIĖRE GÓMEZ: Orientalismo y nacionalismo español..., p. 48.
} 
patrimonio. En diciembre de 1862 elevaba al gobierno una petición de fondos en la que equiparaba su proyecto al de la España Sagrada, la colección de historia eclesiástica que venía siendo publicada bajo los auspicios de la monarquía desde hacía más de un siglo.

La exigua ayuda de las instituciones estatales que Fernández y González consiguió reunir forzó a que la colección hubiese de interrumpirse tras la publicación de un único volumen inicial. Pero la noción de que las obras de autores musulmanes -y judíosibéricos debían quedar incluidas en el patrimonio literario nacional estaba calando desde hacía tiempo en los principales círculos historiográficos. Amador de los Ríos en 1861 comenzó a publicar una Historia crítica de la literatura española en diversos volúmenes, en cada uno de los cuales se incluían secciones para las letras hebreas y árabes. En 1862, tras una reunión en el seno de la Academia de la Historia en la que estuvieron presentes figuras como Cánovas del Castillo o Modesto Lafuente se tomaba la decisión de constituir una comisión encargada de editar y publicar obras de historiadores árabes de interés para la historia de España. La Colección de obras arábigas de historia y geografía iniciaba su andadura en 1867 con la traducción por Emilio Lafuente Alcántara de la crónica anónima del siglo XI conocida en su transliteración al castellano como Ajbar Machmúa. Sin embargo, la inestabilidad general que siguió a la revolución Gloriosa de 1868 impidió la continuidad del proyecto.

Ya hemos visto como la Academia de la Historia se erigió en foro principal de discusión sobre el pasado "oriental” del país. La nómina de arabistas engrosando las filas de la institución también iba en aumento. En 1864 lo hacía Moreno Nieto, a quien había precedido como miembro de la egregia institución su propio discípulo Emilio Lafuente Alcántara un año antes. Fue a este a quien se encomendó la contestación al discurso de recepción de su maestro, y en ella Lafuente Alcántara iba a trazar una especie de genealogía de la disciplina que remontaba a la llegada a España durante el reinado de Carlos III del monje maronita libanés Miguel Casiri con el encargo de catalogar los manuscritos árabes del monasterio de El Escorial. Así, Lafuente afirmaba la existencia de tres generaciones de arabistas que ya se sucedían en el seno de la Academia, lo que potenciaba la imagen del arabismo como un campo de investigación coherente y con objetivos propios, que se situaba como sub-disciplina especializada dentro del panorama historiográfico del momento. Por su parte, Moreno Nieto lamentaba en su discurso la perenne indiferencia que en España se había mostrado hacia los árabes, pero celebraba 
que la traducción hecha por Gayangos de la obra de Al-Maqqari había "marcado una época nueva en los estudios sobre la historia arábigo-española". Y si era cierto "que el impulso dado por ella más se ha dejado sentir hasta ahora fuera que dentro de este país", se notaban ya "consoladoras señales de la gran renovación que llamaban tiempo hacia los amantes de nuestras glorias". 19

Como hemos visto, el arabismo del tercer cuarto del XIX tenía sus dos ejes fundamentales en Madrid -donde gravitaba sobre la RAH y la cátedra de Gayangos en la Central- y en Granada. Allí destacaba, junto a Fernández y González, Francisco Javier Simonet, cuya obra sin embargo se caracterizaría por su hostilidad hacia los antiguos pobladores islámicos de la Península. La islamofobia de Simonet de hecho se acrecentaría con los años. En su discurso de habilitación como catedrático en 1862 había dado muestras de admiración hacia la cultura andalusí y censurado incluso la mala disposición de la historiografía tradicional hispana hacia los árabes. Sin embargo, en un breve lapso de cuatro años publicaría una versión "corregida" del mismo discurso en la que, entre otras afirmaciones, hablaba del islam como una versión degenerada de judaísmo y cristianismo. Curiosamente, Simonet no se desdecía de los elogios hacia los logros de la civilización andalusí. Estos, sin embargo, pasaban a quedar explicados como el resultado de la entrada en contacto de los árabes con la matriz hispano-goda que vivía en la Península y cuyas virtudes en último término habían hecho posible el florecimiento de una sociedad islámica ibérica que, gracias a esa "hispanización”, había podido brillar por encima de lo que cualquier otra población islámica lo había hecho. Ya vimos que Modesto Lafuente habla de la adaptación de las artes orientales se "aclimataron" al suelo español con los árabes. Aunque Simonet presentará quizá la versión más desmesurada de la supuesta aculturación de los musulmanes ibéricos, la idea de que Al-Andalus había conformado una sociedad única y bien diferenciada del resto del mundo islámico sería constante en el arabismo español moderno. ${ }^{20}$

\footnotetext{
${ }^{19}$ Discursos leídos ante la Real Academia de la Historia en la recepción pública de don José Moreno Nieto, el día 29 de mayo de 1864. Cursiva añadida.

${ }^{20}$ De hecho, Manuela Marín afirma que un cambio de perspectiva historiográfico que permitiese entender la historia andalusí dentro de las coordenadas arabo-islámicas a las que pertenecía solo se produjo de forma sustancial a raíz de una obra del arabista francés Pierre Guichard publicada en 1976 (!). Ver Manuela MARÍN: "Reflexiones sobre el arabismo español: tradiciones, renovaciones y secuestros", Hamsa. Journal of Judaic and Islamic Studies, 1 (2014), pp. 1-17.
} 
En su figuración de ese hispanizado Al-Ándalus, Simonet sacralizaba el papel jugado por los mozárabes, aquellos cristianos que habían mantenido su fe bajo la dominación islámica. La perspectiva histórica de Simonet se articulaba en términos racistas. Así, argumentaba que, aunque la mayor parte de la población andalusí era musulmana, lo era por conversión, siendo el sustrato racial hispano el que verdaderamente marcaba el carácter de esa sociedad. Pero por encima de todos, los mozárabes destacaban como el grupo de mayor pureza española, habiendo rechazado la conversión y por ende habiendo mantenido viva la esperanza de una reconquista cristiana de la Península, a pesar de las penurias a las que habían quedado expuestos con esa afirmación de su fe. Las loas de Simonet hacia los mozárabes iban a despertar un renovado interés sobre la cuestión de la situación de las minorías religiosas en el contexto peninsular medieval que a su vez revelaría la existencia de una divisoria en el propio campo arabista. ${ }^{21}$ En 1866 , Fernández y González, por entonces en Madrid como titular de la cátedra de Estética en la Central, publicaba una obra, a expensas de la RAH, sobre la población que componía el reverso de la moneda de Simonet, los mudéjares, musulmanes que quedaban bajo control político cristiano a medida que avanzaba la reconquista. ${ }^{22}$ Con dicha obra quedaba abierto un debate que iba a permear la historiografía arabista hasta la actualidad, hablamos de la cuestión acerca de la realidad histórica sobre la tolerancia y coexistencia de las religiones que profesaban los pobladores medievales de la Península.

Algunas líneas más arriba hemos hecho alusión a la existencia de una divisoria presente en el interior del campo arabista. Con ellos queríamos referirnos a la distancia que separaba a algunos arabistas en cuestiones que iban desde el grado de empatíahostilidad mostrado hacia el sujeto que historiaban, los musulmanes andalusíes, a la importancia que concedían a estos en la formación histórica de España. El cisma estaba por tanto vinculado necesariamente a apreciaciones opuestas sobre aquello que era constitutivo de las “esencias nacionales". Percibimos así que lo que en principio aparecía como una polémica de carácter erudito estaba inherentemente imbricado con discursos de

\footnotetext{
${ }^{21}$ Sobre las tesis de Simonet acerca de los mozárabes y la profundización de las diferencias ideológicas en el seno del arabismo, ver James T. MONROE: Islam and the Arabs in Spanish scholarship (sixteenth century to the present), Leiden, Brill, 1970, pp. 86-100.

${ }^{22}$ El rigor en el uso de fuentes y el estilo sobrio de la obra de Fernández y González sobre los mudéjares ha llevado a Bernabé López García a declarar que esta marcaba una ruptura frente al romanticismo característico de la escritura arabista previa. Ver Bernabé LÓPEZ GARCỈA: Orientalismo e ideología colonial en el arabismo español (1840-1917), Granada, Universidad de Granada, 2011, pp. 59-61.
} 
mayor contenido político que competían por definir el curso de la nación. Simonet, un católico devoto cercano a los círculos más tradicionalistas del país, veía a la Iglesia católica como la institución española por antonomasia, depositaria de las esencias nacionales. Por el contrario, Fernández y González, quien hacía gala de un nacionalismo donde primaban los factores étnicos y culturales, mostraba una mayor disposición a aceptar que elementos semíticos habían coadyuvado a gestar la identidad cultural española. Tal posición podía además ser instrumentalizada a la hora de combatir estereotipos sobre el atraso cultural español respecto al resto de Europa. Así, ante las voces que desde el norte de Europa menospreciaban la capacidad intelectual de los españoles, Fernández y Gónzalez respondía:

\begin{abstract}
Unidos los españoles por su elemento semítico y africano a las primogénitas ramas del humano linaje, podemos argüir a nuestros vecinos que presuman de más merecimientos de cultura: Pueblos del septentrión, sois unos niños que no sabéis más que lo de hoy y lo de ayer; nuestra historia es antigua, nuestra literatura inmensa, múltiple en idiomas, monumental y arqueológica, nuestra cultura está llena de esplendores que lucieron un día con más brillo que vuestros esplendores actuales. ${ }^{23}$
\end{abstract}

\title{
El debate sobre la coexistencia
}

El arabismo de Fernández y González armonizaba más fácilmente con un nacionalismo liberal que, aunque en ningún momento negaba la fuerte presencia del catolicismo en el ser nacional, miraba con buenos ojos un mayor distanciamiento entre Iglesia e instituciones estatales. Conocedor de la filosofía alemana, parece que fue quien introdujo a un joven Giner los Ríos en la misma cuando este era un estudiante en Granada. También existen evidencias de que mantenía relaciones cordiales con Julián Sanz del Río desde al menos $1857 .{ }^{24}$ Ciertamente hay que situar a Fernández y González en la órbita del krausismo español, quizá el movimiento intelectual más proclive a la separación de Iglesia y Estado en la España de entonces. ${ }^{25}$ Fue él quien hizo más por movilizar la atención de los krausistas hacia las temáticas arabistas, e incluso afirmaba que el estudio

\footnotetext{
${ }^{23}$ Citado en Aurora RIVIÈRE GÓMEZ: Orientalismo y nacionalismo español..., p. 81. Cursiva añadida.

${ }^{24}$ Estas conexiones de Fernández y González con los principales representantes del krausismo español están documentadas en Bernabé LÓPEZ GARCÍA: Orientalismo e ideología colonial ..., pp. 90 y 120.

${ }^{25}$ El historiador del krausismo Gonzalo Capellán de Miguel de hecho habla de él como un catedrático de la Central "próximo a los círculos krausistas españoles". Ver Gonzalo CAPELLÁN DE MIGUEL: La España Armónica: El proyecto del krausismo español para una sociedad en conflicto, Madrid, Biblioteca Nueva, 2006, p. 37.
} 
arabista era en España "una de las necesidades más urgentes para el proceso aplicado de la filosofía de la historia", ${ }^{26}$ un término historiográfico de cariz netamente krausista.

Dentro del debate abierto entre Simonet y Fernández y González sobre la cuestión de la tolerancia hacia las minorías religiosas, este último apuntaba que en la mayoría de los casos los enfrentamientos militares por el control del territorio entre los reinos cristianos y musulmanes peninsulares llegaban a su fin mediante acuerdos de paz que muy habitualmente garantizaban la seguridad y el respeto a las prácticas religiosas de las minorías que quedaban a merced del ejército triunfante. El fanatismo religioso era el único culpable de que durante siglos se hubiesen obviado del registro histórico esas relaciones de coexistencia y tolerancia, y a aclarar tal situación se debía el arabista moderno. En el marco de dicha polémica iba a intervenir un joven arabista aragonés que con el tiempo iba a marcar el devenir del arabismo español, Francisco Codera.

Codera desarrollaría su faceta de arabista de forma algo tardía, y a pesar de haber estudiado con Gayangos, aparecería inicialmente en el debate entre Simonet y Francisco Fernández y González debido a su interés hacia la religiosidad de los mozárabes. ${ }^{27}$ Tras haber recibido una educación fuertemente católica en su provincia natal de Huesca, el en el acto de su recepción como doctor en la Universidad Central en 1866, Codera disertaba sobre la situación religiosa y social de los mozárabes, sembrando serias dudas sobre la realidad histórica de la tolerancia presentada por Fernández y González. ${ }^{28}$ Si con el tiempo el legado historiográfico de Codera sería encomiado por la sobriedad en sus juicios y una actitud casi obsesiva con circunscribirse a lo que podía dar como válido en base a las fuentes históricas, lo que le desmarcaba de una historiografía que en general era mucho más ampulosa en su estilo narrativo, sin embargo comenzaba Codera su primera intervención académica esbozando un planteamiento teórico sobre la Historia, a la que él veía regirse por leyes dibujadas por la Providencia. En su aplicación al medievo hispano, este primer Codera parecía subscribir la versión más canónica sobre la "pérdida de España”. La invasión islámica se explicaba -al más puro estilo de Mariana- por la “caída

\footnotetext{
${ }^{26}$ Citado en Bernabé LÓPEZ GARCÍA: Orientalismo e ideología colonial..., p. 108.

${ }^{27}$ Un extenso estudio sobre la figura de Codera se puede encontrar en el estudio introductorio que hace María Jesús Viguera en la edición preparada por ella de la obra de Francisco CODERA: Decadencia y desaparición de los Almorávides en España, Pamplona, Urgoiti, 2004.

28 "Discurso leído ante el Claustro de la Universidad Central en el solemne acto de recibir la investidura de Doctor en Filosofía y Letras por don Francisco Codera y Zaidín”. Lérida, Establecimiento de José Sol e Hijo, 1866.
} 
en la molicie" de los visigodos, favorecida por una falta de cohesión entre los habitantes de la Península, siendo que una parte se refugió en las montañas del norte peninsular para no quedar bajo el dominio de "los sectarios del Islam".

Al pasar a analizar el estado de las relaciones entre los cristianos sometidos y los conquistadores islámicos, Codera concedía que a la luz del estudio de las Capitulaciones impuestas a las ciudades conquistadas y que regían las relaciones entre ambas sociedades, estos permitían aparentemente dar la razón a Fernández y González acerca de la posibilidad de niveles aceptables de convivencia entre los invasores y los sometidos. Sin embargo, Codera sugería que probar la realidad efectiva de los acuerdos era una cuestión muy distinta, y para calibrar la realidad o no de esa coexistencia recurría a las fuentes mozárabes que se conservaban del periodo inmediatamente posterior a la invasión. De estas aducía una situación muy gravosa para los cristianos, debido a la alta carga fiscal que recaía sobre ellos, a lo que debía añadirse la existencia de documentados casos de arbitrariedad de las autoridades islámicas, que desdibujaban el panorama de tolerancia sugerido por Fernández y González.

Pero el tema central del discurso de Codera giraba en torno a los martirios de mozárabes cordobeses a mediados del siglo IX, a cuya narración dedica Codera tonos marcadamente apologéticos. La sucesión de casos en que devotos mozárabes osaban defender la "verdadera religión" frente a quienes Codera constantemente alude con epítetos tales como "adoradores del Islam", desencadenó una verdadera persecución religiosa en tiempos de Abderramán II que daba fe según Codera de la difícil situación que pasaban los cristianos bajo la dominación musulmana. Como hemos podido ver, el arabismo de Codera juega un papel muy superficial en esta etapa inicial de su trayectoria académica, haciendo uso en el discurso de fuentes cristianas casi exclusivamente. De sus tenues intereses arabistas en ese momento quedaba casi como único testimonio una breve consideración que hacía el autor hacia el final del discurso sobre de lo que el estudio de las fuentes árabes podría aportar a este capítulo de la historia española, resaltando la positiva importancia de la creciente atención que la Real Academia de la Historia estaba otorgando a este tipo de estudios. 


\section{Fuentes árabes al servicio de la historia de España... y de Aragón}

En un breve lapso de tiempo las prioridades de investigación de Codera iban a dar un vuelco. Tras un paso de dos años en Granada como catedrático de griego, en 1868 se trasladaba a la Universidad de Zaragoza, donde además de esa materia iba a iniciar una cátedra de árabe. En 1870, emplazado a dar el discurso de apertura del curso académico en esa institución, Codera iba a dar muestras de su reciente giro arabista, dedicando tan magna ocasión a resaltar la importancia de los estudios árabes para el esclarecimiento de la historia de Aragón. ${ }^{29}$ Según el propio testimonio del historiador, era esta preocupación historiográfica lo que había motivado su interés hacia el estudio del árabe, y lo que le convertiría, en palabras de María Jesús Viguera, en "el arabista historiador por excelencia". ${ }^{30}$ En este sentido, el referido discurso se puede considerar como el inicio de una etapa en la carrera del historiador aragonés -que continuaría durante el resto de la misma- marcada por la infatigable búsqueda de fuentes árabes sobre las que construir una historia política del periodo posterior a la invasión que estaba aún por hacer.

Si tan solo cuatro años antes, en su recepción como doctor, Codera había dado continuas muestras de hostilidad hacia los musulmanes andalusíes y apenas había hecho referencia a las fuentes escritas dejadas por estos, su discurso de 1870 defendía de forma vehemente la importancia del estudio del árabe. Codera articulaba esa justificación en cuatro frentes. Primeramente, y en el más claro contraste con el mencionado discurso de 1866, se pronunciaba sin ambages sobre la superioridad cultural en casi todos los ámbitos del saber de los musulmanes medievales sobre la cristiandad. Su aportación en ámbitos tan dispares como la filosofía, la geografía, la medicina... resultaba en que el estudio de esa lengua era de por sí valioso meramente para el conocimiento sobre la edad media. En un segundo ámbito, más próximo a las sensibilidades personales del arabista, este defendía que el estudio del árabe era esencial para el desarrollo de la filología comparada moderna. La argumentación de Codera en tal sentido evidenciaba algunas de las preocupaciones intelectuales del académico, de convicciones profundamente religiosas, que quizá expliquen en buena medida su acercamiento al arabismo. Tras describir la ciencia filológica como la disciplina que permitía percibir, a través del estudio lingüístico,

\footnotetext{
29 "Discurso de apertura en la Universidad Literaria de Zaragoza por Don Francsico Codera, catedrático de Lengua griega y de Lengua árabe”, 1 de octubre de 1870.

${ }^{30}$ En su estudio introductorio a Francisco CODERA: Decadencia y desaparición ..., p. XLIX.
} 
los grandes desplazamientos de poblaciones en la historia, Codera sugería que la identidad de raíces que se encontraban en muchas palabras de las lenguas de familia indoeuropea y de las de familia semítica, permitía concluir que ambas "razas" habían formado parte de un tronco común previo. Este no sería otro, en su origen, que la bíblica Mesopotamia. Si esa comunidad de origen no era ampliamente reconocida en medios científicos, esto era debido según Codera a que "se teme que esto sea una prueba más en favor de la revelación de la Biblia”. El estudio del árabe se entroncaba en un trascendental impulso para afirmar la narrativa bíblica.

Pero había dos dimensiones adicionales del estudio del árabe que tocaban de forma mucho más específica a los españoles. Esto se debía a que la historia andalusí debía entenderse como "historia propia", puesto que "españoles como nosotros" habían sido los habitantes del Al-Ándalus, a pesar de entregarse espiritualmente "al impostor de la Meca". Este pasaje es ampliamente revelador de la aproximación historiográfica de Codera y del carácter que imprimirá a la escuela arabista que iniciará con sus discípulos. Si por un lado el estudio del árabe se circunscribe dentro de las inquietudes religiosas de un Codera que mantiene hacia el islam un lenguaje en consonancia con la tradición teológica católica, se abre a la vez camino no ya al elogio de las virtudes de los árabes y sus logros científicos, sino al reconocimiento sin reservas de la "españolidad" de los musulmanes andalusíes. Se cerraba así el círculo del proceso que desde el XVIII iba a ir desvinculando la identidad española de sus versiones más teologales, paradójicamente en un autor fuertemente católico.

Persistía, frente a todo, el interés en el empleo de las fuentes árabes desde la perspectiva de lo que estas podían aportar para el esclarecimiento de la historia de los reinos cristianos peninsulares. Así Codera aportaba ejemplos de cómo las crónicas árabes podían despejar dudas sobre episodios históricos tales como la traición del Conde don Julián y de los hijos de Witiza, sobre la realidad histórica del Cid, o sobre las guerras civiles que se dieron en León a la muerte de Alfonso IV. Y todo esto nos lleva al cuarto frente en el que Codera sitúa al interés arabista, el de la propia historia aragonesa. Y en este ámbito resultaba más crítico el estudio del árabe que en ningún otro, puesto que la escasez de fuentes cristianas sobre lo que sucedió en los valles pirenaicos de Navarra y Aragón oscurecían la propia cuestión del origen del reino aragonés. El discurso se erigía así en apelación a los estudiantes para subsanar el incomprensible desinterés que había 
existido hacia lo árabe en España. Codera expresaba su deseo de que de esa forma "quizá se consiga lavar a nuestra querida patria de la especie de baldón que sobre ella pesa por haber descuidado estos estudios".

De este breve recorrido por el desarrollo del arabismo español en las décadas fundamentales para su consolidación académica, hemos podido comprobar la estrecha relación que vinculaba este campo de estudios con el proceso de construcción de una historiografía nacionalista que acontecía de forma paralela. Si es completamente cierto que en el marco del arabismo cabía una diversidad historiográfica -desde el filokrausismo de Fernández y González al integrismo católico de Simonet-que reflejaba la complejidad y conflictividad de las disputas que sobre la Historia se daban en ese periodo, resulta igualmente manifiesto que la figura de Codera haría orbitar de forma principal al arabismo de finales de siglo sobre el ámbito de la historiografía oficial, centrada durante el periodo inicial de la Restauración en la Academia de la Historia.

En 1873 Codera recibía una cátedra en la Universidad Central de Madrid, y su presencia en la capital fortalecería su relación con la institución académica. Cánovas, en su papel de gran artífice de la Restauración borbónica, se cuidó de que el modelo cimentado en las academias marcara la pauta cultural del régimen que estaba por consolidar. Si el leitmotiv de esa política cultural canovista era el de "mantener la continuidad histórica", entendiéndose por tal continuidad la conformidad con una visión histórica sobre la nación netamente conservadora, la Real Academia de la Historia se erigía como el gran guardián de esa "continuidad". ${ }^{31}$ En muchos aspectos la labor de Codera sería representativa de las líneas metodológicas que se irían a promover desde la Academia. En el caso del mencionado discurso de 1870, por ejemplo, el interés en poner de relieve la importancia que algunas fuentes árabes podían tener para la historia de Aragón se inscribía dentro de una mayor sensibilidad hacia la historia local y regional, vista como un complemento indispensable de la historia nacional y con un marco de investigación previo necesario para poder hacer síntesis globales con posterioridad.

Esa renuencia hacia la síntesis prematura sería precisamente lo que en adelante marcaría por encima de toda la labor historiográfica de Codera. Frente al primer Codera de 1866, que argüía sobre las leyes de la Providencia en la historia, la gran parte de su

${ }^{31}$ Ver Ignacio PEIRÓ MARTÍN: Los guardianes de la historia... 
producción histórica quedaría determinada por una cierta frialdad narrativa que le llevaba a autocensurar cualquier juicio que no pudiera confirmarse de forma rigurosa aludiendo a las fuentes. Por ello, ante la percepción en el historiador de que existía un auténtico desconocimiento de las fuentes básicas para explicar el período andalusí, renunció expresamente a elaborar obras de síntesis en favor de una exhaustiva búsqueda y edición de documentos árabes que tuvieran relevancia para la historia española, tarea a la que se entregó el resto de su vida profesional. Ese talante congeniaba con los pasos que en el seno de la Academia de la Historia se daban hacia una historiografía más centrada sobre la crítica de documentos y que iba a permitir una primera profesionalización del oficio histórico en esas décadas finales de siglo.

De hecho, tras el inicio en 1876 de la publicación del Boletín de la Real Academia de la Historia, Codera pasaría a ser unos de los más frecuentes colaboradores de la publicación, si no el mayor. Su dedicación a esa tarea documental, la prolijidad de sus publicaciones y su capacidad para formar discípulos y establecer relaciones con orientalistas extranjeros harían que el arabismo de finales de siglo quedara inextricablemente vinculado al nombre de Codera y, por ende, a su práctica historiográfica. 


\title{
¿Por qué se olvidó el final de la guerra del Rif?
}

\author{
Why did the end of the Rif War fall into oblivion?
}

\author{
Alejandro Rey Millán \\ Universidad de Málaga
}

\section{Resumen}

Es difícil discutir que las guerras del pasado son un foco sempiterno de atracción para la curiosidad del ser humano. Pero, si nos centramos en la historiografía española del siglo XX, vemos un hiato, casi un silencio entre el desastre de Annual (1921) y la aparición de la última guerra civil española (1936-1939). En dicho intervalo la atención de los historiadores se ha centrado en el Protectorado marroquí de manera monotemática sobre Annual, Alhucemas (1925) y la rendición de Abd el-Krim (1927). En este documento dirigimos la atención hacia un acontecimiento olvidado: el segundo cautiverio (19241926) sufrido por soldados españoles.

\section{Palabras clave}

Historiografía, Protectorado, Segundo cautiverio, Soldados, 1924-1926.

\begin{abstract}
It is difficult to argue that the wars of the past are an everlasting focus of attraction for the curiosity of the human being. But if we focus on the Spanish historiography of the twentieth century, we see a hiatus, almost a silence between the disaster of Annual (1921) and the appearance of the last Spanish Civil War (1936-1939). In this interval the attention of the historians has centered on the Moroccan Protectorate in a monothematic way on Annual, Alhucemas (1925) and the surrender of Abd el-Krim (1927). In this document we turn our attention to a forgotten event: the second captivity (1924-1926) suffered by Spanish soldiers.
\end{abstract}




\section{Palabras clave}

Historiography, Protectorate, Second Captivity, Soldiers, 1924-1926.

\section{Introducción}

Después de un momento reflexionando, quizás habría sido más acertado modificar el título del presente documento y sustituirlo por: ¿por qué han caído en el olvido los últimos soldados españoles que fueron prisioneros de Abd el-Krim?

De la presencia militar española en el Norte de África no faltan estudios y de los momentos más llamativos de las diferentes guerras ocurridas tampoco se puede acusar carencia de información. Es decir, los desastres de Barranco del Lobo 1909 y Annual 1921, han sido analizados en profundidad (aunque siempre se podrá verter más información al respecto).

Las consecuencias de las derrotas militares sufridas por las tropas españolas en suelo marroquí se hicieron notar con fuerza en suelo peninsular; tras los avances rifeños sobre posiciones como Annual, Igueriben o Abarrán, el descontento de muchas familias con hijos, hermanos o sobrinos destinados a la guerra encontró apoyo en algunos personajes influyentes como fue Indalecio Prieto.

Gracias a la presión ejercida en los momentos inmediatamente posteriores al llamado "Desastre de Annual", las autoridades gubernamentales del momento se vieron en la tesitura de negociar la liberación de aquellos soldados españoles que llevaban cautivos bajo el control rifeño desde la pérdida de Annual. Corría el año 1922 y el industrial Horacio Echevarrieta fue el encargado de realizar las negociaciones con Abd el-Krim.

No estamos refiriéndonos en este documento a la liberación de los soldados que fueron apresados durante el "Desastre de Annual", episodio ya analizado con puntería desde la perspectiva política. 
El asunto en torno al cual orbita esta intervención tiene su origen inmediato en una de las decisiones tomadas por Miguel Primo de Rivera como Presidente del Directorio Militar respecto a la presencia española en el Protectorado marroquí. Nos referimos a la decisión de retirar a las tropas españolas y acantonarlas en zonas próximas al litoral atlántico y a Tetuán, al norte de una línea imaginaria que fue conocida como la Línea Estella (por haber sido el Marqués de Estella -Miguel Primo de Rivera- el artífice de la decisión).

Esa intención de replegar las tropas no se tradujo en órdenes efectivas que avisaran a los defensores de los diferentes blocaos diseminados entre Tetuán y Xauén y la retirada no fue un movimiento organizado con apoyo entre las unidades destacadas y las de recambio; solamente lograron alcanzar la Línea Estella los defensores de las posiciones y blocaos más próximas a la misma; mientras que los soldados destinados a los puntos más alejados de la mencionada Línea Estella sufrieron una suerte parecida a la de los infelices que murieron o fueron apresados en 1921.

Si varios cientos de soldados españoles fueron convertidos en prisioneros por los rifeños en 1921 y liberados tras el pago de un rescate en el año 1922, no correrían la misma suerte los que cayeron en manos de los rebeldes en el año 1924.

Hace un par de años tuve la ocasión de contactar con la familia de uno de aquellos soldados hechos prisioneros por los rifeños en 1924; era, y creo que sigue siendo, el único testimonio conocido de aquel episodio. José Caballero Reyes escribió sus memorias, una de sus hijas las conserva y gracias a ella ha sido posible que uno de los bisnietos de José las haya transcrito y editado con un prólogo de quien ahora les habla. ${ }^{1}$

Y es aquí dónde encuadramos la pregunta que funciona como eje de esta intervención: ¿por qué ha caído en el olvido el segundo cautiverio de soldados españoles a manos de Abd el-Krim?

\section{Contexto}

Durante el proceso de investigación que tenía como objetivo la elaboración de una Tesis Final de Máster - defendida hace ya un trienio- fueron muchos los interrogantes

\footnotetext{
${ }^{1}$ José CABALLERO REYES: Historia de un prisionero en Marruecos 1922-1926, Editorial Lulú, 2016. Prólogo de Alejandro Rey Millán.
} 
planteados a partir del análisis de fuentes -puede que demasiadas-.

Espero no ser el único que haya tenido que poner fin -de manera temporal- al atractivo apartado de "análisis de fuentes" para afrontar el, digámoslo así, tedioso trance de pasar al papel una parte importante del trabajo de investigación que tan bien diseñado aparecía antes de empezar a rellenar folios.

Una de aquellas preguntas se me grabó en la memoria, aunque también la anoté en un documento de Word: ¿por qué los historiadores han prestado una atención vaporosa al período 1922-1926 de la presencia española sobre territorio norteafricano? Con las excepciones vinculadas a rescatar y resaltar la importancia del desembarco sobre la bahía de Alhucemas a finales del verano de 1925.

A primera vista parece que entre el desastroso verano de 1921 -Abarrán, Igueriben, Monte Arruit, Annual- y el victorioso de 1925 el tiempo se congeló; podríamos pensar que la tranquilidad reinó en el Rif entre Annual y Alhucemas, y nos equivocaríamos irremediablemente.

No vamos a resaltar la importancia que tuvo el asunto marroquí en la vida política, social y económica española a raíz de la serie de escabechinas sufridas por el ejército en el verano de 1921. Este aspecto ha sido destacado en casi todas las publicaciones que de manera directa o indirecta tienen en la Dictadura de Miguel Primo de Rivera su objeto de estudio.

No todos los soldados españoles implicados en el caótico verano de 1921 murieron perseguidos, muchos fueron apresados por el enemigo y mantenidos con vida a la espera de poder canjearlos por dinero, produciéndose el rescate de los soldados españoles, cautivos de los rifeños en 1923. Episodio estudiado por los profesores Martín $\operatorname{Arce}^{2}$ y Ramiro de la Mata. ${ }^{3}$

El silencio historiográfico respecto a la situación militar española en el Protectorado marroquí tras Annual y antes de Alhucemas no corresponde a un período de inactividad, tranquilidad o concordia general aceptada por la fuerza metropolitana y los rebeldes

\footnotetext{
2 José Ma MARTÍN ARCE: "El Gobierno de Concentración Liberal: el rescate de prisioneros en poder de Abd el-Krim”, Espacio, tiempo y forma. Serie V, Historia contemporánea, 1 (1988), pp. 163-182.

3 Javier RAMIRO DE LA MATA: "Los prisioneros españoles cautivos de Abd-el-Krim: Un legado del desastre de Annual”, Anales de Historia Contemporánea, 18 (2002), pp. 343-354
} 
rifeños contrarios también a la autoridad central de Marruecos.

Por tanto, centraremos nuestros esfuerzos en:

a) intentar dilucidar algunos episodios que permanecen a la penumbra en los márgenes de la historiografía.

b) buscar explicaciones plausibles para comprender una marginación que en breve será centenaria.

\section{Momentos}

¿Guerra o campañas?

La presencia española en el norte de África es anterior a la creación y reconocimiento del Protectorado (1912), y todavía no queda claro ${ }^{4}$ si debemos hablar de una guerra duradera y larga con objetivos y líneas de acción bien definidas, o de campañas afrontadas sobre la marcha. ${ }^{5}$

Por lo menos desde comienzos del siglo XX de la sensación que lo más adecuado es hablar de campañas: siempre en las proximidades de Melilla y para recomponer un prestigio militar dañado -y por ello sujeto a críticas-.

Resulta atractivo para la curiosidad del historiador actual rastrear los ecos de las derrotas más memorables: Barranco del Lobo (1909), Annual, Igueriben, Abarrán, Monte Arruit (1921) y ver la escasa atención prestada a las campañas de recuperación-venganza entre 1912 y 1922. La primera -tras la catástrofe de 1909- permitió ampliar el control en los alrededores de Melilla; la segunda-como reacción a las consecuencias territoriales de Annual- supuso, entre otros hitos, la ocupación de la ciudad de Xauén. Sin embargo, la pauta de resaltar la derrota se rompe, hay un silencio tras el varapalo de 1921 y solamente es anulado para alabar el logro del desembarco en Alhucemas 1925.

Así, tras la derrota de 1909 vino un ciclo expansivo destrozado en 1921, expansión que se recupera entre 1922-1923 para ser detenido en 1924; siendo Alhucemas el inicio

\footnotetext{
${ }^{4}$ Sobre todo, si nos introducimos en las diferentes obras centradas en aspectos militares tales como Gabriel MAURA GAMAZO: Al servicio de la Historia. Bosquejo histórico de la dictadura, T.I, 1923-1926, Madrid, Morata, 1930; o Juan ALBI DE LA CUESTA: En torno a Annual, Madrid, Ministerio de Defensa, 2014.

${ }^{5}$ No será esta la única ocasión para acercarnos a las dudas sobre términos: ¿retirada o repliegue?
} 
de una victoria sobre los rifeños que no culmina con la rendición de Abd el-Krim en mayo de 1926 sino casi un año más tarde.

\section{Tras el verano de 1921}

Ya hemos hablado, muy brevemente, del cautiverio y rescate de un grupo numeroso de soldados españoles prisioneros de los rifeños rebeldes a raíz de la mala organización en el verano de 1921. Desorganización que venía arrastrada por lo menos desde Barranco del Lobo (1909).

A pesar del rechazo de la opinión pública -Semana Trágica 1909, sublevación de quintos en Málaga 1923- el destino de muchos reclutas seguía siendo, en muchos casos, Marruecos.

Si la formación militar no mejoró, el armamento no fue renovado y se carecía de estrategia, objetivos y vías de escape: ¿qué impedía a los bisoños soldados destinados a África en 1922 suponer que su suerte sería diferente a la de los soldados machacados en $1921 ?$

\section{Chumberas y babuchas ${ }^{6}$}

Es una novela corta publicada en el año 1934 editada en una pequeña imprenta de un pueblo barcelonés cuyo autor sitúa el marco de la narración dentro del período que ahora nos ocupa: la zona occidental del Protectorado tras Annual y antes de Alhucemas.

Esta obra figura en varias antologías centradas en la literatura colonial española, ${ }^{7}$ pero no ha sido objeto, por el momento y según las fuentes manejadas, de un análisis por parte de ningún historiador. E incluso esta obra ha sido sintetizada de forma errónea en alguna compilación, ${ }^{8}$ al afirmar que el personaje central logra salvarse gracias a casarse con una musulmana, lo cual no se menciona en la narración.

\footnotetext{
${ }^{6}$ Francisco FUSIMAÑA SABATÉS: Chumberas y babuchas, Roda de Ter (Barcelona), Imprenta Rodenca, 1934.

7 Valgan como ejemplos los siguientes trabajos: Mohamed KADDUR: Antología de textos sobre la guerra del Rif, Málaga, Algazara, 2006; Juan José LÓPEZ BARRANCO: La guerra de Marruecos en la narrativa española 1859-1927, Madrid, Universidad Complutense, 1999; y Alejandro VARGAS: La guerra de Marruecos en la literatura, Málaga, Algazara, 2001.

${ }^{8}$ Así lo afirma Mustapha Allouh en la página 76 de su compendio titulado Le Rifface aux visées coloniales, 1921-1927, editado por la Fundación del Rey Abdul-Aziz Al Saoud para estudios islámicos y de humanidades, en la ciudad de Casablanca el año 2004.
} 
Lo primero que debemos anotar de la obra de Francisco Fusimaña es se contenido parcialmente autobiográfico ya que el autor recibió Marruecos como destino en el sorteo de quintos, ${ }^{9}$ encuadrado en la $1^{\text {a }}$ Compañía del Batallón 1 de Cazadores de África, ${ }^{10}$ aunque poco tiempo después fue enviado al Batallón de Intervención Militar de Melilla con destino a la zona de Bocoia. ${ }^{11}$ Luego, en agosto de 1926 fue enviado al sector de Axdir, ${ }^{12}$ hasta que finalmente fue licenciado en el verano del año 1927.

A diferencia del personaje principal de su relato, Fusimaña no desertó, sino que cumplió los tres años de servicio militar marcados por la normativa de la época -según se puede analizar en su expediente militar conservado en el Archivo General de la Administración-. ${ }^{13}$

\section{José Caballero Reyes}

Si en el párrafo anterior destacamos una obra publicada hace más de ochenta años con una gran potencialidad para ofrecer información a cualquier investigador interesado en el tema: ${ }^{14}$ ahora nos centramos en un testimonio que lleva más de setenta años conservado en un cajón de una casa familiar viendo la luz por primera vez en mayo de $1926 .{ }^{15}$

Este texto autobiográfico fue redactado al finalizar la guerra, no la de Marruecos en 1927 sino la civil española por un motivo de fuerza mayor: José Caballero no sabía escribir durante su primer contacto con la guerra. Fue durante la defensa de Madrid, en un momento que no podemos precisar, cuando pidió a uno de sus compañeros de armas que le enseñara para poder dejar a sus hijos y nietos por escrito todo lo que sufrió en Marruecos.

Gracias al uso de las tecnologías y después de múltiples fracasos encontré la página web de un fotógrafo madrileño donde aparecía una fotografía de la primera página de las

\footnotetext{
${ }^{9}$ Archivo Municipal Roda de Ter, Quintos de 1925. Información complementada con la conservada en la Caja 1021 del mismo Archivo, que contiene los recibos de los diferentes envíos realizados por la "Comisión municipal para socorrer a los rodencos en la Campaña de África 1921-1926”.

${ }^{10}$ Como figura en los recibos conservados.

${ }^{11}$ Archivo General de la Administración (en adelante AGA) 64-00124-00000, hoja 2.

12 AGA, 81-05075-00000, hoja 2.

13 AGA, 81-05075- 00000 y 64 -00124-00000.

${ }^{14} \mathrm{Y}$ capaz de acceder a ella, porque hubo una sola edición de pocos ejemplares.

15 José CABALLERO REYES: Historia de un prisionero..., Prólogo de Alejandro Rey Millán.
} 
memorias de José Caballero. Siendo cartesiano un historiador por definición (o por necesidad), no podía otorgar rango de fuente primaria fiable a un documento de cuyo autor solamente conocía el nombre: las dudas empezaron a quedar despejadas no solo por la información relativa a su nacimiento localizada en el Registro civil de Puebla del Maestre (Badajoz) sino por una página del diario El Sol. ${ }^{16}$

El autor había nacido dónde y cuándo su relato (y su hija ${ }^{17}$ decían, y su nombre aparecía en una de las listas de soldados españoles liberados en el momento de la rendición de Abd el-Krim ante el ejército francés.

Ante tales evidencias no había motivos para mantener las sospechas: se trata del único relato conocido que habla en primera persona de un acontecimiento ausente -hasta donde he podido saber- en la historiografía española: el segundo cautiverio de soldados españoles sufrido frente a los rebeldes rifeños en menos de una década.

Aquellos soldados liberados por Horacio Echevarrieta en 1923 cayeron en manos de los rifeños durante el denominado "desastre de Annual".

Pero Historia de un prisionero en Marruecos 1922-1926 no se refiere a aquel momento; su autor es muy claro cuando se refiere a su momento de llegada a Marruecos y dice que:

[...] estando en la zona de Zafra leímos en los periódicos lo de aquel dichoso rescate de los infelices exprisioneros del Desastre del 21 [...] quién nos iba a decir, a mí y a otros compañeros, que en aquellos trances tan serios y tan amargos nos íbamos a ver, al poco tiempo, otros tantos compañeros, como así nos sucedió a los veinte meses de esto. ${ }^{18}$

Es una prueba palmaria, o al menos evidente, de que todavía debemos mantener abierta la puerta al debate en torno al desarrollo de las maniobras de retirada o repliegue del año 1924 con destino a la llamada "línea de Primo de Rivera".

\section{Repliegue/ Retirada de 1924}

Afirmar que, durante el verano del año 1924, una cantidad importante (aunque todavía pendiente de concretar) de las posiciones controladas por el ejército español en la

\footnotetext{
${ }^{16}$ El Sol, 3 de junio de 1926. Tercera lista de soldados españoles liberados del cautiverio rifeño.

${ }^{17}$ Entrevista telefónica con María Caballero Arranz el día 11 de septiembre de 2014.

18 José CABALLERO REYES: Historia de un prisionero..., p. 26.
} 
zona occidental del Protectorado fueron abandonadas es algo ya sabido.

Diferente éxito alcanzará la curiosidad del historiador centrada en este período si intenta detallar el trazado de la denominada "línea Primo de Rivera". Lo más que podrá afirmar es que dicha línea buscaba mantener como hitos las carreteras que unían los puntos estratégicos de Larache, Arcila, Tetuán, Tánger, así como los contornos inmediatos a Ceuta y Melilla.

Gracias al testimonio de José Caballero es posible abrir interesantes puntos de debate en torno a la intención de los mandos a la hora de marcar dicha "nueva frontera segura": no buscaba facilitar el regreso de la mayor parte de las guarniciones que permanecían acantonadas en los desperdigados blocaos, tenía la función primordial de evitar el corte de las comunicaciones por tierra, de ahí que los soldados destinados a enclaves cercanos a las mencionadas carreteras tuvieran más fácil salir de una zona que en breve se convertiría en un "segundo Annual".

Y el "segundo Annual" tuvo lugar, a pesar de la fama creciente de tropas de elite como la Legión y los Regulares fueron innumerables los soldados españoles abandonados a su suerte (a veces un simple mensaje por heliógrafo avisando de la imposibilidad de enviarles auxilio), que murieron sin dejar testimonio o fueron tomados como prisioneros por los rifeños.

Quienes tenían muy presente la rentabilidad obtenida con la venta de los supervivientes de 1921, buscaban el mismo resultado con los apresados en 1924. Pero para desgracia de los soldados cautivos, entre ellos no figuraba ningún cargo elevado de la oficialidad militar: nadie iba a rescatarlos.

Igual que tras Annual se iniciaron las investigaciones del General Picasso, tras la rendición de Abd el-Krim en mayo 1926, cuando el Alto Mando se percató del eco que tenía en la sociedad del momento las noticias referentes a las "listas de soldados españoles exprisioneros", pronto se abrió una tanda de interrogatorios a cargo del Teniente auditor Miguel Gambra.

Si el señor Gambra llevó a cabo tales indagaciones estas no han tenido consecuencias directas en la historiografía española. El Informe Picasso fue guardado en un cajón: ¿habrá pasado lo mismo con la labor de Miguel Gambra? 


\section{Análisis de la última guerra del Rif a lo largo del tiempo}

\section{Periodistas}

A pesar de lo que a primera vista pudiéramos suponer, fueron periodistas los que más atención prestaron a los acontecimientos ocurridos en Marruecos entre 1924 y 1926. Figuras como Rafael López Rienda o Francisco Hernández Mir resultan imprescindibles para ahondar en muchos de los aspectos cotidianos de esta última fase de la Guerra del Rif. Aunque cuando acudimos a una obra que analiza la historia del periodismo nos encontramos sin referencias concretas referentes a aquellos periodistas que enviaban sus crónicas desde los lugares más próximos a las zonas de los ataques. ${ }^{19}$

Remontarnos al período de Primo de Rivera hablando del papel del periodismo en torno a la última fase de la Guerra del Rif y no mencionar las "Notas Oficiosas" sería un descuido difícil de justificar. Si seguimos la línea interpretativa marcada por las autoras del trabajo recién mencionado, la intención de la autoridad detentadora del poder en aquella época sería resaltar la importancia de acontecimientos poco valorados por la prensa; tales como las "operaciones victoriosas en Marruecos". ${ }^{20}$

Del granadino López Rienda conocemos toda su obra periodística y una decena de libros cuya publicación casi siempre gira alrededor del tema africano que conocía de primera persona. Llegó a ser denunciado por una parte de la información reflejada en su libro más conocido El millón de Larache, cuyo título completo es clarificador. ${ }^{21}$

Otra fuente de información muy interesante para ser analizada desde la perspectiva del historiador es la formada por los libros escritos por Francisco Hernández Mir entre los años 1922 y 1930 con un hilo conductor fácil de identificar: la culpa de la Dictadura en los sucesos ocurridos en Marruecos. ${ }^{22}$

Del primer libro de Hernández Mir que hemos mencionado, es necesario presentar un fragmento para poder contextualizar la importancia de las opiniones de su autor, en

\footnotetext{
${ }^{19}$ María CRUZ SEOANE y María Dolores SÁIZ: Historia del periodismo en España El siglo XX 18981930, Madrid, Alianza, 1998.

${ }^{20}$ Ibid., p. 324.

${ }^{21}$ Rafael LÓPEZ RIENDA: El escándalo del millón de Larache; datos, antecedentes y derivaciones de las inmoralidades en Marruecos, Madrid, Sáez Hermanos, 1922.

${ }^{22}$ Francisco HERNÁNDEZ MIR: Del desastre a la victoria (II) Del Rif a Yebala 1921-1926, Madrid, Librería Fernando Fe, 1926; e ÍD.: Un crimen de lesa patria. La dictadura ante la historia, Madrid, Compañía Iberoamericana de Publicaciones, 1930.
} 
este caso respecto a las maniobras de repliegue preparadas para el verano de 1924:

Sería un simple traslado de la zona de agresiones, porque hubiese sido cándido esperar que el enemigo abandonase su táctica de desgaste por el solo hecho de haberle dado la satisfacción de regalarle varios kilómetros del territorio que ocupábamos. ${ }^{23}$

Es posible, muy probable, que exista un mayor número de periodistas cuyas obras datadas a partir de la segunda mitad de los años veinte del siglo XX sigan a la espera de ser tenidas en cuenta como fuentes de información interesantes a la hora de historiar un período atractivo por encontrarse en el gozne entre el famoso desastre de Annual y la famosa victoria de Alhucemas.

\section{Literatos}

Podemos repasar antologías u obras completas de una gran cantidad de poetas, dramaturgos o novelistas en activo desde la segunda mitad de la década 1920-1930; hacerlo buscando menciones más allá de lo pasajero. ${ }^{24}$

Una vez terminado nuestro repaso por la producción, conocida hasta el momento, de la llamada Generación de plata de las letras españolas estaremos en condiciones de evidenciar una diferencia fundamental respecto a la generación del Siglo de Oro: mientras la guerra contemporánea es un tema propio, fuente de inspiración y realidad innegable para la generación de Lope de Vega y Quevedo, se convierte en un tabú, un eje central de silencio para quienes se reunieron en el III Centenario de la muerte de Luis de Góngora.

Lorca, Alberti, Altolaguirre... que sepamos en este momento, ninguno de los integrantes de la "Generación del 27" concedió atención al panorama bélico que provocaba la muerte de miles de españoles. Tampoco los integrantes de la "otra Generación del 27" -Enrique Jardiel Poncela, Miguel Mihura, Tono, etc.- dieron espacio a la realidad mortífera que se anclaba en el Protectorado. ${ }^{25}$

Buscar una explicación a este cambio en la perspectiva hacia la realidad de cada

\footnotetext{
${ }^{23}$ Francisco HERNÁNDEZ MIR, Del desastre a la victoria ..., p. 246.

${ }^{24}$ Como hace Valle-Inclán en Luces de Bohemia, p. 49, Escena Cuarta, verso 13, al mencionar al Sargento Basallo que fue héroe del cautiverio que siguió al rescate de Annual (1921); cuya fama llenó las columnas de los periódicos, especialmente después del rescate (1923). Ramón María del VALLE-INCLÁN, Luces de Bohemia, Madrid, Espasa Calpe, 1973.

${ }^{25}$ Emilio GONZÁLEZ-GRANO DE ORO: La otra Generación del 27. El Humor Nuevo español y La Codorniz primera, Madrid, Polifemo, 2004.
} 
momento puede ser una tarea más acorde a las funciones de la Teoría de la Literatura, sin embargo no podemos desaprovechar la ocasión para proponer una interpretación plausible al respecto: durante el Siglo de Oro no faltaron soldados que narrasen sus experiencias en los campos de batalla ni un público con ganas de conocer los pormenores de las diferentes batallas, mientras que tras la Primera Guerra Mundial se generalizó una situación internacional de calma y sosiego alejada del panorama bélico donde solamente las familias de los que recibían Marruecos como destino para cumplir los tres años de servicio a la Patria se preocupaban por conocer el desarrollo de los acontecimientos coloniales.

Volviendo al nulo protagonismo o presencia directa de la última Guerra del Rif en la literatura española del momento, hemos de reconocer que solamente Valle-Inclán se centró en la guerra de África en una de sus obras inéditas hasta hace muy poco tiempo: El soldado de África, pero desafortunadamente todavía no he podido acceder a ella.

\section{Historiadores}

Podemos calificar el silencio historiográfico mantenido durante la dictadura de Primo de Rivera como comprensible.

Nuestra mirada pasa a los historiadores contemporáneos de la Segunda República, quienes optaron por trabajar otros campos temáticos dejando en un silencio sempiterno aquellos acontecimientos rifeños que tan bien conocían de manera más o menos directa.

La atención prestada durante la dictadura franquista a los acontecimientos coloniales del Norte de África tenía como finalidad destacar, alabar y elogiar la personalidad de unos mandos militares que serían protagonistas innegables de la vida española con anterioridad a la última guerra civil española.

La importancia de la experiencia bélica adquirida durante la guerra del Rif posterior a 1921 resulta indiscutible a la hora de valorar el desarrollo militar de buena parte de la guerra civil.

Ahora bien, el hecho del protagonismo evidente de los acontecimientos englobados durante el período 1936-1939 en la historiografía contemporánea española no debe llevarnos a justificar el silencio, olvido ni desinterés respecto a acontecimientos no tenidos en cuenta hasta el momento presente. 


\section{Listado de soldados españoles liberados tras la rendición de Abd el-Krim}

Hemos podido conocer y consultar, hasta la fecha de redacción del presente documento, un total de 46 testimonios, en su mayoría muy breves, pertenecientes a soldados españoles que regresaron a sus hogares tras sufrir el segundo cautiverio.

Siempre teniendo presentes las cautelas necesarias al trabajar con fuentes hemerográficas, las cuales debemos incrementar a la hora de centrarnos en el período de 1924 a 1926 por hallarse incluido dentro del Directorio Militar que caracterizó de manera temporal a la dictadura implementada por el general jerezano Miguel Primo de Rivera.

Tales testimonios nos abren la posibilidad de suponer que por lo menos el $30 \%$ de aquellos soldados que recuperaron la libertad tras la rendición de Abd el-Krim regresó a sus hogares.

Hemos mantenido la repetición de nombres para no olvidar que cualquier información ha de ser contrastada sin conceder credibilidad prematura a ninguna fuente por mucho que convenga al desarrollo de una investigación.

Sin embargo, he corregido los errores recogidos en los textos periodísticos consultados, ya que en diversas ocasiones que no puedo recordar de memoria figuran nombres de municipios con una nomenclatura incorrecta. También he optado por actualizar los nombres de municipios que han cambiado su denominación desde el momento en el cual sucedieron los acontecimientos aquí analizados.

También he valorado, en base a los objetivos marcados para dar forma al presente texto, no incluir la relación de personas no vinculadas de manera directa a ninguna de las unidades implicadas en el segundo cautiverio. Me refiero a varios hombres que regentaban pequeñas tabernas a las afueras de localidades atacadas por los rifeños, a mujeres (siendo las nacidas en la provincia de Málaga las más numerosas) e incluso varios niños. Logrando aquellas y estos últimos un trato diferente al aplicado a los militares, pero recuperando la libertad al unísono.

Toda persona interesada en acceder a las informaciones recogidas en los periódicos analizados (que se encuentran citados en la tabla siguiente) solamente tiene que buscar en 
la página web de la Hemeroteca Digital. ${ }^{26}$

No tenemos en cambio, por el momento, forma de saber cuál es la cifra total de soldados españoles que fueron capturados a raíz del "repliegue" ordenado por Primo de Rivera en 1924. El hecho de entrecomillar el término anterior responde a las dudas que provoca ver la falta de previsión a la hora de intentar replegar las fuerzas diseminadas por el interior del Protectorado. Aunque durante años se haya mantenido la imagen de un movimiento fruto de una minuciosa estrategia, cabe la posibilidad de no ser tan fidedigna dicha imagen.

\begin{tabular}{|c|c|c|c|c|c|c|c|}
\hline & Nombre y Apellidos & Rango & Unidad & Nacimiento & Periódico & Fecha & Día regreso \\
\hline 1 & José García Marcos & Sgto & $\begin{array}{l}\text { Centro } \\
\text { Electrotécnico }\end{array}$ & Archena & El Sol de Madrid & $31 / 05 / 1926$ & \\
\hline 2 & Dionisio Sánchez infante & Sgto & Reg. Las Navas & $\begin{array}{l}\text { Jimena de la } \\
\text { Frontera }\end{array}$ & El Sol de Madrid & $31 / 05 / 1926$ & \\
\hline 3 & Juan Pardo Cebrián & Sgto & Reg. Las Navas & Carcelén & El Sol de Madrid & $31 / 05 / 1926$ & $31 / 07 / 1926$ \\
\hline 4 & Bernardo Ballesteros & Sgto & Reg. Las Navas & $\begin{array}{ll}\text { Paterna del } \\
\text { Madera }\end{array}$ & El Sol de Madrid & $31 / 05 / 1926$ & \\
\hline 5 & Luis Gordillo Martínez & Cabo & Reg. Las Navas & $\begin{array}{l}\text { Fuente de } \\
\text { Cantos }\end{array}$ & El Sol de Madrid & $31 / 05 / 1926$ & $31 / 07 / 1926$ \\
\hline 6 & Manuel Saez Antolino & Soldado & Reg. Las Navas & Jacarilla & El Sol de Madrid & $31 / 05 / 1926$ & $28 / 09 / 1926$ \\
\hline 7 & Fulgencio Cerón Lucas & Soldado & Reg. Las Navas & Alhama & El Sol de Madrid & $31 / 05 / 1926$ & $14 / 07 / 1926$ \\
\hline 8 & Francisco Correa & Soldado & Reg. Las Navas & Lorca & El Sol de Madrid & $31 / 05 / 1926$ & \\
\hline 9 & Antonio Mateo Martínez & Soldado & Reg. Las Navas & Hospitalet & El Sol de Madrid & $31 / 05 / 1926$ & $17 / 07 / 1926$ \\
\hline 10 & Isaac Parra Salmerón & Soldado & Reg. Las Navas & Priego & El Sol de Madrid & $31 / 05 / 1926$ & $22 / 06 / 1926$ \\
\hline 11 & Valentín Muñoz & Soldado & Reg. Las Navas & $\begin{array}{l}\text { Cabeza de } \\
\text { Buey }\end{array}$ & El Sol de Madrid & $31 / 05 / 1926$ & \\
\hline 12 & Hilario Galto/Gayte & Soldado & Reg. Las Navas & Palencia & El Sol de Madrid & $31 / 05 / 1926$ & \\
\hline 13 & José Novau & Soldado & Reg. Las Navas & Assentiu & El Sol de Madrid & $31 / 05 / 1926$ & $07 / 07 / 1926$ \\
\hline 14 & Miguel Puey & Soldado & Reg. Las Navas & Gandesa & El Sol de Madrid & $31 / 05 / 1926$ & \\
\hline 15 & José Sauna Rodríguez & Soldado & Reg. Las Navas & $\begin{array}{l}\text { Estrecho San } \\
\text { Ginés }\end{array}$ & El Sol de Madrid & $31 / 05 / 1926$ & \\
\hline 16 & $\begin{array}{l}\text { Hermenegildo Valderas } \\
\text { Galán }\end{array}$ & Soldado & Reg. Las Navas & Valdepeñas & El Sol de Madrid & $31 / 05 / 1926$ & $19 / 06 / 1926$ \\
\hline 17 & Francisco Hevia & Soldado & Reg. Las Navas & $\begin{array}{l}\text { San Julián de } \\
\text { Arbas }\end{array}$ & El Sol de Madrid & $31 / 05 / 1926$ & \\
\hline 18 & Manuel de la Mano & Soldado & Reg. Las Navas & Salamanca & El Sol de Madrid & $31 / 05 / 1926$ & $04 / 07 / 1926$ \\
\hline 19 & Francisco González Martín & Soldado & Reg. Las Navas & Lepe & El Sol de Madrid & $31 / 05 / 1926$ & $21 / 06 / 1926$ \\
\hline 20 & Evaristo Guerrero & Soldado & Reg. Las Navas & Granada & El Sol de Madrid & $31 / 05 / 1926$ & \\
\hline 21 & Francisco Soto Santos & Soldado & Reg. Ceuta & Padul & El Sol de Madrid & $31 / 05 / 1926$ & $20 / 07 / 1926$ \\
\hline 22 & Martín Civera Sanz & Soldado & Reg. Ceuta & Alcublas & El Sol de Madrid & $31 / 05 / 1926$ & $21 / 06 / 1926$ \\
\hline 23 & Francisco Martínez & Soldado & Reg. Ceuta & Abanilla & El Sol de Madrid & $31 / 05 / 1926$ & \\
\hline 24 & Luis Ventura & Soldado & Cazad. Chiclana & Traiguera & El Sol de Madrid & $31 / 05 / 1926$ & \\
\hline 25 & Miguel Trujillo Gómez & Soldado & Cazad. Chiclana & Gádor & El Sol de Madrid & $31 / 05 / 1926$ & $12 / 07 / 1926$ \\
\hline
\end{tabular}

${ }^{26}$ Hemeroteca Digital, http://hemerotecadigital.bne.es/index.vm [consulta 20 de agosto 2019]. 


\begin{tabular}{|c|c|c|c|c|c|c|c|}
\hline 26 & Albino García & Soldado & Cazad. Chiclana & Bolmir & El Sol de Madrid & $31 / 05 / 1926$ & \\
\hline 27 & Ignacio Fernández & Soldado & Reg. Badajoz & Pola de Lena & El Sol de Madrid & $31 / 05 / 1926$ & \\
\hline 28 & Santos Tornero & Soldado & Reg. Badajoz & $\begin{array}{l}\text { Siero de la } \\
\text { Reina }\end{array}$ & El Sol de Madrid & $31 / 05 / 1926$ & \\
\hline 29 & Aquilino Garrido Díaz & Soldado & Reg. Badajoz & Avilés & El Sol de Madrid & $31 / 05 / 1926$ & $24 / 07 / 1926$ \\
\hline 30 & Ramón Ollé Juan & Soldado & Reg. América & Barcelona & El Sol de Madrid & $31 / 05 / 1926$ & $07 / 07 / 1926$ \\
\hline 31 & Luis del Toro Fernández & Soldado & Reg. Vizcaya & Mula & El Sol de Madrid & $31 / 05 / 1926$ & $18 / 06 / 1926$ \\
\hline 32 & Antonio Fernández & Soldado & Reg. Vizcaya & Ricote & El Sol de Madrid & $31 / 05 / 1926$ & \\
\hline 33 & $\begin{array}{l}\text { Constantino López } \\
\text { Sánchez }\end{array}$ & Soldado & Reg. Vizcaya & Moratalla & El Sol de Madrid & $31 / 05 / 1926$ & \\
\hline 34 & José Ferrando Bernabeu & Soldado & Reg. Vizcaya & Alcoy & El Sol de Madrid & $31 / 05 / 1926$ & \\
\hline 35 & José Álvarez García & Soldado & Reg. Vizcaya & Moratalla & El Sol de Madrid & $31 / 05 / 1926$ & \\
\hline 36 & Antonio López Martínez & Soldado & Reg. Vizcaya & Esparragal & El Sol de Madrid & $31 / 05 / 1926$ & Muere \\
\hline 37 & José Herrera Cabrerizo & Soldado & Reg. Granada & Huelva & El Sol de Madrid & $31 / 05 / 1926$ & $21 / 06 / 1926$ \\
\hline 38 & Aquilino Ochando & Soldado & Tercio & $\begin{array}{l}\text { Kios. Plz Ant. } \\
\text { Martín }\end{array}$ & El Sol de Madrid & $31 / 05 / 1926$ & \\
\hline 39 & José Gelabert & Soldado & Tercio & Menorca & El Sol de Madrid & $31 / 05 / 1926$ & \\
\hline 40 & Nicolás Ruiz & Soldado & Tercio & Madrid & El Sol de Madrid & $31 / 05 / 1926$ & \\
\hline 41 & Luis Sánchez Martín & Soldado & Tercio & Plasencia & El Sol de Madrid & $31 / 05 / 1926$ & \\
\hline 42 & Benigno Ripalda & Soldado & Tercio & Valladolid & El Sol de Madrid & $31 / 05 / 1926$ & \\
\hline 43 & Pedro Anillo & Soldado & Tercio & El Gastor & El Sol de Madrid & $31 / 05 / 1926$ & \\
\hline 44 & Aquilino Cerrando & Soldado & Tercio & Alcoy & El Sol de Madrid & $31 / 05 / 1926$ & \\
\hline 45 & Germán Fraso & Soldado & Tercio & Colber & El Sol de Madrid & $31 / 05 / 1926$ & \\
\hline 46 & Manuel García & Soldado & Tercio & Sin domicilio & El Sol de Madrid & $31 / 05 / 1926$ & \\
\hline 47 & Agustín Maya & Soldado & Tercio & $\begin{array}{l}\text { Jerez de la } \\
\text { Ftra }\end{array}$ & El Sol de Madrid & $31 / 05 / 1926$ & \\
\hline 48 & Juan Román Vega & Soldado & Tercio & El Coronil & El Sol de Madrid & $31 / 05 / 1926$ & \\
\hline 49 & Antonio Vaquero Arias & Soldado & $\begin{array}{l}\text { Caz. Cdad } \\
\text { Rodrigo }\end{array}$ & $\begin{array}{l}\text { Alcázar San } \\
\text { Juan }\end{array}$ & El Sol de Madrid & $31 / 05 / 1926$ & \\
\hline 50 & Juan Heredia Muñoz & Soldado & $\begin{array}{l}\text { Reg. } \\
\text { Extremadura }\end{array}$ & Fonelas & El Sol de Madrid & $31 / 05 / 1926$ & \\
\hline 51 & Andrés Pallás & Soldado & Reg. Príncipe & Forna & El Sol de Madrid & $31 / 05 / 1926$ & \\
\hline 52 & Francisco Cepero Chaves & Soldado & Cia del Mar & Ceuta & El Sol de Madrid & $31 / 05 / 1926$ & $09 / 06 / 1926$ \\
\hline 53 & Carmelo Trujillo Velasco & Soldado & Reg. Serrallo & & El Sol de Madrid & $31 / 05 / 1926$ & \\
\hline 54 & Antonio Navarro & Soldado & Reg. Serrallo & Utrera & El Sol de Madrid & $31 / 05 / 1926$ & \\
\hline 55 & Dionisio Castor & Soldado & Reg. Serrallo & Toledo & El Sol de Madrid & $31 / 05 / 1926$ & \\
\hline 56 & Domingo Pérez & Soldado & Reg. Serrallo & Toledo & El Sol de Madrid & $31 / 05 / 1926$ & \\
\hline 57 & Francisco González Núñez & Soldado & Reg. Serrallo & $\begin{array}{l}\text { Cazalla de la } \\
\text { Sierra }\end{array}$ & El Sol de Madrid & $31 / 05 / 1926$ & \\
\hline 58 & Luis Moratalla & Soldado & Reg. Serrallo & Vara de Rey & El Sol de Madrid & $31 / 05 / 1926$ & \\
\hline 59 & $\begin{array}{l}\text { Manuel } \\
\text { Torremocha }\end{array}$ & Soldado & Reg. Serrallo & $\begin{array}{l}\text { Puente } \\
\text { Vallecas }\end{array}$ & El Sol de Madrid & $31 / 05 / 1926$ & $08 / 08 / 1926$ \\
\hline 60 & Benito Esquina & Soldado & Reg. Serrallo & Los Morales & El Sol de Madrid & $31 / 05 / 1926$ & \\
\hline 61 & José Garis Moya & Soldado & Intendencia & $\begin{array}{l}\text { Monforte del } \\
\text { Cid }\end{array}$ & El Sol de Madrid & $31 / 05 / 1926$ & $25 / 06 / 1926$ \\
\hline 62 & Mariano Ripoll & Soldado & Intendencia & Tarrasa & El Sol de Madrid & $31 / 05 / 1926$ & \\
\hline 63 & Carlos Pelegrín & Soldado & Intendencia & Zaragoza & El Sol de Madrid & $31 / 05 / 1926$ & $19 / 06 / 1926$ \\
\hline 64 & Antonio Castro & Soldado & Ingenieros & Turón & El Sol de Madrid & $31 / 05 / 1926$ & \\
\hline 65 & Juan José Ruiz Peláez & Soldado & Ingenieros & Málaga & El Sol de Madrid & $31 / 05 / 1926$ & $23 / 06 / 1926$ \\
\hline
\end{tabular}




\begin{tabular}{|c|c|c|c|c|c|c|c|}
\hline 66 & Manuel Vázquez López & Soldado & Cab. Caz. Galicia & $\begin{array}{ll}\text { Villar } & \text { de } \\
\text { Corrales } & \end{array}$ & El Sol de Madrid & $31 / 05 / 1926$ & \\
\hline 67 & $\begin{array}{l}\text { Tiburcio } \\
\text { Fernández }\end{array}$ & Soldado & Cab. Caz. Galicia & Correcillas & El Sol de Madrid & $31 / 05 / 1926$ & \\
\hline 68 & Gerardo Agudín & Soldado & Cab. Caz. Galicia & $\begin{array}{l}\text { Posada de } \\
\text { Rengos }\end{array}$ & El Sol de Madrid & $31 / 05 / 1926$ & $18 / 06 / 1926$ \\
\hline 69 & Juan Escat García & Soldado & Reg. Sicilia & Barcelona & El Sol de Madrid & $31 / 05 / 1926$ & $07 / 07 / 1926$ \\
\hline 70 & Fermín/Germán Lecuona & Soldado & Reg. Sicilia & Ibarguren & El Sol de Madrid & $31 / 05 / 1926$ & $23 / 06 / 1926$ \\
\hline 71 & Juan Martínez Espósito & Soldado & Reg. Sevilla & Viator & El Sol de Madrid & $31 / 05 / 1926$ & \\
\hline 72 & Rafael Roncero Rincón & Soldado & Reg. Las Navas & Valdepeñas & El Sol de Madrid & $01 / 06 / 1926$ & $18 / 06 / 1926$ \\
\hline 73 & Miguel Núñez/ Muñoz & Soldado & Reg. Las Navas & Lorca & El Sol de Madrid & $01 / 06 / 1926$ & \\
\hline 74 & Ignacio Paredes García & Soldado & Reg. Las Navas & Mazarrón & El Sol de Madrid & $01 / 06 / 1926$ & \\
\hline 75 & $\begin{array}{ll}\text { Francis. } & \text { Pérez } \\
\text { Poza/Coronad. } & \\
\end{array}$ & Soldado & Reg. Las Navas & Guadalajara & El Sol de Madrid & $01 / 06 / 1926$ & \\
\hline 76 & Ramón García González & Soldado & Reg. Las Navas & Balazote & El Sol de Madrid & $01 / 06 / 1926$ & \\
\hline 77 & Emilio Bonilla & Soldado & Reg. Las Navas & Mahora & El Sol de Madrid & $01 / 06 / 1926$ & \\
\hline 78 & Juan Martínez Jiménez & Soldado & Reg. Las Navas & $\begin{array}{l}\text { Zarcilla de } \\
\text { Ramos }\end{array}$ & El Sol de Madrid & $01 / 06 / 1926$ & $14 / 06 / 1928$ \\
\hline 79 & Gregorio Garavilla & Soldado & Reg. Las Navas & Chiloeches & El Sol de Madrid & $01 / 06 / 1926$ & \\
\hline 80 & Luis Val/Ranch Vicente & Soldado & Reg. Las Navas & Maranchón & El Sol de Madrid & $01 / 06 / 1926$ & \\
\hline 81 & Adolfo Campoy & Soldado & Reg. Las Navas & Caravaca & El Sol de Madrid & $01 / 06 / 1926$ & $11 / 06 / 1926$ \\
\hline 82 & José Miñarro Guerrero & Soldado & Reg. Las Navas & Lorca & El Sol de Madrid & $01 / 06 / 1926$ & \\
\hline 83 & Antonio Pérez Borbalán & Soldado & Reg. Vizcaya & Bullas & El Sol de Madrid & $01 / 06 / 1926$ & \\
\hline 84 & Domingo Martínez Pérez & Soldado & Reg. Vizcaya & El Algar & El Sol de Madrid & $01 / 06 / 1926$ & \\
\hline 85 & Genaro Cascales Alenza & Soldado & Reg. Vizcaya & Ulea & El Sol de Madrid & $01 / 06 / 1926$ & \\
\hline 86 & Antonio Pina Martínez & Soldado & Reg. Vizcaya & $\begin{array}{l}\text { Molina de } \\
\text { Segura }\end{array}$ & El Sol de Madrid & $01 / 06 / 1926$ & $19 / 06 / 1926$ \\
\hline 87 & $\begin{array}{l}\text { Miguel Fornes/Cornet } \\
\text { Rivero }\end{array}$ & Soldado & Reg. Vizcaya & Denia & El Sol de Madrid & $01 / 06 / 1926$ & $16 / 06 / 1926$ \\
\hline 88 & Melchor Amate & Soldado & Reg. Vizcaya & Murcia & El Sol de Madrid & $01 / 06 / 1926$ & $30 / 06 / 1926$ \\
\hline 89 & Isidoro Rodríguez & Soldado & Reg. Badajoz & $\begin{array}{l}\text { Cangas } \\
\text { Narcea }\end{array}$ & El Sol de Madrid & $01 / 06 / 1926$ & \\
\hline 90 & Constantino Díaz & Soldado & Reg. Badajoz & Seroiro & El Sol de Madrid & $01 / 06 / 1926$ & \\
\hline 91 & José Serrano González & Soldado & Reg. Ceuta & Sevilla & El Sol de Madrid & $01 / 06 / 1926$ & $16 / 06 / 1926$ \\
\hline 92 & Manuel Matías Moreno & Soldado & Bat. Chiclana & Chiclana & El Sol de Madrid & $01 / 06 / 1926$ & \\
\hline 93 & Ángel Esteller & Soldado & Bat. Chiclana & Benicarló & El Sol de Madrid & $01 / 06 / 1926$ & $21 / 06 / 1926$ \\
\hline 96 & $\begin{array}{l}\text { Élías } \\
\text { Dospedra/Rospepredra }\end{array}$ & Soldado & Bat. Chiclana & La Salzadella & El Sol de Madrid & $01 / 06 / 1926$ & \\
\hline 97 & Pedro Corrales González & Soldado & Bat. Chiclana & $\begin{array}{ll}\text { Soto } & \text { de } \\
\text { Valdeón } & \\
\end{array}$ & El Sol de Madrid & $01 / 06 / 1926$ & \\
\hline 98 & Manuel García Pérez & Soldado & Reg. Serrallo & $\begin{array}{l}\text { Monforte de } \\
\text { Lemos }\end{array}$ & El Sol de Madrid & $01 / 06 / 1926$ & $22 / 06 / 1926$ \\
\hline 99 & Vicente Caldero & Soldado & Reg. Serrallo & Puertollano & El Sol de Madrid & $01 / 06 / 1926$ & \\
\hline 100 & Eduardo González & Soldado & Reg. Serrallo & La Iglesuela & El Sol de Madrid & $01 / 06 / 1926$ & \\
\hline 101 & José Hernández & Cabo & Reg. Luchana & Villena & El Sol de Madrid & $01 / 06 / 1926$ & \\
\hline 102 & Miguel García Herrero & Soldado & Reg. Luchana & Alicante & El Sol de Madrid & $01 / 06 / 1926$ & $18 / 06 / 1926$ \\
\hline 103 & Juan Martínez Marzo & Soldado & Reg. Luchana & Alicante & El Sol de Madrid & $01 / 06 / 1926$ & \\
\hline 104 & Joaquín Cabrera Hilera & Soldado & Reg. Luchana & Alicante & El Sol de Madrid & $01 / 06 / 1926$ & $18 / 06 / 1926$ \\
\hline 105 & Ángel Monje Ladevesa & Soldado & Ametralladoras & Valle de Arán & El Sol de Madrid & $01 / 06 / 1926$ & \\
\hline 106 & Faustino González Longo & Cabo & Tercio & Madrid & El Sol de Madrid & $01 / 06 / 1926$ & \\
\hline
\end{tabular}




\begin{tabular}{|c|c|c|c|c|c|c|c|}
\hline 107 & Ernesto Buitrago & Cabo & Tercio & Málaga & El Sol de Madrid & $01 / 06 / 1926$ & \\
\hline 108 & Francisco López & Cabo & Tercio & Fortuna & El Sol de Madrid & $01 / 06 / 1926$ & \\
\hline 109 & Francisco Núñez Molina & Cabo & Tercio & $\begin{array}{l}\text { Fuente de } \\
\text { Cantos }\end{array}$ & El Sol de Madrid & 01/06/1926 & \\
\hline 110 & Antonio Ríos Santiago & Cabo & Tercio & La Morera & El Sol de Madrid & 01/06/1926 & \\
\hline 111 & Aberto Querol & Cabo & Tercio & Madrid & El Sol de Madrid & $01 / 06 / 1926$ & \\
\hline 112 & Pancracio Mario Asgo & Cabo & Tercio & Vicenza & El Sol de Madrid & 01/06/1926 & \\
\hline 113 & Cándido Sertores & Cabo & Tercio & Trento & El Sol de Madrid & $01 / 06 / 1926$ & \\
\hline 114 & Francisco Segarra & Cabo & Tercio & Espiel & El Sol de Madrid & 01/06/1926 & \\
\hline 115 & Julián Ayesa Recalde & Cabo & Tercio & Eznériz & El Sol de Madrid & $01 / 06 / 1926$ & \\
\hline 116 & Arturo Haye & Cabo & Tercio & Ceuta & El Sol de Madrid & $01 / 06 / 1926$ & \\
\hline 117 & Ayacops Menol & Cabo & Tercio & Alemania & El Sol de Madrid & $01 / 06 / 1926$ & \\
\hline 118 & José Reina Rodríguez & Cabo & Tercio & Archidona & El Sol de Madrid & $01 / 06 / 1926$ & \\
\hline 119 & Eduardo Laiglesia Expósito & Cabo & Tercio & Gijón & El Sol de Madrid & 01/06/1926 & \\
\hline 120 & Luis Herrero Fernández & Cabo & Ingenieros & Madrid & El Sol de Madrid & $01 / 06 / 1926$ & $01 / 06 / 1926$ \\
\hline 121 & Joaquín Bru & Cabo & Ingenieros & Villena & El Sol de Madrid & $01 / 06 / 1926$ & \\
\hline 122 & Marcelino Luceno & Cabo & Ingenieros & Acebuche & El Sol de Madrid & 01/06/1926 & \\
\hline 123 & Ignacio García Fernández & Soldado & Intendencia & Murcia & El Sol de Madrid & 01/06/1926 & \\
\hline 124 & Vicente Pérez Bermejo & Soldado & Sanidad & Viana & El Sol de Madrid & $01 / 06 / 1926$ & \\
\hline 125 & José Caballero Reyes & Soldado & Reg. Las Navas & $\begin{array}{l}\text { Puebla del } \\
\text { Maestre }\end{array}$ & El Sol de Madrid & 03/06/1926 & $\mathrm{JCR}$ \\
\hline 126 & José Pérez González & Soldado & Bat. Chiclana & Masera & El Sol de Madrid & 03/06/1926 & $12 / 07 / 1926$ \\
\hline 127 & $\begin{array}{l}\text { Bernardino Camarero } \\
\text { Martín }\end{array}$ & Soldado & Reg. Serrallo & Logrosán & El Sol de Madrid & 03/06/1926 & \\
\hline 128 & Vicente Calero Pérez & Soldado & Reg. Las Navas & Puertollano & Diario La Voz & 05/06/1926 & $19 / 06 / 1926$ \\
\hline 129 & Bartolomé Espina & Soldado & Reg. Las Navas & & Diario La Voz & 05/06/1926 & \\
\hline 130 & $\begin{array}{ll}\text { Francisco } & \text { Adriano } \\
\text { Fernández } & \\
\end{array}$ & Soldado & Tercio & & Diario La Voz & 05/06/1926 & \\
\hline 131 & Juan Martínez Jiménez & Soldado & Reg. Las Navas & & El Sol de Madrid & 08/06/1926 & \\
\hline 132 & Fulgencio García Lucas & Soldado & Reg. Las Navas & & El Sol de Madrid & $08 / 06 / 1926$ & \\
\hline 133 & Alfonso Campo García & Soldado & Reg. Las Navas & & El Sol de Madrid & 08/06/1926 & $08 / 07 / 1926$ \\
\hline 134 & Mateo Macías Moreno & Soldado & $\begin{array}{ll}\text { Bat. } & \text { Caz. } \\
\text { Chiclana } & \\
\end{array}$ & Chiclana & El Sol de Madrid & 08/06/1926 & $17 / 06 / 1926$ \\
\hline 135 & Manuel Montero & Soldado & $\begin{array}{ll}\text { Bat. } & \text { Caz. } \\
\text { Chiclana } & \\
\end{array}$ & & El Sol de Madrid & 08/06/1926 & \\
\hline 136 & Ignacio Martínez Viesca & Soldado & Reg. Badajoz & & El Sol de Madrid & 08/06/1926 & \\
\hline 137 & Blas Ruiz Rodríguez & Soldado & Tercio & & El Sol de Madrid & $08 / 06 / 1926$ & \\
\hline 138 & $\begin{array}{l}\text { Enrique Carbonell } \\
\text { Florenza }\end{array}$ & Soldado & $\begin{array}{ll}\text { Bat. } & \text { Caz. } \\
\text { Chiclana } & \\
\end{array}$ & & El Sol de Madrid & 08/06/1926 & \\
\hline 139 & $\begin{array}{ll}\text { Manuel } & \text { González } \\
\text { González } & \\
\end{array}$ & & & Eirasvedra & La Libertad & $26 / 07 / 1926$ & \\
\hline 140 & Miguel Encino & & & Murcia & Diario La Voz & 09/08/1926 & $08 / 08 / 1926$ \\
\hline 141 & José López Amate & Sgto & Ingenieros & & Diario La Voz & $07 / 04 / 1927$ & $6 / 04 / 1927$ \\
\hline 142 & Arcadio García Ruiz & & & Herrera & Diario La Voz & $22 / 04 / 1927$ & $01 / 04 / 1927$ \\
\hline 143 & Miguel Arcas Fuentes & & Reg. Art. Mixta & & Heraldo Madrid & $18 / 06 / 1927$ & \\
\hline 144 & Eleuterio Garay Gutiérrez & & Reb. Art. Mixta & & Heraldo Madrid & $18 / 06 / 1927$ & \\
\hline 145 & Paulino Ceballos Manzano & & Reg. África & & Heraldo Madrid & $18 / 06 / 1927$ & \\
\hline 146 & Desiderio Martín Pérez & & Reg. África & & Heraldo Madrid & $18 / 06 / 1927$ & \\
\hline
\end{tabular}


ALEJANDRO REY MILLÁN

\begin{tabular}{|c|c|c|c|c|c|c|}
\hline 147 & Antonio Álvarez Rodríguez & Reg. África & & Heraldo Madrid & $19 / 06 / 1927$ & \\
\hline 148 & Adolfo de la Torre Guillén & Interv. Beni Ider & & Heraldo Madrid & $18 / 06 / 1927$ & \\
\hline 149 & Juan Rebull Juana & & Tarragona & Diario Libertad & $02 / 08 / 1927$ & Agosto 1926 \\
\hline
\end{tabular}

Solamente tenemos testimonios hemerográficos de que 46 soldados regresasen a sus hogares.

Eso supone que podemos demostrar que regresó a sus hogares el 30,8\% de los soldados que fueron recuperados tras la rendición de Abd el-Krim

No tenemos forma de saber cuántos fueron cautivados a raíz del "repliegue" ordenado por Primo de Rivera en 1924.

$\square$

$<$ José Caballero Reyes: superviviente que redactó unas memorias publicadas en mayo de 2016

$<$ Soldados que volvieron a sus hogares 


\title{
Las grandes narrativas de la Historia del Arte en la España de la Transición: el caso de la Nueva Figuración Madrileña*
}

\author{
Great narratives of the Art History in Spanish Transition: the case of the \\ Nueva Figuración Madrileña
}

Beatriz García Pérez

Universidad Autónoma de Madrid

\section{Resumen}

El presente artículo analiza los clichés historiográficos que se consolidan a finales de los años setenta y comienzos de los ochenta en torno a la Nueva Figuración Madrileña para realizar una labor de desmontaje de los mismos. Se pretende, con ello, ofrecer algunas herramientas que inviten a cuestionar el marco general de discusión instituido entonces por los críticos afines al grupo, y que ayuden a deshacer la visión monolítica que ha identificado a estos críticos con los propios artistas, mostrando las fricciones y las distancias entre ambos y la relevancia historiográfica que tiene la consideración de las mismas.

\section{Palabras clave}

Nueva Figuración Madrileña, arte español contemporáneo, crítica del arte, pintura.

\footnotetext{
* Este artículo ha sido desarrollado gracias a una beca FPI-UAM y forma parte del proyecto de investigación Larga exposición: las narraciones del arte contemporáneo español para los "grandes públicos" - HAR201567059-P (MINECO/FEDER) y del grupo de investigación Arte, cine y culturas audiovisuales del mundo contemporáneo.

Beatriz García Pérez es licenciada en Filosofía por la Universidad Complutense de Madrid, en Historia del Arte por la Universidad Autónoma de la misma ciudad y Máster en Estudios Literarios, así como Máster en Historia del Arte Contemporáneo y Cultura Visual. Ha desarrollado su carrera en torno a la mediación y la gestión cultural en galerías, museos e instituciones públicas y actualmente realiza su tesis doctoral sobre la relación de Guilles Deleuze con los artistas de la Nueva Figuración Madrileña, gracias a un contrato FPI, en el Departamento de Historia y Teoría del Arte de la Facultad de Filosofía y Letras de la UAM, bajo la dirección de Patricia Mayayo Bost.
} 


\begin{abstract}
At the end of the seventies and beginnings of the eighties certain historiographic clichés where been consolidated about the New Figuration Madrileña. This article analyzes the theoretical keys that are in the root of those clichés to try to disassembly them. The propose is to offer some tools that incite to a deeper examination both of the general framework established by the critics, and the monolithic vision that has identified acratically those critics with the artists themselves. This article will point out the frictions and the distances between the critics and the artists and the historiographical relevance that the consideration of those distances could have.
\end{abstract}

\title{
Palabras clave
}

Nueva Figuración Madrileña, contemporary Spanish art, art criticism, painting.

\section{Introducción}

Nueva Figuración Madrileña (en adelante NFM) es el apelativo fundamental con que la historiografía contemporánea del arte se ha referido a aquel conjunto de artistas que comenzaba su andadura en el Madrid de los años setenta y cuyo núcleo fundamental contaba, entre sus miembros, con Carlos Alcolea, Chema Cobo, Carlos Franco, Herminio Molero, Rafael Pérez-Mínguez, Guillermo Pérez Villalta, Manolo Quejido y Javier Utray. La inscripción de este grupo de artistas en la historia del arte contemporáneo español está indisolublemente ligada a la vinculación de la NFM con una serie de críticos, intelectuales e historiadores del arte que unen su fortuna a la de estos pintores al situarse, en el marco de un incipiente sistema de las artes, como los defensores teóricos de una vuelta a la pintura de la que los artistas de la NFM parecían ser los perfectos representantes. Juan Antonio Aguirre, Juan Manuel Bonet, Francisco Rivas y Ángel González García libran, en los últimos años de la década de los setenta y comienzos de los ochenta, una contienda en defensa de la pintura que, a grandes rasgos, se producía en la triple trinchera de la defensa de la figuración, de la pintura y de la autonomía del arte frente a la abstracción 
pictórica, las prácticas conceptuales y el arte con contenido político. De manera que la NFM será presentada por estos críticos, a través de artículos en la prensa escrita y de textos en catálogos de exposiciones, como un movimiento rupturista que ofrecía una alternativa teórica y estilística a las tendencias artísticas que se habían desarrollado en la España de los años cincuenta (informalismo) y sesenta (realismos sociales y tendencias conceptuales).

En conjunto, la visión de los críticos afines a la NFM establecía un marco de discusión polarizado en el que parecía necesario posicionarse en un escenario donde había dos grandes alternativas: defender la vuelta a la pintura o preferir las tendencias no pictóricas, decantarse por la figuración o por la abstracción, situarse de parte de una idea del arte como fin en sí mismo o de parte de una visión del arte como instrumento político. El presente artículo busca señalar los problemas e inconsistencias existentes en el marco teórico que han legado los críticos de los setenta a la historiografía del arte español contemporáneo mediante una revisión profunda de sus argumentos para mostrar, por una parte, las grietas existentes en este marco de discusión y, por otra, la falacia inherente a identificar, de manera inmediata y sin formular más cuestiones, a los artistas de la NFM con sus defensores teóricos. Será el objetivo de estas páginas, por lo tanto, mostrar los motivos por los que este marco argumental y conceptual merece ser cuestionado en sí mismo, quizás incluso con más urgencia que rebatido, y como este cuestionamiento puede incidir en la creación de narrativas alternativas para el arte español de la época de la Transición. ${ }^{1}$

\section{¡Más madera, es la guerra! Exposiciones programáticas y batallas teóricas}

Para comprender la génesis de la Nueva Figuración es de una enorme importancia histórica la figura de Juan Antonio Aguirre (1945-2016), autor de una obrita publicada en 1969 por un editor menor gracias a una beca de la Fundación Juan March y que llegaría, sin embargo, a convertirse en el libro de referencia de todo un movimiento artístico y en

\footnotetext{
${ }^{1}$ Existiendo una relativa falta de consenso sobre la periodización más adecuada de la época transicional tomaremos aquí la Transición como el periodo que comienza con la muerte de Franco y que finaliza, aproximadamente, con el golpe de estado de Tejero. Esta periodización es interesante, desde el punto de vista de la situación de las artes visuales en España, porque nos permite enfocar en el marco temporal que va desde la desarticulación de las políticas culturales franquistas hasta la llegada al poder del PSOE, un periodo en el sistema del arte en nuestro país comienza a desarrollarse y dónde se producen algunos hechos decisivos que marcarían el destino del arte contemporáneo español.
} 
punta de lanza de la defensa intelectual de un cambio de paradigma teórico y estético del que también formará parte, en cierto y tardío sentido, la NFM. Se trata de Arte último. La “Nueva Generación” en la escena española, una obra en la que se expone el trabajo de una serie de pintores que encarnan, a ojos del autor, la promesa de una pintura postinformalista capaz de ofrecer una alternativa, no sólo al informalismo, sino también a los realismos sociales que se presentaban como las opciones figurativas imperantes en la España de la época. Este arte de la Nueva Generación que, tal y como señala Calvo Serraller, romperá con el pasado artístico inmediato, será aséptico en lo político y se mostrará beligerante con el typical dramatism de la pintura española ${ }^{2}$ legará, al menos, dos cosas a la NFM: su tono rupturista con ciertas tradiciones patrias y un referente fundamental: Luis Gordillo.

Juan Antonio Aguirre, que perfiló en Arte último una parte del campo teórico en que brotaría la Nueva Figuración Madrileña, dotará, asimismo, a algunos miembros del grupo, en los primeros años setenta, de un espacio físico dónde realizar sus exposiciones: se trataba de la sala Amadís, espacio expositivo dependiente de la Delegación Nacional de la Juventud, a través del Servicio de Actividades Culturales, en la época del Tardofranquismo y de la cual será director desde 1967 por un periodo total de cinco años. Será allí donde algunos artistas de grupo, como Carlos Alcolea, Rafael Pérez Mínguez, Guillermo Pérez Villalta y Carlos Franco, encontrarán un primer espacio donde exponer sus obras. Sin embargo, Amadís no es el único espacio que acoge, en sus primeros años, a estos artistas. Desde su nacimientola Galería Buades, con un jovencísimo Juan Manuel Bonet como Director Artístico, dedica exposiciones individuales, grupales y colectivas a artistas como Herminio Molero, Rafael Pérez-Mínguez, Chema Cobo, Carlos Alcolea, Carlos Franco o Manolo Quejido, quienes muestran su obra en las dos primeras temporadas de la galería, correspondientes a los años que van desde 1973 a 1975 . Además de la presencia de aquellos jóvenes pintores en galerías más o menos emergentes como Daniel, Amadís y Buades se producirán, con el cambio de década, una serie de tres exposiciones consecutivas que resultarán decisivas para la creación de la gran narrativa del arte contemporáneo español y para la consolidación teórica y fáctica de los artistas de la NFM, una consolidación en la cual jugará un papel fundamental el trabajo de una serie

\footnotetext{
${ }^{2}$ Francisco CALVO SERRALLER: Del futuro al pasado. Vanguardia y tradición en el arte español contemporáneo, Madrid, Alianza Editorial, 1988, p. 138.
} 
de jóvenes críticos y teóricos que se alinearon rápidamente a favor de esta nueva pintura, manteniendo con los artistas una estrecha relación profesional y personal y haciendo, de la pintura de estos, una beligerante defensa teórica.

Esta cercana relación con los artistas y una cierta disputa por la hegemonía teórica y por señalar el destino del arte español serán los detonantes que empujen a varios de estos críticos a la realización de exposiciones programáticas. Tal es el caso del poderoso trío 3 formado por Juan Manuel Bonet (1953-), Ángel González García (1948-2014) y Quico Rivas (1953-2008) cuando se ponen al frente de la exposición 1980, realizada durante los meses de octubre y noviembre de 1979 en la Galería Juana Mordó. Se trataba de un acto de defensa teórica y de un intento de promoción comercial de la pintura en dónde tendrían cabida artistas de la NFM, como Alcolea, Cobo, Pérez Villalta o Quejido, así como Broto, artista proveniente del grupo Trama (que desde Barcelona defendía un nuevo camino para la abstracción pictórica en una línea influida por el colour field americano y el pensamiento de Marcelin Pleynet) o pintores neoabstractos como Delgado, Enrique Quejido, Ramírez Blanco, así como dos pintores pertenecientes a la nómina de artistas de la galería: Campano y Ortuño.

Firmando 1980, lo que deseamos subrayar es el carácter estratégico y saturado de sentido de esta muestra. Tras varios años de apostar fuerte por una serie de nombres, ¿tiene algo de extraño que estemos con ellos en el ruedo expositivo? Sencillamente doblaríamos la apuesta $[\ldots] .^{4}$

Pero 1980 no era sólo el intento de elaborar "un muestrario representativo de lo que iba a ser la pintura de los ochenta" en el ámbito español, era también una llamada a excitar el mercado de los diez artistas allí presentes y un acercamiento estratégico a Juana Mordó, en una tentativa de que la dama de las vanguardias y el gran referente de la generación del cincuenta incorporará a aquellos artistas emergentes a su programación. ${ }^{5}$ Lo cierto es que todos ellos fueron intentos fallidos. A Juana Mordó el tono bravucón del brevísimo

\footnotetext{
${ }^{3}$ Victoria COMBALIA: “Arte en España 1980-1995: algunas acotaciones personales”, en A la pintura. Pintores españoles de los años 80 y 90 en la colección Argentaria, Madrid, Fundación Argentaria (Catálogo de la exposición celebrada en septiembre de 1995), 1995. Citado en Julián DÍAZ SÁNCHEZ y Ángel LLORENTE: La crítica de arte en España: (1939-1976), Madrid, Istmo, 2004, p. 103.

${ }^{4}$ Juan Manuel BONET, Ángel GONZÁLEZ GARCÍA y Francisco RIVAS: Brochure-manifiesto de la exposición 1980, Madrid, Galería Juana Mordó (Catálogo de la exposición realizada en noviembre de 1979), 1979, s.n.

${ }^{5}$ Cfr. Juan Manuel BONET: "Para un mapa de la galaxia Buades", en VV.AA.: Galería Buades. 30 años de arte contemporáneo, Valladolid, Sociedad Estatal de Conmemoraciones Culturales, 2008, pp. 39-40.
} 
texto del catálogo, que despachaba el arte de las dos décadas anteriores como mediocre y que pugnaba por que se produjera un relevo generacional en la pintura española, le causó alguna que otra incomodidad con sus pintores. Así las cosas, la galerista decidió no incorporar a ninguno de aquellos jóvenes artistas de 1980 a su galería y la colaboración con los autores de la exposición quedó teñida por un cierto barniz de tensión. En cuanto al carácter profético de la exposición que pretendía "reunir a diez pintores bajo la emblemática advocación de una nueva década" no han sido pocas las voces que han señalado su ineficacia. José Luis Brea, calificó la muestra de exposición terminal ${ }^{6}$ al considerar que, más que profetizar lo que vendría en los 80 la exposición destacaba por haber recogido lo que había sucedido en los 70. Por Su parte Kevin Power señaló la total falta de repercusión internacional de la muestra en un contexto en el que el arte español no había alcanzado, bajo su punto de vista, la mayoría de edad. ${ }^{7}$

A pesar de estos fracasos, 1980 tuvo un papel decisivo en la creación de la gran narrativa del arte español contemporáneo y supone, simbólicamente, un hito importante en la historia de nuestro arte contemporáneo y en la historia de la crítica por haber precipitado un ardiente combate entre posiciones ideológicas y estéticas muy dispares. Lo cierto es que el texto del tríptico que acompañaba a 1980, aunque recogía alguna que otra fanfarronada como la advocación de una época nueva para la pintura o la apelación abierta al mercado y el llamamiento a las instituciones a alinearse con aquellos artistas, no era especialmente provocativo ni belicoso (como si lo serían, un año más tarde, los que formaban parte del catálogo de Madrid D.F.). Aun así, una disputa que había comenzado a partir de la publicación, en el verano del 79, de un artículo de Victoria Combalia en la revista Batik sobre la crítica del arte se entrelaza de inmediato con la polémica en torno a la exposición de 1980 con conocidos resultados. ${ }^{8}$ Combalia había calificado de alambicado el estilo de aquellos críticos que se alineaban con lo que ella consideraba una no menos alambicada pintura. La respuesta de Quico Rivas en Pueblo defendía el carácter silvestre y amateur de la crítica y señalaba como sospechosa la actitud

\footnotetext{
${ }^{6}$ José Luis BREA: “Los 70 son los 90”, en Atlántica. Revista de arte y pensamiento, 16 (1997), pp. 116117.

${ }^{7}$ Kevin POWER: "Los gozos y las sombras en los ochenta", en El Paseante, 18-19 (1991), p. 84.

${ }^{8}$ Victoria COMBALIA: "La crítica desde la crítica", Batik, Barcelona, 50 (junio de 1979), pp. 13-15.
} 
de aquellos que hacen de la crítica una profesión, y no un mero ejercicio. ${ }^{9}$ Si este intercambio de pareceres entre Rivas y Combalia contribuyó a afilar algunas plumas, será la discusión reflejada en sendos artículos de Bonet y Llorens la que eleve significativamente el grado de crispación de la querella. La devastadora crítica que publica Tomás Llorens en el número 52 de Batik a la exposición 1980 enfadó a muchos. En ella se despachaba mordazmente con la exposición (a la que considera un batiburrillo vestido con verborrea pseudoautopsicoanalítica), con los críticos (a los que atribuye falta de reflexión, un carácter pretencioso y a los que acusa de ejercer como funcionarios al servicio de una nueva derecha advenediza) y con los pintores (a los que califica de torpes y a los que augura un breve futuro en la pintura). ${ }^{10}$ Tanto Juan Manuel Bonet como Ángel González García responderán airadamente en sendos textos a estas críticas. Bonet escribe para Pueblo un texto donde arremete contra los críticos que habían defendido un arte político. "Entre tanto Bozal y tanto Rubert, entre tanto Tomás Llorens y tanta traducción de Umberto Eco, entre tanto pop y tanto op y tanto medio y tanto mensaje, casi consiguen hacernos olvidar la verdad de la pintura, la necesidad y la pasión y el placer de pintar". ${ }^{11}$ Por su parte Ángel González García elabora unas acusaciones similares en el catálogo de Madrid D.F. al arte político y a "un cierto crítico de arte valenciano, secuaz a lo semiótico de un realismo social maquillado". ${ }^{12}$

Coincidiendo plenamente con el recrudecimiento del debate se presenta la segunda de las exposiciones impulsada por el poderoso trío, Madrid D.F., en cuyo catálogo, como ya se ha dicho, continúa el debate en unos términos cada vez más hostiles. Madrid D.F. era una exposición organizada por Narciso Abril, con la colaboración de Juan Manuel Bonet, en la que se buscaba dar visibilidad a los artistas de la Galería Buades para dibujar con ellos el perfil de la pintura que marcaría el destino artístico del Madrid de la época. Participaron en la muestra los pintores Juan Antonio Aguirre, Alfonso Albacete, Carlos Alcolea, Campano, Navarro Baldeweg, Ortuño, Pérez Villalta, los hermanos Quejido,

\footnotetext{
${ }^{9}$ Quico RIVAS: "Sólo tengo ojos para ti", en Francisco CALVO SERRALLER: España: medio siglo de arte de vanguardia. 1939-1985, Madrid, Ministerio de Cultura y Fundación Santillana, 1985, pp. 10011003.

${ }^{10}$ Cfr. Tomás LLORENS: "El espejo de Petronio”, Batik, 52 (noviembre 1979), pp. 6-9.

${ }^{11}$ Juan Manuel BONET: "Después de la batalla", en Francisco CALVO SERRALLER: España: medio siglo de arte de vanguardia. 1939-1985, Madrid, Ministerio de Cultura y Fundación Santillana, 1985, pp. 99-1001.

12 Ángel GONZÁleZ GARCÍA: “Así se pinta la historia del arte (en Madrid)”, en Madrid D.F., Madrid, Museo Municipal (Catálogo de la exposición realizada en octubre de 1980), 1980, s.n.
} 
Santiago Serrano y los escultores Eva Lootz y Adolfo Schlosser. En el catálogo de esta muestra Ángel González García, acometiendo contra Llorens, afirmaba defender la pintura de la "morralla ideológica" y de la "moralina sociológica" que la cercaba para localizar en ese (supuesto) distrito federal de Madrid el futuro de una pintura gozosa, retiniana y ecléctica que venía a plantarle cara a aquellas "vanguardias letales que auguraban, en 1970, la muerte de la pintura".

La reyerta teórica entre los defensores y los detractores de la vuelta a la pintura evidenciaba la existencia de dos grandes narrativas en disputa sobre el lugar que el arte debía ocupar en la sociedad y en la vida. Esta disputa debe entenderse a la luz de una época convulsa, llena de cambios políticos y sociales. Debe entenderse, así mismo, como una disputa abierta por la hegemonía teórica y el prestigio profesional en una época en la cual el sistema de las artes no estaba formado y en la que el destino del arte contemporáneo no había sido, aun, forjado por las instituciones. En estas dos grandes narrativas en disputa había, de una parte, una generación de intelectuales nacidos mayoritariamente en la España de la guerra o a comienzos del periodo dictatorial, como era el caso de Tomás Llorens (1936), Rubert de Ventós (1939) o Valeriano Bozal (1940) (aunque hay algunas excepciones como la de Victoria Combalia, nacida algo después, en 1952). Estos críticos se alinean con las diversas manifestaciones del arte que se desarrolla en la España de los sesenta y defienden la importancia del arte político: las nuevas prácticas artísticas, la denuncia pop del realismo social valenciano y el conceptual catalán son sus focos de interés. De otra parte, estaba una generación cuyos miembros son, mayoritariamente, algo más jóvenes, como Juan Manuel Bonet (1953), Ángel González García (1948), Fernando Huici (1952) o Quico Rivas (1953) (pero que también cuenta con la excepción de Juan Antonio Aguirre, nacido en 1945). Una generación (entiéndase el término en sentido laxo) que defiende la autonomía del arte respecto de la esfera política y que se alinean con los artistas que representan el regreso a la pintura generando, en el campo artístico, un espacio en disputa y estableciendo los términos de dicha disputa. La primera generación consideraba que la vuelta a la pintura y la defensa de "el arte por el arte" pecaba de relamida en sus formas y que enmascaraba, en su fondo, un proceso de olvido político de sesgo conservador. La segunda generación sentía que el pasado inmediato era oscuro y pesado y que había que formular el futuro del arte desde un lugar más aireado, dónde hubiera un lugar para la ligereza y la búsqueda del placer en el arte. Como explicaba Juan 


\section{Pablo Wert Ortega:}

Su política era la de no hacer caso al reclamo de la trascendencia [...] para poder ejercer sin trabas la libertad de hacer lo que les diera la gana, cosas como, por ejemplo, pintar [...]. Política camp que es la reivindicación de lo "estéticamente incorrecto", de un gusto insurrecto, teóricamente irreductible y risueño para abrir una brecha en los muros de la seriedad dogmática con que se abordaba, desde el resto de las posiciones, la tarea artística. ${ }^{13}$

Por supuesto que la cuestión generacional no explica la diferencia de pareceres expresada más arriba, pero tal vez si pueda arrojar alguna luz sobre una parte de su sentido: la primera generación había crecido en los peores años del régimen y pasaban, con mucho, de los 35 años cuando fallece el dictador, por su parte la generación más joven crece en la época del desarrollismo y viven con algo más de desapego la experiencia de la dictadura: son, mayoritariamente, hijos de familias cultas y acomodadas cuyas vidas no están marcadas por la experiencia más dura y terrible de la dictadura. Este hecho explica, en parte, el lugar desde el que se produce aquel intento de creación de un discurso que aspira a ignorar, por decadente y yermo, el sistema dictatorial. "Realmente nuestra forma de lucha consistía en ignorar que existía una dictadura: para nosotros ya estaba muerta y como tal nos comportábamos", afirmaba en 1987 Herminio Molero. ${ }^{14}$ Este hecho explica, igualmente, la mezcla de indignación y suspicacia que esta actitud despertaba en los críticos más comprometidos políticamente de la generación anterior.

En 1981 Ángel González García y Juan Manuel Bonet firmaban los textos del catálogo de la tercera de estas exposiciones programáticas que, como hemos señalado, serían claves en la consagración historiográfica de la NFM. Esta exposición se presentaba bajo el título de Otras Figuraciones y era una muestra comisariada por María Corral para la Sala de Exposiciones del Centro de Servicios de la Caja de Pensiones y en la que participaban artistas vinculados a la NFM como Aguirre, Alcolea, Cobo, Franco, Pérez Villalta y Quejido junto a otros representantes de la joven pintura española que no pertenecían a la línea del gordillismo, como Miquel Barceló, Alfonso Galván, García Sevilla, Pérez Juana y Francisco Soto Mesa. Los textos del catálogo mantenían el tono

\footnotetext{
${ }^{13}$ Juan Pablo WET ORTEGA: "Desengaño de la pintura", en Los esquizos de Madrid: figuración madrileña de los 70, Madrid, Museo Nacional Centro de Arte Reina Sofía (Catálogo de la exposición celebrada del 2 de junio al 14 de septiembre de 2009), 2009, pp. 49-50.

${ }^{14}$ Raúl EGUIZÁBAL: "La vida densa. Entrevista con Raúl Eguizábal", en Buades. Periódico de arte, Madrid, 10 (1987), pp. 65-71.
} 
agresivo consagrado en Madrid D.F. y señalaban, una vez más, cuáles eran los enemigos doctrinales contra los que supuestamente batallaba la pintura: Ángel González García arremetía en su texto contra las derivas abstractas de la pintura mientras que Bonet hostigaba al realismo valenciano y al conceptual, alegrándose de que hubieran llegado a su fin las "aleluyas político-conceptuales" y que hubiera emergido, en el panorama artístico nacional, pintores orgullosos de serlo. ${ }^{15}$

De esta manera y con este tono los componentes del poderoso trío marcarán el tono de la discusión sobre la pintura en la España transicional, elaborando un encendido discurso que ponía todo su esfuerzo en presentar batalla en defensa de una pintura figurativa, culta y sin carga política, frente a cualquier otra opción artística. Se trataba, en fin, de librar los combates intelectuales que presentaba una época convulsa y en la que el destino de la institución arte estaba aún por forjarse. Ahora bien, aquella primera aproximación historiográfica, dado que se encontraba en una posición abiertamente combatiente y demasiado atravesada por la pugna por la hegemonía teórica, había puesto el acento en explicar la NFM, fundamentalmente, como un movimiento a contracorriente que ejecuta un alejamiento explícito de las metáforas pictóricas e históricas imperantes en la España de las dos décadas precedentes. Resulta indispensable hacer notar, llegados a este punto, que esta aproximación resulta notablemente sesgada por cuanto ha tendido a explicar la actividad artística del grupo desde un punto de vista que podríamos definir provisionalmente de historiografía negativa o reactiva: es decir han pretendido explicar lo que estos artistas hacían, definiendo, no tanto lo que propiamente hacían, como contra quién o contra qué lo hacían, en un proceso dónde, por una parte, quedaban ocultos y silenciados muchos elementos interesantes de la práctica de estos artistas y por otra parte, se teatralizaba un triple combate con las prácticas artísticas de las décadas anteriores: contra la abstracción informalista, contra los realismos sociales y contra los comportamientos conceptuales. Se trata de un combate cuyo alcance y sentido sería interesante, hoy en día, poner en perspectiva para, desarmando los clichés historiográficos que aquella batalla por el poder consolidó, encontrar nuevas perspectivas historiográficas desde la que observar la actividad de los artistas vinculados a la NFM.

\footnotetext{
15 Otras figuraciones, Madrid, Caixa de pensiones (Catálogo de la exposición celebrada en diciembre de 1981), 1981, s.n.
} 


\section{La retórica del antagonismo: enemigos muertos y falsas batallas}

Como hemos visto, el marco de discusión creado por el poderoso trío y sus antagonistas teóricos se planteaba en unos términos fuertemente polarizados, un grupo se enfrentaba a otro y de esta manera se libraba, en los periódicos y galerías, una batalla por la hegemonía teórica y por el poder discursivo. En cierto sentido, podríamos considerar que la retórica del antagonismo era inherente a ciertos códigos dualistas del ambiente intelectual que reinaba antes de que una cierta actitud posmoderna se asomara a los pensares. Ya, en este sentido, destacaba Javier Montes, con muy buen criterio, como debe ser entendido como significativo el hecho de que Juan Manuel Bonet hubiera escrito para el Periódico de arte, que publicaba Buades, un artículo sobre Satie dónde ubicaba al artista por el lugar combatiente que ocupaba con respecto a otros y lo definía, por tanto, como "antiwagneriano en 1887, antidebussysta en 1908, antiraveliano en 1915". ${ }^{16}$ Efectivamente, esto es sólo un ejemplo de cómo la retórica del antagonismo, caracterizada por propugnar visiones polarizadas de los hechos, marcaba el tono de los discursos del poderoso trío, cuyo estilo dialéctico estaba marcado por los posicionamientos combatientes, los análisis dicotómicos y las claves de un pensamiento dialéctico pasado por el peculiar aire de la época y descargado de cualquier rastro de materialismo.

Detengámonos, por un momento, a analizar esta problemática retórica moderna del antagonismo que hemos detectado como fundamental para esta historiografía negativa: desde el punto de vista de muchos de aquellos críticos parece que el vivo colorido de obras de los artistas de la NFM cobraba sentido en la medida en que se alejaba de la tradición patria de la pintura negra, que su estilo y temas se explicaban fundamentalmente por un apartamiento explícito de la veta brava que Tàpies había recogido de Goya, que, desde luego, estos pintores regresan a lo figurativo en oposición a la proliferación y hegemonía de la pintura abstracta en la década de los cincuenta. Parecía, de igual manera, que si estos pintores ejercitaban la pintura era como una forma de rechazo al conceptual y que escogían temas asépticos en lo político porque estaban enseñando a los valencianos cómo usar el pop sin banalizarlo con consignas ideológicas. Se trata, en fin, de un conjunto de premisas que crean, en torno al grupo, toda una narrativa basada en la existencia de una serie de supuestos posicionamientos combativos, exagerando enormemente los

\footnotetext{
${ }^{16}$ Javier MONTES: "El aire de Buades”, en VV.AA. Galería Buades. 30 años..., p. 68.
} 
aspectos agonísticos de la práctica artística de estos pintores, al tiempo que silenciaban muchas experiencias, matices, temas y momentos que no habrían cabido cómodamente en dicha narrativa de conflictos.

La cuestión es que parece muy posible que los críticos que defienden a la NFM, modernos por su estructura cognoscitiva y estilo intelectual, formados, en su mayoría, bajo el influjo de un marxismo dialéctico (en el que luego, efectivamente, no ejercen) estuvieran escribiendo sobre artistas que creaban sus obras y regían sus sensibilidades con coordenadas bien diferentes y, tal vez, mucho más cercanas a la sensibilidad posmoderna que a la moderna. Si tal fuera el caso los críticos, usando la palabra como medio y desde un pensamiento que funcionaba en clave moderna, habrían escenificado una batalla que no existía para los artistas, quienes trabajan desde un espacio mucho más cercano a la hibridación posmoderna. Como señala Daniel Verdú Schumann:

Paradójicamente, aunque la pintura que propugnaban se moviese en un terreno ambiguo entre la modernidad y la posmodernidad, la propuesta de los tres comisarios se realizaba desde los postulados de la modernidad triunfante [...]. La filiación moderna de González y Bonet (no así en Rivas, mucho más próximo a postulados posmodernos) se percibe nítidamente tanto en sus propias declaraciones como en el trato despectivo dado al arte de las décadas anteriores, característico de ese espíritu darwinista de la vanguardia [...]. ${ }^{17}$

En este sentido, es interesante analizar el clima teórico antes de la aparición de la NFM y durante su desarrollo para matizar algunas afirmaciones o presuposiciones que conformaban el punto de partida de aquellos primeros críticos. Los años 50 españoles se han identificado sistemáticamente con la consagración del informalismo, que quedaba oficialmente reconocido en el Congreso de Arte Abstracto celebrado en Santander en 1953. Los artistas que nos ocupan que, debemos recordar aquí, comenzaba su andadura en el Madrid de los años setenta, han sido frecuentemente presentados por el poderoso trío como un grupo que se caracterizaba por abrazar una pintura figurativa, y que se situaba, por lo tanto, al margen de las convenciones estéticas imperantes en la época, marcadas por el interés por el informalismo y la abstracción. En el catálogo de la exposición Otras Figuraciones, celebrada en 1981, Ángel González García seguía intentando defender la vigencia de las pugnas entre figuración y abstracción. "Habían pasado diez años desde la

\footnotetext{
17 Daniel A. VERDÚ SCHUMANN: Crítica y pintura en los años ochenta. Madrid, Universidad Carlos III: Boletín Oficial del Estado, 2007, p. 173.
} 
disolución de El Paso, y sin embargo, en el Madrid de 1970, la generación del cincuenta, la generación abstracta, seguía siendo lo más relevante y lo más "visible" del arte anterior". ${ }^{18}$ Sin embargo, esta imagen de España como un desierto informalista resulta poco sostenible cuando llevamos la vista más allá de los textos de Bonet o García. De hecho, numerosos testimonios constatan que la crisis del informalismo español se produjo en los primeros años de la década de los sesenta, una década a lo largo de la cual diversos artistas y grupos ensayan, ya, las más variadas salidas del camino informalista.

Carlos Areán en su libro Treinta años de arte español (1943-1972), publicado en 1972, hablaba ya del agotamiento del arte abstracto a comienzos de los años 60 cuando "algunos de los grandes maestros abstractos, incluido Tápies, dejaron de plantearse un nuevo problema en cada obra y se limitaron a resolver una vez más los que habían hallado acertada solución en años anteriores". ${ }^{19}$ En 1966, Vicente Aguilera Cerni confirmaba ya la crisis del informalismo en su obra Panorama del nuevo arte español como también lo haría Manuel García Viño en su obra de 1969, Pintura española neofigurativa. "Nuestra operación de recorte histórico no es arbitraria o gratuita. Las artes plásticas abandonan, a partir de 1960, el informalismo introvertido de la década anterior”, afirmara Simón Marchán en la frase inicial de la introducción de Del arte objetual al arte de concepto, publicado en 1972. De manera que el enemigo informalista, contra el que parece que luchaban los críticos de los años 70, había pasado hacía tiempo a mejor vida. La pretendida batalla era, por tanto, más bien la escenificación de una lucha simbólica por la hegemonía teórica y una lucha por el mercado del arte, que sí seguía dominado por el informalismo de la generación del cincuenta.

Podemos preguntarnos, entonces, si algo similar sucedía con otras de las batallas teóricas que libraban aquellos críticos. Analizadas desde la perspectiva actual podemos decir que aquellas hostilidades tenían un respaldo real y una imbricación con el pensamiento de los pintores de la NFM mucho menos sólido de lo que la lectura de los textos de la época nos podría hacer pensar. Tal es el caso de la batalla contra el conceptual. $\mathrm{Si}$ bien es cierto que personajes vinculados a la NFM como Juan Antonio Aguirre

\footnotetext{
18 Juan Manuel BONET: "Un cierto Madrid de los setenta", en 23 artistas. Madrid años 70, Madrid, Sala de exposiciones de la Comunidad de Madrid (Catálogo de la exposición realizada de febrero a abril de 1991), 1991, p. 13.

${ }^{19}$ Carlos AREAN: Treinta años de arte español (1943-1972), Madrid, Guadarrama, 1972, p. 36.
} 
considerarían el conceptual como "un verdadero derroche de chorradas" no parece que su posición pueda presuponérsele a la totalidad de los críticos, ni muchísimo menos a los artistas a ella vinculados. La valoración de Bonet sobre el panorama de los setenta nos permite matizar esta idea: "El ángulo más nítido de aquella escena [refiriéndose a la de 1970] lo integraban los geómetras de diversa extracción, los poetas visuales o experimentales, los Zaj, y algún solitario como Lugán o Valcárcel Medina”. ${ }^{20}$ De manera que, más allá de las diatribas contra el conceptual más politizado que venía de Cataluña, ni siquiera el propio Bonet miraba con el recelo que cabría suponer otros comportamientos "alternativos". Contamos, no cabe duda, con no pocas afirmaciones que señalan una significativa distancia entre los conceptuales y los nuevos figurativos de Madrid. En 2008 Guillermo Pérez Villalta escribía:

\footnotetext{
Buades llegó en un momento en el que personalmente estaba cambiando: me planteaba un nuevo modo de entender la pintura, el cuadro, en un momento en que el dogmatismo conceptual campaba por el mundo. También los aspectos estéticos de este mundo cambiaron para mí; algo así como pasar del hipismo al glam, de la Increíble Street Band a Bowie y a Roxy Music; de la protesta a una actitud más hedonista, irónica y quizás dramática. ${ }^{21}$
}

Por su parte, y como ya hemos señalado, los teóricos afines al conceptual, que trabajan desde una metodología fuertemente comprometida con el marxismo, no dejarían de señalar lo relamido del estilo literario de los críticos afines a la NFM, remarcando así notables diferencias entre ambos, como lo haría Victoria Combalia en su conocido artículo en Batik:

Coincidiendo con una joven generación madrileña de pintores que comenzaron trabajando influidos por Gordillo y cuyas obras retoman la figuración, el gusto por el trompe l'oeil, las veladas alegorías y un interés desenfrenado por el sujeto, han salido a la luz unos textos, bien distintos, por cierto, a los que se escriben en Barcelona. Su base radica en un intento por escapar al formalismo reinante mediante un tono poético y muy personal y muchas veces tan alambicado como las propias pinturas que "comentan". Un extracto del escrito de Patricio Bulnes para Alcolea nos dará una imagen de esta tendencia: "La topologización del pintor, ese naufragio en la superficie, pasa entonces por la fabricación de un arco bizco, dar en la diana es el fraude de la pintura, pintar en cambio,

\footnotetext{
${ }^{20}$ Juan Manuel BONET: "Un cierto Madrid...”, p. 13.

${ }^{21}$ Guillermo PÉREZ VILLALTA: "Buades”, en VV.AA., Galería Buades. 30 años ..., p. 152.
} 
"Matisse de día, Matisse de noche" es el arquero frustrado, el arquero dando con el pie en el suelo $[\ldots] "{ }^{22}$

Sin embargo, esta separación no fue nunca rotunda y existen, fuera de las disputas sobre el papel, numerosas ocasiones de mezcla y encuentro entre los artistas, que se encontraban en una posición bastante menos combatiente que los críticos que los defendían. Mientras que los críticos usaban la palabra para batallar por su fortuna profesional en busca de un lugar hegemónico en el sistema de las artes, los artistas trabajaban desde las más diversas prácticas explorando un ámbito de acción mucho más extenso de lo que podría parecer cuando leemos al poderoso trío. Como reseñaba María Escribano:

El arte conceptual, al que los futuros figurativos se sintieron muy próximos, estuvo representado ya por Luis muro en la exposición inicial de Amadís que organizó Juan Antonio Aguirre. En la misma galería, en 1971, expuso Nacho Criado, amigo de todos ellos. Paz Muro era seguida y admirada por todos. Por esos mismos años Antoni Muntadas y Alberto Corazón expondrían varias veces en la Galería Vandrés. ${ }^{23}$

No deja de resultar interesante, en este sentido, el hecho de que fuera, precisamente, el conceptual Alberto Corazón quien diseñara como logo de la galería Buades un tubo de pintura. Una galería en cuya primera exposición conviven (precisamente bajo la batuta de Juan Manuel Bonet) figurativos y conceptuales evidenciando que era con el conceptual político de Cataluña, defendido por Combalia y Bozal, con el que el poderoso trío no se sentía cómodo y con el que los pintores de la NFM menos tenían en común por su postura combatiente. Sin embargo, existía una vinculación de los artistas de la NFM con respecto a ciertos comportamientos conceptuales: Resulta reseñable, en este sentido, la absoluta fascinación que muchos de los artistas de la NFM sentían por Duchamp o Cage, la importante presencia de algunos de ellos en Los Encuentros de Pamplona, así como la existencia de prácticas extrapictóricas que coqueteaban con las actitudes del conceptual de algunos de ellos. No olvidemos que José Vericat no duda en calificar la fotografía de Rafael Pérez- Mínguez de conceptualismo-figurativista, ${ }^{24}$ de hecho "Rafael PérezMínguez fue uno de los primeros en fijarse en un conceptual mallorquín llamado Ferrán

\footnotetext{
${ }^{22}$ Victoria COMBALIA: "La crítica...", p. 14.

${ }^{23}$ María ESCRIBANO: "Pinturas que nunca se hubieran hecho", en Los esquizos de Madrid..., pp. 21-22.

${ }^{24}$ José VERICAT: “El arte contra el arte”, en Los esquizos de Madrid..., pp. 93-105.
} 
García Sevilla, que reivindicaba al Dalí o al Giorgio de Chirico tardíos y que en una librería de París descubrió asombrado la similitud de su mirada con la Pier Klossowski”. ${ }^{25}$

De la misma manera, podemos apuntar que la separación entre figuración y abstracción no parece tan severa si, por un momento, olvidamos las rencillas textuales. En 1983, Pilar Rubio y Rosa Olivares señalaban, en un artículo publicado en el segundo número de la revista Lápiz, la presencia en la escena artística española de una serie de "jovencísimos" pintores, entre los que se encontraba Chema Cobo, que utilizaban "la libertad como tema y la alegría como estilo", pintores de los que dirán que son "un puente colgante que comunicaba la abstracción y la figuración". No por casualidad los artistas elegidos por el poderoso trío para la muestra 1980 suponían, en cierta medida, "una síntesis conciliadora del debate figuración/abstracción". ${ }^{26}$ En fin, no se trata aquí tanto de negar la premisa de que existieran una serie de desavenencias teóricas y personales entre varios grupúsculos intelectuales y artísticos de la época, como de negar la premisa de que el marco de discusión instituido entonces por el poderoso trío sea el más pertinente para entender el grueso de la historia de la NFM. Como hemos visto, la retórica del antagonismo desplegada por los críticos está, en cierto modo vacía, o, por lo menos, hace aguas. La realidad artística de la España de la época de la Transición era mucho más compleja, ni en los setenta reinaba el informalismo, ni el conceptual estaba en su momento de mayor gloria cuando el poderoso trío defiende la pintura, ni los pintores a los que defienden eran sólo pintores. Además, cabe objetar a aquellos primeros críticos el hecho de que, en su obsesión por defender la pintura y por asegurarse un puesto en el sistema del arte, pasaron por alto la atención a comportamientos creativos alejados del paradigma retiniano como, por ejemplo, la interesantísima práctica poética de Javier de Utray o la vinculación de Herminio Molero con la música.

Sin embargo, y a pesar de todo esto, la inscripción de la NFM en la gran narrativa del arte contemporáneo español está indisolublemente ligada a la vinculación de estos pintores con los críticos arriba referidos y la fortuna de ambos, en la historia del arte español, está entrelazada con notable fuerza. Sería interesante desarmar la red que une, de manera tan sólida, a los críticos del grupo con los artistas de la NFM. A pesar de las

\footnotetext{
25 Juan Manuel BONET: "Para un mapa de...," p. 27.

${ }^{26}$ Daniel A. VERDÚ SCHUMANN: Crítica y pintura ..., p. 157.
} 
innegables amistades, las notables afinidades y algunos clarísimos intereses compartidos hay también un cierto desajuste entre las sensibilidades y las necesidades de ambos. Refiriéndose a la exposición 1980, en donde Pérez Villalta expone un solo cuadro que "roba" a su individual en Vandrés, el artista comenta el abismo existente, en un cierto sentido, entre los pintores y los críticos:

La imagen que me dio aquello, allí colgado en Juana Mordó y con ese aire que le quisieron dar era que se trataba un asunto de críticos, pero no de pintores; una especie de oficialización del crítico por encima del pintor. [...] Las exposiciones como estas han sido importantes de cara a este tinglado de la cultura del papel-periódico. ${ }^{27}$

No esta la única ocasión en que Pérez Villalta señala estas diferencias, hablando sobre el comisariado de 1980 afirmaba que "La elección de obras era desbarrante en algún aspecto, y estuvo muy influenciada por esa moda de la pintura 'matissiano-francesa' que nos estuvo invadiendo a finales de los 70 de una manera exhaustiva, dirigida aquí por Juan Manuel Bonet". ${ }^{28}$ Una moda que debe entenderse a la luz de la influencia teórica que tuvo en España la actualización que Marcelin Pleynet hiciera de Matisse y que, claramente, respondía al gusto de los críticos antes que al de los pintores. Afirmaciones como estas denotan que la postura de los críticos y de los artistas no era plenamente coincidentes. Una serie de significativas fisuras nos invitan a preguntarnos hasta qué punto el poderoso trío hablaba por los artistas de la NFM, cuántos elementos de la práctica de estos artistas no habrán quedado velados en sus discursos por no caber cómodamente en la narrativa del antagonismo.

Los críticos afines a la NFM escenificarán durante los últimos años de la década de los setenta y primeros años de la década de los ochenta una serie de batallas teóricas en las que se jugaban la hegemonía teórica y, con ella, su destino en un incipiente sistema de las artes. En esta batalla se exageran y se teatralizan una serie de desavenencias que sólo cobran pleno sentido en el juego dialéctico y en el contexto de una disputa por la influencia teórica. Los críticos libraban, en términos de una dialéctica moderna, la batalla por una pintura cuyos protagonistas habían cruzado el umbral de la posmodernidad. La poderosa influencia de los textos de aquellos críticos en la narrativa del arte español

\footnotetext{
${ }^{27}$ Guillermo PÉREZ VILLALTA: "El futuro sólo se ve desde el campo de la pintura”, La luna de Madrid, 14 (enero de 1984), p. 30.

${ }^{28}$ Ibid.
} 
BEATRIZ GARCÍA PÉREZ

contemporáneo ha afectado no sólo a la historia de la crítica si no a la historia de la NFM. Hemos establecido aquí algunas ideas para continuar separando amabas historias y para avanzar en el desarrollo de una narrativa de la NFM cuyo marco teórico no reproduzca el que habían instituido aquellos poderosos críticos. 


\title{
Las prácticas de un historiador: Carlos E. Corona Baratech
}

\author{
The practices of an historian: Carlos E. Corona Baratech
}

\section{Eduardo Acerete de la Corte}

Universidad de Zaragoza

\section{Resumen}

La trayectoria de Carlos E. Corona, por su singularidad historiográfica, nos permite adentrarnos en la realidad del modernismo y de la reorganización de la historiografía en la posguerra, así como su evolución durante todo el franquismo. En el presente artículo, a modo de introducción, abordamos sólo su proceso formativo y de consolidación académica, desde que inició su licenciatura al final de la guerra hasta que obtuvo la cátedra de historia moderna y contemporánea e historia general de la cultura en la Universidad de Zaragoza.

\section{Palabras clave}

Historiografía, modernismo, franquismo, oposiciones a cátedra, historiadores.

\begin{abstract}
The trajectory of Carlos E. Corona, for its historiographical singularity, allows us to delve into the reality of modernism and the reorganization of post-war historiography, as well as its evolution throughout the Franco era. In the present article, by way of introduction, we address only his formative process and academic consolidation, since he began his degree at the end of the war until he obtained the chair of modern and contemporary history and general history of culture at the University of Saragossa.
\end{abstract}

\section{Key Words}

Historiography, modernism, Franco’s Era, opposition to professor, historians. 


\title{
Introducción
}

El cuatro de febrero de 1981, Carlos E. Corona Baratech elevaba una pequeña carta al rectorado de la Universidad de Zaragoza:

\begin{abstract}
Tengo el honor de dirigirme a V.S.Ilma rogándole acepte mi dimisión como Director del Departamento de Historia Contemporánea, que he tenido a mi cargo desde su formación. Después de 28 años transcurridos desde mi acceso a la cátedra, el cansancio por las preocupaciones inherentes a dicho cargo, me inclinan a desear solamente la dedicación a la enseñanza de las asignaturas que me corresponden, a la tarea de la investigación y a la dirección de las tesis de licenciatura y de doctorado. ${ }^{1}$
\end{abstract}

Habían transcurrido dieciséis años desde el decreto de 1965 que reconfiguraba la estructura universitaria en España y dos menos desde que asumió el cargo de director. Veintiocho, como el mismo recordaba, desde su acceso a la cátedra en 1953. Pero el cansancio y las preocupaciones inherentes al cargo, no eran las mismas entre ambas fechas. No podían serlo. La lenta evolución de la historiografía, pero también de la sociedad española, generaban un marco distinto al que amoldarse, enfrentarse o ignorar. No podían serlo porque ser catedrático y hacer historia, no quedaba delimitado por los mismos contornos en la década de los cincuenta que en 1981.

Nos proponemos, a través de quien fuera el modernista catedrático de contemporánea en el distrito universitario zaragozano, acercarnos a diversos problemas de la historiografía española durante el franquismo. Entre ellos: la formación de un modernista en la década de los años cuarenta; el acceso a una cátedra en los cincuenta y la investigación modernista; o los cambios en el modernismo y los procesos de obsolescencia. Una obsolescencia historiográfica y una desadecuación política en democracia visible a la altura de 1981 que nos lleva a plantearnos, a través de un hombre, las variaciones institucionales y en las prácticas producidas en la historiografía española desde que Carlos Corona asentase en la cátedra zaragozana su lugar en la profesión. Recorreremos por tanto tres grandes lugares: la formación y la creación de un catedrático; el asentamiento disciplinar y la consolidación de una especialización investigadora; y el lento y definitivo proceso de obsolescencia.

Por la extensión establecida en las bases de la presente comunicación,

\footnotetext{
${ }^{1}$ ACRUZ, Expediente del catedrático Carlos E. Corona Baratech, Carpeta 4565, pliegos sin foliar.
} 
restringiremos el texto al proceso formativo y el desarrollo de la trayectoria profesional de Carlos Corona, desde su licenciatura hasta la oposición por la que fue nombrado catedrático de Historia moderna y contemporánea en Zaragoza.

\section{De Jaca a la Cátedra: la formación de un catedrático (1939-1953)}

Acabada la guerra y con la apertura del nuevo curso académico de 1939-1940, Carlos Corona comenzó su periodo formativo en la Universidad de Zaragoza. Habiendo superado las pruebas de acceso y con Premio Extraordinario en Bachillerato en $1936^{2}$ el comienzo de una guerra en la que intentó alistarse como voluntario en el ejército de Franco, paralizó el comienzo de su carrera hasta la reapertura de los cursos académicos una vez declarado el final de la contienda. En tan sólo tres cursos académicos, Carlos Corona cubrió la antigua licenciatura en Filosofía y Letras, especializándose en la sección de historia. Una rapidez en la que se entrelazarían dentro de su marco formativo varios aspectos. En primer lugar, la realidad académica de la inmediata posguerra, nos presenta una universidad en proceso de reconfiguración en dos vertientes. Por un lado, la universidad sumida en procesos de depuración, reinstitucionalización y cobertura de los lugares académicos, adolecía de la ausencia de cabezas capaces de dotar a los estudiantes de herramientas para el proceder investigador. Por otro lado, en cambio, los debates sobre la Ley de reforma universitaria y la que sería la consiguiente reordenación de 1943, podían incidir en las perspectivas de quienes desde 1939 cubrieron las antiguas licenciaturas por un hipotético cambio en los planes y la consiguiente desadecuación de la titulación en curso con la nueva licenciatura reorganizada.

Además, las características de la reordenación universitaria, en la que debemos atender a las competencias conferidas al CSIC y las reconocidas a la universidad, favorecieron la limitación de competencias de los nuevos licenciados. ${ }^{3}$ Una universidad

\footnotetext{
${ }^{2}$ Un acercamiento a la trayectoria de Carlos Corona en Jesús LONGARES, "Carlos E. Corona Baratech en la Universidad y en la historiografía de su tiempo", Introducción a Carlos CORONA BARATECH, José Nicolás de Azara, Universidad de Zaragoza, Zaragoza, 1987, Gustavo ALARES LÓPEZ, Diccionario biográfico de los consejeros de la Institución "Fernando el Católico", 1943 1984: una aproximación a las elites políticas y culturales de la Zaragoza franquista, IFC, Zaragoza, 2008.

${ }^{3}$ Ley de 24 de noviembre de 1939 creando el Consejo Superior de Investigaciones Científicas en B.O.E. Núm. 332, 28-11-1939, pp. 6668-6671 Gonzalo PASAMAR ALZURIA, Historiografía e ideología en la postguerra española. La ruptura de la tradición liberal, PUZ, Zaragoza, 1991, y Mariano PESET REIG, "La ley de ordenación universitaria de 1943" y Alicia ALTED VIGIL, "Bases políticoideológicas y jurídicas de la universidad franquista", ambos en Juan José CARRERAS ARES y Miguel
} 
mermada y en proceso de recomposición de sus cabezas sumada a los contornos que la dictadura fascista le estableció, no albergando más competencia que la docente, imprimieron las características de los curricula de los licenciados de posguerra. Es, desde esta delimitación, desde donde comprendemos la carrera de Carlos Corona. Ejemplifica un proceso de rápida obtención del título, en donde la asunción de contenidos y datos y el contacto con algunas técnicas- como la paleografía y diplomática- llevaban a definir en los años del doctorado, entre Madrid y el centro en que ocupaban ayundantías, sus formas de hacer historia, volcando en su tesis doctoral las primeras muestras de su labor de historiador. $^{4}$

Si bien, desde Madrid, realizaba una tesis de corte modernista, la trayectoria institucional de Carlos Corona anduvo entre el modernismo y el medievalismo, al igual que parte de su actividad investigadora. Esta no es una trayectoria atípica en la historiografía de los años cuarenta y para comprenderla debemos atender, previamente, a la evolución del modernismo en la década de los cuarenta. Antes del golpe de Estado de julio de 1936 el modernismo era prácticamente inexistente en la Universidad española, terreno profesional donde el medievalismo ocupaba los principales lugares y las prominentes cabezas de la historiografía. Un hecho que marcó, claramente, la reordenación universitaria de posguerra.

Los pocos estudios modernistas existentes, a excepción de algunos nombres como Eduardo Ibarra, habían estado vinculados al incipiente americanismo desarrollado durante la Segunda República. ${ }^{5}$ Ausencia de una tradición modernista que marcó los

Ángel RUIZ CARNICER, La Universidad española bajo el régimen de Franco (1939-1975), IFC, Zaragoza, 1991, pp. 125-158 y 95-124, respectivamente. Carolina RODRÍGUEZ LÓPEZ, La Universidad de Madrid en el primer franquismo: ruptura y continuidad (1939-1951), Biblioteca del Instituto Antonio de Nebrija, Madrid, 2002. También apuntado en Gonzalo PASAMAR ALZURIA, Historiografía e ideología... La ley en BOE, Ley de 29 de julio de 1943 sobre ordenación de la Universidad española, 31-07-1943, pp. 7406-7431.

${ }^{4}$ Una visión general de la historiografía durante el franquismo en Ignacio PEIRÓ MARTÍN, Historiadores en España. Historia de la historia y memoria de la profesión, PUZ, Zaragoza, 2013, ÍD. En los altares de la Patria: la construcción de la cultura nacional española, Akal, Madrid, 2017; y en colaboración con Miquel Á. MARÍN GELABERT, "Catedráticos franquistas, franquistas catedráticos. Los 'pequeños dictadores' de la Historia", en Francisco Javier CASPISTEGUI e Ignacio PEIRÓ (eds.), Jesús Alonso: el maestro que sabía escuchar, Pamplona, EUNSA, 2016, pp. 251-291.

${ }^{5}$ Sobre el americanismo previo a la guerra Palmira VÉLEZ, La historiografía americanista en España, 1755-1936, Ibreroamericana \& Frankfurt am Main, Vervuert, 2007; Salvador BERNABÉU ALBERT, "Los americanistas y el pasado de América: tendencias e instituciones en vísperas de la Guerra Civil", en Revista de Indias, vol. LXVII, 239 (2007), pp. 251-282. La ruptura de la tradición americanista, en torno al ejemplo de Américo Castro y la revista Tierra Firme, en Leoncio LÓPEZ-OCÓN CABRERA, "La 
inicios del proceso de institucionalización de la historia moderna en la Universidad española. Falta que se evidencia si abordamos la práctica histórica del modernismo de principios de los años cuarenta, que no sigue sino las pautas de la actividad medievalista: estudios políticos y diplomáticos que tan sólo se diferencian del medievalismo en la delimitación del marco cronológico, pero que interrogaron y analizaron de un modo similar las fuentes, aunque sin una jerarquía de objetos de investigación, sin ortodoxia en el manejo de las fuentes, ni delimitación del campo de saber y, además, carentes de circuitos profesionales. ${ }^{6}$

Así, como expusiera Miquel Marín, ${ }^{7}$ en estos primeros años de reorganización del mundo académico no iba a ser extraño que quienes optaban a la cátedra lo hicieran indistintamente a las de historia medieval, de historia de España, o de Historia Moderna y Contemporánea. Aunque no nos centraremos en esta cara del proceso, sino en el camino transitado por quienes en aquellos años terminaban su carrera universitaria y comenzaban a dar los primeros pasos en la actividad investigadora (entre 1943-1947): la senda de los adjuntos de los años cuarenta, que fue la de Carlos Corona. A comienzos de los años cuarenta, cuando Carlos Corona finaliza su licenciatura, las posibilidades de publicación y desarrollo de una carrera profesional eran mayores entre quienes cultivaban la disciplina medievalista. O lo que es lo mismo, las posibilidades de reproducción del medievalismo eran mayores que las del modernismo naciente.

Si observamos a quienes accedieron a la cátedra entre mediados de los años cuarenta y el final de la década de los cincuenta advertimos un proceso de definición disciplinar de los jóvenes doctorados. A caballo entre el medievalismo predominante y el modernismo en proceso de institucionalización, los jóvenes investigadores fueron perfilando sus carreras atendiendo a las posibilidades de campo. Para comprenderlo, observaremos dos aspectos: por un lado, el proceso de institucionalización y la apertura de condiciones, dentro del modernismo, de una consolidación académica y; por otro, y de

ruptura de la tradición americanista en el CSIC: la evanescencia de la revista Tierra Firme", en Arbor, vol. 160, 631-632 (1998), pp. 387-411.

6 Miquel À. MARÍN GELABERT, La historiografía española de los años cincuenta. La institucionalización de las escuelas disciplinares 1948-196, Tesis doctoral, Zaragoza, 2010, pp. 988989.

${ }^{7}$ Para comprender el proceso de institucionalización y el desarrollo de las escuelas disciplinares del modernismo en los años cuarenta y cincuenta seguimos los planteamientos expuestos en su tesis doctoral por Miquel À. MARÍN GELABERT, Ibid. 
la mano de este primero, el surgimiento de circuitos de publicación.

En el proceso de institucionalización del modernismo en los años cuarenta, encontramos dos vertientes. Por un lado, desde el primer momento, se fueron abriendo posibilidades para el desarrollo investigador modernista con la constitución del CSIC. Aunque, eso sí, controlado desde su nacimiento hasta los años sesenta, principalmente, por los catedráticos matritenses. Así, desde las primeras Memorias del CSIC observamos desfilar, como regentes de los Institutos de investigación histórica del Patronato Menendez Pelayo. Encontramos a Pío Zabala como director del Jerónimo Zurita y encargado de la sección de historia moderna y contemporánea; Antonio de la Torre en el mismo instituto como vicedirector y llevando las riendas de la sección de historia medieval; mientras que Cayetano Alcázar y Miguel Lasso figuraban como secretarios. Por otro lado, en el Gonzálo Fernández de Oviedo de Historia Hispanoamericana, veremos desde su formación a Antonio Ballesteros Beretta, Cristóbal Bermúdez Castro y Ciriaco Pérez Bustamante. ${ }^{8}$

Estos, desde la primera mitad de los cuarenta, fueron estableciendo, a través de sus discípulos, secciones en las distintas universidades de provincia-Rumeu de Armas en Barcelona, Luciano de la Calzada en Murcia- cuajadas mediante la creación de diversas Escuelas, como la Escuela de Estudios Medievales, la Escuela de Estudios Hispanoaméricanos o la Escuela de Historia Moderna. ${ }^{9}$ Un proceso de extensión de redes que, para el caso del modernismo, implicó un paso más en el proceso de institucionalización a través de los primeros discípulos de los catedráticos de la Universidad Central que comenzaron a acceder a las cátedras, como serían el caso de los mencionados Antonio Rumeu, Luciano de la Calzada o Vicente Rodríguez Casado.

\footnotetext{
${ }^{8}$ Para observar esta composición y el proceso de institucionalización baste recurrir a las Memorias del CSIC en la década de los cincuenta. También Gonzalo PASAMAR, Historiografía e ideología en la postguerra española: la ruptura de la tradición liberal, PUZ, Zaragoza, 1991 e ÍD., "La formación de la historiografía profesional en los inicios del franquismo (academicismo y legitimación)" en Perspectiva Contemporánea, vol. I., 1 (1988), pp. 135-149.

${ }^{9}$ La misma creación de las distintas Escuelas nos hace observar la realidad diferencial del modernismo con el modernismo americanista y el medievalismo. Si la Escuela de Estudios Hispanoamericanos de Sevilla fue creada en 1942 y la Escuela de Estudios Medievales también por la misma fecha, completada en 1943, la Escuela de Historia Moderna no lo haría hasta 1950. Un proceso que tuvo, además, mucho que ver con la evolución de la reorganización universitaria, puesto que las distintas secciones del Consejo no fueron constituidas hasta que no se fueron cubriendo y consolidando las distintas cátedras, por disciplinas, en provincias.
} 
Y tras estos primeros accesos, este proceso de institucionalizaición del modernismo se hizo también visible en el incremento de las cátedras modernistas y americanistas en la segunda mitad de los cuarenta. De las cuarenta y tres cátedras de historia entre $1940 \mathrm{y}$ 1953, dieciséis de ellas abarcaron contenidos modernistas mediante el acceso, en su mayoría, de investigadores doctorados en los primeros años cuarenta. ${ }^{10}$ Un incremento de cátedras modernistas que marcó las experiencias profesionales de los jóvenes adjuntos de aquellos años y contribuyó de modificar y definir las expectativas de un conjunto amplio de doctorandos y doctores que encaminaron, entre la segunda mitad de los cuarenta y los primeros años de los cincuenta, su camino profesional al modernismo y acabaron transitando exclusivamente por oposiciones modernistas. ${ }^{11}$

TABla 1. ACCESOS A CÁtedra POR CENTro UNiVERSiTARio (1940-1953)

\begin{tabular}{|l|l|l|c|}
\hline \multicolumn{1}{|c|}{ Accede } & \multicolumn{1}{|c|}{ Tipo de cátedra } & Lugar & Año \\
\hline $\begin{array}{l}\text { ALMAGRO BASCH, } \\
\text { Martín }\end{array}$ & $\begin{array}{l}\text { Historia Antigua Universal y de } \\
\text { España, Prehistoria e Historia Antigua } \\
\text { Universal y de España, Prehistoria }\end{array}$ & Santiago & 1940 \\
\hline $\begin{array}{l}\text { FERRARI NúÑEZ, } \\
\text { Ángel }\end{array}$ & Historia Universal de la Edad Media & Santiago & 1940 \\
\hline $\begin{array}{l}\text { BALLESTEROS } \\
\text { GAIBROIS, Manuel }\end{array}$ & $\begin{array}{l}\text { Historia Universal, Historia de la } \\
\text { América Prehispanica y Arqueología }\end{array}$ & Valencia & 1940 \\
\hline
\end{tabular}

${ }^{10}$ Los procesos de oposición a cátedras han sido, en la última década, una de las formas más comunes de acercarse a la historiografía española y su proceso de institucionalización en la inmediata posguerra. Unos trabajos, que más allá de incidir en la evolución institucional de la profesión de historiador han estado marcados por dos intereses. El primero, la reestructuración de la Universidad española ${ }^{9}$ en la inmediata posguerra y, derivado de este, un segundo interés centrado en estos concursos y oposiciones como centro privilegiado de la pugna política entre las distintas familias del régimen, en la que las pugnas historiográficas y el despliegue disciplinar queda reducido al conflicto Falange-Opus Dei, olvidando las sinergias que entre distintos sectores, o profesionales no encuadrados en ninguna de estas dos familias, posibilitaron la consolidación de la Universidad franquista. Así, disponemos de un estimulante cuadro de la depuración y la reconstrucción universitaria, sobre el que los estudios de historia de la historiografía podrían avanzar en el camino de la comprensión de las prácticas de los historiadores. Para esto, sería necesario fijar una metodología de análisis de las oposiciones desde la historia de la historiografia, en la que nos encontramos trabajando. Las oposiciones patrióticas en Yolanda BLASCO GIL y Feredica MANCEBO, Oposiciones y concursos a cátedras de historia de la Universidad de Franco (1939-1950), Publicacions de la Universitat de València, València, 2010 y para el caso de la historia el amplio estudio de Rubén PALLOL, "La Historia, la Historia del Arte, la Paleografía y la Geografía en la Universidad nacionalcatólica”, en Luis Enrique OTERO CARVAJAL, La Universidad nacionalcatólica. La reacción antimoderna, Universidad Carlos III de Madrid, Madrid, 2014, pp. 535-684 y Rubén PALLOL, "Las oposiciones a cátedra de historia en la Universidad nacionalcatólica”, en Historia del Presente, Madrid, 20 (2012), pp. 37-50

${ }^{11}$ Este proceso de paso del medievalismo al modernismo lo presentamos a través del caso de Joan Reglà en Eduardo ACERETE DE LA CORTE, "Joan Reglà, un modernista en el franquismo", Revista de Historia Jerónimo Zurita, IFC, Zaragoza, pp. 225-244. 


\begin{tabular}{|c|c|c|c|}
\hline & $\begin{array}{l}\text { Americana, Historia de la América } \\
\text { Prehispánica }\end{array}$ & & \\
\hline $\begin{array}{l}\text { PÉREZ VILLANUEVA, } \\
\text { Joaquín }\end{array}$ & $\begin{array}{l}\text { Historia de España Moderna y } \\
\text { Contemporánea, Historia Moderna }\end{array}$ & Santiago & 1940 \\
\hline $\begin{array}{l}\text { LACARRA Y DE } \\
\text { MigUEL, José María }\end{array}$ & $\begin{array}{l}\text { Historia de España de las Edades } \\
\text { Antigua y Media }\end{array}$ & Zaragoza & 1940 \\
\hline URÍA RIU, Juan & Historia General de España & Oviedo & 1940 \\
\hline $\begin{array}{l}\text { CALZADA RODRÍGUEZ, } \\
\text { Luciano de la }\end{array}$ & Historia de España & Murcia & 1942 \\
\hline $\begin{array}{l}\text { RUMEU DE ARMAS, } \\
\text { Antonio }\end{array}$ & $\begin{array}{l}\text { Historia de España, Historia Moderna } \\
\text { de España }\end{array}$ & Granada & 1942 \\
\hline $\begin{array}{l}\text { PALOMEQUE TORRES, } \\
\text { Antonio }\end{array}$ & $\begin{array}{l}\text { Historia Universal, Historia General } \\
\text { de la Cultura, Historia General } \\
\text { Moderna }\end{array}$ & Granada & 1942 \\
\hline $\begin{array}{l}\text { RODRÍGUEZ CASADO, } \\
\text { Vicente }\end{array}$ & $\begin{array}{l}\text { Historia Universal Moderna y } \\
\text { Contemporánea, Historia Universal } \\
\text { Moderna }\end{array}$ & Sevilla & 1942 \\
\hline $\begin{array}{l}\text { ÁLVAREZ RUBIANO, } \\
\text { Pablo }\end{array}$ & $\begin{array}{l}\text { Historia Universal Moderna y } \\
\text { Contemporánea, Historia de España } \\
\text { Moderna y Contemporánea, Historia } \\
\text { Universal }\end{array}$ & Zaragoza & 1942 \\
\hline $\begin{array}{l}\text { MATEU Y LLOPIS, } \\
\text { Felipe }\end{array}$ & Paleografía y Diplomática & Oviedo & 1943 \\
\hline $\begin{array}{l}\text { MARCO DORTA, } \\
\text { Enrique }\end{array}$ & $\begin{array}{l}\text { Arte Hispano Americano, Historia del } \\
\text { Arte Hispanoamericano }\end{array}$ & Sevilla & 1943 \\
\hline $\begin{array}{l}\text { CANELLAS LÓPEZ, } \\
\text { Ángel }\end{array}$ & Paleografía y Diplomática & Santiago & 1944 \\
\hline $\begin{array}{l}\text { FLORIANO } \\
\text { CUMBREÑO, Cristino }\end{array}$ & Paleografía & Oviedo & 1944 \\
\hline $\begin{array}{l}\text { GÁMIR SANDOVAL, } \\
\text { Alfonso }\end{array}$ & $\begin{array}{l}\text { Historia General de España, Historia } \\
\text { de España }\end{array}$ & Granada & 1944 \\
\hline $\begin{array}{l}\text { GONZÁLEZ } \\
\text { GONZÁLEZ, Julio }\end{array}$ & $\begin{array}{l}\text { Historia de España(después ocuparía } \\
\text { la de Moderna y Contemporánea) }\end{array}$ & Sevilla & 1944 \\
\hline $\begin{array}{l}\text { JIMÉNEZ-PLACER Y } \\
\text { SUÁREZ DE LEZO, } \\
\text { Fernando }\end{array}$ & Historia del Arte & Salamanca & 1945 \\
\hline $\begin{array}{l}\text { LÁINEZ ALCALÁ, } \\
\text { Rafael }\end{array}$ & $\begin{array}{l}\text { Historia del Arte, Historia General del } \\
\text { Arte }\end{array}$ & $\begin{array}{l}\text { La Laguna, } \\
\text { Salamanca }\end{array}$ & 1945 \\
\hline
\end{tabular}




\begin{tabular}{|c|c|c|c|}
\hline $\begin{array}{l}\text { SALAS BOSCH, } \\
\text { Francisco Javier }\end{array}$ & Historia del Arte & Murcia & 1945 \\
\hline $\begin{array}{l}\text { ARRIBAS ARRANZ, } \\
\text { Filemón }\end{array}$ & Paleografía y Diplomática & Valladolid & 1947 \\
\hline VICENS VIVES, Jaime & $\begin{array}{l}\text { Historia Universal Moderna y } \\
\text { Contemporánea }\end{array}$ & Zaragoza & 1947 \\
\hline $\begin{array}{l}\text { PALACIO ATARD, } \\
\text { Vicente }\end{array}$ & $\begin{array}{l}\text { Historia de España Moderna y } \\
\text { Contemporánea, Historia de España en } \\
\text { la Edad Contemporánea }\end{array}$ & Barcelona & 1948 \\
\hline $\begin{array}{l}\text { SAN VALERO APARISI, } \\
\text { Julián }\end{array}$ & $\begin{array}{l}\text { Historia general de la Cultura, } \\
\text { Prehistoria e Historia Universal de las } \\
\text { Edades Antigua y Media e Historia } \\
\text { general de la Cultura (antigua y } \\
\text { media), Historia Antigua }\end{array}$ & Granada & 1948 \\
\hline $\begin{array}{l}\text { SUÁREZ VERDEGUER, } \\
\text { Federico }\end{array}$ & $\begin{array}{l}\text { Historia de España Moderna y } \\
\text { Contemporánea }\end{array}$ & Santiago & 1948 \\
\hline $\begin{array}{l}\text { CALDERÓN QUIJANO, } \\
\text { José Antonio }\end{array}$ & $\begin{array}{l}\text { Historia de América e Historia de la } \\
\text { Colonización española }\end{array}$ & Barcelona & 1949 \\
\hline $\begin{array}{l}\text { CÉSPEDES DEL } \\
\text { CASTILLO, Guillermo }\end{array}$ & $\begin{array}{l}\text { Historia de América en la Edad } \\
\text { Moderna y Contemporánea, Historia } \\
\text { de los Descubrimientos Geográficos y } \\
\text { Geografía de América }\end{array}$ & Sevilla & 1949 \\
\hline $\begin{array}{l}\text { PÉREZ EMBID, } \\
\text { Florentino }\end{array}$ & $\begin{array}{l}\text { Historia de los Descubrimientos } \\
\text { Geográficos y Geografía de América }\end{array}$ & Sevilla & 1949 \\
\hline $\begin{array}{l}\text { AZCÁRATE RISTORI, } \\
\text { José María }\end{array}$ & Historia del Arte & Santiago & 1949 \\
\hline $\begin{array}{l}\text { CAMPS CAZORLA, } \\
\text { Emilio }\end{array}$ & Historia del Arte & Oviedo & 1949 \\
\hline $\begin{array}{l}\text { BELTRÁN MARTÍNEZ, } \\
\text { Antonio }\end{array}$ & $\begin{array}{l}\text { Arqueología, Epigrafía y } \\
\text { Numismática, Prehistoria }\end{array}$ & Zaragoza & 1949 \\
\hline $\begin{array}{l}\text { MALUQUER DE MOTES } \\
\text { NICOLAU, Juan }\end{array}$ & $\begin{array}{l}\text { Arqueología, Epigrafía y } \\
\text { Numismática, Prehistoria }\end{array}$ & Salamanca & 1949 \\
\hline $\begin{array}{l}\text { GIL MUNILLA, } \\
\text { Octavio }\end{array}$ & $\begin{array}{l}\text { Historia Universal de las Edades } \\
\text { Moderna y Contemporánea y de } \\
\text { Historia General de la Cultura(Antigua } \\
\text { y Media), Prehistoria e Historia } \\
\text { Universal de las Edades Antigua y } \\
\text { Media y de Historia General de la } \\
\text { Cultura (antigua y media), Historia }\end{array}$ & Zaragoza & 1949 \\
\hline
\end{tabular}




\begin{tabular}{|c|c|c|c|}
\hline & Universal Moderna y Contemporánea & & \\
\hline $\begin{array}{l}\text { JOVER ZAMORA, José } \\
\text { María }\end{array}$ & $\begin{array}{l}\text { Historia Universal Moderna y } \\
\text { Contemporánea, Historia de España en } \\
\text { la Edad Moderna, Historia Universal } \\
\text { Contemporánea }\end{array}$ & Valencia & 1949. \\
\hline $\begin{array}{l}\text { PÉREZ SANTIAGO, } \\
\text { Justo }\end{array}$ & Historia de España en la Edad Media & Madrid & 1950 \\
\hline $\begin{array}{l}\text { NAVASCUÉS Y DE } \\
\text { JUAN, Joaquín María }\end{array}$ & Epigrafía y Numismática & Madrid & 1950 \\
\hline $\begin{array}{l}\text { HERNÁNDEZ DÍAZ, } \\
\text { José }\end{array}$ & $\begin{array}{l}\text { Historia del Arte, Historia del Arte } \\
\text { español }\end{array}$ & Sevilla & 1950 \\
\hline $\begin{array}{l}\text { SOLANO COSTA, } \\
\text { Fernando }\end{array}$ & $\begin{array}{l}\text { Historia de España de las Edades } \\
\text { Moderna y Contemporánea, de } \\
\text { Historia general de España (moderna y } \\
\text { contemporánea) y de Historia de } \\
\text { América e Historia de la Colonización } \\
\text { española, Historia Moderna }\end{array}$ & Zaragoza & 1951 \\
\hline $\begin{array}{l}\text { SÁNCHEZ MONTES, } \\
\text { Juan }\end{array}$ & Historia General de la Cultura & Granada & 1952 \\
\hline $\begin{array}{l}\text { ABBAD-JAIME DE } \\
\text { ARAGÓN Y RÍOS, } \\
\text { Francisco }\end{array}$ & Historia del Arte & $\begin{array}{l}\text { Oviedo, } \\
\text { Zaragoza, } \\
\text { Madrid }\end{array}$ & 1952 \\
\hline $\begin{array}{l}\text { GARÍN Y ORTIZ DE } \\
\text { TARANCO, Felipe } \\
\text { María }\end{array}$ & Historia del Arte & $\begin{array}{l}\text { La Laguna, } \\
\text { Valencia }\end{array}$ & 1952 \\
\hline $\begin{array}{l}\text { LUCAS ÁLVAREZ, } \\
\text { Manuel }\end{array}$ & Paleografía y Diplomática & Santiago & 1952 \\
\hline $\begin{array}{l}\text { CORONA BARATECH, } \\
\text { Carlos }\end{array}$ & $\begin{array}{l}\text { Historia Universal de las edades } \\
\text { moderna y contemporánea y de } \\
\text { Historia general de la cultura } \\
\text { (moderna y contemporánea) }\end{array}$ & Zaragoza & 1953 \\
\hline
\end{tabular}

Fuente: Elaboración propia a partir de BOE y Escalafón de catedráticos de universidad $1964 . .^{12}$

Aunque en cada caso la trayectoria personal pueda ser diferida del conjunto, en este

${ }^{12}$ Del total de las 43 cátedras de historia, 16 fueron directamente dedicadas a historia moderna y contemporánea, con diversas denominaciones. A ellas, habría que sumar algunas, como la de Luciano de la Calzada, dedicadas a la Historia de España y que, en muchos casos, escondieron parte de trayectorias modernistas. Además, la mayoría de quienes accedieron a ellas, y todos a partir de 1943, habían leído sus tesis después de la guerra. 
proceso encontramos principalmente a los discípulos de Antonio de la Torre como Rafael Olivar Bertrand, Florentino Pérez Embid, de Felipe Mateu como Joan Reglà, el último en transitar este camino o historiadores como Carlos E. Corona, que desarrollaron una actividad investigadora entre el medievalismo y el modernismo hasta que entre el último tercio de la década y el primero de la siguiente definieran definitivamente su especialidad disciplinar. Pero, en definitiva, el predominio de oposiciones a cátedra de corte modernista incidió sobre las expectativas de un conjunto de historiadores que pretendían asentar su trayectoria académica.

Además, con este proceso de institucionalización, las posibilidades de publicación de quienes pretendían promocionar hasta las cátedras modernistas se ampliaron. De las primeras publicaciones como Hispania, donde el peso del modernismo anduvo parejo al del medievalismo desde su nacimiento, la Revista de Indias y Misionalia Hispanica, a lo largo de la década y derivadas del nacimiento de nuevos centros del consejo y la reordenación universitaria, surgieron diversas publicaciones como el Anuario de Estudios Americanos (1943) y Estudios Americanos, ya en 1948. Y conforme se extendieran y nacieran los institutos dependientes del Patronato Quadrado, ${ }^{13}$ orientados historiográficamente conforme a la especialidad de los catedráticos predominantes en cada distrito universitario y centro local, sirvieron desde las provincias como elemento de promoción mediante la publicación.

Un incremento de las posibilidades de publicación dentro del modernismo que, entre 1947 y los años sesenta, se visualizó también a través de iniciativas públicas. Las conmemoraciones de hitos pasados, en la década de los años cuarenta y cincuenta, sirvieron como lugar de promoción para quienes intentaban consolidarse académicamente en la historiografía del franquismo. Si bien, en la primera mitad de los años cuarenta observamos la celebración del Milenario de Castilla en 1943, ${ }^{14}$ avanzada la década el

\footnotetext{
${ }^{13}$ El Patronato José María Quadrado ha sido estudiado en profundidad por Miquel MARÍN GELABERT, Los historiadores españoles en el franquismo, 1948-1975. La historia local al servicio de la patria, IFC, Zaragoza, 2005; ÍD, “Por los infinitos rincones de la patria', la articulación de la historiografía local en los años cincuenta y sesenta”, en Ignacio PEIRÓ MARTÍN y Pedro RÚJULA LÓPEZ, La historia local en la España contemporánea: estudios y reflexiones desde Aragón, IFC, Zaragoza, 1999, pp. 341-378. Estudios de institutos locales, a modo de ejemplo, Gustavo ALARES LÓPEZ, Diccionario biográfico...; María Celia FONTANA CALVO, Instituto de Estudios Altoaragoneses: cincuenta años de historia (1949-1999), IEA, Huesca, 2004.

14 Gustavo ALARES LÓPEZ, "La conmemoración del Milenario de Castilla en 1943. Historia y espectáculo en la España franquista", Revista de Historia Jerónimo Zurita, 86 (2011), pp. 149-180; Jesús
} 
anclaje del discurso oficial y la definición del presente político sobre el pasado, puede parecer que viró hacia el modernismo. El centenario de Hernán Cortés en 1947, la Paz Westfalia en 1948, el dilatado V Centenario del nacimiento de los Reyes Católicos con actos entre 1951 y 1953, el Centenario de la muerte de Carlos V en 1958 o, en el mismo año, el 150 aniversario de la Guerra de la Independencia generaron lugares de encuentro y promoción, entre la presentación pública en congresos y las posibilidades de publicación, para la definición de las trayectorias investigadoras.

Fastos que anduvieron entre la investigación y el uso público de la historia, entre el archivo y la vulgarización ideológica, del que los historiadores de la posguerra fueron participes. Y no lo hicieron sólo aportando conocimiento sobre el pasado, sino contribuyendo en la articulación de los elementos referenciales traídos del pasado que servían para construir el entramado ideológico de la dictadura legitimando la realidad política de la España franquista. Y no podía ser de otra forma, pues como afirmó Ignacio Peiró “al fin y al cabo, en la España de Franco se vivía del pasado y en el pasado". ${ }^{15}$ Un del pasado y en el pasado que fue, esencialmente, modernista.

En conclusión, entre la profesión y la política, no podemos dejar de advertir un hecho. Las características de la evolución institucional del modernismo, con el incremento de cátedras, el crecimiento de la investigación y el predominio temático en la historiografía modernista, no ocuparon sino un lugar más en la articulación ideológica de la dictadura en la posguerra. Un incremento y primacía del modernismo acorde con las bases ideológicas de un régimen que concebía la historia moderna y el americanismo como el lugar pasado en que se albergaba la esencia, las luces y el comienzo de las sombras de la Patria; donde se proyectó la unidad de destino de la comunidad nacional, el esplendor, pero también el lento camino de la decadencia, de la inclusión de ideas extranjeras y el final de una España posible muerta a manos del liberalismo en el siglo XIX. Un elemento de normalización externa, que incidió de forma clara en la normalzación interna del modernismo en los cuarenta y cincuenta. Quizá no podía ser de

CRESPO REDONDO, "Castilla, cumple mil años. Historia y política de la conmemoración del milenario de Castilla, 1943", Biblioteca: estudio e investigación, 28 (2013), pp. 17-50. También, para un conjunto más amplio de conmemoraciones, Gustavo ALARES LÓPEZ, Políticas del pasado en la España franquista (1939-1964). Historia, nacionalismo y dictadura, Marcial Pons, Madrid, 2017.

${ }^{15}$ Ignacio PEIRÓ MARTíN, La guerra de la independencia y sus conmemoraciones (1908, 1959 y 2008): un estudio sobre las políticas del pasado, IFC, Zaragoza, 2008, p. 137. 
otra forma, pues el falangismo y el nacionalcatolicismo españoles, el franquismo, en suma, habían sido, eran y serían esencialmente modernistas.

No ha de extrañarnos, por tanto, que en este contexto fuesen dos medievalistas los principales referentes en la construcción de Carlos Corona Baratech como historiador. El primero de ellos, conocido y en contacto desde 1942 en el mismo distrito universitario de Zaragoza, no fue otro que Jose María Lacarra ${ }^{16}$ y de Miguel. De José María Lacarra ${ }^{17}$ aprendió la escrupulosidad en el trabajo con las fuentes; el lento proceder en los archivos; y a través de su magisterio fue forjando una de sus características, el apego al documento, su método erudito. Pero cómo preguntar, a qué documentación atender y cómo estructurarla en un marco interpretativo no fueron sólo tarea adquirida bajo el magisterio de José María Lacarra. De trasfondo encontramos la influencia de Santiago Montero Díaz. ${ }^{18}$ De él, adquirió una teoría de la historia a través de la cuál, a lo largo de una década desde la lectura de su tesis, fue moldeando los marcos interpretativos de sus estudios. El sujeto en la historia, el predominio de las individualidades históricas sobresalientes, la búsqueda del espíritu de un tiempo, hasta la concepción del Estado moderno se filtraron a lo largo de diversos trabajos siguiendo, punto a punto, las interpretaciones del catedrático jonsista. ${ }^{19}$ Un período de formación, de asunción de prácticas, que concluyó

\footnotetext{
${ }^{16}$ Sobre José María Lacarra y sus prácticas Miquel MARÍN GELABERT, "La formación de un medievalista: José María Lacarra (1907-1940)", Revista de Historia Jerónimo Zurita, 82 (2007), pp. 39-98; Enrique PÉREZ BOYERO, "José María Lacarra, un archivero en la Guerra Civil española (1936-1939)”, Huarte de San Juan. Geografía e historia, 17 (2010), pp. 257-294; Ángel J. MARTÍN DUQUE, “José María Lacarra, maestro de historiadores”, Príncipe de Viana, Año 51, 189 (1990), pp. 15-18; José Ángel SESMA MUÑOZ, "El discreto magisterio de don José María Lacarra", Revista de historia Jerónimo Zurita, 73 (1998), pp. 69-87.

${ }^{17}$ Un breve análisis fue expuesto en 1987 por Jesús Longares.

${ }^{18}$ Sobre la influencia de Santiago Montero y lo que suponía estudiar y realizar una tesis en Madrid lo realizamos a través del caso de Juan José Carreras Ares en Eduardo ACERETE DE LA CORTE, "De la España medieval, a la Alemania contemporánea. El tránsito historiográfico de Juan José Carreras Ares", en Juan José CARRERAS ARES, España medieval, Alemania contemporánea. Primeros escritos, IFC, Zaragoza, 2015. Para un acercamiento a la teoría de la historia de Santiago Montero, Eduardo ACERETE DE LA CORTE, "La historia, disciplina imperial. La teoría de la historia de Santiago Montero Díaz", Actas de Franquismo a debate, UV, Valladolid, 2018, [en prensa]. Una aproximación biográfica a Santiago Montero en Xosé-Manoel NÚÑEZ SEIXAS, La sombra del César. Santiago Montero Díaz, una biografía entre la nación y la revolución, Comares, Madrid, 2012; aunque más breve, indispensable también la introducción de Antoni DUPLÁ, "Santiago Montero Díaz. Un itinerario historiográfico singular" en Santiago MONTERO DÍAZ, De Caliclés a Trajano, Urgoiti Editores, Pamplona, 2004, pp. IX-XC, donde además plantea un acertado acercamiento a la formación historiográfica de Montero Díaz.

${ }^{19}$ Un claro ejemplo de la influencia de Santiago Montero sobre Carlos Corona se puede observar en su Hernán Cortés, una obra de divulgación que sigue la estela teórica e interpretativa de Santiago MONTERO DÍAZ (en), Alejandro Magno, Atlas, Madrid, 1944. Una obra que, además, pese a ser publicada en 1951, fue escrita y fechada a la altura del centenario de Cortés, en 1947 y varió el original
} 
con la lectura del José Nicolás de Azara en 1945. Aunque, como hemos apuntado, el proceso de formación de un modernista en los años cuarenta no fue tan simple como la delimitación voluntaria de un período histórico.

Si bien el acercamiento al tema de estudio de su tesis pudo ser voluntario y su delimitación favorecida por los escasos materiales que en la Facultad de Letras zaragozana pudo encontrar, ${ }^{20}$ para comprender el tránsito de algunos modernistas en formación en la década de los cuarenta debemos atender a las posibilidades existentes en el campo. Si abordamos la bibliografía de Carlos Corona y los lugares que fue ocupando en el mundo académico veremos cómo, pese a su tesis, el modernismo no lo ocupaba todo.

En los primeros años de publicación de trabajos científicos de Carlos Corona, leída su tesis, observamos cómo el medievalismo y el modernismo comparten fechas en su producción. Contando con la base económica de una beca del Centro de Estudios Medievales, entre 1943-1944 y 1947-1948, ${ }^{21}$ practicó de la mano de José María Lacarra un conjunto de investigaciones medievalistas que fue vertiendo a lo largo de toda la década en diversas publicaciones. ${ }^{22}$ Mientras, junto a Santiago Montero, aplicaba el análisis documental aprendido en Zaragoza y daba sus primeros pasos en el modernismo con su José Nicolás de Azara, que leyó sólo dos años después de terminar la licenciatura.

\footnotetext{
con respecto a su publicación. Además, podemos observar la citada influencia a nivel teórico en su Memoria de oposición, AGA, 31/5766.

${ }^{20}$ En la revista Universidad, una de las pocas a las que en la más dura autarquía cultural de la posguerra podían tener entre sus manos los estudiantes de Historia de la Universidad de Zaragoza.

${ }^{21}$ ACRUZ, Carpeta 1, folio 1, Hojas de servicios de Carlos E. Corona Baratech.

${ }^{22}$ De su producción medievalista, bastante avanzada, dio a la luz tres publicaciones que le valieron cierto reconocimiento por el pulcro manejo de las fuentes. Estas, además, estuvieron vinculadas a iniciativas locales, bien desde la Sección de Zaragoza de la Escuela de Estudios Medievales del CSIC o desde el Instituto de Estudios Pirenaicos, bajo el amparo de Francisco Ynduráin y los estudios pirenaistas y lingüísticos que emprendió en los cuarenta. "Las tenencias en Aragón desde 1035 a 1134", en Estudios de la Edad Media de la Corona de Aragón, T. II, CSIC-EEM, Zaragoza, 1946, pp. 379-396; "Los abades del monasterio de San Salvador de Leyre", Pirineos, Zaragoza, 9-10 (1948), pp. 477-495; Toponimia navarra en la Edad Media: extraída de diferentes colecciones de documentos, Estación de Estudios Pirenaicos, Huesca, 1947. Además, los trabajos medievalistas, en esa suerte de indefinición disciplinar de los aspirantes y debido a las trayectorias sobre las que iban asentando sus carreras, fueron presentados y admitidos a la fase de concurso en el apartado de publicaciones de la oposición.
} 
Gráfica 1. Producción historiográfica de Carlos E. Corona Baratech ${ }^{23}$

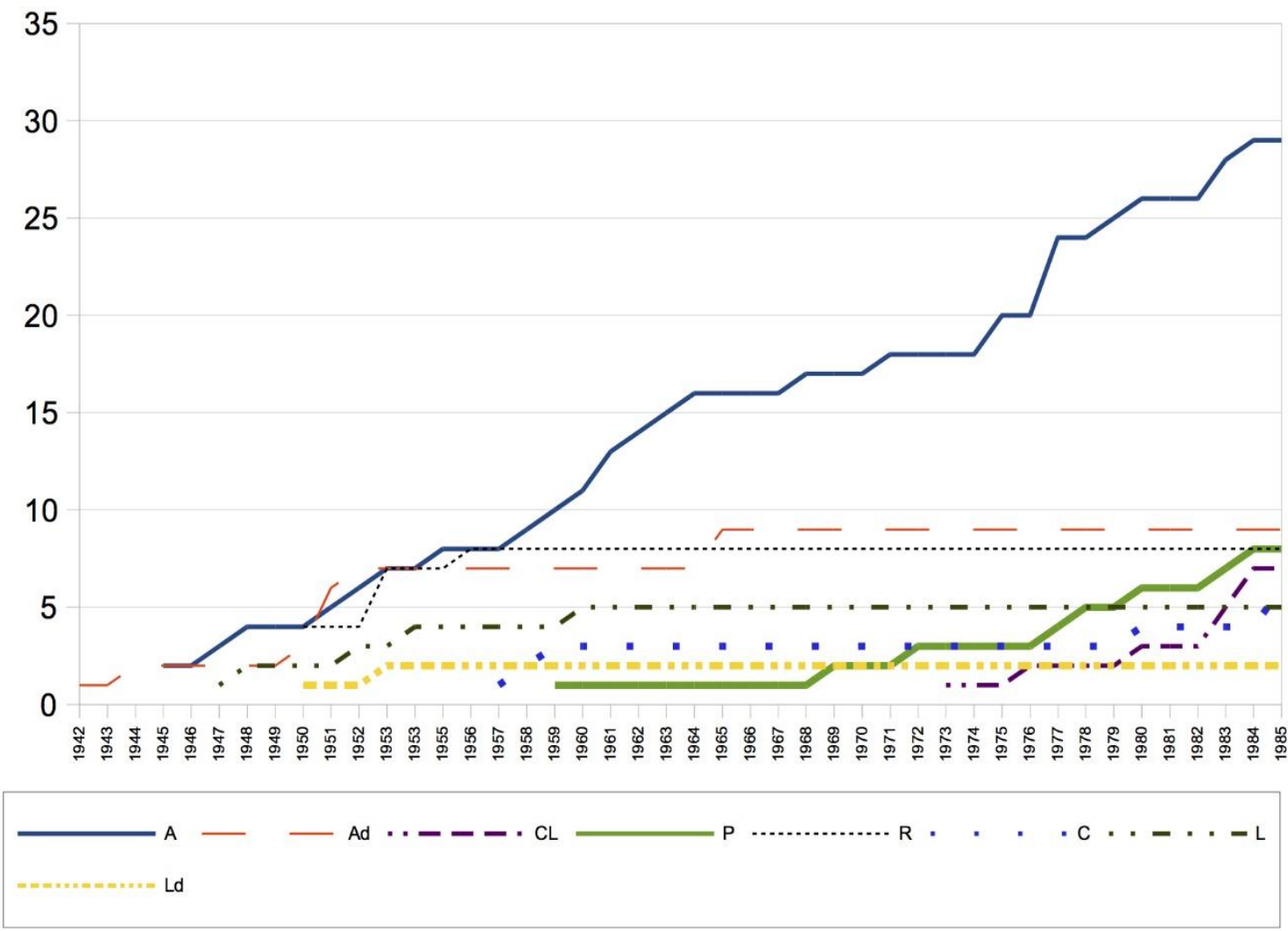

Algo similar sucede, también, en su carrera profesional. Recién licenciado, comenzó desempeñando, a parte del puesto de ayudante de clases prácticas de la facultad de letras, la acumulación de la auxiliaría provisional de árabe, que volvería a ocupar mediada la década de los cuarenta. Si bien siempre que las posibilidades del entramado universitario lo posibilitaron regentó cargos vinculados a las cátedras de Historia moderna y Contemporánea, cuando las condiciones institucionales no lo permitiesen se encaminó indistintamente hacia los lugares de la historia medieval. Muestra de ello es que, tras un acceso fallido al Departamento de Historia Moderna de Granada en $1947^{24}$ y ante la ocupación de la cátedra homónima por Jaume Vicens Vives en Zaragoza, Carlos Corona desempeñó la adjuntía de las cátedras de Prehistoria e Historia de España de las edades Antigua y media e Historia General de España Antigua y media; Prehistoria e historia universal en las edades antigua y media e Historia General de la Cultura, antigua y media y Paleografía y diplomática, hasta que obtuvo la plaza, en 1950, en el Departamento de

\footnotetext{
${ }^{23}$ Las abreviaturas corresponden a: (A) Artículo; (Ad) Artículo de divulgación; (CL) Capítulo de Libro; (P) Prólogo; (R) Reseña; (C) Comunicación a congreso; (L) Libro; (Ld) Libro de divulgación.

${ }^{24}$ ACRUZ, Carpeta 1, folio 26.
} 
Historia Moderna y Contemporánea de Sevilla. ${ }^{25}$

Observamos una indefinición disciplinar que, si atendemos a las posibilidades de campo que antes hemos establecido para la definición disciplinar en los cuarenta, nos permiten comprender cómo Carlos Corona fue asentándose en el modernismo entre 1947 y su acceso a la cátedra en 1953. En este tránsito, debemos tener presentes tres aspectos que se vinculan con lo ya establecido. El primero, el acceso en 1950 a la adjuntía en la Universidad de Sevilla ${ }^{26}$ que le pondría en contacto con el americanismo y modernismo sevillano y abrió sus posibilidades de promoción académica mediante la publicación en Estudios Americanos ${ }^{27}$ y el Anuario de Estudios Hispano Americanos, y también mediante la participación en los cursos de la Universidad de Verano de Santa María de la Rábida. ${ }^{28}$ Pero además, el contacto con el grupo encabezado por Vicente Rodriguez Casado, ${ }^{29}$ terminó de asentar el ámbito de estudio de Carlos Corona, vinculando el incipiente estudio del XVIII en Sevilla con el ámbito de investigación de que éste perfilase en su tesis ${ }^{30}$ y ampliase en algunos artículos hasta $1950 .{ }^{31}$ Cercanía a un grupo

\footnotetext{
${ }^{25}$ ACRUZ, Carpeta 1, Carta del Decano, Ángel Canellas López, declarando los servicios prestados por Carlos E. Corona Baratech a fecha de 18-IV-1950.

${ }^{26}$ El acceso en Sevilla se produjo del acuerdo entre quienes gestionaban parte de la política académica zaragozana, como José Navarro Latorre y Fernando Solano, y el grupo opusdeísta de Rodríguez Casado. Carlos E. Corona era enviado a Sevilla y, a cambio, José Navarro gestionó la concesión de la cátedra en Zaragoza a Octavio Gil Munilla, después de quedarse vacante tras el traslado de Jaume Vicens Vives a Barcelona. Estos movimientos pueden seguirse en las correspondencias de José Navarro Latorre, Vicente Rodríguez Casado y Florentino Pérez Embid.

${ }^{27}$ Miembro, desde 1950, del Comité de redacción de Estudios Americanos. Fuente: Fondos de la revista.

${ }^{28}$ La relación de asistentes y ponentes en El espíritu de la Rábida, obra homenaje a los cursos impartidos en la universidad de verano de la Rábida

29 Antonio CAÑELLAS MAS, "Vicente Rodríguez Casado: premisas intelectuales para un proyecto cultural", en Feliciano MONTERO GARCÍA y Joseba LOUZAO VILLAR (ed.), La restauración social católica en el primer franquismo, 1939-1953, Universidad de Alcalá de Henares, 2015, pp.45-69; ÍD, "Vicente Rodríguez Casado: las implicaciones políticas del americanismo científico de posguerra", en Antonio César MORENO CANTANO (coord.), Cruzados de Franco: propaganda y diplomacia en tiempos de guerra (1936-1945), Ediciones TREA, Gijón, 2013, pp. 271-301. Del mismo autor, sobre la Escuela de Estudios Hispanoamericanos y sus vinculaciones con el proyecto tradicionalista "La Escuela de Estudios Hispanoamericanos: génesis y contenido de una empresa cultural", Historia y política, 32 (2014), pp. 189215.

${ }^{30}$ En la oposición ya se encuentran algunos manuscritos sobre temática del siglo XVIII con los que Carlos Corona desarrollaría su trayectoria profesional posterior. A su vez, el núcleo de americanismo sevillano, encabezado por Vicente Rodríguez Casado y su interés por Carlos III, avanzó paralelamente al estudio del pasado americano la realidad española del siglo XVIII. Dentro, incluso, del americanismo se produjo también ese viraje hacia el XVIII, superando la revisión del pasado de conquista y primeros años de dominación, para centrarse en el estudio del XVIII y los reinados borbónicos como el verdadero aporte español al mundo americano.

31 "Notas para el reinado de Carlos IV. La fracasada mediación de España para la paz de Portugal con Francia (1789-1799)", Universidad, T.XXIII, Zaragoza, 1946, pp. 353-402 y "Notas para el reinado de
} 
que le ayudó a consolidar su trayectoria profesional, como observaremos más adelante conforme se desgajen los nombres que tomaron parte en sus procesos de promoción.

Con la llegada a Sevilla se había abierto un conjunto de posibilidades para Carlos Corona. Aunque, en el marco general de institucionalización del modernismo, no fueron las únicas. Los fastos, los actos público-profesionales, donde la política y la profesión se daban la mano, generaron un nuevo lugar desde el que ampliar la carrera literaria a presentar para acceder a la cátedra. Así, en 1947 Carlos Corona, en pleno aniversario, redactó un breve esbozo biográfico sobre Hernán Cortés que no sería publicado hasta 1953. Su intención, imbuido del pensamiento de Montero, no era sólo relatar las principales características del conquistador extremeño, sino establecer el espíritu del tiempo que se reflejó y tomó forma en la figura de Cortés:

\begin{abstract}
El propósito en las páginas que siguen pretende esbozar, en una prócer figura de la Historia de España, a la proyección de los factores inmediatos de momento histórico sobre Hernán Cortés; el cual, con este acervo cultural en virtud de la capacidad y voluntad resolutiva, se revela como agente productor de ecos de valor históricos trascendente.

Hernán Cortés se manifiesta esenciando la realización de las tendencias características del primer tercio del siglo XVI. Como un tipo cultural representativo del estado y del estilo del renacimiento y del humanismo español [...] Hernán Cortes es uno más entre aquellos españoles; pero es también uno de los mejores: un héroe. Cortés aparece ahora ante nuestros ojos como función de su mundo contemporáneo, pero revelando en su personalidad y en sus acciones el sentido profundo de la perduración de los valores que es la nota hispánica, el sentido de la hispanidad. ${ }^{32}$
\end{abstract}

Tres años después, y con una motivación puramente política y militante, escribiría una obra de urgencia encargada por la Institución Fernando el Católico sobre el monarca aragonés. Pero en el camino a la cátedra, aun faltó una iniciativa de la que iba a tomar parte. Mediante este pequeño precedente de El rey de España don Fernando el Católico

Carlos IV. La cuestión entre el ministro Urquijo y el embajador francés Guillemardet”, en Hispania, Núm. 29, T. VII, CSIC, Madrid, 1947, pp. 635-662.

${ }^{32}$ Proyección de Hernán Cortés sobre el espíritu de su tiempo, pp. 45-46. El original aparece fechado en Zaragoza a junio de 1947, aunque no vería la luz, con escasas modificaciones. Quedaron fuera de las páginas que salieron a la calle parte de los comentarios y la introducción a esta obra en las que se pueden rastrear algunas interpretaciones sobre sobre el concepto de cultura y la práctica histórica de Carlos Corona, fuertemente influenciada por Santiago Montero, algo que queda firmemente reflejado en su memoria de oposición. Su localización en AGA, 31/5766. La fecha de 1947 del original es coincidente con las conmemoraciones del Centenario de Hernán Cortés. 
publicado en 1950, ${ }^{33}$ en febrero de 1951 Carlos Corona enviaba una carta desde Sevilla a su viejo camarada José Navarro Latorre donde le informaba:

\begin{abstract}
Me han encargado un capítulo de la Historia del reinado de los Reyes Católicos, que editará la Comisión del V Centenario. Seguramente estás enterado ya. El caso es que esto me dará 20.000 ptas. Dada mi indigencia y que me alimento de los socorros de todas las especies que me dais unos y otros, no he podido decir que no; menos aun padreando. ${ }^{34}$
\end{abstract}

Fue a partir de la prolongada conmemoración del nacimiento de los Reyes Católicos desde la que Carlos Corona continuó prolongando su quehacer literario. Del encargo de la comisión, en la que se encontraban entre otros su cercano Vicente Rodríguez Casado, Antonio de la Torre o Jaume Vicens Vives, elaboró rápidamente una obra que nunca llegó a salir al mercado. Formando parte de la abortada Historia general del reinado de los Reyes Católicos, resumió a lo largo de las páginas inéditas los principales puntos que construían la visión que del reinado de Isabel y Fernando sustentaban los pilares ideológico-historicistas del régimen. En El reinado de los Reyes Católico. ${ }^{35}$ Crisis y afirmación de la unidad, seguido, dependiendo de la referencia, de unidad de España, Carlos Corona rastreó de nuevo el espíritu de un tiempo. Un espíritu, o estilo en para el siglo XVIII, que conducía a la unidad de la patria y daba rienda suelta a la vocación imperial de la hispanidad, pero que se vio amenazada por intrigas a la muerte de Isabel y en la convalecencia de Fernando. Más de cuatrocientas páginas, donde Carlos Corona estableció un relato en el que se podían seguir los grandes nombres que habrían seguido las instrucciones de los dos monarcas en pos de la unidad, la grandeza y la libertad de la patria sobre los intereses particulares. Una obra, como la proyectada colección, que legitimaba y daba soporte al discurso oficial y que contiene, en sus ideas-fuerza, las líneas de interpretación del falangismo sobre la Edad Moderna hispana.

\footnotetext{
${ }^{33}$ Gustavo ALARES LÓPEZ, "Fernando el Católico en el imaginario del Aragón franquista" en Carmelo ROMERO SALVADOR y Alberto SABIO ALCUTÉN (coords.), Universo de micromundos. VI Congreso de Historia Local de Aragón, IFC, 2009, p. 283.

${ }^{34}$ Carta de Carlos E. Corona a José Navarro Latorre, 16-II-1951, Sevilla. Archivo Personal de José Navarro Latorre, 101-7103. Agradezco a Gustavo Alares la consulta de la correspondencia relativa a Carlos Corona contenida en el archivo personal de José Navarro Latorre. Sobre este archivo, Gustavo ALARÉS LÓPEZ, Nacional-sindicalismo e Historia. El archivo personal de José Navarro Latorre (1916-1986), IFC, Zaragoza, 2015.

${ }^{35} \mathrm{El}$ inédito de Carlos Corona formó parte del proyecto inconcluso de la Historia General del reinado de los Reyes Católicos, un ejemplo de uso público de la historia. Estudiado en Gustavo ALARES LÓPEZ, Políticas del pasado en la España franquista (1939-1964). Historia, nacionalismo y dictadura, Marcial Pons, Madrid, 2017.
} 
Y queda un punto de la producción historiográfica de Carlos Corona a analizar. Más allá de estas publicaciones entre el medievalismo y el modernismo, que nos indican las delimitaciones de campo, continuó, aunque tímidamente, con el estudio de algunos aspectos del siglo XVIII español. Así, antes de emprender el viaje sevillano, encontramos dos artículos que, si bien siguen las líneas de trabajo de su tesis doctoral, ahondan en otros problemas del reinado de Carlos IV, publicados en los principales circuitos existentes: Universidad, Hispania y Pirineos (en esta última, las medievalistas, marca de la distribución de poderes en torno a las revistas). Pero esos trabajos, con su paso por Sevilla, abrirían nuevas problemáticas.

Además de sus trabajos americanistas, al que nunca volvería después de 1953, de circunstancia y delimitados por el espacio institucional sevillano y sus líneas de investigación, así como por las necesidades de promoción hacia la cátedra, comenzó a interesarse por la problemática de las ideas políticas. Un texto que, publicado en 1954, aparece ya como original en los trabajos presentados a su oposición, pero que sentaron la base sobre la que Carlos Corona, una vez asentado en la cátedra de Zaragoza, definió su proceso de especialización.

Hasta aquí hemos atendido a las publicaciones y estudios, rayando entre el interés unas y moldeadas otras por las circunstancias y las necesidades de promoción. Y es que, no debemos olvidar cuál era el objetivo principal de quienes se adentraban en la profesión de historiador en estos años. Dentro del cursus honorum de los historiadores, desde el proceso de profesionalización, la cúspide la ocupaba la cátedra. Ser catedrático implicaba dos cosas: primero, la adquisición de una posición social; en segundo lugar, y en el plano profesional, la posibilidad de gestión de recursos, participando de la organización administrativa del marco universitario y permitiendo la reproducción académica y disciplinar y el reconocimiento público y oficial como representante del saber histórico. Un lugar, la cátedra, en torno a la que en la España franquista había de organizarse la Universidad. En aquellos años, 1953, el objetivo final era la cátedra y lo seguiría siendo, al menos, hasta la década de los setenta y ochenta. Ser catedrático, en definitiva, implicaba controlar parte de los mecanismos para hacer historia. Y en el caso de Carlos Corona, como veremos, sirvió para asentar su disciplinarización y especialidad en el siglo XVIII, desligado de la multitud de anclajes que el campo imponía a los adjuntos. Aunque cabe retener, por no magnificar la realidad que, pese al acceso a la cátedra, las relaciones 
de dependencia y obligación con el antiguo director-catedrático y la relación cuasi vasallática con quienes gestionaban los elementos institucionales en los que se asentaba la matriz disciplinar de origen, marcaron algunas realidades y formas de actuación de diversos catedráticos de provincias.

El mismo Carlos Corona, en la carta referida más arriba, lo reconocía, cuando hablaba del que sería su inédito:

Pienso hacer todo lo posible para terminar este trabajo antes del verano, pero, aun así, el negocio de la oposición tendré que descuidarlo un poco. En cambio, de octubre a enero podría volcarme en él totalmente. Estos son mis cálculos. Si no me salen afrontaré la cosa como sea. Siempre importa más la oposición.

\section{Conclusión}

Obtenida la cátedra de Zaragoza, ${ }^{36}$ Carlos Corona asentó su trayectoria. Con su acceso, las cátedras y los catedráticos de historia de Zaragoza no cambiarían ya hasta que la edad y las respectivas jubilaciones, desde las décadas de los setenta, obligaran a ello. Así, con su acceso, se asentaba la realidad académica que regiría la universidad zaragozana y las prácticas profesionales durante más de treinta años. Pues con la misma formación y las mismas concepciones patrimoniales, de aquella universidad de pequeños dictadores, desarrollaría sus labores al frente de su cátedra, primero, y del departamento de historia moderna y contemporánea de la Universidad de Zaragoza, después, hasta que fuese destituido. Pero todo eso se aleja de motivo de la presente comunicación que no es otro que trazar las líneas generales, historiográficas e institucionales, que lo llevaron a ser una de las cabezas visibles de la historiografía española. Eso, por tanto, es ya otra historia.

\footnotetext{
${ }^{36}$ Hemos prescindido del análisis pormenorizado de la oposición y del trasunto detallado, con los juegos de poder que había tras esta y las oposiciones precedentes, por estricto imperativo de espacio. La oposición ganada por Carlos Corona puede consultarse en AGA, 31/5765 y 31/5766. Baste nombrar, como ejemplo de quienes como él transitaron en la segunda mitad de los cuarenta, y en adelante, las oposiciones a cátedras modernistas, la nómina de aspirantes: Rafael Olivar Bertrand, Miguel Artola Gallego, Juan Mercader Riba, Valentín Vázquez de Prada, Manuel Tejado Fernández, Rafael Ballester, Eugenio Serrablo Arguareles, Juan Reglà Campistol, Manuel Fernández Álvarez, Alfonso Vázquez Martínez, Carlos Seco Serrano, Claudio Miralles de Imperial y Gómez, Odón de Apraiz Buesa (rehabilitado y que contaría con diversos problemas por su relación con el nacionalismo vasco, no llegando nunca a ocupar cátedra) y Felipe Ruiz Martín.
} 


\title{
CAPÍTULO III
}

\section{¿Cómo Pensar los Problemas Históricos Concretos? Historia y CAMbio Social}

\author{
Julio Lisandro Cañón Voirin (ILAS, Columbia University) \\ Alba Díaz Geada (Universidade de Santiago de Compostela) \\ David Vale Díaz (Universidade de Santiago de Compostela)
}

O pensamento histórico é unha práctica pola que se intentan captar -ou recrear conceptualmente- as realidades concretas do pasado e do presente nas súas manifestacións máis complexas. Esa trama, tan dada por feito, eríxese sobre a resolución previa dos problemas do coñecemento histórico. Inútil sería enumerar tódolos compoñentes que o subxacen, mais algúns antóllanse imprescindíbeis, comezando polos suxeitos que se consideran para construír o saber historiográfico; os actores que se toman en conta para abordar os procesos; e, cunha forza maiúscula, as interpretacións que se empregan para realizar as análises.

Pensar os problemas históricos faise nun aquí e nun agora. É dicir, dende un determinado lugar e momento. Por iso, somos plenamente conscientes de que a produción historiográfica se inscribe no tempo no que se produce e, polo tanto, atópase condicionada 
por un xeito de enfocar a realidade e polo desenvolvemento global do pensamento científico.

O obxecto central deste capítulo é pensar de modo crítico os criterios interpretativos empregados nas Ciencias Sociais e as diversas teorías que intentan definir o cambio social en relación coa explicación histórica. O obxectivo principal que agardamos é: xerar un ámbito onde se presente e discuta o debate epistemolóxico entre o coñecemento científico e a súa relación coa historia.

De alí nosa convocatoria, e de alí, as estimulantes artigos que recibimos. Todos e cada un dos cales se refire, de modo distinto, ós puntos convocantes que enunciamos no momento de realizar a proposta: a historia e o cambio social, e como pensar os problemas históricos concretos.

Se ben recibimos unha multiplicidade de textos referidos a realidades distintas e con preocupacións diversas, finalmente, ao cabo do traxecto comezado na convocatoria, contamos con cinco propostas. Destas daremos conta a continuación. En primeiro lugar, debemos precisar a elección organizativa escollida, xa que decidimos non realizar un agrupamento por afinidade temática senón vertebralas a través dunha relación dialóxica entre si. Isto antóllase máis enriquecedor, pois establecer os puntos vinculantes, os nexos que entrelazan unhas proposicións coas outras, aumenta a comprensión da forma na que se entrecruzan os procesos de conformación do coñecemento e xeración do mesmo. Así, abordaxes que parecen, nun comezo, inconexas e distantes en canto a preocupacións e intereses, conéctanse e achéganse, dando como resultado un frutífero lugar común. Un exemplo do anterior constitúeno os puntos de diálogo que podemos establecer, por un lado, entre El anarquismo insurreccionalista en el siglo XXI de Miguel Morán, e polo outro, ¿Historia de las mujeres y/o historia de(l) género? de Uxía Otero. Ámbalas dúas aportacións, referidas ó movemento social anarquista e ó ingreso da muller e do xénero á historia, lidas nunha clave de aporte crítico permiten ampliar os seus contidos. Máis adiante volveremos sobre as mesmas e faremos referencia ao dito.

Ao marcar os puntos de encontro entre as distintas liñas de investigación que nos achegan os traballos, pretendemos propiciar unha reflexión entre categorías de análise, estruturas de poder e procesos sociais. Estes desexos, que superan o interese específico 
dos proxectos de investigación aos que se refire cada unha das comunicacións, exixiron establecer unha articulación como a mencionada en parágrafos anteriores. Neste marco, a vella dicotomía entre as categorías cuantitativa e cualitativa semellan disolverse. $\mathrm{O}$ cualitativo e o cuantitativo aparecen como dimensións distintas do mesmo problema. Quizais o importante sexa identificar a dimensión do problema que queremos enfatiza ou a dimensión do problema que di máis da súa propia natureza ou resposta máis ás preguntas que nos facemos. Entón, imponse a necesidade de establecer un espazo de reflexión sobre o emprego dos diferentes recursos de captación de información no marco das diferentes perspectivas de análise.

O capítulo inscríbese nese contexto e na intención de profundar nas posibilidades e os límites de diferentes recursos de captación de información e de sentido, no marco de diferentes enfoques teórico-metodolóxicos. No contexto dos traballos concretos que recibimos, é posíbel propor, dende a práctica mesma, os problemas de orde procedimental e técnico e, dende as exixencias concretas dun problema de investigación, os problemas teórico-metodolóxicos. Tal vez se poda deslindar o procedimental e técnico do teóricometodolóxico, e precisar a pertenza de cada técnica e de cada enfoque para os obxectivos dunha investigación concreta e o achegamento a diferentes formas e niveis de expresión dun mesmo problema.

De acordo co mencionado anteriormente, debemos sinalar que os traballos de Concepción López Sánchez, De micro a macro: propuesta metodológica para el estudio de las actitudes sociales ante contextos de violencia estatal masiva, e de Daniela Ferrández, El mercado de la democracia: una propuesta analítica del clientelismo político en escala microhistórica, evidencian a armazón metodolóxica, o esqueleto procedimental sobre como constrúen e analizan o seu obxecto de estudo. Un e outro, explicitan dun xeito expositivo a relación coas fontes que lles permiten afondar nas súas temáticas de estudo, os chamados intermediarios no proceso de violencia estatal persecutoria desatado tralo golpe de Estado do 18 de xullo de 1936, no caso da primeira autora; e a aplicación ou non da teoría do clientelismo para analizar mudanzas e pervivencias do sistema caciquil tralo golpe de Primo de Rivera, no caso da segunda. Pola súa parte, no caso do xa mencionado traballo de Uxía Otero, contamos cun suxerinte estado da cuestión, un verdadeiro estado da cuestión, respecto da incorporación da muller 
como suxeito histórico e os fundamentos que o fixeron posíbel. Trátase dun repaso e unha análise crítica de como se foi compoñendo o campo dos estudos sobre as mulleres e do xénero como categoría de análise. Pablo Ortega en Del honor a la honradez: una propuesta para la arqueología del cambio social, España 1700-1900, aporta un interesante enfoque para observar o cambio social producido no territorio do Estado español nos séculos XVIII e XIX. Unha aproximación sociolóxica ao proceso de transformacións sociais que recorda ós estudos de Norbert Elías referidos ó proceso civilizador. Finalmente, Miguel Morán, achéganos a unha episteme distinta, afastada dos canons máis clásicos, para entender a sociedade, o seu funcionamento e amosarnos as propostas de cambio social propugnadas polo anarquismo insurreccionalista.

Dito isto, tres dos traballos (López, Ferrández e Ortega) auscultan os seus obxectos de estudo a través de proposicións elaboradas ex professo para iso. Isto é, enuncian as categorías analíticas a partir das que pousan o seu eixo analítico, a súa interpretación: intermediario, clientelismo e honor. Se a vida social se expresa en nocións, actividades, representacións, prácticas e contextos, a enunciación das súas conexións significativas, dos atributos que integran unha descrición, a súa interpretación ou simple rexistro, responden en boa medida á organización cognitiva do investigador. Por iso, se ben existen suxeitos reais de investigación, só é posíbel coñecer o seu mundo a través de conceptos. É dicir, o marco teórico incide no proceso xeral de investigación, xa que a postura teórica orienta a selección da problemática e a batería de conceptos, así como preceptos metodolóxicos que establecen o ámbito e a identidade dos suxeitos de estudo, os indicadores que permitirán indagar na problemática formulada, a relación existente entre esta e un entorno maior, os aspectos que estruturan a descrición e a orientación explicativa do traballo final.

Á súa vez, dos tres traballos enumerados no parágrafo anterior, dous, os de Ferrández e Ortega, xunto co de Morán, avanzan, ademais, nas súas propostas concretas, facendo un exercicio práctico de aplicabilidade das súas ferramentas. O de Morán, en tanto que traballa sobre o pensamento propugnado polos anarquistas, posibilita reflexións diverxentes. Neste senso, a ideoloxía refractaria ás sociedades opresoras, o pensamento anarquista que da contorno ó imaxinario antixerárquico, antagonista do dominio do home polo home, é de sumo interese para poñelo en diálogo co texto de Otero. Pois, a 
aprendizaxe da submisión ó imaxinario xerárquico aparece como marca indeleble nas correntes científico-sociais que comezaron a visibilizar á muller. Se se repara na literatura acerca do obxecto de coñecemento como construción teórica observaremos que os principais aportes proveñen da Crítica da Economía Política de Karl Marx. Alí aprendemos que o naturalizado se desnaturaliza e adquire un carácter dunha realidade problematizada. Os marcos teóricos son as ferramentas para problematizar o real con fins de investigación. As interrogantes lévannos a observar os feitos dende un ángulo diferente, en definitiva, a introducir as preguntas acerca do que sucede; a transformar un feito aparentemente intranscendente ou habitual nun problema e incorporalo a un tema maior de investigación.

Sobre isto último, Otero, interrelaciona os climas da época de contestación e reflexión, os cales lle deron un lugar á muller dentro do saber, co proceso de acumulación e aquilatamento da historia coa muller. É neste punto nodal, onde os textos de Otero e Morán terían que establecer pontes para facer intelixible unha novidosa historia, onde repensar que non se reclama nin demanda un lugar para a muller dentro dos roles preestablecidos pola sociedade patriarcal, senón que claman por unha sociedade distinta.

Deste modo, o percorrido dentro da ciencia histórica do suxeito muller, como rescata Otero, debe ser unha vía válida para rescatar un suxeito social subalterno invisibilizado. Como ben apunta, sinalar os aspectos culturais que rexen a división xerárquica do mundo en función do sexo de nacemento, debería dirixirse non só a reclamar ás autoridades establecidas o rol da muller, senón a propor a busca de novas alternativas sociais.

O estudo de Ortega, centrado na pasaxe de súbditos a cidadáns, ancorado na mudanza social acontecida nos séculos XVIII e XIX, é unha boa mostra de como se moldean os imaxinarios e as sensibilidades dominantes. Ao observar os lugares de produción de sentido, onde se dota de significante aos parámetros que han de rexer a vida en sociedade, debería permitir entender como estimular o pensamento crítico para reconfigurar a armazón que sostén o funcionamento social. Isto lévanos a recuperar as ideas de Bourdieu respecto dun coñecemento que se leva a cabo a través da organización cognitiva propia do suxeito, organización que resposta a certa anticipación ou conceptualización daquilo que se desexa coñecer. Porén, se ben non abonda replicar a 
empiria tal e como se nos presenta, tampouco abonda con enunciar corpos teóricos para avanzar no coñecemento social. Superar o empirismo non significa desprezar a existencia do real nin restar esforzos por mellorar as vías do seu coñecemento.

En termos xerais, podemos afirmar que os obxectivos propostos e descritos ao longo do capítulo foron acadados moi satisfactoriamente. Débese, en boa medida, ó atino dos participantes á hora de poñer en tea de xuízo os criterios interpretativos propios da disciplina e, por conseguinte, das súas investigacións. Non resulta baladí subliñar o esforzo realizado, pois cuestionar os liñamentos fundamentais que inciden no marco xeral das súas pescudas pode chegar a alterar os resultados obtidos nas mesmas. De aí o noso interese en afrontar a pregunta que da orixe a esta mesa, como pensar os problemas históricos concretos? A multiplicidade de respostas que poderían resolver esta interrogante supón un activo fundamental da nosa disciplina, tomar conciencia desta realidade e aplicalo de xeito radical ós nosos estudos exixe tamén un determinado compromiso tanto coa sociedade como co presente. 


\title{
De micro a macro: propuesta metodológica para el estudio de las actitudes sociales ante contextos de violencia estatal masiva*
}

\author{
From Microhistory to Macrohistory: a methodical proposal for the study of \\ social behaviour facing contexts of mass violence from the state
}

\section{Concepción López Sánchez}

Universidad de Santiago de Compostela

\section{Resumen}

El estudio de la gente corriente es una vertiente de análisis cada vez más explotada para conocer la realidad de la sociedad de a pie ante los cambios históricos. La historia de los grandes hombres deja paso a una pluralidad de historias con las que afloran nuevas herramientas analíticas, enfoques y ópticas de estudio. Así, se pretende mostrar un ejemplo de la utilidad de la historia local y el análisis de trayectorias de vida desde una perspectiva micro conjugando fuentes de diferente naturaleza.

\section{Palabras clave}

Historia local, Enfoque micro, Redes sociales, Actitudes sociales.

\begin{abstract}
The study of ordinary people is an area of research which has increasingly been used to know how ordinary people faced the changes of the history. The history of great men gives way to a plurality of stories where new analytical tools and different approaches

\footnotetext{
* Concepción López Sánchez es licenciada en Historia con Máster en Historia Contemporánea por la Universidad de Santiago de Compostela y miembro del grupo de investigación Histagra. Actualmente desarrolla su tesis doctoral "Las actitudes sociales ante las persecuciones del golpe de estado de 1936 y la retaguardia de la guerra en perspectiva comparada. Galicia. 1936-1939" en la Universidad de Santiago de Compostela contratada por el proyecto "Procesos de construcción y destrucción de la ciudadanía. Práctica genocida, memoria y justicia transicional en perspectiva comparada" cuyo I.P. es Antonino Míguez Macho.
} 
emerge. Thus, it is intended to provide an example of the usefulness of local history and the research of life courses from a micro perspective combining sources from different nature.

\section{Palabras clave}

Local History, Individualistic Approach, Social Networks, Social Attitudes.

\section{Presentación, tema y objeto de estudio}

En torno a la pregunta, ¿cómo pensar los problemas históricos concretos?, nace una reflexión acerca de las herramientas metodológicas y enfoques de estudio que se han tomado como punto de partida en el desarrollo del actual proyecto de investigación. Éste versa sobre las actitudes sociales ante las persecuciones del golpe de estado de 1936 y la retaguardia de la guerra para el ámbito gallego. Esto supone, en principio, manejar el marco temporal 1936-1939, no obstante, la necesidad de buscar explicaciones en los antecedentes más inmediatos o en el desarrollo posterior de los hechos, supone introducir cuestiones de la segunda república y el franquismo. La intención principal de este escrito es evaluar y poner encima de la mesa de debate toda una propuesta metodológica que emana de los últimos cambios historiográficos en el campo de las ciencias sociales. Sin intención de tratar toda esa trayectoria, ni aglutinar en párrafos las diferentes perspectivas y formas de "crear" conocimiento histórico, se analizará de forma práctica y dinámica la toma de postura elegida y su eficacia en la labor histórica. Así, en los tres puntos siguientes se traerán a colación cuestiones referidas al enfoque micro, a la historia local, a la historia oral o de vida, a las metodologías cualitativas y cuantitativas o al estudio de las redes sociales.

No obstante, se considera pertinente empezar por aclarar nuestro objeto de estudio y las fuentes utilizadas, compendio con el que opera una determinada metodología. Se parte del análisis micro con un patrón metodológico compartido de cuatro localidades gallegas situadas en diferentes provincias y seleccionadas según criterios variados: 
disponibilidad de fuentes, similares parámetros violentos o un determinado volumen poblacional. Este patrón toma como punto de partida el estudio de las causas militares que atañen a dicha población, a partir de las declaraciones en dichos juicios de guerra se extrae un listado de individuos que según los clásicos patrones no se ubicarían ni en el perfil de víctimas ni en el de perpetradores. Estos serían los denominados "intermediarios", ${ }^{1}$ concepto que apela a una posición media entre quien ejerce la violencia de forma directa en todas sus modalidades y quién la recibe. Es decir, alguien que interviene en el proceso violento, que lo modula e interactúa con y en él.

Una vez seleccionado ese perfil compuesto por individuos con identidad y nombre propio, se trata de dibujar su trayectoria vital a través del cruce de datos de diferentes fuentes y la interacción de diferentes redes sociales. El resultado de interrogar su comportamiento en los juicios en relación a su evolución personal dentro de la comunidad nos lleva a determinar diferentes manifestaciones, dualidades y realidades.

Todo lo anterior explica el armazón instrumental del proyecto que parte de una historia de la vida cotidiana que emana desde abajo, poniendo el foco en la gente corriente, la sociedad de a pie. Por lo tanto, nuestro principal objeto de estudio son las personas y, de forma concreta, sus actitudes en un contexto de implantación de violencia estatal masiva. Al tratar con individuos resulta muy eficaz recurrir a la popular interdisciplinariedad, muchas veces aclamada pero poco utilizada. Así, echar mano de herramientas del campo de la sociología puede ayudar a adentrarnos en el mundo de los comportamientos. Esto no quiere decir que este trabajo inaugure esta vertiente, ya que tenemos importantísimos ejemplos de estos enfoques para los casos italiano, alemán o argentino, entre otros; lugares que comparten con España la implantación de un sistema dictatorial que hace uso de la violencia para implantarse y/o perpetuarse en el poder. ${ }^{2}$

\footnotetext{
${ }^{1}$ Para más información sobre este concepto consultar: Concepción LÓPEZ y Magali TRILLO: "Las actitudes sociales ante el golpe. La intermediación a través del caso de Bueu (Pontevedra)" en Antonio MÍGUEZ MACHO (ed.): Ni verdugos ni víctimas. Actitudes sociales ante la violencia, del franquismo a la dictadura argentina, Granada, Comares, 2016, pp. 101-121.

${ }^{2}$ Cuestiones sobre la culpa colectiva iniciadas por K. Jaspers (El problema de la culpa. Ediciones Paidós, I.C.E de la Universidad Autónoma de Barcelona, España, 1998), sobre la zona gris de Primo Levi (Trilogía de Auschwitz. Si esto es un hombre. La tregua. Los hundidos y los salvados, Barcelona, Ed. El Aleph, 2005), el debate acerca del consenso iniciado por Renzo de Felice (Mussolinni Il Duce I. Gli anni del consenso, 1929-1936, Torino, Einaudi, 1974) o el giro dado por la historiografía alemana de los setenta sobre la resistencia en relación a la gente corriente dentro del marco de la Altagsgeschichte. Esto viene de la mano de I. Kershaw, (La dictadura nazi. Problemas y perspectivas de investigación, Bs As, Siglo XXI, 2004). En este sentido, se puede interpretar que resistenz es un concepto similar al de James Scott y que ha sido
} 
De micro a macro: propuesta metodológica para el estudio de las actitudes sociales ante contextos de violencia estatal masiva

Por lo tanto, para poner de manifiesto dicha interdisciplinariedad, nos situamos desde un ángulo que integra paradójicamente la psicología microcultural -en tanto que trabajamos con perspectivas que enfatizan el nivel individual y la interacción interpersonal- con la psicología macrocultural -en tanto que atendemos a comportamientos en los que intervienen factores macro como diferentes instituciones sociales, artefactos o conceptos culturales-- Así, siguiendo la noción de cultura de la escuela de Göttingen, "se trata de mentalidades compartidas, colectivas, que se convierten en la norma y el órgano de la actividad de las personas". ${ }^{3}$ Un vez más, en relación a la capacidad de acción del individuo en un contexto, se opta por una posición media en la que se conjuga la libre agencia con la condición de artefactos a nivel macro acumulados a lo largo de la historia. No obstante, esto queda fuera de nuestro objeto de estudio, ya que no pretendemos adentrarnos en cuestiones abstractas y subjetivas como son las emociones o las intenciones, sino que nuestro terreno de análisis se circunscribe a las prácticas y a los hechos, es decir, a los comportamientos y a las actitudes.

Esto nos deriva hacia dos aproximaciones concretas de la psicología cultural en algunos apartados de nuestro trabajo. Estamos hablando, por un lado, de la "dimensional" en la medida en que tiene como finalidad especificar las dimensiones de una determinada cultura que explican las diferencias en las creencias, los valores, las conductas y las actitudes. Por otro lado, resulta interesante la "eco-cultural", pues analiza los factores ecológicos y sociopolíticos que dirigen la adaptación de la persona a un determinado medio cultural. ${ }^{4} \mathrm{Si}$ bien es necesario recordar que nuestra investigación no se encierra en cuestiones psicológicas, pero sí toma herramientas de esta disciplina que puedan servir en la labor histórica.

\section{Enfoque micro e historia local como referentes metodológicos}

Nuestro trabajo arranca desde el estudio de lo local, corriente epistemológica que emerge como un rasgo de época relacionado con los cambios de la institución EstadoNación y su Historia. Todo ello en un momento postparadigmático, a finales del s. XX, en donde nace como respuesta a la crisis de los paradigmas en ciencias sociales y, por lo

profusamente retomado por la historiografía anglosajona de los últimos 20 años, Scott, J. C., Weapons of the Weaks: Everyday forms of peasant resistance, New Haven, Yale University Press, 1995.

${ }^{3}$ Moisés ESTEBAN y Carl RATNER: "Historia, conceptos fundacionales y perspectivas contemporáneas en psicología cultural”, Revista de Historia de la Psicología, 31, 2-3 (2010), pp. 117-136, esp. p. 129.

${ }^{4}$ Ibid. 
tanto, ayuda a subvertir ciertas jerarquías de la historia tradicional. Siguiendo las palabras de sus iniciadores, Ginzburg lo explicaba como un constructivismo consciente, antiescepticista, racionalista y antirelativista que, según Jacques Revel significaba una consciencia explícita sobre la construcción del objeto, una relevancia de la dimensión experimental y de las formas argumentativas; así como una reducción de las escalas de observación, más que una comprobación de las tesis macro. ${ }^{5}$

Por ello, somos conscientes de las pautas preventivas específicas que supone trabajar con este enfoque ya que para nosotros es fundamental evitar caer en ciertos tópicos que desdibujan la intención primaria, como el localismo o lo anecdótico. Pues estos caminos convierten el objeto local en algo incomparable que lo encierra en sí mismo; cuando la intención, precisamente, al optar por este enfoque, es totalmente la contraria. La finalidad última es “estudiar EN", la historia local microanalítica es más que confirmar casos generales (pregunta de la representatividad) o construir anécdotas de lo cotidiano. ${ }^{6}$ Precisamente, Cornejo $^{7}$ y K. Jacob $^{8}$ explican muy bien las potencialidades del enfoque biográfico porque lo ponen en relación con el comportamiento y el contexto en el que actúa, llamado marco de referencia. Abogan, no sólo por un estudio desde abajo ( in el cual esta apuesta metodológica carecería de razón de ser), sino también por un análisis desde dentro asumiendo que la realidad es cambiante y dinámica, así como nuestro concepto de "intermediación".

Debido a las múltiples connotaciones que encierra, se considera necesaria una previa matización de lo que significa para nosotros trabajar con semejante modus operandi. Se trata de optar por el estudio de un espacio físico delimitado por factores territoriales y administrativos con una función determinada: facilitar el análisis de pautas de una comunidad social y establecer barreras que permitan un estudio comparado de diversas fuentes. Esto no quiere decir que todos los microcosmos de estudio tengan que seguir estos parámetros espaciales, pero en nuestro caso son por los que se han optado

\footnotetext{
${ }^{5}$ Ronen MAN: "La microhistoria como referente teórico-metodológico. Un recorrido por sus vertientes y debates", Historia Actual Online, 30 (2013), pp. 167-173.

${ }^{6}$ Justo SERNA y Anaclet PONS: "En su lugar. Una reflexión sobre la Historia local y el microanálisis", Contribuciones desde Coatepec, vol. 2, 4 (2003), pp. 35-56.

${ }^{7}$ Marcela CORNEJO: "El enfoque biográfico: trayectorias, desarrollos teóricos y perspectivas", Psykhe, vol. 15, 1 (2006), pp. 95-106.

${ }^{8}$ Mariane KRAUSE JACOB: “La investigación cualitativa: un campo de posibilidades y desafíos", Revista temas de educación, 7 (1995), pp. 19-39.
} 
De micro a macro: propuesta metodológica para el estudio de las actitudes sociales ante contextos de violencia estatal masiva

debido a su operatividad. Así, se "abordan singularidades para demostrar como esas especificidades pueden contradecir y deconstruir casos generales". ${ }^{9}$ La mejor prueba de ello ha sido la elaboración de nuevos esquemas analíticos y conceptuales que dan cuenta de esos comportamientos sociales, tales como el término "intermediario" y su connotación en el escenario de la cotidianidad.

Siguiendo al mismo autor, otro intento de superar esa barrera cerrada de lo exclusivamente local es el hecho de formular preguntas generales a objetos reducidos, y hacerlo de tal modo que éstos cobren una dimensión universal. Y una vez más, como prueba de dicho intento, mostramos a continuación un ejemplo de las hipótesis de partida que motivan los interrogantes sobre los que se intenta arrojar luz y se convierten en objetivos de nuestro proyecto:

- Evaluar los grados de politización de la sociedad y en qué medida esto actúa como un condicionante a la hora de posicionarse ante el golpe de estado de 1936.

- Detectar las lógicas de actuación y dinámicas sociales que intervienen en el comportamiento humano en este contexto histórico.

- Analizar cómo se produce el paso del ámbito privado a la esfera pública.

- Conocer el grado de implicación de la gente corriente con los sublevados y los factores que intervienen en ello.

- Procurar concretar el abanico de posturas que otros autores señalan como grises espacios de intermediación.

- Dibujar el perfil de individuo que los agentes sublevados tratan de captar para su causa.

- Determinar el papel de los diferentes sectores sociales tras el golpe de estado.

- Comprobar en qué medida la lógica de la recompensa económica personal actuó como aliciente a la hora de colaborar con el régimen.

- Incorporar al discurso histórico sobre el golpe de estado y la guerra civil aquellas actitudes intermediadoras que no encajan en viejos esquemas interpretativos dicotómicos y excluyentes.

Una reflexión importante también gira en torno al contexto, pues adquiere un valor explicativo y significativo fundamental para el desarrollo del estudio e incluso la elección

\footnotetext{
${ }^{9}$ Ronen MAN: "La microhistoria como referente...".
} 
del enfoque utilizado. Nosotros partimos de una determinada concepción del contexto violento en el que se insertan nuestras actitudes (objeto de estudio); y es que este viene marcado por un golpe de estado que repercute en todos los aspectos vitales y altera las relaciones vecinales, las redes de sociabilidad y la vida comunitaria. Así, la práctica violenta se concibe como un fenómeno que involucró a toda la vecindad, al que nadie resultó ajeno, que ahondó en las diversas esferas (tanto públicas como privadas) y que influyó en la actuación de la sociedad bajo un compendio de lazos sociales, intereses y presiones que, en muchos casos, modulan dichos procesos represivos.

\section{Historias de vida como método cualitativo}

Como un escalón más de nuestro armazón metodológico, se requiere enunciar el uso dado a la historia oral o enfoque biográfico desde los puntos de vista que más aportan al estudio -técnicas que abogan por el uso de nuevas fuentes-. No obstante, se considera necesario realizar en primer lugar un matiz terminológico para aclarar nuestra postura al respecto, ya que partimos de una multiplicidad de vocablos para explicar un mismo concepto. Este es un rasgo frecuente en las ciencias sociales por la conocida tendencia hacia el escaso consenso conceptual, una guerra en la que cada autor parece llevar la bandera ganadora sin que interese adoptar puntos comunes que faciliten la investigación. No nos detendremos en analizar toda la trayectoria historiográfica de esta vertiente, pero sí señalamos, como apunte, los variados términos que usa la academia para evitar confusión. Estamos hablando de fuente oral, historia oral, enfoque biográfico o historias de vida; todas ellas se consideran válidas con pequeños matices, no obstante, las dos primeras tendemos a asociarlas en mayor grado con el ámbito histórico y las restantes con el ámbito psicológico o sociológico.

La teoría sobre el método biográfico lo define por la intención desde el actor de reconstruir situaciones, contextos, comportamientos, percepciones o evaluaciones ubicando estos procesos históricamente. ${ }^{10}$ En la práctica, en nuestro estudio, una de las vías por las que este enfoque adquiere materialidad es a través de entrevistas orales; no realizadas expresamente para la propia investigación, sino tomadas de un importante fondo realizado por el proyecto interuniversitario "Nomes e voces" al calor de la conocida

\footnotetext{
${ }^{10}$ Ruth SAUTU (ed.): El Método Biográfico: la reconstrucción de la sociedad a partir del testimonio de los actores sociales, Buenos Aires, Editorial de Belgrano, 1999.
} 
De micro a macro: propuesta metodológica para el estudio de las actitudes sociales ante contextos de violencia estatal masiva

como Ley de Memoria Histórica de 2007. De modo sucinto, señalaremos que nacen de la premisa de ofrecer a la sociedad los datos relativos a las personas que sufrieron algún tipo de persecución por culpa de su ideología o de su posición favorable a la democracia republicana. Por lo tanto, dan cuenta del registro oral de la guerra desde un punto de vista muy concreto, el de las víctimas y éste, precisamente, no coincide exactamente con el punto de mira que nos interesa, si bien es cierto que también interactúan de forma paralela. En relación a su uso; se ha utilizado un criterio de selección territorial, ya que se toman todas las entrevistas que atañen a ese determinado espacio de estudio. Pero también, se ha recurrido a su ordenación temática, pues están indexadas según este parámetro, lo que permite ir directamente a la información que buscamos.

Ahora bien, ¿cómo empleamos esta fuente? ¿Qué posibilidades nos ofrece? Para ello resulta clave reconocer que se concibe como una herramienta que comparten varias disciplinas. Aquí nos interesan dos, la Historia y la Psicología porque ambas hacen ligeramente un uso diferente de ella que, no obstante, aquí se conjuga por su vertiente cualitativa. Siguiendo a Berríos, ${ }^{11}$ el método cualitativo es aquella investigación de la que emana información de carácter descriptivo e interpretativo mediante la cual los individuos manifiestan de forma personal el comportamiento detectado. Nos son de utilidad porque es información que emana de la vida cotidiana desde la perspectiva de las personas, es decir, se interesa por el entendimiento del fenómeno social desde el punto de vista del actor. $^{12}$

Si seguimos la clasificación de Bertraux, ${ }^{13}$ podemos encajar nuestro uso de las historias de vida en una determinada fase del proceso de investigación. Ésta es la analítica porque contribuyen a la construcción de una teoría y al esbozo de una tipología. En la práctica, esto se plasma en la ayuda a delimitar el perfil de individuo intermediario y a identificar su rol social en la comunidad ante el momento del golpe de estado. Así mismo, según las variantes de Santamarina y Marinas ${ }^{14}$, que dan cuenta del vínculo entre el

\footnotetext{
${ }^{11}$ R. BERRÍOS RIVERA: "La modalidad de la historia de vida en la metodología cualitativa", Paideia Puertorriqueña, vol. 2, 1 (2000), pp. 1-17.

12 J. I. RUÍZ OLABUÉNAGA: "Historias de vida" en Metodología de la Investigación Cualitativa, Bilbao, Universidad de Deusto, 2012, pp. 267-313.

${ }^{13}$ D. BERTRAUX.: "Los relatos de vida en el análisis social", en Jorge ACEBES: Historia oral. Parte II: Los conceptos, los métodos, México, Instituto Muro-UAM, 1989, pp. 136-148.

${ }^{14}$ Cristina SANTAMARINA y José Miguel MARINAS: “Historias de vida e Historia oral” en José Manuel DELGADO y Juan GUTIÉRREZ DELGADO (coords.): Métodos y técnicas cualitativas de investigación en ciencias sociales, Madrid, Síntesis, 1999, pp. 259-287.
} 
individuo y el contexto, nos ubicamos desde una vertiente dialéctica porque "las historias de vida se entienden como historias que se construyen a partir de las constricciones del sistema social pero no están absolutamente determinadas por él". ${ }^{15}$ La materialidad de dicha afirmación se encuentra en el hecho de que hubo diferentes reacciones, comportamientos y actitudes ante un mismo contexto violento que afectó a toda la sociedad. Por lo tanto, no es éste el que condiciona totalmente las experiencias individuales, aunque, evidentemente, tampoco pueden actuar completamente ajenas al mismo.

Tomar al respecto los conceptos de "trayectoria" y "carrera" de Bourdieu puede resultar interesante para calibrar, enunciar o desdibujar los comportamientos de cada individuo como decisiones fruto de unos marcos variables. Así, las actuaciones personales cobran vida en un campo de fuerzas generales que hace que sus comportamientos adquieran una dimensión social. Otro concepto muy útil de Bertraux que rescata Kornblit ${ }^{16}$ es el de puntos de viraje, "momentos vitales identificados por el sujeto y/o por el investigador como una encrucijada a partir de la cual el itinerario biográfico de la persona tomó un rumbo distinto o inició una nueva etapa". Para nuestra investigación esto supone replantearse si las nuevas formas de sociabilidad que trajo el golpe de estado marcaron puntos de viraje personales. En ese caso, resulta interesante analizar el calibre de éstos, en qué términos se producen y si fueron alcanzables a toda la sociedad. Esto entronca de forma intrínseca con el apartado anterior sobre el enfoque micro. Y es que estos escenarios sociales se detectan a un nivel de análisis muy reducido dentro de un marco general que las envuelve y que demanda un estudio comprensivo.

El enfoque cualitativo de esta herramienta también nos da pistas sobre el diseño de la investigación, pues necesita que sea flexible, cíclico y dinámico porque parte de que la sociedad es un constructo de diferentes significados y símbolos que no son perennes ni en el tiempo ni en el espacio. Por lo tanto, a través del lenguaje y otras construcciones simbólicas se trata de ver cómo se conforma la experiencia individual que, por estar

\footnotetext{
${ }^{15}$ Ana Lía KORNBLIT: "Historias y relatos de vida: una herramienta clave en metodologías cualitativas", en Ana Lía KORNBLIT: Metodologías cualitativas en ciencias sociales. Buenos Aires, Editorial Biblos, 2007, pp. 9- 33, esp. p. 19.

${ }^{16}$ Ibid., p. 23.
} 
De micro a macro: propuesta metodológica para el estudio de las actitudes sociales ante contextos de violencia estatal masiva

inserta en un contexto, transmuta en colectiva. ${ }^{17}$ Esto conecta directamente con los vectores individuo-colectividad de los que habla Sanz Hernández ${ }^{18}$ para explicar su interacción entrelazada, a pesar de ser campos de análisis interdependientes en el documento de vida. En otras palabras, si trabajamos desde estos enfoques la tensión entre lo individual-particular-personal-privado y lo colectivo-general-social-público siempre va a estar patente porque son ámbitos que se entrelazan para comprender el fenómeno macro, pero se trabajan de forma independiente.

Retomando la cuestión terminológica con la que iniciábamos el apartado, frecuentemente en este terreno se confunden los términos "relatos de vida" y "historias de vida" al ser usados indistintamente, pero conviene matizarlos. Cornejo, Mendoza y Rojas $^{19}$ recogen las distinciones de Lainé que entienden al primero como "la enunciación, escrita u oral, por parte de un narrador, de su vida o parte de ella" y al segundo como "una interpretación que hace el investigador al reconstruir el relato en función de distintas categorías conceptuales, temporales, temáticas, entre otras”.

Para nuestro estudio se ajusta en mayor medida el uso del segundo término, cuyo manejo desde el punto de vista histórico viene dado, por la mayoría de autores, a través de la fuente oral. Ésta es vista actualmente como una forma de hacer historia, una técnica o una fuente fundamental, pero gracias a superar la crítica positivista a su subjetivísimo debido al empleo de relatos y documentación personal. ${ }^{20}$ No obstante, aquí nos planteamos la posibilidad de que existan más formas de hacer historias de vida más allá del mero testimonio directo oral o de la carta personal. Y debido a la experiencia que nace fruto de las demandas de la investigación, entendemos que sí, aunque sin desechar los elementos anteriores que, en nuestro estudio han sido utilizados como fuente de contraste o de rastreo. A continuación, explicaremos este uso.

Las hipótesis de partida señaladas en párrafos anteriores, apuntan hacia el estudio de sujetos que no se encuentran incluidos dentro de los clásicos patrones dicotómicos de

\footnotetext{
${ }^{17}$ Mayra CHÁRRIEZ CORDERO: "Historias de vida: una metodología de investigación cualitativa", Revista Griot, vol. 5, 1 (2012), pp. 50-67.

18 Alexia SANZ HERNÁNDEZ: "El método biográfico en investigación social: potencialidades y limitaciones de las fuentes orales y los documentos personales", Asclepio, vol. 57, 1 (2005), pp. 99-115.

${ }^{19}$ Marcela CORNEJO, Francisca MENDOZA y Rodrigo C. ROJAS: "La Investigación con Relatos de Vida: Pistas y Opciones del Diseño Metodológico", Psykhé, vol. 17, 1 (2008), pp. 29-39. esp. p. 30.

${ }^{20}$ Eliane VERAS: "Historia de vida: ¿un método para las ciencias sociales?", Cinta de Moebio, 39 (2010), pp. 142-152.
} 
estudio; estos son las víctimas y los perpetradores. Por lo tanto, las entrevistas orales que tenemos no ponen el foco directo en estos sujetos, así como tampoco la bibliografía tradicional sobre el tema. Esto significa la búsqueda de alternativas documentales que nos permitan analizar su comportamiento tangible y trazar una línea evolutiva en relación a su desarrollo vital. Consecuentemente, esto nos lleva a una reflexión sobre las fuentes utilizadas y su uso en la que las historias de vida cumplen una determinada función.

En definitiva, la relevancia de las historias de vida radica en que permiten investigar rupturas y cambios a diferentes escalas, bien las de carácter social y cultural; así como las individuales y personales. ${ }^{21}$ Por lo tanto, se produce una "resocialización de la persona dentro de mores antagónicos". ${ }^{22} \mathrm{Si}$ bien es cierto, que como señala Eliane Veras, comprender la historia de vida como método requiere la aceptación de varias premisas. La primera de ellas está relacionada con el concepto de la "imaginación sociológica", entendida como aquello que permite transformar la biografía en historias de vida. $^{23}$ Y la segunda supone admitir el papel activo del hombre en la Historia; esta cuestión muy relacionada, por un lado, con la renovada trayectoria historiográfica de la Historia Social, desde abajo y, por otro, desde nuestro ámbito de estudio, con las perspectivas que otorgan protagonismo a la gente corriente frente a las grandes personalidades.

\section{Utilidad de indicadores cuantitativos, ¿paradoja?}

Frecuentemente la metodología cuantitativa y la cualitativa han sido presentadas como antagónicas y excluyentes debido a su propia naturaleza, al menos para una misma fase de la investigación. No repasaremos aquí los orígenes de ambas corrientes, pero sí replantearnos su utilidad para estudios de carácter histórico dentro de las ciencias sociales. Esto nos lleva a formularnos la posibilidad de una conjugación entre ambas denominada por los últimos estudios sobre el tema como la tercera vía o el principio de complementariedad. Hablamos así, de multimétodo o método mixto que puede manifestarse a través de tres diferentes estrategias de integración, según Bericat: a) complementaria: incorporan una doble visión de los hechos que se mezclan para lograr

\footnotetext{
21 Ibid.

${ }^{22}$ José de Souza MARTINS: "Vida e história na sociologia de Florestan Fernandes: reflexões sobre o método da história de vida", en: J. S. MARTINS, Florestan: sociologia e consciência social no Brasil, São Paul, Editora da Universidade de São Paulo, 1998, pp. 87-96. esp. pp. 92-93.

${ }^{23}$ Charles Wright MILLS: A imaginação sociológica, Rio de Janeiro, Zahar Editores, 1965.
} 
De micro a macro: propuesta metodológica para el estudio de las actitudes sociales ante contextos de violencia estatal masiva

entender el fenómeno observable, no se solapan y es el grado mínimo de integración; b) combinada: supone la supeditación de un método a otro y por lo tanto no son independientes; c) triangulación: se reconocen en ambas aproximaciones un mismo rasgo de la realidad social, es el grado máximo de integración. ${ }^{24}$

En nuestro caso partimos de una integración combinada, no por el mayor o menor aprecio a una aproximación u otra, sino porque los datos analizados y los objetivos que se pretenden alcanzar apelan a un uso común pero diferenciado. A continuación, explicaremos la fase de nuestra investigación en la que se ambos actores juegan en un mismo equipo y cuál es el sentido de esta actuación.

La dimensión cualitativa cobra sentido a la hora de aproximarnos a los sujetos y de analizar las fuentes en donde se halla su microcosmos deteniéndonos en determinados parámetros. Puede ser considerado como un método descriptivo, pero va más allá porque demanda un papel crítico activo del investigador para analizar las tipologías psicológicas sobre la comprensión de los hechos históricos. El eje hermenéutico también es relevante ya que la interpretación de los lenguajes culturales y los textos históricos suponen comprender por partes para comprender el todo. No obstante, la vertiente etnometodológica cobra alta relevancia en la aproximación cualitativa en la medida en que hace hincapié sobre la práctica discursiva en la esfera de lo social. Para el análisis del contenido, se trata de investigar la racionalización de prácticas cotidianas por medio de determinadas variedades de enunciados de lenguaje ordinario. ${ }^{25}$

Estamos hablando de la fase en la que se estudian las declaraciones de los intermediarios en las causas militares y se establece una tipología de su discurso en función de diferentes criterios como son la edad, la profesión, los antecedentes políticos, el hecho sobre el que emiten declaración, hacia quién la emiten y los términos en los que se materializa su discurso. Así, observamos en qué medida se hace una declaración positiva, negativa o neutra en relación a su efecto en el proceso judicial del acusado; así como el carácter general o selectivo de ese discurso, observando hacia quién se focaliza.

\footnotetext{
${ }^{24} \mathrm{M}^{\mathrm{a}}$ Cruz SÁNCHEZ GÓMEZ: "La dicotomía cualitativo-cuantitativo: posibilidades de integración y diseños mixtos", Campo Abierto, vol. monográfico, 2015, pp. 11-30.

${ }^{25}$ Mariane KRAUSE JACOB: "La investigación cualitativa: un campo de posibilidades y desafíos", Revista temas de educación, 7 (1995), pp. 19-39; Ana María RUSQUE: "Paradigmas cuantitativos (sociología estándar) y paradigma cualitativo (sociología interpretativa) ¿un continuo o una polarización?", en Thierry LULLE, Pilar VARGAS y Lucero ZAMUDIO (dir.): Los usos de las historias de vida en las ciencias sociales. I, Lima, Antropohos, 1998, pp. 297-321.
} 
Junto con ello, se recopilan datos en función de la trayectoria vital de cada individuo según sea conocida o desconocida; en el primer caso se determina si ésta entra en retroceso, permanece igual o mejora después de su participación en el juicio militar. Todos estos datos se recogen en una tabla con la siguiente estructura:

\begin{tabular}{|c|c|c|c|c|c|c|c|c|c|c|}
\hline \multicolumn{10}{|c|}{ ACTITUDES INTERMEDIARIAS } & \\
\hline \multirow[t]{4}{*}{ INDIVIDUOS } & \multirow{4}{*}{$\begin{array}{l}\text { ROL SOCIAL: } \\
\text { » Profesión } \\
\text { » Edad } \\
\text { » Antecedentes } \\
\text { Políticos }\end{array}$} & \multicolumn{6}{|c|}{ DECLARACIÓN } & \multicolumn{3}{|c|}{$\begin{array}{c}\text { PROYECCIÓN VITAL } \\
\text { POSTERIOR }\end{array}$} \\
\hline & & \multicolumn{2}{|c|}{ Hacia QUIÉN } & \multicolumn{3}{|c|}{ Hacia QUÉ } & TIPO & \multicolumn{3}{|c|}{ Conocida } \\
\hline & & \multirow{2}{*}{ Enc. } & \multirow[b]{2}{*}{ Otros } & \multirow{2}{*}{ Ars. } & \multirow{2}{*}{ Pnte. } & \multirow[t]{2}{*}{ A. M.G. } & & & \multicolumn{2}{|c|}{+} \\
\hline & & & & & & & & & & $\uparrow$ \\
\hline $\begin{array}{l}\text { Alonso Fernan- } \\
\text { dez, Dámaso }\end{array}$ & Marinero-43 & & & & & & & & & \\
\hline
\end{tabular}

Tabla 1: Herramienta metodológica para el análisis (Fuente: elaboración propia).

Una vez recolectados los datos, se someten a varios interrogantes para tratar de poner en relación diferentes parámetros de las actitudes sociales que ineludiblemente precisan de la dimensión cuantitativa para ser contestados. Estas preguntas son las siguientes: a) determinar en qué grado pueden establecerse tendencias y correlaciones entre la promoción personal tras el Golpe y su papel acusatorio premeditado en Causa; b) situación inversa, ver en qué medida hubo promoción vital posterior sin que estuviese asociada a una declaración negativa, tanto selectiva como general. Para dar respuesta se necesita recolectar datos en forma de puntuación, analizar datos numéricos en términos de su variación y comparar los análisis mediante técnicas estadísticas.

Así, las respuestas numéricas fundamentales para dotar de sentido al análisis cualitativo previo nos remiten, para la primera pregunta, a un total de 45 individuos que emiten, en algún momento, 14 declaraciones negativas (que siempre son selectivas) y conocemos la trayectoria política posterior de 10 de ellos. En todos esos casos, salvo en dos, tenemos datos que nos permiten afirmar que, por lo menos, lograron mantener el mismo estatus social, nos encontramos con una evolución positiva de su trayectoria vital posterior, pues todos ascendieron en diferentes escalas. Para la segunda, las cifras 
muestran un total de 21 casos conocidos en los que sí hubo una trayectoria vital posterior positiva, de los cuales, 15 emanan de individuos que en un determinado momento emitieron una declaración positiva o neutra; por lo tanto, puede concluirse que sí hubo esa promoción.

En palabras de Flick, uno de los niveles de relación entre ambas metodologías es la delimitación de los campos de aplicación de cada una. Y es que, en nuestro caso, no sería posible una integración triangular porque la aplicación de cada una depende del problema y la pregunta de investigación. No obstante, la dicotomía que reinaba en el siglo XX entre lo cualitativo y lo cuantitativo se ha roto en el nuevo siglo, donde el pluralismo y la compatibilidad enriquecen los estudios en ciencias sociales y fuerzan a una mayor interacción entre el investigador, el fenómeno y los participantes. A modo de recopilación podemos acudir al compendio que realiza Sánchez Gómez ${ }^{26}$ sobre las ventajas de los enfoques mixtos:

- Corrobación de hipótesis.

- Complementación: arrojar luz a los resultados.

- Visión holística: abordaje completo e integral.

- Desarrollo: utilizar los patrones o resultado de un método como soporte del otro; como en nuestro caso.

- Iniciación: hallar contradicciones, ambivalencias, nuevos marcos de referencia y replantear premisas iniciales.

- Expansión: ampliar el conocimiento permitiendo llegar a más rincones de la realidad objeto de estudio.

- Compensación: el contrapeso entre ambos métodos que suplen sus carencias y fortalecen sus aspectos positivos.

- Diversidad: pluralizar las visiones de un interrogante.

- Claridad: visibilizar elementos que quedarían ocultos con el uso de una sola metodología.

- Credibilidad y mejora: apuntalar argumentos y razonamientos.

Quizás es por todo ello que a pesar del indiscutible avance de los enfoques cualitativos sobre los cuantitativos desde 1995 y especialmente desde el 2005, se ha

${ }^{26}$ M Cruz SÁNCHEZ GÓMEZ: "La dicotomía cualitativo-cuantitativo...”, pp. 25-26. 
detectado una tendencia notoria al aumento del uso de la metodología mixta. Éste sería un punto a medio camino entre ambas metodologías que recoge lo mejor de cada una, permitiendo un uso adaptado según las circunstancias, el tema y las fuentes empleadas.

\section{Las redes sociales como puente micro-macro}

Ya hemos aclarado en puntos anteriores el enfoque micro utilizado y su relación con la perspectiva general o macro. Por lo tanto, ahora ahondaremos en uno de los puentes clave para conjugar esa relación e integrar estudios locales en perspectivas más amplias de estudio. Y en nuestro caso, para ello resultan clave el estudio y manejo de las redes sociales, concepto tomado de la sociología. Éstas son entendidas aquí, en palabras de González y Badalsúa, ${ }^{27}$ como un modelo dinámico de estudio aplicado para "mostrar y explicar el entramado de relaciones entre diversos individuos y grupos en su interacción social dentro de un sistema y estructura". Así, cobran relevancia en este plano las esferas particulares o privadas con las esferas colectivas o públicas de los individuos que conforman la comunidad y que actúan en un determinado contexto histórico. Todo ello conlleva un análisis de las prácticas y de los vínculos que conectan los miembros de una red.

No obstante, un aspecto que resulta todavía más interesante para nuestro objeto de estudio (actitudes sociales) es la relación costo beneficio, pues otra de las formas en que se basa la relación entre micro y macro es el intercambio de bienes y servicios. Según G. Homans esta relación traerá beneficios para el actor, que a su vez también es el que paga el costo; no obstante, P. M. Blau determina que el beneficio individual implica costos para la comunidad. Para un análisis en estos términos se debe partir de la delimitación del tipo de relaciones sociales y las tramas que entrarían en juego; de la reciprocidad como elemento clave y de la doble dirección de las redes, forma horizontal o vertical. $^{28}$

La relevancia de este entramado de redes sociales para el estudio de las actitudes sociales radica en poner en relación los comportamientos o manifestaciones individuales

\footnotetext{
${ }^{27}$ Carmen Imelda GONZÁLEZ GÓMEZ y Manuel BASALDÚA HERNÁNDEZ: "La formación de redes sociales en el estudio de actores y familias. Perspectiva de estudio en historia y antropología", Revista hispana para el análisis de redes sociales, vol. 12, 8 (2007). http://revista-redes.rediris.es/htmlvol12/Vol12_8.htm. [consultado el 3 de abril].

${ }^{28}$ Ibid.
} 
De micro a macro: propuesta metodológica para el estudio de las actitudes sociales ante contextos de violencia estatal masiva

ante el viraje de la cotidianidad hacia un contexto violento: a) detectar, tal y como enunciábamos en nuestros objetivos, la existencia de una correspondencia entre una toma de postura concreta ante los sublevados y un determinado desarrollo de la trayectoria individual. b) calibrar hasta qué punto la lógica de la recompensa económica personal actuó como aliciente a la hora de colaborar con el régimen. c) determinar cómo funcionaban las diferentes relaciones familiares, laborales, económicas, de poder y en qué grado influían en la conformación de determinadas actitudes. A su vez esto está interconectado, como todos los subapartados de este escrito, con el empleo de las historias de vida. Precisamente éstas permiten captar esas redes, ver cómo interactúa la persona en su cosmos social y detectar las ambigüedades o contradicciones; lo que en resumen significa, descifrar las claves que explican fenómenos sociales de carácter general e histórico, como es el caso. ${ }^{29}$

Estos estudios han sido muy fructíferos para el análisis de las relaciones familiares o el estudio de élites como es el caso de Larissa Adler Lomnitz y de Marisol Pérez Lizaur $^{30}$ o Daniel Santilli ${ }^{31}$, que recoge un interesante manejo de este tipo de redes para el estudio de redes que derivan de relaciones de parentesco a través de soportes tecnológicos como el sistema "Reseaulu". Pero no tenemos la misma trayectoria para estudios micro sobre nuestro tema, a pesar de ser señalados cada vez con más frecuencia como herramientas fructíferas para estudios sociales de ámbito antropológico o histórico.

Como señala el balance de Bertrand y Lemercier ${ }^{32}$ sobre la situación del análisis de redes en Historia, es una introducción en nuestro campo bastante novedosa ligada frecuentemente con aproximaciones micro cualitativas que no echaban mano de sistemas de representación gráficos. No obstante, desde su asentamiento formal en los años noventa las redes se incluyen como factor explicativo en investigaciones de carácter estructural o macro para determinar las pautas sistémicas. Actualmente lo más característico es un uso residual y sin diálogo científico entre expertos; en donde los temas estrellas estarían relacionados con las relaciones de parentesco, los movimientos

\footnotetext{
${ }^{29}$ José Ignacio RUÍZ OLABUÉNAGA: Metodología de la investigación cualitativa, Bilbao, Universidad de Deusto, 2003.

${ }^{30}$ Ver Una familia de la élite mexicana, parentesco, clase y cultura 1820-1890, México, Alianza Editorial, 1993.

${ }^{31}$ Ver "Representación gráfica de redes sociales. Un método de obtención y un ejemplo histórico", Mundo Agrario, vol. 3, 6 (2003).

${ }^{32}$ Michel BERTRAND y Claire LEMERCIER: "Introducción: ¿en qué punto ...”.
} 
migratorios, las relaciones interpersonales subyacentes a las jerarquías entre élites, los interlocks, la circulación del saber o las movilizaciones sociales y políticas. Por lo tanto, podemos observar cómo está ausente una aplicación para el estudio de las actitudes sociales ante la implantación de contextos de violencia estatal masiva. No obstante, la observación anterior puede estar vinculada con la dificultad de establecer representaciones gráficas de redes que operan en contextos de este tipo, lejanos en el tiempo con respecto al que se estudian. Pues, suele asociarse un uso formalizado de estas redes con dichas representaciones, lo que menoscaba la importancia de aproximaciones cuantitativas como la nuestra.

\section{Conclusiones}

El anterior recorrido por las vertientes metodológicas empleadas en nuestro proyecto de investigación nos lleva a realizar un compendio de las principales ideas a modo de cierre. La ubicación desde una historia social con una temática relacionada con las actitudes sociales justifica los enfoques desde los que se ha abordado la investigación en el sentido que permiten analizar las hipótesis de partida y ofrecen herramientas prácticas, y por lo tanto útiles para la tarea del historiador.

Sobre cómo entendemos el enfoque micro, es fundamental un aproximación integral e interdisciplinar; así como una utilización de la escala con miras generales, más amplias. Por lo tanto, no es que no sea válida una suma de microhistorias para una Historia, sino que los términos explicativos no giran en torno a esa órbita. Así, el marco macro está presente en el microzoom dotándolo así mismo de un sentido propio. Esto ha sido señalado en el texto de forma tanto concreta y puntual como general y transversal, haciendo hincapié en el "estudio EN" y señalando ejemplos concretos de nuestro estudio que así lo reflejan. De este modo, mostrar una concepción rigurosa del contexto histórico, así como los soportes que la sustentan es una parte fundamental de toda investigación. Aquí también entra en juego la delimitación espacial del zoom, los bordes -sean de la tipología que sean- deben de ser claros y precisos para no producir confusión en la fase analítica. Pongamos un ejemplo ilustrador real; como parte de la lógica procesal de las causas militares, no era extraño que la fiscalía recurriese a solicitar testimonio de agentes -como informes de conducta de autoridades de otras provincias- sobre los encausados que nada o poco tuviesen que ver con los autos. Al respecto, la posición tomada por parte 
De micro a macro: propuesta metodológica para el estudio de las actitudes sociales ante contextos de violencia estatal masiva

del investigador ha sido dejar fuera de análisis dichos sujetos por considerarse que no formaban parte del círculo espacial social en el que se movían los sujetos objeto de estudio.

Si nos detenemos en el uso proclamado de las historias de vida, debemos en primer lugar, señalar una conexión con lo expuesto inmediatamente en el párrafo anterior. Y es que se observa una relación dialéctica entre el contexto y la utilización de las entrevistas orales en la fase analítica a modo de contraste y rastreo de los perfiles intermediarios. Con la información de esta fuente completamos parte de las trayectorias personales, siendo posible la identificación de esos puntos de viraje que comportan las actitudes duales, cambiantes y llenas de paradojas.

En relación a qué y cuánto nos aporta una técnica mixta entre lo cualitativo y lo cuantitativo, mediante una integración combinada de ambas, podemos ofrecer datos de diferente naturaleza que enriquecen nuestro estudio. Así, hemos podido argumentar o cuestionar con datos concretos ciertas afirmaciones tópicas acerca del comportamiento de la sociedad ante el golpe de estado. Esto significa que esta investigación puede someterse en el tiempo a remodelaciones, críticas o refutaciones porque ofrece datos sobre los que apoyarse y no afirmaciones abstractas y generales que nacen a modo de carrerilla verbal sin fundamento empírico.

Por último, una última aportación sobre las potencialidades de un recurso poco explotado en las ciencias sociales y sobre todo en Historia, las redes sociales. Para nosotros ha sido uno de los mecanismos que nos ha permitido enlazar el espacio micro con el macro porque interconecta diferentes roles sociales a dos planos diferentes, el público y privado. Este entramado está detrás de los comportamientos y de las motivaciones, a pesar de escaparse estas últimas de nuestro análisis por ser terreno subjetivo. La dicotomía entre costo y beneficio explicado anteriormente puede arrojar luz sobre los mecanismos bajo los que operan estos entramados sociales; y dicha comprobación sólo puede llevarse a cabo bajo estudios muy concretos como es el caso. Por lo tanto, se proclama un mayor uso de esta herramienta para el ámbito histórico más allá de estudios biográficos o económicos. 


\title{
El anarquismo insurreccionalista en el siglo XXI: un fenómeno internacional
}

\author{
Insurrectionary Anarchism in the 21st century: An International \\ Phenomenon
}

\section{Miguel Morán Pallarés}

Universidad Nacional de Educación a Distancia

\section{Resumen}

El tema de este trabajo es el llamado anarquismo insurreccionalista. Sus antecedentes históricos se remontan a Max Stirner y su "egoísmo" y a algunos elementos del anarquismo clásico (propaganda por el hecho, ilegalismo, etc). Los autores insurreccionalistas más importantes (Alfredo Bonanno, Costantino Cavalleri, Feral Faun/Wolfi Landstreicher) ven la sociedad como opresiva y preconizan el ataque directo contra el Estado, sus instituciones y representantes. Los insurreccionalistas asumen una organización no jerárquica basada en la afinidad entre sus miembros y defienden involucrarse en las luchas sociales sectoriales o "intermedias". Se describe el desarrollo histórico desde los setenta del siglo XX hasta la actualidad.

\section{Palabras clave}

Anarquismo insurreccionalista, Control social, Ataque, Afinidad, Luchas intermedias.

\begin{abstract}
The object of this work is the so called insurrectionary anarchism. Its historical background goes back to Max Stirner and his "egoism" and to some elements of classic anarchism (propaganda by the deed, illegalism, etc). The most important insurrectionalist authors (Alfredo Bonanno, Costantino Cavalleri, Feral Faun/Wolfi Landstreicher) see society as oppressive and invoke direct attack against State, its institutions and
\end{abstract}


representatives. They assume a non-hierarchical organization based on affinity between its members and defend their involvement in "intermediate" social struggles. It's described its historical development from the 20th century seventies until nowadays.

\section{Palabras clave}

Insurrectionary anarchism; social control; attack; affinity; intermediate struggles.

\section{Antecedentes históricos del anarquismo insurreccionalista}

El alemán Max Stirner (1806-1856), autor de "El único y su propiedad”, es una de las principales referencias ideológicas para el anarquismo insurreccionalista. En su obra Stirner mantiene que el individuo es único y perfecto en sí mismo y debe buscar siempre su propio interés en función de sus deseos y necesidades, lo que no impide la relación y colaboración con otros individuos o "egos" (en una "unión de egoístas") para liberarse de todo tipo de opresión, siempre que dicha colaboración beneficie a todos por igual.

Dentro ya de la trayectoria histórica propiamente dicha del anarquismo, iniciada con los escritos de Mijaíl Bakunin en 1860, se aprecian determinados hechos y visiones relacionados con la utilización de la violencia política y con el modelo de organización, que pueden considerarse también antecedentes del anarquismo insurreccionalista.

Los intentos de insurrección popular llevados a cabo en Francia, como la insurrección de Lyon en 1870, en la que participaría Bakunin, o la conocida como “Comuna de París”, además de otras experiencias similares en Italia y España a lo largo del último tercio del siglo XIX y principios del siglo $\mathrm{XX}$, suponen experiencias referenciales en algunos aspectos para el insurreccionalismo.

En el mismo período de tiempo se produjeron una serie de magnicidios e intentos de asesinato contra jefes de estado y de gobierno europeos. Entre los líderes políticos asesinados por anarquistas se encuentran el presidente francés Sadi Carnot (1894), el presidente del Consejo de Ministros español Antonio Cánovas del Castillo (1897) o el rey de Italia Humberto I (1900), así como los intentos de regicidio contra el emperador 
Guillermo I de Alemania o el atentado de Mateo Morral contra Alfonso XIII. Estas acciones violentas tenían como objetivo conseguir hacer presentes ante la opinión pública las ideas y acciones anarquistas. Es el concepto que se ha denominado como "propaganda por el hecho", ${ }^{1}$ precedente del valor que el anarquismo insurreccionalista atribuye a las actividades violentas y a su reivindicación en los medios de comunicación.

En el seno del anarquismo se produjeron en esta fase histórica fuertes debates y disensiones respecto al modelo organizativo y al empleo de la acción violenta para alcanzar sus objetivos. Muchos abogaban por la creación de organizaciones sindicales de estructura formal y federal que abanderaran las luchas de los trabajadores y ampliaran la base de afiliados. Por el contrario, otros optaban por la organización en grupos sin jerarquías internas y por la continuación de la acción violenta, como los "ilegalistas" italianos, entre los que se encontraba Luigi Galleani.

Durante la primera mitad del siglo XX se produjeron las dos aplicaciones concretas más importantes del anarquismo. Por un lado, la insurrección generalizada liderada por Néstor Makhnó en Ucrania, desde finales de la I Guerra Mundial hasta inicios de los años veinte, caracterizada por el uso de guerrillas contra las potencias centrales y la URSS, y por el intento de organización socioeconómica mediante un sistema de comunas autogestionadas. Por otro lado, la breve experiencia colectivizadora y de autogestión de la CNT y la FAI en zonas de Cataluña, Aragón y Valencia durante la Guerra Civil española (1936-1939). ${ }^{2}$ Muchos anarquistas ven ambos casos como ejemplo de las posibilidades de implantación del anarquismo que no llegaron a culminarse.

El movimiento anarquista entró en un período de declive tras la II Guerra Mundial marcado por la división interna y el proceso de descomposición de las principales federaciones anarcosindicalistas europeas.

A partir de la aparición de los movimientos de protesta surgidos en Mayo del 68, en los que participaron, entre otros, jóvenes influidos por las ideas anarquistas,

\footnotetext{
${ }^{1}$ Juan AVILÉS.: "Propaganda por el hecho y regicidio en Italia", en Juan AVILÉS y Ángel HERRERÍN. (eds.): El nacimiento del terrorismo en Occidente. Anarquía, nihilismo y violencia revolucionaria, Madrid, Ed. Siglo XXI, 2008, pp.1-28.

${ }^{2}$ Aparte de los testimonios propios de anarquistas como Diego Abad de Santillán o José Peirats, uno de los estudios referenciales acerca de este tema es el del historiador alemán Walther L. Bernecker. Ver en: Walther L. BERNECKER.: Colectividades y revolución social. El anarquismo en la guerra civil española, 1936-1939., Barcelona, Crítica, 1982, pp. 524.
} 
aparecieron nuevas corrientes renovadoras, críticas con las organizaciones tradicionales del anarquismo. Estos movimientos, conocidos como post-anarquismos o neoanarquismos, fueron impulsados por autores como Murray Bookchin (ecología social), John Zerzan (anarco-primitivismo) o Hakim Bey (creador del anarquismo ontológico y del concepto de las TAZ, Temporary Autonomous Zones o Zonas Temporalmente Autónomas).

En tanto que la mayor parte de estas corrientes optaban por un enfoque pacifista, algunos grupos e individuos se mostraban partidarios de recuperar la acción violenta contra el sistema, caracterizándose por su enfoque antiautoritario, antipolítico y anticapitalista. Entre estos últimos, destacan grupos armados de estructura horizontal que realizaron atentados contra políticos, empresas y delegaciones diplomáticas, como el británico The Angry Brigade y la Azione Rivoluzionaria italiana, hasta su desaparición a comienzos de la década de los ochenta del siglo XX.

Es en este período en el que comienza a gestarse en Italia una corriente anarquista, descontenta con la, a su juicio, rigidez y falta de iniciativa de la Federación Anarquista Italiana, en torno a las ideas aportadas por el siciliano Alfredo Maria Bonanno, entre otros, de las que deriva el llamado anarquismo insurreccionalista.

\section{La visión de la sociedad según el anarquismo insurreccionalista.}

Tal y como se reflejaba en un escrito anónimo de gran difusión en el mundo "insurreccionalista", el insurreccionalismo no sería propiamente una ideología, "sino una praxis continua que tiene como objetivo acabar con la dominación del Estado y la continuidad del capitalismo[...] una práctica enfocada a la organización del ataque". 3

En este aspecto coincidía con lo expuesto en un artículo aparecido en la publicación anarquista Do or Die, en el que se afirmaba no como una ideología propiamente dicha, sino como algo más parecido a una práctica centrada en el ataque, que encuentra formas de auto-organización en la lucha y el combate que pueden servir en un proyecto futuro (tras la derrota del Estado y sus instituciones). ${ }^{4}$

\footnotetext{
3 Manual Insurreccionalista. https://resistenciayevolucion.wordpress.com/manual-insurreccionalista/. [Consulta 6 abril, 2017].

4 "Insurrectionary Anarchy. Organising for Attack!", Do or Die, 10, 2003, pp.258-266. http://www.ecoaction.org/dod/no10/anarchy.htm. [Consulta 6 abril, 2017].
} 
Estas ideas se inspiran en textos publicados desde la década de los setenta del siglo XX por algunos ideólogos que han influido de manera decisiva en el desarrollo teórico y práctico del anarquismo insurreccionalista. Entre éstos destacan de forma especial los italianos Alfredo Maria Bonanno y Costantino Cavalleri, el estadounidense conocido bajo los seudónimos Feral Faun/Wolfi Landstreicher y el estadounidense de origen cubano Gustavo Rodríguez.

La visión de la sociedad y las estructuras productivas del "insurreccionalismo" pretende diferenciarse claramente de los análisis propios del marxismo y de otras corrientes anarquistas. El primero en exponer en sus obras su análisis acerca de esta cuestión fue Bonanno, impulsor y principal referente de esta corriente anarquista desde sus orígenes en Italia.

Bonanno denominó como "sociedad postindustrial" a la surgida a finales de los años setenta, tras la crisis económica provocada por la subida de los precios del petróleo y el fuerte proceso de reconversión industrial que países como Italia vivieron con especial turbulencia política y social. Según él, la población se dividiría en dos categorías principales: "incluidos" y "excluidos", entre "los que tienen derechos y los que no los tienen. Entendiendo cuando por derechos se entiende la posibilidad sustancial de acceder a las fuentes de riqueza". Entre los incluidos se encontrarían los individuos y organizaciones que formarían parte de la estructura de opresión capitalista, se beneficiarían activamente de ella y defienden su existencia. Por su parte, los anarquistas insurreccionalistas se identifican con los excluidos por el sistema capitalista, entre los que se encontrarían los trabajadores afectados por el cambio de modelo productivo iniciado en los años setenta, los vecinos de los barrios urbanos, o las personas marginadas en "guetos sociales".

Para Bonanno, el capitalismo crea una falsa realidad en la que el hombre es a la vez "medio y fin", dentro de la lógica que impone el sistema referente a la producción y al trabajo, según la cual la persona cree satisfacer sus necesidades a través de la obtención de bienes (o "mercancías"). En realidad, el beneficiado sería el propio sistema, por partida doble, al ser las personas mano de obra y consumidores a la vez. En su opinión, la realidad

\footnotetext{
${ }^{5}$ Alfredo M. BONANNO.: "Esclusi e inclusi", en Alfredo M. BONANNO: Anarchismo insurrezionalista (seconda edizione), Trieste, Edizioni Anarchismo, 2009, p.44.
} 
estaría en la liberación de estas ataduras impuestas mediante la lucha, para pasar a una nueva situación en la que se alcanzara la verdadera satisfacción de las necesidades que derivan de los impulsos naturales.

A diferencia de los marxistas, Bonanno considera que cambiar el modo de producción no es la solución, ya que la propia producción, tanto en el modelo capitalista como en el del llamado socialismo real, está en la raíz de la explotación. Incluso el control autogestionado de la producción sería otra forma de explotación.

En su opinión se ha mitificado por parte del capitalismo el concepto de trabajo como forma de realización personal del hombre en cuanto indispensable para satisfacer sus necesidades. Esta concepción habría contribuido a:

La transformación de gente en "cosas" y de todo lo demás junto con ellos. La naturaleza se convierte en una "cosa". Utilizada, es corrompida y con ella los instintos vitales del hombre. Un abismo se abre entre la naturaleza y el hombre [...]. Si rechazan la forma de englobarlos o una forma alternativa de codificación, son criminalizados. ${ }^{6}$

Bonanno rechaza a los "viejos anarquistas" y a los sindicatos de trabajadores, a los que acusa de estar corrompidos y demasiado condicionados por lo que define como "ética del trabajo". Sería necesaria la sustitución de esta ética por lo que define como "estética del placer", que no implica no producir, sino impedir que la producción defina a la persona en cuanto a tal para que se sitúe en:

La esfera del juego y del placer[...]. Así sería posible parar de producir en cualquier momento, cuando haya suficiente. Sólo el placer será incontrolable [...]. Una fuerza que multiplicará por mil el impulso creativo de la revolución [...]. La acumulación cualitativa, no cuantitativa, debe sustituir a la acumulación capitalista. ${ }^{7}$

El término cuantitativo haría referencia a las estructuras políticas, sociales y económicas que constituyen el sistema y que están interesadas en el crecimiento numérico tanto de sus apoyos como en el ámbito de la producción. Frente a este concepto, lo cualitativo indica la transformación de la realidad mediante la revolución y la ruptura con las imposiciones del sistema, junto al interés mostrado no tanto por aumentar numéricamente las personas implicadas en la lucha revolucionaria sino en lograr sus objetivos.

\footnotetext{
${ }^{6}$ Alfredo M. BONANNO.: Armed Joy, Londres, Elephant Editions, 1998, p.7.

${ }^{7}$ Alfredo M. BONANNO: Armed..., p.13.
} 
Para el anarquista estadounidense Feral Faun/Wolfi Landstreicher, las dos funciones fundamentales del Estado son la protección de la propiedad y el mantenimiento de la paz social, que desarrolla ejerciendo una violencia institucionalizada a través de legislación y de sus fuerzas armadas y policiales. El Estado y el capital funcionan de manera conjunta, ejerciendo el dominio y la explotación. La propiedad, el intercambio de bienes y el trabajo, son las bases socioeconómicas sobre las que la clase dominante sustenta su poder. Así, se produciría una alienación social fundamental consistente en usurpar a la inmensa mayoría de la población su capacidad para decidir sobre su propia existencia.

En su opinión, la alienación del sistema se produciría también a través de conceptos y roles sociales, como los de raza, género, religión, preferencias sexuales, que contribuyen al mantenimiento del orden social vigente. El movimiento feminista, por ejemplo, no habría logrado alcanzar un análisis apropiado de la forma de dominación ejercida por el poder a través de la asignación de un rol específico de género, al buscar la liberación de la mujer respecto al hombre y no respecto al sistema. Sería necesario ir más allá de ciertas reivindicaciones parciales respecto al género, para profundizar en la lucha contra todo aquello que impide la realización plena del individuo. ${ }^{8}$

La relación entre el trabajador y su empleador es desigual, ya que el primero se ve obligado a vender su tiempo y su trabajo para sobrevivir, en una situación de chantaje. Esta sería la base de lo que él denomina sumisión de esclavos:

Éste es el mundo que debemos destruir en el proceso de recuperar nuestras vidas, y la necesidad de esta destrucción hace que el proyecto de reapropiación de nuestras vidas sea uno con los proyectos de insurrección y revolución social. ${ }^{9}$

Al igual que Bonanno y otros anarquistas insurreccionalistas, Landstreicher considera que la tecnología no es neutral, sino que es una herramienta de la clase dominante para controlar a los individuos. Por tanto, el sistema tecnológico, que forma parte de lo que define como "maquinaria de control", tendrá que ser destruido. El autor insurreccionalista critica también el ecologismo, ${ }^{10}$ por centrarse en la protección de la

\footnotetext{
${ }^{8}$ Análisis del feminismo en Wolfi LANDSTREICHER: Against the logic of submission, 2005, pp.11-13.

${ }^{9}$ Wolfi LANDSTREICHER: The Network of Domination, 2005, p.11.

${ }^{10}$ Wolfi LANDSTREICHER: Barbaric Thoughts: On a Revolutionary Critique of Civilization, 2010, pp. $5-6$.
} 
naturaleza, sin analizar la realidad social o las causas últimas del daño que se le hace, que estaría relacionado con la existencia de un sistema tecnológico de producción a gran escala propio de la estructura de dominio.

Dentro de las ataduras que impone el control social, Landstreicher considera especialmente relevantes la religión, la psiquiatría y el concepto de familia. La religión, al igual que la psiquiatría, se arrogaría, negándosela al individuo, la capacidad para interpretar sus relaciones con el mundo y con su propia personalidad, a través de especialistas cuyas interpretaciones de la realidad y de la persona estarían al servicio del poder. Por su parte, la familia tendría como objetivo principal la reproducción de la sociedad, no sólo mediante la reproducción de seres humanos sino transformándolos en seres útiles para la sociedad, sujetos leales, buenos ciudadanos, trabajadores aplicados y ávidos consumidores. La familia también serviría para transmitir una serie de actitudes vitales y comportamientos sociales inspirados en patrones propios de la sumisión al poder. $^{11}$

La lucha de determinados grupos que se sienten discriminados en la sociedad, tales como las mujeres, los homosexuales o las minorías étnicas, no debería consistir en el recurso a la "victimización" y en la reclamación de sus derechos a las autoridades, sino en la aceptación de sus pasiones y sus deseos que les permita vivir más allá de cualquier rol social como base para la rebelión total contra la sociedad.

Concibe la anarquía como una forma de vida libre de imposiciones morales, al entender que cualquier tipo de moral restringe la libertad del individuo para rebelarse contra lo establecido y vivir su propia vida en plenitud. Y critica la religión por considerarla una justificación ideológica de la explotación al concebir una división entre el espíritu, en el que sitúa la libertad o la creatividad, y la materia, que sería el ámbito del sufrimiento y la esclavitud. Para él:

La religión pretende devolvernos la libertad, la creatividad, la plenitud apasionada de vida que nos fue robada, pero, de hecho, es parte de la conspiración para mantener la plenitud lejos de nosotros. Al relegar la creatividad, la pasión, la libertad y el éxtasis al ámbito de lo

${ }^{11}$ Ver en Wolfi LANDSTREICHER: The Network ..., 2005, pp.15-20. 
espiritual, la religión lo saca con seguridad del ámbito de la vida diaria y lo sitúa en el lugar “adecuado" donde no puedan convertirse en una amenaza para la civilización... ${ }^{12}$

\section{Las propuestas del anarquismo insurreccionalista.}

Tal y como se ha indicado anteriormente, los autores anarco-insurreccionalistas vinculan constantemente la aplicación de los fundamentos teóricos y organizativos a la práctica de la acción directa contra el Estado y el sistema capitalista. El enfrentamiento directo con el Estado no debería limitarse únicamente al terreno de las ideas, sino que tendría que incluir, al mismo tiempo y de forma paralela, la práctica del ataque armado contra sus instituciones, instalaciones y representantes (entre los que se encuentran las fuerzas de seguridad del Estado, los políticos, los eclesiásticos, los banqueros, empresarios y especuladores, así como los edificios e instalaciones en los que desarrollan su actividad).

Ambos aspectos del ataque estarían estrechamente relacionados. La teoría sin la práctica podría quedar reducida al campo de las ideas políticas o filosóficas. Por su parte para que la práctica del ataque sea realmente efectiva debe sustentarse en el análisis crítico de las ideas de su enemigo. Se produciría así una dinámica interactiva entre teoría y acción práctica: "Un materialismo libertario debe necesariamente superar la separación entre idea y hecho. Una vez se identifica al enemigo hay que golpearlo, y golpearlo del modo adecuado". ${ }^{13}$ Para alcanzar esa conexión indispensable entre teoría y práctica sería necesario elaborar un proyecto: "[...] el trabajo del revolucionario es, esencialmente, la elaboración y la realización de un proyecto". ${ }^{14}$

Bonanno señala las cualidades que debe tener un revolucionario para poder elaborar su proyecto. En primer lugar, la valentía para comprometerse a fondo con la elaboración del proyecto revolucionario. En segundo lugar, la constancia en el trabajo para dotarse de los medios culturales, mediante el conocimiento de diferentes lenguas y de disciplinas tales como economía, filosofía y otras ciencias sociales. Incluso la mejora de las habilidades para escribir, expresarse en público, estudiar o la habilidad para manipular

\footnotetext{
12 FERAL FAUN: “The Quest for the Spiritual: A Basis for a Radical Analysis of Religion”, en Feral Revolution and..., p.31.

${ }^{13}$ Alfredo M. BONANNO: Anarchismo ..., p.169.

${ }^{14}$ Alfredo M. BONANNO: Anarchismo ..., p.170.
} 
objetos. ${ }^{15}$ Y finalmente, lo que Bonanno llama materialidad, es decir, la capacidad para determinar qué medios son necesarios para realizar la acción que se pretende y la forma más adecuada para obtenerlos.

Bonanno rechaza el papel de las organizaciones revolucionarias tradicionales, incluidas las anarquistas, a las que considera ancladas en el pasado e ineficaces a la hora de pasar a la lucha directa contra el Estado:

La gente está cansada de reuniones, de los [autores] clásicos, de las marchas inútiles, de las discusiones teóricas innecesarias, de las distinciones sin fin, de la monotonía y pobreza de ciertos análisis políticos. Prefieren hacer el amor, fumar, escuchar música, caminar, dormir, reír, jugar, matar policías, lisiar periodistas, asesinar jueces, volar cuarteles [...]. Date prisa camarada, dispara al policía, al juez, al jefe. Ahora, antes de que una nueva policía te lo impida. Date prisa en decir No, antes de que una nueva represión te convenza de que decir no es inútil, loco, y que deberías aceptar la hospitalidad del manicomio. Date prisa en atacar al capital antes de que una nueva ideología lo haga sagrado para ti. Date prisa en rechazar el trabajo antes de que un nuevo sofista te diga de nuevo que "el trabajo te hace libre". Date prisa en jugar. Date prisa en armarte. ${ }^{16}$

Bonanno así mismo advertía sobre el riesgo de que el sistema capitalista asimilara y finalmente llegara a controlar o integrar en su ámbito los procesos revolucionarios. Para evitarlo es necesario que se rechace entrar en la lógica del capitalismo y enfrentarse directamente con él hasta destruirlo completamente:

El capital lo devora todo, incluso la revolución. Si ésta no rompe con el modelo de producción, sino que meramente aspira a imponer formas alternativas, el capitalismo la engullirá en el espectáculo de la mercancía. Sólo la lucha no puede ser engullida.[...] El juego ilusorio del capital (el espectáculo de la mercancía) debe ser sustituido por el juego real del ataque armado contra él para la destrucción de lo irreal y del espectáculo. ${ }^{17}$

Para Feral Faun/Wolfi Landstreicher el proceso revolucionario en realidad consiste, sobre todo, en un proceso de transformación personal para romper los condicionamientos sociales y utilizar las convenciones que la sociedad impone únicamente en la medida

\footnotetext{
${ }^{15}$ Cabe la posibilidad de que Bonanno haga aquí una referencia velada a la fabricación y colocación de artefactos explosivos caseros y de otros "instrumentos" utilizados en la lucha revolucionaria.

${ }^{16}$ Alfredo M. BONANNO.: Armed ..., p.19.

${ }^{17}$ Alfredo M. BONANNO: Armed ..., p.21
} 
necesaria para sobrevivir en ella. ${ }^{18}$ Así el mundo se transformaría, según él, en un lugar donde la realización de los deseos fuera algo normal, no esporádico:

Tenemos que atrevernos a destruir todo lo que destruye nuestro desenfreno y actuar según nuestros instintos y deseos. Tenemos que atrevernos a confiar en nosotros mismos, en nuestras experiencias y nuestras pasiones. [...] Nuestra energía salvaje rasgará la civilización a jirones y creará una vida de libertad salvaje y placer intenso. ${ }^{19}$

Para desarrollar el proyecto insurreccional anarquista es necesaria la liberación por parte del individuo de toda atadura impuesta a través del control social, y su propia transformación personal y en cuanto al modo de relacionarse. Los actos de rebelión individuales ya son formas de insurrección. Impulsado por la energía del deseo liberado, el proyecto de insurrección personal, con su dinámica de libertad y alegría, tiende a compartirse con otros individuos mediante relaciones de afinidad en la forma de vivir y ser. El odio a los individuos, instituciones y estructuras del sistema, proporciona también energía al proyecto anarquista insurreccional. El objetivo final seguiría siendo la destrucción de la sociedad actual para conseguir la realización plena de las personas. ${ }^{20}$

Landstreicher ataca a las organizaciones que denomina "izquierdistas", entre las que se encontrarían algunos partidos políticos y también organizaciones "autodenominadas anarquistas", por entender que aspiran a modificar el sistema, pero no a destruirlo. Estos grupos asumirían un proyecto de introducción gradual de reformas sociales, sin poner en cuestión el sistema en cuanto a tal. ${ }^{21}$

Un aspecto fundamental en el insurreccionalismo es el modelo organizativo a adoptar. Según Bonanno, en el movimiento anarquista se han enfrentado dos visiones opuestas y extremas en cuanto al modelo de organización. Por un lado, estarían las estructuras permanentes, con organización jerarquizada, y con objetivos programáticos aprobados en asambleas y congresos, propias de las federaciones anarquistas clásicas (tanto las surgidas en los orígenes del anarquismo durante el s. XIX, como las creadas o refundadas en el período posterior a la Segunda Guerra Mundial):

\footnotetext{
${ }^{18}$ Aquí se puede apreciar la influencia de Bonanno y Max Stirner.

${ }^{19}$ Feral FAUN: Feral Revolution and other essays, Londres, Elephant Editions, 2001, pp.13-14.

${ }^{20}$ En Wolfi LANDSTREICHER: Against the logic..., pp.3-5 y 9.

${ }^{21}$ Wolfi LANDSTREICHER: From Politics to Life: Ridding anarchy of the leftist millstone, 2009, $6 \mathrm{pp}$.
} 
Quien trabaja dentro de estructuras de masas (por ejemplo, desde una óptica anarcosindicalista) espera que se pase de los pequeños resultados defensivos de hoy al gran estado revolucionario de mañana. ${ }^{22}$

Por otro lado, se encontrarían los anarquistas individualistas, reacios a debatir y a colaborar con otros compañeros en el seno de una rígida organización preestablecida y partidarios de la acción en solitario:

[...] es necesario establecer contactos entre compañeros para pasar a la acción. Solos no se está en condiciones de actuar, salvo reduciéndose a una protesta platónica, lo cruenta y terrible que se quiera, pero siempre platónica. Si se busca actuar de una manera incisiva sobre la realidad es necesario ser muchos. ${ }^{23}$

Bonanno rechaza ambas opciones y también la propia de las organizaciones revolucionarias armadas de estructura militar. Entiende incluso que estas últimas son más fácilmente controlables por el sistema, dada su estructura jerárquica, con división de roles y tareas, asemejándose en este sentido a la organización propia del sistema capitalista:

La lucha armada no debe convertirse en algo profesional, evitando la división de tareas que el aspecto externo de la producción capitalista quiere imponer sobre ella. [...] Rompiendo las ataduras de centralización (del partido militar) se obtiene el resultado de confundir las ideas del capital [...]. La acción coordinada por el placer es un enigma para el capital. No es nada. Algo sin objetivo preciso, desprovisto de realidad. Y esto es así porque la esencia, los objetivos y la realidad del capital son ilusorios, en tanto que la esencia, los objetivos y la realidad de la revolución son concretos. ${ }^{24}$

Bonanno introduce su concepto de afinidad. ${ }^{25}$ La afinidad no consistiría en un sentimiento de amor, amistad o simpatía, sino que haría referencia a la "profundización del conocimiento recíproco". ${ }^{26}$ Tal conocimiento se obtendría del análisis en común de los problemas sociales que se enfrentan a través de la lucha. Y cuánto más amplio y en profundidad fuera ese análisis de la realidad, mayor sería la capacidad de actuar conjuntamente, e incluso de aumentar el número de miembros $\mathrm{y}$, por tanto, la potencialidad del grupo:

\footnotetext{
${ }^{22}$ Alfredo M. BONANNO: Anarchismo ..., p.156.

${ }^{23}$ Alfredo M. BONANNO: Anarchismo ..., p.157.

${ }^{24}$ Alfredo M. BONANNO: Armed ..., pp.23-24.

${ }^{25}$ El término afinidad fue utilizado con anterioridad por autores y organizaciones anarquistas más antiguas como la CNT gaditana, si bien en un sentido distinto al que le da Bonanno.

${ }^{26}$ Alfredo M. BONANNO: Anarchismo ..., p. 157.
} 
El grupo de afinidad es pues una organización específica que se forma en torno a afinidades comunes. [...] el conjunto de estos compañeros tendrá una tendencia al crecimiento cuantitativo, pero limitada y no consistente en la única finalidad de la actividad. El desarrollo numérico es indispensable para la acción y también una confirmación de la amplitud del análisis que se está desarrollando y de capacidad de descubrir poco a poco afinidades con un mayor número de compañeros. ${ }^{27}$

El grupo anarquista, formado por miembros unidos por la afinidad común, se realiza a través de la acción, fundamental también para la dinámica del grupo.

Bonanno diferencia entre la que denomina como organización de síntesis, y el modelo que él propone, la organización informal. La organización de síntesis ${ }^{28}$ es una estructura organizativa permanente, con órganos de control internos y cargos de responsabilidad designados, que toma las decisiones más importantes desde el punto de vista programático en asambleas y congresos celebrados de forma periódica. En las luchas sociales, este tipo de organizaciones se ven supeditadas y, en cierta medida, coartadas, al tener que seguir sus miembros las estrictas directrices programáticas aprobadas en los congresos y asambleas.

En su opinión, este tipo de organizaciones de síntesis tienden a caer en la lógica de los partidos, en un proceso en el que empezarían relajando sus posiciones en las luchas sociales y en los métodos empleados en ellas, y continuarían por hacer cesiones y tratar de llegar a acuerdos con las estructuras del poder, moderando cada vez más sus acciones para asegurar los consensos internos:

Así, la presencia de la organización de síntesis en el interior de las luchas reales, de las luchas que se insertan en la parte viva del enfrentamiento de clase, constituye un freno y un control a menudo involuntario, pero siempre un control. ${ }^{29}$

En cambio, la organización informal se basa en los grupos de afinidad cuyos miembros se unen, no por adherirse a un programa establecido en un congreso, sino en torno a un proyecto realizado por ellos mismos a partir de sus análisis de la realidad social y de sus acciones. Sus miembros no tienen que solicitar a nadie un ingreso formal (como

\footnotetext{
${ }^{27}$ Alfredo M. BONANNO.: Anarchismo ..., pp.159-160.

28 Cuando Bonanno hace referencia a la organización de síntesis, se refiere principalmente a las organizaciones anarcosindicalistas como la CNT en España, o los sindicatos anarquistas italianos de la posguerra.

${ }^{29}$ Alfredo M. BONANNO: Anarchismo ..., p.164.
} 
sería necesario en un sindicato o en un partido político), sino que forman parte de la organización de forma automática al reconocerse afines a otros en la lucha y la acción.

La acción revolucionaria necesita incorporar la participación de las masas. Para ello, los anarquistas han de involucrarse en las luchas sectoriales o, como Bonanno las denomina, "luchas intermedias". Es en este contexto en el que los grupos de afinidad contribuirían a la creación de núcleos autónomos de base, estructuras constituidas por anarquistas insurreccionalistas y no anarquistas. Los anarquistas aportan a estos núcleos su método propio insurreccionalista de ataque, definido por tres elementos básicos: la conflictividad permanente contra las estructuras capitalistas y contra sus gestores; la autogestión, entendida como la independencia absoluta respecto a cualquier partido político, sindicato, etc.; y el ataque, entendido como el rechazo a cualquier pacto, negociación o compromiso con el enemigo de clase: ${ }^{30}$

Lo que caracteriza el insurreccionalismo anárquico es el método puesto en marcha, no el contenido de cada lucha. El método se justifica por sí mismo, por lo que excluye una valoración de tipo cuantitativo: no se actúa en función del aumento del número de los anarquistas, sino de los estímulos que el método llega a difundir en lo social o en las luchas específicas. $^{31}$

Distintos núcleos autónomos de base podrían crear estructuras informales de coordinación entre ellos. Al describir la finalidad de la coordinación entre los núcleos de base, Bonanno oscila entre una perspectiva puramente informal y las necesidades derivadas de la acción directa:

La función de la "coordinación de los núcleos autónomos de base" es, por tanto, la de enlazar las luchas. Aquí sólo se sugiere un problema (extremadamente indigesto para los anarquistas, pero muy sencillo para quién no es anarquista): la necesidad, en el caso de un ataque masivo contra las estructuras de poder, de distribuir las tareas de cada uno antes del ataque mismo, es decir, de ponerse de acuerdo, en los mínimos detalles, sobre lo que es necesario hacer. ${ }^{32}$

Estas luchas parciales tendrían el objetivo de provocar una serie de insurrecciones que se convertirían, en un futuro siempre aplazado e indeterminado, en una insurrección

\footnotetext{
${ }^{30}$ Ver Alfredo M. BONANNO "Nueva "vuelta de tuerca" del capitalismo", 1993. En BONANNO, A. M. (y otros): No podréis pararnos. La lucha anarquista revolucionaria en Italia., Ed. Klinamen y Ediciones Conspiración, 2005, pp.21-36.

${ }^{31}$ Constantino CAVALLERI: El anarquismo en la sociedad postindustrial..., p.24.

${ }^{32}$ Alfredo M. BONANNO: Anarchismo ..., p.39.
} 
generalizada que en último término acabaría con la destrucción completa del Estado y sus estructuras.

Sin embargo, en los últimos años algunos autores y organizaciones empezaban a abogar por una reelaboración teórico-práctica del anarquismo insurreccionalista, de un nuevo "ilegalismo", en el que una serie de anarquistas informales asumen la práctica anarquista contemporánea, incidiendo en la autonomía individual, una organización mínima y la práctica antisistémica negadora y destructiva, basada en la acción directa y en la conflictividad permanente. En esta propuesta confluyen también elementos del nihilismo anárquico, anticivilización y antitecnología. Por otra parte, no creen en una sociedad ideal utópica:

Estamos convencidos que la "sociedad anarquista" no se concretará mañana en la mañana. Es más, tenemos casi la certeza que muy probablemente nunca se concrete. Y nos tiene sin cuidado. [...] esto no significa que la Anarquía no sea posible aquí y ahora. Para nosotros la Anarquía no sólo es posible, sino que se concreta de manera efímera cada vez que se realiza una expropiación exitosa; se constata en esos breves instantes en que se ilumina la noche con el fuego refractario; se confirma en cada fuga de prisión; se verifica con la eliminación física de nuestros enemigos. [...] Es la búsqueda incesante de Libertad irrestricta. Es la propagación consciente del Caos y sus consecuencias. ${ }^{33}$

Gustavo Rodríguez establece la diferencia entre los conceptos de "vía armada" y "lucha armada". La "vía armada", sin renunciar a la violencia como método para hacer frente a la violencia del sistema, incluye también la batalla contra las ideologías de los adversarios. La "lucha armada" sería una estrategia de guerra utilizada por proyectos políticos de múltiple naturaleza, cuya finalidad sería alcanzar el poder. El anarquismo insurreccionalista no debe reducirse a la "lucha armada", dado que su objetivo no sería alcanzar y sustituir al poder, sino la destrucción del sistema.

\section{Desarrollo histórico del anarquismo insurreccionalista hasta la actualidad}

Los orígenes históricos del movimiento anarco-insurreccionalista se encuentran en la Italia de los años setenta. En este período convulso, conocido como los "años de plomo", la violencia terrorista ejercida por organizaciones clandestinas de extrema izquierda, como las Brigadas Rojas, y de extrema derecha, en ocasiones con conexiones

\footnotetext{
${ }^{33}$ Gustavo RODRIGUEZ: "Diálogos anarquistas. Un coloquio sobre teoría y práctica en torno a la denominada Tendencia Informal Anarquista”, Conspiración Ácrata, 18 (2012), p.33.
} 
con cuerpos de seguridad del Estado, marcaban la agenda política y social del país. La sucesión de atentados y acciones terroristas de extrema gravedad, como el secuestro y asesinato del líder de la Democracia Cristiana Aldo Moro en 1978 o el atentado en la estación de tren de Bolonia en 1980, causaron enorme conmoción social y pusieron en cuestión el propio sistema.

En esta misma época, las protestas sociales y laborales en Italia alcanzaron su máxima expresión con los movimientos del Sesantotto (68) y del Settantasette (77), protagonizados principalmente por "jóvenes desempleados y subempleados atrapados en empleos sumergidos no regulados" ${ }^{34}$ que rompieron su vinculación con los partidos y sindicatos de izquierda tradicionales y realizaron numerosos actos de protesta $\mathrm{y}$ enfrentamiento violento, contra éstos últimos y contra la policía. Se empezaron a formar pequeños grupos de anarquistas descontentos con el funcionamiento y la actuación de las organizaciones anarcosindicalistas italianas. Eran partidarios de la organización informal y de la acción directa violenta dirigida a acabar con el Estado y el capitalismo.

Durante los años ochenta, el anarquismo insurreccionalista fue sumando partidarios para su causa, aunque continuaba siendo un movimiento muy minoritario y localizado en Italia. En esta época tienen un especial significado para sus miembros las protestas contra la construcción de una base de misiles norteamericana en Comiso, Sicilia. Los anarquistas actuaron como catalizador de las protestas de los habitantes de la zona. Una gran manifestación promovida por los activistas concluyó con enfrentamientos con la policía. La base se puso en funcionamiento a mediados de los ochenta, pero dejó de estar operativa en 1992.

A partir de inicios de la década de 1990 comenzó una segunda etapa en la evolución de este movimiento, caracterizada por el inicio de la expansión de las ideas “insurreccionalistas" entre círculos anarquistas de fuera de Italia, especialmente en Grecia y España, pero también en otros países. En 1993, los italianos Alfredo Bonanno y Constantino Cavalleri impulsaron, en colaboración con activistas griegos, la convocatoria de una Internacional Antiautoritaria Insurreccionalista, que pretendía ser un lugar de encuentro, conocimiento mutuo e intercambio de ideas. Esta iniciativa no llegó a

\footnotetext{
${ }^{34}$ Gun CUNINGHAME, P.: "A Laughter That Will Bury You All": Irony as Protest and Language as Struggle in the Italian 1977 Movement", International Review of Social History, vol. 52, 15 (2007), pp. $153-168$
} 
desarrollarse plenamente, en parte por el inicio de operaciones policiales y procesos judiciales contra Bonanno y otros anarquistas italianos por pertenencia a organización criminal.

En la segunda mitad de los noventa y hacia principios de los 2000, se produjo un incremento en el número de acciones y organizaciones clandestinas "insurreccionalistas". Algunos hechos de especial gravedad crearon controversia en el seno del anarquismo, como el asesinato de dos agentes de policía en la ciudad española de Córdoba a manos de unos anarquistas italianos, que previamente habían atracado una sucursal bancaria y que algunos medios de prensa identificaron inicialmente como delincuentes comunes. ${ }^{35}$ También hubo participación de anarquistas insurreccionalistas (junto a grupos de extrema izquierda, ecologistas y antiglobalización) en las violentas protestas de Seattle, en 1999, con motivo de la celebración de una cumbre de la Organización Mundial del Comercio (O.M.C.), y de Génova, en julio de 2001, contra la cumbre del G-8, en las que murió el joven manifestante de izquierdas Carlo Giuliani durante un enfrentamiento con la policía.

En este mismo período de tiempo, una serie de atentados con explosivos y artefactos incendiarios contra empresas y medios de comunicación en España e Italia supusieron en la práctica el germen de la organización anarco-insurreccionalista italiana autodenominada Federazione Anarchica Informale (Federación Anarquista Informal, FAI). ${ }^{36}$ Este grupo, que adoptó una estructura informal sin jerarquías internas, estaba formado desde sus orígenes por pequeños grupos o células, unidas por las ideas “insurrecionalistas" de afinidad, solidaridad con los presos y la acción directa contra Estado y el capitalismo a través de "campañas revolucionarias", como exponían en un comunicado difundido en internet y medios de comunicación. ${ }^{37}$ En realidad, la creación de la FAI a finales de 2003 supone el inicio de una nueva etapa en la evolución del anarquismo insurreccionalista, en cuanto que adquiere una mayor complejidad

\footnotetext{
35 José L. RODRÍGUEZ.: “Asesinadas dos mujeres policías en Córdoba”, El País, 19-12-1996. http://elpais.com/diario/1996/12/19/espana/850950016_850215.html. [Consulta 8 abril, 2017].

${ }^{36}$ No hay que confundir estas siglas con las de la Federación Anarquista Ibérica (FAI), creada en 1927 y vinculada a la CNT, que tuvo un papel relevante durante la Guerra Civil (1936-1939); ni con las de la Federazione Anarchica Italiana (FAI), la principal organización anarcosindicalista italiana durante la segunda mitad del siglo XX.

${ }^{37}$ FAI: Carta abierta de la FAI y presentación, diciembre 2003, 4 pp. http://old.kaosenlared.net/notici a/carta-abierta-fai-presentacion. [Consulta 9 abril, 2017].
} 
organizativa y de coordinación, incluso a nivel internacional, superior a la contemplada por la "informalidad" preconizada en sus escritos por Alfredo Bonanno.

Las primeras acciones propiamente reivindicadas por la FAI tuvieron lugar en diciembre de 2003, con el envío de paquetes bomba a políticos e instituciones europeas en lo que denominaron de forma un tanto sarcástica "Operación Santa Claus". En los años siguientes nuevos grupos se adhirieron a la FAI, ampliando el ámbito de actuación a campos como el ecologismo y la protección de los animales en su visión más radical, ${ }^{38} \mathrm{o}$ la solidaridad con los inmigrantes internados en el equivalente italiano a los CIE (Centros de Internamiento para Extranjeros) españoles, manifestada en atentados contra directivos de estos centros.

A finales de 2006 se produjo en el seno de la FAI un debate interno sobre la evolución de la organización y la valoración de su experiencia desde sus inicios. El resultado del debate se plasmó en un documento, difundido en páginas web "insurreccionalistas", bajo el título "Quattro anni". ${ }^{39}$ Los miembros de la FAI consideraban que, a pesar de algunas carencias técnicas y de comunicación, habían conseguido hacer llegar su mensaje, sobre quiénes y qué pretendían los anarquistas con sus acciones, a estratos sociales más amplios. Se congratulaban de que en el período de tiempo transcurrido desde la constitución de la Federación no había sido desarticulado en su totalidad ningún grupo. ${ }^{40}$ Así mismo, consideraban que la acción era la mejor forma de extender sus ideas y que la propaganda armada seguía siendo útil en pleno siglo XXI.

Alguno de los asistentes planteaba la situación de un cierto estancamiento del movimiento anarquista, con escasas incorporaciones de nuevos miembros y las bajas de algunos veteranos para incorporarse a las luchas sociales:

Por desgracia hay por ahí quién piensa que el conflicto social se puede accionar con el papel impreso, con proclamas más o menos incendiarias o, peor todavía, haciendo asistencialismo, entrismo asistencialista...se acabará por entrar en las asociaciones católicas...(risas)”. ${ }^{41}$

\footnotetext{
${ }^{38}$ Hubo diversos ataques, como el producido a finales de 2004 contra un centro de animales para peletería en la provincia de Cremona (Italia).

${ }^{39}$ FAI: Quattro Anni, diciembre de 2006, 14 pp. http://feartosleep.blogspot.com.es/2011/11/documentoincontro-federazione.html. [Consulta 9 abril, 2017].

${ }^{40}$ FAI: Quattro ..., p.3.

${ }^{41}$ FAI: Quattro ..., p.7.
} 
Para solucionar esta situación algunos miembros proponían suavizar y diversificar el nivel de las acciones, que, en el caso de ser demasiado violentas, podían suscitar rechazo. Este enfoque era rechazado de plano por otros participantes en la reunión:

Según yo el problema es el contrario. Tenemos que hacer ver que vamos en serio, que no nos escondemos detrás de razonamientos intelectualoides y que no tenemos problemas para pasar al ataque aún a riesgo de jugarnos la vida. ${ }^{42}$

Se comentaba también el problema planteado sobre la necesidad de evitar daños a inocentes en las acciones violentas. Consideraban que el exceso de cuidado en esta materia les había llevado a utilizar a veces medios de ataque poco eficaces. En cualquier caso, las acciones fallidas en su objetivo principal, habían logrado alcanzar objetivos colaterales, como los daños económicos o el sentimiento de inseguridad y ridículo en los cuerpos de seguridad del Estado.

Frente al pesimismo mostrado por algunos participantes en cuanto a la evolución del movimiento, otros resaltaban algunos efectos positivos: un crecimiento pequeño pero constatable; en inicio en los periódicos y luego en internet, se había abierto el debate sobre la lucha insurreccionalista; y se valoraba también como positivo que muchos jóvenes se habían aproximado gracias a los sucesos producidos a raíz de las protestas contra la cumbre del G8 en Génova, donde "las prácticas puestas en marcha no eran ciertamente de pacifistas o de las FAI-formales". ${ }^{43}$

En los años siguientes, de 2007 a 2009, la presión policial y judicial sobre la FAI produjo la disminución temporal de sus acciones, que adquirieron un perfil menor. Sin embargo, la labor de propaganda y adhesión de miembros, principalmente a nivel internacional fuera de Italia, continuó merced a una intensa actividad en internet. En este período, caracterizado por el comienzo de la crisis económica a nivel mundial, en Grecia se vivía un creciente malestar de la sociedad con la situación política y económica del país. A principios de 2008 surgió, influida por las ideas anarco-insurreccionalistas y por una cierta visión nihilista y anti-social, la organización Synomosía Pyrínon Tis Fotiás (Conspiración de las Células de Fuego, CCF).

${ }^{42}$ FAI: Quattro ..., p.9.

${ }^{43}$ FAI: Quattro ..., p.14. 
La CCF, identificada con los postulados más radicales de autores como Gustavo Rodríguez, realizó a partir de ese momento numerosos atentados con explosivos contra policías, jueces, políticos y figuras del ámbito académico y de la prensa, y participó de forma violenta en las protestas sociales vividas en Grecia desde entonces.

A partir de 2011 y hasta la actualidad se vive un nuevo período en el desarrollo histórico del anarquismo insurreccionalista, marcado por la alianza y coordinación de las acciones entre la FAI, que pasó a denominarse FAI-FRI (Federación Anarquista InformalFrente Revolucionario Internacional), y la CCF, que respondía a los llamamientos de sectores del insurreccionalismo para la creación de una nueva "Internacional Negra" a nivel global, en la que se incluirían células y grupos de Europa, algunos países del continente americano (especialmente México y Chile) e incluso de lugares aparentemente más alejados de esta dinámica como Indonesia.

En estos últimos años se han producido altibajos en la actividad de estas organizaciones, alternando periodos de mayor inactividad, debido a operaciones policiales, con la comisión de atentados de mayor repercusión de los que se han hecho eco los medios de comunicación. Entre estos destacan el atentado sufrido en 2012 por Roberto Adinolfi, ingeniero directivo de la empresa italiana Ansaldo Nucleare, disparado en la pierna a la salida de su domicilio en la ciudad de Génova.

La campaña revolucionaria de 2013 denominada "Proyecto Fénix", con una serie de atentados con explosivos que supusieron el retorno a la actividad armada de la CCF; la colocación de artefactos explosivos en la Catedral de la Almudena de Madrid ${ }^{44}$ (febrero de 2013) y la Basílica del Pilar de Zaragoza (octubre de 2013), por parte de los anarquistas chilenos Mónica Caballero y Francisco Solar, miembros del autodenominado Comando Insurreccionalista Mateo Morral; o la reciente puesta en marcha por parte de la CCF del "Plan Némesis", con una serie de envíos de paquetes bomba a políticos e instituciones internacionales a mediados de marzo de 2017.

\footnotetext{
${ }^{44}$ COMANDO INSURRECCIONALISTA MATEO MORRAL: "Madrid: Reivindicación de la colocación de artefacto explosivo en la catedral La Almudena", 7-2-2013. http://es.contrainfo.espiv.net/2013/02/07/madrid-reivindicacion-de-la-colocacion-de-artefacto-explosivoen-la-catedral-la-almudena/. [Consulta 10 abril, 2017].
} 


\section{Conclusiones}

Como se ha podido observar, el insurreccionalismo, a pesar de su rechazo a experiencias anarquistas anteriores, ha recibido numerosas influencias de pensadores de la etapa del llamado anarquismo clásico (segunda mitad del siglo XIX-primera mitad del siglo XX). Algunas de estas ideas han tenido un papel importante en la elaboración del corpus teórico insurreccionalista, como el "egoísmo stirneriano", la "propaganda por el hecho" o la acción directa violenta preconizada por los "ilegalistas" italianos.

$\mathrm{Su}$ análisis de la sociedad no resulta especialmente original, dado que el insurreccionalismo está más centrado en la respuesta que dar ante el "sistema opresor". En sus inicios históricos fue relevante la división de la sociedad en dos categorías, “incluidos" y "excluidos". Sin embargo, desde los inicios del siglo XXI, sobre todo a raíz de las aportaciones nihilistas de Gustavo Rodríguez y de la organización griega Conspiración de las Células de Fuego, se vive un alejamiento de esta idea, central en Bonanno, en cuanto que todo aquel que no se oponga activamente a la "opresión" es cómplice de la misma.

Algunas ideas ocupan un lugar central en el plano teórico, como la de la búsqueda de la liberación personal y ruptura de las ataduras sociales "impuestas" (como la asignación de roles sociales), como primer paso en el proceso revolucionario. No obstante, los principales ideólogos insurreccionalistas se centran más en cuestiones prácticas como la forma de organización y, sobre todo, en la acción directa destructiva contra el Estado y el capitalismo.

Sin embargo, su modelo adolece de un posible proyecto de futuro alternativo en caso de alcanzar el objetivo de que se produzca finalmente la aspirada insurrección generalizada que, según ellos, daría fin al sistema vigente. Los escasos avances en este sentido, atisbados por Feral Faun/Wolfi Landstreicher se confunden en ocasiones con un enfoque primitivista.

En cuanto a la implicación de los insurreccionalistas en las que denominan "luchas intermedias" o sectoriales, conviene resaltar que, aunque éstas puedan tener en principio unos objetivos de protesta social concretos, en la práctica histórica la aportación insurreccionalista ha convertido en violentas formas de reivindicación social pacíficas como manifestaciones, huelgas o incluso "okupaciones". 
En el desarrollo histórico propiamente dicho del anarquismo insurreccionalista se aprecian diferentes etapas o períodos según la evolución que vive este movimiento. En las dos primeras etapas, la inicial (años setenta-principios de los noventa), circunscrita al ámbito italiano, y la segunda (década de los noventa), en la que se empieza a expandir este movimiento a otros países del sur de Europa, se aprecia el papel central de la elaboración teórica insurreccionalista marcada por Bonanno y, en menor medida, Constantino Cavalleri, y por una mayor importancia atribuida a las luchas intermedias, como las de Comiso.

En las dos últimas etapas, iniciadas con la creación de la FAI en diciembre de 2003, y con la alianza entre FAI-FRI y CCF a partir de 2012, respectivamente, se produce un punto de inflexión respecto a las ideas originarias del insurreccionalismo, con un progresivo abandono del "espontaneísmo informal” bonannista en favor de una visión más radical y, en cierto modo, más estructurada. 


\title{
¿Historia de las mujeres y/o Historia de(l) género? La mujer como sujeto histórico*
}

\author{
Women's History and/or Gender History? The Woman as a Historical \\ Subject
}

\section{Uxía Otero-González}

Universidad de Santiago de Compostela

\section{Resumen}

Esta comunicación tiene por objeto reflexionar sobre la trayectoria historiográfica de la mujer como sujeto histórico. En primer lugar, se aborda de forma sucinta el paso de una historia sin mujeres a una historia de las mujeres. En segundo lugar, se presta atención al "género" como categoría de análisis histórico y al desplazamiento hacia una historia de(1) género. A continuación, se considera la andadura hacia la institucionalización y el reconocimiento de estos estudios. Por último, se piensan problemas y se plantean algunos retos actuales para este campo de investigación a fin de lograr la plena consolidación de una historia relacional.

\section{Palabras clave}

Historia, mujeres, (relaciones de) género.

\section{Abstract}

This paper aims to reflect on the historiographical trajectory of women as historical subjects. Firstly, we succinctly address the transition from a history without women to a

\footnotetext{
* Esta comunicación pretende ser el estado de la cuestión primigenio de la investigación doctoral en curso La mujer en España. Del franquismo a la Transición democrática, dirigida por los profesores Ramón Villares Paz y Margarita Barral Martínez, y financiada gracias a un contrato FPU del MECD.
} 
history of women. Secondly, we pay attention to "gender" as a category of historical analysis and to the displacement to a history of gender. Next, we consider the path towards institutionalization and recognition of these studies. Last but not least, we think through some problems and propose some current challenges for this field of research in order to achieve the full consolidation of a relational history.

\section{Palabras clave}

History, Women, Gender (Relations).

\section{Introducción}

Desde hace ya algunas décadas, algunas historiadoras -y algún historiadorcomenzaron a preguntarse por el silencio con respecto a la mujer como sujeto histórico y a cuestionar el carácter marcadamente androcéntrico de la historia hecha casi en exclusiva por y para el hombre, entendiendo a este como medida de la significación histórica.

De una manera progresiva se ha ido imponiendo la necesidad de reescribir la historia incluyendo a la mujer, un hecho nada baladí en la medida en que corresponde a más de la mitad de nuestro objeto de estudio, la humanidad. Las mujeres no son una minoría sino un grupo "minorizado". Siempre han estado ahí y han sido más, porcentualmente, que las elites políticas, económicas o culturales, a las que siempre se ha prestado más atención.

El creciente interés historiográfico suscitado en los últimos tiempos por el sujeto femenino constituye el punto de partida para una Historia con mayúscula, construida por y para mujeres y hombres. Su exclusión tradicional en la disciplina justifica la pretensión actual de restituir a las mujeres en el lugar que les corresponde y, consecuentemente, la proliferación de estudios sobre la mujer, en la medida en que se trata de una historia igual de rica y complicada que la de "el hombre". 1

\footnotetext{
${ }^{1}$ Gisela BOCK: "La historia de las mujeres y la historia del género: Aspectos de un debate internacional", Historia Social, 9 (1991), pp. 55-77, esp. p. 57.
} 
En suma, se está tratando de rescatar un sujeto social que aparecía como subalterno, oculto y eludido en la historiografía existente, a pesar de su peso demográfico y del papel indiscutible de las mujeres en todo tipo de sociedad. ${ }^{2}$ La mujer ya no puede ser un "ente" al margen de la historia, sino un sujeto histórico de pleno derecho, un agente activo que ha de ser considerado por su contribución a los procesos, sistemas, sociedades, etcétera, con mayor o menor capacidad de agencia y protagonismo.

\section{De una historia sin mujeres a una historia de las mujeres}

La preocupación por las mujeres en la disciplina histórica ha sido más bien tardía y su invisibilidad en las fuentes históricas convencionales dejó oquedades historiográficas hasta el último tercio del siglo XX. Hubo que esperar a la década de los setenta para que comenzara a retoñar un campo de estudio que prestara atención al pasado de las mujeres. No es casual que el acta fundacional tuviera lugar en una coyuntura convulsa y plagada de significados políticos, sociales y culturales, en un clima de: combates ciudadanos por la paz y los derechos civiles en Norteamérica, luchas por la libertad en los países sometidos a regímenes dictatoriales -España, Portugal y Grecia-, rebeldía estudiantil y protestas obreras en Francia, denuncia de la esclerosis política e ideológica en los países del Este -como la fugaz "primavera de Praga"- y expansión de la segunda ola del movimiento feminista. En este sentido, la historia de las mujeres está tremendamente ligada al feminismo. Feminismo que no debe interpretarse, sin embargo, como un pensamiento único, rígido y dogmático, sino rico, plural, contaminador y a la vez contaminado por teorías críticas, compromisos políticos y movimientos sociales. ${ }^{3}$

Los derechos civiles alcanzados, la nueva situación sociopolítica, así como la incorporación de la mujer a la élite intelectual y universitaria les permitieron replantearse los conocimientos adquiridos y cuestionar la veracidad de la historia que les fue transmitida. Comenzaron así a investigar su pasado, cuál era el papel de la mujer a lo largo de los siglos, dónde estaba escondidas las mujeres y cuáles eran las causas del silencio sobre la participación de las mujeres en el devenir histórico. Y descubrieron algunas cosas fundamentales: que la mujer había quedado siempre fuera del discurso

\footnotetext{
${ }^{2}$ Elena HERNÁNDEZ: "Historia, historia de las mujeres e historia de las relaciones de género", en M. ${ }^{a}$ Isabel del VAL et al.: La Historia de las mujeres: una revisión historiográfica, Valladolid, Universidad de Valladolid, 2004, pp. 29-55, esp. p. 29.

${ }^{3}$ M. ${ }^{a}$ Dolores RAMOS: "Historia de las mujeres y género. Una mirada a la época contemporánea", Revista de Historiografía, 22 (2015), pp. 211-233, esp. p. 212.
} 
histórico, que su contribución había sido omitida de forma consciente y que la mujer occidental había estado siempre subordinada, legal e ideológicamente, al varón. Las mujeres "no estaban" y "de ellas nada se sabía". El "androcentrismo", la consideración del mundo bajo la perspectiva exclusiva del varón, era la norma: la historia de los varones era contada como la historia de la humanidad. ${ }^{4}$

Así, por caminos diferentes, las mujeres occidentales "encontraron" su pasado y aparecieron los primeros trabajos que consideraban a las mujeres como sujetos de la historia, atendiendo a cuestiones relacionadas eminentemente con la historia política, como el sufragismo o el movimiento obrero. La idea era hacer visible lo invisible, brindarles un pasado, pero sin mayores pretensiones historiográficas. ${ }^{5}$ Progresivamente se entendió también necesario reconstruir el discurso y asumir la tarea de investigar y reinterpretar las fuentes, cuestionándose todo lo aprendido y dado por sentado hasta la fecha, incorporando nuevos datos y nuevas categorías. El resultado había de ser, necesariamente, una transformación de la visión de la historia, y del mundo por extensión.

Fue a partir de los años ochenta cuando el reto pasó a ser el de dotarse de un marco teórico, conceptual y metodológico. El estudio de las mujeres del pasado, o, si se prefiere, del pasado de las mujeres, demandaba la búsqueda de nuevas fuentes y formas de interpretación originales en tanto que se evidenciaban deficiencias en la metodología tradicional. En este aspecto concreto ha de reconocerse la beneficiosa influencia de la renovación historiográfica que se estaba desarrollando en el seno de la historia social o de los novedosos, por aquel entonces, estudios sobre la vida cotidiana privada y de la familia. Los historiadores atentos a estas nuevas formas de aproximarse al estudio del pasado acogieron favorablemente las nuevas propuestas que concebían una historia de y para las mujeres. Al fin y al cabo, estos campos se presentaban más propicios que otros para el cultivo de esta temática. ${ }^{6}$ Pero, sin negar la importancia de estas nuevas tendencias,

\footnotetext{
${ }^{4}$ Consuelo VEGA: "La mujer en la historia y la historia de las mujeres", en Ana GONZÁLEZ y Carlos LOMAS (eds.): Mujer y educación. Educar para la igualdad, educar desde la diferencia, Barcelona, Graó, 2002, pp. 13-20.

${ }^{5}$ Renate BRIDENTHAL y Claudia KOONZ: Becoming Visible: Women in European History, Boston, Houston Mifflin, 1977.

${ }^{6}$ Otras corrientes historiográficas excluyeron a las mujeres en su concepción de la historia. La escuela positivista ignoró a las mujeres en tanto que no intervenían directamente en los hechos políticos. Por su parte, la escuela marxista, en la que todo viene determinado por el hecho económico, concedió únicamente valor económico como al varón como productor, al considerar que la producción era solamente extradoméstica; cayendo así en un evidente anacronismo, por olvidar que la familia era una unidad
} 
lo cierto es que había ciertas limitaciones, en tanto que las mujeres quedaban recluidas en el ámbito doméstico, reproduciendo nuevamente esquemas que identificaban lo doméstico con lo no productivo, presentándolas a veces como un colectivo genérico homogéneo - por su posición subordinada- y olvidando las grandes diferencias entre clases sociales, culturas políticas, creencias, naciones, etcétera.

Como respuesta a la history, las anglófonas acuñaron el significativo término de herstory, réplica invertida de esta disciplina que solo entiende de hombres y de actividades masculinas. Este concepto apareció en numerosos artículos norteamericanos de los años setenta y ochenta para caracterizar el primer enfoque de la historia de las mujeres. Pero, ¿acaso las promotoras de la herstory lo acuñaron en su entusiasmo por hacer algo nuevo? ¿O se reapropiaron de un término peyorativo empleado para desacreditar los nuevos trabajos de investigación y denotar su no pertenencia a la disciplina histórica? En todo caso, la sutileza del juego de palabras rápidamente dotó al término de una fuerza movilizadora incontestable, favoreciendo así una historia en femenino en fase de acumulación. ${ }^{7}$

\section{El concepto de "género" y la historia de(l) género}

La introducción del "género" como categoría de análisis histórico en los años ochenta marcó sin lugar a dudas el devenir de las ciencias sociales y humanas. El punto de inflexión lo constituyó el artículo de la historiadora norteamericana Joan W. Scott en el cual proponía el género como "elemento constitutivo de las relaciones sociales basadas en las diferencias que distinguen los sexos, y como forma primaria de las relaciones significantes de poder". ${ }^{8}$ Sus planteamientos partían de la oposición sexo y género conceptos no intercambiables- al considerar que el segundo se elaboraba histórica y socioculturalmente y, por ende, estaba sometido a transformaciones. En otras palabras, proponía el estudio de las diferencias sistemáticas estructurales entre hombres y mujeres, las cuales no eran solamente biológicas y naturales, sino también sociales y culturales, de lo que se deriva una clasificación en categorías, masculina y femenina. Para Scott, el

productiva fundamental, cuanto menos hasta el desarrollo del capitalismo. Consuelo VEGA: "La mujer en la historia..., pp. 13-20.

${ }^{7}$ Françoise THÉBAUD: Escribir la historia de las mujeres y del género, Oviedo, KRK, 2014, p. 109.

${ }^{8}$ Joan W. SCOTT: "Gender: A Useful Category of Historical Analysis", American Historical Review, Vol. 91, 5 (1985), pp. 1.053-1.075. 
"género" era un elemento constitutivo de las relaciones sociales (y de poder) basado en diferencias percibidas entre los sexos.

Sin embargo, el término gender ya había sido empleado con anterioridad; por ejemplo, por la filósofa Simone de Beauvoir, ${ }^{9}$ quien distinguía entre hechos biológicos y sociales al juzgar que "lo femenino" y "lo masculino" eran creados, troquelados por la socialización, y que, en definitiva, eran aprendizajes. En palabras suyas: "La mujer no nace, sino que se hace". En cuanto a la diferencia entre sexo y género, fue recogida por primera vez en los sesenta, por Robert Stoller en un libro poco conocido, titulado Sex and Gender. ${ }^{10}$ Fue utilizado además por la antropóloga cultural Gayle Rubin ${ }^{11}$ con el propósito de nombrar y poder estudiar bajo este epígrafe todo aquello que concierne a los aspectos culturales que rigen la división jerárquica del mundo en función del sexo de nacimiento. Y también fue introducido en un libro de ensayos titulado Sex and Class in Women's History. ${ }^{12}$

El género es hoy un concepto ampliamente empleado, acreditado por el uso desde hace varias décadas y asumido por las ciencias sociales y humanas, incluso en aquellos idiomas en los que supone una trasposición de un concepto gramatical a otro sociocultural de carácter más amplio. Pero no estuvo ni está exento de polémica. Aun admitiendo que no es posible establecer límites precisos entre lo biológico-natural y lo sociocultural, sin dejar de considerar los matices que imprime lo multicultural ni las diferencias que provienen de la particular vivencia del género por parte de cada mujer, y sin pasar por alto que también se podría entrar en el debate de si el sexo está sometido a influencias culturales, ${ }^{13}$ es necesario dejar claro que no constituye nuestro objeto detallar los aspectos de dicha controversia, sino simplemente indicar qué se entiende por "género": una construcción sociocultural, con un marcado carácter histórico que le imprime modificaciones con relación a las condiciones de vida y al contexto económico, político

\footnotetext{
${ }^{9}$ Simone de BEAUVOIR: El segundo sexo, trad. Alicia Martorell, Madrid/Valencia, Cátedra/Universidad de Valencia, 2016.

${ }^{10}$ Robert STOLLER: Sex and Gender. On the Development of Masculinity and Femininity, New York, Science House, 1968.

${ }^{11}$ Gayle RUBIN: “The Traffic in Women: Notes on the 'Political Economy' of Sex", en Rayna R. REITER (ed.), Toward an Anthropology of Women, New York, Monthly Review, 1975, pp. 157-210

${ }^{12}$ Judith N. NEWTON, Mary P. RYAN y Judith R. WALKOWITZ: Sex and Class in Women's History, London, Routledge, 1983.

${ }^{13}$ Thomas LAQUEUR: La construcción del sexo: cuerpo y género desde los griegos hasta Freud, Madrid, Cátedra, 1990.
} 
y social concreto en el que se presenta; un instrumento útil para aproximarnos a la realidad social de las mujeres del pasado, si bien insuficiente por sí solo.

La noción de "género" parte de la diferencia sexual, que es construida y derivada de una biología reproductiva diferenciada. ${ }^{14}$ Así, el sexo se percibe como una constante, mientras que el "género" es variable en el tiempo y en el espacio, de modo que la masculinidad y la feminidad -el ser hombre o mujer o el ser considerados como tales- no ha tenido el mismo significado en todas las épocas y en todas las culturas, sociedades... No son identidades arquetípicas, esencialistas ni atemporales. Sobre la idea de la diferencia sexual basculan pues los significados cambiantes de masculinidad y femineidad, pero también un sistema de poder desfavorable para las mujeres, que impregna las relaciones sociales y se transmite (y perpetua) mediante el lenguaje, la publicidad, las leyes, la religión, la educación, los textos médicos e higiénicos, las costumbres, la literatura, entre otros mecanismos. ${ }^{15}$

La historia de las mujeres se ha interesado en concreto por la construcción sociocultural de esta diferencia sexual y sus implicaciones político-sociales. Uno de los presupuestos analíticos de la historia de las mujeres es precisamente la naturaleza, percepción y realidad de "género", clave en la formación de la sociedad contemporánea y en la organización de la política del mundo contemporáneo. Pero, en realidad, puede considerarse que la historia de(l) género es más bien la hija conceptual de la historia de las mujeres, puesto que pluralizó la categoría de "mujeres", produjo un conjunto abigarrado de historias e identidades colectivas, así como reconsideró los interrogantes previamente planteados. Dando un paso más allá, se comenzó a cuestionar una historia de las mujeres sectorial, alejada del proceso histórico general, y se abogó por la necesidad de integrar la historia de las mujeres en la construcción de una visión más globalizadora de la historia y una reconceptualización en clave de "género". Es decir, se planteó una concepción más amplia de la historia en la que no había solo un sujeto (masculino), sino que se reconocía que en el transcurso de los tiempos y de las sociedades había (al menos)

\footnotetext{
${ }^{14}$ Sin embargo, se ha demostrado que la propia biología está influida por determinadas ideas acerca de la diferencia de género. Se convirtió en sentido común que la diferencia real entre todas las mujeres y todos los hombres estaba en el papel que sus respectivos cuerpos desempeñaban en la reproducción. Genitalidad, hormonas y cromosomas se entendieron como el fundamento de la diferencia sexual, a pesar de que existen seres humanos cuya fisiología y anatomía no concuerdan exactamente con ninguna de las dos categorías. Sonya O. ROSE: ¿Qué es historia de género?, Madrid, Alianza, 2012, p. 50.

${ }^{15}$ M. ${ }^{a}$ Dolores RAMOS: "Historia de las mujeres..., esp. p. 213.
} 
dos sujetos, mujeres y hombres, bien es cierto que con posibilidades sociales diferentes y con una relación desigual y asimétrica de dependencia uno del otro. Los hombres eran quienes habían ostentado el poder y decidido cuál era el espacio en el que se debía desarrollar la vida de las mujeres y cómo debían comportarse. La valoración de la situación de las mujeres en la sociedad era global, pero desde entonces empezaron a incorporarse matices tan importantes como la época, el lugar o la clase social. ${ }^{16}$

\section{La andadura hacia su institucionalización y reconocimiento}

Los propios debates epistemológicos en las ciencias sociales y humanas sobre esta cuestión coadyuvaron a la institucionalización académica de los denominados Women's o Gender Studies. Empero este conocimiento que analiza las singularidades y características que afectan al comportamiento y relaciones sociales de mujeres y hombres, no es pensable sin el movimiento político de las vindicaciones de los derechos de las mujeres. El movimiento feminista, en tanto que "praxis política anterior", fue clave y abrió el camino al desarrollo de un conocimiento científico sobre las mujeres y los roles y relaciones de género. ${ }^{17}$ Ciertamente la relación entre feminismo e historia ha crecido más fuerte que nunca de la mano de este campo. Sin embargo, su vínculo se mantiene inestable. Incluso dentro del campo de la historia de las mujeres y de(l) género, el feminismo se muestra como un punto de apoyo inseguro y erosionable. ${ }^{18}$

A pesar de que en España esta clase de estudios empezaron a elaborarse más tarde, en la historiografía española no existe una actitud monolítica (ni mucho menos consenso) a la hora de analizar el pasado de las mujeres. Esta demora se explica por la dilatada eclosión del movimiento feminista, el cual había desempeñado un papel muy importante en países como Estados Unidos, lugar donde se produjeron (y se siguen produciendo) innovaciones teóricas y metodológicas sobre la cuestión historiográfica de(l) género. El franquismo había frenado el tímido movimiento feminista preexistente, lo que empujó a muchas mujeres que albergaban inquietudes sociales hacia la lucha antifranquista, más que feminista; así, el feminismo en el Estado español que se manifestaba en pro de la

\footnotetext{
${ }^{16}$ Cristina SEGURA: "Cómo construimos la Historia de las Mujeres desde las Universidades españolas", Revista de Historiografía, 22 (2015), pp. 255-271, esp. p. 261.

${ }^{17}$ Rita RADL: “A modo de introducción: Aspectos epistemológicos de las investigaciones de las mujeres y del género", en ÍD.: Investigaciones actuales de las mujeres y del género, Santiago de Compostela, Universidade de Santiago de Compostela, 2010, pp. 9-21, esp. p. 13.

${ }^{18}$ Judith M. BENNET: "Feminism and History", Gender \& History, Vol. 1, 3 (1989), pp. 251-272.
} 
igualdad emergió en los años setenta, coincidiendo con el ocaso de la dictadura y la llegada de la democracia.

En los años noventa se llegó al punto de no retorno. La publicación de la monumental Historia de las mujeres en treinta volúmenes de Georges Duby y Michelle Perrot ${ }^{19}$ dio buena muestra de ello. En España estos años también fueron especialmente significativos con el surgimiento de organizaciones como la Asociación Española de Investigación de la Historia de las Mujeres (AEIHM), fundada por la historiadora Mary Nash, y publicaciones periódicas como la revista Arenal, que contribuyeron a su institucionalización como corriente historiográfica dentro de la disciplina histórica. De igual forma se empezaron a desarrollar interesantes investigaciones referidas al conjunto español que sirvieron para engendrar un instrumental conceptual y metodológico. ${ }^{20} \mathrm{Con}$ el fin de abrir nuevas puertas epistemológicas y disciplinares también se fomentó la interdisciplinariedad con otras ciencias sociales y humanas, todo lo cual se vio favorecido por la crisis de los grandes paradigmas historiográficos.

Aunque en sus comienzos persistió la resistencia o indiferencia de algunos ante el desarrollo de una forma de analizar la historia que pretendía rescatar a las mujeres del olvido al que habían sido relegadas por la historiografía tradicional, se constata un avance inequívoco y renovador que multiplica los puntos de vista, modifica los enfoques previos y cuestiona el saber histórico anterior, participando al mismo tiempo de la complejidad general. De este modo, la labor de las profesionales de la historia ha sido pionera. Valga la redundancia, resulta artificioso ignorar que fueron fundamentalmente mujeres las que introdujeron los estudios de mujeres en nuestro país y sus publicaciones siguen siendo hoy las más numerosas en el conjunto de la producción bibliográfica. La disciplina histórica se sitúa además en cabeza en el marco de los estudios sobre la mujer, siendo una de las áreas de la investigación que más ha evolucionado en los últimos tiempos; y dentro de ella, en particular, la historia contemporánea es la más desarrollada.

No obstante, esta línea de investigación sigue esforzándose por conseguir su pleno reconocimiento y se encuentra en "vías de normalización” en la Academia. A pesar del

\footnotetext{
${ }^{19}$ Georges DUBY y Michelle PERROT (eds.): Historia de las mujeres en Occidente, Madrid, Taurus, 1991.

${ }^{20}$ James S. AMELANG y Mary NASH (eds): Historia y género: las mujeres en la Europa moderna y contemporánea, Valencia, Edicions Alfons el Magnànim - Institució Valenciana d'Estudis i Investigació, 1990; Elisa GARRIDO et al.: Historia de las mujeres en España, Madrid, Síntesis, 1997.
} 
notable desarrollo y el grado de institucionalización logrado, no se han alcanzado los niveles de otras historiografías occidentales, especialmente de la historiografía angloamericana. Entre los obstáculos con los que hubo de enfrentarse la consolidación de este tipo de estudios, se encuentra la hostilidad de ciertos sectores académicos, y las dificultades estructurales que se desprenden de un sistema centralizado y poco flexible en la articulación de los planes de estudio, a excepción del posgrado, que permite una mayor especialización. Ahora bien, el progresivo aumento del interés y del número de los escritos en esta materia, además de la conciencia de que es preciso estimular una mayor reflexión teórica y metodológica, son signos esperanzadores respecto del creciente desarrollo de esta disciplina. ${ }^{21}$

En la actualidad se constata una tendencia a la apertura y proliferación de nuevos temas en esta línea. ${ }^{22}$ Cada vez son más las historiadoras e historiadores que tienen la voluntad de reflejar la realidad histórica desde una perspectiva de género, no solo en universidades en el ámbito internacional, sino también estatal. Resulta cada vez más frecuente dedicar sesiones específicas a las mujeres en los coloquios, seminarios y congresos de historia y evaluar colectivos o personajes femeninos en las obras sobre temas concretos - trabajo, movimientos sociopolíticos, etcétera-o épocas específicas, y en los planes de estudio del grado, posgrado, máster y doctorado de historia se incorporan materias vinculadas a estas cuestiones. Existen también departamentos, grupos de investigación, cátedras, asociaciones, publicaciones periódicas, premios y certámenes, entre otros elementos específicos. Además, se financian proyectos de investigación y tesis doctorales relacionados con esta línea temática, como es el caso. En suma, dicho campo está cada vez más presente en el mundo académico.

Hoy es impensable abordar con rigor cualquier problema histórico sin tener en cuenta a las mujeres, sin un enfoque que permita aprehender sus vicisitudes históricas, su lugar dentro de la sociedad, sus relaciones, sus actuaciones, sus roles, su género. Se ha pasado de la pregunta “¿tienen las mujeres una historia?” a “¿es posible una historia sin mujeres?". En general, las mujeres han ganado cierta presencia tanto en los estudios históricos como en otras disciplinas, quedando manifiesto que se trata de un complejo

\footnotetext{
${ }^{21}$ Mary NASH: "Dos décadas de historia de las mujeres en España", Historia Social, 9 (1999), pp. $137-$ 161; ÍD.: Mujeres en el mundo: Historia, retos y movimientos, Madrid, Alianza, 2005.

${ }^{22}$ Cristina BORDERÍAS: La historia de las mujeres: perspectivas actuales, Barcelona, Icaria, 2009.
} 
campo de estudio que no puede, en modo alguno, quedar reducida a un único eje interpretativo ni teórico-metodológico. Por tanto, se puede hablar de un avance a nivel formativo e investigador en la temática de las mujeres y de(l) género.

\section{Retos actuales para una historia relacional}

La gran tarea pendiente es la integración de este conocimiento de las mujeres y de(l) género en el cuerpo teórico-científico de las distintas disciplinas. Es una cuestión complicada. En este sentido, por ejemplo, la creación de asignaturas específicas sobre tales temas entraña un peligro porque la mayoría suelen ser opcionales. Así no se consigue alcanzar a las personas que no conocen ni preocupa la situación de las mujeres en las diferentes épocas y sociedades. Pero, aunque las materias optativas no son el deseo alcanzar, al menos ilustran a quien tenga interés. El riesgo es que se conviertan en una mera declaración de buenas intenciones, recogida en los planes de estudios y proyectos curriculares que queda en papel mojado en la práctica. De este modo, la transversalidad de este conocimiento se plantea no pocas veces como una cuestión contraria a la existencia de áreas y materias concretas de conocimiento. De lo que no hay dudas es de que se necesita una mayor interdisciplinariedad. Las diversas disciplinas han de dialogar y realizar el esfuerzo de integrar las aportaciones de los Women's y Gender Studies, extremo que, sin embargo, no puede significar la desaparición del campo de los estudios de las mujeres y de(l) género como campo científicamente especializado, si cabe, incluso en un mayor grado. ${ }^{23}$

Una de las críticas que se realizan con respecto a estos estudios es su carácter parcial y fragmentario; una historia escrita en paralelo, periférica de la historia "normal", que provoca distorsión y engaño (por supuesto, aplicable a cuantas historiadoras puedan contribuir al respecto). Esta corriente específica y mixtilínea (por descontado controvertida) fue asegurando su espacio y consiguió una justificación. Pero, lejos de suponer una especialización o subdisciplina histórica, su aparición -un manojo de enfoques historiográficos recientes e innovadores, pues como tal ha de ser entendida desde ahora para no generar equívocos- ha provocado cambios muy importantes en la

\footnotetext{
${ }^{23}$ Rita RADL: “A modo de introducción..., esp. p. 18.
} 
historiografía en general. ${ }^{24}$ Muestra de ello es que ha permitido completar la historia de la humanidad.

El puzle de la historia ha cambiado mucho, en tanto que el "hombre", considerado en términos abstractos y universales, no es, como se creyó durante mucho tiempo, la unidad de medida de la humanidad, sino que dicha medida incluye a hombres y mujeres, y se ve surcada, entre otras variables, como la clase social, las opciones u orientaciones sexuales, los orígenes étnicos o nacionales, etcétera. Por consiguiente, si hay alguna nota distintiva que defina en términos historiográficos la trayectoria de la historia de las mujeres y de(1) género en las últimas décadas, esta podría resumirse en: riqueza, pluralidad, eclecticismo, divergencia en las formas de interpretar las experiencias históricas femeninas y capacidad de expansión. ${ }^{25}$ Para lo bueno y para lo malo, su cultivo ha dado frutos y se ha convertido en un campo más de la historia convencional y mainstream, ¿o no tanto?

A pesar de su extraordinaria expansión e institucionalización, quizás el aspecto más discutido es el ambivalente espacio que ocupa en la disciplina. En no pocas ocasiones se ha ganado un espacio a costa de la segregación y el aislamiento. Esta "guetización" académica ha permitido una historia separada pero no un verdadero enclave en la profesión histórica. Por ejemplo, a la hora de asesorar al alumnado, se la suele ignorar o trivializar considerándola "historia ligera" (o de "segunda división") y recomendándola únicamente a las alumnas. Más aún, historiadoras de esta rama del conocimiento son ignoradas (incluso ridiculizadas). Además, son consideradas excesivamente especializadas y por ende no válidas para abarcar áreas de estudio geográfica y/o cronológicamente amplias. Y, a pesar de algunas modificaciones realizadas en los libros de texto y en algunos (solo algunos) programas de estudio, quizás lo más preocupante es el hecho de que la historia de las mujeres y de(l) género no ha alcanzado ni repercutido en otros historiadores. Es decir, no ha despertado ni interés ni se ha entendido como una necesidad para todas y, sobre todo, para todos ${ }^{26}$ No son muchos los historiadores que $a$ priori dan la bienvenida con entusiasmo a una historia que pretende criticar y transformar

\footnotetext{
${ }^{24}$ Elena HERNÁNDEZ: "Historia, historia de las mujeres..., esp. p. 30.

${ }^{25}$ M. a Dolores RAMOS: “Arquitectura del conocimiento, historia de las mujeres, historia contemporánea. Una mirada española. 1990-2005”, Cuadernos de Historia Contemporánea, Vol. 28 (2005), pp. 17-40; ÍD.: "Historia de las mujeres..., pp. 211-233.

${ }^{26}$ Judith M. BENNET: "Feminism..., pp. 251-272.
} 
relacionalmente la disciplina histórica. Aunque de un tiempo a esta parte sí se están rompiendo lanzas para acabar con el cerco por parte de los varones de la comunidad científica y que la autoría masculina se haya incrementado es un dato significativo sobre las nuevas generaciones.

Lamentablemente, tampoco se ha logrado una divulgación eficaz de las investigaciones realizadas hasta el momento, de manera que no han cuajado en la sociedad ni en la opinión pública. Aunque es evidente que, si no existe un pleno reconocimiento dentro del mundo académico, difícilmente puede producirse una transmisión del conocimiento o una comunicación fluida, bidireccional y recíproca con el mundo "extramuros". En virtud de ello, se requiere una dosis de autocrítica a fin de impedir que dichos estudios caigan en saco roto. No basta con investigar rigurosamente, que por supuesto, sino que hay que ir más allá: transmitir, divulgar y educar consecuentemente. En otras palabras, este campo de estudio se halla en una situación paradójica. Por un lado, las relaciones entre hombres y mujeres ocupan el centro de muchos interrogantes sociales, y el público lector manifiesta un interés por los trabajos históricos. Hay demanda y receptores potencialmente comprometidos. Por otro lado, aún no disfruta, salvo contadas excepciones, de un reconocimiento auténtico como dimensión de la historia y ocupa un lugar muy poco significativo en las instituciones educativas y de investigación. ${ }^{27}$

De forma paralela, tampoco se ha sabido cómo ensamblar de forma firme los procedimientos teóricos del "género", cuya metodología dista mucho de estar normalizada, con los planteamientos historiográficos más convencionales. "Porque el método que aquél exige no lleva a la reconstrucción de un todo sin aristas, sino, muy al contrario, a la más explosiva exasperación de esas aristas, a la abierta exhibición de las piezas quebradas, quedando abierto el asunto a tratar". ${ }^{28}$ Además, su mero uso no asegura siempre el poder analítico ni la validez explicativa que promete para revisar los viejos paradigmas. Y el uso abusivo del mismo y la generalización de su manejo puede resultar ineficaz, derivar en un vacío heurístico y convertir a dichos estudios en un bucle que no

\footnotetext{
${ }^{27}$ Françoise THÉBAUD: Escribir la historia ..., p. 253.

${ }^{28}$ Elena HERNÁNDEZ: "Historia, historia de las mujeres..., esp. p. 52.
} 
encuentra salida. ${ }^{29}$ En consecuencia, parece necesario iniciar nuevos debates epistemológicos y metodológicos. Por ejemplo, cabría preguntarse si el "género" puede ser simultáneamente origen y solución de la diferencia histórica entre hombres y mujeres, o más bien un modo de analizar y hacer ostensible esa diferencia; o todo lo contrario: una pantalla que oscurece la realidad de los sujetos que son objeto de discriminación, ${ }^{30}$ en tanto que un excesivo énfasis en los discursos, las representaciones y las normas u hormas de género puede ir en detrimento de la percepción de las actitudes y respuestas sociales, consonantes o disonantes con estos.

Asimismo, es importante el esfuerzo por incluir en el análisis otros elementos identitarios que atraviesan al sujeto femenino además del "género". La historia de las mujeres y de(l) género es productora de conocimiento porque reconsidera acontecimientos y fenómenos históricos desde una perspectiva sexuada contribuyendo así a la explicación de problemas generales y a una reescritura de la historia. Pero es productiva también porque, como toda historia relacional que no se pone una venda en los ojos, debe reconocer la existencia de otros tipos de relaciones socioculturales aparte de la relación entre los sexos. Esta categoría de análisis debe ser enfrentada y confrontada con otras, ya que no es por sí sola un principio explicativo universal, sino una categoría significativa más del contexto. Ningún grupo -ni de sexo, ni de clase, etcétera- es homogéneo y la historia debe prestar atención tanto a las relaciones sociales que se gestan en el interior de un grupo como a las que se establecen con el exterior. Por consiguiente, no se trata de buscar la dimensión más fundamental sino, más bien, de descubrir interacciones entre las distintas relaciones humanas -entre clases, entre naciones, entre religiones, entre culturas...- intentar elaborar una historia inclusiva que explique la complejidad de las distintas categorías de análisis. ${ }^{31}$ En ningún caso puede emplearse el "género" como una plantilla de lectura universal puesto que, además, no es una noción fija, sino inestable.

Otro aspecto relevante es el hecho de que la historia de las mujeres y de(l) género se ha ido alejando progresivamente de la militancia feminista de sus orígenes en un

\footnotetext{
${ }^{29}$ Pilar DÍAZ: "Historia social e Historia cultural de las mujeres: Apuntes para un debate", Revista de Historiografía, 22 (2015), pp. 13-23, esp. pp. 17-20; Cristina BORDERÍAS: Joan Scott y las políticas de la Historia, Barcelona, Icaria, 2006.

${ }^{30}$ Silvia TUBERT: Del sexo al "género". Los equívocos de un concepto, Madrid, Cátedra, 2003.

${ }^{31}$ Françoise THÉBAUD: Escribir la historia ..., p. 198.
} 
intento de "objetivación". Desde la propia Academia se ha venido acusando de hacer política a las profesionales dedicadas a estos estudios en lugar de historia, quizás porque el desarrollo de los mismos es deudor de personas que lucharon de diversas maneras para reivindicar a las mujeres y sus derechos, ${ }^{32}$ Además, en tanto que se ha convertido en más dependiente de la aprobación del sistema académico, ciertos conceptos se han vuelto menos comunes, como por ejemplo "opresión" y "patriarcado". Estos términos incluso han pasado a considerarse ofensivos o poco encomiásticos y se han ido suavizando. Por ende, en muchas ocasiones se ha priorizado un lenguaje y una conceptualización más afable y pretendidamente "objetiva", menos sospechosa por "feminista" y "militante".

Ahora bien, deberíamos partir de la premisa de que toda historia está indisolublemente politizada y subjetivada por el agente que la construye. La objetividad puede, y debe ser una meta, pero siendo justos, difícilmente puede ser un logro alcanzable en esta disciplina, y no solo en esta. En este sentido, Antoine Prost señalaba: “[...] Todo historiador, incluso aquel que se percibe más 'científico', se halla personalmente comprometido con la historia que escribe, eso no significa que haya de concebir su discurso como simple opinión subjetiva, fruto de sus humores, reflejo de un inconsciente rebosante. Es precisamente para alcanzar una mejor racionalidad por lo que el historiador debe aclarar sus implicaciones". 33

El desafío fundamental como profesionales de la historia es trabajar para recuperar una cierta visión moral, un poco de nervio político y un punto indignación y denuncia; no olvidar el ingrediente de crítica en aras de una historia comprometida, reivindicativa por necesidad y contestataria con quien la excluye. Esto no quiere decir que la historia de las mujeres y de(l) género se deba convertir en "a poor and oddly politicized stepchild of history in general" 34 Se debe combatir el escepticismo y los prejuicios sobre una presunta historia militante y por ende "menos científica". Quizás la carga ideológica, más que un lastre, es un cariz .lógico, intrínseco e indisoluble al propio historiador(a) que escribe la historia desde sus propios postulados personales y metodológicos. ${ }^{35}$ Es una cuestión de

\footnotetext{
${ }^{32}$ Cristina SEGURA: "Cómo construimos la Historia..., esp. p. 261.

33 Antoine PROST: "Las preguntas del historiador", en ÍD.: Doce lecciones sobre la historia, Madrid/Valencia, Cátedra/Universitat de València, 2001, pp. 90-111, esp. p. 110.

${ }^{34}$ Judith M. BENNET: "Feminism..., esp. p. 256.

35 Beatriz CABALLERO: "Algunas consideraciones acerca de la historiografía de la historia de las mujeres”, en Carlos FORCADELL et al. (coords.): Usos públicos de la Historia. Actas VI Congreso de la Asociación de Historia Contemporánea, Zaragoza, AHC, 2002, pp. 351-363
} 
rigor profesional el mantener una cierta objetividad y aspirar a la imparcialidad en esa subjetividad imposible de suprimir, sin renunciar a la honestidad para con el lector ni creer que se debe hacer justicia redentora, en lugar de historia (aunque cierto sesgo compensatorio sea inevitable). Si las mujeres estaban ausentes, igual es tan interesante (o más) explicar el porqué, el cómo han sido históricamente condicionadas socioculturalmente, en lugar de únicamente realizar adendas y correcciones. ${ }^{36}$

Alejarse del victimismo, de cuyo fomento se ha acusado a estos estudios, puede parecer una simple reacción de defensa. Sin embargo, es evidente que la historia de las mujeres y de(l) género están más interesadas en otros aspectos que en remarcar el papel de víctimas de las mujeres a lo largo de la Historia, que implica infantilizar y enfatizar su debilidad. Sin poder desaparecer del todo, el victimismo es solo un punto más a considerar dentro de la riqueza de elementos que constituyen una verdadera historia relacional, que evoluciona, toma nuevos caminos, y de la que podría afirmarse, sin temor a errar, que está en un momento de tránsito. En consecuencia, se requieren nuevas formas de mirar e investigar, nuevos métodos que permiten la entrada de aire fresco a unas formas de análisis que, de lo contrario, podrían quedarse pronto obsoletas. ${ }^{37}$

Durante bastante tiempo se ha constatado un empeño por estudiar a las "abejas reina", esas pocas excepciones sobre las que se tenía constancia documental por pertenecer a la aristocracia, a las artes o a las organizaciones femeninas de carácter benéfico, lúdico o político. Pero quedaban todas las demás, las "sin nombre", las que se encuentran al mirar "desde abajo". De acuerdo con esto, cabe traer a colación la célebre cita de Laurel T. Ulrich: "Las mujeres que se portan bien no suelen hacer historia" (wellbehaved women seldom make history). ${ }^{38}$ Hay que puntualizar que la "historia seria" responde a los eslóganes y en lo que se refiere a la atención pública, los eslóganes suelen ganar. Tómese como ejemplo dicha frase. Durante años figuró tranquilamente entre las páginas de una revista académica. Actualmente pasea su ambigua sabiduría en tazas de café y demás merchandising. Pero entonces, ¿qué significado tenían esas palabras para Ulrich cuando las escribió en 1976? Su intención era la de establecer un compromiso para la recuperación de la vida de algunas mujeres. "Las mujeres hacen historia con poca

\footnotetext{
${ }^{36}$ Cfr. Pilar DÍAZ: "Historia social e Historia cultural..., pp. 13-23, esp. p. 22.

${ }^{37}$ M. ${ }^{a}$ Jesús FUENTE: Introducción al monográfico "Del ayer al mañana. La historiografía de la historia de las mujeres, del género y del feminismo", Revista de Historiografía, 22 (2015), pp. 10-11.

${ }^{38}$ Laurel T. ULRICH: Las mujeres que "se portan bien" no suelen hacer historia, Barcelona, Nabla, 2008.
} 
frecuencia o en raras ocasiones" no únicamente porque las normas y hormas de género han limitado y determinado históricamente el alcance de la actividad femenina, sino también porque la historia no ha sabido capturar las vidas de las que han hecho contribuciones en el ámbito local, privado y doméstico. Así, las mujeres hacen historia cuando juegan un papel destacado, realizan cosas poco ortodoxas, inesperadas y/o escandalosas, cuando sus historias quedan documentadas y cuando las generaciones futuras prestan atención.

Dicha aproximación se topa con otro imperativo histórico: la confianza depositada en las fuentes escritas. Hasta hace poco la mayoría de las mujeres (y muchos hombres) eran analfabetas. Por esta razón, sus actividades fueron recogidas por otros en el mejor de los casos. Los que causaban problemas podían aparecer en los registros de los juicios, en los periódicos, etcétera. Los que no causaban ningún problema eran olvidados, observados desde lejos, permaneciendo en el anonimato. Durante mucho tiempo se elaboró una historia en la que interesaba lo excepcional, lo irrepetible, lo que se desarrollaba en lo público. Era pues una historia sin mujeres. Cuando ellas aparecían eran mujeres excepcionales, célebres y singulares, celebradas y magnificadas, como reinas o santas. De lo contrario, eran transgresoras que cuestionaban o amenazaban el sistema vigente. El resto parecía carecer de historia y se las silenciaba ${ }^{39}$. Este argumento es el que se pretende refutar al apostar por una historia que las trate de recoger a la totalidad, no solo a las "famosas e importantes", ni tampoco a "grandes hombres" merecedores de que su vida fuera reconstruida y estudiada. Al fin y al cabo, son las pequeñas acciones de un gran número de personas, a menudo "sin nombre ni apellidos", las que traen consigo las grandes transformaciones.

La conservación de las fuentes no es siempre neutra e inocente, como tampoco lo es la constitución de los fondos de un archivo o la elaboración de un registro. Las omisiones aparentemente anodinas encierran a veces significados más profundos. Junto a la falta de atención, las fuentes relativas a las mujeres no siempre se han conservado o muy raras veces se las ha catalogado como tales, manteniéndose ocultas bajo clasificaciones más convencionales. De igual forma, las huellas directas de las mujeres son escasas, algo que contrasta con la una abundancia de discursos masculinos sobre la

\footnotetext{
${ }^{39}$ Cristina SEGURA: “Cómo construimos la Historia..., esp. pp. 261-262.
} 
mujer, construidos por “el otro". Juristas, moralistas, pedagogos, médicos, decían qué es lo que debe ser y hacer la mujer, al tiempo que militantes y maridos hablaban en su nombre. ${ }^{40}$ Rastrear su propia palabra en los documentos resulta difícil entre tanto discurso ajeno. Si bien no todas las fuentes han resultado ser igual de silenciosas. Por ejemplo, las judiciales, las orales, las epistolares, las fotográficas o las literarias son fuentes que aportan información al respecto y que han ido alcanzando lentamente el estatus de dignas de consideración. Las fuentes que a ellas les conciernen "existen", pero tiene que haber voluntad de descubrirlas, leerlas (a menudo entre líneas), (re)interpretarlas, interrogarlas y confrontarlas adecuadamente para luego organizar con ellas una polifonía de voces, timbres y matices coherente. ${ }^{41}$

No obstante, la historia no es un mero relato del pasado basado en las fuentes que se han conservado, sino que también es un modo de hacer que el presente tenga sentido. Así, la historia no es solo lo que sucedió sino lo que las generaciones posteriores deciden recordar. Y en ocasiones incluso la ficción supera a la realidad histórica y la gente es recordada por cosas que no hicieron. Es lícito reconocer que, aunque la historia no pertenece en exclusiva a los historiadores e historiadoras, tenemos experiencia (o en su defecto, aspiramos a tenerla algún día) en separar y distinguir lo que resulta evidente de lo que no lo es tanto. La investigación histórica es una especie de trabajo detectivesco. Recreamos los sucesos a partir de fragmentos de información, intentando discernir la evidencia creíble de lo que nos gustaría creer. Una de nuestras tareas ha de consistir en explorar lo que a menudo se olvida o se da por supuesto e incuestionable desde tiempos inmemoriales.

Por último, pero no menos importante, ¿historia de las mujeres y/o historia de(l) género? Ambas denominaciones son problemáticas. La primera parece mostrarse excluyente en tanto que la mujer forma parte de una sociedad constituida no solo por mujeres; la segunda puede ser interpretada en términos de exclusión encubierta al ser empleada erróneamente como sinónimo de la primera. Pero, en realidad, no son actividades de producción del conocimiento diferentes, con distintos resultados. Al menos

\footnotetext{
${ }^{40}$ Françoise THÉBAUD: Escribir la historia ..., p. 114.

${ }^{41}$ M. a Dolores RAMOS: “Arquitectura del conocimiento..., esp. p. 24.
} 
no si las preguntas sobre el "género" son las que están dirigiendo la historia que se está escribiendo sobre las mujeres. ${ }^{42}$

Aunque haya sido lo predominante en el lenguaje historiográfico, quizás ya no es tan conveniente emplear exclusivamente "historia de las mujeres". Parece ser la hora de la coletilla “y de(1) género". El éxito puede deberse a su carácter abstracto y aséptico, políticamente correcto, así como a la necesidad de dar apariencia de cientificidad a unos estudios que aspiran a ser reconocidos en el mundo académico y al afán de alejar cualquier sospecha de militancia. Pero su difusión actual, que tanto en historia como en otras disciplinas tiende a eclipsar expresiones más clásicas tales como "diferencia de sexos", "relaciones entre hombres y mujeres" o "relaciones sociales de sexo", constituye un fenómeno al que no hay que desdeñar, sino dar la bienvenida. Efectivamente, lo que denota es una concienciación sobre la dimensión sexuada de los fenómenos y de las sociedades, así como los intereses de una desnaturalización de la diferencia de los sexos. Revela, también, la adquisición de una cierta valoración y legitimidad intelectual de los enfoques de género, forjados en el debate desde hace unas décadas. Contrariamente a lo que se cree, el interés del -globalizante-concepto de "género" y del-polisémico- término que lo designa reside justamente en estas características. Se ha producido entonces un desplazamiento desde las mujeres hasta el "género", desde una historia del grupo social de las mujeres hasta una historia comparada de hombres y mujeres.

La utilización del "género" abre, así, las puertas a una historia de las relaciones reales y simbólicas entre los hombres y las mujeres, una historia que coloca con mayor firmeza a las mujeres del pasado en su contexto histórico, que analiza dentro del mismo la construcción de los roles y de las diferencias sexuadas, así como los sistemas de representación que vienen asociados. Igualmente, se han producido otros desplazamientos: ${ }^{43}$ desde lo neutro hasta el género, hacia una relectura sexuada de los acontecimientos, procesos, fenómenos históricos, etcétera; desde el grupo como entidad homogénea hasta heterogeneidad y diversidad de sus componentes, desde la mujer a las mujeres, algo que invita a comparar al género con otras categorías de análisis multirrelacionales (clase, religión, etnia, cultura, sexualidad...), todas ellas objeto de

\footnotetext{
${ }^{42}$ Tania NAVARRO-SWAIN: "Entrevista con la profesora Joan W. Scott", en Anuario de Hojas Warmi, 16 (2011), http://www.ub.edu/SIMS/hojasWarmi/hojas16/articulos/TaniaNavarro.pdf [consulta 3 de abril, 2017].

${ }^{43}$ Françoise THÉBAUD: Escribir la historia..., pp. 278-295.
} 
diferenciación jurídica o discriminación en sociedades del pasado y/o del presente; y desde el género a los géneros, e incluso, a lo transgénero.

No obstante, es oportuno recordar que la línea promovida por Joan W. Scott reclamaba efectivamente un estudio de las mujeres en interrelación con el de los hombres y, por ende, no aislado en sí mismo. Se trata de una historia propia, ${ }^{44}$ que presenta una gran complejidad y riqueza por sí sola, pero que en ningún caso es independiente. Por ello, para hacer si cabe más ostensible este matiz, sería preferible utilizar la expresión "relaciones de género", utilizada ya hace más de veinte años en el número 17 de la revista Ayer, coordinado por Guadalupe Gómez-Ferrer, que constituyó una invitación, un desiderátum para futuras prácticas historiográficas, una llamada a integrar las relaciones sociales entre los sexos. ${ }^{45}$

Sea cual sea la denominación, lo verdaderamente fundamental es el pensar la historia de(1) género desde la perspectiva de ambos, mujeres y hombres, y no solo como sinónimo de las primeras. La incorporación de este carácter relacional ampliará la visión del proceso histórico, permitirá examinar las involuciones y los cambios sociales desde ambas perspectivas, definirá el estatuto de unas y otros en diferentes etapas históricas, contribuirá a la reconstrucción de sus identidades desde diversos enfoques y la evolución de sus roles sociales. Una óptica relacional que dinamice la disciplina. Una historia contributiva a la reescritura de la historia toda y general, más allá de la intención de explorar los territorios de lo femenino, a fin de evitar un gueto intelectual, una historia aislada y en paralelo. Una historia inclusiva que tenga en cuenta todas las dimensiones de los problemas humanos y no consista únicamente en la inversión de la historia en masculino. ${ }^{46}$ Un espacio discursivo "habitado" por sujetos históricos con historias diferentes, pero relacionadas.

\footnotetext{
44 Bonnie S. ANDERSON y Judith ZINSSER (eds.): Historia de las mujeres: una historia propia, Barcelona, Crítica, 2009.

${ }^{45}$ M. a Dolores RAMOS: “Arquitectura del conocimiento..., esp. pp. 37-38.

${ }^{46}$ Isabel MORANT et al.: "Arenal y la historiografía feminista española e hispanista en las dos últimas décadas", Arenal. Revista de Historia de Las Mujeres, Vol. 20, 1 (2013), pp. 81-105.
} 
Por tanto, lo masculino y la(s) masculinidad(es) constituyen un extenso campo a explorar, ${ }^{47}$ de forma conjunta con lo femenino y la(s) femineidad(es). ${ }^{48}$ La historia en masculino relegó a otras historias al silencio y en su pretendida "neutralidad" también se negó a someterse al examen de la masculinidad. Uno tampoco nace hombre, sino que se hace hombre dentro de determinados contextos históricos y los roles masculinos, así como las percepciones de lo masculino, son construcciones sociales y culturales. Al respecto, la historia de las mujeres y de(l) género ha contribuido a actualizar el espacio y el tiempo en que los hombres se ven como tales y defienden sus propios intereses.

Ahora bien, en la línea de lo señalado por Gisela Bock, ${ }^{49}$ es conveniente no caer en simples definiciones dicotómicas vinculadas a la distinción entre hombres y mujeres y arraigadas en la historiografía tradicional, como la separación entre los ámbitos público y privado. Las oposiciones binarias falsean la compleja realidad al obviar las interdependencias e interferencias recíprocas, los intersticios, los límites difusos y discontinuos, así como los desbordamientos que pueden darse en cualquier identidad, relación y espacio. Y es que lo masculino no siempre significa dominación ni lo femenino sumisión, porque depende del contexto histórico, político, social, cultural... Estos estudios son, por ende, un punto de confluencia de diferentes categorías de análisis y de debate sobre cuestiones y problemáticas relacionadas con las identidades, la ciudadanía, los movimientos sociales, las relaciones de poder y jerarquía, las culturas políticas, el sistema de representaciones, entre otros.

\section{Reflexión final}

En el transcurso de los últimos años han ido apareciendo trabajos sobre cuestiones concretas que atraviesan al sujeto femenino de nuestro pasado, algo que podemos vincular con un nuevo contexto, los cambios en la forma de entender la sociedad y el desarrollo de varios campos en los que la mujer desempeña un papel cada vez más notorio. No podemos obviar que en la elección de los temas de investigación pesan mucho las

\footnotetext{
${ }^{47}$ Nerea ARESTI: Masculinidades en tela de juicio. Hombres y género en el primer tercio del siglo XX, Madrid, Cátedra, 2010; Nerea ARESTI, Karin PETERS y Julia BRÜHNE: ¿La España invertebrada? Masculinidad y nación a comienzos del siglo XX, Granada, Comares, 2016.

${ }^{48}$ Mary NASH y Mercedes ARBAIZA: Feminidades y masculinidades: arquetipos y prácticas de género, Madrid, Alianza, 2014.

${ }^{49}$ Gisela BOCK: "Challenging Dichotomies: Perspectives on Women's History", en Karen OFFEN, Ruth R. PIERSON y Jane RENDALL: Writing Women's History: International Perspectives, London, MacMillan, 1991, pp. 1-23.
} 
inquietudes del momento, lo que podríamos llamar "presentismo" de la investigación histórica. Al respecto, podríamos debatir sobre cuánto hay de oportunismo y cuánto de verdaderas aportaciones y avances del conocimiento. Pero, en cualquier caso, hoy disponemos de una extensa bibliografía a la que recurrir, un abanico de diversas tendencias y temáticas, e incluso, de publicaciones especializadas: obras de carácter teórico, manuales generales, obras de síntesis, antologías de textos, diccionarios biográficos y biografías, revistas, monografías, tesis doctorales, etcétera.

Sin embargo, aún no han sido cubiertas muchas lagunas, algunos temas pendientes de abordar o que deben ser reinterpretados, y siguen repitiéndose tópicos en la línea de las grandes interpretaciones y de la periodización lineal clásica, que necesitan ser redefinidas y contrastadas con nuevos estudios y nuevas fuentes, por recién descubiertas, por inéditas, por poco conocidas, por menos tradicionales o por ser convencionales pero revisitadas con otros interrogantes. A medida que se van quemando etapas, es deber de las historiadoras e historiadores superar las fases obsoletas e intentar caminar por nuevos derroteros en favor de nuevas perspectivas de análisis, así como un bagaje metodológico y objetivos de investigación renovados. Hay que superar una historia de hombres en cuya construcción las mujeres parecían no haber colaborado más allá de participar como buenas esposas, paridoras y cuidadoras de hijos. Estos estereotipos, que aún se mantienen en algunos espacios, resultan inadmisibles y sustenta la idea de que la historia de las mujeres y de(l) género aún está por hacer. Por ello, incidimos aquí en la necesidad de "historiar" a la mujer componiendo una suerte de collage, colocando cada pieza de tal forma que otorgue sentido a nuestro análisis histórico de las relaciones de género, un vastísimo campo de potencial investigación interdisciplinar. Todo fenómeno, acontecimiento, proceso, sistema, puede observarse desde este punto de vista y adquirir, por tanto, otras dimensiones y significados.

En otro orden de cosas, la historia de las mujeres y de(l) género está consolidada solamente dentro de los grupos a los que interesa y consideran que es necesaria, por iniciativa propia e implicación voluntaria del personal docente-investigador y del alumnado, pues la historia que mayoritariamente se escribe, enseña y aprende sigue siendo una historia en la que las mujeres aparecen accidentalmente, de forma secundaria, en páginas anexas, “prescindibles”. En proporción, los profesionales que se han adentrado en las relaciones de género siguen siendo una minoría, pese al magnificado fenómeno de 
su visibilidad actual. Falta aún que las mujeres sean reconocidas sin evasivas como sujeto histórico en la investigación (no solo en nuestra disciplina, sino en la investigación en general), y que ello permee de forma efectiva a la sociedad y la opinión pública a través de la docencia y la divulgación. Tomando como inspiración la metáfora constructivista de $\mathrm{M}^{\mathrm{a}}$ Dolores Ramos, ${ }^{50}$ la construcción de la disciplina histórica es una suerte de obra en la que intervienen arquitectos, aparejadores, maestros de obras, albañiles y peones. La perspectiva de las mujeres y de(l) género únicamente podrá formar parte de la arquitectura si tanto expertos como aspirantes se implican y hacen los ajustes, revisiones y reubicaciones pertinentes en el edificio de la historia.

Siendo conscientes de que aún queda un largo camino, cabría ser optimistas sobre el porvenir que le aguarda a la mujer como sujeto histórico. El campo de estudio en cuestión ha mostrado últimamente una enorme vitalidad y ha irrumpido con fuerza en el mundo académico y en otros espacios culturales. Es por ello que, con la idea de seguir avanzando en esta senda, las páginas de nuestra investigación doctoral pretenden contribuir a incorporar la perspectiva de las mujeres y de(l) género a la disciplina histórica; aportar, en definitiva, nuestro grano de arena al entendimiento de (por lo tanto, erradicación) de la desigualdad y de la opresión de las mujeres. Todas y todos somos responsables de la historia que se escriba y se transmita en el siglo XXI. La meta es lograr una disciplina capaz de entender el presente y transformar el futuro aprendiendo del conocimiento del pasado.

${ }^{50}$ M. ${ }^{\mathrm{a}}$ Dolores RAMOS: “Arquitectura del conocimiento..., pp. 17-40. 


\title{
El Mercado de la democracia: Una propuesta analítica del clientelismo político en perspectiva microhistórica
}

\author{
The market of democracy: An analytical proposal of political \\ clientelism in microhistorical scale.
}

Daniela Ferrández Pérez

Universidad de Santiago de Compostela

\begin{abstract}
Resumen
El texto pretende realizar un repaso conceptual por la teoría del clientelismo y sus propuestas metodológicas que se muestre en relación con experiencias investigadoras concretas desarrolladas por la autoría de la comunicación. El punto central reside en la búsqueda de nuevas preguntas sobre el fenómeno clientelar que permitan analizarlo como un mecanismo de organización social que trasciende de un plano meramente institucional. Para ello también se propondrán actuaciones metodológicas basadas en la citada experiencia investigadora.
\end{abstract}

\section{Palabras clave}

Clientelismo político; Dictadura de Primo de Rivera; Metodología.

\begin{abstract}
This text is a review about the theory of clientelism and its methodological proposals regarding research experiences carried out by the authors of this study. The main objective is to seek new questions about the clientele phenomenon that allows an analysis as a mechanism of social organization that transcends from a merely institutional level. For this purpose, methodological actions based on the research experience will be proposed.
\end{abstract}

Keywords 
Political clientelism; Primo de Rivera dictatorship; Methodology.

\section{Introducción}

El presente trabajo trata, en primer lugar, de realizar una síntesis conceptual sobre la tan debatida teoría del clientelismo. No se trata de exponer todos los puntos de vista existentes ni contrastarlos, sino de asumir el intercambio como elemento definitorio de las relaciones de patronazgo en el que se encuentra cierta unanimidad entre sociólogos, antropólogos e historiadores. A partir de esta definición, intentaremos reflexionar sobre cómo el uso exclusivo de fuentes provenientes de la política formal no es suficiente para realizar un análisis que disgregue la complejidad de las relaciones clientelares. Para ello, y en base a la prosopografía, propondremos alternativas metodológicas que pasen por un retorno a las fuentes de prensa desde una óptica que no sitúe en primera línea los discursos políticos. No se trata tampoco de caer en la prensa como fuente exclusiva, sino de señalar que, complementada con otras fuentes documentales, puede suponer una herramienta de primer orden para analizar cuestiones básicas del patronazgo que de otro modo pueden pasar desapercibidas, como lo son las relaciones de parentesco entre las élites o su confluencia en diversos espacios de sociabilidad. Para terminar, se ofrece una puesta en práctica de la metodología descrita centrada en el debate sobre la pervivencia o no del sistema caciquil tras el golpe de Primo de Rivera. Ésta aportación no pretenderá esclarecer las cuestiones a las que se hace referencia, pues se trata de un estudio incompleto fruto de una tesis en construcción, pero sí tratará de demostrar cómo los análisis superfluos de las fuentes exclusivamente políticas pueden inducir a posibles errores interpretativos.

\section{El clientelismo político como relación de intercambio y sus principales estrategias de reproducción}

El clientelismo político es un concepto que ha sido teorizado e investigado desde distintas perspectivas en el conjunto de las ciencias sociales. Desde la antropología hasta la historia, pasando por la ciencia política o la sociología, no son pocos los autores que han tratado de dar respuesta a las características internas del fenómeno, difiriendo, en cuestiones relativas a sus causas, significados y resultados. Pero si existe cierta unanimidad en algo es a la hora de definir el proceso clientelar como una "relación de intercambio desigual", donde dos actores, el "patrono" y el "cliente", sustentan un sistema de reciprocidad interpersonal. 
Dentro del abanico de definiciones, el sociólogo James Scott es quizá quién más profundiza en el aspecto del intercambio, pues lo disgrega en categorías fijas que explicarán el concepto yendo más allá de una dominación oligárquica per se. Partiendo de la base de la desigualdad propiciada por el control de los recursos por parte del Patrón, las categorías definidas por Scott nos muestran que la sumisión del cliente tenía como claro objetivo la reproducción de sus condiciones materiales básicas de subsistencia, algo que, podemos considerar que sustituye a la utilización de la apatía y el analfabetismo como principales explicaciones de participación en un sistema claramente desigual. ${ }^{1}$

Tal que así, para Scott, el patrono proporcionaba al cliente medios básicos de subsistencia al otorgarle el acceso a la tierra de cultivo y la provisión de útiles de labranza. Esto, se complementaba con una hipotética protección frente a peligros privados (bandidaje) o públicos (tribunales...), y una mediación a través de la utilización de la influencia ante el Estado y los poderes públicos. La relación se completaba con la caridad, mediante la cual el patrón podía subvencionar bienes públicos o privados en beneficio de la comunidad, así como proporcionar un seguro de subsistencia para tiempos de crisis. Por su parte, el cliente responderá a estas concesiones mediante la provisión de mano de obra básica, ya sea en calidad de empleado del patrón o con la prestación de trabajos y bienes suplementarios, y, como concepto en el que la mayor parte de las investigaciones ponen su punto de mira, la promoción de los intereses del patrono. Dicha promoción se puede traducir en fidelidades políticas que se expresan en forma de sufragio, pero también de extensión de corrientes de opinión favorables, o defensa de intereses generales. ${ }^{2}$

Como se ha mencionado, la desigualdad es la base de la relación clientelar, la cual descansa en la disposición por parte del patrón de los recursos básicos para la subsistencia del cliente. Con todo, se crea lo que ha sido definido como una "amistad desequilibrada". 3 Un contrato renovable y extensible en el tiempo, basado en la confianza mutua, donde

\footnotetext{
${ }^{1}$ Poniendo un ejemplo entre lo que podemos considerar una corriente interpretativa bastante extendida, Teresa Carnero explica la sumisión al sistema clientelar en base a la apatía, desmovilización y analfabetismo de la población rural, todo ello ejemplo del atraso del mundo campesino. Teresa CARNERO: "Democratización ilimitada y deterioro político en España, 1874-1930" en VV.AA.: Democracia, elecciones y modernización en Europa: siglos XIX y XX. Alicante: Instituto de cultura Juan Gil-Albert, 1997, pp. 203-240, esp. p. 205.

2 James SCOTT: “¿Patronazgo o explotación?” en Ernest GELLNER: Patronos y clientes, Madrid: Júcar, p. 38.

3 Javier MORENO LUZÓN: "Teoría del clientelismo y estudio de la política caciquil", Revista de Estudios Políticos Nueva Época, 89 (1995), pp. 191-224, esp. p. 197.
} 
intercambios aislados como la compra de votos no corresponderían un ejercicio propio de esta relación, sino transacciones circunstanciales que no entran en los principios básicos descritos de la diada.

Una vez expuestas las bases de la relación clientelar cabe señalar los mecanismos a través de los cuales se conformaban y extendían las llamadas "redes". Como hemos señalado con anterioridad, la motivación del cliente para formar parte de una red se sustentaba en un intento por reproducir sus condiciones básicas de subsistencia. El acceso a los recursos del patrón, a la protección y a la mediación garantizaba una estabilidad que difícilmente podían proporcionar fórmulas alternativas de obtención de recursos como la reivindicación del derecho a los mismos a través de la acción colectiva y la protesta. En la base de ésta afirmación se encuentra el hecho de que la pertenencia a una red, dónde la relación cliente-patrón será siempre jerárquica y vertical, se sustenta en la desigualdad y es antagónica a la existencia de relaciones horizontales que posibiliten la acción colectiva. $^{4}$

En lo que respecta a los patrones, la capacidad de ofertar a sus clientes recursos, protección y mediación, sustentaba su posición. No se establece como necesario que el patrón dispusiera de un gran patrimonio para garantizar estas condiciones, pues el control de las decisiones de los organismos de gestión de los recursos públicos posibilitaba el beneficio constante a la clientela. A la hora de acceder a dichos organismos de gestión, la familia y el territorio se mostraban como marcos sociales básicos, por lo que el parentesco es un elemento indispensable a la hora de analizar la reproducción de las redes clientelares. Tal que así, la familia actúa como elemento transmisor de un poder y prestigio acumulados durante generaciones, algo que se puede observar en la repetición de apellidos en multitud de dirigentes políticos. Además, su extensión garantizaba una "cantera de apoyos políticos", 5 que se iría aumentando mediante matrimonios concertados, que unirían y ampliarían extensas redes clientelares.

Pero el control de unos recursos limitados a través de la esfera institucional podía propiciar la existencia de familias o redes en pugna por los puestos de gestión del poder. ${ }^{6}$

\footnotetext{
${ }^{4}$ Ibid., p. 208.

${ }^{5}$ Xoxé R. VEIGA ALONSO: "Los marcos sociales del clientelismo político" Historia social, 34 (1999), pp. 27-44, esp. p. 28.

${ }^{6}$ Alex WEINGROD: "Patronazgo y poder” en Ernset GELLNER: Patronos y clientes, Madrid: Júcar, 1977, pp. 63-79, esp. p. 67.
} 
Dependiendo de la posición pública por la que compitieran, concretamente si se referían a instituciones locales, estatales o de gestión económica -como los Juzgados de Aguas en el caso estudiado-, dichas redes podían agruparse en lo que se conoce como "bandos", "facciones" o incluso "partidos", 7 pero todo ello sin pretender alterar el statu quo existente. $^{8}$

\section{Nuevas perspectivas y metodologías de análisis}

Teniendo en cuenta la definición de clientelismo como instrumento de intercambio, y a la hora de enfrentarse a las fuentes históricas para construir un relato claro, surge la pregunta de quién es un cacique y quién no. En dichas fuentes es frecuente encontrar acusaciones de caciquismo encaminadas a debilitar rivales políticos, señalar injusticias o mostrar disenso con el sistema, tratándose de un término que nace de una construcción mental propia de una época concreta. ${ }^{9}$ Pero si centramos la atención en la teoría del clientelismo, veremos que la etiqueta de cacique es mucho más compleja de lo que parece, pues su identificación en el ámbito de las ciencias sociales con el término "patronazgo"10 o clientelismo, determinará un sistema de reproducción sociológica que va más allá de lo político. Esto no es un asunto baladí, pues sin un análisis profundo que determine la existencia de una relación clientelar, existe el peligro de calificar de caciques a ciertos individuos basándose únicamente en una participación continuada en el ámbito público, pero carente de señales de intercambio"1. Por ello, "es prioritario que cualquier investigación sobre caciquismo deje claro por qué algunas personas -los caciques- son

\footnotetext{
${ }^{7}$ Javier MORENO LUZÓN: “Teoría del clientelismo y estudio...”, p. 209.

8 Salvador CRUZ ARTACHO: "Estructura y conflicto social en el caciquismo clásico. Caciques y campesinos en el mundo rural granadino (1890-1923)" en ROBLES EGEA, (coord.): Política en penumbra: Patronazgo y clientelismo político en la España contemporánea, Madrid: Siglo Veintiuno, 1996. pp. 191-213, esp. p. 199.

9 Hans DE GOEJE: "El cacique como "political middleman", el poder local en el concejo de Ponga (Asturias)", en: FERNÁNDEZ PRIETO; NÚÑEZ SEIXAS; ARTIAGA REGO; BALBOA: Poder local, elites e cambio social na Galicia non urbana (1874-1936), Santiago de Compostela: Universidad de Santiago de Compostela, 2007, pp. 393-415, esp. p. 394.

${ }^{10}$ Para González Alcantud "caciquismo" es el concepto utilizado por los historiadores para describir las relaciones de patronazgo existentes en una época concreta y un lugar particular: La España de la Restauración. José Antonio GONZÁLEZ ALCANTUD: “Jerarquía versus Igualdad: El clientelismo político Mediterráneo desde la Antropología" en ROBLES EGEA (coord): Política en penumbra: Patronazgo y clientelismo político en la España contemporánea, Siglo Veintiuno: Madrid, 1996, pp. 2141, esp. p. 32.

${ }^{11}$ Como veremos al hablar de la Dictadura de Primo de Rivera, muchas investigaciones analizan la pervivencia del caciquismo entre distintos regímenes basándose únicamente en las continuidades de individuos en Ayuntamientos o Diputaciones. Un ejemplo es el trabajo realizado por Santiago DE PABLO: "Continuidad y cambio en las élites políticas locales, de la Restauración a la II República, el caso de Alva", Espacio, tiempo y forma, Serie V (Historia Contemporánea), 3 (1990), pp. 237-248.
} 
consideradas objeto de estudio, por qué otras no, y cuáles son los parámetros utilizados para ello". 12

Para este ejercicio se muestra de vital importancia situar las perspectivas en una escala local, puesto que, como dijimos, el territorio es junto con la familia uno de los principales ámbitos de reproducción clientelar. Tal que así, las relaciones interpersonales a analizar se desarrollan principalmente en una escala municipal/comarcal que, aunque en ocasiones puedan exceder estos límites para el empleo de funciones de mediación tan útiles dentro del intercambio clientelar, constituye el mejor espejo para los análisis clientelares. $^{13}$

En este sentido, resulta de especial interés el estudio del clientelismo fuera de su dimensión puramente política, pues los procesos electorales no suponen otra cosa que manifestaciones externas de una realidad clientelar mayor que las subyace. ${ }^{14}$ Teniendo en cuenta que la familia es uno de los marcos sociales básicos de reproducción clientelar, supone de especial interés poner el punto de mira en las relaciones de parentesco dentro de la red a estudiar. Dichas relaciones pueden explicar el acceso de nuevos miembros a instancias públicas que mediante otras perspectivas analíticas difícilmente podríamos relacionar con la red, y que, siendo básicas para su funcionamiento, no se circunscriben a los espacios clásicos que se suelen tomar como objeto de estudio: el Ayuntamiento, la Diputación o las Cortes. De esta forma, el estudio de la familia puede responder a muchas cuestiones a la hora de situar individuos como directores de oficinas bancarias, miembros de la carrera judicial, propietarios de empresas y/o tierras, registradores de la propiedad, y una larga lista de posiciones básicas a la hora de proveer bienes de intercambio a la clientela. Además, es cuestión de lógica que, si una red clientelar trabaja unida para mantener y extender su poder, no será estrictamente necesario que la cabeza de la pirámide, el patrón principal, sea siempre el individuo visible de la red en el ámbito público, pues puede situar en esa posición a un subalterno, pariente o amigo político que responda a sus demandas.

\footnotetext{
${ }^{12}$ Ibid.

${ }^{13}$ Pedro CARASA SOTO: "El poder local en la Castilla de la Restauración: fuentes y metodología para su estudio", Hispania: Revista española de Historia, 20 (1999), pp. 9-39, esp. p. 16.

${ }^{14}$ Salvador CRUZ ARTACHO: "Estructura y conflicto social...", p. 200.
} 
Para desgranar todas estas relaciones desarrolladas fuera de lo que podríamos considerar "política formal", es necesaria una metodología que abarque aspectos de la vida cotidiana con una mayor amplitud que los análisis enjaulados en el espacio oficial ${ }^{15}$ -discursos, elecciones, candidaturas...-. Así, toma cada vez más peso en los estudios sobre clientelismo la metodología prosopográfica, consistente en la redacción de pequeñas biografías de los actores a investigar. ${ }^{16}$ Dichas biografías deberán superar el plano individual para acercarse a los problemas concretos del contexto histórico del biografiado, su relación con la vida cotidiana del momento, con el resto de actores de su entorno, "buscando ese punto de equilibrio entre o xeral e o concreto tan difícil de acadar nos traballos biográficos". Con todo, éste análisis no solo nos permitirá conocer la extensión de las redes sino las características propias de las élites, sus similitudes y diferencias en un acercamiento a las motivaciones concretas de sus actuaciones. ${ }^{17}$

Para ello se necesita una amplitud documental a la que es difícil poner límites, pues como veremos, datos a priori insignificantes pueden aportar una información muy valiosa para la reconstrucción de la red y su funcionamiento:

En primer lugar, se aboga por una vuelta a la prensa, la cual, debido al aumento de la catalogación y digitalización on-line se ha convertido en una fuente cada vez más accesible para los investigadores. En la búsqueda hemerográfica podremos encontrar dos tipos de informaciones sobre las élites que precisamos conocer, siendo la primera -y que más cuidadosamente hay que tratar- la que tradicionalmente ha sido empleada en múltiples investigaciones históricas: los discursos. A la hora de tratar con un discurso, es condición indispensable tener en cuenta que no tiene por qué definir al individuo que lo pronuncia, sino que refleja la imagen que dicho individuo quiere mostrar en un ámbito público. De esta forma, un actor político que recicle su posición pública dependiendo del contexto en el que se encontrase -véase el caso de Antonio Girona, conservador durante la Restauración, upetista durante la dictadura de Primo de Rivera y radical-socialista en

\footnotetext{
${ }^{15}$ Raúl SOUTELO VÁZQUEZ: "En torno a las élites y el poder local en la Galicia no urbana de anteguerra (1874-1936)" Noticiario de Historia Agraria, 12 (1996), pp. 221-258, esp. p. 258.

${ }^{16}$ Pedro CARASA SOTO: "La recuperación de la Historia Política y la prosopografia" en Pedro CARASA SOTO (ed.): Élites: prosopografía contemporánea, Valladolid: Universidad de Valladolid, 1994, pp. $42-$ 51.

${ }^{17}$ Alicia YANINI; Patricia GASCÓ: "Élites políticas en Transición. España de 1875 a 1975”, Saitabi, 58 (2008), pp. 443-464, esp. p. 450.
} 
la Segunda República ${ }^{18}$ - transformará constantemente su discurso, por lo que el mismo no nos estará mostrando una definición del individuo, sino de cómo trata de presentarse ante la sociedad.

Para conocer con una mayor profundidad su esfera cotidiana, el universo de relaciones que lo definen, será necesario prestar atención a otro tipo de informaciones que suelen aparecer en prensa y que fácilmente pueden pasar desapercibidas para el investigador. Tal que así, un anuncio -por ejemplo, de una fábrica- puede mostrar la fuente básica de recursos del individuo investigado, al igual que una concesión estatal de una mina:
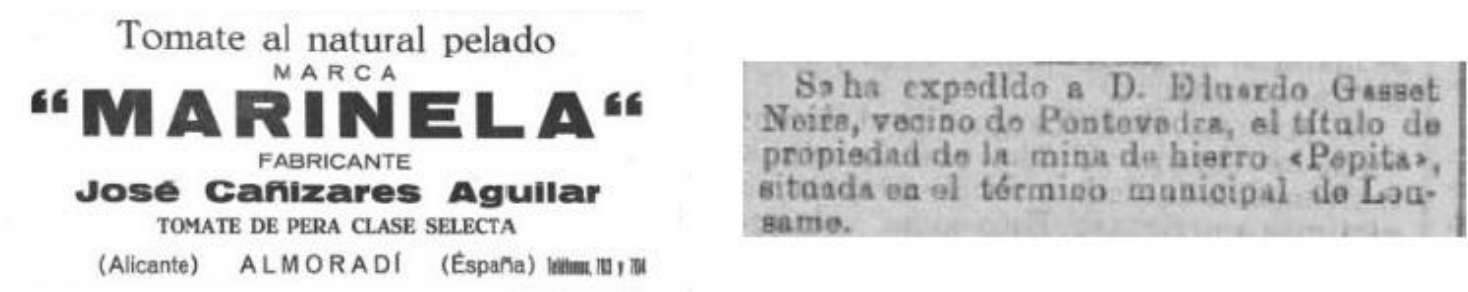

Figura 1: Ejemplos de relaciones económicas de individuos concretos encontrados en prensa (Fuente: Elaboración propia a partir de El pueblo: Semanario social y agrario, 01/04/1926, p. 20, Orihuela (Alicante) y El Eco de Santiago, 11/05/1915, p.3, Santiago de Compostela, A Coruña).

A la hora de reconstruir las relaciones de parentesco dentro de una red, la prensa también puede suponer una fuente de gran utilidad, sobretodo en espacios dónde no se conservan padrones o la documentación se encuentra disgregada. ${ }^{19}$ Además, en el caso de conservar fuentes cuyo análisis relacione composiciones familiares, informaciones aparecidas en prensa como esquelas, bautizos o bodas, podrán presentar los datos de una manera resumida.

\footnotetext{
${ }^{18}$ Daniela FERRÁNDEZ: "Continuidad y sustitución clientelar durante la Segunda República desde una perspectiva a largo plazo: El caso de Almoradí (Alicante), Espacio, tiempo y forma, Serie V, Historia Contemporánea, 2016. pp. 163-186.

${ }^{19}$ Concretamente, en las investigaciones desarrolladas en el municipio de Almoradí no fue posible contar con padrones municipales.
} 

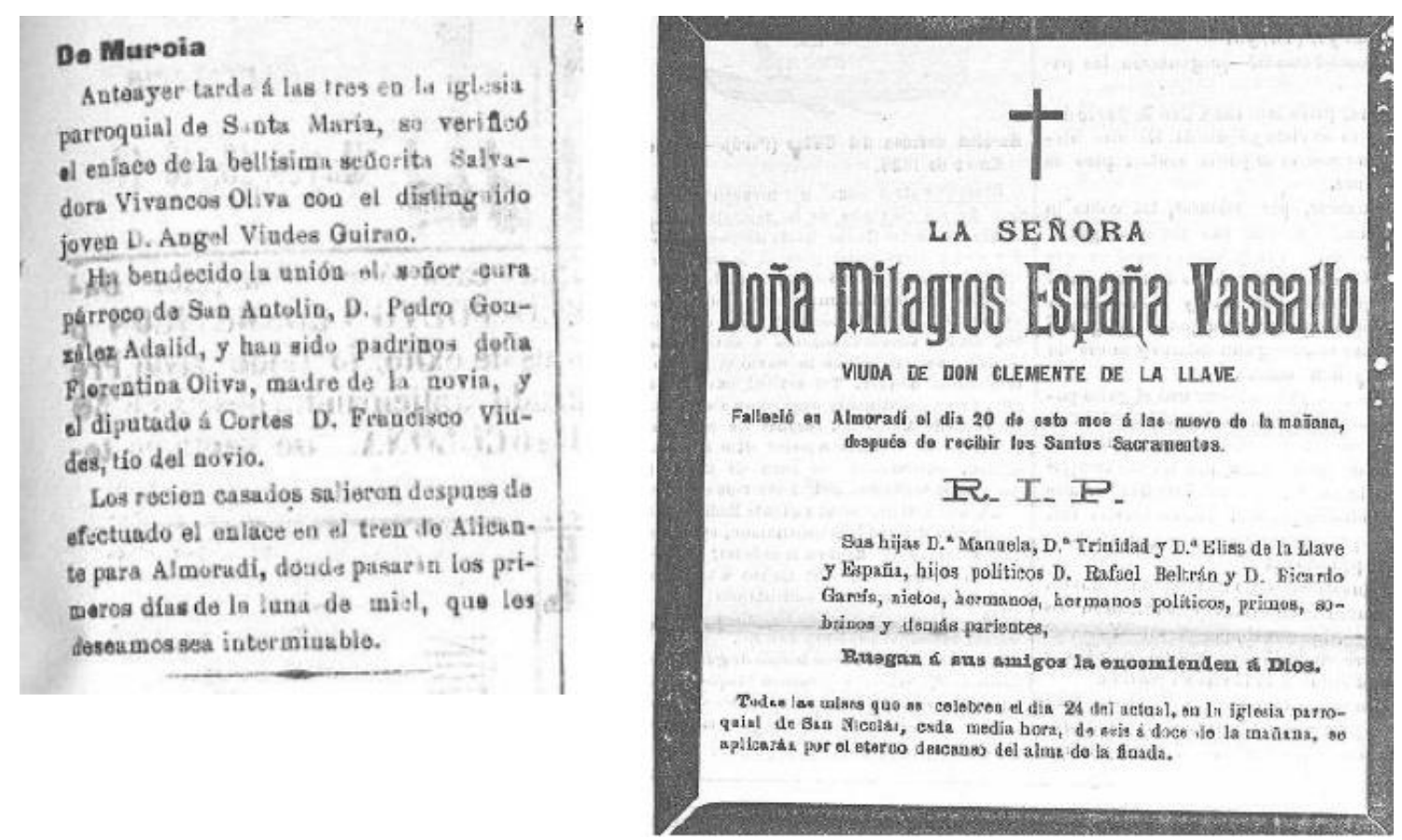

Figura 2: Ejemplos de relaciones familiares de individuos concretos encontrados en prensa (Boda y esquela) (Fuente: Elaboración propia a partir de El Graduador: Periódico político y de intereses materiales, 20/10/1907, p. 3, Alicante y El Liberal, Diario político y de intereses materiales, 23/01/1900. P. 1, Alicante).

En el caso de las bodas la información puede trascender el ámbito estrictamente familiar para permitirnos conocer las llamadas "amistades políticas", ${ }^{20}$ que comúnmente aparecen en las listas de invitados e incluso los más influyentes podrían apadrinar a los novios. Estos datos también se pueden extraer de las listas de invitados a banquetes, fiestas privadas, inauguraciones de negocios, acompañamientos a visitas oficiales y un largo etcétera que nos describe el universo cotidiano de estas élites, sus espacios de sociabilidad y las formas de relacionarse entre sí.

Además de lo expuesto, en la prensa es posible encontrar todo tipo de informaciones difíciles de catalogar que nos acerquen al universo cotidiano del investigado, sus relaciones, actuaciones y motivaciones. Como ejemplos de este amplio abanico podemos citar las listas de viajeros -tan comunes en la prensa del primer tercio del siglo XX- que indicaban desplazamientos a capitales, en muchas ocasiones en compañía, e incluso

\footnotetext{
${ }^{20}$ Para Veiga Alonso los "amigos políticos" suponían el colectivo conformado por amistades, conocidos y vecinos de la familia que aportaban apoyo político a la red y la extendían. Xoxé R. VEIGA ALONSO: "Los marcos sociales...", p. 30.
} 
llegan a referir reuniones con políticos de las altas esferas. También es común que se cite la asistencia a mítines, encuentros con el Gobernador Civil, listas de directivos de casinos, bancos, partidos políticos... fuentes en general nada descartables y difíciles de encontrar fuera del campo hemerográfico.

Pero la prensa puede suponer una guía útil que en general se muestra incompleta a la hora de realizar las biografías de los investigados, puesto que los datos que muestra, sin prejuicio de su valía, en muchas ocasiones resultan aislados. De esta forma es indispensable contar con todo el abanico de fuentes posible que enriquezca la investigación: desde las ya conocidas actas municipales hasta las listas de contribuciones, padrones de habitantes, expedientes de asociaciones... Como dijimos es difícil establecer un límite claro. Por ejemplo, para conocer escenarios de relación entre las élites puede ser interesante analizar los expedientes de los matriculados en derecho -carrera predilecta entre los notables de este momento- que muestren con quién compartieron promoción, con qué profesores tenían relación, etc.

Con todo, se trata de romper el corsé analítico de la fuente estrictamente política a la hora de comprender un fenómeno que se desarrollaba sobre todo en una esfera privada. ${ }^{21}$ La perspectiva multidisciplinar resulta más que interesante para este ejercicio, pues aporta distintos puntos de vista que no harán más que enriquecer el análisis, como afirma el antropólogo González Alcantud:

La oposición entre una y otra visión no es gratuita (historiadores vs antropólogos): para los historiadores, la relación política determina necesariamente las relaciones de jerarquía que establecen caciques y clientes, marcados en última instancia por el aparato electoral. Para los antropólogos, el aparato electoral de la Restauración constituiría un epifenómeno de unas relaciones más profundas de orden sociológico, cuales son las relaciones entre patronos y clientes en ámbitos de la vida económica, doméstica y simbólica, que incluyen ante todo prestaciones fuera del mercado, protección, parentesco espiritual e identidad comunitaria. Los antropólogos políticos ven en la síntesis el mecanismo adecuado para comprender el clientelismo político. ${ }^{22}$

\footnotetext{
${ }^{21}$ Salvador CRUZ ARTACHO: "Estructura y conflicto social...", p. 200.

22 José Antonio GONZÁLEZ ALCANTUD: "Jerarquía versus Igualdad...", p. 32.
} 


\section{Variaciones interpretativas en función de la estrategia metodológica: El caciquismo más allá de la Restauración}

Como se verá en este punto, la metodología empleada en las investigaciones sobre caciquismo y clientelismo tiene la capacidad de influir abiertamente en las conclusiones que se extraigan del fenómeno. Un ejemplo bastante claro lo encontramos en las reflexiones sobre la extensión del sistema caciquil fuera de los límites de la Restauración, ya que la sustitución que llevó a cabo Primo de Rivera en multitud de instituciones oficiales -Ayuntamientos, Diputaciones...- ha propiciado variadas reflexiones sobre el fin del sistema clientelar.

Como señalábamos, la falta de una estrategia metodológica común que supere las barreras de la política formal ha derivado en la existencia de múltiples interpretaciones sobre la extensión del clientelismo con posterioridad a 1923. Así, contamos con estudios que se basan en la continuidad institucional de las élites para extraer conclusiones sobre la pervivencia del fenómeno, ${ }^{23}$ ejercicio con un claro riesgo de señalar como caciques a individuos por su continuidad, o eximirlos de dicha etiqueta por su sustitución en la política oficial. Junto con esto, otros trabajos profundizan en las reflexiones económicosociales, pero sin dejar de basarlas en un plano meramente electoral, lo que puede llevar a la realización de juicios poco sustentables sin un estudio más profundo. La conclusión del estudio de Salvador Cruz Artacho sobre el caciquismo granadino puede servir como ejemplo:

La pérdida progresiva de fuentes alternativas de recursos para las economías domésticas campesinas, la mercantilización de las mismas, la ruptura, en definitiva, de buena parte de los lazos comunitarios (...) y el incumplimiento, por tanto, de las funciones de protección que en la relación clientelar tradicional se reconocía la patrón con respecto a sus clientes, unido a la difusión del sindicalismo de clase y el socialismo, hizo que las tradicionales fórmulas de articulación y alineamiento político comenzaran a no "tener sentido" para el campesino (...). La opción fue la lucha encarnizada contra el patrón y, para ello, el apoyo en los eventos electorales a candidatos extramuros al sistema, esto es, republicanos y socialistas.

\footnotetext{
${ }^{23}$ Juan LINZ "Continuidad y discontinuidad en la élite política española: De la Restauración al régimen actual”, Estudios de Ciencia Política y Sociología, Homenaje al Profesor Carlos Ollero, Madrid: Gráficas Carlavilla, 1972, pp. 361-423; Santiago DE PABLO: “Continuidad y cambio en las élites...", pp. 237-248.
} 
Lo que acontece en la circunscripción de Granada con la candidatura del socialista Fernando de los Ríos Urruti es un claro ejemplo al respecto. ${ }^{24}$

Pese a que la reflexión de Cruz Artacho sobre la coincidencia del final de la Restauración con el fin de un modelo de organización social puede ser válida en cierta medida y para ciertos territorios, supone una afirmación muy optimista si la comparamos con lo acaecido en otras regiones y, sobre todo, si tenemos en cuenta que la está sustentando en un ámbito meramente electoral. Teniendo en cuenta lo que expusimos en los primeros puntos, afirmaciones tales deberían ir acompañadas de un análisis más profundo sobre la erosión en las relaciones clientelares de las que habla. Tal que así, sería necesario comprobar a largo plazo y en perspectiva comparada si el sistema de intercambio realmente se resquebrajó, si la ocupación del espacio público por parte de las élites se vio mermada y si, por lo tanto, la sustitución de las relaciones verticales propias del clientelismo por relaciones horizontales características de la democracia se impuso ya en la Dictadura de Primo de Rivera.

Dentro de los autores que abogan por una extensión del sistema clientelar a largo plazo encontramos propuestas analíticas que lo dividen en modelos para facilitar su estudio y comprensión. Ahora bien, en este punto también será indispensable señalar qué elementos nos muestran un cambio de modelo, todo ello sin dejar de tener en cuenta que las relaciones clientelares se desarrollan más allá de un plano únicamente electoral. En este sentido citaremos dos ejemplos de esta división, siendo el primero el de Cazorla Pérez, quien delimita el clientelismo de la España del Siglo XX en dos subsistemas: el clientelismo tradicional y el clientelismo moderno o de Partido. Para Cazorla, las diferencias entre uno y otro radican en que en el clientelismo moderno los recursos ya no constituyen un monopolio del patrón, sino un rasgo definitorio del Estado de Bienestar que el intermediario distribuirá entre unos y otros a cambio de fidelidad política, utilizando un partido como instrumento. ${ }^{25}$ En este modelo, la desigualdad económica entre patrón y cliente no es indispensable, y las relaciones familiares se sustituyen por

\footnotetext{
${ }^{24}$ Salvador CRUZ ARTACHO: "Estructura y conflicto social en el caciquismo clásico. Caciques y campesinos en el mundo rural granadino (1890-1923)" en ROBLES EGEA (coord.): Política en penumbra: Patronazgo y clientelismo político en la España contemporánea, Madrid: Siglo Veintiuno, 1996. pp. 191213, esp. p. 212-213.

${ }^{25}$ José CAZORLA PÉREZ: "El clientelismo de partido en la España de hoy: una disfunción de la democracia" en ROBLES EGEA (coord.): Política en penumbra: Patronazgo y clientelismo político en la España contemporánea, Siglo Veintiuno: Madrid. 1996, pp. 291-306, esp. p. 300.
} 
otras basadas en la confianza, el oportunismo y la complicidad. ${ }^{26}$ El segundo ejemplo lo constituye Robles Egea (1996), quien, asumiendo el clientelismo tradicional y el clientelismo de partido, introduce para la Dictadura de Primo de Rivera -y la franquistael llamado modelo de "clientelismo de partido único", basándose para ello en la ausencia de elecciones. No es la intención de este trabajo contradecir a Robles Egea, pero sí lanzar la pregunta sobre si basarse en las elecciones para delimitar un modelo clientelar no supone, al fin y al cabo, obviar toda una serie de relaciones más profundas que lo definen en su esencia.

Con todo, diremos que todavía no existe una postura clara y extendida sobre lo que ocurrió más allá de 1923, aunque no son pocos los trabajos que señalan una sustitución de élites en instancias superiores de la administración -Diputaciones y Cortes- y una pervivencia en planos inferiores, ya fuera en los ayuntamientos ${ }^{27}$ o en otras instituciones. $^{28}$

Siguiendo las directrices de Moreno Luzón, quien propone una visión que supere las barreras de la política formal para adentrarse en los espacios de la vida cotidiana o la cultura -algo que considera "una historia social del poder político"29- e indagar sobre supervivencia del caciquismo más allá del período de la Restauración, a la vez que utilizando la metodología descrita con anterioridad, atenderemos a investigaciones propias para reflexionar sobre la continuidad del modelo caciquil en la Dictadura de Primo de Rivera.

Para ello nos centraremos en el municipio de Almoradí -provincia de Alicante-, dónde se está realizando un estudio sobre readaptaciones de redes clientelares entre 1905 y 1940 en perspectiva comparada con el distrito de Noia -provincia de A Coruña-. En el citado espacio demostraremos cómo el uso de una u otra metodología puede condicionar los resultados de la investigación y las conclusiones, principal intención de este trabajo.

\footnotetext{
${ }^{26}$ Ibid...., p. 301.

${ }^{27}$ Santiago DE PABLO: “Continuidad y cambio en las élites...”, p. 242.

${ }^{28}$ Manuel VEIGA: "O Réxime de Primo de Rivera en Vigo e na provincia de Pontevedra: Da esperanza á desilusión”, Pontevedra, Revista de estudos provinciais, 20 (2004), pp. 41-50, esp. p. 42; Ana P. VIGO FERNÁNDEZ: A ditadura de Primo de Rivera en Lugo (1923-1930): Continuidade ou cambio?, Lugo: Deputación de Lugo, 2010, p. 100.

29 Javier MORENO LUZÓN: "A historiografía sobre o caciquismo espanhol: balanço e novas perspectivas”, Analise Social, vol. XLI, 168 (2006), pp. 9-29, esp. p. 26.
} 
A través del estudio de las actas municipales del Ayuntamiento conocemos las distintas composiciones que éste tuvo desde principios de siglo, lo que puede servir como base para un análisis de las continuidades de los concejales entre ambos regímenes. Surge la problemática de que entre 1923 y 1925 no hay actas disponibles, por lo que el salto temporal complica la comparación de los ediles. Pese a esto, una noticia aparecida en prensa $^{30}$ nos indica los individuos que constituyeron la Unión Patriótica (en adelante U.P.) en el municipio en 1924, información que ayuda a llenar los vacíos existentes sobre la dirección de la política local para estos años. Si atendemos a un cruce de estos datos concejales anteriores a 1923, composición de la UP en 1924 y concejales de 1925podemos comprobar que tras el golpe apenas existe continuidad de las élites en el consistorio y la política local:

\begin{tabular}{|l|l|l|l|}
\hline $\begin{array}{l}\text { Miembros de la U.P. } \\
\text { en } 1924\end{array}$ & $\begin{array}{l}\text { Participación política } \\
\text { anterior a 1923 }\end{array}$ & $\begin{array}{l}\text { Concejales en 1925 } \\
\text { política anterior a } \\
1923\end{array}$ \\
\hline $\begin{array}{l}\text { Antonio Girona } \\
\text { Ortuño }\end{array}$ & Concejal 1905-1906 & $\begin{array}{l}\text { Antonio Girona } \\
\text { Ortuño }\end{array}$ & $\begin{array}{l}\text { Concejal 1905- } \\
1906\end{array}$ \\
\hline $\begin{array}{l}\text { Manuel González } \\
\text { Pérez }\end{array}$ & & $\begin{array}{l}\text { Manuel González } \\
\text { Pérez }\end{array}$ & \\
\hline Mariano Cortés & & $\begin{array}{l}\text { José } \\
\text { Martínez Canales }\end{array}$ & \\
\hline Mariano Cortés & & $\begin{array}{l}\text { José } \\
\text { Martínez Canales }\end{array}$ & \\
\hline José Illescas García & & $\begin{array}{l}\text { Francisco Illéscas } \\
\text { García }\end{array}$ & \\
\hline
\end{tabular}

30 “Almoradî", El Liberal de Murcia, 07/06/1924. 


\begin{tabular}{|l|l|l|l|}
\hline $\begin{array}{l}\text { Manuel González } \\
\text { Sampere }\end{array}$ & Concejal 1912 & $\begin{array}{l}\text { Manuel } \\
\text { Chinchilla }\end{array}$ & \\
\hline Pedro Reig Macià & $\begin{array}{l}\text { Concejal 1910; 1912; } \\
1915\end{array}$ & Manuel Rufete Ruíz & \\
\hline Miguel Pertusa Martí & Alcalde 1912-1913 & Ramiro Pertusa Martí & \\
\hline José Canales Orturio & Concejal 1914-1919 & $\begin{array}{l}\text { Antonio Mateo } \\
\text { Monge }\end{array}$ & \\
\hline Antonio Gutierrez \\
Mompeán
\end{tabular}

Figura 3: Continuidad y sustitución de los miembros del Consistorio almoradidense tras 1923 (Fuente: Elaboración propia a través de "Actas municipales del Ayuntamiento de Almoradí” y “Almoradí”, El Liberal de Murcia, 07/06/1924).

En base a esta evidente sustitución de actores las conclusiones fácilmente podrían apoyar la tesis de que la dictadura de Primo de Rivera supuso el fin de la política caciquil. En apariencia, casi ninguno de estos individuos pertenecía al grupo de los "trinistas" que durante la Restauración dominó la vida pública local siendo constantemente acusados de "caciques", que ganaban con asiduidad las elecciones y dominaban el ayuntamiento. Pero la visión a largo plazo y el análisis de fuentes ajenas a la denominada "política formal" otorgan otro punto de vista, como veremos a continuación.

Para el estudio de las redes clientelares almoradidenses durante la Restauración se tuvo la suerte de encontrar un acta notarial publicada en prensa ${ }^{31}$ relativa a la elección en 1908 de la junta directiva del Juzgado de Aguas del municipio. En el acta se intuía la importancia que tenía dicha institución para las élites locales, algo comprensible si atendemos a que era el organismo encargado de repartir el agua entre los regantes. Debido a la escasez y necesidad de este recurso para el principal medio de producción de la zona, la agricultura, el agua constituía además de una fuente de poder, un mecanismo de intercambio clientelar de primer orden. Tal que así, en el acta notarial se observa el

31 "Los escándalso en la elección de aguas de Almoradí", Heraldo de Alicante, 22/01/1909. 
enfrentamiento de dos grupos de individuos que constantemente se acusan de querer controlar la elección a base de fraudes. Las protestas que elevaban a la mesa encargada de supervisar las votaciones los identificaban como miembros de un bando u otro, $\mathrm{y}$, además, el hecho de que cada individuo votara en nombre de grandes cantidades de agricultores permitía señalarlos como posibles patrones de una masa de clientes. En base a este documento se pudo intuir la existencia de dos redes clientelares enfrentadas, de modo que se procedió a estudiar individualmente a los citados actores señalando sus relaciones, patrimonio, posición política...

De esta forma, el análisis pormenorizado descubrió toda una serie de relaciones de parentesco extendidas en el tiempo que se basaban sobre todo en matrimonios entre las élites, algo que permitió estructurar los grupos enfrentados en la elección del juzgado en familias. Además, la coincidencia en espacios de sociabilidad tales como banquetes, reuniones, casinos... determinaba la existencia de amistades políticas que unían a unas familias con otras. Con todo, se procedió a un estudio del patrimonio de estas personas a través de listas de contribución y anuncios en prensa, que acabó por situarlos como los individuos con más recursos del término municipal y la comarca: no solo poseían tierras, sino que también eran los dueños de las principales fábricas, bancos, etc. Los datos que continuamente se agregaban a las fichas de los individuos no hacían más que confirmar la existencia de las dos redes clientelares enfrentadas que sugería el acta notarial, que entre ellas se denominaban "trinistas" y "chapistas". Como siguiente paso, se procedió a cotejar los nombres de los individuos identificados con las listas de concejales en el Ayuntamiento y políticos de la diputación, observando que la red de los trinistas poseía una gran cantidad de actores situados en estas esferas. Además de esto, los trinistas constituían una importante fuente de apoyo a una de las familias políticas que dominaba el distrito, con la que también mantenían lazos de sangre, la de los Ruíz Valarino: tres hermanos diputados a cortes durante el período de la Restauración. ${ }^{32}$

Contando con esta información, se hacía necesario volver a analizar los nombres que ganaron presencia en el espacio público a partir de 1923, algo que llevó a observar

\footnotetext{
${ }^{32}$ Una explicación más concreta de la organización de estas redes durante el período de la restauración en Daniela FERRÁNDEZ: "Continuidad y sustitución clientelar...".
} 
que el fin del sistema clientelar con la Dictadura de Primo de Rivera no era algo tan evidente como mostraban las actas municipales:

Antonio Girona Ortuño, que según las actas municipales había sido concejal entre 1905 y 1906 era, además, una de las figuras clave del bando chapista en la elección del Juzgado de Aguas de 1908. Hijo de Antonio Girona Mora, apoderado político del Marqués de Rafal - una de las cabezas visibles del Partido Conservador en la Provincia ${ }^{33}$ , Girona Ortuño aparecía en las listas de contribuyentes por rústica e industrial como mayor propietario de varios municipios de la comarca. ${ }^{34}$ Participaba en los espacios de sociabilidad de las élites característicos del momento, como el Casino, del que ganó la elección a la junta directiva en 1907, ${ }^{35}$ y acompañaba a visitas oficiales, llegando a prestar un automóvil para el paseo por el municipio del obispo. ${ }^{36}$ Durante la dictadura no solo fue concejal, sino que acumuló cargos tales como cabeza de la U.P en la comarca o Diputado Provincial, ${ }^{37}$ llevando a cabo importantes obras de caridad mediante la cesión de terrenos para la construcción de una ermita y un hospital. En esta época se erigiría como Juez de Aguas y síndico por Almoradí en la nueva institución encargada de repartir agua a los pueblos: La Confederación Hidrográfica del Segura. Participaría, además, en importantes labores de mediación en pro de los intereses de sus clientes cuando a partir de 1926 la comarca sufrió una tremenda crisis por la caída de los precios del cáñamo, principal cultivo del municipio. Para ello, acompañó a su cuñado Francisco Lucas, director del Banco de Cartagena, al I Congreso Nacional del Cáñamo celebrado en Valencia ${ }^{38}$ y a constantes visitas a políticos. ${ }^{39}$ Observamos en esta biografía que la disponibilidad de recursos, el control de los votos de sus clientes en la elección del juzgado de aguas, la capacidad de decisión en la gestión pública, la caridad, la mediación y su relación con otras élites sobre todo a través de lazos familiares, permiten calificar a Antonio Girona como un auténtico patrón.

\footnotetext{
${ }^{33}$ Rafael ZURITA; Jesús MILLÁN: "Élites terratenientes y tipos de caciquismo: La casa de Rafal/Vía Manuel: entre la Revolución Liberal y la crisis de la Restauración”, Revista Historia Agraria, 16 (1998), esp. p. 162.

${ }^{34}$ AHPA. 17707, Dirección general de Contribución Territorial; Servicio catastral de la riqueza rústica.

35 "Desde Almoradí: Que no t'angañen", La Huerta, 13/12/1907.

36 "Almoradí, El Conquistador, 25/10/1915.

37 "Almoradí", El Pueblo: semanario social y agrario, 01/04/1926.

38 "I Congreso Nacional del Cáñamo", El Pueblo: Semanario social y agrario, 04/11/1927.

39 "El cáñamo", El Pueblo: Semanario social y agrario, 04/04/1928.
} 
A pesar de que la investigación a la que nos referimos está todavía en construcción $\mathrm{y}$, por lo tanto, no poseemos una biografía tan completa del resto de miembros del consistorio, sí que encontramos distintas señales que nos permiten relacionarlos con la red clientelar gestada durante la Restauración que lideraba Antonio Girona Ortuño. Por ejemplo, el concejal Vicente Díez López y su hermano José Díez López regentaban junto con otros hermanos- la compañía "Diez Hermanos" que poseía una fábrica de conservas y un banco. La prensa señala que, en 1908, los Díez, "ante la carestía de la clase agrícola" facilitaban cantidades en metálico sin interés ni plazo, ${ }^{40}$ un claro ejercicio de caridad que se podían permitir al aparecer José como uno de los mayores contribuyentes del vecino municipio de Dolores. ${ }^{41}$ José Díez no solo había sido concejal en repetidas ocasiones durante la Restauración, además de Juez de Paz en 1900, sino que en la elección del Juzgado de Aguas fue uno de los individuos que más votos pudo presentar. En 1908, José Díez acompañó a Mariano Girona -hermano de Antonio- a una visita al que en esos momentos era el elegido para representar esta clientela en Cortes, Joaquín Chapaprieta - por eso llaman a esta clientela Chapista-, al igual que haría el propio Vicente Díez en 1919.

Otro miembro de la familia de los Díez, Rafael, estaba casado con Obdulia González, que a su vez era hermana de Manuel González Pérez, Alcalde de Almoradí durante la mayor parte del período primoriverista y vicepresidente de la U.P. del municipio. La crónica de su boda se encuentra en un periódico definido como "Órgano de la Juventud Maurista local de Orihuela" ${ }^{42}$ lo que puede suponer una pista relativa al encuadramiento de Manuel González en el Partido Conservador, principal ámbito de actuación de la clientela "Chapista". Definido como "acreditado comerciante", a su boda asistieron importantes miembros de la oligarquía comarcal comenzando por los citados “Díez" y la familia "Lucas" de Orihuela, relacionada con Francisco Lucas, el cuñado de Antonio Girona. En este sentido, Manuel Lucas, registrador de la propiedad y concejal de Orihuela apadrinó la boda como tío de la novia. Al acto también acudieron miembros de los "Rebagliato" -importante familia oriolana-, Ricardo García Alonso -alcalde durante largos períodos en la Restauración, fue secretario del Juzgado de Aguas y Diputado

\footnotetext{
40 "Almoradí", Heraldo de Alicante, 22/08/1908.

${ }^{41}$ AHPA. 17707 (...).

42 “Sociedad”, Ciudadanía: Órgano de la juventud maurista local, 25/03/1917.
} 
Provincial- quién además fue testigo de la boda, y su sobrino Rafael Beltrán de la Llave -hijo de Rafael Beltrán Ausó, quien fue diputado provincial y presidente de la Diputación, presidente de la Sociedad Económica de Amigos de País, senador, Diputado a Cortes, presidente del Casino de Alicante...- o Mariano Cortés.

Como se puede comprobar en la figura 3, Mariano Cortés era miembro junto con Manuel González Pérez de la directiva de la U.P. de Almoradí. Hijo del administrador del Marqués de dos Aguas, este abogado había sido durante la Restauración juez municipal, y, según el Archivo Histórico Provincial de Alicante, constaba como uno de los mayores contribuyentes del municipio de Dolores. Su fama en Almoradí se extiende hasta nuestros días por ser el constructor del teatro, obra por la que recibió no pocos halagos, ${ }^{43}$ y que además cedía constantemente para obras benéficas. ${ }^{44}$ Además de lo expuesto, en 1903 fue nombrado "cajero" en la junta directiva de la Caja Rural que se inauguraba en el pueblo, donde coincidió con Manuel González Sampere, cuarto consejero de dicha caja y también miembro de la junta directiva de la U.P.

Manuel González Sampere -quien posiblemente tuviera una relación de parentesco con Manuel González Pérez, de la que no hay datos- también aparecía en el acta notarial del Juzgado de Aguas votando por una gran cantidad de personas, algo que puede estar relacionado con que en 1915 fuera el tercer contribuyente por rústica del municipio.

Otro individuo que aparece en las listas de la U.P. y que podemos relacionar con la clientela chapista es José Canales Ortuño, concejal entre 1912 y 1919. Pensamos que él y su hermano Antonio Canales Ortuño -también concejal durante la Restauración- eran primos de Antonio Girona Ortuño, aunque a falta de datos que clarifiquen esta relación en prensa se vuelve necesario actuar con un padrón de habitantes que no se encuentra en los archivos investigados. Lo cierto es que Antonio Canales Ortuño y Antonio Girona Ortuño aparecen como aliados en la elección de la junta directiva del Casino de 1907. Puede que si esclareciéramos esta relación de parentesco también acabara encajando la figura de José Canales Martínez, concejal en 1925 y propietario del campo y el equipo de

\footnotetext{
43 “Almoradí”, La Federación: periódico republicano, 07/06/1908.

44 “Almoradí”, Liberal de Murcia,09/12/1924.
} 
fútbol municipal en 1923, ${ }^{45}$ quien según el AHPA poseía tierras conjuntas con Antonio Girona.

Para terminar con esta relación citaremos a individuos cuya posición en las redes no acaba de esclarecerse, como los hermanos Miguel Pertusa Martí y Ramiro Pertusa Martí. Miguel fue miembro de la junta directiva de la U.P. y tras la dimisión de la directiva del Juzgado de Aguas en 1924, síndico del mismo. Lo conocemos por haber sido alcalde en un período en el que la clientela trinista fue desplazada de la dirección del consistorio, 1912-1913. Por su parte, de Ramiro solo sabemos que fue fiscal municipal en 1916. Sea como fuere, personas con el apellido "Pertusa" aparecen constantemente relacionadas en las contribuciones por rústica sitas en las actas municipales. En lo que respecta a Ramiro y Francisco Illéscas García, solo sabemos que poseían fincas en Granja de Rocamora y Dolores en las que se cultivaba cáñamo.

Con todo, un acontecimiento aparecido en prensa en 1918 puede aportar datos sobre la pugna clientelar que los individuos descritos mantenían con la élite trinista, controladora de las instituciones públicas durante la Restauración. En la noticia ${ }^{46}$ se refiere la existencia de un déficit en las cuentas municipales que el consistorio local intenta cubrir a través de la subida de impuestos inmobiliarios de un cierto grupo de personas, tachados por la prensa como grandes contribuyentes, comerciantes y propietarios. En este grupo encontramos a Antonio Girona Ortuño, Manuela Ortuño Galant, Pedro Reig Maciá - directivo de la U.P. local y alcalde a finales de la dictadurao Joaquín Mazón -pariente del concejal de la corporación de 1925-, todos ellos pertenecientes a las familias que dominaron la escena pública a partir de 1923.

Además, contamos con noticias en prensa que podían ser tomadas como pistas al referirse a los "Canales", "Girona" y "Díez" como familias de caciques aliadas y contrarias -durante la Restauración- a los trinistas, ${ }^{47}$ pero el uso del término como construcción mental de la época, junto con su aparición en un discurso de prensa, no puede ser tomado como válido en una metodología que pretende traspasar los límites del lenguaje político.

\footnotetext{
45 “Almoradí, Murcia Deportiva, 27/12/1923.

46 "Almoradí: Cobra buena fama, y échate a dormir", El Diario de Alicante, 01/06/1918.

47 "Dios le guarde buen señor", La huerta: diario defensor de los intereses morales y materiales de la región, 03/01/1908.
} 
Ciertamente, todavía quedan muchos vacíos por cubrir en la investigación, pero las evidencias obtenidas a partir de fuentes de prensa complementadas con documentación archivística, presentan un claro indicio de que en 1923 se dio una sustitución de actores, pero no un cambio claro de modelo. Los nuevos personajes de la política no habían mantenido una posición privilegiada en las instituciones entre 1905 y 1923 a excepción de cortos períodos, pero quizá, si ampliásemos el estudio al siglo XIX no observaríamos lo mismo en la generación anterior. Es posible que el predominio de los trinistas se debiera a su parentesco con los Ruiz Valarino, algo que también puede explicar la sustitución municipal cuando perdieron su primacía al cesar Primo de Rivera a los diputados provinciales y a Cortes.

Pero de una u otra forma, resulta evidente que los individuos que irrumpieron en las instituciones a partir del Golpe seguían estructurados por fuertes relaciones de parentesco, realizando funciones de intercambio clientelar y recurriendo constantemente a la caridad y la beneficencia. Eran grandes poseedores de recursos y dirigían importantes masas de clientes, que, en tiempos de crisis, podían sentirse respaldados por su mediación con las instancias superiores de la administración. La relación de intercambio no se basaba en la compra de votos, como citamos al principio del trabajo, sino que constituía un sistema mucho más complejo que se extendía en el tiempo y que, sus múltiples categorías -patrón cliente y cliente patrón- no precisaban de elecciones para funcionar. Durante la dictadura, los patronos seguirían necesitando a personas que promocionaran sus intereses -ya fuera mediante opiniones, apoyos en instituciones de control de los recursos, participación en sindicatos agrarios, etc. -, que ofrecieran mano de obra barata, o trabajos suplementarios; mientras que muchos individuos -los clientes- continuaron una dinámica que les garantizaba unas mínimas condiciones de supervivencia. Con esto, no queremos obviar el hecho de que cada vez más se fueran articulando otro tipo de relaciones entre la población rural, las cuales tejían canales horizontales que se traducían en la proliferación de sindicatos, huelgas, mítines, manifestaciones, etc. Pero lo que se pretende demostrar es que su estudio es mucho más complejo y mucho más profundo que el simple recuento de una lista de concejales. 


\section{Conclusiones}

Sea como fuere, el uso de la metodología prosopográfica demuestra en gran nivel que las élites que asumieron el poder local tras el golpe de Primo de Rivera se encontraban ligadas a familias y redes clientelares que en épocas anteriores estuvieron desplazadas de la política. El control de los recursos permitía su intercambio por fidelidades políticas, algo que pueden observarse en delegación del voto por parte de grandes cantidades de regantes en la asamblea del Juzgado de Aguas. Junto con esto, el desarrollo de importantes funciones de mediación ante instancias superiores de la administración véase la crisis del cáñamo citada- o el recurso de la caridad -ejemplificado en préstamos baratos, cesión de terrenos para construcciones, etc- acababan de conformar los elementos necesarios para el establecimiento de la relación de intercambio. Además, ha quedado atestiguada la existencia de una relación entre estas élites basada en el parentesco: bodas y eventos sociales sellaban alianzas, que no tenían por qué trasladarse exclusivamente a la política local ya que también se plasmaban en los espacios de sociabilidad de las élites, como el casino, o el consejo de administración de una caja rural.

Si atendiéramos únicamente a las fuentes de la política oficial la conclusión podría ser bien distinta, puesto que queda demostrado que una sustitución en los actores no implica un cambio profundo en el sistema. Así, pese a la ausencia de elecciones el funcionamiento de la política continuó estando basado en el intercambio y la familia, algo que nos lleva a la pregunta realizada con anterioridad sobre si podemos considerar el clientelismo de partido único como un auténtico modelo intermedio entre el clientelismo tradicional y de partido, o simplemente como una categoría que expresa la dependencia electoral de muchas investigaciones tal y como señalan algunas voces procedentes de la antropología.

Es por esto que el presente trabajo aboga por el uso de metodologías alternativas que tengan en cuenta fuentes que fácilmente pueden pasar desapercibidas. El uso de informaciones aparecidas en prensa tales como listas de bodas, esquelas de entierros, miembros de juntas directivas e incluso publicidad, ha resultado sustancial para alcanzar estas reflexiones. Como se señaló en el segundo punto, sería difícil dar sentido a todos estos datos aislados si no se procede a un cotejo y ampliación con documentación archivística como actas municipales o listas de contribuyentes. Con todo, hemos tratado 
de ejemplificar cómo la metodología puede influir en los resultados y las conclusiones, por lo que la investigación presentada se muestra incompleta. Ésta no es una comunicación que trate de zanjar los debates sobre lo que acaeció en la dictadura de Primo en un nivel general, sino una propuesta metodológica concreta llevada a la práctica. Esperamos pues poder esclarecer las cuestiones incompletas en futuros trabajos que precisan de una especificidad y una amplitud de la que no se dispone en esta comunicación. 


\section{CAPÍTULO IV}

\section{Historia ORAL Y FUENTES DOCUMENTALES}

Gabriel Benavides Escrivá (Cultural Instituto Obrero, Valencia)

La historia oral es la especialidad dentro de la ciencia histórica que utiliza como fuente principal para la reconstrucción del pasado los testimonios orales. A pesar de no tratarse de una técnica de investigación nueva, ya que lleva décadas siendo utilizada en distintos campos de estudio, la historia oral supone una aportación bastante innovadora. ${ }^{1}$ En este sentido, no sólo reivindicamos su utilidad para llenar huecos existentes en otro tipo de fuentes, sino por su propia potencialidad. Sin embargo, no todo son ventajas, sino que las fuentes orales presentan evidentes dificultades entre las que se encuentran: la localización, la toma de contacto o relación inicial con las personas a entrevistar, o los criterios de selección a seguir.

Todos los autores cuyos textos se encuentran inmersos en este capítulo apuestan por esta visión, es decir, por la utilización de las fuentes orales por su potencionalidad intrínseca. Así, comenzamos con el texto de Víctor Benavides Escrivá que aborda el archivo personal del libertario Ricardo Sanz. Tras unos apuntes biográficos, el estudio se centra en la documentación depositada en el Archivo de la Fundación Salvador Seguí de

\footnotetext{
${ }^{1}$ David MARIEZKURRENA ITURMENDI: "La historia oral como método de investigación histórica", Gerónimo de Uztariz, 23/24 (2008)., p. 227.
} 
Valencia. En este contexto, pone en valor la donación de los documentos a través de Sara Berenguer, amiga personal de Ricardo Sanz, y describe la tipología de la documentación. A continuación, nos encontramos con el artículo de Marta Vicente Carrasco. Esta realiza un trabajo sobre el estudio de la cerámica del Archivo de la Escuela de Artes y Oficios de Valencia. Describe el Archivo y los diferentes Talleres que aloja, centrándose en el de Cerámica y en el estudio tanto de las fichas de matrícula y expedientes del alumnado, así como la técnica utilizada.

La comunicación de José Manuel Maroto Blanco y Rosalía López Fernández describe y valora la importancia de la fuente oral y las historias tradicionales para trabajos en los que las fuentes documentales son escasas o nulas. Un texto basado en la Historia de los invisibles, trabajando la historia desde abajo para poder documentar fases históricas, que no aparecen en la historiografía tradicional. Junto a este texto se encuentra el de Aldara Cidrás. Su trabajo está bien definido, abarcando un tema muy importante, la memoria familiar. Para el correcto tratamiento de esta, la autora ha procedido a la realización de entrevistas colectivas (con la dificultad añadida) y ha realizado una profunda reflexión sobre la memoria. Así mismo, se defiende, y no podemos estar más de acuerdo, la escasa utilización académica de la fuente oral, por considerarla algo secundario.

Originalmente redactado en portugués, el texto de Sueny Oliveira de Souza pretende recuperar y rescatar historias olvidadas y retratar las distintas relaciones entre los habitantes en la región de Turiaçu (Brasil). Por último, el artículo de José Carlos Aránguez y Ferrán Martínez Lliso, cuestionan la veracidad de las fuentes, siempre que no se puedan contrastar. Aun así, afirman, siguiendo las pautas del maestro Portelli, que las fuentes orales son un recurso con un determinado número de inconvenientes que obligan a revisar y a complementar el testimonio obtenido, pero que no impiden destacar el valor potencial de las investigaciones de historia oral en relación con la historia del tiempo presente. 


\title{
El archivo Ricardo Sanz, documentos para la historia
}

\author{
Ricardo Sanz Archive, documents for the History
}

Víctor Benavides Escrivá

Fundación Salvador Seguí

\section{Resumen}

Estudiando el archivo personal del exiliado libertario Ricardo Sanz García (Canals, Valencia 1898 - Toulouse 1986), nos damos cuenta de la importancia de los documentos primarios para las investigaciones históricas. El Archivo de la Fundación Salvador Seguí de Valencia conserva una parte significativa de los documentos de Sanz. El objetivo de esta comunicación es explicar los problemas con los que nos enfrentamos ante un archivo personal. Desde la complejidad de elaborar un discurso con los datos que nos proporcionan, sino se completan con las investigaciones paralelas necesarias, hasta la objetividad de interpretarlos para explicar su significado.

\section{Palabras clave}

Ricardo Sanz García, fuentes documentales primarias, exilio en Francia, Movimiento Libertario Español.

\begin{abstract}
Studying the personal archive of the liberated exile Ricardo Sanz García (Canals, Valencia 1898 - Toulouse 1986), we realize the importance of the primary documents for historical investigations. The Archive of the Salvador Seguí Foundation in Valencia retains a significant part of Sanz's documents. The purpose of this communication is to explain the problems that we face before a personal archive. From the complexity of elaborating a discourse with the data they provide us, they are complemented by the
\end{abstract}


necessary parallel researches, to the objectivity of interpreting them to explain their meaning.

\section{Keywords}

Ricardo Sanz García, primary documentary sources, exile in France, Spanish Libertarian Movement.

\section{Introducción}

En el curso 2015-2016 realice las prácticas externas curriculares del Grado de Historia de la Universitat de València en la Fundación Salvador Seguí (FSS). ${ }^{1}$ Allí tuve la oportunidad de entrar en contacto con documentos primarios generados por el Movimiento Libertario Español (MLE). ${ }^{2}$ Libros, publicaciones periódicas, folletos, carteles, cartas, octavillas, etc. y algunos objetos, como banderas y cuños. En una de aquellas sesiones de trabajo mi tutor, Rafael Maestre Marín, cuando nos hablaba de los archivos personales, nos mostró el archivo de la militante libertaria Sara Berenguer Laosa, haciendo hincapié en el epistolario, por la importancia que tenía al haber mantenido correspondencia con gran cantidad de militantes libertarios exiliados en Francia y América latina. Al ir enumerando los nombres de las personas, me llamó la atención el de Ricardo Sanz García. Su nombre me sonaba de algo. Pregunté, indagué y averigüé que había formado parte de Nosotros y Los Solidarios, grupos de acción de la FAI, y que a la muerte de Durruti él lo había reemplazado al mando de su célebre Columna de milicianos. Me interesó el personaje y pedí a mi tutor si tenía más documentación de Sanz, facilitándome buena parte de su archivo personal que se conservaba gracias a la fraterna relación de amistad que tenían Ricardo Sanz y Sara Berenguer.

\footnotetext{
${ }^{1}$ Rafael MAESTRE MARÍN: “Una aproximación a la Fundación Salvador Seguí”, Hispania Nova. Revista de Historia Contemporánea, 6 (2006), http://hispanianova.rediris.es (consultado 25 marzo, 2017).

${ }^{2}$ Se entiende por MLE el conjunto de organizaciones que lo componen: Confederación Nacional del Trabajo (CNT), Federación Anarquista Ibérica (FAI), Juventudes Libertarias (JJLL) y Mujeres Libres (MMLL).
} 
Acabaron mis prácticas y, tiempo después, al enterarme de la convocatoria del VI Encuentro Internacional de Jóvenes Investigadores en Historia Contemporánea, pensé que era una buena oportunidad para abordar el estudio del archivo personal de Ricardo Sanz, en adelante RS.

\section{Metodología}

El método de trabajo utilizado se ha basado en la descripción y análisis crítico de las fuentes documentales primarias de RS referidas a su vida como exiliado en Francia. Se analiza su archivo original que está formado por documentos personales (pasaportes, visados, permisos de trabajo...), epistolario y libros escritos por él. Se describen las diferentes series documentales y nos detenemos en los documentos que detallan la vida orgánica del MLE en el exilio en Francia. También describimos el epistolario tanto desde los diversos campos de concentración donde estuvo internado (Le Vernet en Francia y Camp de Djelfa en Argelia) como de sus diferentes domicilios como exiliado (Bab-el-Oued, Argelia; Golfech y Toulouse, Francia). Así mismo, analizamos la faceta de RS como escritor.

Quedan excluidos del estudio la parte del archivo que contiene manuscritos de sus libros, que mecanografiaba Sara Berenguer; reflexiones sobre el MLE; ensayos; fotografías, etc. Aunque reconozco que las fuentes no incluidas podrían contener informaciones de un valor inestimable, pero excede del propósito de esta investigación. En realidad, el estudio de las fuentes documentales del archivo de la FSS es un trabajo todavía pendiente para el MLE.

\section{El exilio de Ricardo Sanz}

Pero ¿quién era Ricardo Sanz García? Él fue un obrero, autodidacta, y militante libertario que nació en Canals (Valencia) el 20 de noviembre de 1898 y falleció en Toulouse (Francia) el 25 de octubre de 1986.

Hijo de obreros agrícolas, desde muy joven trabajó en una fábrica de harinas hasta su marcha a Barcelona (1916), donde ingresa en la CNT, sección tintoreros del textil (su oficio por entonces) y se hizo amigo de Sabater, el Tero, que fue asesinado. A partir de 1920 su activismo se acelera: conoce a Ascaso, mitinea por la comarca barcelonesa, participa en las actividades de los Solidarios y entra en la cárcel (1920) durante cerca de dos años. Apenas liberado se traslada a Zaragoza (juicio de Torres Escartín por el caso 
del cardenal Soldevila) y seguidamente a Francia por Barcelona para evitar nueva detención (1924). En Paris permanece poco tiempo porque no le gustó el ambiente del destierro y porque se le encargó comprar mil fusiles en Eibar.Guernica, cruza la frontera por Vera y sele detiene por San Sebastián (dos años de prisión en Madrid, donde conoce a Bajatierra, Romero, Inestal y otros) Liberado, vive en Barcelona, trabaja en la construcción (presidente del sindicato del ramo en 1930-1931) y sufre frecuentes encierros. Con la República se convierte en uno de los mitineros oficiales de la CNT (giras por Canarias, Alicante, País Vasco, La Rioja, Castilla, etc., con Ascaso, Antona, Magriñá, Inestal y otros); actividades que alternaba con el trabajo en el ramo del agua, y que no le impedían participar en las sublevaciones faístas ni en la vida orgánica (miembro del Comité Regional catalán de la CNT en 1934, delegado al congreso de 1931y mitinero ese año en el 1 de mayo zaragozano, delegado por el sindicato mercantil en el comité nacional, y en el comité regional en 1934, entrevista con Companys en mayo de 1934, en diciembre de 1932 reunión con Los Solidarios para preparar la insurrección de 1933). Iniciada la guerra desempeñó numerosos cargos: responsable de la organización de las milicias, inspector de fortificaciones de Aragón y Cataluña, jefe de la columna Durruti (al morir el leonés el 20 de noviembre de 1936) hasta el fin de la guerra (ya como 26 División, con la que pasó a Francia tras la derrota). El destierro lo llevó al campo de concentración de Vernet (1939-1942) y luego al de Djelfa (Argelia) de donde salió libre. En Argel trabajó de panadero y por fin en julio de 1945 volvió a Francia, por Marsella, instalándose en Toulouse donde siguió vinculado al Movimiento Libertario en el exilio. Colaboró en la prensa confederal del exilio y escribió diversos libros. ${ }^{3}$

Como exclusivamente para este trabajo sobre RS nos interesa su exilio en Francia, que duró una parte importante de su vida, 47 años, hemos elaborado un cuadro ${ }^{4}$ que describe los diversos territorios donde desarrolló su itinerario vital:

$\begin{array}{lr}\text { Camp de Vernet d'Ariège (Francia) } & \text { abril 1939 - agosto } 1939 \\ \text { Confinado en Latroquière (Depto. Lot. Francia) } & \text { agosto } 1939-23 \text { octubre } 1939 \\ \text { Camp de Vernet d'Ariège (Francia) } & 25 \text { octubre } 1939-12 \text { julio } 1942\end{array}$

\footnotetext{
${ }^{3}$ Miguel ÍNIIGUEZ: Esbozo de una enciclopedia histórica del anarquismo español, Madrid, FAL, 2001, pp. 559-560.

${ }^{4}$ Elaborado consultando la correspondencia y los documentos personales de Ricardo Sanz, así como su libro autobiográfico, El sindicalismo español antes de la Guerra Civil, Barcelona, Petronio, 1976.
} 


\begin{tabular}{|lr|}
\hline Camp de Djelfa (Alger. Argelia) & 14 julio 1942 - 30 marzo 1943 \\
Bab-el-Oued (Alger. Argelia) & marzo 1943 - julio 1945 \\
Toulouse (Francia) & 18 julio 1945 - [años1960] \\
Golfech (Francia) & [años 1960] - octubre 1976 \\
Toulouse (Francia) & octubre 1976 - 25 octubre 1986 \\
\hline
\end{tabular}

\section{Fondo documental de Ricardo Sanz}

La estrategia para identificar las fuentes documentales plantea conocer las funciones de la institución que las alberga, en este caso la FSS. El centro de estudios libertarios e investigación social Fundación Salvador Seguí (FSS), es una fundación cultural de carácter privado, nacida en Madrid en el año 1986 con el objetivo de recuperar, ordenar, conservar y divulgar la documentación de todo tipo referente al Movimiento Libertario.

La Fundación quiere rendir homenaje a la figura del legendario sindicalista Salvador Seguí, "El Noi del Sucre”, una de las figuras más importantes del Movimiento Libertario de nuestro país. Salvador Seguí creyó siempre que la principal arma revolucionaria de la clase obrera era la cultura y la elevación del nivel intelectual. Heredera de este espíritu, la Fundación Salvador Seguí nació con la intención de constituir un archivo que conserve la memoria (escrita, oral y gráfica) de los movimientos sociales, en especial del Libertario, y contribuir al desarrollo de una cultura crítica y emancipadora que sepa responder al reto de la sociedad actual.

En el año 1988 se crearon los centros de Barcelona y de Valencia para mejor desarrollar sus objetivos y ampliar su radio de acción. La Fundación Salvador Seguí en su compromiso con la transmisión de la memoria ha especializado a sus tres delegaciones: La delegación de la Fundación en Valencia, además de conservar fuentes escritas, desde el año 1990 ha creado un importante archivo de fuentes orales. La delegación de la Fundación Salvador Seguí en Barcelona, aunque también ha cultivado estas fuentes, se ha dedicado con mucha más intensidad a la localización y conservación de los testimonios escritos. Igualmente, la sede de la Fundación Salvador Seguí en Madrid, se ha especializado en la atención a investigadores para quienes ha puesto su fondo documental 
a disposición de numerosas tesis y publicaciones. Por todo ello, el fondo documental de la FSS recoge un significativo material de la historia del Movimiento Libertario Español.

El Archivo de la FSS está formado por una serie de archivos históricos y bibliotecas de diversas entidades y particulares. La reunión de los distintos archivos ha sido posible gracias a las donaciones de particulares (los propios militantes o sus familiares: Gómez Peláez, Liberto Sarrau, Marco Nadal, Sara Berenguer, Ángel Marcos...), y a la repatriación de archivos de las organizaciones del Movimiento Libertario en el exilio (Centro de Estudios Sociales y Económicos de París, Federación Local de la CNT de Cachan, Francia, etc.).

El archivo que estamos analizando, el fondo documental Ricardo Sanz, es un corpus documental cuyo origen se encuentra en la incorporación al Archivo de la FSS de la Biblioteca Sara Berenguer. Pero ¿quién era Sara Berenguer Laosa? Fue una destaca militante de Mujeres Libres, exiliada en Francia que nació en Barcelona el 1 de enero de 1919 y falleció en Montady (Francia) el 8 de junio de 2010. Tuvo una relación fraterna con Ricardo Sanz a quien, como hemos comentado anteriormente, mecanografiaba los manuscritos de sus libros. Era tanta su amistad que RS dispuso que, a la hora de su muerte, pasara a custodiar su archivo personal. ${ }^{5}$

El fondo documental RS, cuyas fechas de los documentos se sitúan entre 1938 y 1982, presenta un excelente estado de conservación y la documentación es única, esta naturaleza genuina le aporta un valor añadido, por tratarse de documentación irrepetible. Por consiguiente, en la actualidad constituye un patrimonio documental de la historia del MLE y un referente de consulta para la investigación histórica del exilio libertario español en Francia.

El archivo cuenta con la particularidad de haber permanecido empaquetado, durante 70 años en Francia y, tras ser rescatado del olvido, se encuentra a disposición pública desde el año 2011, fecha en que fue cedido por la familia de Sara Berenguer a la FSS.

El fondo documental de RS que vamos a describir y analizar estuvo depositado dentro de un voluminoso sobre, ${ }^{6}$ donde los documentos estaban plegados, según nos contó el documentalista de la FSS. Así que lo primero que se realizó fue desplegarlos, para que

\footnotetext{
${ }^{5}$ Miguel ÍNIIGUEZ: Esbozo de una enciclopedia histórica ..., p. 86.

${ }^{6}$ Con la anotación mecanográfica de Sara Berenguer "correspondencia personal de Ricardo Sanz".
} 
recuperaran la posición correcta y evitar que se cuartearan por los pliegues. También observamos la ausencia de instrumentos de descripción documental normalizada, como inventario, catálogo y cuadro de clasificación del fondo y solamente encontramos accesible para consulta una organización del fondo en dos series documentales: Documentos personales y correspondencia, ordenados cronológicamente, que vamos a pasar a describir en los siguientes apartados.

\section{Documentos personales de Ricardo Sanz}

El fondo contiene la documentación personal generada durante sus primeros años de exilio en Francia. Las fechas que abarcan son de 1938 a 1946. El volumen asciende a 19 documentos, que describimos a continuación:

-Declaración de RS haciendo constar que Floreal y Violeta Sanz Not son sus hijos legítimos y disponiendo que Violeta quedará bajo la custodia de Flora Barranco García, fechado en el puesto de mando de la 26 división, posición J.9 el 8 de junio de 1938. El texto está mecanografiado, con el membrete encabezado por el escudo de la República y Ejército del Este. 26 División. Cuartel General. Jefatura. FSS RS 1/1.

-Pasaporte del Ministro de la Gobernación de la República Española a favor de Ricardo Sanz García, nacido en Canals (Valencia) de 39 años de edad, viudo, para que pueda trasladarse a Francia o a cualquier nación de América, dado en Figueras el 2 de febrero de 1939. Con fotografía. FSS RS 1/2.

-Pasaporte del Consulado General de España en Paris, a favor de Ricardo Sanz García, nacido en Canals (Valencia) en 1898, viudo y de profesión tintorero. Válido para Europa y América, dado en Paris el 26 de febrero de 1939. Con fotografía. FSS RS 1/3.

-Declaración jurada remitida por el Servicio de Evacuación de Refugiados Españoles (SERE) el 26 de septiembre de 1939. FSS RS 1/4. El texto es el siguiente:

\footnotetext{
A los efectos del acuerdo tomado por el SERE en fecha 26 de agosto de 1939, declaro: Que reconozco al citado Organismo como el único capacitado para la distribución de los fondos que procedentes de las aportaciones de la solidaridad internacional, administra el último Gobierno-Constitucional de España, presidido por D. Juan Negrin.

Así mismo, declaro por mi honor que no mantengo ninguna relación ni percibo fondos de ningún Organismo similar al SERE.
}

Paris, de septiembre de 1939 
-Carta mecanografiada de Ricardo Sanz al SERE fechada el 26 septiembre de 1939, donde renuncia al subsidio del SERE. FSS RS 1/5:

Pueden retirarme el subsidio que venían pasándome mensualmente como Jefe de División, pues a pesar de las dificultades económicas que atravieso, no estoy dispuesto a subordinar mi conciencia por 1.750 francos mensuales, como al parecer pretenden Ustedes.

Sus desavenencias con el SERE se deben a:

Considero que la forma de distribución de los fondos no ha podido ser más parcial y absurda, tan sólo un reducido número de privilegiados, nos hemos beneficiado de dichos fondos, mientras que miles de nuestros compatriotas, en los campos de concentración carecen de la más imprescindible asistencia que ese organismo tiene la obligación de atender.

También se queja de que: "Idénticamente igual ha ocurrido en lo referente a la emigración hacia el continente americano, a donde sólo han embarcado, con preferencia escandalosa, los españoles pertenecientes al Partido Comunista".

-Tarjeta de identidad y viaje para inmigrantes españoles, expedida por la Legación de los Estados Unidos Mexicanos en Francia, a nombre de Ricardo Sanz García. Hija, Violeta Sanz Nat y prima hermana, Flora Barranco García, con fotografías. Fechada y firmada en Vichy el 20 de mayo de 1941 por el Ministro de México, con el visado especial, firmado y fechado en Marsella el 28 de mayo de 1941. FSS RS 1/6.

-Telegrama del Ministro de México (Vichy), dirigido a RS Camp de Vernet, quartier B, barraque 8, fechado el 8 de abril [1942], (el texto está en francés y tiene un sello “controlé au Camp de Vernet): "Estando autorizado a emigrar a México debe presentar la autorización de salida de Francia, en nuestro Consulado en Marsella, antes del 10 de abril". FSS RS 1/7.

-Telegrama de RS dirigido al Ministro del Interior francés (Vichy), sin fecha [abril 1942], desde el Camp de Vernet, quartier B, barraque 8 (el texto está en francés): “por telegrama Ministro de México me anuncia la salida hacia México para que me presente en Marsella el diez de los corrientes stop espero telegráficamente su visa favorable de salida". Hay un papel sujeto al telegrama con un alfiler oxidado, con un texto manuscrito en francés, denegando la expedición del telegrama, con el sello del Camp de Vernet y firma ilegible: "los telegramas de los internados a las autoridades francesas están prohibidos". FSS RS 1/8. 
-Recibo de la petición de carné de identidad como trabajador industrial (récépissé) de RS residente en 40, rue Valentin de Alger, con fecha diciembre de 1943 (con fotografía). Contiene diversas autorizaciones de residencia, la última hasta el 5 de agosto de 1945. FSS RS 1/9.

-Recorte de prensa con la siguiente noticia: "Chez les anciens combattants espagnols" Fraternité Alger, 15 marzo 1945. FSS RS 1/10:

L'assemblée locale de l'Amicale des anciens combattants espagnols s'est tenue à Alger, le dimanche 4 , en présence des délégués du Conseil exécutif central, le lieutenant-colonel d'infanterie Sanz, et le commandant du génie, breveté d'état major Verardini $[\ldots]$

Por su interés, resaltamos una documentación relativa a la vida orgánica del MLE en el exilio en Francia:

-Circular "A los compañeros exilados", firmada por eg [Germinal Esgleas] fechada el 2 de septiembre de 1939 (texto mecanografiado). FSS RS 1/11:

Ante la inminencia del inicio de la II Guerra Mundial, se pide prudencia a los exilados españoles y que la correspondencia debe reducirse a lo más indispensable. Se informa de la circular del ministro de Agricultura a los prefectos con el propósito de utilizar en los servicios agrícolas y en los trabajos de utilidad a los exilados españoles.

-Carta abierta "A la familia libertaria” firmada por García Vivancos, en Marsella, agosto de 1945, dirigida a Antonín Serrano (texto impreso). Da un "repaso" a los "puritanos" de la Organización confederal y destapa la trama de la familia Urales para capitanear una escisión en el ML en Francia. FSS RS 1/12:

\footnotetext{
Algunos olvidan que la CNT, que es de origen libertario, lleva marcada en su corazón las ideas de la democracia pura y democracia quiere decir libertad de pensamiento, tolerancia y respeto a todo el mundo, libertad para que cada cual pueda expresar sus ideas, sus sentimientos, sus aspiraciones, lo que él entiende más conveniente para el engrandecimiento y vida de la Organización, más eficaz para la emancipación de los trabajadores.
}

-Convocatoria mecanografiada firmada por RS Hotel St. Sernin, 2 Place St. Sernin Toulouse (Francia), fechada en Toulouse el 14 de agosto de 1945 (encabezada con la palabra RESERVADO). FSS RS 1/13:

Estimado compañero Salud. Al objeto de tener un amplio cambio de impresiones entre varios compañeros responsables de la 26 División, sobre los momentos actuales, en previsión de acontecimientos probables relacionados con nuestra entrada en España y estudiar 
conjuntamente el plan a seguir, te invito a la reunión que celebraremos el día 26 de agosto a las 9 horas, en punto, en el Café de la Paix, sito en la Place du Capitole de Toulouse. Por tener gran importancia los asuntos a tratar, espero realices un esfuerzo para desplazarte y asistir a la reunión, por considerar indispensable tu presencia. Interesa la presentación de esta convocatoria. Fraternalmente te saluda tu compañero.

Por su interés destacamos la celebración en Toulouse del IX aniversario de la muerte de Buenaventura Durruti.

-Carta mecanografiada en francés de la Prefecture de la Haute-Garonne, dirigida a Mr. Michel Cabra i Massana, 17 rue Perchepinte de Toulouse, fechada en Toulouse en 15 de noviembre de 1945: "Autorizando la realización en la Maison Coopérativiste du SudOuest, 1 Boulevard d'Arcole a Toulouse, del 18 al 25 de noviembre de 1945, de una exposición biográfica con la ocasión del IX aniversario de la muerte de Buenaventura Durruti”. FSS RS 1/14.

-Recibo mecanografiado en francés de la Maison Coopérativiste du Sud-Ouest, 1 Boulevard d'Arcole a Toulouse, dirigido a Mr. Michel Cabra i Massana, 17 rue Perchepinte de Toulouse, fechado en Toulouse en 16 de noviembre de 1945. FSS RS 1/15:

Recibo de M. Michel Cabra i Massana, la cantidad de 500 francos por el alquiler del Hall de nuestra sede social, a los efectos de la exposición biográfica organizada con la ocasión del IX aniversario de la muerte de Buenaventura Durruti, autorizada por la_Prefecture de la Haute-Garonne.

-Programa de la celebración del IX aniversario de la muerte de Buenaventura Durruti, de la Comisión organizadora, fechado en Toulouse noviembre de 1945: "El 19 de noviembre de 1936 murió en Madrid defendiendo la causa del Pueblo Español, cuando la lucha era más enconada entre el fascismo y la LIBERTAD, el gran hijo del pueblo Buenaventura Durruti”. FSS RS 1/16:

En ocasión del IX aniversario de su muerte preparamos una EXPOSICIÓN BIOGRÁFICA, en la que se presentarán documentos, fotografías, revistas, folletos y otras muchas cosas de gran valor artístico. Como complemento se proyectará una película inédita en el mismo local, con un conjunto de imágenes de la Exposición biográfica homenaje a Durruti, celebrada en el mes de noviembre de 1938 en Barcelona.

Señalamos el interés especial que tal exposición representa para todos los compatriotas y cuantos se interesan por las cuestiones de la España antifascista. El calor aportado por los 
visitantes, significa un gesto de solidaridad y gratitud para con nuestros gloriosos caídos por la Libertad y para con los valerosos pioneros de la Gran Batalla Antifascista que continúa pujante en el seno de nuestro País.

-Manifiesto "Llamamiento de concordia", firmado por "El Grupo no 11", en Bordeaux, diciembre de 1945 (texto impreso). Se trata de un llamamiento a la unidad, a la sensatez y a la concordia, para evitar la fractura entre el exilio y el interior. FSS RS 1/17:

¡Alto! Alto ya, insensatos, vosotros que un juego de personalismo elitista ciega hasta el extremo de jugar irresponsablemente con lo que es patrimonio nuestro, vuestro, de todo el proletariado español y de esperanza señorial del oprimido del Mundo. [...] A la Organización se la ama cuando se la defiende y se le sirve. Cuando, por el contrario, se trata de servirse uno de ella, entonces no se la ama ni se la defiende, ¡Se la ataca! Y todo aquel que la ataca es un enemigo de los derechos inconfundibles de la masa trabajadora. [...] Nuestro llamamiento a la sensatez y a la concordia tiene que tener la cordura de ser escuchado por todos vosotros, si, como afirmáis, solo el interés de la Organización y su trayectoria moral os guía.

Termina el Manifiesto proclamando: "España es el órgano legal de nuestro Movimiento... por y para España debe ser el afán de todos”. Y acaba con la siguiente proclama “¡Viva nuestra única CNT, nuestro solo ML!”.

-Carta mecanografiada dirigida a los compañeros ASCASO, PÉREZ, BARRIOS, ORTIZ y SANTA, en MAYAN par Vendays-Médoc. (Gironde), firmada por RS Hotel St. Sernin, 2 Place St. Sernin Toulouse (Francia), fechada en Toulouse el 18 de enero de 1946, [contestando el Manifiesto]. Acusa recibo del paquete de manifiestos que se encargó de distribuir entre los compañeros. Muestra su disconformidad con el Manifiesto "no me ha satisfecho, precisamente por lo que no decís". Se queja de la falta de concreción: "en la primera cara no dice absolutamente nada y en la segunda página, sois demasiado tímidos en enfocar las cosas tal como son". Les recrimina que se hayan escondido en el anonimato, al no poner las firmas de los que suscriben el Manifiesto: "Por aquí ya se hacen chistes en ese sentido. Se dice: El grupo 11; y bien, en sus casas les conocen”. FSS RS 1/18. Sanz explica su posición al respecto:

\footnotetext{
Nosotros ya marcamos nuestra posición en 1939, cuando entramos en Francia, y entonces estábamos solos. Y, por dicho motivo, fuimos ya expulsados del Movimiento, por decreto, por los que entonces manejaban las cosas desde el tristemente célebre Consejo. Las
} 
posiciones ambiguas jamás fueron posiciones respetuosas, fueran quienes fueran los que las mantuvieran $[\ldots]$ ¿De cara a España? No os atormentéis, solo nos encontraremos a los mismos. Los que están con España. A los demás, no vayáis a buscarles, que no los encontraréis.

-Resumen de las palabras de RS pronunciadas en el mitin comunista el día 6 de octubre en Toulouse [1946]. Sanz asiste al mitin y al estar disconforme con lo que se dice sobre Cipriano Mera, es acusado de ser un traidor, sale en su defensa, pidiendo a González Peña, Presidente del acto permiso para intervenir, lo que le es concedido. FSS RS 1/19:

Mera es un militante activo de la CNT al cual ésta reivindica contra todos los que puedan atacarla. [...] Yo Ricardo Sanz de una manera solemne apelo al testimonio de Rafael Vidiella que se encuentra en la mesa presidencial, para que diga si no es cierto que en el año 1926, hace exactamente veinte años no nos encontrábamos ya, Vidiella, Mera y el que os habla, entre muchos otros cenetistas en la cárcel de Madrid. Todos los obreros de Madrid saben que Mera fue siempre un Militante de primera fila en el Sindicato de la Construcción de la CNT. Durante nuestra guerra Mera fue el más destacado defensor de Madrid y por sus dotes de mando y arrojo, llegó a ser Jefe de un Cuerpo de Ejército. [...] Posteriormente, Mera pudo llegar a África del Norte donde conjuntamente con los demás antifascistas españoles fue internado en un campo de concentración.

Franco, así como Mussolini, no podían perdonar a Mera su brillante actuación en la Defensa de Madrid y en la batalla de Guadalajara, pidieron a Francia, en su época vergonzosa de Vichy, la extradición de Mera, como la de Peiró, Companys y otros, la mayor parte de los cuales fueron vilmente fusilados por Franco.

El General Nogués que entonces era Alto Comisario de Francia en Marruecos, recibiendo órdenes del Gobierno de Vichy, entregó a Mera a Franco con la condición de que no fuera fusilado.

Acaba su intervención atacando a los comunistas: "El camino que los comunistas seguís en estos momentos no lo creemos el más apropiado para llegar a esa unidad de que tanto hacéis gala pero que en la práctica contradecís y negáis a cada paso. Nada más".

\section{Correspondencia de Ricardo Sanz}

El fondo epistolar es la serie de mayor documentación, esta sección contiene cartas autógrafas y escritas a máquina, originales y copias en papel cebolla de las cartas enviadas y, en menor volumen, telegramas. Está clasificado por los diferentes domicilios que tuvo RS debido a los sucesivos desplazamientos realizados por Francia y Norte de África, la Argelia francesa, ordenado cronológicamente. Las fechas extremas son 1940 y 1978, y el volumen asciende a 26 documentos. Esta parte de fondo epistolar podría ser una 
interesante fuente de información para estudios sobre la historia social de la cultura escrita en diferentes ejes temáticos, en torno al análisis de la escritura, a los discursos, a las prácticas y a las representaciones de dichos testimonios escritos. Además, para profundizar sobre las relaciones entre los compañeros libertarios exiliados y los procesos de comunicación de RS con representantes de las instituciones públicas francesas y mexicanas.

\section{Subserie Camp de Vernet (Francia)}

Correspondencia de RS desde el Camp de Vernet d'Ariège, Quartier B.B.6, del 20 de julio de 1940 al 7 de abril de 1942:

Explica las múltiples gestiones realizadas ante el Consulado General de México en Marsella y la Legación de los Estados Unidos Mexicanos en Francia, para conseguir emigrar a México. A pesar de que el 9 de marzo de 1942 la Legación le comunica que: "Su nombre figura en la lista de refugiados españoles que deben embarcar en primera oportunidad para mi país", no pudo salir pues fue trasladado por el Gobierno francés a los campos del norte de África, aunque RS siguió intentándolo desde Argel.

-Carta de Ignacio I. Rodríguez, Ministro de la Legación de México en Francia, dirigida a los Sres. Isidro Sánchez y Francisco Carralero, fechada en Vichy el 20 de Julio de 1940. FSS RS 2/1:

El Ministro de México en Francia tiene el gusto de informarle, con respecto a su atenta carta, que por instrucciones del Sr. Presidente Cárdenas está gestionando con el Gobierno lo relativo a la emigración de los refugiados españoles que se encuentran en Francia.

-Carta mecanografiada del Consulado General de México en Marsella, dirigida a RS Camp de Vernet, fechada en diciembre de 1940, pidiendo que rellene el cuestionario adjunto e incluya diez fotografías de frente, "tamaño pasaporte, de usted y de cada uno de los miembros que lo acompañan”. FSS RS 2/2.

-Carta mecanografiada del Consulado General de México en Marsella, dirigida a RS Camp de Vernet, sin fecha [diciembre de 1940]. Acusan recibo del cuestionario y le indican: "Que ha sido trasladado a la ficha definitiva que con el número 11.916 ha sido enviada a Vichy a los efectos de tramitación y firma. Me es grato devolverle las dos fotos que han sobrado". Hay un texto añadido en la carta, firmado por el compañero cenetista Abel Velilla, que se dirige a Sanz en estos términos: "Querido Sanz. A los efectos de 
evitar entorpecimientos en el momento del embarque hemos puesto a la Sra. que cuida de tu hijita el parentesco de cuñada, visto tu interés en que embarque contigo. Abrazos. Fraternalmente". FSS RS 2/3.

-Carta manuscrita en francés de RS desde el Camp de Vernet d'Ariège, Quartier B.B.6, dirigida a Monsieur le Commandant du Camp, fechada el 8 de enero de 1941. Le recuerda la carta enviada el 19 de diciembre en que solicitaba autorización para recibir visita de la familia, una vez por semana, y que no ha respondido. FSS RS 2/4.

-Carta mecanografiada de Abel Cifuentes Spinetti, Délegué pour l'Inmigration des Etats-Unis du Venezuela en Europa, fechada en Cannes, 28 de enero de 1941. (También intentó emigrar a Venezuela para después pasar a Norteamérica): Acusa recibo de la solicitud para inmigrar a Venezuela, fechada el 11 de diciembre de 1940. Le comunica: “Como Ud. está interesado en ir a Venezuela solamente en tránsito para dirigirse a Norteamérica, no me es posible resolver su solicitud, pues esta clase de visas corresponde otorgarlas a los Consulados". Y le da la dirección del Consulado en Marsella. FSS RS $2 / 5$.

-Carta manuscrita en francés desde el Camp de Vernet d'Ariège, Quartier B.B.6, dirigida por RS a Monsieur le Capitaine Chêf d'Information fechada el 13 de febrero de 1941. Solicitando le permita enviar al Cónsul General de Venezuela en Marsella las 20 fotografías que le hicieron " 10 de face et 10 de profil" para la visa de su pasaporte para ese país. FSS RS 2/6.

-Atestado mecanografiado en francés, firmado por Gabriel Lucio, Segundo Secretario de la Legación de los Estados Unidos Mexicanos en Francia, firmado en Vichy el 30 de enero de 1941. Certificando que "Ricardo Sanz García ha sido aceptado como inmigrante por el Gobierno de México al haber justificado una asignación suficiente para cubrir las necesidades de su familia”. FSS RS 2/7.

-Carta manuscrita de Casajuana fechada en Marsella 15 de marzo de 1941. A petición de las hermanas de Ricardo Sanz, se ofrece a hacer gestiones en las Oficinas Consulares de México en Marsella, a través del compañero cenetista Sánchez, que se encuentra trabajando allí como taquígrafo. FSS RS 2/8.

-Carta manuscrita en francés de RS desde el Camp de Vernet d'Ariège, Quartier B.B.8, nationalite Espagnole dirigida a Monsieur le Capitaine d'Information, fechada el 
9 de julio de 1941. Le informa que ha recibido una carta de la Legación de México en Vichy donde le comunica el envío de la carta de viaje así como la visa para ir a México. Y no teniendo noticias por parte de las autoridades del Campo, le solicita una entrevista para aclarar la situación. FSS RS 2/9.

-Carta mecanografiada, firmada por Francisco J. Aguilar, Ministro de la Legación de los Estados Unidos Mexicanos en Francia, firmado en Vichy el 9 de marzo de 1942. FSS RS 2/10. Le comunican a RS que:

Su nombre figura en la lista de refugiados españoles que deben embarcar en primera oportunidad para mi país. Interesa que obtenga el permiso de salida de Francia, facilitado por las autoridades francesas. Tan pronto como le sea concedida la visa de salida prepararemos su salida eventual a Casablanca, hasta cuya localidad le serán pagados los pasajes por esta Legación. Una vez en Casablanca, ya recibirá instrucciones respecto a sus pasajes para México, así como de la fecha de salida del barco. Los organismos españoles me piden se avise a los interesados que una vez en México no disfrutarán de subsidio alguno, dándoseles, en cambio, por una vez, el equivalente de tres meses del subsidio que recibían aquí, por lo tanto deben dedicarse a actividades que les permitan atender a los problemas de su subsistencia.

-Carta manuscrita en francés de RS dirigida al Ministre de l'Interieur, fechada en el Camp de Vernet el 7 de abril de 1942. Acompañado de una nota "Vue et transmis" del Cdt. du Quartier y el sello del Camp de Concentration du Vernet d'Ariège. Majors des internés: Le pide dé las órdenes oportunas para que le entreguen la carta de identidad y de viaje para partir hacia México, que se encuentra en la Oficina de la Dirección del Campo, al haber recibido una carta del Ministro de México anunciándole la posibilidad de tener una plaza en un barco que partirá en el mes de abril. FSS RS 2/11.

\section{Subserie Camp de Djelfa (Argelia)}

Correspondencia de RS desde Alger, Camp de Djelfa (Barague 29 CSS), desde el 1 diciembre 1942 al 17 febrero 1943.

-Carta manuscrita de RS dirigida al Consul General de los Estados Unidos Mexicanos en Casablanca fechada en Camp de Djelfa (Barague 29 CSS) el 1 de diciembre de 1942 (firma como Teniente Coronel Jefe de la 26 División de la República Española). FSS RS 2/12: Depositamos en los representantes de México la defensa de los intereses y la representación de los refugiados españoles”. Se queja de que han dejado de percibir el 
subsidio "hasta el mes de junio lo hemos percibido, después ya no lo hemos vuelto a recibir". Además, informa que no les dejan salir del país "varios de nosotros poseemos los telegramas de convocatoria para embarcar en mayo rumbo a México, cosa que no pudimos hacer porque el Gobierno de Vichy no nos concedió el visado de salida de Francia". Para continuar diciendo: "El 10 de julio [1942] fuimos deportados al África del Norte, Camp de Djelfa". Muestra su satisfacción por el desembarco de los ejércitos aliados en África del Norte. Pide haga gestiones para "conseguir la inmediata liberación de todos los compatriotas españoles residentes en el Campo de Djelfa. Ofreciéndose a "contribuir fervientemente con nuestro esfuerzo desinteresado en la liberación de todos los pueblos sometidos brutalmente a los países del Eje".

-Carta manuscrita de RS dirigida al Consul General de México en Casablanca fechada en [Camp de Djelfa (Barague 29 CSS)] el 17 de febrero de 1943. FSS RS 2/13:

Le comenta que hace aproximadamente dos meses le envió una carta que aún espera respuesta, por lo que le vuelve a escribir: "Como pensionado permanente por la Legación de México en Vichy, por el cargo desempeñado en España durante la guerra, me fue suspendido el pago a raíz de mi traslado de Francia a África del Norte el mes de julio de 1942”. Le pide información para poder recurrir y se le integre la suma correspondiente a los ocho meses adeudados, "cuyo dinero me es necesario por encontrarme en situación precaria”. También le pregunta si continúa en vigor el Convenio franco-mexicano del 22 de agosto de 1940, con relación a los refugiados españoles. Y acaba diciendo: “desearía me informara qué es lo que hay en concreto, en lo que se refiere a los españoles internados, pues se asegura, se están ultimando los trabajos para nuestro traslado a México".

\section{Subserie Bab-el-Oued (Argelia)}

Correspondencia de RS desde Alger, Chez José Fuster, 48 Rue Montaigne, Bab-elOued, del 24 de septiembre de 1943 al 13 de marzo de 1944.

-Informe manuscrito sin fecha [1943] [probablemente de un compañero libertario recién liberado del Campo de Djelfa]: Narra cómo después de desembarcar las Fuerzas Aliadas en África del Norte y continuando aun en el campo de concentración, las gestiones que hicieron "encaminadas en vistas a hacer algo útil para la causa del antifascismo". Explica cómo se puso al habla el compañero Doménech, en calidad de Jefe 
español del Campo, con el Comandante Jefe francés, y de la petición que presentó en nombre de un grupo de deportados solicitando fueran puestos en libertad para poder volver a España a luchar contra Franco. El Comandante se comprometió a "trasladar la petición de inmediato a la Oficina Central del Servicio de Investigación Militar”. También cuenta la visita que recibieron de oficiales ingleses "con el propósito de alistar voluntariamente a cuentos internados lo desearan para engancharse en el Ejército inglés". Después de pasados dos meses, y sin respuesta a la petición, volvieron los ingleses para intentar alistarlos en una compañía de "Pioners Corps". Las autoridades francesas acceden a liberar a un grupo de 8 que son "instalados en un Villa de [Alger] "donde vivimos todos juntos como soldados en activo". [...] "Percibiendo una modesta paga". Allí entran en contacto con Ricardo Sanz, como responsable, que los pone en contacto con otros compañeros dispuestos a marchar a luchar a España. Finalmente se organiza un grupo: "Ricardo Sanz nos comunica que cinco de los que componían el grupo debían partir acto seguido para España". Termina el informe diciendo:

Nosotros rogamos a quien sea que se interese por la suerte de nuestros compañeros caídos en España, que hagan cuanto puedan para salvarlos y a ser posible, para arrancarlos de las garras de Franco y traerlos de nuevo a África, pues de poder lograr tal cosa, realizarían una obra que la CNT de España les agradecería siempre. FSS RS 2/14.

-Carta manuscrita sin fecha [1943] [en el mismo sentido que la anterior pidiendo la liberación del Campo de Djelfa] [dirigida a Alonso Mallol, representante de la Junta de Auxilio a los Republicanos Españoles (JARE) en Casablanca, en el Marruecos francés]. Le recuerda la carta remitida el 20 de diciembre dirigida al Cónsul General de México en Casablanca. Al no obtener respuesta, vuelve a escribirle, quejándose de la situación de los refugiados en el Campo de Djelfa y solicitando asilo en México. FSS RS 2/15:

Nos encontramos en este Campo aproximadamente unos 450 españoles [...] Antes de verificarse el desembarco de los ejércitos aliados en el África del Norte, la esperanza de muchos de nosotros radicaba en marchar a ser posible a México, acogiéndonos al convenio franco mexicano del 22 de agosto de 1940.

El hecho de la ocupación de estos territorios por parte de los ejércitos de las democracias, abría en nuestra mente un rayo de esperanza inmediata de libertad, para así poder ponernos todos los españoles antifascistas al servicio de los que luchan por la libertad.

De manera más o menos fidedigna se nos había asegurado que se había tomado la resolución de disolver todos los campos de concentración de África, y en particular el Campo de Djelfa, 
por considerar que en este campo la inmensa mayoría de internados eran políticos y habíamos sido llevados aquí, por combatir a los enemigos de la democracia [...] Pero pasa el tiempo, más de dos meses y nosotros continuamos aquí en las mismas circunstancias de antes y con mayor incertidumbre. [...] ¿Qué debemos hacer los españoles de este campo? ¿Qué partido tomar? ¿Cuerpo francés? ¿Compañía de trabajo? ¿Esperar más?

-Carta mecanografiada de Juan Perea Capulino fechada en Ramón Guzmán, 51, Dep. 204 México, el 24 de septiembre de 1943. Muestra la solidaridad desde México: "La numerosa colonia de refugiados españoles de aquí no ha dejado de pensar un solo día en los compatriotas refugiados en tierras africanas". Informa de la constitución de una Junta Central de la que forma parte Perea como representante del Partido Federal "tengo grandes esperanzas de que en breve se producirá la unidad de todos los españoles en el exilio". Comunica que "las dos ramas de la CNT están celebrando reuniones para llegar a su unificación”. FSS RS 2/16.

-Carta mecanografiada de RS dirigida a Juan Perea Capulino [en México] fechada en Chez José Fuster, 48 Rue Montaigne, Bab-el-Oued el 1 de enero de 1944. Se queja de la falta de relación entre los 6.000 refugiados españoles residentes en África del Norte y los compatriotas residentes en México. Y descarta la posibilidad de ir a México. Le cuenta que está trabajando de panadero para los americanos y que tiene toda la familia en España. Sobre la JARE le comenta: "Sabía algo de la disolución de la JARE, lo que ignoraba que fuera el Gobierno de Mexicano el encargado de administrar los fondos de los refugiados españoles". FSS RS 2/17.

-Carta mecanografiada de RS dirigida a Juan García Oliver [en Montezuma, 119 México] fechada en Chez José Fuster, 48 Rue Montaigne, Bab-el-Oued el 13 de marzo de 1944. Al principio le recrimina que haya tardado tanto en ponerse en contacto con él a pesar de la relación fraterna que tenían: "Si como parece, no has hecho nada para ponerte en relación con nosotros, mereces un fuerte tirón de orejas... ¿Acaso es amigo García, que has pensado alguna vez de mí, algo que puede parecerse a la desconfianza?”. Después le reitera su profunda amistad: "Si hay en la tierra un amigo tuyo, que te quiere y que jamás ha de abandonarte, en los momentos más difíciles de nuestra existencia, ese soy yo Ricardo SANZ. No lo olvides”. Sigue el texto informándole de las relaciones que mantienen entre los compañeros libertarios, Progreso Alfarache; Doménech; Alberola; Antonio Vidal "Vidalet", que vive con Ricardo Sanz; Viadiu, director del periódico 
Solidaridad Obrera... Y da dos datos autobiográficos relevantes: "Vivo en Argel, desde que fui puesto en libertad el 30 de marzo del año pasado [1943]" y "Mandé a mi hijita a España con mi hermana hace ya dos años. Allí están pasándolas bastante mal en el plan económico. Yo desde aquí no puedo hacer nada por ellas. Mi hermana vive en la calle Alta de San Pedro, 38-3 izq., se llama Amparo". FSS RS 2/18.

\section{Subserie Toulouse (Francia)}

Correspondencia de RS desde Toulouse, Hotel St. Sernin, 2 Place St. Sernin; 2 rue Arnaud Bernard y 82 Golfech, del 5 de octubre de 1945 al 10 de marzo de 1978.

-Carta mecanografiada dirigida a Francisco Mancisidor, Agregado Naval Legación de México en París, de RS Hotel St. Sernin, 2 Place St. Sernin, Toulouse (Francia), fechada el 5 de octubre de 1945. FSS RS 2/19:

Llegué a Toulouse procedente del continente africano a últimos del mes de julio pasado. El viaje lo hice en las peores condiciones, pero yo necesitaba volver aquí. Por fin el 18 de julio llegué a Marsella, desde donde me trasladé definitivamente a Toulouse... Yo por mi parte he fijado mi residencia en Toulouse, mientras no se resuelva el problema de España, donde pienso trasladarme en la primera ocasión.

-Carta mecanografiada dirigida a Francisco Mancisidor, de RS Hotel St. Sernin, 2 Place St. Sernin, Toulouse (Francia), fechada el 31 de octubre de 1945. Acusa recibo de su carta del 24 de octubre y le comenta: "Yo continúo bien de salud y de ánimos. Dentro de las escasas posibilidades, voy relacionándome con mis compatriotas, con el fin de sumar esfuerzos en vista a la más rápidamente posible liberación de España". Acaba diciéndole: "La solución del problema interior de España se alarga más de lo que en principio teníamos previsto. Con ello se alarga también el dolor de mi pueblo, y el deseo de todos los españoles honrados de volver de nuevo a su Patria”. FSS RS 2/20.

-Carta manuscrita de Juan dirigida a RS con papel del Hotel Novel, calle Santa Ana, 20 de Barcelona, fechada en Barcelona el 2 de febrero de 1946: "Hoy he hablado extensamente con Amparo quien me ha permitido, con gran alegría, que me prohíje a una sobrinita suya de 7 años que es una monada... Para mí, que tanto conozco y quiero a su padre, es un deber gratísimo..." [Seguramente se refiere a Violeta, la hija de RS. Ver documento de 8 de junio de 1938 en el que nombra como tutora de la niña a la compañera Flora Barranco García]. FSS RS 2/21. 
-Carta de Palau fechada en Sete el 24 de agosto de 1947: "Durante esta corta suspensión de correspondencia han pasado algunas cosas de interés para el problema de nuestro querido pueblo y al mismo tiempo rumores muy continuados de unidad de nuestro movimiento...”. FSS RS 2/22.

-Carta mecanografiada de Ramón Garriga fechada en Buenos Aires el 26 de julio de 1969: Se presenta diciendo que, gracias a un amigo común, Diego Abad de Santillán, ha podido adquirir los dos libros de recuerdos publicados recientemente por RS. Le pide que le preste un ejemplar de su folleto Francia, Argentina y México, publicado en 1946 sobre Durruti. El motivo es que R. G. está escribiendo un libro que se titulará Durruti y su tiempo. FSS RS 2/23. Acaba diciéndole:

Quiero repetirle mi felicitación por las obras escritas que viene realizando, ya que usted quedará como el último gran testigo de unos tiempos heroicos que parece que no volverán a repetirse porque, desgraciadamente, las energías que ustedes emplearon en la lucha social ahora se destinan a la 'conquista' del televisor, el auto, la heladera y otras cosas que ha inventado el neocapitalismo.

Incluye sobre remitido por R. G., San Martín 344 AP. Buenos Aires, dirigido a Monsieur Ricardo Sanz, 82 GOLFECH (France).

-Carta de Joaquín Romero Maura, encabezada por Nuffield College. Oxford y fechada el 24 de agosto de 1971 (texto manuscrito): Acusa recibo del libro dedicado y se disculpa por el retraso en contestarle a su carta debido a un viaje a América. FSS RS 2/24.

-Carta mecanografiada de Joaquín Romero Maura, encabezada por Iberian Centre. St. Antony's College. Oxford y fechada el 6 de noviembre de 1972: Le pide a RS que le envíe «a un amigo mío, inglés, que lleva tiempo trabajando sobre la dictadura de Primo de Rivera y los primeros tiempos de la República", un ejemplar de "Los solidarios y el Grupo Nosotros". Y añade: "El chico merece que se le atienda; ya lo verá cuando salga su trabajo". Al final añade: "Las señas del muchacho son Mr. Paul Preston. 72A Redlands Road. READING-Inglaterra". Incluye sobre remitido por J. Romero Maura, St. Antony’s College. Oxford, dirigido a Monsieur Ricardo Sanz, 82 GOLFECH (France). FSS RS $2 / 25$.

-Carta de Paul Preston, fechada en Reading Inglaterra 10 de marzo de 1978 (texto manuscrito): Responde a su carta y le felicita por el libro "Sindicalismo y política" 
diciéndole: "Ya es un pequeño clásico y no tengo dudas respecto a su éxito". Le habla sobre la posibilidad de verse en España y charlar. Se despide con "un fuerte abrazo de tu amigo inglés". Incluye sobre remitido por P. Preston 7 Allcroft Road. Reading, Anglaterre, dirigida a M. Ricardo Sanz, 2 rue Arnaud Bernard. 3100 TOULOUSE France. FSS RS 2/26.

\section{Ricardo Sanz escritor}

Sanz fue un escritor autodidacta muy prolífico. Aunque se nos presenta como un "hijo del trabajo", que se inició en la actividad laboral, en una fábrica de harinas, cuando comenzaba su infancia en el pueblo de Canals, llegó a publicar nueve libros y varios folletos entre 1933 y 1979. En ellos además de relatarnos su vida como trabajador y militante de la CNT, también reflexiona sobre las luchas del movimiento obrero y el anarcosindicalismo. A continuación, vamos a destacar frases de alguno de sus libros:

El sindicalismo español antes de la guerra civil. Escrito en el Campo de Vernet, 20 septiembre 1941). Libro de memorias prologado por su amiga y compañera de ideales, Sara Berenguer. Estas son algunas de sus palabras:

Tengo la satisfacción de haberle dedicado meses de incesante trabajo para darle vida en un campo de concentración de Francia, en el que se ejercía riguroso control... con cuyo método se pretendía impedir que se diese a conocer al mundo la verdad de lo que aquí ocurría. [...]

Mi libro de memorias pensé que podría escribirlo, no solamente para mi hija, sino también para todos aquellos que sienten inquietud, por desentrañar la realidad de los entresijos e inquietudes que alentaron nuestro quehacer como español. ${ }^{7}$

La política y el sindicalismo. Un libro que está vivo, grita desde el principio denunciando todo lo que ha sido la España que RS conoció.

\footnotetext{
No basta llamarse anarquista para serlo. [...] No todos los que se llaman anarquistas lo son.

También hay muchísimos que lo son sin llamárselo. [...] Es en la conducta donde se aprecia la calidad de los verdaderos idealistas.

Los que además de estudiar en los libros, hemos tenido ocasión de estudiar en los hombres por haber estado por la fuerza de las circunstancias obligados a hacer la vida común con ellos, hemos aprendido cosas muy curiosas y provechosas a la vez. Aquellos tiempos venturosos no se borrarán de nuestra memoria. ${ }^{8}$
}

\footnotetext{
${ }^{7}$ Ricardo SANZ: El sindicalismo español antes de la guerra civil, Barcelona, Petronio, 1976, p. 18.

${ }^{8}$ Ricardo SANZ: La política y el sindicalismo, Barcelona, Petronio, 1978, pp. 78-79.
} 
Los que fuimos a Madrid. Escrito en el Campo de Concentración de Vernet $\mathrm{d}^{\prime}$ Ariège (Francia), datado por el autor en el interior del libro con fecha del día 3 de abril de 1939.

La guerra civil en España, no fue una guerra simplista de clan político. Nuestra guerra, fue una guerra Social, fue una guerra de clases. Una guerra sin cuartel, entre el feudalismo y el proletariado en armas. De no ser así nuestra guerra no hubiera tenido razón de ser, ni hubiera durado tanto tiempo con la consecuencia tan desastrosa para todos los españoles, ya no solamente de las generaciones que intervinieron en la contienda, sino también para las generaciones que la sucedieron. Por experiencia sabernos que, en nuestra guerra murió en la lucha, lo mejor que militaba en la avanzada social y política de España. Y no fueron pocos los que murieron durante y después de la guerra. Fueron centenares de miles de vidas inmoladas. ${ }^{9}$

\section{Conclusiones}

El archivo de la Fundación Salvador Seguí es una de las principales fuentes de documentación para la investigación del exilio libertario en Francia. Gracias a la donación de la Biblioteca Sara Berenguer se conserva el fondo documental Ricardo Sanz.

A través del epistolario, de los documentos personales y de sus libros hemos podido reconstruir la etapa del exilio en Francia del libertario Ricardo Sanz. Además, nos ha dado una buena descripción de las duras condiciones de vida en los campos de concentración en Francia y el Norte de África, la Argelia francesa.

El estudio de estos legajos nos ha demostrado la importancia de los documentos primarios para documentar la historia del Movimiento Libertario Español exiliado en Francia.

\footnotetext{
${ }^{9}$ Ricardo SANZ: Los que fuimos a Madrid, Barcelona, Petronio, 1977, p. 13.
} 


\title{
El Archivo de la Escuela de Artes y Oficios de Valencia y su taller de cerámica
}

\author{
The Archive of the School of Arts and Crafts of Valencia and its \\ workshop of ceramics
}

Marta Vicente Carrasco

Universidad de Valencia

\section{Resumen}

En la presente comunicación intentaremos realizar una pequeña aproximación al archivo de la Escuela de Artes y Oficios de Valencia, desde sus principales fuentes documentales hasta su estado actual de conservación y cómo, a través de él, se puede trazar las características de la sociedad valenciana y los diferentes periodos históricos desde finales del siglo XIX hasta los últimos años del franquismo. Especialmente nos centraremos en los datos que se recogen de la enseñanza del taller de cerámica, una institución pionera en la educación artística en Valencia.

\section{Palabras clave}

Taller, Cerámica, Archivo, Valencia, Educación.

\begin{abstract}
In this paper we will try to make a small approximation to the archive of the School of Arts and Crafts of Valencia, from its main documentary sources to its current state of conservation and how, through it, can trace the characteristics of Valencian society and The different historical periods from the end of the nineteenth century to the last years of
\end{abstract}


the Franco regime. Especially we will focus on the data collected from the teaching of the ceramics workshop, a pioneer institution in artistic education in Valencia.

\section{Palabras clave}

Workshop, Ceramics, Archive, Valencia, Education.

\section{Introducción}

A pesar de que el tema de la cerámica en Valencia sea una disciplina muy estudiada por la larga tradición que ha tenido desde tiempos inmemoriales, los fondos cerámicos de la Escuela de Artes y Oficios de Valencia (EAO) reconvertida en la actual Escuela de Arte Superior y Diseño (EASD) no habían sido estudiados en profundidad, por lo que podemos decir que, una de las razones por las que elegí este tema, es por la singularidad que entraña. Me sentí atraída por la idea de sacar a la luz unas obras que se hallaban olvidadas y en condiciones precarias, de manera que, trabajando a partir de ellas, se consiga el reconocimiento que se merecen.

El descubrimiento de los fondos de la Escuela surgió hace dos años cuando alumnos del Máster en Patrimonio Cultural de la Universidad de Valencia, descubrieron la precaria situación en la que se encontraba este patrimonio. Éstos son muy extensos ya que abarcan obras de diversas tipologías y géneros (mobiliario, vaciados, obra gráfica, cerámica, textiles, vidrieras, etc.), además de un amplio archivo, caso del artículo que nos ocupa, apenas estudiado con información sobre planes de estudio, profesores, alumnos o requisitos de ingreso, entre otros asuntos de interés para el historiador o historiadora del arte.

Mi intención es ofrecer una idea del contexto histórico del estudio en la EAO en general y del Taller de Cerámica en particular, a través de los perfiles del estudiante y los documentos de archivo con el fin de contextualizar los periodos históricos por los que ha pasado dicho taller, haciendo partícipe a la sociedad valenciana que originó y formó parte 
del mismo, con el fin de convertir esta cerámica en un símbolo de identificación de la propia cultura valenciana.

Nos centraremos también en el estudio, tanto del alumnado como del profesorado, pues nos ofrecen un retrato de las características históricas de la época en la que vivieron, lo que nos permite extraer conclusiones acerca de temas tan variados como la demografía o aspectos intrínsecos del tiempo en el que vivieron con eventos tan determinantes, como la Guerra Civil o la posguerra.

La presente comunicación pues, tiene como objetivo analizar los devenires políticos e históricos del Taller de Cerámica en la primera mitad del siglo XX, investigando a través del archivo el contexto de estudio y los perfiles del alumnado, así como sus profesores y corrientes artísticas.

Es básico destacar en esta introducción que el importante archivo, que se encuentra en los sótanos de la institución, está sometido a unas condiciones de conservación negativas, con el deterioro que ello supone para los documentos, algunos con casi dos siglos de antigüedad. Estas deplorables condiciones del archivo histórico de la escuela, se encuentra ubicado en un sótano con graves problemas de humedad, en especial cuando llueve, y expuesto al peligro de incendio, máxime cuando es allí donde se localiza el cableado eléctrico de todo el edificio. En este espacio, los documentos están almacenados sin orden ni catalogación, lo que complica la labor de búsqueda e investigación.

\section{Los inicios del taller de cerámica dentro de la escuela de artes y oficios (1914-} 1931)

Los inicios del taller de cerámica en la Escuela de Artes y Oficios de Valencia nacen, por una parte, debido a la demanda local de larga tradición alfarera y, por otra, como resultado de la reforma de la enseñanza en estos centros. El cambio se produjo ante la incapacidad de formar debidamente a los futuros trabajadores de la industria ya que su instrucción era puramente teórica, cuya base se sustentaba en "Las Enseñanzas Elementales de Dibujo" impartidas en las Escuelas de Artes e Industrias a partir de 1900. Esta limitación fue fruto del convencimiento académico decimonónico amparado por la Academia de San Carlos, que veía en la producción industrial una mera traslación del dibujo a los diferentes objetos. 
Será en 1910 cuando se acuñe que las Escuelas de Artes e Industrias pasen a denominarse Escuela de Artes y Oficios y se introduzca finalmente la "Enseñanza de Taller" como principal objetivo docente. En 1913 el gobierno demanda a las diferentes escuelas que soliciten los talleres necesarios atendiendo a la utilidad de los mismos en cada localidad. Según relata Maota Soldevilla Liaño en la Junta de Profesores del 22 de agosto de 1913, será en este momento cuando se decida cuál es el más adecuado para la Escuela valenciana. ${ }^{1}$ Se proponen los talleres de Abaniquería, Ebanistería y Cerámica, de los cuales, los dos primeros eran más abundantes en la región. Evidenciándose una necesidad de apostar por el tercero y será el profesor de Composición Decorativa Juan Peyró, el que defienda reconvertir en Taller la clase de Cerámica que formaba parte de su asignatura.

En las memorias del curso 1913-1914, consultadas, podemos encontrar un documento que hace referencia a la decisión que fue tomada por la junta de profesores sobre la creación de dicho taller y las reformas que serían necesarias para ello:

A propuesta de la Real Orden del 12 de agosto de 1913, se ha creado el taller de Cerámica y sus aplicaciones, a cuyo efecto se edificó un cambio de locales de los existentes en el mismo edificio a fin de poder instalar dicho taller en las mejores condiciones posible. ${ }^{2}$

Maota Soldevilla Liaño afirma que los cambios en la distribución del edificio, con el fin de poder instalar los hornos en la planta baja del Convento del Carmen, produjeron problemas con la vecina Academia de San Carlos a consecuencia de la falta de espacio, ralentizando con ello su creación. También relata que las clases de Taller empiezan a impartirse en 1914 con dos grupos, uno dedicado a la cerámica y otro a los esmaltes de vidrio. $^{3}$

Tal como observamos en los historiales del profesorado, durante el periodo de la Segunda República advertimos que como maestro del Taller de Cerámica se nombra desde la creación del mismo a Gaspar Polo Torres, que fue nombrado por la junta de profesores el 12 de febrero de 1914. "Por la Subsecretaría, Decreto de 15-12-14 se

\footnotetext{
${ }^{1}$ Maota SOLDEVILLA LIAÑO: Del artesano al diseñador. 150 años de la Escuela de Artes y Oficios de Valencia, Valencia, Diputación de Valencia Institución Alfonso el Magnánimo, 2000, pp. 47-93.

2 "Memoria del curso 1913-1914 de la Escuela de Artes y Oficios de Valencia", 1914, Archivo de la Escuela de Arte Superior y Diseño de Valencia: Memorias Anuales 1908-1944.

${ }^{3}$ Maota SOLDEVILLA LIAÑO: Del artesano al diseñador..., p. 127.
} 
dispone que el director de acuerdo con la Junta de Profesores proceda al nombramiento definitivo y hacer constar el jornal". 4

Como fruto de la investigación observamos en un documento que, a fecha de 1 de octubre del año 1915, detalla los gastos de la escuela en general, los generados por el nuevo taller de cerámica en particular, y los ligados al número de alumnos.

Sobre los gastos generales, comprobamos que el apartado relativo a los costes del personal se contemplan tres subdivisiones: una para los facultativos, otra para los administrativos y un último referente al personal dependiente de la Escuela, categoría a la que pertenece el profesorado. Estos emolumentos alcanzaban un total de 44.697,47 pesetas. Otro de los apartados de los gastos generales es el generado por el material, que en este mismo curso fue de 3.327,97 pesetas, lo que hace un total de 48.025,44 pesetas por curso.

Más abajo, encontramos la siguiente apreciación: "Personal y material del taller de cerámica y sus aplicaciones 6.000 pesetas. Se reintegrarán 22 pesetas pertenecientes a jornadas continuas [...] matriculas hasta febrero para los enseñantes gráficos y alumnos". 5

Mediante este documento, podemos afirmar que el coste total del primer curso del taller cerámica alcanzó 6.000 pesetas, que no se incluyeron en la memoria de gastos anuales. Posiblemente esto se deba a que, en el primer año, el taller de cerámica comenzó cuando el curso ya estaba en marcha, lo que obligaría a contratar personal y material con un presupuesto distinto al que ya tenían asignado.

Los problemas económicos interrumpen el funcionamiento del taller en 1918 debido a la falta de ingresos para el mantenimiento de los hornos, por lo que los alumnos dejaron de acudir hasta que la escuela contó con dotación económica para retomar las clases. En las memorias del curso 1918-1919 observamos que se solicita a la administración un nuevo local en los siguientes términos: "Se solicita un local en el que instalar el Taller de Cerámica por no ser posible su desarrollo en el que hoy ocupa". ${ }^{6}$

\footnotetext{
4 "Listado de profesores y personal subalterno adscrito a la Escuela desde de 1936, 30 de septiembre de 1936, Archivo de la Escuela de Arte Superior y Diseño de Valencia: Documentos profesorado 1936-1939. 5 "Escuela de Artes y Oficios Valencia. Curso 1914 a 1915. Gastos", 1 de octubre de 1915, Archivo de la Escuela de Arte Superior y Diseño de Valencia: Memorias Anuales 1908-1944.

6 "Memoria estadística (1918-1919)", Valencia, 1919, Archivo de la Escuela de Arte Superior y Diseño de Valencia: Memorias Anuales 1908-1944.
} 
Como fruto de la reiterada insistencia por parte de la Junta de Profesores de ofrecer al Taller de Cerámica unos espacios adecuados, en 1928 profesores y alumnos de esta especialidad abandonan la clase de "Composición Decorativa y Pintura", dónde habían sido instalados desde su creación, y adquieren un local propio para la actividad. Esto supuso una mejora en el desarrollo lectivo de ambas especialidades:

\begin{abstract}
Aprovechando unos pequeños locales que por su escasa luz y su insalubridad estaban dedicados a almacén de inservibles y otros servicios, se han transformado en el taller de cerámica después de dotarles de las convenientes luz, ventilación e higiene. Y si bien no resulta un modelo de locales pues a ello no se presta su escasa capacidad y baja techumbre nos resuelve por ahora un complicado problema, porque no solamente ha mejorado este taller con su deseada independencia, sino también este traslado a permitido ampliar las clases de Composición Decorativa y las de Dibujo Artístico con esta nueva y estudiada distribución. ${ }^{7}$
\end{abstract}

Debemos tener en cuenta que los alumnos que asistían al Taller de Cerámica recibían formación paralela en otras asignaturas, las cuales permitían instruir convenientemente al alumnado para que pudiera ejecutar las obras en el taller. Hemos de tener en cuenta que estas asignaturas estaban ancladas en el academicismo basado en la enseñanza de dibujo, por lo que tanto antes como después de la creación del taller ésta fue la asignatura primordial cursada por el alumnado de la especialidad.

Del estudio de las fichas de matrícula y expedientes de estudiantes deduce que las asignaturas que acompañaban la formación en el taller en los primeros años de su creación fueron las de "Dibujo Lineal" y "Dibujo Artístico".

Además, otra de las asignaturas que se cursaban en Cerámica fue "Composición Decorativa", la cual también estaba basada en el dibujo, siendo esta asignatura, como hemos comentado, a la que se debe la creación del Taller de Cerámica por iniciativa del profesor de esta materia: Juan Peyró Urrea. Cabe decir que los diseños que ejecutaban los alumnos sobre cerámica eran tomados de modelos realizados por los profesores de la asignatura de "Composición Decorativa", los cuales gozaban de mayor reconocimiento y formaban parte del Claustro de la Escuela, a diferencia de los maestros de taller que

\footnotetext{
7 "Memoria de los trabajos realizados en esta Escuela en el curso 1928-1929 y las aspiraciones de este centro", Valencia, octubre de 1929, Archivo de la Escuela de Arte Superior y Diseño de Valencia: Memorias Anuales 1908-1944.
} 
debían obedecer las órdenes de los anteriores por tener una categoría de asesores y subordinada a los anteriores.

El alumnado también cursaba la asignatura de "Concepto de Arte" e "Historia de las Artes Decorativas”, lo que les permitía conocer la evolución de las tipologías y diseños más comunes a lo largo de la historia, para poder readaptarlos a la contemporaneidad de sus obras. La importancia académica con la que contaba esta asignatura llevó a solicitar por parte de la Junta de Profesores la creación de una cátedra de la misma, aunque la poca afluencia de alumnos llevará a su suspensión hacia los años 1950.

Más adelante, después de la Guerra Civil, se introducen las asignaturas de "Modelado y Vaciado", así como las de "Mecánica" o "Física y Química", esta última propuesta por que fuera Director de la Escuela durante el último periodo republicano, D. Lorenzo Miralles, con la intención de mejorar notoriamente el plan de estudios.

De las diferentes facturas de compra observadas en la documentación, entre los años 1914 y 1928, podemos extraer la serie de materiales más utilizados, destinados al Taller de Cerámica, los cuales se enumeran a continuación:

- Esmaltes, cubiertas, barnices y colores vitrificables para vidriado.

- Puntas de cobre, cánulas de antimonio y tubos del $\mathrm{n}^{\mathrm{o}} 7$ para la técnica del entubado.

- Gramos de reflejo metálico para trabajar la técnica del entubado.

- Pintura especial para porcelana y placas en bizcocho.

- Utensilios como esponjas, barreños, recipientes, pesos para medir las cantidades, morteros de bronce para moler colores, espátulas, pinceles, lápices, papel continuo y compases, reglas y cartabones de madera y celuloide.

- Muflas, tierra refractaria de primera calidad y leña para el mantenimiento de los hornos.

- Tierras de diferentes tipos para componer las pastas.

En esta primera época del Taller de Cerámica las piezas eran elaboradas mediante torno en vez de molde, mientras que las técnicas decorativas más comunes fueron la decoración de óxidos y esgrafiados bajo cubierta o esmalte transparente. 
En cuanto a las técnicas más innovadoras introducidas por Gaspar Polo en los primeros años del taller, éstas fueron el entubado sobre piezas bizcochadas y el reflejo metálico sobre piezas vidriadas. Ambos métodos alcanzaron fama a finales del XIX y principios del XX siendo la primera la más empleada en la azulejería modernista por presentar visualmente semejanzas con el cartelismo de la época. En cuanto al reflejo metálico, su fama se debe a la utilización extendida en fábricas como "La Ceramo" en Valencia bajo las tendencias historicistas que pretendían recuperar el estilo mudéjar, así como por la revalorización y la leyenda forjada en torno a la fórmula de dicha técnica. ${ }^{8}$

Gaspar Polo también se interesó por introducir técnicas más vanguardistas como la cerámica de alta temperatura, aunque encontró impedimentos para conseguir la instalación de un horno capacitado para este tipo de obras. Será después de la guerra, cuando Alfonso Blat ocupe el puesto de maestro de taller, introduciendo técnicas aplicadas a pastas más duras como la mayólica, el gres o la porcelana mediante cocciones de alta temperatura y cubiertas reactivas.

\section{El alumnado}

La evolución del perfil del alumnado en la Escuela de Artes y Oficios de Valencia ha sido diversa. Esos cambios se han debido a las circunstancias políticas y sociales de cada periodo.

En primer lugar, los alumnos que asistían en su origen a esta escuela respondían a tres tipos de perfil: los de edad más adulta que tenían un oficio y pretendían aprender otro o perfeccionar el que dominaban "por ser este el aprendizaje más eficaz para su perfeccionamiento profesional", ${ }^{9}$ los jóvenes que utilizaban estas enseñanzas de puente y formación para preparar los exámenes de acceso a la carrera de Bellas Artes, en especial las asignaturas de dibujo y, por último, escolares que recibían una formación integral, que aunaba los conocimientos en artes plásticas y los propios de las enseñanzas de secundaria.

Estos perfiles variaron con el paso de los años y la introducción de la enseñanza de práctica en los talleres, entre ellos en el de Cerámica que nos ocupa, cuya apertura, según ya se ha señalado, aconteció en 1914. En esta segunda década del siglo XX el alumnado

\footnotetext{
8 Jaume COLL CONESA: Cerámica Valenciana. Apuntes para una síntesis, Valencia, Asociación Valenciana de Cerámica, 2009, p. 241.

${ }^{9}$ Maota SOLDEVILLA LIAÑO: Del artesano al diseñador..., p. 132.
} 
de este taller ya dominaba un oficio, y aprendía cerámica como complemento de éste o para aprender nuevas técnicas.

Como reflejo del perfil del alumnado en edad adulta que estaba interesado en formarse de manera práctica en el Taller de Cerámica para mejorar su oficio, cabe destacar que, en la memoria del curso 1918-1919 se propone a la administración las siguientes propuestas:

Creación de becas y pensiones a los alumnos que asistan al taller con el fin de estimular su asistencia y compensarles de esta manera, del jornal que dejen de percibir en los talleres en que trabajen o estén colocados. [...] Títulos o certificados de aptitud que les sirvan para ser admitidos preferentemente en los talleres particulares. ${ }^{10}$

Todos los años se otorgaban premios a los alumnos más destacados de cada especialidad, siendo el Taller de Cerámica uno de ellos. Uno de los alumnos premiados fue Ángel Carot Portolés, del cual se conserva un gran panel cerámico realizado en el Taller de la Escuela.

Con el paso del tiempo, la enseñanza en taller se fue asentando y el tipo de alumno que asistía a ellos fue creciendo. No obstante, las transformaciones sociales de la década

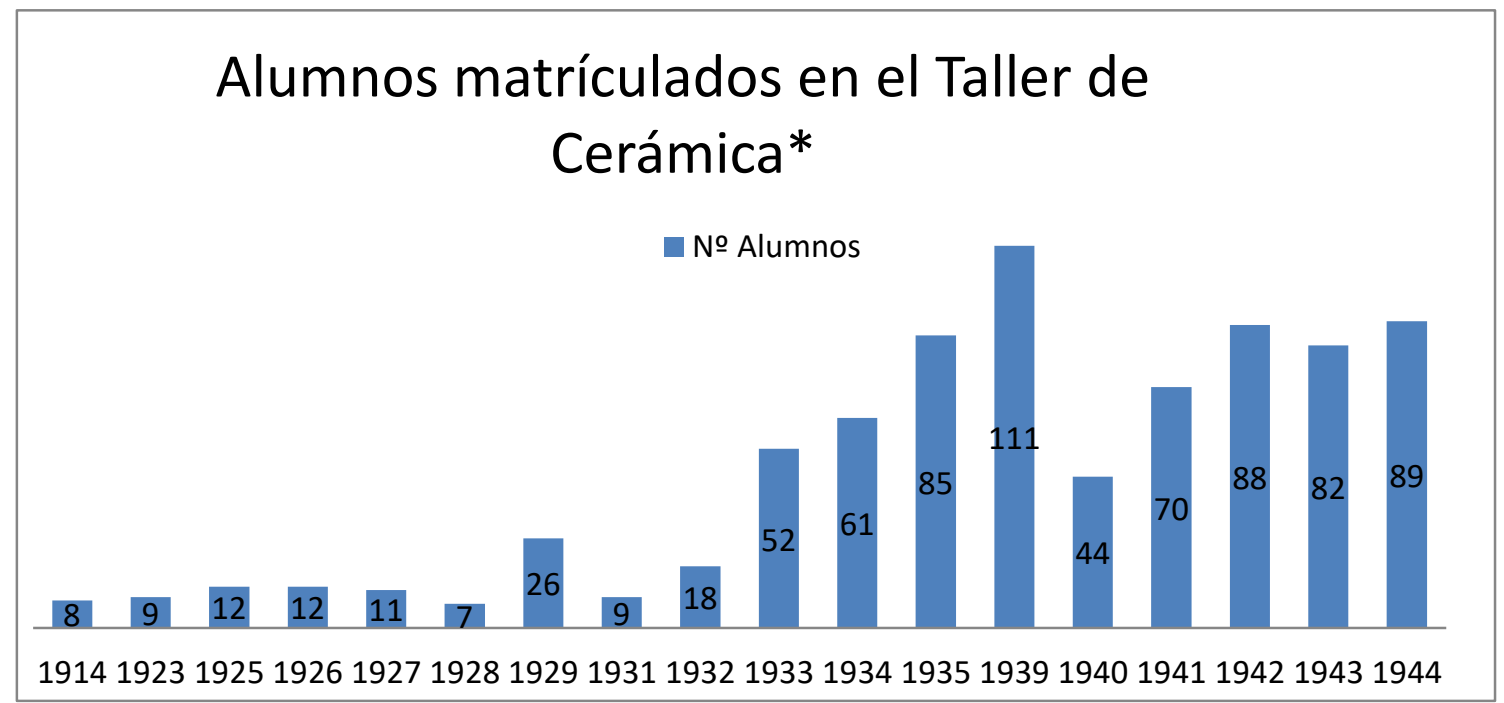

de los años 1930 en España, y la Guerra Civil Española que aconteció a finales de esta década, produjeron un cambio de mentalidad que influyó en el devenir de la EASD y el perfil de alumnos que pasaron por las aulas de sus talleres, entre ellos los que recibieron formación en el Taller de Cerámica que nos ocupa.

10 “Memoria estadística (1918-1919) ...", p. 32. 
Fuente: Elaboración propia a partir de los datos incluidos en las memorias anuales de la Escuela.

En esta gráfica que registra la afluencia de alumnos puede observarse que el periodo, comprendido entre los primeros años de funcionamiento del Taller de Cerámica hasta que se instaura la República, hubo una escasa afluencia de alumnos, debido seguramente a la falta de medios y reconocimiento con los que se contaba. En el año 1929 se identifica un aumento en el número de matrículas, sujeto a las más mejoras que este taller experimentó al contar con local de enseñanza propio.

En cuanto al periodo que abarca la Segunda República, 1931-1939, se advierte un aumento progresivo de los alumnos que se matricularon en el Taller de Cerámica debido a la apuesta que realizó el Gobierno por las enseñanzas de taller mediante una mayor dotación presupuestaria, tanto de manera directa como incentivando la asistencia de los alumnos mediante becas y premios, en especial para los de recursos económicos más limitados. Este aumento también estuvo favorecido por la nueva mentalidad que se fue forjando en la sociedad española, que cada vez veía más útil y necesaria la asistencia a los talleres prácticos que les capacitasen para entrar de forma cualificada en el mundo laboral, lo que explica ese progresivo aumento al margen de coyunturas tan desfavorables como la que introdujo la Guerra Civil Española en este periodo, y más exactamente entre los años 1936 y 1939.

Con el estallido de la guerra y la posterior represión, los alumnos que se matricularon en el Taller de Cerámica en el año 1940 fueron menos de la mitad que el año anterior, en lo que influyó la situación de pobreza y desánimo posterior al conflicto armado. Sólo con la instauración de la dictadura la situación fue mejorando gradualmente, en parte por el futuro que muchos jóvenes debieron percibir en esta clase de enseñanzas que garantizaban su capacitación en oficios con los que aumentar sus rentas familiares.

La Segunda República española supuso un cambio que favoreció el progreso en muchos campos de la sociedad, incluido el educativo, otorgó gran importancia a la instrucción pública, elevando así el número de escuelas y dándoles un nuevo enfoque, intentando reducir el analfabetismo, lo que, en última instancia, sirvió para elevar el nivel cultural de la población. Paradójicamente, no fue hasta el golpe de estado militar cuando estas ideas se llevaron a cabo con más intensidad por parte del gobierno del Frente 
Popular. La creación de Institutos para que los hijos de los obreros y obreras pudieran acceder a la Universidad y el nuevo enfoque de protección especial de la clase obrera tuvo su reflejo en las enseñanzas de la Escuela de Artes y Oficios, mediante una enseñanza mixta, que favoreció la plena igualdad entre hombres y mujeres.

En el artículo 48 de la Constitución Española de 1931 se refiere claramente a la necesidad de reforzar el sistema educativo como eje del progreso de este nuevo Estado:

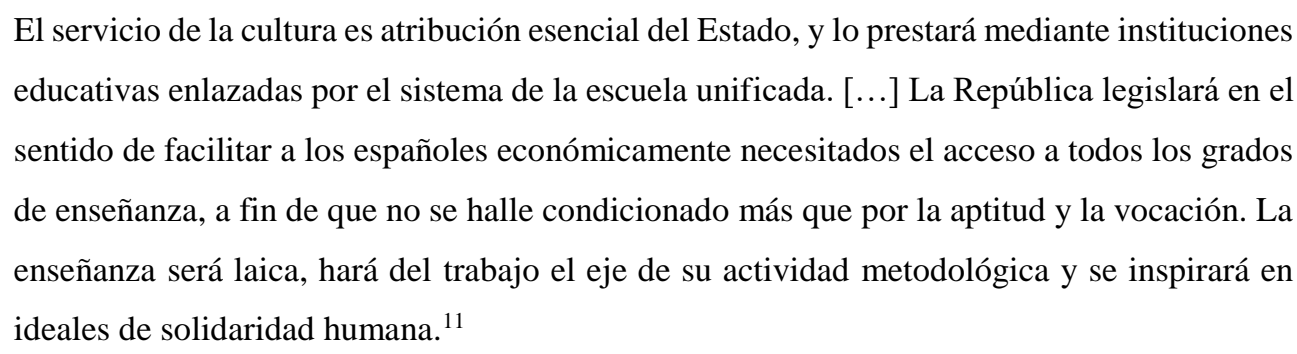

En este extracto de la Constitución se observa que la Segunda República tenía la intención de que las enseñanzas fueran más prácticas, y de que el trabajo fuera la parte fundamental de la metodología en la enseñanza.

Por lo que respecta al alumnado de esta época, se observa claramente un aumento de los estudiantes en lo que al Taller de Cerámica respecta. Esta apuesta de la Segunda República por el Taller se debió a la democratización de la enseñanza, instruyendo debidamente a la población para que pudiera valerse por sí misma para formar una ciudanía autosuficiente, que pudieran ejercer una profesión con la máxima capacitación posible. Esto se tradujo en una mayor inversión económica por parte de la Administración con el fin de ampliar la oferta académica y los medios con los que contaban los talleres existentes. Aunque no todos los docentes estuvieron a favor de apoyar estas enseñanzas, algunos profesores, como José Catalá, evidenciaron la necesidad de aprovechar la oportunidad que se les estaba presentando para mejorar el aprendizaje en estos oficios, como vemos a continuación: "dada la facilidad que presta el gobierno para formar al alumno en este sentido hay que hacer todo lo posible para que este hecho tenga realidad". 12

\footnotetext{
${ }^{11}$ Constitución española, 1931, Art 48.

12 "Libro de Actas de la Junta del 13 de mayo de 1933", Valencia, Archivo de la Escuela de Arte Superior y Diseño de Valencia: Libros de Actas.
} 
De esta manera, se pretendía producir un salto cualitativo entre la metodología educativa academicista basada en el dibujo y la copia de modelos frente a la capacitación práctica del taller, que introducía de manera eficaz a los estudiantes en el mundo laboral. Todo esto sin dejar de lado la escolarización de los alumnos más jóvenes para que adquirieran una cultura básica que les permitiera orientarse como individuos a lo largo de su vida.

La posguerra obligó a paralizar este proyecto. Pero si bien es cierto que el ideario educativo de la Segunda República no pudo llevarse a cabo, la iniciativa sí sentó las bases de una nueva filosofía de enseñanza que apostaba por impulsar la formación y trabajo en el contexto del taller, lo que se retomaría tiempo después.

La Guerra Civil conllevó un cambio profundo y circunstancial en el alumnado de la ESAD. Por un lado, la edad de ingreso y la edad media del alumnado descendió radicalmente, y por el otro hubo muchas más mujeres que hombres matriculadas, ya que los últimos se vieron obligados a participar en el conflicto armado.

La contienda bélica obligó a cancelar las actividades de la EASD entre septiembre de 1936 y 1938, si bien es cierto que este centro continuó realizando gestiones burocráticas y recibiendo solicitudes de matrícula. Oficialmente las clases se reanudaron en el curso 1938-1939 con el objetivo de capacitar técnicamente a hijos de obreros, con la finalidad de dotarles de un oficio práctico e impulsor de economías familiares maltrechas debido a la guerra. En esta misma línea, se impulsaron nuevos oficios que darían trabajo en el nuevo contexto político-social. En Valencia hubo un aumento de la burocracia y la administración pues se produjo el traslado de la capitalidad de la República a Valencia entre el 6 de noviembre de 1936 y el 31 de octubre de 1937, lo que dio lugar a que una máquina de escribir se considerase un objeto muy valioso, como observamos en la correspondencia del entonces director de la Escuela D. Lorenzo Miralles. Mecanografía y Taquigrafía fueron dos de esos oficios favorecidos por la nueva coyuntura, que por ello contaron con un impulso en la EAO, en esas fechas, con un aumento significativo en las matrículas, a pesar de que el centro los tuviera integrados en su plan de estudios desde 1924, como podemos observar comparando las matriculaciones del curso 1925-1926, (36), con las del curso 1936-1937, (140). 
También los requisitos de acceso cambiaron, limitándose a los cuatro que se reseñan a continuación: una instancia al director solicitando el ingreso, el certificado de nacimiento, el certificado médico que constataba la revacunación del alumno, (algo muy común, con el fin de evitar la propagación de enfermedades infecciosas), y una cédula o documento personal, (de los padres, para los menores de 14 años). A todos estos requisitos, se añaden, a partir del curso 1937-1938, un aval o documento "acreditativo de ser sus padres afectos al régimen", ${ }^{13}$ otorgado por una organización política, sindicato u organización antifascista.

En este periodo se observa la creación de becas para el estudio en la EAO para jóvenes sin recursos, en la línea de lo expresado por la Constitución y apoyados en diversos Decretos que el Gobierno aprobó para el sustento a las enseñanzas artísticas. Diversas solicitudes se enviaron a la EASD en esta dirección entre el 1936 y 1937. No hay que olvidar que fue durante la Guerra Civil Española cuando los proyectos e ideas republicanas sobre la cultura y la educación pudieron aplicarse de manera efectiva, aunque siempre condicionadas por el contexto bélico, de ahí que sea encomiable el esfuerzo que se hizo por parte del profesorado de la EAO y de los responsables del Gobierno para sostener las enseñanzas artísticas en una coyuntura más que desfavorable.

La derrota de la Segunda República abrió el periodo de inestabilidad y miedo que caracterizó a la posguerra. Muchos de los profesores fueron represados y apartados de la docencia por tribunales de depuración y, el terror y la complacencia hacia los líderes del régimen, se hizo patente en los documentos de este periodo.

El número de alumnos y alumnas del Taller de Cerámica descendió poco antes del fin del conflicto armado, debido las circunstancias bélicas, de una sociedad que debía luchar para ganar la guerra. Los documentos que el nuevo director enviaba a la autoridad competente resumiendo los cursos académicos (memorias anuales), dejan patente la escasez de material y la penuria económica por la que transcurría la institución, ya que su presupuesto apenas alcanzaba para costear los gastos de electricidad. Todo ello afectó

\footnotetext{
13 "Certificado de las Juventudes Socialistas Unificadas", Valencia, 30 de octubre de 1937, Archivo de la Escuela de Arte Superior y Diseño de Valencia: Matrículas 1935-1939.
} 
principalmente a alumnos de corta edad que hubieran podido formarse en algún oficio con el que contribuir a sus maltrechas economías familiares.

En lo que respecta al campo educativo, una vez concluido el conflicto bélico, la Iglesia Católica volvió a ser parte indisoluble del Estado y principal responsable en la labor de instruir a la población. La educación dejó de ser laica, dejando de inspirarse en ideales de solidaridad humana y de equidad de género.

En lo que respecta a la EAO, muchos de los profesores se mantuvieron en su puesto, excepto los que fueron depurados, por lo que quizás este cambio político no se apreciara de manera tan radical. No obstante, nuevas asignaturas aparecieron como obligatorias dentro de Escuela, entre ellas "Formación del Espíritu Nacional" y "Religión Católica". Otros cambios fueron: la separación de las clases por sexos y la instauración de la asignatura "Labores de la Mujer" para las alumnas de sexo femenino, fiel reflejo de la mentalidad de una época que relegaba a la mujer a actividades y talleres como los de “Corte y Confección", al punto de que en 1954 la asignatura de "Dibujo Artístico" tenía que enfocarse a las mujeres con aplicación a sus labores por orden de la dirección de D. Roberto Rubio. ${ }^{14}$

A pesar de todo ello, la media de alumnos del Taller de Cerámica durante la posguerra fue bastante alta en comparación con otros talleres y, respecto a los años 1920, prosiguiendo con su labor de forma similar a años anteriores, si bien con menor presupuesto, tal y como relatan las memorias estadísticas del curso 1941-1942: “Los hornos de cerámica no pueden funcionar por no disponer de cantidad para adquisición de leña". 15

Esta situación afectó a las enseñanzas y al alumnado, que pese volver a crecer de nuevo de manera progresiva en número, no podían adquirir una formación adecuada por el escaso presupuesto del que disponía la EAO.

Por último, inspirándose en el ideario de la Segunda República y su insistencia en la democratización de las enseñanzas y sus docentes, los maestros de taller de la EASD que no formaban parte de la plantilla oficial de profesores, se admiten en ella. Esto

\footnotetext{
${ }^{14}$ Maota SOLDEVILLA LIAÑO: Del artesano al diseñador..., p. 33.

15 "Memoria estadística del curso 1941-42", Valencia, 1 de octubre de 1942, Archivo de la Escuela de Arte Superior y Diseño de Valencia: Memorias Anuales 1908-1944.
} 
provocó la reacción de otras jerarquías de profesorado del mismo Centro, que no estuvieron de acuerdo en quedar al mismo nivel que los anteriores en Juntas y en la consecuente toma de decisiones.

\section{El profesorado}

Una figura muy importante para el desarrollo fructífero de toda empresa que tenga como objetivo la docencia es el de profesor o maestro y en la Escuela de Artes y Oficios de Valencia existía un profesorado de gran calidad, tal y como se evidencia dentro de esta investigación: el Taller de Cerámica. Su primer profesor fue D. Gaspar Polo, nombrado profesor responsable el 12 de febrero de 1914 y destituido de su función docente en 1939, como consecuencia del proceso de depuración que se vivió tras la Guerra Civil Española. Desde 1925 a la citada función asumió una nueva: la de impartir el "Taller de Repujado y Cincelado en Cuero", de carácter extraoficial, por el que no fue remunerado hasta el año 1934 con una subida de sueldo de 2.000 pesetas, que dos años más tarde ascendieron a 3.000 pesetas. No obstante, en el año 1938 dejó de cobrar 2.000 pesetas por el repujado.

Ya en tiempos de la Guerra Civil Española, Alfonso Blat Monzó entró como ayudante del Taller el 13 de marzo de 1936, con un sueldo 2.000 pesetas que sólo disfrutó, durante menos de dos años, pues en julio de 1938 fue llamado a filas. Después de la contienda, se declaró afecto al régimen franquista, y fue ascendido a maestro de Taller en 1939. Otro de los docentes del Taller de Cerámica en este periodo, y más exactamente desde el 17 de octubre de 1935, fue Arturo Almer Alió, ayudante interino del "Taller de Cerámica y sus Aplicaciones" con un sueldo anual de 1.500 pesetas, cargo que desempeñó hasta el año 1939, que no vuelve a figurar en el cuadro del profesorado.

Durante los primeros años de la posguerra, fue Alfonso Blat Monzó el único responsable de Taller de Cerámica, hasta que José Esteve Medina y Manuel Andrés Badia fueron nombrados ayudantes del Taller, este último entre el 26 de julio de 1948 hasta el 7 de octubre de 1954.

Enseñar es siempre una labor no exenta de dificultades, pero hacerlo en medio de un estado de guerra hace que la enseñanza se convierta no solo en la transmisión de conocimientos, si no en una labor que en ocasiones iba más allá de la tarea de instruir. En los albores de la contienda civil, el 26 de marzo de 1935 fue nombrado director de la EAO José Ventura Grau, que al que poco después, y más exactamente el 18 de agosto de 1936, 
sustituyó Lorenzo Miralles Solbes, con el que se inicia el proyecto de reestructuración del sistema pedagógico de este centro para adaptarlo a la difícil coyuntura.

En un informe de este director fechado el 1 de septiembre de 1938, en él se explica que la EAO tuvo cerradas sus clases los cursos 1936-37 y 1937-38, por estar elaborándose un nuevo plan de estudios, solicitando la reapertura oficial del centro para el curso 193839. No obstante, como hemos comentado en apartados precedentes, la actividad burocrática no se detuvo en este centro de enseñanza durante esos años, con ceses, nombramientos, compra de material escolar y correspondencia, y recibiendo constantemente, numerosas solicitudes de ingreso.

En el nuevo Plan Académico elaborado en estos años desde la escuela valenciana con destino a todas las escuelas de artes y oficios del país y titulado "Indicaciones para una nueva estructuración de las escuelas de artes y oficios artísticos", se puso de manifiesto la deficiente estructuración de estas enseñanzas y a su vez, mediante tres postulados fundamentales, se ofreció una serie de ideas para mejorar la formación integral del alumnado. Apunta Miralles a la "deficiente cultura general del alumno [...] pues acudía solo a las [enseñanzas] que su limitada visión consideraba más en relación a sus propósitos, dándose con gran frecuencia el caso de alumnos que copiando maravillosamente láminas no saben interpretar lo que han copiado". ${ }^{16}$ Estos casos remarcaban la necesidad de ofrecer al alumno una formación que englobara diversos aspectos, y como postulado fundamental para Miralles "un alumno hasta los 15 años debe estar sometido a un régimen de trabajo variado [...] que permita descubrir sus aptitudes y le prepare para mayores empeños". ${ }^{17}$ Apunta también que esto sería imposible para muchos de los alumnos pertenecientes a familias modestas que tuvieran que aportar un jornal al hogar, por lo que se debe imponer un "establecimiento de becas para los alumnos que se encuentren en esta situación" $" 18$.

Los estudios para Miralles debían abarcar todas las "necesidades de todo orden de un futuro miembro de la sociedad, obrero de un oficio artístico", ${ }^{19}$ por lo que debían ser

\footnotetext{
16 "Indicaciones para una nueva estructuración de las escuelas de artes y oficios artísticos. Consideraciones acerca de la enseñanza en las escuelas de artes y oficios de España”, Valencia, 5 de marzo de 1938, Archivo de la Escuela de Arte Superior y Diseño de Valencia: Documentos profesorado 1936-1938.

17 "Certificado de las Juventudes Socialistas Unificadas", Valencia, 30 de octubre de 1937...

${ }^{18}$ Ibid.

${ }^{19}$ Ibid.
} 
de muy diversa índole e incluir disciplinas tan distintas como ciencias exactas, naturales y sociales, literatura, dibujo artístico, modelado y vaciado e idiomas. Incluso se sugiere que se introduzca la educación del oído "con el propósito de despertar el buen gusto en la música y no privar al futuro obrero de un placer tan exquisito", ${ }^{20}$ así como la educación física y las excursiones por la naturaleza.

Después de tres cursos formándose en estas materias, el alumno sería destinado al taller que eligiera o para al que hubiese demostrado aptitudes, alternando estas horas de taller con las de historia del arte, artes decorativas y demás asignaturas que requiera el oficio al que se dedique. En esta línea se apunta que un "alumno de cerámica, recibirá la enseñanza especial de química que le haga falta". También se señala que las clases deben ir en armonía con el arte autóctono tradicional de cada región. ${ }^{21}$ Finalmente, Miralles también sugería que estas enseñanzas debían fusionarse con las llamadas "Escuelas de Trabajo" para evitar solapamientos en área y especialidades tan próximas.

En cuanto al Taller de Cerámica, Miralles sugiere que el de la Escuela de Valencia se debería reubicarse en un lugar que reuniese todos los elementos necesarios, apuntando a la Escuela de Manises como referente para la enseñanza de la Cerámica.

Como ya se apuntó en apartados precedentes, con la llegada de la administración franquista, se nombra como nuevo director a José Ventura Grau, que había sido director en el año 1935, y que recibió a los nuevos responsables con una admiración extraordinaria, renegando de los años del periodo republicano, ya fuese por convencimiento o por miedo.

En la memoria del curso 1939-1940 se detallan los profesores que causaron baja. De esta manera se indica que:

Liberada la ciudad de Valencia, fueron baja en sus cargos respectivos a consecuencia de la formación de expediente por la Comisión Depuradora del Ministerio de Educación Nacional, encarcelamiento, procesos y condenas por los tribunales Militares los siguientes señores. ${ }^{22}$

\footnotetext{
${ }^{20}$ Ibid.

${ }^{21}$ Ibid.

22 "Memoria estadística del curso 1939-40. Variaciones en el personal", Valencia, 1 de noviembre de 1940, Archivo de la Escuela de Arte Superior y Diseño de Valencia: Memorias Anuales (1908-1944).
} 
Entre los profesores que sufrieron estos tristes destinos encontramos al antiguo director de la EAO, Lorenzo Miralles Solbes, ${ }^{23}$ y al maestro del Taller de Cerámica Gaspar Polo Torres.

Por instrucción de los responsables del bando franquista que entraron en Valencia el 30 de marzo de 1939, hicieron firmar a los profesores una carta documentando su situación en la EAO después del 18 de julio de 1936. En ella, tanto Lorenzo Miralles como Gaspar Polo certificaron que continuaron trabajando en sus cargos respectivos, pero otros como Alfonso Blat Monzó utilizaron esta ocasión para demostrar su afección al régimen franquista.

El lenguaje en este periodo cambió notablemente. La falta de libertad se hace patente en las memorias estadísticas anuales del director de la escuela José Ventura Grau, con frases de apoyo y admiración al régimen:

La escuela $[\ldots]$ ha saludado con el alborozo de un renacer de gloria el dichoso amanecer que las armas victoriosas de Franco han procurado a la España imperial. [...] Por primera vez los destinos de la nación están firmemente regidos, [gracias a] su confianza absoluta en la capacidad rectora que Dios deparó a nuestra Patria. ${ }^{24}$

Además, se afirma en dicha memoria que incluso se erigió un monumento loando la fecha de la entrada del General Franco en la ciudad de Valencia formado por "laudes cerámicas". En las memorias posteriores se comenzó a demandar un mayor presupuesto y atención hacia la EAO poniendo de manifiesto las dificultades económicas que subyacieron después del conflicto.

En definitiva, los años de la posguerra fueron años objetivamente muy complicados, con una baja o nula financiación, con unas instalaciones devastadas precisamente por los bombardeos del bando franquista, y por la carencia de material alarmante que prácticamente imposibilitaba el poder impartir algunas clases, especialmente la del Taller de Cerámica, por no poder mantener los hornos en funcionamiento.

\footnotetext{
${ }^{23}$ Acusado por el Tribunal Especial para la Represión de la Masonería y el Comunismo.

24 “Memoria estadística del curso 1939-40". 1 de noviembre de 1940, Valencia, 1 de noviembre de 1940, Archivo de la Escuela de Arte Superior y Diseño de Valencia: Memorias Anuales (1908-1944).
} 


\section{La escuela de artes y oficios dentro de la sociedad: Aportaciones}

Haciendo una retrospectiva histórica podemos decir que la Escuela de Artes y Oficios de Valencia desempeñó una gran labor social por ser un espacio accesible para formar en un oficio tanto a jóvenes como adultos desde comienzos del siglo XX. A pesar de las dificultades que tuvo que afrontar, la sociedad valenciana encontró en ella un medio para poder formarse de manera gratuita, democratizando así la enseñanza a todas las capas sociales. Como hemos visto, la enseñanza en el taller dentro de la Escuela fue clave para la inserción laboral de los jóvenes valencianos, siendo un medio esencial para el sustento de muchas familias.

No hay que olvidarse de que mediante este tipo de enseñanza se oficializaron los antiguos oficios, heredando en cierta manera lo que antaño fueron los gremios, es por ello que también podemos observar una labor etnológica en cuanto a esta recuperación de los oficios artesanales autóctonos, los cuales estaban siendo absorbidos por la industrialización y mecanización en todos los procesos de manufactura. En ella se han reflejado todos los avatares y devenires políticos afectando a profesores y alumnos que se han adaptado a los consecuentes cambios, de manera que en su recorrido podemos leer la historia de nuestra sociedad.

Así mismo ha sido y sigue siendo un punto de partida de artistas que luego han consagrado su carrera compaginando las enseñanzas de la Escuela de Artes y Oficios de Valencia con las de Bellas Artes. 


\title{
¿Pueden ser útiles los cuentos populares y la tradición oral africana para deconstruir estereotipos de raíz colonial?*
}

\author{
Can folk tales and oral african tradition be used to deconstruct \\ stereotypes of colonial origin?
}

\author{
José Manuel Maroto Blanco \\ Instituto de Migraciones, Universidad de Granada \\ Rosalía López Fernández \\ Instituto de Migraciones, Universidad de Granada
}

\section{Resumen}

El objetivo del siguiente trabajo es plantear las posibilidades del estudio de la tradición oral y lo cuentos populares para acercarnos desde otra perspectiva al pasado africano. Es imprescindible poner en valor la importancia de la historia oral, no sólo como fuente histórica, sino también como un medio por el cual se debe reconocer de forma plena la historicidad de los pueblos africanos, muchas veces relegados desde planteamiento hegelianos al lugar de la "no historia". Por otro lado, su estudio contribuye a romper con ciertas ideas hegemónicas de un marcado carácter eurocentrista y de raíz colonial, que todavía tienen vigencia en el imaginario de gran parte de la sociedad occidental.

\footnotetext{
* José Manuel Maroto Blanco ha realizado este trabajo con un contrato predoctoral de Formación de Profesorado Universitario (FPU 15/01266) del Ministerio de Educación, Cultura y Deporte en la Universidad de Granada. Rosalía López Fernández ha realizado este trabajo con un contrato predoctoral de Formación de Profesorado Universitario (FPU 13/03547) del Ministerio de Educación, Cultura y Deporte en la Universidad de Granada.
} 


\title{
Palabras clave
}

historia oral, cuentos populares, estereotipos, colonialismo, África

\begin{abstract}
The objective of the present text is to pose the possibilities of the oral tradition and the folk tales to approach, from a different perspective, the past of the African continent. It is essential to emphasize the importance of oral history, not only as a historical source, but also as a means by which the historicity of the African peoples should be acknowledged, and which is often relegated, from the Hegelian point of view, to the position of the "no History". Besides that, its study contributes to the breaking down with certain hegemonic and Eurocentric ideas of colonial origin, which are still prevailing in the imaginary of much of the western society.
\end{abstract}

\section{Palabras clave}

oral history, folk tales, stereotypes, colonialism, Africa.

\section{Introducción}

La importancia de la palabra hablada es clave en aquellas sociedades en las que escritura estuvo en un segundo plano frente a la oralidad. Tal es el caso de África Subsahariana, que se ha caracterizado prácticamente en su totalidad por haber transmitido su historia y los valores que ha abanderado a través de la transmisión oral.

Ante este hecho, la mirada occidental se ha distinguido por un profundo eurocentrismo que ha tratado de explicar este fenómeno en relación con la existencia de un estado de "primitivismo" de la sociedad africana frente a los avances que se han generado desde Europa y Norteamérica. La mirada colonial, pese a que haya pasado más de medio siglo de la década de las independencias africanas, sigue aún vigente.

Huyendo de estas interpretaciones, nuestro objetivo es contribuir a deconstruir estas ideas preconcebidas de profunda raíz colonial a través de un ejemplo de la tradición oral africana -la Carta de Mandén de 1222 como primer ejemplo de defensa de los Derechos 
¿Pueden ser útiles los cuentos populares y la tradición oral africana para deconstruir estereotipos de raíz

Humano- y de varios cuentos populares africanos, que nos ilustran sobre el modo en el que ciertos elementos clave para entender las relaciones humanas de forma digna y harmoniosa no son, ni mucho menos, patrimonio exclusivo de origen europeo.

\section{Representaciones del negro africano: un color que deshumaniza}

La imagen del negro africano en determinadas sociedades occidentales y mayoritariamente blancas, ha estado cargada de fuertes prejuicios y estereotipos que han dado lugar una serie de representaciones mediante las cuales se identifica a un colectivo numéricamente muy grande, de procedencias geográficas muy variadas y culturalmente muy diverso. Según Hall

la estereotipación es, en otras palabras, parte del mantenimiento del orden social y simbólico.

Establece una frontera simbólica entre lo "normal" y lo "desviante", lo "normal" y lo

"patológico", lo "aceptable" y lo "inaceptable", lo que "pertenece" y lo que no pertenece o

lo que es "Otro", entre "internos" y "externos", nosotros y ellos. ${ }^{1}$

Estas representaciones, que progresivamente se van instalando en el imaginario simbólico colectivo de determinados grupos y que son expresadas por medio de ideas, discursos, creencias, prácticas o actitudes, son las que a continuación trataremos de abordar.

La construcción de la imagen del negro africano en el imaginario de distintas sociedades, principalmente occidentales, no es un producto de reciente elaboración pues desde las primeras expediciones europeas hacia África en el s. XV, el negro fue concebido como un esclavo salvaje sin derechos y sin alma que había que humanizar. Manifiestamente, en palabras de Frantz Fanon, ${ }^{2}$ la humanidad les fue negada al ser situados debajo de la línea de lo humano, del no-ser, relegándoles así a una posición de inferioridad existencial "que ha sido políticamente producida y reproducida durante siglos por el sistema imperialista/occidentalocéntrico/capitalista/patriarcal/moderno/colonial". ${ }^{3}$ Entre los siglos XVIII y XIX, la imagen del negro como atrasado, premoderno y extemporáneo fue ratificada al atribuir dichas características a "la naturaleza" y a la

\footnotetext{
${ }^{1}$ Stuart HALL: "El espectáculo del "Otro", en Eduardo RESTREPO, Catherine WALSH y Víctor VICH (eds.): Sin garantías. Trayectorias y problemáticas en estudios culturales, Popayán, Universidad JaverianaInstituto de Estudios Peruanos-Universidad Andina Simón Bolívar-Envión, 2010, p. 430.

${ }^{2}$ Frantz FANON: Piel Negra, Máscara Blanca, Madrid, Akal, 2010.

${ }^{3}$ Ramón GROSFOGUEL: "La descolonización del conocimiento: diálogo crítico entre la visión descolonial de Frantz Fanon y la sociología descolonial de Boaventura de Sousa Santos", en CIDOB (editor) FormasOtras: Saber, nombrar, narrar, hacer, Barcelona, CIDOB, 2011, p. 98.
} 
herencia biológica, que, a su vez, no dejaba lugar a dudas del correlato de la supremacía blanca. Este hecho contribuyó a la representación esencialista del negro desde su primitivismo, desde la pereza innata, la falta de cultura, la simplicidad, la incapacidad del refinamiento civilizado, como naturalmente nacidos y equipados para la servidumbre, como tercamente reacios a trabajar de forma apropiada a su naturaleza o como moralmente depravados, etc. A juicio de Hall esta "naturalización" fue "una estrategia representacional diseñada para fijar la "diferencia” y así asegurarla para siempre"”. 4

En la actualidad, los atributos mediante los cuales se representa al negro africano, más que ir corrigiéndose se han ido refinando dentro de unas fuertes lógicas de inferiorización y de exaltación del racismo cultural. Entre estos atributos tenemos, en primer lugar, la imagen del negro como una figura social amenazante que representa el "antisujeto europeo", que en el contexto de la Unión Europea es el "no comunitario" y para cada país es el "no ciudadano o el infraciudadano". Este sujeto no solo carecería de los valores necesarios para llegar a ser un miembro más de la sociedad, sino que además encarnaría todos aquellos valores contrarios a los que un sujeto blanco y occidental debe poseer, por lo que su presencia en determinados contextos supone una amenaza para "la cohesión social, la seguridad económica, la homogeneidad cultural e incluso la estabilidad política". ${ }^{6}$ Desde los medios de comunicación, cuyo papel en la formación de representaciones sociales es innegable, la imagen del negro ha sido fuertemente producida como un inmigrante sin papeles, ilegal, irregular, indocumentado o clandestino que llega a otros territorios en forma de avalancha, invasión u ola migratoria. Estas imágenes son activamente apoyadas por parte de determinados grupos de poder y partidos políticos y cuyo fin es el de convertir a la población migrante en las víctimas propiciatorias de los males sociales, desviando la atención de otras posibles causas de malestar social.

La sobrevisibilización a la que están constantemente sometidos en cuestiones que afectan a cualquier grupo poblacional (altercados policiales, controles de inmigración...), genera que sobre la población negra exista una imagen persistente de este colectivo como una fuente de peligro o un problema a resolver, convirtiéndose de forma casi automática en personas hostiles, violentas, agresivas o en potenciales delincuentes. Este marcaje

\footnotetext{
${ }^{4}$ Stuart HALL: "El espectáculo del "Otro... p. 428.

${ }^{5}$ Enrique SANTAMARIA LOZANO: "Inmigración y barbarie. La construccion social y politica del inmigrante como amenaza", Papers: Revista de Sociologia, 2002,66, p. 72.

${ }^{6}$ Ibíd., pp. 68-69.
} 
etnicista, generador de discursos de inseguridad y que emplea el color de piel como principal fuente de diferenciación, es posteriormente utilizado para justificar el establecimiento de políticas de inmigración más restrictivas o para representar el colectivo negro como un colectivo criminalizado. Por otro lado, desde determinadas políticas públicas la población africana ha sido sometida a una suerte de "invisibilidad social" que vuelve a negar su existencia y la sitúa de nuevo una zona del no-ser. El no reconocimiento de la discriminación y segregación que esta sufre por motivos raciales provoca que determinados colectivos se encuentren permanentemente marginalizados y excluidos de los circuitos de influencia social lo que contribuye a su guetización y a su relegación a espacios privados.

Entre el entramado de construcciones discursivas que conforman la imagen del negro africano están todas las referencias relativas a las particularidades culturales de la población negra que impedirían su integración cultural. El negro africano es "una figura de la carencia y de la diferencia cultural, como una figura de alteridad radical; de la aliedad". ${ }^{7}$ En este sentido, las dinámicas y posibilidades de integración no son solo puestas fuera de la sociedad que recibe, sino que las dificultades de integración de determinadas personas y colectivos negros son atribuidas a una "cultura defectuosa" que les impide integrar las pautas culturales que se suponen adecuadas en las sociedades de destino. Esta desvalorización constante de su capital cultural les lleva a un desprestigio social que les convierte en menos válidos y menos capaces para desarrollar determinadas acciones. De esta forma, en el terreno laboral, la población negro africana es identificada como aquella que no posee cualificación y que por lo tanto debe ser considerada como mano de obra barata. En este ámbito, así como en el social, los negros africanos se erigen como una competencia por los recursos sociales y por el trabajo en tanto que, independientemente de su situación jurídico administrativa y fiscal, son penados como aquellos que, sin haber adquirido los derechos, copan todas las ayudas públicas, impidiendo que la población autóctona pueda ser beneficiaria.

Podríamos decir también que el negro africano ha sido construido como un colectivo homogéneo que es el "totalmente otro", el extraño, el externo, el ajeno que

\footnotetext{
7 Enrique SANTAMARÍA LOZANO: "Imaginación sociológica y migraciones transnacionales", en Carmen LARREA KILLINGER y Ferrán ESTRADA BONELL (editores) Antropología en un mundo en transformación, Barcelona, Universitat de Barcelona (col. Estudis d'Antropologia Social i Cultural), 2004, p. 68.
} 
posee un componente "exótico", a caballo entre su esencia débil y el desconocimiento que sobre él se tiene, y que, en su imagen más benigna, se constituye como la condición de posibilidad de la bondad del hombre blanco. La imagen del negro como víctima y como necesitado de ayuda invierte el sujeto de la acción para situar al hombre blanco como garante de dicha ayuda y como el único capaz de proveer oportunidades vitales a esta población. Las actitudes paternalistas y asistencialistas a las que se somete a esta población son un signo más del infantilismo al que los negros africanos deben hacer frente en su relación con los blancos. ${ }^{8}$

"Lo negro" ha sido históricamente definido desde "lo blanco" ejerciendo así una violencia formal y simbólica al imponer, por un lado, ciertas categorías pensadas desde otros contextos que únicamente contribuyen a crear una imagen desventajada y distorsionada del negro y, por otro, al negar la capacidad de "lo negro" para definirse a sí mismo. Estas dinámicas recogidas por Edward Said ${ }^{9}$ en Orientalismo, están imbricadas en el argumento de poder/saber de Foucault cuyo resultado es una forma de conocimiento y representación racializada del "otro" en la que quien describe, domina ${ }^{10}$ y subordina ${ }^{11}$. De acuerdo con estos procedimientos, se siguen reproduciendo distintas formas de dominación basadas en la superioridad epistémica de "lo blanco" sustentadas, a su vez, en la auto-atribuida hegemonía cultural de Occidente.

En definitiva, el negro/africano, cuyo significado peyorativo emerge de la experiencia conquistadora y colonizadora de los poderes europeos, nace para oponerse a lo europeo y occidental, representando éstos últimos el progreso y la civilización y autoatribuyéndose todos los logros éticos y técnicos de la experiencia humana. ${ }^{12} \mathrm{Y}$ a consecuencia de esta posición nada cómoda a la que se ven sometidos los significados de

\footnotetext{
${ }^{8}$ Véase para el caso concreto del colonialismo español y la construcción del negro como homo infantilis a: Javier BANDRÉS y Rafael LLAVONA, "Psicología y Colonialismo en España (II): en busca del Cociente Intelectual del Negro", Psychologia Latina, 1(2), 2010, pp. 154-162. http://psicologia.ucm.es/data/cont/docs/29-2013-04-25-art12.pdf

${ }^{9}$ Edward W. SAID: Orientalismo, Barcelona, Editorial Anagrama, 1978.

${ }^{10}$ Ted L. SCHEFFLER: "The Ideology of Binary Opposition: Subject/object Duality and Anthropology." Dialectical Anthropology, 6, no. 2, 1981, p. 166.

${ }^{11}$ Bryan S. TURNER: Orientalism, Posmodernism and Globalism, London, Routledge, 1994, p. 21.

${ }^{12}$ Véase obras de prestigiosos investigadores africanos como Valentin-Yves MUDIMBE: The invention of Africa. Gnosis, philosophy, and the order of knowledge, Indianapolis, Indiana University Press. 1988; e ÍD: The idea Africa, London, Indiana University Press, 1994; Achille MBEMBE: Crítica de la Razón Negra. Ensayo sobre el racismo contemporáneo, Ulzama, NED Ediciones, 2016.
} 
¿Pueden ser útiles los cuentos populares y la tradición oral africana para deconstruir estereotipos de raíz colonial?

las palabras negro y africano, cualquier científico debe desmentir una amplia gama de "afirmaciones inferiorizadoras antes de poder empezar cualquier trabajo sobre África". ${ }^{13}$

\section{La historia oral. Una historia de los sin poder}

En su obra cumbre Oralidad y escritura: tecnologías de la palabra de 1982 el historiador cultural y lingüista Walter Jackson Ong afirmó que,

a pesar de las raíces orales de toda articulación verbal, durante siglos el análisis científico y literario de la lengua y la literatura ha evitado, hasta años muy recientes, la oralidad. Los textos han clamado atención de manera tan imperiosa que generalmente se ha tendido a considerar las creaciones orales como variantes de las producciones escritas; o bien como indignas del estudio especializado serio. ${ }^{14}$

Quince años más tarde Jacint Creus, denunciaba en las primeras páginas de su obra Identidad y conflicto. Aproximación a la tradicional oral en Guinea Ecuatorial la facilidad con la que aceptamos clichés primitivos sobre la literatura oral en vez de hacer de ella un verdadero objeto de estudio. ${ }^{15} \mathrm{Y}$ es que desgraciadamente, relegar a un segundo plano lo oral frente a lo escrito no es sino una muestra de eurocentrismo, pues se pretende presentar la experiencia europea y occidental como la punta de lanza de una carrera hacia el desarrollo, quedando la oralidad relegada a la experiencia de pueblos, considerados desde este perspectiva, como prehistóricos o carentes realmente de historia. ${ }^{16}$

Sin embargo, ello no puede hacernos olvidar una serie de problemas a la hora de enfrentarnos a las fuentes orales. José Miguel Marinas nos señala acertadamente que a la hora de trabajar con historias de vida, así como con tradición oral y los cuentos populares, nos encontramos con una serie de componentes limitadores llamados síntoma, simulacro, reproducción del discurso e invención y que hacen alusión a que todo lo reproducido

\footnotetext{
${ }^{13}$ Antumi TOASIJÉ: Si me preguntáis por el Panafricanismo y la Afrocentricidad. Artículos, conferencias, discursos y entrevistas..., Madrid, Centro de Estudios Panafricanos, Kituo ya Masomo cha Wanafrica, 2013, p. 220.

14 Walter J. ONG: Oralidad y escritura: tecnologías de la palabra México D.F., Fondo de Cultura Económica, 2011, p. 18.

15 Jacint CREUS: Identidad y conflicto. Aproximación a la tradición oral en Guinea Ecuatorial, Madrid, La Catarata, 1997, p. 15.

16 José Manuel MAROTO BLANCO y Miriam BOLÍVAR MUELA: “África y la Prehistoria: la conceptualización de un continente basándose en el prejuicio de la no historia y la atribución de valores "prehistóricos", en Alia VÁZQUEZ MARTÍNEZ, Rebeca CORDEIRO MACENLLE, Miguel CARRERO PAZOS, Mikel DÍAZ RODRÍGUEZ, Alba Antía RODRÍGUEZ NÓVOA y Benito VILAS ESTÉVEZ (Ed): (Re) escribiendo a Historia. Achegas dos novos investigadores en Arqueoloxía e Ciencias da Antigüidade, Santiago de Compostela, Andavira Editora, 2017, pp. 99-112.
} 
oralmente no deja de ser una construcción social, hija de un tiempo y un espacio determinado y que está sujeta a sucesivos cambios conforme se va repitiendo por las personas y los colectivos. ${ }^{17}$

Para el historiador africano Joseph Ki-Zerbo, la tradición oral ofrece a través de un uso metodológico apropiado, un grado de certeza suficiente para poder construir un relato histórico veraz. El problema no reside ni en legitimar la historia oral como adecuada o no, ya que cada relato oral sufre de la subjetividad de los autores al igual que el relato escrito, ni en conocer si "goza de apoyos exteriores", es decir, si existen otro tipo de fuentes que las avalen. La clave está en "conocer qué método es preciso adoptar para estudiar las tradiciones y seleccionar, del modo más seguro, las que sean dignas de servir de fuentes históricas". ${ }^{18}$

Y pese a que la fuente oral ha sido fuertemente criticada por todo un conjunto de limitaciones que no vamos a negar, existen áreas de la historia como la propia historia social, la historia local, la historia de la familia, la historia con perspectiva de género o la historia de la política entre otras, donde las fuentes orales tienen un papel fundamental para perfeccionar el relato histórico. Ni que decir tiene, como asegura Pilar Folguera, que "la fuente oral es sobre todo de especial interés en aquellos casos en los que se quieren analizar aspectos de la realidad histórica referidos fundamentalmente al campo de las ideas o de las mentalidades". ${ }^{19}$

Por otro lado, la historia oral nos permite realizar un juicio mucho más equitativo de la historia, ya que permite contar con el testimonio de individuos y colectivos que han tenido un papel subalterno o no han formado parte del discurso hegemónico. Así, las clases bajas, los desheredados, los derrotados, en definitiva, aquellos que han formado y forman parte de la zona del no-ser pueden ver como sus "historias" son puestas en valor. Esto “propicia una reconstrucción del pasado más realista y más justa, una alternativa a la interpretación establecida. De este modo la historia oral tiene unas implicaciones radicales para el mensaje social de la Historia en su conjunto". ${ }^{20}$

\footnotetext{
${ }^{17}$ José Miguel MARINAS: La escucha en la historia oral. Palabra dada, Madrid, Editorial Síntesis, 2007, p. 77.

${ }^{18}$ Joseph KI-ZERBO: Historia del África negra. I. De los orígenes al siglo XIX, Madrid, Alianza Editorial, 1980, pp. 26-27.

${ }^{19}$ Pilar FOLGUERA: Cómo se hace historia oral, Salamanca, Eudema, 1994, p. 14.

${ }^{20}$ Paul THOMPSON: La voz del pasado. Historia oral, Valencia, Alfons el Magnànim. 1988, p. 14.
} 
¿Pueden ser útiles los cuentos populares y la tradición oral africana para deconstruir estereotipos de raíz

La recuperación del testimonio de individuos y grupos debe ser un elemento central $^{21}$, así como sus formas de relacionarse entre sí y de pensar en momentos determinados. No hay emancipación si no hay historia y es que:

el carácter renovador de la historia oral consiste en considerar que ésta permite una mayor aproximación a la realidad de aquellos grupos sociales alejados de las esferas de poder y que por ello no han dejado testimonio escrito de su experiencia y su participación en la Historia ${ }^{22}$.

Además, el hecho de que la historia oral sea tan antigua como la Historia misma y que "la destreza en el manejo de la evidencia oral sólo ha dejado de ser un rasgo del gran historiador en época bastante reciente" ${ }^{23}$ nos obliga a replantearnos el escaso protagonismo que se le ha dado tradicionalmente, más si cabe cuando la historia oral no se queda en un mero cambio de enfoque, sino que puede abrir también nuevas e importantes áreas de investigación". ${ }^{24}$

Por otro lado, hay que trascender la idea de que la historia oral permite reconstruir la Historia únicamente a través de historias individuales. Pueblos que se han expresado fundamentalmente de manera oral a lo largo del tiempo verían lastrada su utilidad, ya que la transmisión de la historia común ha sido un proceso social en donde la palabra hablada ha jugado un papel imprescindible. De hecho, este "interés" comunitario en la palabra hace "más probable que se dé una memoria exacta cuando hay en liza un interés social o una necesidad". 25

La construcción de la memoria tanto individual como colectiva del pasado, al igual que su difusión, es un proceso social activo que requiere unas destrezas, un arte, aprende de los demás y una capacidad imaginativa. Sus historias sirven sobre todo para caracterizar comunidades e individuos y para transmitir sus actitudes. ${ }^{26}$

Así mismo, la historia oral, que es clave para entender la conciencia colectiva de un pueblo a través de las transmisiones a lo largo del tiempo "puede ser utilizada por todos

\footnotetext{
${ }^{21}$ Antonio M. RODRÍGUEZ GARCÍA, Rosa M. LUQUE PÉREZ y Ana M. NAVAS SÁNCHEZ: "Usos y beneficios de la Historia Oral", en ReiDoCrea: Revista electrónica de investigación y docencia, Granada, 3, 2014, p. 199 [Consultado el día 15 de septiembre de 2016 en la web http://digibug.ugr.es/bitstream /10481/32326/6/ReiDoCrea3-A24.pdf].

${ }^{22}$ Pilar FOLGUERA: Cómo se hace historia ... p. 7.

${ }^{23}$ Paul THOMPSON: La voz del pasado... p. 31.

${ }^{24}$ Ibid., p. 15.

${ }^{25}$ Ibid., p. 130.

${ }^{26}$ Paul THOMPSON: La voz del pasado. Historia... p. 159.
} 
aquellos que deseen rescatar y salvaguardar [...] la construcción de esa comunidad u organización". ${ }^{27}$ De esta manera la historia oral se erige como un instrumento imprescindible para reivindicar la historicidad de los pueblos africanos del pasado y para luchar contra las barreras simbólicas que sitúan a los negros africanos/as en la zona del no-ser.

\title{
La fuerza de la palabra en el África negra
}

Se cuenta que fue en 1962, año en el que Amadou Hampaté Ba estaba inmerso en una acción urgente para rescatar y poder así recopilar tradiciones orales africanas, cuando éste pronunció una de las frases más recordadas y que se ha hecho tan celebre que es citada como si de un proverbio africano se tratase: "En África cuando un anciano muere, una biblioteca arde". ${ }^{28}$ Esta oración no hace sino alusión a la importancia de la palabra en las sociedades africanas, palabra llena de conocimiento que es transmitida de los más ancianos a los más jóvenes.

El propio Hampaté Ba ya nos dejó claro que

\begin{abstract}
Ningún intento de penetrar la historia y el alma de los pueblos africanos podría ser válido si aquélla no se apoya en esa herencia de conocimientos de todo orden, pacientemente transmitidos de boca a oído y de maestro a discípulo a través de los tiempos. ${ }^{29}$
\end{abstract}

Este etnólogo maliense que trabajó en el marco de la UNESCO entre 1962 y 1970 como miembro del Consejo ejecutivo, consideró la tradición oral como "la gran escuela de la vida, que recubre y abarca todos los aspectos", ${ }^{30}$ siendo tal su complejidad y su particularidad africana, que podría "parecer un caos a aquel que no penetra su secreto y desconcertar al espíritu cartesiano habituado a dividir todo en categorías bien definidas". ${ }^{31}$ Y es que adentrarse en la historia oral es adentrarse en un mundo en donde lo espiritual y lo material no están disociados y en donde la palabra hablada dialoga con la sociedad que la escucha, lo representa todo, desde la religión hasta el conocimiento de la naturaleza pasando por la diversión y, evidentemente, por la Historia. ${ }^{32}$

\footnotetext{
${ }^{27}$ Pilar FOLGUERA: Cómo se hace historia... p. 91.

${ }^{28}$ Amadou HAMPATÉ BA: Cuentos de los sabios de África, Madrid, Paidós, 2010, p. 12.

${ }^{29}$ Amadou HAMPATÉ BA: "La tradición viviente", Joseph KI-ZERBO (ed): Historia general de África. I. Metodología y prehistoria africana, Madrid, UNESCO, Tecnos, 1980, p. 185.

${ }^{30}$ Ibid., p. 187

${ }^{31}$ Ibid., p. 187

${ }^{32}$ Ibid., p. 187.
} 
El historiador recientemente fallecido Jan Vansina, puso siempre en valor lo transmitido oralmente, ya que ello afectaba desde los estatutos sociales, hasta los derechos y obligaciones de cada persona dentro del grupo. La importancia de la tradición en una sociedad oral hace que la palabra lo abarque todo, algo que no siempre captaron los historiadores, cuando muchos han caído inducidos "a error cuando creían que las tradiciones eran una especie de cuentos de Calleja, de canciones de cuna o de juegos de niños". 33

Además, la capacidad que tienen las culturas orales que no utilizan o utilizaron la escritura para reunir conocimientos populares en "manifestaciones relativamente sustanciales y extensas que resultan razonablemente perdurables", ${ }^{34}$ es de enorme importancia. Esta perdurabilidad se justifica porque las narraciones producidas, sean extensas o no, están sujetas a la repetición y acaban erigiéndose como "las depositarias más amplias del saber popular de una cultura oral". ${ }^{35}$ He aquí donde hallamos utilidad e interés en las narraciones, lo que las hace más sólidas al paso del tiempo.

Pese a que la cultura de la mayoría de sociedades africanas es oral y han sido las personas mayores fundamentalmente las encargadas de transmitirla "cuando encuentran a alguien que quiera escucharles" ${ }^{36}$ esto es cada día más difícil, ya que las escuelas alfabetizan desde cánones occidentales, lo que obliga a las sociedades africanas a aceptar una concepción de "progreso" cada vez más globalizada. ${ }^{37}$ No obstante, Ambrosio Ipuwa, uno de los informantes de Jacint Creus, nos avisa: "Pero tened cuidado, porque nos quedan muchas cosas en el recuerdo". 38

Si bien la tradición oral ha pasado del descrédito a la relativa aceptación (pasando por estadios en los que se la ha considerado mucho menos fiables que la escrita a pesar de tratarse del contexto africano), ${ }^{39}$ lo oral también ha sido importante en sociedades de otros continentes. De hecho, los skald escandinavos (poetas guerreros vikingos de la corte

\footnotetext{
${ }^{33}$ J. VANSINA: "La tradición oral y su metodología”, Joseph KI-ZERBO (ed): Historia general de África. I. Metodología y prehistoria africana, Madrid: UNESCO-Tecnos, p. 167.

${ }^{34}$ Walter J. ONG: Oralidad y escritura ..., p. 138.

${ }^{35}$ Ibid., p. 138.

${ }^{36}$ Agnès AGBOTON: Eté Utú. (Cuentos de tradición oral). De por qué en África las cosas son lo que son, Palma de Mallorca, José J. de Olañeta, 2009, p. 9.

${ }^{37}$ Ibid., p. 9.

${ }^{38}$ Jacint CREUS: Identidad y conflicto. Aproximación a la tradición oral..., p. 16.

${ }^{39}$ Joseph KI-ZERBO: Historia del África negra. I. De los orígenes al siglo XIX, Madrid, Alianza Editorial, 1980 , p. 26.
} 
real) o los rajput ${ }^{40}$ (miembro de un clan de la india), así como el propio mester de juglaría en España, que alude a poesía de carácter popular que se difundió durante la Edad Media, dejan constancia de ello.

Sin embargo, a pesar de que se han reconocido a los maestros de la palabra en África (guardianes de la memoria tradicional), durante la época colonial se atribuyeron estos comportamientos a un estado de civilización menor del africano "recurriendo a un evolucionismo unilineal más o menos velado" 41 que tiene implicaciones hasta nuestros días. No debemos olvidar que aunque hace ya más de medio siglo que comenzó la década de las independencias en África, la literatura oral, en palabras de Mamá Ganet de ochenta años, para los europeos no es sino algo "dulce pero que debe situarse bajo la reputación de cosas antiguas". 42

\section{Carta de Mandén: Los africanos se adelantaron a los europeos}

El caso paradigmático de la Carta de Madén, iniciada en 1222 y adoptada en 1236 en Kurukan Fuga (antiguo imperio de Malí) por Sundiata Keita, es el ejemplo más antiguo que consta en el desarrollo de instrumentos jurídicos para la protección de DDHH. No ha sido, sino mediante la transmisión oral, como nos ha llegado su apuesta por "el derecho a la vida, a la integridad física, y a la propiedad". ${ }^{43}$

De hecho, Sundiata Keita y sus hazañas políticas están íntimamente ligadas a la aprobación de esta carta en 1236, ya que se erigió como una auténtica Constitución del nuevo imperio de Malí y que tuvieron como objetivo, por un lado, conseguir la unidad de un imperio muy heterogéneo y, por otro, garantizar una paz estable. ${ }^{44}$ Es destacable que

\footnotetext{
${ }^{40}$ Paul THOMPSON: La voz del pasado..., p. 33.

${ }^{41}$ Albert ROCA y Ferrán INIESTA: "Raíces: ¿Por qué la historia es un conocimiento vital en el África del siglo XXI?”, en Antonio SANTAMARÍA y Jorge GARCÍA BURGOS (coords.): Regreso al futuro. Cultura y desarrollo en África, Madrid, La catarata, 2013, pp. 15-16.

42 Jacint CREUS: Identidad y conflicto ... p. 15.

${ }^{43}$ Eric TARDIFF: "Acercamiento al sistema africano de protección de los Derechos Humanos: avances y retos", Anuario de Derechos Humanos, 9 (2013), p. 140. http://revistaestudiosarabes.uchile.cl/index.php /ADH/article/viewPDFInterstitial/27058/28692; Véase también Raymond WEBER: "Quelle gouvernance pour la culture et le secteur culturel?". Kultur: revista interdisciplinària sobre la cultura de la ciutat, 1(1) (2014), pp. 69-100, dentro de una exposición mayor sobre gobernanza cultural a nivel global; En el trabajo Siriman KOUYATE: "La Charte de Kurukan Fuga". Atelier régional de concertation entre traditionalistes mandingues et communicateurs des Radios Rurales, Kankan, Republic of Guinea: Radio Rurale de Guinee. (Kankan du 02 au 12 mars 1998) http://www.aaalfa.org/doc/KaboreLaCharteDeKurukafuga.pdf podemos tener acceso a la Carta de Mandén y a un comentario realizado entre expertos en las temáticas mandingas. ${ }^{44}$ Carlos BAJO ERRO: "La aportación de Sundjata Keita. Derechos huma-nos antes de los derechos humanos", Nova Africa, 27 (2012), p. 8, http://www.africafundacion.org/IMG/pdf/Bajo_Erro_aportacion _de_Sundjata_Keita.pdf.
} 
¿Pueden ser útiles los cuentos populares y la tradición oral africana para deconstruir estereotipos de raíz

en la Carta de Manden se hable del derecho a la vida o de la protección a mujeres y niños, partiendo de la premisa de que la educación de los más pequeños incumbe a todos los miembros de la comunidad y que las mujeres hay que tratarlas bien porque, como nos cuenta la tradición, son nuestras madres.

En la línea de Sanou Mbaye ${ }^{45}$ debemos destacar que la recuperación de la Carta de Mandén pone en cuestión que los buenos valores hayan sido institucionalizados por primera vez en Occidente. El siguiente fragmento de la Carta pone de manifiesto el respeto a la libertad individual, la apuesta por la solidaridad o su oposición al sistema de esclavitud:

Los cazadores declaran: toda vida humana es una vida. [...] pero una vida no es más "antigua", más respetable que otra. [...] Los cazadores declaran: el hambre no es una buena cosa, la esclavitud tampoco lo es; son las peores calamidades que pueden suceder en este bajo mundo. [...] nadie colocará a partir de ahora el freno en la boca de su semejante para llevarlo a la venta; nadie será tampoco azotado, mucho menos ejecutado, porque sea hijo de esclavo. Los cazadores declaran: el espíritu de la esclavitud se ha apagado desde el día de hoy [...] En consecuencia, los cazadores declaran: a partir de ahora, todos son dueños de su persona, a partir de ahora, cada uno es libre de sus actos, cada uno dispone de los frutos de su trabajo. Éste es el juramento de Manden, que todo el mundo lo oiga. ${ }^{46}$

Sin duda se trata de un precedente de inspiración únicamente africana que adelanta en más de siete siglos a la Carta africana de los derechos humanos y de los pueblos en 1986, conocida como carta Banjul. ${ }^{47}$ Pero no debemos quedarnos aquí. Como asegura Nick Nesbitt, una de las lecciones de la Carta Manden es que rompe con la idea de que la dignidad humana o los DDHH nacen en este mundo de las mentes de los ilustrados europeos. Supera en el tiempo ideas como la de la universalización de la dignidad humana de la ética kantiana cuando afirma que:

\footnotetext{
${ }^{45}$ Sanou MBAYE: África al socorro de África, Madrid: Los Libros de La Catarata, 2010.

${ }^{46}$ Ibid., pp. 133-134.

${ }^{47}$ Entre otros sistemas de protección jurídicos tenemos la Convención de la OUA sobre refugiados, adoptada en 1969; la Carta africana sobre los derechos y el bienestar del niño (1990); la Convención de Bamako sobre desechos peligrosos (1991); el Protocolo sobre los derechos de las mujeres en África (2003); la Convención de la Unión africana sobre la prevención y el combate a la corrupción (2003); y, la Carta africana sobre democracia, elecciones y buen gobierno (2007). Cabe destacar la Declaración y Plan de acción de Grand Bay de 1999. Recogido de Eric TARDIFF, Acercamiento al sistema africano de protección de los Derechos Humanos: avances y retos, Anuario de Derechos Humanos, 9, 2013, p. 143, http://revistaestudiosarabes.uchile.cl/index.php/ADH/article/viewPDFInterstitial/27058/28692.
} 
Everyone has the right to life and the preservation of his physical integrity. Consequently, any attempt to take the life of one's fellow man is to be punished by death ${ }^{48}$.

Así mismo, la Carta Manden fue la primera declaración que se conoce que, con mucha más antelación que otros escritos como la Pensylvania Constitution de 1776 o la Déclaration des droits de l'homme et du citoyen aprobada por la Asamblea Nacional Constituyente francesa en 1789, fundó un régimen político con una clara vocación emancipadora. ${ }^{49}$ Antecede incluso la Magna Carta o Magna charta libertatum presentada en su versión última a Carlos I de Inglaterra en 1297 d.C. quedando demostrado que ni Europa inventó los DDHH ni "tampoco inventó la idea de dignidad humana" 50

A parte de todo lo que significa la Carta Manden, hay que destacar que se ha llegado al reconocimiento como el antecedente más remoto de los DDHH a través de la recuperación y difusión de ella mediante una iniciativa que organizó una red de radios rurales "que sólo pretendía hacerse eco de una antigua tradición oral común a varios países". 51

Sin embargo, no debemos olvidar que, tristemente y tal y como denuncia Djibril Tamsir Niane, si no llega a ser porque "Ibn Battuta en 1353 y, después de él, Ibn Khaldun, en 1376, no hubieran mencionado al conquistador en sus escritos", ${ }^{52}$ los historiadores occidentales aún creerían que hablar de Sudiata Keita es hablar de un antepasado mítico o legendario habrían considerado ciertamente a Sundjata Keita como a un antepasado mítico o legendario ${ }^{53}$.

Como se muestra anteriormente, la tradición oral africana nos ayuda a deconstruir ideas ampliamente arraigadas en Occidente, y en el resto del mundo a causa de la posición hegemónica del discurso occidental, como que el sistema de protección de DDHH es un

\footnotetext{
${ }^{48}$ Nick NESBITT: "Resolutely Modern: Politics and Human Rights in the Mandingue Charter", The Savannah Review, 4 (2014), pp. 13-17, http://kwasu.edu.ng/kwasupress/The\%20Savannah\%20Review\% 204\%20-\%20Chapter\%202.pdf.

${ }^{49}$ Ibíd., pp. 13-17.

${ }^{50}$ Salvador GARRIDO SOLER: "El papel de la historia en la fundamentación de los derechos humanos: las cartas de Mandén y Kurukán Fuga y su posición en el sistema africano de protección de los derechos humanos", Universitas: Revista de filosofía, derecho y política, 16 (2012), p. 150, http://universitas.idhbc .es/n16/16-07.pdf.

${ }^{51}$ Ibíd., p. 150.

${ }^{52}$ Carlos BAJO ERRO: "La aportación de Sundjata Keita..." p. 1, http://www.africafundacion.org /IMG/pdf/Bajo_Erro_aportacion_de_Sundjata_Keita.pdf.

${ }^{53}$ Ibid., p. 1.
} 
¿Pueden ser útiles los cuentos populares y la tradición oral africana para deconstruir estereotipos de raíz

invento occidental y al cual nada han aportado el resto de los mortales. Como ya señalara Paulin Hountondj

Ciertamente Europa no inventó los derechos humanos, como tampoco inventó la idea de dignidad humana. Simplemente fue capaz de realizar sobre este tema -y ese fue su méritouna investigación sistemática que adquirió la forma de una discusión progresiva abierta. De esta forma produjo, no la cosa, sino el discurso sobre la cosa, no la idea del derecho natural o de la dignidad humana, sino el trabajo de expresión relativo a esa idea, el proyecto de su formulación y sus consecuencias, en resumen, el proyecto de una filosofía de los derechos humanos $^{54}$.

\section{La transmisión de valores a través de los cuentos populares africanos}

"La transmisión oral ha sido desde el comienzo de la historia de la humanidad la forma más tradicional de aprender" ${ }^{\prime 55}$. En este proceso de aprendizaje, el cuento, el relato o la leyenda han jugado un papel fundamental, ya que su finalidad ha transcendido la del mero entretenimiento. Además, "las narraciones sirven de lazo vehicular entre los pueblos, sus generaciones y sus tradiciones"56 y, tal y como comentábamos anteriormente, en África ha sido el anciano el que se ha dedicado a transmitir saberes a los más jóvenes. Pese a que instituciones como la escuela han propiciado que estas prácticas sean cada vez menos comunes, es también la escritura la que ha permitido recuperar y salvar de la extinción miles de cuentos populares africanos. Así mismo, la imagen del cuento contado por un anciano sigue siendo utilizada por instituciones africanas como símbolo de la transmisión de conocimiento y valores.

El Laboratoire Genre et Recherche scientifique de l'Ifan de la Université Cheikh Anta Diop de Dakar ha publicado revisiones de cuentos en formato tebeo que tienen como objetivo "réécrir l'histoire des héroïnes du Senegal, pour rappeler à la jeunesse qu'elle peut s'adosser à ses propres valeurs pour mene le combat de l'égalité de genre"57 a través

\footnotetext{
${ }^{54}$ Paulin HOUNTONDJI: "Observaciones sobre el problema de los derechos humanos en África", en VVAA: Los fundamentos filosóficos de los derechos humanos, Barcelona, Ediciones del Serbal-Unesco, 1985, p. 355.

${ }^{55}$ Pilar FOLGUERA: Cómo se hace historia... p. 73.

${ }^{56}$ Mamaru BNGONE y Olga ROIG: Cuentos africanos. Al ponerse el sol: historias, relatos y metáforas, Madrid, Ediciones Karma 7, 2009, p. 10.

${ }^{57}$ Fatou SARR: “Avant propos", Laboratoire Genre et Recherche scientifique de l'Ifan, Ndatte Yalla Mbodj. Reine du Waalo (1846-1855), Dakar, Université Cheikh Anta Diop, 2011, p. 4.
} 
de la puesta en valor de las figuras femeninas en los acontecimientos más importantes de la historia de Senegal. ${ }^{58}$

Imagen 1. Talaatay Nder. La véritable histoire de Nder racontée aux enfants

Fuente: Talaatay Nder. La véritable histoire de Nder racontée aux enfants, Dakar, Université Cheikh Anta Diop, 2010, p. 5.

En la Imagen 1 aparece la figura del anciano contando un cuento y son un claro ejemplo de cómo se busca un reconocimiento entre los dibujos y el lector y una simbiosis

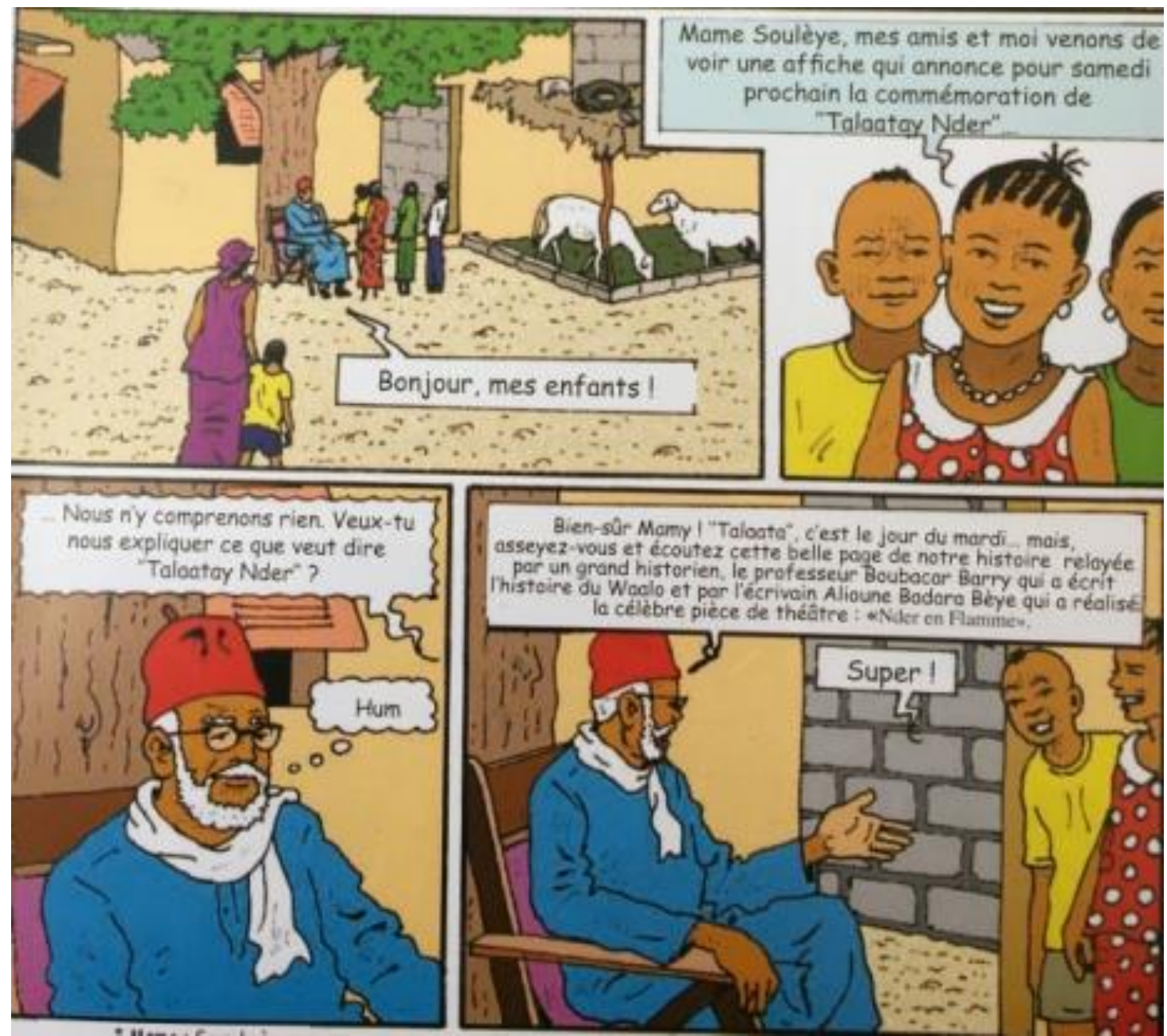

entre el conocimiento histórico y valores como la dignidad o, en estos tebeos reseñados, la importancia de la mujer en la historia de Senegal. De hecho, estos cuentos narran acontecimientos históricos bien definidos y contrastados por otras fuentes y que recogen una visión afrocéntrica de los acontecimientos, escapando así de una reconstrucción

\footnotetext{
${ }^{58}$ Véase otros ejemplos elaborados bajo la dirección de Fatou Sarr como: Talaatay NDER, La véritable histoire de Nder racontée aux enfants, Dakar, Université Cheikh Anta Diop, 2010, en donde se narra la primera fuerza de resistencia a la invasión colonial francesa y cómo esta fue dirigida por una mujer.
} 
histórica dependiente de los relatos de los reinos de la zona del Magreb o de los escritores franceses.

Los hechos narrados corresponden a la defensa de Nder, capital del reino de Waloo (en el actual Senegal) el 7 de marzo de 1820 de las fuerzas enemigas bereberes y fulanis, así como a la subida al trono de la reina Ndatté Yalla. Esto será considerado un ejemplo de cómo el rol de las mujeres se ha construido socialmente a lo largo de la historia de una manera distinta a la establecida por Occidente. Y pese a su traducción al francés, consiguen plasmar el sentido de la historia. No obstante, sí que es cierto que a la hora de transcribir lo oral, perdemos, desgraciadamente, "una infinidad de matices, porque ni el gesto, ni el tono, ni la malicia en la mirada del narrador son plasmables; y no lo son, tampoco, las risas y la mayoría de las interrupciones de la alboroza audiencia". ${ }^{59}$ A ello hay que añadir que la traducción de una lengua africana a una lengua romance transforma ostensiblemente el relato. ${ }^{60}$

Este problema se acentúa cuando los cuentos no tienen tanto un carácter histórico, sino que están destinados a transmitir alguna enseñanza a los más pequeños y para ello se recurre a las fábulas cuyos protagonistas son animales. La colección de Amadou Hampaté Ba recoge, bajo el título de Cuentos de los sabios de África, una serie de catorce cuentos africanos tradicionales destinados a ser un instrumento con el que el lector/a pueda dialogar con la sabiduría de sus palabras. En todas ellas aprendemos enseñanzas de distintos pueblos africanos y, a través de sus moralejas, podemos comprender de una forma más precisa el carácter tradicional de diversas sociedades, fundamentalmente del África Occidental.

De este modo, podemos observar cómo estas narraciones están orientadas, no sólo a explicar el origen del mundo o de determinados pueblos, sino también a instruir a aquellas personas que las escuchan en valores cívicos como la humildad, la lucha contra el despotismo, los males de la mentira o la resolución pacífica de los conflictos.

La pelea de los dos lagartos, ${ }^{61}$ por ejemplo, cuenta la historia de una anciana que debe custodiar la casa ante la ausencia de sus familiares y, ante el cansancio que siente,

\footnotetext{
${ }^{59}$ Agnès AGBOTON: Eté Utú. (Cuentos de tradición oral... p. 10

${ }^{60}$ Ibid., p. 10

${ }^{61}$ Este cuento hace alusión al cuento utilizado por Amadou Hampaté Ba con motivo del conflicto árabeisraelí en el Consejo ejecutivo de la UNESCO en octubre de 1969.
} 
manda al perro a realizar la labor. Un día, el perro, alertado por un ruido que proviene de la cabaña de la madre, decide preguntarle al gallo sobre este asunto, a lo cual le responde que se trata de dos lagartos que se están peleando y que, si quiere separarlos para que no se peleen más y dejen de molestar a la anciana, vaya él sólo. El perro, que no debe moverse ya que está custodiando la casa, le pide ayuda al macho cabrío primero, y al caballo y al buey después, que rechazan de malas maneras echarle una mano. Al rato, los lagartos que se peleaban cayeron del tejado tirando al suelo una lámpara de aceite e incendiando la casa. La madre sufrió unas terribles quemaduras que acabaron con su vida.

Desde que se intentó sanar a la madre hasta que se celebraron los rituales de enterramiento fueron necesarios elaborar un caldo de pollo (con la carne del gallo), ir a prisa a caballo hacia donde estaba la familia de la madre (provocando la muerte por extenuación del semental), sacrificar un macho cabrío y, a los cuarenta días, cuando se celebraba una fiesta en honor a la madre, dotar a los invitados de carne, para lo que se sacrificó, en esta ocasión, al buey.

En palabras de Hampaté Ba, en África, los ancianos enseñan a los jóvenes:

Si presenciáis una pelea, por pequeña que sea, intervenid, separad a los combatientes y haced todo lo posible por reconciliarlos. Pues el fuego y las peleas son las dos únicas cosas que, en este mundo, pueden engendrar hijos más colosales que ellos mismos: un incendio o una guerra. ${ }^{62}$

En El loco y el rey, el rey Hediala, terco y malvado, pone a prueba a un sabio preguntándole:

Cuando dejas caer un palo dentro de un mortero vacío, el ruido que hace ¿sale del mortero o del palo? Piénsalo bien y contesta, de lo contrario ordenaré que te ahorquen inmediatamente.

El sabio guardó unos minutos de silencia y dijo:

-El ruido sale de ambos.

-Pero ¿en qué proporción?

\footnotetext{
${ }^{62}$ Cuento tradicional del pueblo peul "La pelea de los dos lagartos", Amadou HAMPATÉ BA: Cuentos de los sabios de África, Madrid, Paidós, 2010, p. 42-43.
} 
¿Pueden ser útiles los cuentos populares y la tradición oral africana para deconstruir estereotipos de raíz

El sabio, que se sentía incapaz de contestar esta pregunta, vio como aparecía un loco que se acercaba al rey al tiempo que le propinaba un guantazo y le decía "y ahora dime, oh, rey, ¿de dónde sale el ruido, de tu mano o de mi mejilla, y en qué proporción?”. 63

La solidaridad es también un valor que aparece reflejado con mucha frecuencia en los cuentos populares africanos. El cuento de La lechuza y el artesano nos narra la historia de un hombre llamado Mawu que quedó maravillado al ver como un halcón daba de comer todos los días a una lechuza que era ciega e incapaz de cazar. Esto le llevó a la conclusión de que dios no dejaba a nadie sin cuidar y, debido a ello, decidió no volver a trabajar jamás. Un día, un vecino y amigo lo encontró pidiendo limosna y, al escuchar la historia de Mawu, le dijo:

-Querido Mawu, creo que no has entendido nada de lo que Dios te ha querido decir. Si te mostró la escena, no lo hizo para que tú te comportaras como la lechuza ciega, sino para que imitases al halcón que ayudó a un ser más necesitado que él. Tú debes ser caritativo, bondadoso, y ayudar a quienes te necesitan.

Mawu, entonces, regresó al trabajo con más empeño que antes para tener con qué ayudar a los demás, más pobres que él. ${ }^{64}$

El respeto al prójimo se ve reflejado, por ejemplo, en el cuento ¿Por qué no debemos reírnos del prójimo? ${ }^{65}$ de los gun del Bénin del Golfo de Guinea. En él se narra la historia de una serie de animales que intentan comerse los unos a los otros y acaban siendo todos la presa de algún otro. Así, la nutria que quería comerse a las langostas acaba en manos de un humano, humano que está siempre vigilado por Aklasu un pájaro carroñero que está siempre al acecho.

Nelson Mandela considera que los cuentos que recopila son "pequeñas muestras de la valerosa esencia de África, que en muchos casos son también universales por el retrato que hacen de la humanidad, de los animales y de los seres místicos". ${ }^{66}$ Los cuentos, por tanto, nos muestran el interés tradicional de los pueblos en inculcar valores positivos a los suyos. Lejos de imaginaciones coloniales, los pueblos africanos, a través de sus cuentos, nos enseñan que lejos del salvajismo y la barbarie, la incultura o la pobreza, las

\footnotetext{
${ }^{63}$ Cuento tradicional del pueblo peul "El loco y el rey", Amadou HAMPATÉ BA: Cuentos de los sabios de África, Madrid, Paidós, 2010, p. 172.

${ }^{64}$ Cuento popular "La lechuza y el artesano", en Mamaru BNGONE y Olga ROIG: Cuentos africanos. Al ponerse el sol: historias, relatos y metáforas, Madrid, Ediciones Karma 7, p. 10.

${ }^{65}$ Agnès AGBOTON: Eté Utú. (Cuentos de tradición oral... p. 153-156.

${ }^{66}$ Nelson MANDELA: Mis cuentos africanos, Anzos, Ediciones Siruela, 2013, p. 12.
} 
sociedades africanas han heredado de sus ancestros sistemas de transmisión de valores positivos de generación en generación. Quizá sea hora de reflexionar sobre qué le ha ocurrido a Occidente para que la palabra hoy valga aquí tan poco.

\section{A modo de reflexiones finales}

Es un hecho probado que la representación del negro africano, ya sea en textos históricos o literarios, ha estado marcada por unas lógicas de inferiorización que, transitando entre las elaboraciones más simples hasta aquellas más sutiles, han construido una imagen de lo negro cargada de prejuicios y estereotipos negativos. Estos han sido intencionalmente reproducidos a lo largo del tiempo, tanto por las élites simbólicas occidentales, por la rutina del discurso como por los consensos hegemónicos que, a modo de control ideológico, político y económico, han promovido una imagen denostada de todo un continente.

En la misma línea tenemos que, las formas de transmisión oral de la historia y la cultura, no han permanecido inmunes a la colonización y han sido consideradas por parte de los historiadores occidentales, en el mejor de los casos, como un medio subsidiario de la palabra escrita. Este hecho nos demuestra que la Historia construida desde occidente ha privilegiado un tipo de archivos frente a otros y que, cuando no ha estimado como válidos o rigurosos determinados soportes empíricos, los ha sustituido tanto por elaboraciones acordes a su propio imaginario, como por epistemologías etnocidas y sin pretensiones de abrir paso a "otras historias". A pesar de esto, la tradición oral ha permitido ser un medio para la articulación de la voz de aquellos subalternos que no han tenido acceso a otros modos más reconocidos por parte de los paradigmas occidentales para dejar constancia de sus propias autorepresentaciones y visiones del pasado, del presente y del futuro. De igual modo, los cuentos populares han podido conversar una idiosincrasia particular que de otra forma hubiera sido sustituida por narraciones producidas desde y para un norte global.

El rescate y puesta en valor de la tradición oral y los cuentos populares puede ser un medio útil, eficaz y necesario para comenzar a deconstruir todo el entramado de elaboraciones que desde Occidente se ha hecho sobre África y sobre lo negro, como así lo demuestran los ejemplos expuestos en el texto. La legitimación y validación de los conocimientos producidos por los pueblos africanos es un paso ineludible para caminar 
hacia una ecología del reconocimiento de otros saberes que no podrá tener lugar sin una previa descolonización de las mentes occidentales. En la medida que las jerarquías que la monocultura occidental impuso a los saberes africanos y que los situaban en la zona del no ser sean desechadas, podremos desarrollar nuevas articulaciones entre estos distintos tipos de saberes y otorgarles el reconocimiento y la valía que merecen.

Por otro lado, es tiempo para la revisión crítica de la historia hegemónicamente producida, contada y enseñada que ha convertido a otras historias en inexistentes. Este camino que proponemos no es otro que el de la justicia cognitiva global ampliamente promovida por distintos paradigmas decoloniales desde los cuales se reivindica la urgencia de la reformulación de los aparatajes académicos tradicionales. Este repensar las bases de la Historia nos lleva a la idea de que la comprensión del mundo es mucho más amplia que la comprensión occidental del mundo y que para elaborar estos espacios cognitivos globales, es condición sine ecuánime incluir esas epistemologías "otras" que fueron negadas y prácticamente aniquiladas durante la colonización africana. 


\title{
Memoria familiar, historia de todos: el caso de Francisco Escáneo Franco
}

\author{
Communal history framed by the lens of our ancestors: the case of \\ Francisco Escáneo Franco
}

Aldara Cidrás

Universidade de Santiago de Compostela

\section{Resumen}

¿Cuál es el interés histórico de la memoria familiar en la actualidad? Partiendo de una perspectiva micro, pero universalizante, en este trabajo se procura demostrar a través de un estudio de caso cómo algunos de los grandes axiomas de la historia del siglo XX español ya no se sostienen hoy en día. Para ello, acompañaremos a Francisco Escáneo a lo largo de sus últimos meses de vida en Bueu (Pontevedra), desde febrero a diciembre de 1936. Pero, ¿cómo es posible seguir las pistas de la gente de a pie? El resultado final se tratará de un ensayo que nos obligue a repensar el discurso histórico y metodológico más dominante, apostando por la interrelación entre memoria, historia y literatura.

\section{Palabras clave}

memoria histórica, historia desde abajo, individualismo metodológico, Bueu, guerra civil española

\begin{abstract}
What is the historical interest of family memory nowadays? Using a microhistorical approach, but with the ambition of giving answers to larger problems, in this paper we intend to show through a case study how some of the most established axioms on Spanish Modern History no longer apply nowadays. In order to do so, we will accompany Francisco Escáneo through his last months of life in Bueu (Pontevedra), from February to December 1936. But, how is it possible to follow the traces of the subaltern? Thus, the
\end{abstract}


final result shall be an essay that will force us rethink the established historical and methodological narrative, betting on the interrelation between memory, history and literature.

\section{Key words}

historical memory, history from below, methodological individualism, Bueu, Spanish civil war

\section{Introducción}

Francisco Escáneo Franco (nacido en Bueu, Pontevedra, en 1896) fue uno de los miles de gallegos que emigraron a Cuba en la década de 1910, trabajando en lo que podían para hacer una pequeña fortuna. Fue uno de los miles que se integraron en el movimiento obrero durante esos años, para después retornar a la terriña y acabar involucrándose en política. Fue uno de los miles que creyeron en el proyecto democrático de la República, tomando una parte activa en ella y en la creación del Partido Galeguista, en el que estaría rodeado de algunas de las más importantes figuras intelectuales del momento. Fue uno de los miles de asesinados por las tropas franquistas después del fallido golpe de Estado de 1936. También fue mi bisabuelo.

Escáneo, por su extracción social (humilde, aunque no pobre), forma parte de un colectivo sociohistórico al que tradicionalmente se le ha prestado poca atención. Son la "gente sin historia", actores pasivos sin voz propia, figurantes que sólo interesan en el relato histórico para la elaboración análisis de carácter cuantitativo. En el devenir historiográfico, hemos pasado de una historia puramente personalista (la teoría del gran hombre decimonónica) a otra tan abstracta que parece que en el proceso hemos olvidado que detrás de la narración histórica existen miles de personas que la han construido de forma inconsciente, a la vez que vieron sus vidas marcadas por la propia evolución de la historia en un feedback continuo. Porque la historia es el estudio de algo tan banal y extraordinario como es la vida.

Hemos optado por un estudio de caso porque, haciendo nuestras las palabras de Conxita Mir, «tenemos el convencimiento de poder avanzar en la comprensión global del 
fenómeno violento a partir de realidades muy concretas, las únicas que permiten captar las relaciones interpersonales que estuvieron en la base de los comportamientos sociales articulador alrededor de las prácticas represivas». ${ }^{1}$ Con todo, no debemos caer en el error de confundir el individualismo metodológico aplicado en el presente trabajo con una mera biografía de la vieja escuela. El presente proyecto no es un monomito renovado. Nos situamos más bien en la línea de la microhistoria italiana, de la alltagsgeschichte alemana, o de la historia desde abajo británica; aunque empleando los razonamientos de la vida personal de la gente corriente y la tradicional lógica orgánica de las instituciones. Así, entendemos las relaciones entre individuos como el elemento clave para entender la historia, a la manera de Lévi-Strauss o E.P. Thompson.

Decía Pierre Vilar en la introducción de La guerra civil española (1986) que el lector tiene derecho a tener un mínimo de información sobre las relaciones entre el investigador y su tema de estudio. Por mi parte (dejo a un lado el plural mayestático momentáneamente), ya han quedado confesadas mis inclinaciones personales al principio del presente artículo: Francisco Escáneo Franco se trata de mi bisabuelo, aunque por la universalidad de su relato, bien podría ser el bisabuelo de cualquiera. La relación familiar en este caso no es un fin en sí mismo, sino un medio para conocer su historia (mejor dicho, el relato transgeneracional), cuyo interés académico excede los vínculos sanguíneos. Sería cínico negar que la egohistoria nos ha servido a muchas y muchos como elemento motriz para dedicarnos a la investigación del pasado: antes de ser historiadores, hemos sido receptores de algún relato. Considero que no tenemos por qué renegar de nuestras motivaciones personales para recubrirnos de una mayor supuesta objetividad, como si éstas fuesen un obstáculo en la procura de la verdad histórica.

Me veo en la obligación de hacer este paréntesis y tratar el tema de forma tan sincera porque es innegable que ciertos sectores de la Academia ven con cierto recelo la cuestión de la memoria, y más aún la familiar. «La memoria no es historia», afirman. Y tienen toda la razón. Pero la memoria puede, y ha de ser, objeto de la historia. Si bien miente, como las demás fuentes, la contraposición entre unas y otras actúa como tamiz y ayuda a la depuración de impurezas en el relato histórico, a la vez que tiene un claro efecto

1 Conxita MIR: Vivir es sobrevivir. Justicia, orden y marginación en la Cataluña rural de posguerra, Milenio, Lleida, 2000, p. 18. 
democratizador: no todo lo que ha sucedido ha sido plasmado por escrito, y nuestra única forma de acceder a su conocimiento es a través de las fuentes orales.

Un ejemplo ideal de cómo seguir la pista de quien es aparentemente anónimo, de un hombre corriente, se trataría del libro de Carlos Gil Andrés Piedralén. ${ }^{2}$ Partiendo de un sumario militar por deserción en la guerra de Cuba, Gil Andrés comienza una investigación en la que reconstruirá la biografía de un agricultor de Cervera del Río Alhama (La Rioja) desde el Desastre del 98 a los primeros años del franquismo. También Thompson sitúa el foco de interés en el proceso de investigación y no tanto en los resultados obtenidos de la misma en las charlas que da en la Universidad de Stanford en 1981 (recogidas y editadas de forma póstuma por su mujer). ${ }^{3}$ En las conferencias, Thompson relata cómo viaja a Bulgaria para reconstruir la vida de su hermano, oficial de enlace británico y miembro del Ejecutivo de Operaciones Especiales en el país durante la II Guerra Mundial que acabaría siendo capturado, torturado y asesinado. Ambas obras son auténticas lecturas recomendadas para quien desee ser testigo de las dificultades y los azares que marcan una investigación, como un making off. Pero, por supuesto, no los podemos tomar (ni ello pretenden los autores) como modelos teóricos: esos mismos azares que mencionamos obligan a cada investigación a decantarse por unas vías u otras. Es el método el que se adapta a las circunstancias y no al revés.

Brevemente: en el caso personal de esta investigación partimos, como ya ha sido dicho, de las fuentes orales, de un relato transgeneracional que habíamos heredado y de una fotografía rota. A continuación, se procedió a la realización de entrevistas de las hijas que todavía vivían de nuestro objeto de estudio, así como también hablamos con aquéllos que habían escuchado de Escáneo como mito. Construimos así un primer relato con el que poder confrontar las fuentes escritas, tanto las documentales como las hemerográficas; a la vez que recurríamos a la literatura académica existente relativa a nuestro tema. Esto nos permitió crear un discurso paralelo con el que poder volver a realizar entrevistas a las mismas personas, con nuevas preguntas, nuevos enfoques y fijándonos en qué partes el relato de los entrevistados había variado y cuáles no. Además,

2 Carlos GIL ANDRÉS: Piedralén. De Cuba a la guerra civil, Marcial Pons, Madrid, 2010.

3 E.P. THOMPSON: Más allá de la frontera. La política de una misión fracasada: Bulgaria, 1944, El Viejo Topo, Barcelona, 2012 [ed. original 1997]. 
fueron usados recursos literarios en la investigación. Les dedicaremos a continuación a éstos un punto aparte.

\section{"El Cubano", entre la ficción y la realidad}

Como decíamos, si bien la historiografía ha tendido a darle la espalda a la vida de la gente común, no ocurre lo mismo con la literatura. Al contrario, la cotidianidad ha sido una constante como fuente de inspiración de las diferentes manifestaciones artísticas. El protagonista de nuestra investigación no es ajeno a esto.

Recordemos por un momento la afamada novela de Gonzalo Torrente Ballester, Los gozos y las sombras (1957 - 1962), que logró mayor popularidad con su adaptación televisiva en 1982 por RTVE. Muchos de los que han leído la trilogía son conocedores de que en el trasunto de Pueblanueva del Conde se encuentra el Bueu de los años anteriores a la guerra civil, momento en el que se está produciendo un choque entre la vieja clase hidalga y poderosa y la nueva burguesía industrial emergente. Es éste un ambiente que Torrente Ballester conocía de sobra, puesto que allí había vivido entre 1931 y 1936. Y del mismo modo que Pueblanueva es Bueu, los personajes que protagonizan la trilogía tienen sus homólogos ficticios entre los bueueses: así, Carlos Deza sería el propio Torrente, el propietario de los astilleros Cayetano Salgado simbolizaría a José María Massó, Juan Aldán estaría inspirado por el periodista y alcalde fusilado Johán Carballeira...

Las analogías se repiten en los personajes secundarios. De este modo, el regente de la taberna donde se desarrolla parte de la acción, conocido como el Cubano, no es más que el espejo narrativo de Francisco Escáneo Franco. Múltiples son las similitudes entre ambos que nos permiten establecer esta aseveración: ambos tenían una taberna que actuaba como centro de reunión de pescadores y sindicalistas, los dos habían estado en Cuba y habían perdido una pierna, etc. Sin embargo y como es habitual, el autor se permite ocasionales licencias literarias con las que se aleja de la realidad: por ejemplo, Torrente nos cuenta en los primeros capítulos de El señor llega que el Cubano había perdido su pierna en la guerra de Cuba, cuando en realidad sabemos que Escáneo se amputa la pierna en un accidente laboral a finales de la década de 1910. Esto no nos debe llevar a conclusiones equivocadas: la relación entre persona y personaje es obvia, especialmente al conocer la profunda amistad entre el autor y Escáneo, quien llegó a ser 
testigo junto a José Gómez de la Cueva (verdadero nombre de Johán Carballeira) de la boda de Torrente con Josefina Malvido en mayo de 1932. Será ésta una amistad que se rompa a partir del golpe del 36, cuando Escáneo y Carballeira sean fusilados y Torrente Ballester acate la orden paterna de alejarse de Bueu y comenzar a militar en Falange.

Es también interesante resaltar la influencia que Los gozos y las sombras tuvo en la construcción de la memoria sobre Escáneo, especialmente después del estreno de la adaptación televisiva de la trilogía (con Fernando Sánchez Polack en el papel del Cubano), ya que algunas de esas licencias literarias que se tomaba Torrente se han acabado mezclado con el recuerdo más "tangible" de Escáneo. Sirva de ejemplo el hecho de que, si bien a Escáneo no se le conoció en vida como "el Cubano", hoy en día no es extraño escuchar a bueuenses utilizando ese sobrenombre para referirse a él.

Quienes hayan leído Los gozos y las sombras ya conocerán al Cubano en Pueblanueva del Conde. Nosotros ahora nos aventuraremos en los últimos meses de Francisco Escáneo en Bueu.

\section{Aires de cambio: la corporación del 36}

Francisco Escáneo Franco nace el 25 de noviembre de 1896 en Beluso, Bueu, un pequeño municipio costero al sur de la ría de Pontevedra. Por su natural proyección hacia el mar, éste fue siempre el sustento por excelencia de la villa. Como en el resto de las Rías Baixas, el principal producto obtenido era la sardina, lo que propició que Bueu se convirtiese en la sede de una de las principales pioneras de la industria conservera moderna: Hermanos Massó S.A. Las innovaciones técnicas adoptadas por los Massó convirtieron a la suya en una de las más grandes empresas del sector, pudiendo llevar a cabo procesos de integración vertical y horizontal gracias a los beneficios obtenidos en la etapa de esplendor de la I Guerra Mundial. ${ }^{4}$ Además, procedieron a la compra de propiedades de una pequeña hidalguía claramente empobrecida, lo que los acabó convirtiendo en los dueños de Bueu: así, prácticamente, desde el primer cuarto del siglo XX, toda la economía del municipio dependía de forma directa o indirecta de los Massó, quienes serán además conocidos por tener un notorio papel en la represión franquista militando varios de los hermanos en la Falange y participando en sus servicios de guardia.

4 Luisa MUÑOZ ABELEDO: Género, trabajo y niveles de vida en la industria conservera de Galicia, 1870 - 1970, Icaria, Barcelona, 2010. 
Como introducíamos anteriormente, Escáneo emigra de forma breve pero fructífera a Cuba a finales de la década de 1910. Después de trabajar unos escasos años en el mundo de los ferrocarriles, pierde una pierna a la altura de la rodilla cuando le pasa un carrito de mantenimiento de la compañía ferroviaria por encima. Con motivo de esto, Escáneo logra volver a casa sin una pierna, pero con algo con lo que muchos emigrantes gallegos soñaban: el capital (no sólo físico, sino también cultural) suficiente para mejorar su nivel de vida. Así, se convierte en un empresario y comerciante de éxito en su retorno a Bueu a mediados de la década de 1920; no lo suficiente como para poder disputar la posición de los viejos y nuevos caciques, pero sí como para ser reconocido por sus vecinos y jugar un papel central en el desarrollo del republicanismo y del galeguismo en el municipio.

Situémonos en marzo de 1936. En este mes, la comisión gestora municipal de Bueu (integrada por personas nombradas por el gobernador civil de la provincia) es substituida por una nueva corporación municipal como resultado de las elecciones generales de febrero de ese mismo año, que habían dado la victoria al Frente Popular. Esta nueva corporación está formada por Francisco Piñeiro, Francisco García Villanueva, Ramón González Soliño, Manuel Gutiérrez López, Francisco Escáneo Franco, Manuel Casaleiro Pereira, José Estévez Villar, José Bernárdez Santaclara, Francisco Padín Novas, José Rodríguez Estévez, Ramón Pastoriza Gestido y José Gómez de la Cueva. Renuncia al nombramiento, aunque también figura en la relación del gobernador civil, José de la Torre López. A continuación, los concejales de la nueva corporación elegirán como nuevo alcalde, por unanimidad, a de la Cueva (mejor conocido por su pseudónimo, Johán Carballeira).

De esta relación de prohombres locales, sólo uno había ejercido el cargo de edil en Bueu de forma ininterrumpida desde junio de 1931 hasta el golpe de Estado: Francisco Escáneo. Sin embargo, en el relato transgeneracional y local, su memoria había quedado vinculada exclusivamente con la corporación del 36, como si nunca antes hubiese participado en política.

¿A qué se debe esta alteración de la realidad histórica? Tenemos que entenderla como el reflejo de un falso mito muy arraigado en la memoria: la identificación reduccionista de la República con el Frente Popular. Como defiende Lourenzo Fernández Prieto, ésta ha sido una idea reconstruida a posteriori, tanto desde la historiografía oficial 
del franquismo como desde el relato contestatario de la oposición. Debemos recordar que, en los primeros momentos, el golpe de Estado era accidentalista, es decir, no consideraba de particular relevancia cuál sería la forma de gobierno posterior (monarquía, república o dictadura): era simplemente un golpe contra el Frente Popular, contra la Antiespaña. Era un mero tumor a extirpar con una rápida cirugía. "Si vuestra madre tuviese un cáncer y se le indicase una operación, ¿dudaríais en aceptarla? ... Es cosa de tres días”, aseguraba el hispanista francés Maurice Legendre un día después del golpe. ${ }^{5}$ Pero a veces las operaciones se complican. Así, con el devenir de la guerra, los sublevados modifican su discurso inicial y el objetivo a aniquilar ya no es simplemente el Frente Popular, sino la República. Para legitimar este cambio de orientación, se acude a una perversión de la lógica aristotélica, empleando un silogismo errado: si el Frente Popular es la Antiespaña y la República engloba al Frente Popular, la República será por consiguiente también la Antiespaña. Dicho de otra forma, lo que se hace es identificar al todo por la parte, como si la República y el Frente Popular fuesen sinónimos totalmente intercambiables y, por lo tanto, el mismo elemento a eliminar.

Por su parte, el discurso de la oposición al régimen, que identificamos principalmente con el del Partido Comunista de España, también acabará cayendo en la misma idea engañosa. Si bien las estrategias del PCE fueron evolucionando con el tiempo, el recuerdo de la guerra civil siempre ha sido un pilar fundamental en su discurso patrimonial, tanto cuando se acaba el conflicto en 1939, como cuando se aposta por la “reconciliación nacional" a partir de 1956, o como cuando se legaliza el partido en 1977. La guerra civil había sido un hecho heroico, el primer estadio en la lucha internacional contra el fascismo, y para resaltar la ilegitimidad del régimen franquista era preciso subrayar la continuidad simbólica existente entre el partido, la legalidad republicana (aunque el PCE sólo hubiese entrado en el gobierno en 1936) y el sistema democrático instaurado tras la muerte de Franco. ${ }^{6}$

En contraposición a estos dos discursos que, como hemos dicho, son construcciones posteriores, justo tras el golpe los sublevados también se sirvieron de una manipulada identificación entre República y Frente Popular a modo de justificación de su

5 Anécdota recogida también en la introducción de: Pierre VILAR: La guerra civil española...

6 José Carlos RUEDA LAFFOND: “ ¿Un pasado que no cesa? Discurso patrimonial y memoria pública comunista en el franquismo y la transición española", Revisa de Estudios Sociales, n 47, 2013, pp. 12-24. 
levantamiento. Sirva de ejemplo el caso del teniente de artillería Jaime Aranda Totsant, encargado de defender a Johán Carballeira, uno de los encartados en el proceso judicial de la causa militar 1363/36, por el que 24 vecinos de Bueu fueron acusados de rebelión militar debido al intento de hacer explotar el puente de Beireses entre los días 18 y 22 de junio. El discurso manejado por el militar se basa en un argumentario de tono victimista, paternalista y exculpatorio:

\footnotetext{
No es mi patrocinado un hombre perverso, peligroso, sino meramente un desgraciado a quien cupo la desgracia de ser alcalde de un ayuntamiento ... bajo los mandos de aquel nefasto bloque político. ... Son gentes que en el nefasto régimen pasado, y bajo las garras de la odiosa política del Frente Popular, se veían obligados, para poder llevar a sus casas el mísero pedazo de pan cotidiano ... a figurar ... en las listas de las diversas sociedades que a manera de comités soviéticos funcionaban ... como baldón y mengua de nuestra Historia. ${ }^{7}$
}

Se recurre así a un discurso simplista, que presenta a los miembros de la corporación del 36 como pobres e ignorantes hombres que fueron seducidos por las detestables políticas del Frente Popular, siendo otros los que los indujeron a la involucración en su antipatriótico propósito. Negando su participación en política con anterioridad, se refuerza esa idea de que simplemente habían estado en el momento equivocado en el lugar equivocado. Esta absurda infantilización de algunos de los hombres más lúcidos de su zona y tiempo puede comprenderse como un recurso retórico en el contexto de un alegato de defensa de un consejo de guerra; el problema es que luego esta idea acabó calando en las conciencias de extensas capas sociales necesitadas de exculpar a quien, en realidad, no tenía culpa.

Así, entendemos que, en la memoria popular y familiar, se creyese que Escáneo sólo hubiese pertenecido a la corporación municipal desde 1936, cuando en realidad fuera miembro de la misma desde los inicios de la República. Se niega su involucración en política en un intento de disminuir su responsabilidad. Se construye de este modo, con la interrelación de estas tres vertientes discursivas (la de la historiografía franquista, la de la oposición y la de tono exculpatorio), esa identificación de la República con el Frente Popular olvidando sus etapas anteriores, mitificación que no favorece al estudio del régimen democrático.

7 Testimonio recogido en: Concepción LÓPEZ SÁNCHEZ: Actitudes sociais diante das persecucións do golpe do 36 e na retagarda da guerra. Bueu. 1936 - 1936, TFM USC, 2015. 
En relación con la memoria, es innegable para cualquier bueués la importante huella que dejó en la villa la corporación del 36. Esto se debe, por una parte, a la brutal represión que sufrieron los concejales (de los catorce miembros, seis fueron asesinados después del golpe y el resto fueron purgados de sus funciones políticas) y, por la otra, a los aires reformistas que trajo consigo el nuevo gobierno local de Carballeira. Ya desde el primer pleno municipal, se recogieron una serie de medidas consideradas de urgencia, entre las que podemos destacar. ${ }^{8}$ la destitución de todos aquellos empleados municipales de significación profundamente contraria al régimen republicano, la readmisión de todos los obreros despedidos por cuestiones políticas y sociales, el cambio de nombre de algunas calles por otros que glorificasen a la República, el establecimiento de unos precios fijos para la compraventa de sardina (anteriormente eran impuestos de forma arbitraria por las conserveras), la gratuidad del aprovechamiento de los montes comunales, la revisión del listado de pobres del municipio para mejorar sus prestaciones, o el intento de creación de un centro de maternidad ante el aumento de mujeres trabajadoras (obra que el golpe impedirá culminar).

\section{Actitudes ante el golpe}

La idea de la sorpresa del golpe, reforzada por episodios como el supuesto "Si ellos se han levantado, yo me voy a acostar" con el que respondería Casares Quiroga a las preguntas de la prensa sobre el levantamiento militar en Marruecos, es otro mito ligado a la historiografía más tradicional que a día de hoy ya no se sostiene. Sin dudas, Azaña era consciente de esas tramas cívico-militares conspiracionistas que se multiplicaron a lo largo de 1936 hasta llegar al fatídico 18 de julio, lo que explica, por ejemplo, el traslado de Goded y Franco a las islas Baleares y a las Canarias, respectivamente. Se intentaron tomar precauciones para evitar la confrontación, precauciones que sólo el tiempo demostraría insuficientes.

Pero este ambiente de tensión creciente distaba mucho de ser algo que se conociese de forma exclusiva entre las esferas más altas del gobierno republicano: la rapidez de actuación de la nueva corporación municipal y, particularmente, la medida anteriormente

8 La siguiente relación de medidas fue extraída de: Xesús PORTELA: Johan Carballeira. Poeta, xornalista, político. O valedor dos homes do mar, Ir Indo, Vigo, 1997 y ratificada por las actas del archivo municipal de Bueu. 
vista por la cual son purgado de la administración local los empleados antirrepublicanos, nos lleva a pensar en que ya se conocían esas tentativas de levantamiento.

Sea como sea, de todos los que hubo durante 1936, el único golpe de Estado que tuvo el éxito suficiente, o que por lo menos no fracasó de todo, como para acabar derivando en una cruenta guerra civil de tres años fue el del 18 de julio (17 si ya contamos la insurrección en África). Si bien en algunos puntos del Estado se logró controlar la sublevación con cierta agilidad, en otras zonas el éxito de los insurrectos fue más rápida, impidiendo que llegase a haber frentes bélicos, como fue el caso de Galicia. Pero no debemos confundir una aparente escasa oposición con el apoyo explícito a la insurrección militar. La construcción de la idea de Galicia como el gran bastión de las tropas rebeldes, como una "nueva Covadonga", es otro de los mitos que pretendemos discutir en el presente artículo: si aquí no hubo resistencia (entendiéndola a la manera en la que sí hubo en otros puntos del Estado, como Madrid o Barcelona), fue porque la «acción en extremo violenta» había exterminado a todos los posibles elementos de amenaza al nuevo orden que los militares querían establecer, antes incluso de que el golpe evolucionara en guerra.

Se convierte así Galicia en uno de los territorios más afectados por la práctica genocida, a pesar de ser una zona de retaguardia prácticamente desde los inicios del levantamiento (o, quizás, precisamente por ello). Ante las noticias del golpe, la primera decisión del gobierno local de Bueu, siguiendo las directrices marcadas por el gobernador civil provincial, Gonzalo Acosta Pan, fue la de requisar todas las armas y munición de los vecinos. Al igual que se hizo en otros lugares de la provincia, como Lalín o Silleda, también se forman milicias armadas para evitar la toma de Pontevedra. Sin embargo, este plan fracasará, ya que los hombres armados que tenían la intención de ponerse a las órdenes de Acosta en defensa de la República son detenidos en Marín (donde se hallaba el polígono de tiro Jaime Janer, base militar de la Marina y donde se impone rápidamente el dominio de los sublevados) y obligados a volver a Bueu. De forma paralela, se convoca una huelga general el 20 de julio en contra de los militares sublevados, día en el que Acosta dimite dejando a entrever que la resistencia era cada vez más difícil. Dos días después, el alcalde Johán Carballeira es llamado desde el ayuntamiento para que se acerque a las oficinas de la Subdelegación de Marina del municipio, en donde se encontrará con un oficial y un grupo de militares del polígono Janer. Coaccionan a Carballeira para que deje su cargo y éste pasa a ser asumido por el propio subdelegado de 
marina, Gonzalo Torrente Piñón (padre del ya mencionado Torrente Ballester); sólo estará en el cargo durante un corto periodo de tiempo, ya que será sustituido el 2 de agosto por Camilo Davila Davila, quien ya había sido alcalde de Bueu durante el directorio primorriverista.

En la misma noche en la que Carballeira es cesado de su puesto, un grupo de 24 vecinos deciden llevar a cabo un acto de sabotaje que venían planeando desde el propio día 18: hacer volar el puente de Beireses en Lapamán, por la entrada este de Bueu, para dificultar la llegada de las tropas nacionales desde Marín y Pontevedra. Con todo, la explosión resulta un fracaso y no daña en gran medida las estructuras de la construcción, por lo que los protagonistas del atentado se ven obligados a refugiarse en Bueu o en los montes colindantes. Conocemos su nombre gracias a la causa militar 1363/36, proceso judicial que se abre como respuesta al acto de sabotaje. En la lista de hombres encartados por rebelión militar, así como en las declaraciones de testigos, nos llama la atención la ausencia de un hombre: Francisco Escáneo. Teniendo en cuenta que, además de ser edil desde 1931, regentaba una taberna que se había convertido en el lugar de reunión habitual de sindicalistas y galeguistas, el hecho de que nadie lo señale durante las declaraciones es tan sorprendente como que no estuviese involucrado en el atentado; aunque quizás no fuese el hombre más capacitado para la acción debido a sus limitaciones físicas, parece imposible que no supiese nada de la organización del acto de sabotaje debido a la notoriedad sociopolítica que había ido adquiriendo en la villa durante los últimos años.

Así, el 24 de julio Bueu cae ante una docena de militares enviados desde el polígono de tiro Janer. Dos días después, cae también Tui y se da por finalizada la conquista de Galicia, convirtiéndose así el territorio en zona de ensayo y error para la creación del Nuevo Estado. Milicias, Falange y Ejército logran imponer su orden a partir de entonces en la vida cotidiana, compatibilizando las labores de gobierno civil con las lógicas militares necesarias de un golpe de Estado.

En unos días en los que el futuro era más incierto que nunca, fueron muchos los que intentaron escapar del país. Escáneo no fue uno de ellos, aunque su mujer habría insistido para que sí lo hiciera. En una situación semejante, los motivos de cada uno para quedarse son diferentes, particulares, aunque a la vez generales. No es necesario llevar a cabo un extenuante ejercicio de empatía para entender por qué un hombre que realmente nunca 
había hecho nada fuera de la legalidad (términos como "bueno" o "malo" son los que quedan en la memoria, pero objetivamente no nos sirven) quiere permanecer junto a su esposa embarazada y sus tres hijas pequeñas. En una situación de tal desesperación, el autoengaño es una forma de resiliencia común: la ingenuidad de creer que los rebeldes no tomarán represalias contra uno se mezcla con la esperanza en la fortaleza de la República. Además, tenemos que tener en cuenta que la propia experiencia animaba a no desistir, ya que, si los anteriores intentos de golpe como en la Sanjurjada del 32 habían fracasado, ¿por qué habría éste de ser distinto?

En el transcurso de los meses de julio a diciembre, se aplica contra Escáneo un tipo de violencia particular, económica: las requisas. Al volver de Cuba y al calor del impulso del mundo de los transportes durante la dictadura de Primo de Rivera, Escáneo había montado una empresa de autobuses y camiones que pasarán ahora a ser objeto de interés de las tropas nacionales. Esto se traduce en repetidas confiscaciones de los mismos, a veces de forma oficial a través de notas firmadas por el alcalde apelando a las órdenes de la Comisión Mixta de Requisas de Pontevedra, y otras veces de forma oficiosa con simples notas escritas a lápiz. Originalmente, las requisas eran incautaciones temporales, sumarias, pensadas para servicios concretos como, por ejemplo, un transporte de tropas. Pero, en aquellas circunstancias, la requisa de bienes de una persona desafecta con el nuevo régimen militar era una forma de espolio, de expropiación sin indemnización, en favor de aquellas personas sí adeptas al nuevo orden. Es un instrumento de guerra, una forma de represión sobre los vencidos, a medio camino entre la cultura de guerra y la cultura de la victoria. Escáneo, conocedor de esto, intentó en la medida de lo posible evitar las entregas de los coches, so pretexto de avería. Sin embargo, esta oposición va dejando paso a la resignación, ya que acabará perdiendo todos y cada uno de los automóviles. Desconocemos la fecha exacta en la que se produce la requisa del último bus de la empresa (que, en homenaje a la revista galeguista de su compañero de partido y también amigo Castelao, se llamaba «Nós»), pero las hijas de Escáneo recuerdan que fue poco antes de que se llevaran a su padre. ${ }^{9}$

Aunque no tenemos constancia exacta del destino de los automóviles requisados, no nos sorprendería que José Collazo Iglesias hubiera tenido algo que ver. Éste era natural

9 Entrevista personal realizada a Rosario y Josefa Escáneo Pérez en Bueu (agosto, 2015). 
del área Arousa-Rianxo y actuaba como recaudador de arbitrios en Bueu, beneficiándose a través de farsas administrativas de los espolios en la zona ${ }^{10}$. Por ejemplo, adquiere por el irrisorio precio de 100 pesetas los bienes usurpados a la Casa del Pueblo de Beluso, lugar de reunión de la sociedad de agricultores "El Progreso" y foco del galeguismo del lugar; curiosamente, será el único inmueble incautado en todo el municipio de Bueu, reforzando la tesis del empleo del espolio como método de represión y violencia contra los vencidos ${ }^{11}$. Collazo será también conocido por ser el responsable de muchos de los paseos habidos en la comarca (era sargento de la Guardia Cívica, el principal cuerpo paramilitar encargado de realizar estas acciones, bajo las órdenes de Víctor Lis Quibén) como, probablemente, el del propio Francisco Escáneo o el del depositario y administrador del ayuntamiento Ricardo Gómez de Buceta. Según relatan diversas fuentes, la mujer del falangista encomiaba las gestas del esposo con el siguiente chascarrillo: "Cada vez que mi marido mata a un rojo, me como un pollo". ${ }^{12}$

\section{De la presión a la represión}

La madrugada del 6 al 7 de diciembre de 1936, la policía acude a la vivienda de Escáneo. Lo llaman desde el ayuntamiento para que vaya a hacer una declaración. Con calma, le da tiempo a vestirse: un gabán, dos chaquetas, un jersey, un chaleco, camisa y elástico, unos pantalones y un zapato. En la otra pierna, "un trozo de madera" en vez de la prótesis que había traído de Cuba. ${ }^{13}$ No era la primera vez que esto sucedía, así que no había señales de que fuese a ser la última. Se despide de su mujer: "Marcho, Pepa, que canto antes vaia, antes hei voltar". ${ }^{14}$

Escáneo es conducido al depósito municipal de Bueu, en donde queda preso durante unas horas junto a otros cuatro compañeros, cuyas identidades intuimos sus identidades por haber sido todos ellos asesinados esa misma noche: Francisco García Villanueva "Xerello", miembro también de la corporación municipal; Jacinto Lamosa Novas,

10 Diario de Pontevedra, 09/02/1937

11 José Ramón ÁLVAREZ PÉREZ y Xosé M. MILLÁN OTERO: A Sociedade de Agricultores "El Progreso" de Beluso (1931 - 1936): unha experiencia de asociacionismo, Asociación de Veciños "O Progreso" de Beluso, Vigo, 1997.

12 D.A.: "Ricardo Gómez de Buceta e a represión no Bueu de Massó", Sermos Galiza, 11/09/2015, http://www.sermosgaliza.gal/articulo/memoria/ricardo-gomez-buceta-bueumasso/20150911123004040634.html [consulta 2 abril, 2017].

13 Descripción del cadáver de Escáneo según su acta de defunción en el Registro Civil de Marín ( $3^{\mathrm{a}}$ sec., tomo 97, p. 52).

14 Traducción del gallego: "Me voy, Pepa, que cuanto antes me vaya, antes volveré". 
fundador de la sociedad "El Progreso"; y José Seijas Camiña, miembro de "El Progreso". La identidad del quinto paseado esa noche permanece desconocida.

En el relato transgeneracional, se fija la idea de que estos hombres intentan fugarse de los calabozos del ayuntamiento, produciéndose un alterado de madrugada durante el cual Escáneo se quitaría su pierna de palo para golpearle con ella a Collazo (de hecho, los vecinos recordarían después verlo durante días con la sien vendada) y escapar. Durante la trifulca, los presos serían abatidos con arma de fuego, aplicándoseles de ese modo la ley de fugas, por lo que son paseados sin posibilidad alguna de juicio o defensa. Al día siguiente, como Escáneo no volvía a casa, se acerca su hermana Luísa al calabozo para llevarle algo de comer. Al llegar a una de las calles adyacentes, advierte que está siendo baldeada y un hombre (uno de los guardias o quizás algún vecino que había escuchado la reyerta) le aconseja que se vaya para casa, que su hermano no está ahí. Comprendiendo por fin lo que había sucedido, vuelve para casa llorando y gritando "Mataron ao meu irmán!". ${ }^{15}$

Un par de días después, la familia conoce a través de un vecino de la zona de la Lameira (Marín) que el cuerpo sin vida de Escáneo había aparecido en las inmediaciones del cementerio municipal de Marín. Junto a él apareció el cadáver de Jacinto Lamosa Novas, mientras que los de Francisco García Villanueva y José Seijas Camiña fueron encontrados cerca del matadero de Marín. Si bien podríamos creer que los fusilamientos se produjeron in situ, es decir, que primero asesinarían a Villanueva y Seijas en el matadero (que está en la carretera entre Marín y Bueu, mientras que el cementerio está pasando Marín) y después a Escáneo y Lamosa en el cementerio; si tenemos en cuenta la imagen que se transmitió en el relato familiar de que Luísa llega a ver cómo se está baldeando la calle próxima a los calabozos, entendiendo que estaban limpiando la sangre, podemos asumir que las víctimas fueron asesinadas en Bueu y que después sus cuerpos fueron abandonados en varios puntos del municipio de Marín.

El 8 de diciembre se levanta el acta de defunción del cadáver de Escáneo, que es inscrito como un anónimo de 40 años fallecido a consecuencia de un disparo de arma de fuego. Sin embargo, las autoridades llaman a la familia escasos días después para que vayan a reconocer al cadáver. Es, de hecho, identificado por su hermano Narciso, aunque

15 Traducción del gallego: “iMataron a mi hermano!”. 
no será inscrito en el registro civil. El cuerpo de Escáneo será enterrado en el propio cementerio de Marín, donde la familia acabará instalando con el tiempo una vistosa lápida de mármol. Entre 1970 y 1972, los restos mortales serán trasladados por fin al cementerio de Bueu con motivo de obras en el de Marín. Con todo, no será hasta 1981 cuando por fin quede constancia en aquella acta de defunción del 8 de diciembre de 1936 con una nota marginal de que el cadáver encontrado era de Francisco Escáneo Franco. ${ }^{16}$

Cuando volvemos a leer detenidamente la supuesta hazaña de la fuga del calabozo, encontramos varias incongruencias. Esa aura heroica parece en realidad fruto de una reconstrucción posterior por parte de los oprimidos, convirtiendo a las víctimas de su bando en mártires. El primer elemento que podemos eliminar del relato es el hecho de que Escáneo se defendiera de Collazo agrediéndolo plausiblemente con su pierna de palo puesto que, aunque es un aspecto que le añade dramatismo al episodio, parece poco práctico que se la quitara para después colocarla cuando su objetivo era escapar corriendo (de hecho, en otra versión de los hechos, el arma empleada es el mástil de una bandera). Pero incluso cabe dudar de la intención de Escáneo y de sus compañeros de fugarse del calabozo, ya que sabían que en cuanto los soltasen podrían ser fusilados. Es más, parece más verosímil que el altercado que tiene lugar en los calabozos se produjera por el motivo contrario al que narra el relato oral: ellos se quieren quedar en las celdas, en donde se sienten más seguros, y la disputa surge cuando los guardias los quieren sacar fuera. Una vez en la calle, la excusa de la "fuga" es empleada para asesinarlos.

Entendemos así la ley de fugas como una forma subrepticia de ejecución extraprocesal, no existiendo propiamente una ley que la regule. Es un subterfugio paralegal aceptado por el cual se simula el uso necesario de la fuerza para impedir la supuesta fuga del preso, legitimando así su asesinato. Frente a los paseos, que no procuraban apariencia ninguna de legalidad, con los ejecutados mediante ley de fugas se levanta atestado, hay una simulación de averiguación judicial, se entierra al muerto, etc. Se trata, en definitiva, de una farsa que echa abajo otro de los dogmas preestablecidos sobre la guerra civil. Durante el proceso bélico, convivirían dos líneas paralelas de violencia: la violencia organizada y legal, que se ejemplifica en las causas militares y

16 Alrededor de estas fechas, se ceden unos terrenos a nombre de Escáneo para la construcción del futuro IES Johán Carballeira. Puede ser que, fruto de los trámites burocráticos, se cayera en la cuenta de que los restos mortales de Escáneo no aparecían en el registro civil y se decida ahora hacer una inscripción provisional. Entrevista personal a Manuel Cidrás Escáneo en Donostia (junio, 2016). 
acaba ganando preeminencia frente a la violencia caótica y pasional, que haría referencia al mito de los "excesos irracionales al calor de los primeros días" y las "venganzas personales de una guerra fratricida" materializada en los paseos (como si estos no funcionasen, al fin y al cabo, como otro de los brazos genocidas de la perfectamente planeada represión franquista). Los lindes entre una y otra, en apariencia tan bien definidos, se vienen abajo cuando estudiamos casos como los de Francisco Escáneo Franco, Jacinto Lamosa Novas, Francisco García Villanueva y José Seijas Camiña.

Si analizamos las gráficas adjuntas en la web del proyecto interuniversitario Nomes e Voces (www.nomesevoces.net) sobre la cronología de las muertes extrajudiciales en Galicia, comprobaremos que casi el 70\% de las mismas se produjeron los primeros meses del golpe. En Bueu, fue tal la magnitud de los hechos que diciembre de 1936 pasará a ser conocido como el "diciembre negro"; es también en este mes cuando se empiezan a relacionar más nombres con el atentado del puente de Beireses y cuando los paseos a altas horas de la madrugada no cesan (el escuadrón de la muerte de Collazo fusilará en estos días a muchos otros hombres con notoriedad en la villa). Ante esto, cabe preguntarse qué está sucediendo en estos momentos para que se reactive la violencia más atroz, algo que nos llama la atención por ser ésta una zona que llevaba meses bajo el mando sublevado. La respuesta la encontramos en que se entra en una nueva fase del conflicto bélico: como señalan autores como Lourenzo Fernández Prieto y Aurora Artiaga, es ahora cuando se evoluciona de la lógica del golpe a la de la guerra. ${ }^{17} \mathrm{El}$ intento de hacerse con el poder centrar había fallado, dejando al país en tablas durante ya medio año y demostrando que la rápida operación de extirpar el tumor que había crecido en la madre España se estaba complicando. Era necesario actuar con más fuerza para superar esta situación de impasse.

Junto con la aniquilación genocida de los considerados afectos al régimen derrotado, se procede también a una cruel intimidación sistemática de los perdedores sobrevivientes para así minar cualquier intento de oposición al nuevo gobierno impuesto. En nuestro caso de estudio, no sólo eliminan físicamente a Escáneo, sino que también privan a su mujer e hijas de su patrimonio como empresario emergente con el espolio de la empresa de automóviles. Sólo logran mantener la taberna, pero enfrentándose de forma continua a la presión de los guardias y a las multas arbitrarias que estos imponían. Josefa,

17 Lourenzo FERNÁNDEZ PRIETO y Aurora ARTIAGA (eds.): Otras miradas sobre golpe, guerra y dictadura, Catarata, Madrid, 2014. 
la viuda de Escáneo, logrará sacar adelante a su familia durante la dura posguerra. Pero quien no sobrevivirá será Francisco, el hijo pequeño así llamado en memoria del difunto padre que no llegará a conocer, y quien morirá a los pocos meses. Josefa siempre se culpará de la muerte del niño, asegurando que tenía tanto dolor en el cuerpo que su leche había quedado emponzoñada. ${ }^{18}$

\section{Actualidad y reconocimiento público}

La dictadura logró enmudecer la historia de miles de hombres y mujeres durante décadas. Sólo con la muerte del dictador puede Bueu empezar a se reconocer a sí mismo y puede decidir quienes serán sus héroes de referencia en la nueva etapa democrática. De este modo, en el pleno del ayuntamiento del 7 de julio del 1979, se llega al acuerdo de cambiarle el nombre a varias calles del municipio, que pasarán a ser llamadas "Alfonso R. Castelao", "Xan Carballeira”, "Alexandre Bóveda", "Rosalía de Castro" y "Francisco Escáneo". ${ }^{19}$ Sin embargo, después de 80 años del fusilamiento de Escáneo, tensiones y odios aún latentes se aprecian en forma de vandalismo: la placa con el nombre de la calle Francisco Escáneo ha sido destrozada en repetidas ocasiones, teniendo a día de hoy todavía dentadas de lo que parecen martillazos.

Demuestra esto que las heridas abiertas en 1936 y agrandadas por una deficiente política de justicia transicional promocionada por el Estado desde 1975 aún no se han cerrado. Para remediar esto, grupos locales de Bueu han impulsado una necesaria lucha contra la desmemoria, retomando de forma simbólica nombre que evocan aspectos relacionados con 1936. Sirvan de ejemplo la Asociación de Amigos de Johán Carballeira, la Asociación para el debate Ricardo Gómez de Buceta, o la Asociación de Vecinos "O Progreso" de Beluso. Su labor, junto al apoyo de la concejalía de cultura e de otras personas a título individual, ha permitido desde la llegada de la democracia saciar los deseos de reconocimiento de los familiares de las víctimas del franquismo. Desde entonces, se tienen divulgado diversas publicaciones y celebrado decenas de homenajes,

18 Entrevista personal a Rosario y Josefa Escáneo Pérez en Bueu (agosto, 2015).

19 Esta última se pasó a denominar así por petición expresa del entonces profesor y concejal por Unidade Galega, Angélico Vidal Mauricio. En las actas no se dan explicaciones a mayores sobre por qué se escoge a Escáneo para tal homenaje y no a otro miembro de la corporación del 36; tampoco hemos logrado contactar con Angélico Vidal. Al preguntarle al entonces alcalde de Bueu, Pepe Novas, afirma que era una decisión "obvia" debido a la "grata" memoria que había quedado de Escáneo entre los vecinos, aunque no logra explicar por qué era una decisión tan evidente. Carpeta 30/1 de las actas del pleno del ayuntamiento de Bueu y entrevista personal a Pepe Novas en Bueu (septiembre, 2016). 
en particular a la corporación del 36, con el objetivo de revitalizar la memoria histórica y política de los que fueron asesinados por mantenerse fiel a la legalidad republicana. El acto más reciente ha sido el del 3 de septiembre del 2015, aprobado en el pleno del 25 de agosto del 2012 a petición de la Asociación de Amigos de Johán Carballeira. En el se nombraron miembros honoríficos e hijos predilectos a los concejales Francisco Escáneo Franco, Francisco Piñeiro Barreiro, Francisco García Villanueva, José Bernárdez Santaclara y Francisco Padín Novas; miembro honorífico e hijo adoptivo a José Gómez de la Cueva (Johán Carballeira); y miembros honoríficos a Ramón González Soliño, Manuel Casaleiro Pereira, José Estévez Villar, José Rodríguez Estévez, Ramón Pastoriza Gestido y Manuel Gutiérrez López.

De forma paralela a los actos, se ha multiplicado la cantidad de publicaciones en la prensa sobre la corporación, lo que da cuenta del interés popular por la historia. Sin embargo, como suelen ser artículos que se basan en entrevistas sin ningún tipo de investigación histórica detrás que actúe como tamiz, el resultado no es más que la plasmación al papel de forma acrítica de los relatos transgeneracionales heredados. Esto, si bien ayuda a la divulgación de la memoria hasta llegar a gente que quizás no se tendría interesado de otra forma por este relato y, de forma más general, por la guerra civil; le hace un flaco favor a la realidad histórica, en la medida en que se siguen a repetir falsas ideas (sirva de ejemplo la idea de que Escáneo sólo había sido edil en 1936).

\section{Entre la historia y la memoria}

Jugar entre la historia y la memoria no es fácil. Walter Benjamin, en su "Tesis sobre la filosofía de la historia" (1940), presenta ambos conceptos como irreconciliables: la historia pertenece al poder y la memoria, a los desposeídos. En el mundo ulcerado en el que Benjamin escribía esas palabras poco antes de suicidarse, ésta podría ser una formulación teórica válida. La historia sólo se podía escribir desde y para el Estado, más aún cuando éste era totalitario. Las voces contrarias al discurso oficial eran silenciadas de todas las vías posibles, bien fuese mediante el ostracismo académico o a base de plomo. Así, lo único que le quedaba a los desposeídos, a los que perdieran guerras, pero lograran sobrevivir a la represión, era la memoria, que funcionó así a modo de historia underground: trasmitiéndose con miedo, pero al fin y al cabo trasmitiéndose. De esta 
forma, el miedo llenó de impurezas el relato histórico de la memoria, así como la soberbia corrompió el discurso histórico oficial.

En el caso español, tras cuatro décadas en las que historia y memoria caminaron por vías paralelas, sólo con la muerte del dictador parece que los caminos de una y otra se entrecruzan. Aunque desde entonces se ha profundizado mucho en el conocimiento sobre la guerra civil, es necesaria una reformulación del discurso académico a la luz de las nuevas investigaciones que discuten el relato heredado. Procuramos en este trabajo mezclar historia, memoria y literatura comparada para reflexionar sobre lo que pueden cada uno de estos campos aportar a nuestra percepción sobre el pasado. Porque no nos podemos permitir el lujo de despreciar ningún tipo de fuente.

Según el padre del análisis psicosocial de la memoria Maurice Halwbacks, aunque no existan dos relatos familiares idénticos, podemos agruparlos a todos según la memoria colectiva a la que hagan referencia, ya que en el recuerdo personal hay mucho que procede de los referentes colectivos. ${ }^{20}$ Es un proceso que se va construyendo con el paso del tiempo y no sólo una instantánea de lo que ocurre en un momento preciso, puesto que cuando un republicano es asesinado en agosto del 36 aún no se sabe qué tipo de mártir será: si de los que ganaron la guerra o de los que la perdieron. Así, la memoria se trata de un fenómeno doblemente interesante puesto que está conformada por distintas capas: la primera, en la que estaría el suceso original; la segunda, en la que estaría cómo fue tal suceso percibido por el receptor; y la tercera, cuarta, quinta... que harían referencia a cómo ese suceso se va trasmitiendo de unas voces a otras con el paso del tiempo. La memoria refleja cómo la propia población aprecia la historia, aspecto que ha de ser tenido en cuenta a la hora de construir un nuevo relato sobre golpe, guerra civil y dictadura.

Por último, no debemos olvidar que la historia se tiene que convertir en un bien de consumo más, lo que no tiene por qué afectar a la calidad final de los trabajos e investigaciones. Simplemente, es necesario recordar que para la supervivencia de la disciplina debemos salir del academicismo que se retroalimenta sin fin, careciendo de valores prácticos. En este sentido, la memoria puede convertirse en un gran aliado (tratada, claro está, con una correcta metodología; del mismo modo que somos críticos

20 Jesús IZQUIERDO MARTÍN y Pablo SÁNCHEZ LEÓN: La guerra que nos han contado. 1936 y nosotros, Alianza Editorial, Madrid, 2006. 
con las fuentes escritas), puesto que la fuerza de un relato de terceros puede engancharnos hasta tal punto que se lo contamos a otros, haciéndolo nuestro y así patrimonio social de todas y todos. El correcto tratamiento de la memoria es un instrumento vital para la historia, puesto que la memoria se comparte, sólo ella nos hace sentir en carne propia algo que en realidad no se ha vivido personalmente. Aprovechando su fuerza, podremos crear un nuevo relato histórico que resulte atractivo para aquellos sectores desencantados con la historia. 


\title{
¿Puerta de la agricultura o refugio de mocambeiros? Las fuentes y las caracterizaciones de la frontera entre Pará y Maranhão (1790-1818)
}

\author{
Agriculture's Door or Shelter of Mocambeiros? The Sources and \\ Characterizations of the Border between Pará and Maranhão (1790-1818)
}

\section{Sueny Diana Oliveira de Souza}

Universidade Federal do Pará

\section{Resumen}

En la frontera entre Pará y Maranhão - establecida en el rio Turiaçu - en los fines del siglo XVIII e inicio del siglo XIX diversos fueron las caracterizaciones atribuidas a la región, construidas a partir de discursos presentes en las fuentes escritas. El objetivo del trabajo es discutir como la elección de una documentación en al revés de otra, y los cuestionamientos levantados, posibilitan asumir visiones distintas de los individuos y procesos. Pues, el historiador trabaja con fuentes producidas por individuos en temporalidades distintas, que fueron pautadas en experiencias, intereses e intencionalidades.

\section{Palabras clave}

Frontera. Turiaçu. Discursos. Fuentes escritas.

\begin{abstract}
On the border between Pará and Maranhão - established in Rio Turiaçu-in the late 18th century and early 19th century many were the characterizations attributed to the region, built from discourses present in written sources. Objective of this work is to discuss how the choice of documentation at the expense of another, and the questions raised, make it possible to take different views of individuals and processes. Yes, the historian works with sources produced by individuals in different temporalities, and which were based on experiences, interests and intentions.
\end{abstract}




\section{Keywords}

border. Turiaçu. Speeches. Written sources.

En la región de Turiaçu, frontera entre Pará y Maranhão de 1790 a 1818, inúmeras fueron las organizaciones sociales, las redes de sociabilidad, conflictos y direccionamientos para establecerse la ocupación y el control sobre los sujetos y el espacio físico de la frontera. Para atingir tal intento las organizaciones y las dinámicas desarrolladas en la frontera, fueron percibidas, entendidas, interpretadas y representadas de maneras distintas por la documentación, variando de acuerdo con la situación de cada sujeto dentro de las relaciones, y el lugar donde las fuentes fueron producidas. $\mathrm{O}$ sea, el espacio de la frontera fue comprendido de formas múltiples variando de acuerdo con los intereses de los diferentes individuos. Desde esa perspectiva podemos asociar las conceptuaciones dadas a las áreas de frontera al concepto sertão. Pues, las áreas de frontera fueron denominadas de sertão por autoridades del gobierno, en su mayoría, por características peyorativas. En ese sentido, Pedro Puntoni afirma que "ao olhar do magistrado, o sertão era o 'receptáculo de tudo que é mau'. Lugar da mistura e confusão de povos, cujo caráter era duvidoso"1. Sin embargo, Janaína Amado presenta diferentes sentidos atribuidos al sertão, donde:

se foi erigido como categoria pelos colonizadores e absorvidos pelos colonos, em especial pelos diretamente relacionados aos interesses da Coroa, "sertão", necessariamente, foi apropriado por alguns habitantes do Brasil colonial de modo diametralmente oposto. Para alguns degredados, para os homiziados, para os muitos perseguidos pela justiça real e pela inquisição, para os escravos fugidos, para os índios perseguidos, para os vários miseráveis e leprosos, para, enfim, os expulsos da sociedade colonial, "sertão" representava liberdade e esperança; liberdade em relação a uma sociedade que os oprimia, esperança de outra vida, melhor, mais feliz. Desde o início da história do Brasil, portanto figurou uma perspectiva dual, contendo em seu interior, uma virtualidade: a da inversão. Inferno ou paraíso, tudo dependeria do lugar de quem falava. ${ }^{2}$

\footnotetext{
${ }^{1}$ Pedro PUNTONI: A guerra dos Bárbaros: povos indígenas e colonização no sertão nordeste do Brasil, 1650-1720, São Paulo, Hucitec - Fapesp, 2002, p.288.

2 Janaína AMADO: "Região, sertão, nação", Estudos Históricos, Rio de Janeiro, v. 8, n. 15, (1995), p.149.
} 
Para Denise Maldi la representación de los sertões y de sus habitantes era caracterizada "pela ausência - seja de limites, seja de fronteiras ou de outras formas de atribuição de plausabilidade à dimensão geográfica". Tal caracterización contradecía la concepción de frontera atribuida por los europeos. ${ }^{3}$ Según la autora "a definição do 'sertão' vai ser a própria indefinição abrindo a consciência européia para um espaço múltiplo e polimorfo". ${ }^{4}$

De esa forma además de una variedad de interpretaciones dadas a la región de Turiaçu, concebida como sertão por diferentes intereses, lo que percibo también son diferentes formas de comprender el social, y, por consiguiente, diferentes formas de construir y comprender el conocimiento histórico, teniendo en vista que este es más que una representación de la realidad, es reconstrucción del pasado. ${ }^{5}$

La región de Turiaçu fue presentada y comprendida a partir de diferentes perspectivas por los documentos y por la historiografía producida, que refleten visiones e intereses acerca la región. En ese sentido, la Narrativa es comprendida como contar una historia y, por lo tanto, desarrollar la experiencia humana en el tiempo, considerando los intereses y perspectivas de quien narra y cuales sentidos son atribuidos a las experiencias y organizaciones de los sujetos en el espacio y en el tempo. ${ }^{6}$

La narrativa fue rechazada por la historiografía, sobretodo, a partir de los Annales. El despreso se dio en virtud de la aversión al estilo descriptivo y factual a través del cual la historia era retratada. Los Annales rompieron con la historia historicizante o tributaria de los sucesos. El objeto de la historia ciencia pasó a ser, no más los grandes hombres y sus grandes factos y hechos, sino los grupos sociales, criticando el suceso en su superficialidad y buscando la serie, el repetido. ${ }^{7}$

Esa forma descriptiva de la narrativa como reflejo de la realidad o de la historia es criticada por François Hartog, Roger Chartier y Benedito Nunes, sin embargo, ninguno de ellos defiende, necesariamente, el fin de la narrativa, sino cambios en la forma como

\footnotetext{
${ }^{3}$ Denise MALDI: "De confederados a bárbaros: a representação da territorialidade e da fronteira indígenas nos séculos XVIII e XIX”, Revista de Antropologia, São Paulo, USP, v. 40, n. 2, (1997), p.192.

${ }^{4}$ Ibid, p. 191 .

${ }^{5}$ Benedito NUNES: "Narrativa histórica e narrativa ficcional”, en Dirce RIEDEL (org.), Narrativa: ficção \& história, Rio de Janeiro, Imago, 1988, p.11.

${ }^{6}$ Ibid, p.13.

${ }^{7}$ François HARTOG: "Disputas a respeito da narrativa", en Evidencia na história: o que os historiadores veem, Belo Horizonte, Autêntica, 2011, p.174.
} 
narrativa fuera desarrollada durante décadas. La narrativa, sobretodo, la de los procesos históricos, deben ser desarrolladas a partir de indagaciones, hipótesis y preguntas, y debe permitir al lector posibilidades de tales indagaciones. ${ }^{8}$

La opción de la discusión en este trabajo es, en un primero momento, la de valorización y rescate de historias que traigan a la luz los intereses y objetivos del gobierno portugués en una distante localidad en el norte del imperio luso, pero a cima de todo retratar las relaciones que se desarrollaron aisladas o como contrapunto de este proceso. $\mathrm{Y}$, en un segundo momento retratar las caracterizaciones negativas y positivas acerca de la región de Turiaçu y sus sujetos por autoridades del gobierno portugués y por la historiografía producida sobre la región. Así, la investigación busca discutir un tiempo partiendo del social y no, necesariamente, del tiempo basado en un grande suceso. ${ }^{9}$

Desde esa perspectiva, la discusión sobre narrativa desarrollada por Hartog, Chartier y Nunes, pueden llevar el lector a percibir las diferentes formas de narrar y construir el conocimiento histórico sobre Turiaçu, partiendo del poder que el discurso posee y las formas como la narrativa producida por medio de este atribuí diferentes sentidos al proceso de "construcción” y ocupación de la frontera entre Pará y Maranhão en fines del siglo XVIII e inicio del siglo XIX, que fue realizado basado en discursos y justificativas, sobretodo, de hombres del gobierno en la tentativa de imponer principios y valores de la colonización portuguesa en la región.

\section{Estrategias de ocupación}

La villa de Bragança fue fundada en 1754. Antes de eso, esta villa era denominada Souza do Caeté y partencia la capitanía do Caeté, una capitanía privada donada a Álvaro de Sousa y repasada a sus herederos. Solamente en 1753 en el gobierno de Mendonça Furtado la capitanía del Caeté fue extinguida y anexada a la Capitanía de Pará y acerca de un año después la villa de Bragança fue fundada. ${ }^{10}$ Por medio del Decreto de 14 de junio de 1753, firmado por el Rey D. José I, se decidió que: “o Porteiro Mor Manoel Antonio cede todos os direitos sobre a Capitania do Caeté que ficará para sempre e

\footnotetext{
${ }^{8}$ Ibid, p. 177.

${ }^{9}$ Roger CHARTIER: “A verdade entre a ficção e a história”, en Marlon SALOMON (org.): História, verdade e tempo, Chapecó, Argos, 2011, p.348.

${ }^{10}$ Luciana de Fátima OLIVEIRA: Projetos de colonização de um território: da vila de Souza do Caeté à vila de Bragança: 1740-1760, Dissertação de mestrado, Universidade Federal de Góias, 2008, p.39.
} 
inteiramente incorporada a Coroa Real". ${ }^{11}$ La posesión de la Capitanía de Caeté seria tomada por el Oidor General de la Capitanía de Pará. Y así, acababa la Capitanía de Caeté por su incorporación a Pará.

Durante el siglo XVII y meados del siglo XVIII, Pará, Maranhão y Caeté eran capitanías distintas, siendo que las dos primeras eran gobernadas por la Corona mientras que la última era privada. Sin embargo, Pará y Maranhão formaban desde 1621 un único Estado, el Estado Maranhão e Grão-Pará, que el 1751 pasó a llamarse Estado Grão-Pará e Maranhão. En esas formaciones ambas las capitanías constituían juntas un gobierno independiente que existió hasta 20 de agosto de 1772, cuando por medio de un decreto Régio fueron separadas en dos capitanías e integradas al Estado de Brasil. Se formaron a partir del entonces las capitanías Grão-Pará e Rio Negro y Maranhão e Piauí. El límite entre estas fue delimitado en este momento y se situaba en el rio Turiaçu.

Turiaçu fue, por lo tanto, una frontera construida lentamente y ganaba importancia conforme los gobernadores deseasen ampliar la comunicación y el comercio entre Maranhão y Pará. A los fines del siglo XVIII, mismo que la delimitación administrativa de la frontera entre Pará y Maranhão fuera delimitada en el rio Turiaçu, es importante resaltar que la ocupación y la propia descripción de la frontera eran hechas siguiendo una línea transversal al rio. La región de Turiaçu por localizarse, de acuerdo con los administradores portugueses, en los confines o sertões de la capitanía era tenida como errante, y los recorridos próximos que llevaban a esa región cuando ocupados por personas consideradas como personas de mala conducta acababan siendo insertados y denominados como siendo parte de esa área de frontera. De esta forma Bragança fuera descrita como frontera, pues a pesar de la villa quedar, aproximadamente, a 50 leguas de distancia del rio, la población de São Francisco Xavier de Turiaçu fue feligresía de Bragança hasta 1834, cuando pasó a la condición de villa.

La región de Turiaçu fue un espacio en lo cual se desencadenaron inúmeros conflictos envolviendo la posesión de tierras, lucha en contra mocambos, desentendimientos en el interior de las poblaciones indígenas entre otros. Por esos motivos el gobierno portugués invistió en un proceso de ocupación pautado, sobretodo,

\footnotetext{
${ }^{11}$ Decreto (cópia) do rei D. José, para o Porteiro-mor, Manuel Antonio de Melo e Sousa, 4/06/1753. Arquivo Histórico Ultramarino. Documentos avulsos. Doc. 3233 Cx. 35.
} 
en la vía de donación de cartas y fechas de sesmarias. Eso queda claro cuando notamos que la carretera de comunicación entre Pará y Maranhão, en la última década del siglo XVIII, en el distrito de Turiaçu, estaba ocupada por haciendas con creación de ganado adquiridas por donaciones de sesmarias. El problema es que en la última década del siglo XVIII, durante el proceso de apertura de las carreteras que interconectarían las capitanías Pará con Maranhão, en el área de las Campinas, ${ }^{12}$ ninguna hacienda de creación de ganado se localizaba a la orilla de la nueva carretera de comunicación. La primera población se localizaba en la cabecera del rio Cararauá a una distancia de una legua de la carretera hacia la costa estando entre el rio Turiaçu y el rio Maracassumé donde el capitán Estevão de Alracida, de la capitanía Maranhão inició la creación de ganado vacum alrededor de 1791 con aproximadamente cien cabezas. La segunda se localizaba en las cabeceras del rio Perucaua, localizada a media legua de la carretera hacia la costa estando entre los rios Maracassumé y Gurupí. La población siguiente se localizaba en las mismas tierras, entretanto casi a la orilla del rio Gurupí y distante a una legua de la carretera, siendo la menos productiva de las tres poblaciones de esa región. Ahí había una hacienda de ganado perteneciente a la viuda del capitán André Corcino.

Con la apertura de carreteras en el área de frontera otras formas de ocupación fueron deseadas. En septiembre de 1793 el Gobernador de la capitanía Pará, Souza Coutinho, pretendía poblar toda la región que interconectaba la capitanía Pará hacia Maranhão, y solicitó en carta encaminada al director de la villa de Bragança, José Maximo, que se formara una población a la orilla de la nueva carretera entre las dos capitanías a la altura del rio Maracassumé. El director de Bragança sugirió entonces que al revés de reclutar sujetos para la formación de la nueva población fuera transferida hacia la orilla de la carretera recién-abierta a la población indígena de Mutuoca. La sugerencia de José Maximo fue acatada por el gobernador de la capitanía Pará, sin embargo, ni el gobernador, ni el director de Bragança consultó a los indígenas de la población.

Al ser comunicados del cambio a lo cual serian obligados, muchos indígenas afirmaron no aceptar la decisión. El Principal ${ }^{13}$ de la población, Firmiano Jozé Nunes, fue adelante y creó obstáculos para el cambio. Muchos indígenas se ausentaron de la población a fin de que no sean dislocados. Mismo sin estar de acuerdo casi trescientos

\footnotetext{
${ }^{12}$ Era área de campo extenso e de poucas árvores.

${ }^{13}$ Era um líder indígena responsável de organizar as atividades dos índios no interior das povoações.
} 
indígenas - hombres y mujeres de diferentes edades - fueron aprehendidos y obligados a cambiaren de vivienda. En noviembre de 1795, 28 indígenas ya habían abandonado la nueva población, denominada de Arroio, y se encontraban en la lista de procurados por el gobierno. ${ }^{14}$

Por los obstáculos creados la réplica de las autoridades en contra el Principal de la población se hizo presente. Usando un discurso peyorativo, José Maximo denunciaba a Souza Coutinho que el Principal de Mutuoca era "hum demonio, orgulhoso, ingusito e atrevidisimo" y que el obstáculo de este se daba en virtud de que este oculta esclavos ajenos en la población y da cobertura a soldados desertores de Maranhão y Pará, y que por eso quedaba siempre lejos del párroco y del director. ${ }^{15}$

Por la posición asumida por el referido Principal el maestro de campo y responsable por la apertura de las carreteras que interconectaban Pará a Maranhão, Antonio Correa Fortado de Mendonça sugirió al director de la villa de Bragança que fuera retirada la patente de Firmiano, ya que este no era hijo ni nieto de un Principal y que tenía conquistado el cargo por ser "astuto". Sobre el traslado de los habitantes de Mutuoca, el maestro de campo afirmaba que solamente con ello el Turiaçu tendría paz, pues como Mutuoca era una isla esta era también un punto estratégico para el estabelecimiento de "criminosos" que allá se alojaban y cuando necesitaban huir tenían la posibilidad de alcanzar rápidamente el mar o atravesar el rio, permitiendo que la región de Turiaçu estuviera siempre ocupada por esos sujetos. ${ }^{16}$

La narrativa construida por las autoridades portuguesas sobre esa área de frontera se refería siempre a conflictos, desobediencia, vagabundos y criminosos, o sea, la de una región que precisaba recibir atención y control del gobierno. El caso descrito involucra muchas personas e intereses. Si el Principal Firmiano era "astuto" para obtener el cargo de líder local, fue también su astucia que se transformó en atrevimiento y orgullo cuando se volteó en contra la voluntad regia de las autoridades absolutistas locales. ¿Pero lo que deseaba hombres como el Principal Firmiano? Los obstáculos presentados por el Principal indígena de Mutuoca, posiblemente no se daba únicamente por la población

\footnotetext{
${ }^{14}$ Arquivo Público do Estado do Pará. Correspondência de diversos com o governo (1793-1800). Cod. 345, doc. 60 .

${ }^{15} \mathrm{Ibid}$, doc. 38 .

${ }^{16} \mathrm{Ibid}$, doc. 36.
} 
encubrir negros y fugitivos. Con todo, este lado de la cuestión quizás efectúe una cierta solidaridad y dependencia de esta comunidad con aquella de los negros amocambados. Había un precio para albergar negros huidos y este precio ciertamente era pago con mercadorías y utensilios que los negros podrían fornecer a los indígenas de Mutuoca.

Todavía, para más allá de cambios y favores a insatisfacción de estos indígenas podría aun refletar la forma negativa por la cual percibían un cambio de local. Alteraciones territoriales eran puntos centrales e influenciaban en su organización local (comunitaria). Pues, además de existieren lazos establecidos con el lugar que ocupaban desde que habían sido retirados de sus pueblos, estos indígenas crearon otros lazos sociales con los sujetos considerados como errantes de la región, con los cuales compartían de una vida en libertad y reinventaban identidades que buscaban preservar. Sin embargo, mismo con todos los embates generados alrededor del cambio y sin estar a favor, los indígenas fueron dislocados forzosamente.

Entretanto los conflictos no cesaron. Los indígenas fueron aprisionados y direccionados al nuevo destino por las propias autoridades portuguesas. Aquí es relevante notar que el dislocamiento también significó una alteración en el nombre de la localidad, lo que más una vez creaba problemas a estos antiguos vivientes de Mutuoca. El cambio de nombre por parte del gobierno podría tener la intención de (des)identificar la población en virtud de la denuncia de esta encubierta de sujetos indeseados por el gobierno y de esa forma amenazar la integridad de los que trillaban por estas paradas.

El gobierno de Pará pretendía hacer de la frontera de Turiaçu un lugar poblado por súbditos reales garantizando tranquilos viajes a los que caminaran en las carreteras entre Pará y Maranhão. Sin embargo, el dislocamiento forzoso de una población y la constitución de una población a las orillas de la nueva carretera, por sujetos que no gastarían de instalarse allí, no resultó la cuestión y, en contra partida creó nuevos problemas. Incluso porque el cambio de los indígenas fue de espacio físico y no de principios. Podemos hacer una asociación al que Patrícia Sampaio defiende. Para la autora, el hecho de los indígenas, durante el proceso de caída, haber sido rebajados y sus pueblos puestos en locales distantes de sus antiguos pueblos no era motivo que le desmotivaría a huir, pues era posible reestablecer una vida en libertad formando un 
mocambo. ${ }^{17}$ El dislocamiento de la población de Mutuoca no resultó o extinguió los sujetos indeseados de esa área de frontera, pues estos sujetos podrían formar nuevas comunidades en otro lugar, recibir la protección de otras poblaciones y hasta mismo la nueva población de Arroio daría cobertura y protección a los errantes de la frontera en áreas más distantes del rio.

Y, en este sentido la fuerte de interacción entre indígenas, hombres blancos pobres y negros, que a lo largo de los siglos siempre fue muy frecuente, generando muchas veces la dificultad de distinguir el espacio y la identidad de cada uno se mantuvo. En la región de Turiaçu esa relación siempre fue muy intensa.

La concepción de frontera atribuida por el gobierno portugués era ambigua, pues al mismo tiempo en el que se establecía un límite físico tratándose de la frontera, esa concepción estaba atada a ocupación del espacio, lo que llevó a una intensificación de la descripción y protección de esos espacios por medio de la ocupación. Pues, si en los embates con las capitanías vecinas el gobierno de Pará se valía de las delimitaciones físicas para imponer y justificar sus acciones dentro de la línea impuesta por el rio. Internamente (a los fines del siglo XVIII e inicio del siglo XIX) la frontera fue concebida, sobretodo, como área de tráfico que necesitaba está "protegida" y preparada para tal. Por esa concepción es que se acababa denominando regiones que daban acceso al rio Turiaçu como área de frontera y que se buscó abrir carreteras y poblar, por vías legales, sus orillas, con propósito de garantizar tal intento. Desde ahí el porqué de la ocupación legal de la región de Turiaçu, o de la frontera de Turiaçu, se haber dado, principalmente, en un sentido transversal al rio, pues eran por esas vías donde se transportaba correspondencias, desertores, ganado y tantas otras cosas entre Pará y las capitanías vecinas.

En este sentido, podemos afirmar que ese proceso marcó la ocupación y organización social de la frontera de Turiaçu. Pues, el gobierno portugués idealizó e instituyó un proyecto de colonización y ocupación pautado, sobretodo, a partir de donaciones de tierras por sesmarias y del control sobre los indígenas poblados. Entretanto, a lo fines del siglo XVIII e inicio del siglo XIX, la frontera parecía dominada por otros sujetos bastante diversos. En ese período, indígenas, negros huidos y hombres blancos

\footnotetext{
${ }^{17}$ Patrícia Melo SAMPAIO: Espelhos Partidos: Etnia, legislação e desigualdade na colônia, Amazonas, EDUA, 2011, p.124.
} 
pobres - los cuales en su grande mayoría contrabandistas y desertores - parecían determinar el proceso de ocupación separado del idealizado por el gobierno. Y, más que determinar el proceso de ocupación esos pueblos parecían ser (o de hecho eran) regidos por otros límites y otras fronteras que eran pautados en sus acciones.

Esos sujetos y sus acciones eran descritos por José Maximo, director de la villa de Bragança. En correspondencia enviada al gobernador de la capitanía, el 1794, el director de Bragança enfatizaba que los sujetos del distrito de Turiaçu no estaban sumisos, ni demostraban obediencia a nadie. Los sujetos de la frontera eran, según Maximo, de este modo,

por se compor aquelle povo de pessoas vagabundas, refugiados de crimes, sempre criados e costumados a viver por mocambos, seguindo huma sempenciosa vida em a qual se temão (...) outro viver mais que em concombinaçoens e em briagues afectivos, para o que estragar toda a mandioca que plantão desfazendoa em licores, em serem gente em quem senão conhece religião. A similhança destes vive a mayor parte dos moradores do distrito desta vila (Turiaçu) a esseção de huns poucos de filhos das ilhas que ainda há já estropiados, e alguns muito poucos filhos da Europa que aqui se tem estabelecido os mais tudo hé gente inferior sem estimolos de honrra, mal criados e sem temor de Deus... ${ }^{18}$

En realidad - como esta era una frontera marcada por la transitoriedad de los sujetos - estos acabaron desenvolviendo características de identidad propias y ambiguas, muchas de estas contrarias a las idealizadas por el proyecto de ocupación y colonización determinado por las autoridades que representaban el gobierno portugués en Pará o Maranhão. Mismo que - al final del siglo XVIII - las fuerzas del gobierno siempre estuvieran intentando mejorar su presencia en la región con el objetivo de transmitir o imponer los principios para ocupación, la obediencia y el vasallaje definidores de ese proceso nunca fue efectividad con éxito.

\section{Caracterizaciones de la frontera}

Hasta 1771, la región de Turiaçu pertenecía al territorio de Maranhão, en la época en que el límite geográfico entre Pará y Maranhão era demarcado en el rio Gurupi. Favorecida por la localización en un territorio cercado por ríos y perforaciones, y en las proximidades del mar, era considerada altamente fértil, visto que la actividad agrícola allí

\footnotetext{
18 Arquivo Público do Estado do Pará. Correspondência de diversos com o governo (1793-1800) ..., doc. 38.
} 
desarrollada era "motivada pelas condições geográficas e produtivas" de la capitanía de Maranhão, que, a pesar de producir diversos géneros, tenia el algodón y el arroz como principales géneros destinados a la explotación, según Augusto Cezar Marques (1864).

Teniendo esto en vista, Marques (1864) recuerda que al inicio del siglo XIX, la región de Turiaçu era tan productiva que "o governador do Pará, Conde dos $\operatorname{Arcos}^{19}$ (1810-1818), chamou-a de 'a porta por onde entrou para o Pará o amor da agricultura', e pela qual já se exportava anualmente para o Maranhão 3:087 sacas de algodão, e 11:210 alqueres de arroz...". ${ }^{20}$ Sin embargo, dos décadas antes, precisamente en 1791, en el inicio del proceso de apertura de las carreteras de comunicación entre Pará y Maranhão, el director de la villa de Bragança, João José de Albuquerque, definía los fregueses de São Francisco Xavier de Turiaçu como un lugar que más se acercaba a un mocambo de fugitivos de lo "que lugar de vasallos de sua Majestade", una vez que los sujetos de la región se recusaron a trabajar en la apertura de las carreteras, así como también a abrir una plantación de yuca para auxiliar los hombres que estaban involucrados en los servicios de las dichas carreteras. ${ }^{21}$

En poco más de dos décadas São Francisco Xavier de Turiaçu pasó de lugar que más parecía un "mocambo de fugitivos" a la puerta por donde entró en Pará el "amor pela agricultura". Esas definiciones sobre el espacio de la frontera nos hacen reflexionar sobre los probables cambios y/o intereses que llevaron las diferentes caracterizaciones de esa zona fronteriza.

En la segunda mitad del siglo XVIII, la administración del Estado al Norte de las poses lusas en la América pasó por una reorganización. La sede del Estado fue establecida en Belém, y el antiguo Estado de Maranhão e Grão-Pará pasó a ser llamado de Estado de Grão-Pará e Maranhão. Entretanto, a constitución del Estado se puso inalterada "até a conjuntura de depressão econômica que se abateu sobre o Império Português nos

\footnotetext{
${ }^{19} \mathrm{D}$. Marcos de Noronha e Brito, ao encaminhar à corte os retratos sobre o teor singular "de trajar das mamelucas e mulheres pardas" que havia encomendado a Antonio Leonardo, pintor recém-chegado de Lisboa, o Conde dos Arcos afirma ser a capitania do Pará, além da mais extensa, "a melhor de todas as possessoens da Coroa Portugueza na America Meridional" (Antônio Ladislau Monteiro BAENA: Ensaio Corográfico sobre a província do Pará, Brasília, Senado Federal, 2004, p.258), possuindo terras de grande fecundidade.

${ }^{20}$ Augusto César MARQUES: Apontamentos para o dicionário histórico, geográfico, topográfico e estatístico da Província do Maranhão, [s.1.], José Maria Correa de Frias Editor, 1864, p.350.

${ }^{21}$ Arquivo Público do Estado do Pará. Correspondência de diversos com o governo (1793-1800) ..., doc. 14.
} 
setecentos". 2223 En un contexto de acentuada reducción de la explotación de oro en Brasil, de dificultades en la comercialización del azúcar y de diminución de las actividades en las minas de diamante, sumado a los gastos exorbitantes en virtud de la participación de Portugal en la Guerra de los Siete Años, los rendimientos de la Corona fueron abalados significativamente. Delante de la crises, el ministro Sebastião José de Carvalho e Mello, el Marquês de Pombal, reforzó las medidas y acciones a fin de reducir, en la América, la dependencia de materias-primas y productos manufacturados venidos del reino y de otras poses portuguesas. ${ }^{24}$ Para atingir tal intento, se buscó "recrutar" para las secretarias y gobiernos hombres habilitados para poner en práctica el proyecto de recuperación económica de la Corona portuguesa. En este escenario de preocupaciones y acciones, el incentivo a la agricultura fue uno de los principales caminos buscados para obtenerse la tan deseada recuperación económica. Mismo que esta política haya sido pensada y aplicada para todas las poses lusas en la América, se buscó, sobretodo, potencializar las producciones agrícolas de las capitanías al Norte e insertalas de manera más notable en el comercio atlántico. ${ }^{25}$ Fue en ese contexto que la esclavitud indígena pasó a ser ilegal y se decretó la liberación. La agricultura volcada para el mercado externo pasó a ser estimulada, sobretodo, por la creación de la segunda Compañía General de Comercio en la región. ${ }^{26}$

La nueva concepción de colonización implementada por el Marquês de Pombal y la institución del Directorio ${ }^{27}$ vinieron acompañadas del monopolio comercial, con la creación de la Compañía de Comercio de Grão-Pará e Maranhão, que actuó de 1756 a 1777. Según

\footnotetext{
${ }^{22}$ Em 1772, o Estado do Maranhão e Grão-Pará foi desfeito e incorporado ao Estado do Brasil, passando a constituir duas capitanias separadamente (Flávio dos Santos GOMES: A Hidra e os Pântanos: mocambos, quilombos e comunidades de fugitivos no Brasil (séculos XVII-XVIII), São Paulo, Ed. UNESP, Polis, 2005, p. 132).

23 Antonia da Silva MOTA: A dinámica colonial portuguesa e as redes de poder local na capitania do Maranhão, Tese de doutorado, Universidade Federal de Pernambuco, 2007, p.15.

${ }^{24}$ Charles BOXER: O Império marítimo português, São Paulo, Companhia das letras, 2002, p.194.

${ }^{25}$ Luiz Felipe de ALENCASTRO: O trato dos viventes: formação do Brasil no Atlântico Sul, São Paulo, Companhia das Letras, 2000, p.142.

${ }^{26}$ Ibid, p. 142 .

${ }^{27}$ Segundo Patrícia Sampaio o Diretório de 1757 foi a primeira e mais importante medida da chamada política pombalina. "Na avaliação dos administradores coloniais, sua implantação configurava-se como um instrumento tutelar necessário de transição para a liberdade considerando o estado incipiente da civilização dos índios recém-aldeados. É sobre esse duplo prisma que o Diretório deve ser avaliado: além de configurarse como instrumento legal de organização da força de trabalho, pretende também viabilizar a civilização dos índios. Trabalho e civilização são conceitos complementares neste século XVIII, e o ócio, a vadiagem são tratados com o rigor de uma falta criminosa" (Patrícia Melo SAMPAIO. Espelhos Partidos..., p. 137).
} 
Sampaio (2011), "a saída pombalina para conter as ações dos regulares, libertar os índios e desenvolver o comércio passaria, também, pela implementação do monopólio mercantil". ${ }^{2}$

El estabelecimiento de la Compañía de Comercio de Maranhão, en 1682, fue un intento pionera de la Corona portuguesa de obtener el monopolio comercial, para solo entonces regularizar la entrada y actuación de la mano de obra negra, esclava en la capitanía de Grão-Pará. Todavía, la Compañía no obtuvo los resultados esperados, siendo extinguida en 1684, debido a los precios altos cobrados a los hacenderos y colonos por la adquisición de esclavos, cuyas insatisfacciones, sobre todo debido al monopolio del comercio conocido como estanco, llevaron a la eclosión de una revuelta denominada "Revolta de Beckman", en la que se destituyó la autoridad del gobernador de Maranhão e Grão-Pará, Francisco de Sá e Meneses, y se constituyó una junta que pasó a controlar las casas del estanco, de la cual uno de los integrantes era Manuel Beckman, considerado como uno de los cabezas de la revolución que llevó a la extinción de la primera Compañía de Comercio de Maranhão ${ }^{29}$. Pero, en 1755, el comercio ganó nuevo impulso en la región, principalmente de esclavos, con la creación de la segunda Compañía de Comercio, ahora nombrada Compañía General de Comercio de Grão-Pará e Maranhão, que previa la introducción de esclavos negros en las provincias de Grão-Pará e do Maranhão, garantizando nuevamente a una compañía el monopolio de importación de africanos. ${ }^{30}$

La empresa debería actuar aun en la "ampliação da produção de cacau manso e a exportação global do produto resolvendo dois problemas cruciais: o do transporte, através do estabelecimento de frotas regulares e o da mão de obra, introduzindo escravos africanos a preços acessíveis". ${ }^{31}$ Para la autora, "os objetivos da Companhia eram ambiciosos: estabelecer com regularidade as ligações das praças de Belém e $\mathrm{S}$.

Luís com a metrópole através de um sistema de frotas e, também, abastecer o mercado local com escravos, incluindo o Mato Grosso". ${ }^{32}$ En ese contexto, Gaioso comparaba la capitanía de Maranhão a la fénix, que como tal, tras la creación de la Compañía de comercio habría renacido y erguido a su "altiva cabeça" para "emparelhar com as províncias mais

\footnotetext{
${ }^{28}$ Ibid, p. 174.

${ }^{29}$ Rafael CHAMBOULEYRON: "Duplicados clamores: queixas e rebeliões na Amazônia colonial (século XVII)”, Projeto História, São Paulo, n. 33, (dez. 2006), p.164.

${ }^{30}$ Vicente SALLES: O negro no Pará: sob o regime da escravidão, Rio de Janeiro, FGV/ UFPA, 1971, p.35.

${ }^{31}$ Patrícia Melo SAMPAIO: Espelhos Partidos..., p.154.

${ }^{32}$ Ibid, p.176.
} 
opulentas do Brasil". ${ }^{33}$ De acuerdo con Gaioso, la creación de la Compañía de Comercio de Grão-Pará e Maranhão fue el grande incentivo dado a la agricultura y al comercio en el Norte de Brasil, visto que, aunque la producción de la región aun fuera incipiente, los labradores no tenían como se lanzar al mar para efectuar el comercio por medios particulares $^{34}$. El autor recordaba que en períodos anteriores a la creación de la Compañía "eram as produçoens da capitania muito insignificantes..." y se realizaban solamente pequeños o ningún comercio, pues la producción agrícola se reducía a pequeños cultivos de arroz rojo, harina de yuca, maíz, ricino y café, afirmando que todo lo que era producido acababa siendo consumido internamente. Además de los géneros descritos había pequeñas producciones de algodón, que eran hiladas por los "naturais" y reducían a "nove-lhos" o rollos de paño y "formavão o representativo da moeda" ${ }^{35}$. Para este autor, además de promover la cultura del algodón, la Compañía de Comercio fue responsable por la explotación, principalmente a partir de $1760^{36}$. Sin embargo, los labradores no se limitaron al cultivo del algodón, habiendo sido incentivados a plantar arroz, no el rojo, que era común en la región y visto como de menor cualidad, sino el arroz de Carolina. ${ }^{37}$

Entre tanto, es preciso hacer las afirmaciones de Gaioso (1818). Chambouleyron (2010) demuestra que en las últimas décadas del siglo XVII fueron construidos discursos o alegaciones que retrataban la "decadência" del Estado de Maranhão, estableciendo la defensa del estanco instituido con la creación de la primera Compañía de Comercio $^{38}$. El autor evidencia como los textos y/o discursos en defensa de la Compañía, como el de João de Moura en el siglo XVII, al mismo tiempo defendían la idea de que la agricultura seria "a forma ideal de desenvolvimento econômico das conquistas". ${ }^{39}$ Por consiguiente, tales ideas se convirtieron en uno de los puntos importantes en el proceso de ocupación y colonización emprendido a lo largo de los siglos XVII y XVIII. Desde el punto de vista económico, el propio Directorio Pombalino incentivó la producción agrícola volcada para la explotación, así como al

\footnotetext{
33 Raimundo José de Sousa GAIOSO: Compêndio histórico-político dos principios da lavoura do Maranhão, Rio de Janeiro, s.e, 1818, p. 21.

${ }^{34}$ Ibid, pp.176-177.

${ }^{35}$ Ibid, pp.168-169.

${ }^{36}$ Ibid, pp. 179.

${ }^{37}$ Ibid, p. 182.

${ }^{38}$ Rafael CHAMBOULEYRON: Povoamento, ocupação e agricultura na Amazônia colonial (1640-1706), Belém, Açaí, 2010, p.122.

${ }^{39}$ Ibid.
} 
cultivo de productos destinados a la subsistencia de las poblaciones y de la capitanía como un todo. ${ }^{40}$

La implementación de la segunda Compañía de Comercio posibilitó un impulso económico en el sector comercial, lo que permitió aumentar los investimentos en la agricultura, por medio de la introducción de la mano de obra esclava negra en las capitanías, teniendo en vista que la utilización de esa fuerza de trabajo fue estimulada por el gobierno, en virtud de la promulgación de la libertad indígena. Sin embargo, mismo que la Compañía haya introducido - de forma sistemática y continua un contingente significativo de fuerza laboral de esclavos africanos - es improbable que antes de eso no haya existido una significativa producción agrícola y del comercio en las capitanías de Pará y Maranhão. En este aspecto, el estudio preciso de José Alves de Souza Júnior (2009) demuestra que ya había un comercio intensivo entre Pará y Lisboa en el período antecedente a la creación de la Compañía de Comercio de Grão-Pará e Maranhão. Todavía, en ese período, los principales productos exportados eran los extractivitas, con destaque para el clavo y el cacao, entre otros ítems que constaban en la pauta de explotaciones. ${ }^{41}$

Si ese comercio existía, sus números eran, todavía, contradictorios cuanto al volumen que salía de Pará y lo que era procedente de Maranhão. Por ejemplo, de acuerdo con Salles (1992), Pará no tendría acompañado integralmente la ascensión de la producción agrícola volcada a la explotación verificada en la capitanía de Maranhão, con la creación de la segunda Compañía de Comercio. ${ }^{42}$ Para el autor, mismo que Pará tuviera una mayor variedad de géneros utilizados como moneda natural en el pasar de los siglos XVII y XVIII, aquí la producción habría se limitado a las pequeñas plantaciones de caña-de-azúcar, arroz, domesticación del cacao, así como su extracción nativa, no obteniendo destaque significativo en las explotaciones a lo fines del siglo XVIII, como ocurrió en la capitanía vecina. Sin embargo, pesquisando los mapas de las cargas de géneros destinados a la explotación partiendo del puerto de Belém en ese período, fue posible percibir, como prueba el estudio de Souza Júnior (2009), en el cual los datos demuestran un cuadro bastante

\footnotetext{
${ }^{40}$ Patrícia Melo SAMPAIO: Espelhos Partidos..., p.139.

${ }^{41}$ José Alves de SOUZA JUNIOR: Tramas do cotidiano: religião, política, guerra e negócios no GrãoPará do setecentos. Um estudo sobre a Companhia de Jesus e a Política Pombalina, Tese de Doutorado em História Social, Pontíficia Universidade Católica de São Paulo, 2009, pp. 333-334.

${ }^{42}$ Vicente SALLES: Memorial da Cabanagem, Belém, CEJUP, 1992, (Coleção Amazoniana), p. 40.
} 
diferente de lo presentado por Salles (1992). En ellos los vapores transportaban, además de grandes cuantidades, una diversidad de productos.

Según Souza Junior (2009), durante la vigencia de la Compañía de Comercio las explotaciones do Pará em nada deixavam a desejar às do Maranhão, e afirma que entre 1760 e 1771 as explotaciones de algodón y arroz tuvieron un aumento en ambas las capitanías, y que "nos 22 anos de vigência da Compañía de Comercio, as exportações da capitania do Pará somaram 2.192:979\$484 réis, tendo a lista de gêneros exportados crescido substancialmente". ${ }^{43}$

Según Salles (1992), tras la independencia de los Estados Unidos, a los fines del siglo XVIII, Inglaterra partió en busca de nuevos proveedores de algodón para suplir la industria textil. En ese período, Maranhão y Pernambuco habían pasado a ser responsables por proveer grande parte del algodón importado por Inglaterra. ${ }^{44} \mathrm{La}$ demanda crecente de explotación de ese producto habría impulsado el proceso de ocupación y poblamiento de tierras de Maranhão, perceptiblemente a partir de la instalación de extensas plantaciones en las cuencas de Mearim, Itapecuru y Pindaré. Según Salles,

[...] a exportação do algodão, insignificante em 1771, em pouco tempo tornou-se apreciável, competindo com Pernambuco. A lavoura algodoeira expandiu-se no Maranhão juntamente com a de gêneros alimentícios exportáveis, como o arroz, possibilitando o florescimento econômico da capitania, que passou a ostentar também grande vitalidade cultural. ${ }^{45}$

Souza Junior (2009) también apunta la guerra de independencias de las colonias inglesas en la América, como el factor "responsável pela dinamização da economia das capitanias do Norte", pues la disminución de la producción agrícola desarrollada en la América del Norte "abriu expressivos mercados para as exportações brasileiras de algodão, arroz, tabaco e açúcar", entretanto, reafirma que esa dinamización e incentivo en las explotaciones no ocurrieron solamente en la capitanía de Maranhão. Por consiguiente, mismo después de extinta la Compañía de Comercio, la explotación de esos géneros tanto

\footnotetext{
${ }^{43}$ José Alves de SOUZA JUNIOR: Tramas do cotidiano..., pp. 340-341.

${ }^{44}$ Vicente SALLES: Memorial da Cabanagem..., p.39.

${ }^{45}$ Ibid, p.40.
} 
por Pará como por Maranhão fueron bastante significativas, estando detrás solamente de Rio de Janeiro, Bahia y Pernambuco. ${ }^{46}$

Según Antonia Mota (2007), con la creación de la Compañía General de Comercio y los estímulos ofrecidos por ese órgano en el período pombalino, en la provincia de Maranhão muchos funcionarios regios constituyeron fortuna a partir de la producción de arroz y algodón para explotación, pasando así a integrar "a elite senhorial da região". ${ }^{47}$ Entonces, ¿lo que habría motivado las diferentes caracterizaciones de la región de Turiaçu?

Como ya mencionado, originalmente el límite de la frontera entre Pará y o Maranhão era el rio Gurupi y la región de Turiaçu estaba insertada en el territorio maranhense. A partir de 1772, el marco de la frontera fue redefinido para el rio Turiaçu, considerando su localización y las condiciones ambientales favorables, como la fertilidad de solo, propiciá a la producción agrícola, pecuaria y extractivita; la facilidad de acceso a las tierras, a los ríos, al mar y a los medios de transporte, que estimula el desagüe de la producción y la comunicación con otras localidades y regiones, entre otras características de la región de frontera del rio Turiaçu.

En su memoria de viajen, el clérigo Romualdo de Seixas (1814) relató que al llegar a Turiaçu, el escriba ${ }^{48}$ de la feligresía ofreció su armasen de arroz para que él y su amigo pasará la noche. Este relato en los permite percibir que había comerciantes establecidos hace algún tiempo en la región, como posiblemente era el caso del dicho escriba, que podría ser también dueño de tierras cultivadas en la región, un comprador y explotador de arroz en esa zona de frontera o, simplemente, el dueño del espacio en que se almacenaba el arroz producido en esas paradas. ${ }^{49}$

En este aspecto, Baena (2004) confirma que la producción agrícola volcada al comercio de la región de Turiaçu era bastante expresiva. ${ }^{50} \mathrm{El}$ autor llegó a afirmar, incluso, que entre el final del siglo XVIII y el inicio del siglo XIX la economía de

\footnotetext{
${ }^{46}$ José Alves SOUZA JUNIOR: Tramas do cotidiano..., pp. 341-342.

${ }^{47}$ Antonia da Silva MOTA: A dinámica colonial portuguesa e as redes de poder local na capitania do Maranhão..., p.11.

${ }^{48}$ Seixas não informa o nome do escrivão. Apenas se refere "senhor escrivão".

${ }^{49}$ Romualdo de SEIXAS: "Memória dos diferentes sucessos de uma viagem: do Pará até ao Rio de Janeiro", Jornal de Coimbra, 1814, https://bdigital.sib.uc.pt/bg4/UCBG-RP-2-1-1812-1_16/UCBG-RP-2-1-18121_16_item1/index.html, p. 324.

${ }^{50}$ Antônio Ladislau Monteiro BAENA: Ensaio Corográfico sobre a província do Pará..., p.256.
} 
Maranhão había sido impulsada en virtud de las remesas de arroz y algodón proveniente de la región de Turiaçu. ${ }^{51}$

Por mucho tiempo los diferentes géneros fueron utilizados como moneda en las capitanías de Grão-Pará e Maranhão. En ese contexto, cada producto poseía un valor en el proceso de cambio, siendo que en Pará el cacao y el tabaco eran los géneros más valerosos, mientras que en Maranhão la moneda de destaque era el algodón. En Pará la variedad de productos utilizados como moneda era mayor de lo que en la capitanía vecina, lo que "sugere que existia uma certa diferenciação na forma da moeda natural, motivada pelas condições geográficas e produtivas de cada capitania", 52

Con el apoyo del Directorio, el comercio de los sertões fue estimulado y las localidades situadas en las proximidades de los ríos o del mar deberían "dedicar-se às feitorias de salgas de peixe destinadas ao comércio; naquelas onde havia disponibilidade de cacau, salsa ou cravo, os índios deveriam ser conduzidos para esse negócio".53

Según Marques (1864), en el final del siglo XVIII, la orilla maranhense del rio Turiaçu que correspondía al termino de Guimarães era un territorio fértil y de grandes potencialidades, que prometía "um futuro cheio de prosperidade e de riqueza", visto que era regado por muchos orificios y ríos, y a las proximidades del mar. Lugar en que alimentos podían ser adquiridos en las matas, en virtud de la abundante caza, y el mar y los ríos llenos de pez, "tanto que é este gênero exportado para a capital, onde se vende por bom preço". En la región del litoral existían “curraes para pescaria, pertencentes aos lavradores abastados do termo". 54

La producción en esa zona de frontera - sea del lado paraense o maranhense del rio Turiaçu - era bastante diversificada, pues, además de los géneros agrícolas direccionados a la subsistencia y al comercio interno y externo, los productos naturales de colecta y el pescado también fueron envueltos en el comercio. Ejemplo de eso es el hecho de que en las islas adyacentes a la villa de Guimarães, en la extensión de la Baía de Turiaçu, en otros

\footnotetext{
51 Ibid.

52 Allan José da Silva LIMA: Do "dinheiro da terra" ao "bom dinheiro". Moeda natural e moeda metálica na Amazônia colonial (1706-1750), Dissertação de Mestrado em História Social da Amazônia, Universidade Federal do Pará, 2006, p.35.

${ }^{53}$ Patrícia Melo SAMPAIO: Espelhos Partidos..., p.139.

54 Augusto César MARQUES: Apontamentos para o dicionário histórico, geográfico, topográfico e estatístico da Província do Maranhão..., pp.161-162.
} 
tiempos, existieron huevos d'átim en abundancia, que eran explotados hasta para São Luís ${ }^{55}$. En el lado Maranhense de Turiaçu, además de los pescados y productos colectados en las matas, se cultiva arroz, algodón, yuca, caña de azúcar, maíz y entre otros. ${ }^{56}$

Por lo expuesto, se puede percibir que en la región había una dinámica económica envolviendo agricultura y extractivismo. Sin embargo, esa dinámica había sido impulsada por empeño de los productores de la capitanía de Maranhão. Explicado lo porqué de la reserva de Cesar Marques en 1864. Según Antonio Baena (1838), responsable por la redacción del Compendio de Fortificaciones de Campaña ${ }^{57}$ de Pará en el gobernó de D. Marcos de Noronha e Brito - el Conde de los Arcos -, este gobernador afirmó que Turiaçu fue el lugar "por onde se entrou para esta parte do Pará o amor pela agricultura”, y eso gracias a las investidas "dos habitadores dos confins occidentaes do Maranhão", que disponían de pocas tierras libres en el lado maranhense y transpusieron sus investidas para la otra orilla de Turiaçu, donde invistieron en la producción agraria. Según el Conde de los Arcos, esta acción de los productores maranhenses habría sido seguida por los paraenses, que pasaron a desenvolver actividades agrarias en la región. ${ }^{58}$ Con el aumento de la demanda de algodón y arroz para el mercado externo, bien como la implementación de laboras en las cuencas de Mearim, Itapecurú y Pindaré, se intensificó la producción de esos géneros, lo que posiblemente aumentó el interese en implantar haciendas tanto en Turiaçu, para agricultura, como para creación de ganado, además de ya ser un espacio de explotación extractivita y creación de pez en corales. Al final del siglo XVIII e inicio del siglo XIX hubo un aumento significativo de las solicitaciones y confirmaciones de tierras por medio de las cartas de fechas de sesmarias en aquella región.

En 1837, cuando el pueblo de Turiaçu ya había sido elevado a la condición de villa, la región contaba con "algumas casas de negocio de seccos e molhados, engenhos d'ássucar movidos por água e animaes, uma fabrica de cal etc.", además de ser cultivado algodón, yuca, arroz, maíz, frijol y otros. En ese período también había algunas

\footnotetext{
55 Ibid, pp.161-162.

${ }^{56}$ Ibid, pp.161-162.

${ }^{57}$ O Compêndio deveria ser consolidado a partir das obras de Gaudy, Bailler e Lecointe.

58 Augusto César MARQUES: Apontamentos para o dicionário histórico, geográfico, topográfico e estatístico da Província do Maranhão..., pp.161-162.
} 
haciendas de ganado en la región, en las cuales "se contam 800 cabeças, que produzem talvez 200 bizerros por anno" 59 (MARQUES, 1864, 161-162).

En este sentido, la economía de Maranhão hubiera sido impulsada por la explotación de algodón y arroz, por su vez, en la primera década del siglo XIX, las tierras paraenses de Turiaçu obtuvieron resultados significativos en la producción y explotación de esos productos. Sin embargo, desde la última década del siglo XVIII, la cuantidad y la variedad de los productos procedentes de las plantaciones de los pueblos indígenas de esa frontera eran expresivas, teniendo la harina de yuca como el principal producto.

La producción agrícola de la región de Turiaçu no era totalmente direccionada hacia la explotación. Una parte de la producción era destinada al mercado interno, visando asegurar la subsistencia de las poblaciones que ahí habitaban, así como la manutención y el pago de los servicios Regios. En aquel contexto, los pueblos indígenas asumieron importante rol en el cultivo de productos volcados al consumo y a la comercialización en la capitanía de Pará. Todavía, aunque las laboras y las plantaciones de los pueblos indígenas generalmente obtuviesen una buena productividad, en la región de Turiaçu, el volumen producido era muy variable.

\section{Conclusión}

En este trabajo presenté algunos intereses presentes en el proceso de ocupación de la frontera entre Pará y Maranhão en los fines del siglo XVIII e inicio del siglo XIX, algunas dificultades y conflictos desencadenados en la región al desarrollar de ese proceso. En este contexto, las aperturas de carreteras de comunicación entre las dos capitanías tuvieron importante rol.

Con el objetivo de alejar esos no quistos el gobierno de Pará buscó ocupar las orillas de las carreteras, haciendo la ocupación de parte de las mismas por medio de un acto de violencia y total falta de respeto a los indígenas que en la ocasión - 1797 - fueron aprehendidos y dislocados de su población hasta la orilla de la nueva carretera en nombre de proceso de ocupación de la región. Sin embargo, esa fue una forma agresiva de ocupación aplicada a la población de Mutuoca y totalmente diferente de la propuesta de ocupación a partir de la instalación de haciendas implementadas en la región por medio

\footnotetext{
${ }^{59}$ Ibid, pp.161-162.
} 
de donación de carta y fecha de sesmarias. Fueron propósitos y procesos distintos de ocupación aplicados sobre la misma región que generó descontentamientos y conflictos, además de no haber sido eficaz en su intento.

La frontera de Turiaçu poseía particularidades que no fueron llevadas en consideración. Esa era una región ocupada desde el inicio del siglo XVIII por sujetos cuya pluralidad étnica y social era importante y que no impidió a estos de compartieren de una rede de solidaridad y sociabilidad que jamás se detuvo a la división administrativa para existir. Eso se daba visto que este era un espacio alejado del control de los gobiernos, tanto de Pará como de Maranhão, permitiendo que Turiaçu se tornara un grande atractivo para muchos negros huidos, indígenas, desertores y hombres blancos pobres, que establecieron a la orilla del proceso de colonización.

Y, en ese sentido es importante observar la opción por la construcción del conocimiento histórico desarrollada en este texto, que busca narrar los sucesos pautados en intereses distintos, cuyo espacio social es comprendido a partir de la propia concepción que el espacio de la frontera asume para los diferentes sujetos, fueron ellos los que representaron la región en los documentos o en la historiografía. Analizar la región y los sujetos privilegiando la visión del gobierno podría levarme a reproducir una discusión pautada en principios de una "elite" portuguesa del final del siglo XVIII e inicio del siglo XIX, y de esa forma producir una historia de grupos dominantes, una vez que, los propios discursos sobre los sujetos de Turiaçu atribuía a estos una carga peyorativa y su depreciación frente a los principios y valores que deberían ser implementados.

Finalmente, lo que este estudio buscó revelar es que en los años finales del siglo XVIII e inicio del siglo XIX el gobierno portugués tenía bajo su dominio en la región de Turiaçu una populación fluida e instable en una frontera que refleja estas mismas características. Y, debe ser analizada a partir de la existencia, actuación e intereses de sujetos múltiplos que se hicieron presentes durante el proceso de ocupación de la frontera. Todavía, las características ni siempre fueron comprendidas con esas especificidades, y atribuyeron al Turiaçu, del final del siglo XVIII y principios del XIX, caracterizaciones polarizadas que reflejaban, mucho más que representaciones sobre la región, más también las políticas y proyectos idealizados para esa frontera. 


\title{
Testigos y protagonistas de la política exterior española: una reflexión metodológica sobre el uso de las fuentes orales y el acceso a las fuentes documentales en historia del tiempo presente*
}

\author{
Witnesses and Leading Actors of Spanish Foreign Policy: A \\ Methodological Reflection on the Use of Oral and the Access to \\ Documentary Sources in Present-day History
}

José Carlos Aránguez

Universidad Complutense de Madrid

Ferran Martínez Lliso

Universidad Complutense de Madrid

\section{Resumen}

El presente trabajo gira en torno a dos grandes ejes de estudio estrechamente relacionados: por un lado, evidenciar la importancia de la utilización de las fuentes orales como recurso metodológico en la investigación histórica a través de los resultados obtenidos por el Grupo de investigación de Historia de las Relaciones Internacionales (GHistRI); y, por el otro, exponer a la comunidad científica de historiadores la problemática actual para acceder a la consulta de la documentación histórica tanto del Ministerio de Asuntos Exteriores como de Defensa, pues ambos contienen información de primer orden para el conocimiento de nuestro pasado más reciente.

\footnotetext{
* Trabajo inscrito en la labor del Grupo de Historia de las Relaciones Internacionales (GHistRI) en el marco del proyecto financiado por el Ministerio de Economía y Competitividad "La política exterior de España: de la Transición a la consolidación democrática (1986-2001)", con ref. HAR2014-53618-P. Contratados predoctorales FPU (Ministerio de Educación, Cultura y Deporte) y FPI (Ministerio de Economía, Industria y Competitividad) en el Departamento de Historia Contemporánea (UCM), jcaranguez@ucm.es y ferran01@ucm.es .
} 


\title{
Palabras clave
}

historia oral, GHistRI, política exterior, archivos, documentación histórica.

\begin{abstract}
This article revolves around two great axes of closely linked studies: on one hand, demonstrate the importance of using oral sources as a methodological resource in historical research through the results obtained by The Research Group on the History of International Relations (Grupo de investigación de Historia de las Relaciones Internacionales, GHistRI); and, on the other hand, present the current problems to the scientific community of historians in order to be able to access to the historical documentation belonging to the Ministry of Foreign Affairs (Ministerio de Asuntos Exteriores) and to the Ministry of Defence (Ministerio de Defensa), both containing top-rated information for a better knowledge of our most recent past.
\end{abstract}

\section{Keywords}

oral history, GHistRI, foreign policy, archives, historical documentation.

\section{Las fuentes orales como instrumento de investigación: ventajas y desventajas}

La historia oral, "la más nueva y la más antigua forma de hacer historia", se ha convertido en las últimas décadas en una de las aportaciones más importantes para la investigación y la docencia de la Historia. ${ }^{1}$

En efecto, la sistematización de la recuperación de la tradición oral ha abierto nuevas perspectivas historiográficas que han supuesto un decidido impulso para la investigación histórica. De hecho, la utilización de las fuentes orales como instrumento metodológico en la historia del tiempo presente ha permitido, en muchos casos, cambiar el enfoque de las investigaciones realizadas en diversas áreas así como subvertir ciertas jerarquías de la historia tradicional: la posibilidad de poder estudiar algunos de los

\footnotetext{
${ }^{1}$ Paul THOMPSON: The voice of the past, Oxford, Oxford University Press, 1978; reimpr. Valencia, Edicions Alfons el Magnànim, 1998.
} 
aspectos más intangibles como son las pautas de comportamiento dominantes en cada período histórico, la interacción entre el poder político y la sociedad civil, la historia de los grupos sociales subalternos, la reconstrucción de la agenda oculta -off the record- de las principales políticas públicas, las redes informales del poder o todos aquellos aspectos de la historia de vida -experiencias, actitudes, creencias, sistemas de valores, etc.- de personajes que, en condiciones normales, hubieran estado condenados a no dejar ninguna traza en la historia son ejemplos de las múltiples capacidades de la historia oral como recurso investigativo.

En todo caso, debemos asumir que este recurso debe ser utilizado como fuente complementaria para reafirmar, contrastar o bien refutar las hipótesis enunciadas a partir de las fuentes escritas. Y es que, pese a sus potencialidades, la utilización de las fuentes orales implica ciertos riesgos que pueden llegar a afectar a la fiabilidad y validez de la investigación. En este sentido, cabe tener en cuenta que el testimonio oral no es sino una representación personal de un acontecimiento pasado, en el que la memoria realiza un proceso de selección sobre los recuerdos almacenados, pudiendo llegar a realizar omisiones y/o distorsiones voluntarias e involuntarias: el deterioro físico, la nostalgia, la propia ideología, la simplificación del discurso, la autojustificación del informante sobre los hechos que describe, la incidencia de la percepción colectiva y retrospectiva del pasado... son una pequeña muestra de los factores que pueden contribuir a la subjetividad del testimonio así como a determinar su veracidad. ${ }^{2}$

De esta forma, y para evitar posibles problemas de fiabilidad, el testimonio oral debe ser analizado como un todo y tratando de que las experiencias relatadas por el informante se incorporen como parte de una experiencia social y colectiva relevante para la interpretación de un hecho o un período pasado. Esto es, el investigador, una vez haya cotejado el relato oral con la documentación y la bibliografía pertinentes, debe reinterpretarlo a la luz de los procesos que se han producido con posterioridad y tratar de

\footnotetext{
${ }^{2}$ Acerca de los problemas relacionados con la utilización de las fuentes orales en la investigación histórica, véase, por ejemplo: Pilar FOLGUERA: Cómo se hace Historia Oral, Madrid, Eudema, 1994, pp. 14-21; ÍD.: "Historia oral y elites políticas: una reflexión metodológica", en Juan Carlos PEREIRA CASTAÑARES y Juan Manuel FERNÁNDEZ FERNÁNDEZ-CUESTA (dirs.): La política exterior y la dimensión internacional de la Transición española”, Pamplona, Thomson Reuters/Aranzadi, 2015, pp. 6585 .
} 
establecer cómo estas interpretaciones de los hechos cambian a través del tiempo, por qué se producen y qué factores históricos han incidido en estos nuevos análisis. ${ }^{3}$

$\mathrm{Y}$ es que cabe recordar que el propósito de la historia oral no es encontrar exactitudes en cuanto a acontecimientos, fechas y otros datos, sino que trata de lograr aproximaciones cualitativas de los procesos pretéritos y de fenómenos colectivos e individuales. De hecho, lo que constituye el verdadero atractivo de la aplicación metodológica de las fuentes orales es que estas revelan el significado de lo que pasó, puesto que, como señalara Alessandro Portelli, la memoria no es un depósito pasivo de datos sino un proceso activo de creación de significados. ${ }^{4}$ Además, no hay que olvidar el hecho de que todas las fuentes poseen una fuerte dosis de subjetividad, por lo que sería un error considerar la subjetividad como algo exclusivo de la historia oral. Al fin y al cabo, todas las fuentes son fruto de la intervención humana en un determinado contexto o realidad y, consiguientemente, todas ellas pueden estar sometidas a procesos de distorsión de la realidad.

En definitiva, las fuentes orales son un recurso con un determinado número de inconvenientes que obligan a revisar y a complementar el testimonio obtenido pero que no impiden destacar el valor potencial de las investigaciones de historia oral en relación con la historia del tiempo presente.

\section{La aplicación práctica de las fuentes orales por parte del GHistRI: análisis de la} política exterior y la dimensión internacional de la transición y la consolidación democrática de España (1976-2001)

El Grupo de Historia de las Relaciones Internacionales (GHistRI) es un grupo de investigación que se constituyó en 2006 en la Universidad Complutense de Madrid bajo la dirección del profesor Juan Carlos Pereira Castañares y que está formado por numerosos investigadores multidisciplinares especializados en la historia de las relaciones internacionales contemporáneas y en la política exterior de España.

El grupo surgió como una respuesta ante lo que se consideraba como un aspecto relegado durante mucho tiempo por los científicos sociales e historiadores del tiempo

\footnotetext{
${ }^{3}$ Pilar FOLGUERA: "Historia oral y elites...", pp. 75-76.

${ }^{4}$ Alessandro PORTELLI: "What makes oral history different", en Robert PERKS y Alistair THOMSON: The oral history reader, London and New York, Routledge, 1991, pp. 63-74.
} 
presente: el factor internacional de la Transición española. El proceso de transición española de un sistema autoritario a otro democrático fue abordado desde un primer momento por la historiografía española. Sin embargo, se desarrolló un importante desequilibrio entre los estudios que abordaron la vertiente interior de la Transición y aquellos que se interesaron por los cambios que se produjeron como consecuencia de la acción exterior española, así como por la manera en la que el contexto internacional, crisis del petróleo, ola democratizadora de finales del siglo XX, etc.- influyó en dicho proceso. De esta forma, y con el objeto de analizar el factor internacional de la Transición en su doble vertiente, hacia el interior y el exterior, se inició una línea de trabajo con el empleo de un recurso que, nos parecía, había sido escasamente utilizado en la investigación de nuestra historia del tiempo presente: las fuentes orales.

De este modo, con una metodología precisa, fruto de la experiencia investigadora con estas fuentes de algunos de los miembros del equipo y tomando como referencia la realización de proyectos de historia oral cuyo objeto de estudio había sido el análisis de las trayectorias de elites políticas y económicas, se decidió comenzar a entrevistar no solo a quienes habían desempañado un papel destacado en el proceso de toma de decisión y ejecución de la política exterior de aquellos años, sino también a algunos de los testigos directos de los acontecimientos que marcaron la transformación de esa política. Con este objetivo, hemos contado con diplomáticos, militares, periodistas, altos funcionarios, representantes empresariales y políticos de diferentes partidos e ideologías que nos han permitido confirmar hipótesis y revisar afirmaciones que se presentaban como inalterables. Todos estos testimonios se encuentran archivados en el Archivo Oral de la Dimensión Internacional de la Transición Española, ubicado en la actualidad en la Universidad Complutense de Madrid, si bien se están realizando las gestiones pertinentes para trasladar estos fondos al Archivo Histórico Nacional (AHN). Las entrevistas realizadas hasta el momento en que se escriben estas líneas ascienden a 37 y pueden ser clasificadas del siguiente modo:

-Políticos (14): Fernando Álvarez de Miranda, Rodolfo Martín Villa, Alfonso Osorio, Ramón Tamames, Marcelino Oreja, Santiago Carrillo, Ignacio Camuñas, José Manuel Otero Novas, Elena Flores, Miguel Ángel Martínez Martínez, Manuel Marín, Alfonso Guerra, Carlos Westendorp y Ramón Jáuregui. Se ha tratado de contar con personajes de una representación ideológica lo más diversa posible, entrevistando desde 
vicepresidentes de Gobierno hasta ministros de Asuntos Exteriores y de la Presidencia y líderes de partidos como UCD, PSOE o el PCE.

-Diplomáticos (13): Raimundo Bassols, Jorge Fuentes, Nuño Aguirre de Cárcer, Eugenio Bregolat, Juan Durán-Loriga, Javier Rupérez, Alonso Álvarez de Toledo, Jaime de Ojeda, Antonio de Oyarzábal, Julio Núñez Montesinos, Ramón de Miguel, Daniel Chamorro y Francisco Villar Ortiz de Urbina. Algunos ocuparon papeles claves en las negociaciones con la Comunidad Europea, Estados Unidos o la OTAN; otros ocuparon embajadas claves como las de París, Washington, Berlín, las Naciones Unidas, etc.

-Altos funcionarios y_personal vinculado a Presidencia (4)): Ángel Viñas, economista e historiador, asesor del ministro de Asuntos Exteriores Fernando Morán, diplomático en la Unión Europea y en la ONU; Aurelio Delgado, secretario de la Presidencia en los Gobiernos de Adolfo Suárez, con el que, además, mantenía vínculos familiares; Josep María Pons Irazazábal, diplomático y asesor en la Secretaría de Estado para las Relaciones con las Comunidades Europeas y del Departamento Internacional del Gabinete de la Presidencia del Gobierno durante la etapa de Felipe González; y Juan Antonio Yáñez-Barnuevo, diplomático de carrera que ha ostentado, entre otros cargos, el de director del Departamento Internacional del Gabinete de la Presidencia del Gobierno y consejero diplomático del presidente González.

-Periodistas españoles ()ㅡ: Fernando Ónega, Juan Luis Cebrián y Ramón Vilaró. Han sido destacados profesionales vinculados a dos periódicos muy importantes del período, El País y La Vanguardia, así como un periodista vinculado a la Presidencia del Gobierno en la etapa del presidente Adolfo Suárez.

- Corresponsales extranjeros (1): El alemán Walter Haubrich, representante en España del prestigioso Frankfurter Allgemeine Zeitung, durante más de cuarenta años.

-Empresarios con vinculaciones internacionales (1): Antonio Garrigues Walter, jurista y hombre de negocios vinculado especialmente con Estados Unidos.

-Militares (1): Luis Alejandre Sintes, quien ha participado en diferentes misiones extranjeras de la ONU (Nicaragua -ONUCA- y El Salvador -ONUSAL-) y ha formado parte del Equipo Negociador del Proceso de Paz en Guatemala. 
Testigos y protagonistas de la política exterior española: una reflexión metodológica sobre el uso de las fuentes orales y el acceso a las fuentes documentales en historia del tiempo presente

Todo este trabajo se ha podido realizar gracias a los tres grandes proyectos competitivos concedidos en los últimos años por el Ministerio de Ciencia y Tecnología y el Ministerio de Ciencia e Innovación, que han contribuido decisivamente en la conformación y consolidación de nuestras líneas de investigación, así como a demostrar el potencial que implica la utilización de fuentes orales en la investigación de la historia del tiempo presente. ${ }^{5}$

Los dos primeros proyectos -"La transición y la consolidación democrática en España y la formulación del modelo de política exterior democrática" y "Dimensión Internacional de la Transición Española (1973-1982): protagonistas y memoria histórica"- se centraron en el análisis del factor internacional durante la Transición y sus conclusiones han sido recogidas recientemente en una publicación en la que han participado veinte especialistas en historia de las relaciones internacionales: La política exterior y la dimensión internacional de la Transición española: testigos y protagonistas $(1976-1986)^{6}$. El último proyecto concedido -"La política exterior de España: de la transición a la consolidación democráticas (1986-2001)"-, todavía está en fase de desarrollo pero, a través de la aplicación de la metodología que tantos frutos ha dado en anteriores proyectos, pretende estudiar la consolidación democrática de nuestra política exterior, abarcando tanto la última etapa socialista en el Gobierno como la primera del Partido Popular, hasta el momento en el que el presidente José María Aznar inició el llamado "giro de la política exterior".

Por consiguiente, consideramos que, con el objeto de crear un espacio de trabajo y de diálogo sobre las fuentes orales y su metodología, puede ser interesante exponer las

\footnotetext{
${ }^{5}$ En septiembre de 2002 la Subdirección General de Proyectos de Investigación del Ministerio de Ciencia y Tecnología aprobó el proyecto de investigación I+D "La transición y la consolidación democrática en España y la formulación del modelo de política exterior democrática" (Referencia BHA2002-01909), con una duración de tres años. Posteriormente, en julio de 2009, el Ministerio de Ciencia e Innovación aprobó el proyecto de investigación titulado "Dimensión Internacional de la Transición Española (1973-1982): protagonistas y memoria histórica” (Referencia HAR2009-13630), también con una duración de tres años. Finalmente, en 2015 el Ministerio de Economía y Competitividad aprobó el proyecto titulado "La política exterior de España: de la transición a la consolidación democráticas (1986-2001)" (Referencia HAR201453618-P), que ha recibido la calificación de A. Este proyecto, con una duración de tres años, se concede dentro de la categoría de proyectos I+D del Programa Estatal de Fomento de la Investigación Científica y Técnica de Excelencia, Subprograma Estatal de Generación del Conocimiento. Para conocer la totalidad de proyectos concedidos al GHistRI véase: https://www.ucm.es/ghistri/proyectos-de-investigacion [consulta 19 marzo, 2017].

${ }^{6}$ Juan Carlos PEREIRA CASTAÑARES y Juan Manuel FERNÁNDEZ FERNÁNDEZ-CUESTA (dirs.): La política exterior y la dimensión internacional de la Transición española: testigos y protagonistas (19761986), Pamplona, Thomson Reuters/Aranzadi, 2015.
} 
dificultades concretas con las que se ha ido encontrando el GHistRI durante su práctica investigadora, así como las soluciones adoptadas ante las mismas.

En primer lugar, y tal y como hemos señalado con anterioridad, las elites políticas tienden a transformar la realidad pretérita con diferentes fines: realzar su participación en un determinado proceso, llegando incluso a atribuirse logros mayores de los que realmente les corresponden; justificar su actuación para evitar posibles responsabilidades políticas; adecuar sus opiniones actuales a su actuación durante el período sobre el que se le pregunta; desvalorizar o simplificar el trabajo de sus oponentes políticos, etc. Para contrarrestar dichos inconvenientes, además de contrastar la información obtenida con otras fuentes documentales, hemos tratado de entrevistar a personajes de un amplio espectro ideológico.

Del mismo modo, hemos intentado mejorar el papel del entrevistador como elemento clave a la hora de minimizar la tergiversación retrospectiva del entrevistado, pues consideramos que su función es determinante para el resultado final de la entrevista: la forma de dirigirse a su interlocutor, la manera de plantear sus preguntas, el tono de voz, el ritmo de sus intervenciones, escuchar con respeto, evitar las interrupciones... reflejan bien la experiencia del investigador en este tipo de proyectos. ${ }^{7}$ Así, la experiencia práctica nos ha llevado a ir reduciendo el número de entrevistadores para que la conversación sea más directa con el informante. De la misma manera, hemos tratado de comenzar las entrevistas con preguntas más abiertas, que permitan ambientar el objeto de la entrevista, relajar al entrevistado, para poder, a continuación, realizar preguntas algo más directas y específicas, que contribuyan a responder de forma más concreta a los objetivos propuestos en la investigación.

A su vez, hemos observado que el hecho de minimizar la presencia de la grabadora es muy importante, pues ayuda a mantener una conversación más distendida con el entrevistado. Es por ello por lo que hemos decido prescindir de la grabación en vídeo durante la entrevista ya que, además de que es preciso tener ciertos conocimientos técnicos -iluminación, enfoque, edición, etc.- que no dominamos, consideramos que esta última no contribuye positivamente en la obtención de un testimonio lo más aproximado posible a la realidad.

\footnotetext{
${ }^{7}$ Pilar FOLGUERA: “Historia oral y elites...”, p. 80.
} 
Por su parte, la experiencia en este campo metodológico nos ha conducido a ir disminuyendo el número de entrevistas a personajes de primera fila política, muy habituados a enfrentarse a las cámaras y a las preguntas de los periodistas, lo que ha motivado que con el tiempo hayan acabado por construir un relato político, una storytelling, que repiten constantemente. Frente a ello, hemos ido aumentando de forma progresiva el número de entrevistas a personajes de "segunda línea", igualmente decisivos en los procesos de elaboración, toma de decisión y ejecución de la política exterior española pero menos propensos a articular un discurso ya aprehendido.

Por último, hemos ido descubriendo otros problemas que son muy difíciles de solventar, a saber: tiempo limitado para realizar la entrevista -pues hay que tener en cuenta que los personajes entrevistados suelen tener una disponibilidad reducida, incluso no estando ya en activo-; estado de ánimo del entrevistado y del entrevistador; la voluntad del informante para transmitir la "verdad" de los hechos; eliminación de algún fragmento de la transcripción para contar con la autorización del informante, etc. De todos modos, y si bien es cierto que estos condicionantes son muy difíciles de minimizar, su detección sí nos ha permitido evitar errores de interpretación en el momento de analizar los testimonios y nos ha facilitado la comprensión del relato oral en su conjunto.

Por consiguiente, desde el GHistRI asumimos la subjetividad de la fuente y los inconvenientes que de su utilización se derivan, ahondando así en las potencialidades de la misma para poder aportar nuevas perspectivas todavía poco abordadas en el estudio de la historia del tiempo presente. En este sentido, la metodología aplicada al objeto de estudio descrito nos ha permitido alcanzar grandes resultados que se recogen, de manera global, en la obra anteriormente mencionada y, de forma concreta, en muchos de nuestros trabajos de investigación ya publicados. ${ }^{8}$ Pese a ello, creemos que es conveniente esbozar aquí algunas de las conclusiones más relevantes obtenidas hasta ahora. ${ }^{9}$

1. Definición del marco temporal de la dimensión internacional: La delimitación cronológica de la Transición ha sido una de las cuestiones que tradicionalmente más

\footnotetext{
8 Una somera descripción de algunas de las publicaciones presentadas puede verse en: https://www.ucm.es/ghistri/publicaciones [consulta 20 marzo, 2017].

${ }^{9}$ Para conocer con mayor profundidad las conclusiones generales alcanzadas por el grupo véase: Juan Carlos PEREIRA CASTAÑARES: "La dimensión internacional de la transición española: el proyecto, el grupo de investigación, los resultados", en Juan Carlos PEREIRA CASTAÑARES y Juan Manuel FERNÁNDEZ FERNÁNDEZ-CUESTA (dirs.): La política exterior y la dimensión internacional de la Transición española”, Pamplona, Thomson Reuters/Aranzadi, 2015, pp. 41-62.
} 
repercusión ha tenido en la historiografía de la historia del tiempo presente en España. Aunque se ha generalizado la opinión de que los días 20/22 de noviembre de 1975, coincidiendo con la muerte del dictador Francisco Franco, suponen las fechas de inicio del proceso de cambio de un sistema autoritario a otro democrático, la definición de las fechas que marcarían el final de la Transición ha provocado mayores diferencias: mientras que unos apuestan por el 15 de junio de 1977, día de la celebración de las primeras elecciones democráticas en España tras la última convocatoria en febrero de 1936, otros concluyen dicho proceso el 6 de diciembre de 1978, una vez ratificada por referéndum la Constitución española; e incluso algunos historiadores y científicos sociales lo alargan hasta finales de octubre de 1982, coincidiendo con la victoria -la primera desde la Segunda República- del PSOE. Sin embargo, desde muy pronto los especialistas en historia de las relaciones internacionales advirtieron que "la periodización empleada para analizar la evolución del cambio político interior no coincide -no nos sirve- a la hora de explicar las transformaciones en la política exterior". ${ }^{10}$

Es por ello que uno de los objetivos del proyecto era el de ajustar las fechas a la propuesta teórico-metodológica planteada, llegándose a la conclusión de que la dimensión internacional de la Transición se desarrolló entre los años 1976 y 1986. La firma del Tratado de Amistad y Cooperación entre España y Estados Unidos, adecuando las relaciones bilaterales a las nuevas condiciones socio-políticas de nuestro país; el viaje de los reyes al extranjero, primero a la República Dominicana -siendo la primera visita de un jefe de Estado español a Latinoamérica- y después a Estados Unidos -donde el rey Juan Carlos ofreció un discurso ante el Congreso americano que encaminó el apoyo internacional hacia el proyecto político que acababa de comenzar-; así como la dimisión de Carlos Arias Navarro y el consiguiente nombramiento de un, hasta entonces, desconocido Adolfo Suárez como presidente del Gobierno determinaron, a nuestro modo de ver, el inicio de la Transición exterior. Por su parte, y en lo referente a la fecha que pone punto final a la conversión de la política exterior española, hemos observado que, pese a la vinculación -linkage- entre la política interior y la política exterior, el proceso de cambio de esta última fue mucho más lento que el de la primera, lo que nos ha llevado a afirmar que el año en el que concluiría la Transición exterior sería el de 1986. El ansiado

\footnotetext{
${ }^{10}$ Juan Carlos PEREIRA y Pedro Antonio MARTÍNEZ LILLO: "Política Exterior, 1976-1997”, en Javier PAREDES (coord.): Historia contemporánea de España, siglo XX, Barcelona, Ariel, 1998, p. 1001.
} 
ingreso en la Comunidad Económica Europea; la consolidación de la política de seguridad y defensa tras la victoria del "sí" en el referéndum sobre la permanencia española en la Alianza Atlántica; además de la consecución de la universalización de nuestras relaciones internacionales tras el restablecimiento de estas con Israel son motivos más que suficientes para poder alegar que 1986, tal y como nos han confirmado los protagonistas entrevistados, fue el año de cambio de una política exterior, todavía en transición, a otra consolidada.

2. El factor internacional: Una de las principales hipótesis formuladas aludía a que el factor internacional de la Transición estaba formado por una doble dimensión que, aunque interrelacionadas entre sí, poseían características propias: una primera dimensión sería el factor internacional hacia el interior, es decir, cómo influyó el sistema internacional, sus actores y su contexto en la Transición española; y una segunda sería el factor hacia el exterior, esto es, cómo, del mismo modo que hubo una transición política, económica o social de un régimen autoritario a un Estado social y democrático de derecho, hubo también una transformación en los procesos de formulación, decisión y ejecución de la política exterior.

-Hacia el interior: Los personajes entrevistados nos han ayudado a corroborar o desmentir ciertas cuestiones relacionadas con la influencia ejercida por los actores internacionales en el proceso de la Transición española. Así, hemos podido concluir que Francia y la República Federal Alemana (RFA) jugaron papeles decisivos pero totalmente opuestos: mientras que la primera dificultó en gran medida nuestra entrada en la Comunidad Europea por la competencia agrícola y puso trabas en un primer momento a la lucha antiterrorista emprendida por España, la RFA se erigió como un actor decisivo en la consolidación democrática del país, contribuyendo a la integración española en las Comunidades Europeas o financiando a través de diversas fundaciones (Fundación Friedrich Ebert, Konrad Adenauer, Friedrich Naumann...) a múltiples partidos del panorama político español. El papel jugado por Estados Unidos queda más difuminado ya que para algunos jugó un papel fundamental en el desarrollo y en el resultado final de la Transición y para otros no fue tan decisivo. Pero no solo hemos analizado la influencia ejercida por los diferentes países extranjeros (México, Unión Soviética, Yugoslavia, Venezuela, Rumanía, etc.) sino que en las 
entrevistas también abordamos el protagonismo de: organizaciones no estatales, entre las que destacan la Comunidad Económica Europea y la OTAN, que, aunque en ocasiones situadas en polos opuestos, siempre estuvieron vinculadas entre sí; organizaciones políticas como la Internacional Socialista; actores individuales como Dieter Koniecki -representante de la Fundación Ebert-, Yuri Dubinin embajador de la URSS en España-, etc.

- Hacia el exterior: Tras la muerte de Franco se inició, de forma lenta pero decidida, un cambio de políticas públicas, entre las que se encontraba la política exterior. Los objetivos que desde el comienzo se marcó la Administración exterior española fueron básicamente tres: conseguir apoyo internacional al proceso político de transformación del país; superar en el plazo de tiempo más corto posible la herencia franquista; y formular una nueva política exterior democrática, de acuerdo con los fines y objetivos del nuevo Estado. Así, para conocer los resultados obtenidos profundizamos en: el papel protagonizado por la opinión pública, la actuación de los partidos políticos en el nuevo régimen pluralista, la Administración exterior, el control democrático por parte del Parlamento, etc.

En definitiva, como hemos tratado de mostrar, la aplicación metodológica de la historia oral a nuestro proyecto nos ha permitido contextualizar la cultura política del momento, mejorar nuestro conocimiento sobre los principales protagonistas de la Transición, profundizar en las relaciones informales del poder e incluso esclarecer procesos decisivos en la articulación de la Transición que no hubiesen podido ser reconstruidos en el caso de no haber contado con tales testimonios, dado que en ocasiones estos procesos no se ven suficientemente bien reflejados en la documentación oficial. De todos modos, las potencialidades derivadas del empleo de las fuentes orales pueden quedar desvirtuadas si estas no pueden complementar la información procedente de otras fuentes documentales.

\section{El historiador y sus fuentes. La problemática actual sobre las restricciones de acceso}

\section{a la "documentación histórica" de los Ministerio de Asuntos Exteriores y de Defensa}

No es ningún secreto si afirmamos que casi todos los Gobiernos del mundo presentan tendencia al secretismo, a la ocultación y a la restricción de acceso a la documentación. No obstante, debemos señalar que en la mayoría de los países 
Testigos y protagonistas de la política exterior española: una reflexión metodológica sobre el uso de las fuentes orales y el acceso a las fuentes documentales en historia del tiempo presente

democráticos existe una legislación específica que ampara y regula el derecho de los ciudadanos a acceder a los archivos y registros administrativos y otras informaciones no protegidas por el secreto o el derecho a la intimidad. De media, existe un lapso de tiempo de protección de la documentación que va de los 25 a los 50 años para acceder a su consulta. En el caso de España, sin embargo, obtener información oficial, acceder a la documentación de los archivos públicos o recabar datos de la administración es, más que un derecho, un calvario. ${ }^{11}$

Las dificultades con las que los investigadores nos encontramos para acceder a la consulta de la documentación histórica conservada en determinados archivos públicos ha hecho que en las últimas décadas hayan aparecido publicadas reiteradas quejas y denuncias en este sentido. ${ }^{12} \mathrm{Si}$ algo tienen en común dichos requerimientos es que todos ellos coinciden en denunciar un retroceso en la aplicación de las normas que, hasta entonces, han regulado el libre acceso al patrimonio histórico documental. ${ }^{13}$

Podemos adelantar que el principal problema con el que los historiadores contemporaneístas nos hemos encontrado para acceder a la documentación histórica conservada en repositorios públicos proviene de la errática legislación promulgada desde hace cuarenta años sobre protección de datos de carácter personal. Pero la cosa no queda ahí, pues también cabe tener presente la mala interpretación que reiteradamente se ha hecho sobre las leyes promulgadas al respecto. En consecuencia, a lo largo de estas cuatro décadas se ha asistido a un giro involucionista en contraposición con las primeras leyes que fueron promulgadas en un ambiente de espíritu aperturista como era el de la transición de un Estado dictatorial a otro democrático. ${ }^{14}$

\footnotetext{
${ }^{11}$ Rosario G. GÓMEZ: "La administración y sus 'altos secretos"”, El País, 27 de octubre de 2008.

${ }^{12}$ Para profundizar en esta problemática, véase: Javier TUSELL: "El historiador y sus fuentes”, El País, 30 de agosto de 1996; Antonio NIÑO: "La acción preventiva y el acceso a los archivos históricos", Cuadernos de Historia Contemporánea, 27 (2005), pp. 299-307; José Ramón URQUIJO GOITIA: “Archivos e historia contemporánea", Ayer, 61 (2006), pp. 311-325; Carme MOLINERO: "El acceso a los archivos y la investigación histórica", Ayer, 81 (2011), pp. 285-297; Daniel DE OCAÑA LACAL: "Ser o no ser'”: el archivero entre el derecho de acceso y la protección de la información”, Tabula, 15 (2012), pp. 149-194.

${ }^{13}$ Para conocer en mayor profundidad la normativa española sobre el derecho de acceso a la documentación pública, su aplicación en los archivos y las consecuencias para la investigación histórica, véase: Antonio NIÑO y Carlos SANZ: "Los archivos, la intimidad de las personas y los secretos de Estado", Cuadernos de Historia Contemporánea, 34 (2012), pp. 309-342.

${ }^{14}$ Véase: "Ley 16/1985, de 25 de junio, del Patrimonio Histórico Español", en B.O.E, núm. 155, de 29 de junio de 1985, pp. 20342-23052, https:/www.boe.es/boe/dias/1985/06/29/pdfs/A20342-20352.pdf [consulta 22 marzo, 2017]; "Real Decreto 111/1986, de 10 de enero, de desarrollo parcial de la Ley 16/1985, de 25 de julio, del Patrimonio Histórico Español", en B.O.E, núm. 24, de 28 de enero de 1986, pp. 3815-1831, https://www.boe.es/boe/dias/1986/01/28/pdfs/A03815-03831.pdf [consulta 22 marzo,
} 
No sería ninguna sorpresa si, a tenor de lo referido en el apartado anterior, nos refiriésemos a España como "el país de los secretos”. En este apartado de la exposición, nuestro propósito no es otro que exponer y compartir con la comunidad científica la problemática actual con la que los investigadores en general -periodistas y archiveros-, y los historiadores contemporaneístas o del tiempo presente, en particular, nos encontramos para acceder a la consulta de la documentación histórica dependiente o albergada en los fondos del archivo del Ministerio de Asuntos Exteriores y de Cooperación (MAEC) y del Ministerio de Defensa.

Como caso paradigmático de restricción de acceso a la consulta de la documentación histórica es de reseñar, por su giro involucionista, el del Ministerio de Asuntos Exteriores y de Cooperación de España ${ }^{15}$. Para ello, es necesario remontarse hasta 1984 cuando, estando al frente de la cartera ministerial de Asuntos Exteriores el

2017]; "Ley Orgánica 5/1992, de 29 de octubre, de regulación del tratamiento automatizado de los datos de carácter personal", en B.O.E, núm. 262, de 31 de octubre de 1992, pp. 37037-37045, https://www.boe.es/boe/dias/1992/10/31/pdfs/A37037-37045.pdf [consulta 22 marzo, 2017]; "Ley 30/1992, de 26 de noviembre, de Régimen Jurídico de las Administraciones Públicas y del Procedimiento Administrativo Común", en B.O.E, núm. 285, de 27 de noviembre de 1992, pp. 40300-40319, https://www.boe.es/buscar/doc.php?id=BOE-A-1992-26318 [consulta 22 marzo, 2017]; "Ley Orgánica 15/1999, de 13 de diciembre, de Protección de Datos de Carácter Personal”, en B.O.E, núm. 298 , de 14 de diciembre de 1999, pp. 43088-43099, https://www.boe.es/boe/dias/1999/12/14/pdfs/A43088-43099.pdf [consulta 22 marzo, 2017]; "Real Decreto 1708/2011, de 18 de noviembre, por el que se establece el Sistema Español de Archivos y se regula el Sistema de Archivos de la Administración General del Estado y sus Organismos Públicos y su régimen de acceso", en B.O.E, núm. 284, de 25 de noviembre de 2011, pp. 125573-125592, https://www.boe.es/buscar/pdf/2011/BOE-A-2011-18541-consolidado.pdf [consulta 22 marzo, 2017]; "Ley 19/2013, de 9 de diciembre, de transparencia, acceso a la información pública y buen gobierno", en B.O.E, núm. 298, de 10 de diciembre de 2013, pp. 97922-97952, https://www.boe.es/buscar/pdf/2013/BOE-A-2013-12887-consolidado.pdf [consulta 22 marzo, 2017].

${ }^{15}$ Para profundizar en la problemática que ha suscitado esta situación, véase: Juan Carlos PEREIRA: "Más trabas a la investigación", El País, 8 de mayo de 2012; Miguel GONZÁLEZ: "Exteriores, ministerio secreto", El País, 4 de junio de 2012; Antonio NIÑO y Carlos SANZ: "Los archivos, la intimidad...", pp. 309-342, esp. pp. 326-340; Juan Carlos PEREIRA: "Una decisión incomprensible", El País, 16 de enero de 2013; Carlos SANZ: "Documentación histórica", El País, 15 de mayo de 2013; Alejandro TORRÚS: "España impide a los historiadores investigar en sus archivos", Público, 12 de julio de 2013; Miguel GONZÁLEZ: "Archivos históricos a cal y canto", El País, 15 de julio de 2013; Carlos SÁNCHEZ: "El Gobierno cierra a cal y canto los archivos históricos de Defensa y Exteriores", El Confidencial, 16 de julio de 2013; Juan Carlos PEREIRA: "No permiten conocer esa historia", El País, 23 de enero de 2014; Fernando GARCÍA: “Archivos clasificados”, La Vanguardia, 4 de febrero de 2014; Juan Carlos PEREIRA y Carlos SANZ: "Saber de dónde venimos", El País, 10 de abril de 2014; H-Spain: "Dossier Plural-21: 300 historiadores denuncian al Gobierno Español por la censura del Ministerio de Exteriores de todos los documentos diplomáticos desde el siglo XV al XX y del Ministerio de Defensa de 10.000 documentos militares de los años 1936 a 1968, ¿por qué?”, publicado el 28 de agosto de 2014, http://plural-21.org/wpcontent/uploads/2014/04/300-historiadores-denuncian-al-Gobierno-por-censura-de-documentos-

diplom\%C3\%A1ticos-del-XV-al-XX-y-militares-del-36.pdf [consulta 28 marzo, 2017]; Juan Carlos PEREIRA y Carlos SANZ: "«Todo secreto». Acuerdos secretos, transparencia y acceso a los documentos históricos de Asuntos Exteriores y Defensa”, Ayer, 97 (2015), pp. 243-257; Carmen REMÍREZ: "Los historiadores, contra Margallo por negarse a abrir los archivos”, El Mundo, 30 de marzo de 2015. 
diplomático Fernando Morán (1982-1985), se procedía a la aprobación de la Orden Ministerial de 16 de enero de 1984, por la que se autoriza la consulta de documentos con fines de investigación en el Archivo General y Biblioteca del Ministerio de Asuntos Exteriores. ${ }^{16}$ En esencia, esta bienaventurada Orden Ministerial no sólo equiparaba legislativamente a España con las democracias de su entorno al reconocer que "el libre acceso a los archivos de interés histórico es un rango común de la legislación de todos los países democráticos", sino que iba más lejos al permitir la consulta de la documentación histórica custodiada en el Archivo General del Ministerio y la procedente del mismo depositada en el Archivo General de la Administración (AGA) en Alcalá de Henares al "público con fines de investigación cuando cumpla los veinticinco años de antigüedad desde la fecha del documento".

Es decir, de la noche a la mañana los investigadores podían acceder a la consulta de la documentación histórica de dichos fondos nada menos que hasta 1959. Con anterioridad a 1984, las circulares administrativas de 11 de mayo de 1933, de 26 de octubre de 1970 y de 3 de febrero de 1977 habían establecido la fecha límite de consulta pública de los fondos en los años 1900, 1931 y 1945, respectivamente. No obstante, cabe señalar que dicha Orden Ministerial introducía ciertas restricciones amparadas en lo estipulado en la Ley 9/1968, de 5 de abril, sobre secretos oficiales, ${ }^{17}$ modificada por la Ley 48/1978, de 7 de octubre, ${ }^{18}$ por las cuales no serían accesibles al público en ningún caso los expedientes de carácter personal mientras las personas a las que hicieran referencia siguiesen vivas; los documentos que expresamente hubieran sido declarados "materia clasificada"; además de tener que atenerse los investigadores a lo establecido en la Ley Orgánica 1/1982, de 5 de mayo, de protección civil del derecho al honor, a la intimidad personal y familiar y a la propia imagen.

Sin embargo, esta norma colocaba a España a la vanguardia del acceso a la libre consulta de la documentación internacional, por delante incluso de consolidadas democracias occidentales como Reino Unido y Francia, como de hecho quedó de

\footnotetext{
${ }^{16}$ B.O.E núm. 42, de 18 de febrero de 1984, p. 4471, https://www.boe.es/boe/dias/1984/02/18/pdfs/A044 71-04471.pdf [consulta 30 marzo, 2017]

17 B.O.E, núm. 84, de 6 de abril de 1968, pp. 5197-5199, https://www.boe.es/boe/dias/1968/04/06/pdfs /A05197-05199.pdf [consulta 30 marzo, 2017]

18 B.O.E, núm. 243, de 11 de octubre de 1978, pp. 23605-23606, https://www.boe.es/boe/dias/1978/10/11 /pdfs/A23605-23606.pdf [consulta 30 marzo, 2017]
} 
manifiesto en la Guide des archives des Ministères des Affaires étrangères, publicada en 1989 coincidiendo con la presidencia de España del Consejo de la Comunidad Económica Europea (CEE) durante el primer semestre. ${ }^{19}$ Es más, la orientación aperturista del Ministerio se mantuvo cuando este adoptó el acceso a sus archivos al marco creado por el artículo 57 de la Ley 16/1985, a través de la promulgación de la Orden de 2 de abril de 1991, por la que se regula el acceso a los archivos del Ministerio de Asuntos Exteriores. ${ }^{20}$ Aunque la norma establecía ciertas excepciones, seguía manteniéndose el principio del acceso a la documentación en un plazo de veinticinco años, y en caso de contener datos personales recogidos en la norma no podrían ser consultados -sin consentimiento expreso de los afectados- hasta que hubiera transcurrido un plazo de veinticinco años desde su muerte, si la fecha es conocida, o de cincuenta años a partir de la fecha de los documentos. Así pues, ambas órdenes ministeriales establecían como aval un plazo temporal por el que los investigadores, en cualquier caso, podrían acceder a la consulta de la documentación albergada en/o dependiente del Ministerio de Asuntos Exteriores.

Diecinueve años después, el 15 de octubre de 2010 el Consejo de Ministros del Gobierno de José Luis Rodríguez Zapatero, a propuesta del titular de la cartera de Exteriores, Miguel Ángel Moratinos, aprobó el Acuerdo sobre política de seguridad de la información del Ministerio de Asuntos Exteriores y de Cooperación por el que se clasifican determinadas materias con arreglo a la Ley de Secretos Oficiales. ${ }^{21}$ Cabe recordar que el contexto en el que se probó este acuerdo coincide con un momento en el que la organización WikiLeaks, creada por Julian Assange, había filtrado a través de su sitio web decenas de miles de documentos oficiales estadounidenses con contenido sensible sobre la guerra de Afganistán, y anunciaba para el otoño de 2010 nuevas filtraciones que afectarían a Estados Unidos y sus aliados. ${ }^{22}$ Es más, el propio Ministerio de Asuntos Exteriores español había sufrido en los últimos años algunas fugas y pérdidas de información que cuestionaban la eficaz custodia de las materias más sensibles por parte

\footnotetext{
${ }^{19}$ Véase: Guide des archives des Ministères des Affaires étrangères des États membres, des Communautés européennes et de la Coopération politique européenne, Luxemburgo, Office des publications officielles des Communautés européennes, 1989.

${ }^{20}$ B.O.E, núm. 87, de 11 de abril de 1991, pp. 10991-10992, https://www.boe.es/buscar/doc.php?id=BOEA-1991-8746 [consulta 30 marzo, 2017].

${ }^{21}$ El contenido íntegro del documento puede consultarse en: http://ep00.epimg.net/descargables/2012 /06/03/81b3c3748773b522e38eb34079877132.pdf [consulta 31 marzo, 2017].

22 Vicente JIMÉNEZ y Antonio CAÑO: "La mayor filtración de la historia deja al descubierto los secretos de la política exterior de EEUU”, El País, 28 de noviembre de 2010.
} 
de la diplomacia española, siendo sin duda el caso más rocambolesco el de la revelación de un informe que daba cuenta de la petición en 2002 de EEUU para que los aviones de la CIA con talibanes y sospechosos de pertenecer a Al Qaeda hicieran escala en aeropuertos españoles camino de Guantánamo. ${ }^{23}$

En esencia, el contenido de este acuerdo secreto -pues ni siquiera apareció publicado en el B.O.E- permitió al Gobierno blindar el acceso a la consulta de la práctica totalidad de la documentación diplomática, al otorgar con carácter genérico la clasificación de secreto a catorce materias cuya revelación no autorizada pudiera dañar o poner gravemente en riesgo la seguridad y defensa de España o de sus aliados y amigos así como los intereses políticos, sociales, económicos y comerciales y las relaciones diplomáticas con terceros países: ${ }^{24}$

1. Posiciones básicas de España y estrategias en negociaciones políticas, de seguridad, económicas y comerciales que conciernan a los intereses esenciales del Estado tanto en el ámbito bilateral como en la Unión Europea, la Organización del Tratado del Atlántico Norte, el sistema de Naciones Unidas, la Conferencia Iberoamericana u otras Organizaciones y Conferencias Internacionales.

2. Información sobre posiciones españolas en conflictos internacionales o internos de naturaleza política, social, económica o comercial que puedan comprometer los intereses españoles o su capacidad de interlocución con terceros países.

3. Información relativa a la actuación de grupos terroristas y movimientos a ellos asociados, delincuencia organizada y tráfico de drogas, personas y armas con implicaciones o ramificaciones en España o en los países con los que España haya suscrito acuerdos sobre dichas materias o mantenga relaciones de amistad.

4. Información relativa al despliegue de unidades de las Fuerzas Armadas y Fuerzas y Cuerpos de Seguridad del Estado españolas y aliadas tanto en España como en misiones internacionales.

\footnotetext{
${ }^{23}$ Véase, Miguel GONZÁLEZ: "El redactor del informe secreto dice que no lo destruyó ni lo mandó destruir", El País, 17 de diciembre de 2008.

${ }^{24}$ El referido Acuerdo tuvo que ser desclasificado para poder comunicar su contenido al profesor Carlos Sanz en base a su solicitud del 27 de abril de 2012. Véase, Miguel GONZÁLEZ: "Exteriores revisará el acuerdo que declara secretos todos sus documentos”, El País, 5 de junio de 2012.
} 
5. Negociaciones y buenos oficios sobre secuestros y liberación de ciudadanos españoles o extranjeros, así como la información relativa a las extradiciones o traslado de personas condenadas.

6. Contactos de mediación o buenos oficios llevados a cabo por España con terceros países y con grupos y líderes de oposición para facilitar procesos de paz y la promoción o defensa de los derechos humanos.

7. Protección de Derechos Humanos, con especial incidencia en casos humanitarios especialmente sensibles y las gestiones con terceros países en este ámbito.

8. Cuestiones de asilo y refugio.

9. Tramitación de beneplácitos de Jefes de Misión españoles y extranjeros.

10. Información relativa a cuestiones que afecten a la soberanía, independencia y a la integridad territorial de España o de países amigos y a las posiciones de España sobre contenciosos de índole territorial inter-estatales o intra-estatales.

11. Informaciones relativas a la aplicación de Acuerdos bilaterales o multilaterales sobre asuntos de seguridad y defensa suscritos por España, incluidas aquellas relacionadas con sobrevuelos, estancias y escalas de buques y aeronaves.

12. Asuntos relacionados con los crímenes más graves de trascendencia internacional sobre los que pueda tener jurisdicción la Corte Penal Internacional $\mathrm{u}$ otros Tribunales Internacionales $\mathrm{y}$ aquellos sometidos ante Tribunales españoles.

13. La información relativa a los preparativos de los viajes de SS.MM. los Reyes y del Presidente del Gobierno y, cuando las circunstancias lo aconsejen, de los Ministros y otras autoridades del Estado.

14. Las claves y material criptográfico.

Si tenemos en cuenta el contenido de lo previsto en la aún vigente Ley 9/1968, de Secretos Oficiales del franquismo y las restricciones estipuladas en el Real Decreto 1708/2011, en relación a la solicitud de consulta de documentos de acceso restringido 
por contener datos personales, y en la Ley 19/2013, de Transparencia, en base a los límites establecidos al derecho de acceso, el acuerdo situó a los historiadores internacionalistas que pretendían consultar la documentación diplomática española en una situación muy complicada. En consecuencia, en el otoño de 2011 la Secretaría Técnica del Ministerio de Asuntos Exteriores comenzó a hacer efectiva la aplicación del acuerdo sobre la documentación histórica de su departamento, custodiada hasta entonces en el Archivo General del MAEC. A partir de este momento se comenzó a denegar a los investigadores el acceso en la Sala de Lectura a la documentación posterior a 1968, pasando a ser esta clasificada como de "acceso restringido". Poco tiempo después, las restricciones se extendieron más allá del siglo XIX. ${ }^{25}$ Las consecuencias de esta aciaga decisión fue la interrupción inesperada de trabajos de investigación y tesis doctorales en marcha, incluso de proyectos de investigación financiados en muchos casos con fondos públicos. $^{26}$

En esta tónica, en junio de 2012 el Ministerio de Asuntos Exteriores acordó con el Ministerio de Educación, Cultura y Deporte trasladar sus fondos a diversos archivos de su competencia. Mientras que la documentación anterior a 1931 fue trasladada al AHN, la comprendida entre 1931 y 1980 fue transferida al AGA, quedando en el Archivo General del MAEC la posterior a 1980. Fue un proceso que se dilató hasta mediados de septiembre de 2013. Mientras que la documentación trasladada al AHN pudo volver a consultarse sin excesivas restricciones desde abril de 2014, no ocurrió lo mismo con la documentación transferida al AGA. Amparándose la administración en el pretexto de la falta de personal, así como de recursos suficientes para acometer su clasificación, a día de hoy sigue siendo casi "misión imposible" acceder a la consulta de dicha documentación en el AGA, archivo calificado como de "intermedio". Únicamente está al alcance de los investigadores acceder a la consulta de la documentación que otrora hubiera sido consultada y referenciada en publicaciones, siempre que se presente el justificante de dicha referencia archivística. En consecuencia, aún sigue siendo una incógnita para los investigadores cuándo podremos acceder a la documentación de exteriores que fue trasladada al AGA y la que ha quedado albergada en el Archivo General del MAEC.

\footnotetext{
25 Juan Carlos PEREIRA y Carlos SANZ: “«Todo secreto». Acuerdos...”, pp. 243-257, esp. p. 247.

${ }^{26}$ Juan Carlos PEREIRA: "Una decisión incomprensible”, El País, 16 de enero de 2013.
} 
En cuanto a la documentación histórica dependiente del Ministerio de Defensa, con la llegada de Carme Chacón (2008-2011) al frente de esta cartera ministerial, en su primera comparecencia ante la Comisión de Defensa del Congreso, el 30 de junio de 2008, la ministra se propuso acometer la desclasificación de documentos que hasta el momento eran inaccesibles a los investigadores y que, debido a su alto valor científico y también sentimental para muchas personas, era necesario permitir el libre acceso a su consulta. ${ }^{27}$ En particular, la documentación afectada por la Ley de Secretos Oficiales y que la ministra había dejado preparada para su acceso público afectaba aproximadamente a 10.000 documentos "clasificados" entre los años 1936 y 1968. En definitiva, un patrimonio documental de gran interés para los historiadores, como lo demostraba el creciente número de peticiones de consulta dirigidas al Ministerio de Defensa en los últimos años. ${ }^{28}$ Sin embargo, con la llegada del nuevo Gobierno popular bajo la presidencia de Mariano Rajoy, el nuevo titular de Defensa, Pedro Morenés (2011-2016), decidió congelar sine die toda esa documentación castrense que ya estaba lista para su consulta. ${ }^{29} \mathrm{Al}$ parecer, acometer la digitalización y desclasificación de otro tipo de documentación como los 1.900 documentos que constituyen los "Expedientes OVNI" ha sido de mayor prioridad para el Ministerio de Defensa que la puesta a disposición pública de la documentación histórica a la que hacíamos referencia para que los historiadores podamos investigar y conocer nuestro pasado más reciente. ${ }^{30}$

\section{Conclusiones}

El acceso de los historiadores a las fuentes, ya sean orales y/o archivísticas, es esencial para que estos puedan acometer sus investigaciones de forma científica. Por suerte, en la mayoría de los casos el historiador del tiempo presente cuenta con la gran ventaja, frente a otros investigadores de tiempos más pretéritos, de poder entrevistar a los

\footnotetext{
${ }^{27}$ Tereixa CONSTELA y Miguel GONZÁLEZ: "Defensa quiere desclasificar miles de papeles secretos de valor histórico", El País, 10 de agosto de 2008.

${ }^{28} \mathrm{El}$ Acuerdo sobre cancelación de la clasificación de determinados documentos militares elevado por la ministra de Defensa Carme Chacón al Consejo de Ministros en octubre de 2011 puede consultarse en: Carlos SÁNCHEZ: "El Gobierno cierra a cal y canto los archivos históricos de Defensa y Exteriores", $E l$ Confidencial, 16 de julio de 2013.

${ }^{29}$ Véase, Eduardo DEL CAMPO: "El búnker de la historia de España”, El Mundo, 6 de mayo de 2013.

30 Véase, Esther MUCIENTES: “"Expedientes OVNI': Defensa saca a la luz los avistamientos de "fenómenos extraños"”, El Mundo, 22 de octubre de 2016; Pablo CANTÓN: "Los expedientes OVNI cercanos a tu casa que Defensa ha publicado en su web", El País, 25 de octubre de 2016; Biblioteca Virtual del Ministerio de Defensa: http://bibliotecavirtualdefensa.es/BVMDefensa/i18n/consulta/resultados _ocr.cmd [consulta 12 de abril, 2017].
} 
“testigos y protagonistas" de los acontecimientos que estudia. No obstante, señalábamos que "el historiador debe asumir que este recurso debe ser utilizado como fuente complementaria para reafirmar, contrastar o bien refutar las hipótesis enunciadas a partir de las fuentes escritas". En efecto, se antoja imprescindible para el historiador del tiempo presente establecer un diálogo entre las fuentes orales y las fuentes escritas, pues unas y otras en ocasiones aportan visiones diferentes, pero por lo mismo también se complementan, se potencian y dinamizan entre sí.

En este sentido, una de las grandes ventajas del Grupo de investigación de Historia de las Relaciones Internacionales (GHistRI) es que, desde hace varios años y ante la referida problemática del acceso a la documentación histórica, ha apostado firmemente por las fuentes orales, entrevistando a un heterogéneo colectivo de "testigos y protagonistas" de nuestra transición democrática en el marco internacional, lo que le ha valido poder constituir un archivo propio de la memoria con más de treinta registros de incalculable valor. ${ }^{31}$ Sin embargo, la problemática actual con las que nos encontramos los investigadores para acceder a la consulta de la documentación en los archivos públicos españoles, y particularmente los historiadores internacionalistas con respecto al acceso a la documentación diplomática dependiente del Ministerio de Asuntos Exteriores, ha hecho que en la práctica sean los testimonios de los entrevistados la principal fuente de documentación con la que contemos para poder analizar e investigar nuestra historia más reciente. Por suerte, no todo está perdido, pues a diferencia de España, democracias consolidaras como Estados Unidos, Reino Unido, Francia o Suecia cuentan con una legislación que contempla -y unos mecanismos que regulan- la desclasificación sistemática de sus papeles "secretos" en un lapso de tiempo de entre 25 y 50 años de media $^{32}$. En consecuencia, los historiadores internacionalistas nos vemos abocados a consultar los repositorios públicos extranjeros para poder conocer nuestra propia historia, y así poder contrastar la información obtenida de dichos repositorios con la de los personajes entrevistados.

\footnotetext{
${ }^{31}$ Miguel Í. CAMPOS, José Carlos ARÁNGUEZ y José Manuel MORALES: “Testigos y protagonistas", en Juan Carlos PEREIRA CASTAÑARES y Juan Manuel FERNÁNDEZ FERNÁNDEZ-CUESTA (dirs.): La política exterior y la dimensión internacional de la Transición española", Pamplona, Thomson Reuters/Aranzadi, 2015, pp. 407-420.

${ }_{32}$ Carmen RENGEL: "Los secretos de Estado son 'eternos' en España", The Huffington Post, 8 de diciembre de 2015.
} 
En cuanto a la problemática actual para acceder tanto a la documentación diplomática como los aproximadamente 10.000 documentos históricos militares que Defensa tenía preparados para su consulta, parece ser que la solución más viable actualmente pasaría por reformar una ley preconstitucional como es la Ley franquista de Secretos Oficiales de 1968. En este punto, podemos señalar que ya durante la fallida XI Legislatura (13/1/2016-3/5/2016) el grupo parlamentario vasco (EAJ-PNV) presentó en abril de 2016 en el Congreso de los Diputados una Proposición de Ley de reforma de la Ley 9/1968, de 5 de abril, sobre secretos oficiales, pero debido a la disolución de las Cortes, esta no prosperó. ${ }^{33}$ Tras constituirse la XII Legislatura, el 19 de julio de 2016, el citado grupo parlamentario volvió a presentar de nuevo en septiembre ante la Cámara Baja la misma Proposición de Ley de reforma de la Ley 9/1968, de 5 de abril, sobre secretos oficiales $^{34}$. Esta proposición de ley que, por primera vez, fija un periodo de desclasificación automática -25 años para materias secretas y 10 para reservadas-, y atribuye en exclusiva al Consejo de Ministros la facultad de clasificar secretos, fue aprobada a trámite por todos los partidos políticos representados en el hemiciclo -a excepción del Partido Popular, que se abstuvo- en la sesión parlamentaria del 29 de noviembre de $2016^{35}$. A la espera de que finalmente se promulgue la ansiada ley que reforme la obsoleta Ley de Secretos Oficiales de 1968, pues se estimó un periodo de aproximadamente seis meses para su debate y desarrollo en la Comisión Constitucional del Congreso, lo que se espera cuanto menos es que esta nos sitúe a la altura de las democracias más avanzadas en materia de desclasificación automática de documentación "histórica", permitiendo así a los investigadores poder continuar con nuestra labor científica.

\footnotetext{
${ }^{33}$ B.O.C.G. Congreso de los Diputados, serie B, núm. 22-1, de 11 de marzo de 2016, http://www.congreso .es/public_oficiales/L11/CONG/BOCG/B/BOCG-11-B-22-1.PDF [consulta 8 de abril, 2017].

${ }_{34}$ B.O.C.G. Congreso de los Diputados, serie B, núm. 32-1, de 16 de septiembre de 2016, http://www.congreso.es/public_oficiales/L12/CONG/BOCG/B/BOCG-12-B-32-1.PDF. [consulta 8 de abril, 2017].

${ }^{35}$ Miguel GONZÁLEZ: "El PP no logra frenar la reforma de la ley franquista de secretos oficiales", $E l$ País, 29 de noviembre de 2016; Ángel VIÑAS: "Archivos para la historia. España requiere de una norma para regular la desclasificación de documentos", El País, 22 de diciembre de 2016.
} 


\section{CAPÍtULO V}

\section{¿El Corto Siglo XX? EXPERIEnCias de Jóvenes \\ INVESTIGADORES DESDE (Y HACIA) UN NUEVO SIGLO}

Alba Fernández Gallego (UCM)

Alejandro Pérez-Olivares (Sciences Po Lyon)

Carlos Píriz (USAL)

Pasado el VI Encuentro de Jóvenes Investigadores auspiciado por la Asociación de Historia Contemporánea, ¿cuáles son las preguntas que aún permanecen en nuestra memoria? ¿Dónde quedan las intenciones con las que llegamos a Zaragoza, la disposición de debatir sobre nuestras experiencias cotidianas y no tanto sobre nuestros objetos de estudio? Cuando planteamos la posibilidad de coordinar este taller pretendíamos alejarnos de nuestras investigaciones lo suficiente como para observar que, en realidad, durante la mayor parte del tiempo, nuestros intereses son fragmentarios, aislados, quizás incluso insuficientes. Uno por uno, los temas que ocupan nuestras preocupaciones académicas no respondían a dos preguntas a las que nos enfrentábamos desde hacía un tiempo: la Historia, ¿para qué y para quiénes? La Historia, ¿por qué y por quiénes? Qué duda cabe 
que gran parte de los paradigmas historiográficos que definieron el siglo $\mathrm{XX}$ se encuentran hoy, por diversos motivos, en crisis. Una crisis que entre el viejo siglo y el nuevo también ha apuntado a la noción misma de historiografía, como disciplina académica. Junto a estas dos nociones, la mesa-taller que coordinamos pretendió responder, en la medida de las posibilidades, a otra crisis, la nuestra, que generacionalmente afecta y condiciona nuestra práctica historiográfica cotidiana en forma de precariedad. ${ }^{1}$

En esta encrucijada múltiple se situó el espacio que planteamos y que ahora presentamos, que pretendió no tanto evaluar trayectorias investigadoras personales o elaborar una revisión historiográfica a partir de ellas, al modo en que Geoff Eley orientó Una línea torcida, sino introducir la experiencia como variable investigadora y reflexiva, como un interrogante que pueda tener cabida en esta tipología de encuentros. ${ }^{2}$ De este modo, entre los objetivos iniciales del taller se encontró la voluntad de relacionar las "crisis de la Historia" con la nuestra propia, en aras de identificar y aprovechar la pluralidad de objetos de estudio y sujetos estudiantes, de intereses investigadores y espacios desde los que se ponen en práctica. Un objetivo que también perfiló un reto: la capacidad de imaginar otras agendas historiográficas, diferentes a las ya exploradas, en tanto que proyección sobre el pasado de nuestros intereses y experiencias actuales. Las aportaciones definitivas han desbordado nuestros objetivos iniciales, subrayando algunas de nuestras motivaciones, pero, principalmente, dibujando otros intereses. Y por eso debemos agradecer a todas aquellas personas que participaron en el taller, aportando un texto o con sus intervenciones, el interés que demostraron en compartir sus preocupaciones y las nuestras. La intención de este taller no se situaba en el análisis individualizado de cada texto y cada experiencia, sino de tomar el conjunto de las aportaciones como puntos de partida, a partir de los cuales construir una reflexión coral y participativa.

En ““Ánimo abuelos (y padres) que ya volvemos': memoria, olvido y posmemoria

\footnotetext{
${ }^{1}$ Sobre la crisis y la precariedad en la investigación actual puede consultarse José Manuel MUÑOZ FÉLIX: "Volver a casa (solo) por Navidad", El País (21/XII/2017). Disponible en: https://elpais.com/elpais/2017/12/19/ciencia/1513692983_422344.html [consulta 20 de agosto 2019].

${ }^{2}$ Geoff ELEY: Una línea torcida: de la historia cultural a la historia de la sociedad, València: Publicacions de la Universitat de València, 2008.
} 
de la militancia radical", Vicent Bellver planteó las tensiones propias del encuentro entre la memoria, la experiencia directa del recuerdo y la reconstrucción de la militancia radical desde los años de la Transición. En un texto donde la subjetividad es protagonista, también aparecen los contextos desde los cuales se afirma la propia personalidad del autor, los espacios donde se reproduce(n) la(s) memoria(s) de la militancia radical y la difícil relación entre militancia e investigación académica. Así, son dos las cuestiones principales que plantea este texto. Primero, ¿a partir de qué realidades se puede hablar de un apoliticismo de la historiografía académica? Y segundo, ¿qué contextos personales, sociales y políticos favorecen la revisión de nuestras interpretaciones sobre el pasado? Situado en lo que se ha denominado como "historia del presente", Vicent apuntó también hacia las ventajas y las dificultades de pensar aquello de lo que sociológicamente somos “hijos” o "nietos”. Por tanto, ¿qué lenguajes, prácticas y horizontes radicales podemos historiar desde nuestras propias experiencias y contextos? Y, en relación a una genealogía del recuerdo, lo que se ha denominado posmemoria, su texto también planteó la posibilidad de revisar un "pasado-presente", la Transición, mediante la revisión de un pasado previo, la experiencia traumática de la Guerra Civil y el franquismo. ${ }^{3}$

Desde una perspectiva más orientada a la revisión historiográfica, Rafael Buhigas nos acercó a la experiencia concreta del Grupo de Historiadores del Partido Comunista de Gran Bretaña, lo que comúnmente conocemos como los "marxistas británicos". "La espiral dialéctica de la historiografía: pasado y presente de los marxistas británicos" planteó una mirada profunda y polemista sobre la constitución y legado de esta forma de entender la práctica historiográfica, fundamental para entender algunos de los principales debates del siglo XX. De este texto cabe rescatar algunos elementos para debatir sobre nuestra propia experiencia en el siglo XXI, sobre todo en relación a la disyuntiva planteada por el autor entre la "intelectualización” y la "erudición”. Así, ¿es la Academia la única vía de normalización del trabajo historiográfico? ¿Qué condicionantes y oportunidades ofrece para revisitar el pasado? De otro modo, y retomando una expresión de E. P. Thompson que el propio Rafael destacó, ¿existe una cultura del comportamiento de clase en la Academia? ¿Qué efectos tiene en la relación de la Universidad con otros espacios de reelaboración del pasado?

\footnotetext{
${ }^{3}$ Aunque el texto de Vicent Bellver no se incluye en esta publicación, agradecemos su contribución y su participación activa en el debate que dio forma al taller.
} 
Una problemática que entronca directamente con la experiencia retratada en "Seminario de Historia y Teoría de la Cultura. Una propuesta de generación de conocimiento colectivo". Esta comunicación coral detalló las tres ediciones de una iniciativa que, originada dentro de la Universidad, se ha propuesto acortar las distancias entre lo académico y el exterior, trascendiendo sus jerarquías especificas mediante la propia práctica. Para ello, identifican el Centre for Contemporary Culture Studies de Birmingham como su referente principal, pero su experiencia también plantea los límites del llamado "sistema comunicativo horizontal", entre otros los retos a los que se enfrenta cualquier iniciativa que pretende ser participativa. En este sentido, cabe identificar algunas líneas de debate fundamentales para entendernos como sujetos productores de relatos sobre el pasado (y entender, a su vez, los propios relatos). Por ejemplo, frente a una visión de lo académico como espacio colegiado, lo que esta comunicación denominó "conocimiento colectivo" o lo que Donna Haraway denominó "red de conocimientos situados", ¿cuál es la realidad cotidiana de nuestra práctica historiográfica? ${ }^{4}$ La experiencia del Seminario de Historia y Teoría de la Cultura permite plantearnos si la Universidad es realmente una "comunidad de aprendizaje" o qué sujetos participan en ella y cómo (la interacción entre el profesorado y el alumnado, las relaciones de competencia/colaboración entre los diferentes tipos de contrato laboral o la estructura y el funcionamiento de seminarios y congresos, por ejemplo). De otro modo, y adoptando la lógica "emisor-receptor", cabe preguntarse por su funcionamiento en, desde y hacia la Universidad. ¿Qué tipo de transferencias es capaz de desarrollar y/o potenciar este espacio, con qué finalidad y de qué formas?

Una cuestión, la del espacio, ampliamente desarrollada en sus términos epistemológicos y posibilidades narrativas por Joan Muñoz. El autor planteó la cuestión de conjugar los debates heredados del siglo pasado con las consecuencias, a varios niveles, de un mundo cada vez más interconectado y global. Frente a una forma de hacer historia que sólo ha tenido en cuenta el tiempo (salvo contadas excepciones), "El espacio como forma de hacer historia. Del giro espacial a la narrativa de la simultaneidad" dibujó algunos de los retos a los que se enfrenta la historiografía actual en sus modos de interpretar y narrar. Anclado sólidamente en sus perspectivas teóricas, este texto nos emplazó a

\footnotetext{
${ }^{4}$ Donna J. HARAWAY: Ciencia, cyborgs y mujeres. La reinvención de la naturaleza, València, Ediciones Cátedra-Universitat de València-Instituo de la Mujer, 1995 [1991].
} 
cuestiones esencialmente prácticas, por ejemplo, a evaluar la forma en que nuestras reflexiones se vinculan a una experiencia espacial y temporal precisa. Así, tras el agotamiento de la longue durée como paradigma, ¿de qué forma se proyecta la inmediatez propia del "efecto Twitter" o de un continuo "Breaking News" sobre la naturaleza de nuestras reflexiones? De otro modo, y en relación con los espacios desde donde se produce la historiografía, ¿qué consecuencias tiene que el conocimiento académico sea un conocimiento esencialmente urbano, producido y consumido en la ciudad?

La variedad temática y metodológica no eclipsó el componente común que atravesaba todas las propuestas: nuestra condición de investigadores y nuestra condición de jóvenes. Éste fue el punto de partida: poner en común el trabajo historiográfico, así como los modos en que nos enfrentamos al mismo. La parte esencial del encuentro tuvo como finalidad favorecer una reflexión conjunta para propiciar la construcción de conocimientos en común y la puesta en práctica de modos de trabajo colectivo. A tal fin, la mesa dio comienzo con un vídeo de elaboración propia. En realidad, se trató de un montaje de audios e imágenes donde al tiempo que sonaba la tradicional canción Había una vez un circo (compuesta por el conocido payaso televisivo Miliki) se representaban visualmente los numerosos conflictos mundiales de las últimas décadas. Llegados a la caída de las Torres Gemelas en 2001, unas imágenes que todos hemos guardado en la retina, el film entró en una dinámica exacerbada apoyada en una música grandilocuente que concluían con una enorme explosión. Esta breve performance tuvo la misión de representar simbólicamente la caída de los grandes paradigmas y la transformación de los valores que rigen nuestro mundo, como contexto desde el que comprendemos lo(s) pasado(s). Con esas imágenes dimos la bienvenida a todos los asistentes a esta mesa centrada en las experiencias de los jóvenes investigadores.

La vida del investigador es, muchas veces, ermitaña. Por ello la mesa trató de formular una serie de preguntas que, individualmente, nos hacemos día a día, con el fín de tratarlas colectivamente. No se trató pues de desarrollar reflexiones teóricas o confrontar líneas metodológicas, sino de un espacio para hablar de la experiencia: aquella que cada uno de nosotros tiene al investigar e historiar, poniendo en común los retos, las preocupaciones, los límites y los contextos que son parte indisociable de nuestro quehacer cotidiano. Se partió así de la presunción de que nuestro oficio, profesión o disciplina (junto con otros nombres que aparecieron durante el taller) se conforma como un conocimiento 
situado, los objetos de estudio se definen siempre más por el lugar del que parten que por el lugar al que quieren llegar. Para facilitar estas reflexiones se habían facilitado, además de los textos de los participantes, una serie de materiales complementarios escogidos por su diversidad en fondo y forma.

Una entrevista a Peter Linebaugh en torno a la relación que establecemos con realidades pasadas aparentemente distantes a la nuestra dio pie a una reflexión sobre las formas en que están situados esos temas de investigación en nuestro presente, acerca de las preguntas que guían nuestras investigaciones porque parten de nuestro propio contexto. ${ }^{5}$ Se planteó la posibilidad de que las preguntas hechas para enfrentarnos al estudio del pasado se puedan proyectar también hacia el futuro, para lo cual se propuso la construcción de una agenda historiográfica nueva. El fragmento del libro de Howard Zinn, Nadie es neutral en un tren en marcha, donde establece líneas convergentes entre su propia experiencia personal como opositor a la guerra de Vietnam y a la segregación racial con sus intereses académicos, permitió reflexionar sobre las subjetividades que operan a la hora de historiar. ${ }^{6}$ Se discutió sobre cómo se proyecta la experiencia personal en la trayectoria investigadora, de qué formas puede orientar esa experiencia no sólo una mesa o una tesis, sino a una trayectoria personal completa.

Por último, una entrevista a Silvia Federici donde se apela a entendernos como sujetos históricos, sirvió como pretexto para detenernos a considerar qué pensamos, qué nos preguntamos y qué escribimos desde coordenadas muy concretas, donde quizás haya que poner en cuestión otras formas de conocimiento, más ligadas a las categorías, y recoger la mirada experiencial sobre cómo escribimos. ${ }^{7}$ Así, entender nuestro presente en el siglo XXI en perspectiva histórica, rastrear las rupturas y continuidades que nos conforman como sujetos, también formó parte de los objetivos de este taller. Quizá esto sea lo esencial para poder imaginar las historias que aún quedan por hacer, puesto que,

\footnotetext{
5 "Peter Linebaugh: Who Owns the Commons? An 800 Year Fight for Public Goods", https://www.youtube.com/watch?v=nSF3m_Uav6Y. Esta cuestión aparece, fundamentalmente, entre los minutos 13:08 y 17:00 [consulta 20 de agosto 2019].

${ }^{6}$ Howard ZINN: Nadie es neutral en un tren en marcha, Hondarribia, HIRU, 2001 [1994]. El fragmento utilizado está disponible en http://files.hoxe.webnode.es/200000019-7084d717ea/Zinn\%2C\%20Nadie\% 20es\%20neutral\%2C\%201994.pdf [consulta 20 de agosto 2019].

7 "Silvia Federici: 'desconfío del feminismo de Estado", Plan V (22/V/2016). Disponible en http://www.planv.com.ec/historias/entrevistas/silvia-federici-desconfio-del-feminismo-estado?nopaging $=1 \% 20 \mathrm{http}: / / \mathrm{www}$.planv.com.ec/historias/entrevistas/silvia-federici-desconfio-del-feminismo-estado?nop aging=1 [consulta 20 de agosto 2019].
} 
como escribió Albert Camus para el siglo XX, "el pensamiento en rebeldía no puede, pues, prescindir de la memoria". 8

Para favorecer el diálogo, la puesta en común y la elaboración de un proyecto común, se decidió dividir la sesión en tres partes. La primera de ellas, "La historia del siglo XX, los porqués" pretendió romper el hielo poniendo en común cómo cada uno de nosotros nos enfrentamos a explicar el siglo XX desde el siglo XXI. La segunda parte, "La historia desde el siglo XXI", quiso ir un paso más allá reflexionando sobre quién y para quiénes producimos discursos historiográficos. Por último, y con carácter más práctico, se desarrolló “¿El fin de la historia?”, cuyo propósito fue el de cuestionar si la labor de los historiadores tiene no ya una finalidad, sino incluso alguna continuidad futura. El objetivo de esta última parte era la de trazar un primer esbozo para una agenda historiográfica común, sino de toda la comunidad historiográfica, al menos de los participantes en el encuentro.

En la primera parte, a la hora de abordar la manera en que nos enfrentamos al siglo $\mathrm{XX}$, el grueso de los debates giró en torno al concepto de militancia y al de sentirse herederos de algo o alguien. El papel que tenemos como jóvenes historiadores es complejo ya que, dependiendo del objeto de estudio, podemos sentirnos directamente afectados o interpelados por cualquiera de las tradiciones ideológicas que atravesaron el siglo XX. Por tanto, ¿cómo podemos historiar aquello de lo que somos o nos sentimos herederos? En la comprensión del pasado, muchas veces se ha partido de visiones estereotipadas e interesadas, y el anhelo de los vencedores ha construido un relato historiográfico que en algunos casos todavía debe superarse. Los historiadores se enfrentar al peligro de ver a la Historia como su propio fruto, conduciéndola con actitud paternalista. Si la proyección subjetiva del historiador hacia el sujeto histórico es clara, ¿cómo podemos abordarla? Debe construirse, sin duda, un escenario de reflexión y crítica, puesto que si es conveniente pensar la historicidad de los procesos, que estudiamos, tampoco podemos quedarnos atrapados por el pasado. Por otra parte, en ocasiones el hecho de sentirnos herederos de algo o alguien no es recíproco, y resulta sumamente complicado establecer un diálogo intergeneracional.

La cuestión de si nuestro trabajo se inscribe en diversas formas militantes se impuso

\footnotetext{
${ }^{8}$ Albert CAMUS: El hombre rebelde, Madrid, Alianza Editorial, 2013 [1951], p. 20.
} 
pronto como preocupación fundamental. Si bien el consenso no fue posible, esto se debió en gran parte a que no todo el mundo comparte la misma concepción de "historia militante”. Está fuera de toda duda que todos los historiadores están impregnados de su presente y que proyectamos nuestras preocupaciones sobre nuestros objetos de estudio. Pero la honestidad no debe confundirse con los continuos dilemas que atravesamos al elegir un tema determinado, un fondo documental concreto o una metodología, dediciones que suponen una toma de posición implícita. Se defendió que, como persona que forma parte de una sociedad, el historiador puede elegir tanto los objetos como los sujetos de estudio en función de una agencia de cambio social, pero no debería hacerlo según la agenda de un partido concreto. Sin embargo, esto debería llevarnos a plantear las implicaciones de pensar que la historia puede convertirse en una herramienta para el cambio social, si se trata de la mejor disciplina académica para dicho fin o cuáles han sido las experiencias pasadas en ese sentido. Lo que sí se concluyó es que, al menos, facilita que podamos comprender y hagamos comprender el mundo que nos rodea. Conviene recordar también que la ideología no es el único factor que limita y atrapa nuestra concepción del campo social, también en el pasado, sino que incluso la utilización de determinados conceptos o categorías analíticas contribuye a ello.

El modo en que nos enfrentamos al siglo XX no es único, y la forma que adquiere nuestra representación del pasado puede tener connotaciones de gran relevancia si atendemos al eje espacial o al temporal. Tal y como se planteaba en el texto "El espacio como forma de hacer historia", esta elección puede condicionar incluso a la hora de pensar. En numerosas ocasiones los paradigmas del siglo XX se han tratado de manera lineal, y eso ha limitado tanto la manera de pensar como la de explicar y comprender. En el siglo XXI debería replantearse si esta fórmula sigue siendo útil o si se puede compaginar con otras fórmulas, como las que se basan en categorías no temporales y sí espaciales. Esto aportaría, por un lado, herramientas conceptuales, ya que los hechos dejarían de tener un significado a través de su mera concatenación, una decisión, por otro lado, arbitraria. Desde el punto de vista de la representación, otras formas son posibles, como el collage.

En la segunda parte dedicada a la historia desde el siglo XXI, se plantearon una serie de cuestiones como la influencia de nuestra experiencia en los relatos que creamos, si existen otros espacios o creadores de relatos fuera de la Academia, nuestro papel en estos tiempos de confusión, o si sólo debemos trabajar en el pasado. Los historiadores deben 
asumir que no son los únicos creadores de relato sobre el ayer, pero, ¿dónde nos ubicamos entonces? En la "era del testigo", según la expresión de Annette Wieviorka, donde asistimos a una continuada explosión de memoria, no cabe duda de que ha habido muchas voluntades de conocer, de recrear y de exteriorizar experiencias, también "desde abajo". 9 En gran número de ocasiones esta demanda no ha encontrado interlocutores en la historiografía académica, por lo que ha tenido que buscarlas en otros espacios o crear sus propios relatos. Sin embargo, no hay duda de que incluso la Academia ha mudado gran parte de sus repertorios con el cambio de siglo y empieza a intentar dar respuesta también a estos retos, con agendas investigadoras más permeables a ciertas reclamaciones muy presentes en "la calle".

¿Cuál sería, entonces, el papel del historiador si la Historia se produce extramuros de la Academia y si las novedades (metodológicas, temáticas, empíricas) se proponen principalmente fuera? No olvidemos que algunas corrientes renovadoras, como la historia social o el feminismo, nacieron fuera de la Academia y poco a poco se fueron institucionalizando. ¿Es la Universidad capaz de generar "buena historia" para la sociedad? Si bien el pasado no es una dimensión única de los historiadores y todos tenemos experiencias desde o hacia el pasado, en la Universidad ese contexto conforma, al fin y al cabo, un oficio. Deberíamos preguntarnos, más bien, qué prácticas desarrollamos, qué preguntas formulamos y a qué sujetos escuchamos, ahora y en los materiales discontinuos y fragmentarios que conforman nuestras fuentes. Y no sólo eso, sino también interrogarnos por los espacios donde se está construyendo actualmente el conocimiento y si la Academia reconoce o no distintos relatos construidos en distintos espacios. No deja de sorprender que, en perspectiva, seguimos escribiendo y enseñando Historia en los mismos espacios que en siglos anteriores -como lo demuestran las históricas aulas de la Universidad de Salamanca donde este año se congratulan con su VIII centenario-. En ellos puede generarse conocimiento a través de la investigación con una base teórico-metodológica o bien difundirse dicho conocimiento. Ambas formas tienen cabida en la Academia. Sin embargo, muchas veces la dicotomía "dentro-fuera" desdibuja otras cuestiones, como los formatos en que se presenta esta elaboración. Cabe preguntarse por cuánto tiempo seguiremos acudiendo a libros y seminarios para encontrarnos en las

\footnotetext{
${ }^{9}$ Annette WIEVIORKA: L'ére du témoin, Paris, Plon, 1998.
} 
explicaciones sobre el pasado.

En ocasiones se desprecia la historia amateur, cuando es un relato que también nos interpela. Es curioso que hablemos de "crisis de la historia", o de las Humanidades en general, en un momento en el que en el espacio público revela un gran interés por sus contenidos. Quizá el problema sea nuestra incapacidad para relacionarnos con la diversidad de relatos y experiencias allí presentes. Debemos preguntarnos por las motivaciones de las personas interesadas en el pasado, y qué influencias tienen, por ejemplo, las llamadas "nuevas tecnologías" a la hora de enfocar nuestro trabajo y nuestra relación con ese interés presente. La propia Academia crea en ocasiones mecanismos que impiden ese encuentro, al menos a la hora de evaluar nuestro trabajo, por lo que no se nos incentiva a usarlo ni se permite su experimentación.

La sesión llegó a su fin con el último bloque, “El fin de la historia?”, donde después de mucho diálogo e intercambio de ideas se ofreció un espacio también para la reflexión individual. El objetivo era que cada asistente imaginara una serie de pautas y directrices comunes que pudiesen lanzar las líneas de una posible agenda historiográfica común en un futuro a medio plazo. Puede que, dentro de unos años, cuando retomemos las propuestas surgidas tras estas reflexiones, comprobemos si se han acometido algunos de los retos esbozados para los historiadores del siglo XXI.

Nuestra intención siempre fue la de plantear un espacio eminentemente reflexivo acerca de nuestras rutinas cotidianas, algo que quedó confirmado desde el primer momento con las diferentes comunicaciones recibidas. Las preocupaciones descritas en los textos fueron compartidas tanto por los comunicantes como por los coordinadores de la sesión. A pesar de la diversidad de temas, todas las reflexiones confluyeron en dibujar algunas de las problemáticas actuales del quehacer historiográfico. Cuando Eric Hobsbawm acuñó su ya famosa expresión sobre el "corto siglo XX", su mirada sobre el pasado encerraba un balance de lo que había supuesto aquel tiempo que no comenzó en 1900 y tampoco terminó en el año 2000. ${ }^{10}$ Casi dos décadas después del comienzo del siglo XXI, ¿qué balance podemos hacer sobre los enfoques, las preocupaciones y las prácticas que definen la historiografía en el nuevo siglo? El objetivo de este taller nunca fue limitarse a una merca crítica destituyente, a impugnar nuestra realidad cotidiana como

\footnotetext{
${ }^{10}$ Eric HOBSBAWM: Age of Extremes: the short twentieth century, 1914-1991, London, Abacus, 1994.
} 
historiadores en formación. Dados a la investigación y a la reflexión entre paradigmas tambaleantes y prácticas heredadas de generaciones anteriores, la mejor aportación que pueda tener el espacio que tuvimos la suerte de coordinar es la de imaginar posibles agendas de temas, preocupaciones y modos de ser historiadores en los años que, con suerte, otras personas estudiarán. Y a buen seguro que en los textos que siguen podrá encontrarse más de una respuesta a las preguntas formuladas. 


\title{
El espacio como forma de hacer historia. Del giro espacial a la narrativa de la simultaneidad*
}

The Space as a Way to Write History. From the Spatial Turn to the Narrative of Simultaneity

\author{
Joan Muñoz González \\ Universitat de Barcelona
}

\section{Resumen}

Entre los retos que el historiador del siglo XXI debe afrontar está el saber conjugar los debates historiográficos heredados con la experiencia de un mundo contemporáneo globalizado, dónde lo geográfico toma un protagonismo ineludible, ya sea por el interés geopolítico como por su resonancia social, económica y ecológica. En este estudio se lleva a cabo una aproximación teórica que considere una perspectiva espacial crítica como forma de interpretación del pasado, aprovechando el impulso del giro espacial. También se realiza una revisión del relato histórico que valora la narrativa de la simultaneidad como estrategia discursiva.

\section{Palabras clave}

Historiografía, tiempo, espacio, giro espacial, simultaneidad.

\begin{abstract}
Among the challenges that the historian of XXI century must confront is the ability to combine the historiographic debates inherited with the experience of a globalized contemporary world, where geography takes an unavoidable relevance, either because of geopolitical interest or its social, economic and ecological resonance. In this paper a
\end{abstract}

*joan.jmg@gmail.com. 
theoretical approach is carried out which considers a critical space perspective as a form of interpretation of the past, taking advantage of the spatial turn. The historical narrative is also reviewed valuing narrative of simultaneity as a discursive strategy.

\section{Palabras clave}

Historiography, time, space, spatial turn, simultaneity.

\section{Introducción}

La interpretación histórica que Eric Hobsbawm realizó sobre el convulso siglo XX ha influido profundamente en la formación de toda una generación de historiadores que, a pesar de no haber sido partícipes de los acontecimientos del denominado corto siglo, hemos recibido toda su herencia, sus debates y su carga simbólica. Los 25 años que nos separan desde el final de la Guerra Fría hacen inevitable, además, que ese legado recibido sea contrastado con la experiencia del nuevo período en el que nos encontramos. No es tanto un esfuerzo de reacción o de ruptura con los discursos del pasado, sino más bien es el hecho de atender a una nueva dialéctica entre presente y pasado y el convencimiento de que las necesidades surgidas durante este cuarto de siglo que llevamos pueden garantizar nuevas miradas interpretativas. Se trata de hecho, de un problema historiográfico que puede formularse con algunos interrogantes. ¿Qué ha sucedido durante estos 25 años? ¿Cuáles son estas nuevas necesidades emergentes? ¿Qué dirección han tomado las investigaciones teóricas y metodológicas?

El siglo XX y los inicios del siglo XXI nos ofrecen numerosos ejemplos donde lo geográfico toma un protagonismo ineludible, ya sea por el interés y significación geopolítica como por la resonancia social, económica o ecológica que despiertan. La caída del muro de Berlín y el fin del mundo bipolar; el proceso de globalización; los fenómenos de crisis medioambiental con episodios de gran resonancia como Chernóbil o Fukushima; el terrorismo del siglo XXI; la crisis económica, acompañada por la respuesta ciudadana en forma de movimientos sociales o de reivindicaciones del espacio público; 
o incluso la gestión frente a los migrantes refugiados. Todo ello no ha hecho más que remarcar este interés social, público y académico hacia el espacio. Es en este sentido que nos planteamos lo siguiente. ¿Se puede analizar la historia a través del espacio? ¿Cómo surge el interés por el espacio y cuáles son los retos que plantea para una teoría historiográfica? ¿Existe una tradición espacial desde la cual pensar la historia? ¿De qué modo podríamos resolver el problema de la explicación de la historia bajo un paradigma espacial?

Partiendo de estas premisas e interrogantes, nuestro objetivo es el de ofrecer una reflexión sobre el estado actual de la teoría historiográfica que integre la experiencia proporcionada por el giro espacial. Se trata de una aproximación teórica que tiene la pretensión de hacer emerger algunos debates sobre la conceptualización de la historia y el uso que hacemos de sus representaciones y sus relatos. Para ello, se ha estructurado la exposición de la siguiente manera. Como punto de partida, dedicaremos unos breves apuntes a valorar la crisis que vive la historiografía hoy en día. Seguidamente nos ocuparemos de la relación que mantienen las categorías espacial y temporal en la teoría historiográfica. Finalmente realizaremos un recorrido por el pensamiento espacial con el fin de valorar las posibilidades conceptuales y narrativas de una historia espacial.

\section{Crisis historiográfica}

Desde finales del siglo XX la historiografía se encuentra inmersa en un estado de crisis generalizada que ha hecho tambalear la disciplina de arriba a abajo al cuestionarse la forma de hacer, de pensar y de explicar la historia. A lo largo de estos últimos años, los debates historiográficos han mostrado un gran interés en tratar de comprender la deriva que las distintas corrientes históricas han ido tomando desde la década de los años setenta hasta los inicios del siglo XXI. ¿Cómo podemos explicar esta crisis? ¿De qué manera afecta a la práctica historiográfica? ¿Cuál ha sido la respuesta de la teoría historiográfica?

Tal y como ha señalado Carlos Barros, la crisis historiográfica se encuentra inserida en "una crisis general, ideológica, política, de valores, que afecta al conjunto de las ciencias sociales y humanas". Es, en esencia, el resultado "de la simultaneidad de la crisis de la historia y la crisis de la escritura de la historia, y atañe a todas las dimensiones de la profesión de historiador, y de su relación con la sociedad". En última instancia -y siguiendo la estela de la noción de cambio de paradigma popularizada por Thomas Kuhn- 
, ${ }^{1}$ debemos entenderla como una crisis paradigmática que tiene su origen en la voluntad de confrontarse con los grandes modelos historiográficos predominantes durante los años sesenta y setenta: el positivismo, el marxismo y la escuela de los Annals. ¿ ¿Pero por qué se dio esta necesidad de confrontación y ruptura con las corrientes tradicionales de la modernidad y cómo se materializó?

La fragmentación que se empezó a insinuar en los años setenta -con el surgimiento de la Nouvelle Histoire y la incipiente proliferación de enfoques, métodos y objetos de estudio-dejó un terreno plural en cuanto a formas de hacer historia, pero completamente desmenuzado desde un punto de vista teórico. ${ }^{3}$ Por un lado, esta diversificación generó un clima de incertidumbre que suscitó dudas sobre el futuro de la disciplina y la validez de la historia como ciencia. Sin embargo, por otro lado, es indudable que la adopción de nuevos enfoques de estudio durante la segunda mitad del siglo XX contribuyó sustancialmente al enriquecimiento y a la transformación de la historiografía en diversos aspectos. A saber, con la superación del horizonte rankeano no sólo se pusieron en duda la univocidad de los relatos decimonónicos, también se desmintió el valor exclusivo del documento, se modificaron las perspectivas de análisis y las escalas de observación e incluso se abrió el debate sobre la elaboración de los relatos históricos con un polémico retorno del narrativismo. ${ }^{4}$

Esta situación se produjo como resultado de una compleja coyuntura en la que confluyeron la apertura académica de la historia -hecho que permitió incrementar el diálogo y las relaciones con otras disciplinas humanísticas- con una incipiente voluntad de explotar la reflexión historiográfica y de buscar nuevas líneas de investigación que permitieran situar a la disciplina histórica en medio de un mundo que se encontraba en pleno proceso de globalización. En esta misma coyuntura cabe destacar, como ha

\footnotetext{
${ }^{1}$ En su obra The structure of Scientific Revolutions (1962) Khun describe los cambios de paradigma epistemológicos en las disciplinas como fórmula para generar rupturas con los paradigmas que quedan obsoletos.

2 Carlos BARROS: "Hacia un nuevo paradigma historiográfico", Conferencia magistral Universidad Autónoma de Chiapas, 1998, http://cbarros.com/vista-cb/?link=http://h-debate.com/wp-content/old_ debates/cbarros/spanish/hacia_castellano.htm [consulta 20 de agosto 2019]. Carlos Barros ha coordinado hasta la fecha cuatro congresos internacionales de Historia a Debate (1993-2010)

${ }^{3}$ Concepto desarrollado por François Dosse en su obra L'histoire en miettes (1987).

${ }^{4}$ En New Perspectives on Historical Writing (2001) Peter Burke ha recopilado muchas de las corrientes, tendencias y formas de hacer y escribir historia que han ido surgiendo durante la segunda mitad del siglo XX: historia desde abajo, historia de la vida cotidiana, microhistoria, historia cultural, historia medioambiental, etc.
} 
señalado Barros, que el agotamiento progresivo de los modelos tradicionales y el período de conservadurismo político que se vivió en los ochenta, contribuyeron a la propagación de concepciones neoliberales y a la divulgación de corrientes posmodernas. ${ }^{5}$ Según este autor, ello habría propiciado una retahíla de críticas sobre la idea de progreso y habría amenazado la relación entre pasado, presente y futuro; hechos que en el peor de los casos se habrían traducido en interpretaciones negacionistas y relativistas de la historia, respectivamente.

Entre los distintos problemas y preocupaciones que surgen a raíz de este convulso desarrollo teórico vale la pena recalcar los perseverantes deseos por parte de historiadores como Barros o Burke de querer dar con un nuevo paradigma historiográfico que permita sortear el estado de crisis. Coincidimos con ellos con que dicho empeño debe pensarse a partir de la síntesis entre viejos y nuevos modelos, capaz de ofrecer una visión amplia y global de un pasado que recupere el legado de la longue durée. ${ }^{6}$

En lo que llevamos de siglo, parece que existe cierto consenso en reconocer a la historia global como una tendencia historiográfica capaz de lidiar con la crisis de la disciplina. ${ }^{7}$ Se trata de una corriente que "nació de la convicción de que los medios que los historiadores han estado usando para analizar el pasado han dejado de ser suficientes". ${ }^{8}$ Dado su carácter holístico, la historia global se postula como una fórmula suficientemente flexible como para hacerse cargo del estado de fragmentación de la historiografía. La laxitud del término "historia global”, la ausencia de una definición clara o cerrada que acote o limite sus posibilidades, la afinidad con las ideas de la historia total braudeliana y la voluntad de quererse presentar como un modelo de análisis que se adecue y se conjugue con los problemas y las necesidades del mundo en lo que vivimos, hacen que la historia global se presente como una solución viable a las dificultades de las últimas

\footnotetext{
${ }^{5}$ Aludiendo explícitamente los trabajos de El fin de la historia de Fukuyama y a los ensayos sobre la postmodernidad de Jean-François Lyotard y de Gianni Vattimo.

${ }^{6}$ Según The History Manifesto, nos encontramos en una crisis de corto-terminisme (short-term), agravadas con los problemas de medio ambiente, de gobierno, de democracia y de capitalismo, que dificulta las investigaciones a gran escala y que sólo podremos superar mediante una ampliación de miras (GULDI y ARMITAGE, 2016: 216).

${ }^{7}$ En pocos años están aumentado mucho los trabajos teóricos que abordan la historia global como tendencia historiográfica. Merece la pena mencionar algunos: Peter N. STEARNS: World History: The Basics (2010); Sanjay SUBRAHMANYAM: Aux origines de l'histoire globale (2014); VV.AA.: The Prospect of Global History (2016); Sebastian CONRAD: What is Global History? (2016).

${ }^{8}$ Sebastian CONRAD: Historia global. Una nueva visión para el mundo actual, Barcelona, Crítica, 2017, p. 8 .
} 
décadas. Por otro lado, no podemos evitar vincular esta corriente con el resurgimiento del pensamiento espacial que ha estado teniendo lugar en la mayoría de las ciencias sociales y humanas sin que la disciplina histórica apenas se haya percatado; más tarde volveremos sobre este punto.

Si hacemos uso del diálogo interdisciplinar, son muchas las experiencias que podemos intercambiar y establecer bajo el objetivo común de superar la crisis de la fragmentación y consolidar un nuevo paradigma que esté a la altura de los nuevos tiempos que corren. Pero para ello es necesario problematizar y sacar a debate algunas cuestiones fundamentales que tienen que ver con la relación entre el tiempo y el espacio, entendidas como categorías históricas.

\section{Tiempo y espacio}

Pensar la historia es pensar en las continuidades y los cambios ocurridos en las sociedades humanas a lo largo del tiempo, pero también es pensar en los espacios vividos, construidos y habitados donde se yuxtaponen y se leen todo tipo de acciones, vínculos, tensiones y experiencias humanas. Desde la Antigüedad, el ostensible vínculo del hombre con lo geográfico y su persistente interacción con el entorno natural y urbano han puesto de manifiesto el desarrollo de una conciencia y una cultura propiamente espaciales. El espacio, entendido como una categoría física, ha contribuido indiscutiblemente a la formación y consolidación de la idea de historia, hasta el punto que no es posible concebir la práctica historiográfica sin acotar su marco espacial, al igual que no podríamos hablar de historia si desatendiéramos la noción temporal. Sin embargo, durante la modernidad los discursos historiográficos han mantenido un fuerte predominio del tiempo sobre el espacio. El paradigma evolutivo, fuertemente condicionado por la construcción occidental de la cronología, se ha impuesto sobre la perspectiva espacial. Así pues, ¿en qué medida el espacio forma parte del interés historiográfico? ¿Qué relación guardan tiempo y espacio y cómo eso repercute en términos teóricos, de representación y de lectura?

"Desde el siglo XVIII espacio y tiempo son habitualmente referidos el uno al otro [...] pertenecen, dicho categorialmente, a las condiciones de posibilidad de la historia". 9

\footnotetext{
${ }^{9}$ Reinhart KOSELLECK: "Espacio e historia" en: Los estratos del tiempo: estudios sobre la historia, Ediciones Paidós - I.C.E. de la Universidad Autónoma de Barcelona, 2001, pp. 93-111 (94-97).
} 
Tal y como nos recuerda Koselleck, durante la modernidad, espacio y tiempo fueron concebidos como categorías supuestamente indisociables la una de la otra, hasta el punto que la contextualización de cualquier hecho histórico la hacemos habitualmente dando por hecho ambas dimensiones, siguiendo un criterio de razonamiento que se asemeja a lo siguiente:

\begin{abstract}
El espacio y el tiempo. El tiempo y el espacio. Dos categorías que sirven para explicar toda la realidad, dos coordenadas que se entrecruzan para decir un algo antes indefinido, inexistente. Todas las preguntas posibles pueden ser respondidas por medio de estos dos ejes: aunque unas realidades sean más "temporales" y otros más "espaciales", el registro “espaciotemporal”, la hibridación o amalgama de ambos es la dimensión de un concepto filosófico que permitirá resolver el dilema por medio de un binomio, de dos términos contrapuestos pero complementarios e inseparables, porque una realidad no puede ser explicada, ni siquiera pensada, sin requerir la presencia de esta doble idea. ${ }^{10}$
\end{abstract}

Según lo citado, la realidad y las representaciones de la misma son percibidas y asimiladas por esta dualidad epistemológica que nos debería servir para "explicar toda la realidad". Los ejes fundamentales del tiempo y el espacio, estas dos categorías teóricamente indivisibles, conforman una aparente unidad que, sin embargo, a efectos de una representación historiográfica no se manifiestan de manera equitativa, sino que el peso y la presión de la temporalidad predomina en el imaginario y la conciencia de la praxis histórica. La combinación de estos dos ejes debería proporcionar una visión amplia y completa del conjunto estudiado, pero el hecho de que estas dos dimensiones puedan ser denominadas por separado también nos indica que conceptualmente pueden ser percibidas y teorizadas de manera independiente.

Así pues, mientras la imagen de la cronología queda plasmada de forma evidente en la elaboración de los discursos historiográficos y en la voluntad de reconstrucción de las representaciones del pasado, la presencia del espacio es más bien modesta y mantiene una relación de ambigüedad dentro del ejercicio historiográfico. Pensar la historia ha sido, durante la modernidad, un ejercicio en el que el espacio quedaba implícito y asumido dentro del propio discurso. ¿En qué nos basamos al afirmar esto? ¿Cómo ocurrió esta supuesta escisión del espacio y el tiempo? Para verlo es preciso adentrarse en el origen

\footnotetext{
10 Jesús CAMARERO: "Escribir y leer el espacio" (Prólogo), en Georges PEREC: Especies de espacios, Barcelona, Montesinos, 1999, p. 9.
} 
conceptual de la idea moderna de historia.

Como sabemos, a lo largo del siglo XVIII, la historiográfica moderna se fue decantando hacia un modelo teleológico y progresivo que, sintonizando con los ideales de la Ilustración, otorgaba al orden temporal unas cualidades de dinamismo que motivaron sustancialmente esa preponderancia del tiempo respecto al espacio. Con la llegada de la historiografía decimonónica y la gradual institucionalización y especialización de la historia como disciplina académica esta división se ensanchó. La tradición rankeana consolidó la cronología como la materia prima de la representación histórica al considerar que la historia debía ocuparse de la ordenación de los acontecimientos mediante una representación discursiva lineal, cronizada, en sintonía con la forma narrativa de la modernidad. Por su lado, el espacio se vio relegado a la mera condición de escenario o decorado de las acciones y los hechos narrados. La dimensión espacial quedaba, por lo tanto, mitigada y aplacada por el peso de una temporalización histórica.

En las postrimerías del siglo XVIII debemos ubicar también el origen moderno del concepto historia. En este sentido, no podemos desestimar las indagaciones que Koselleck efectuó sobre el nacimiento de un término que, a su entender, se encuentra estrechamente vinculado a las prácticas discursivas promovidas por las instituciones científicas y es fruto de un proceso dictado por una voluntad estrictamente funcional, la de "aglutinar una serie de eventos en un todo coherente". ${ }^{11}$ Si tiramos de este hilo, la historia se convierte entonces en "el concepto regulativo de todas las experiencias pasadas y futuras, reúne con más intensidad que cualquier otro los cuatro rasgos de temporalización, ideología, politización y democratización." Este proceso se va configurando durante el siglo XIX, momento en que "nace la Ciencia histórica, estableciéndose como ciencia autónoma dedicada a estudiar el pasado". ${ }^{12}$

Esta revisión nos permite ahondar en la relación desigual que se da entre la percepción histórica del tiempo y el espacio. Lo verdaderamente relevante del asunto es ver que esta relación de subordinación afecta también a la construcción del relato histórico. Así pues, llegados a este punto parece razonable hacer algunas matizaciones

\footnotetext{
${ }^{11}$ Reinhart KOSELLECK: historia/Historia, Madrid, Trotta, 2011, pp. 29-30.

12 Ibid., pp. 21-22.
} 
sobre este proceso de elaboración del relato histórico que Michel De Certeau ha denominado operación historiográfica.

Historiar la realidad, tal y como ha señalado Darío Villanueva, no significa comprender ni tampoco interpretar, sino realizar una reconstrucción coherente de la historia que le otorgue sentido. ${ }^{13}$ Vista desde esta perspectiva, la historiografía trabaja en la amalgamación de una selección de hechos dispersos en el tiempo que no tienen por qué mantener una correlación significativa para ser expuestos, sino que la disposición diacrónica del pasado se centra en enlazar un hecho tras otro. Naturalmente, la imposibilidad de hacerse cargo de la totalidad de los hechos históricos conlleva la obligatoriedad de realizar una selección de lo que se quiere historiar. Tal selección se verá expuesta, además, al problema de cómo exponer la narración histórica.

¿De qué manera la elaboración del relato histórico viene determinada por concepciones teóricas u otros agentes? Como sabemos, el producto resultante de la investigación histórica se expone siguiendo un "orden cronológico" que puede jugar más o menos con las técnicas de presentación y organización, pero que, en cualquier caso, se articula en torno a un eje que "proyecta sobre el texto la imagen invertida del tiempo". El relato historiográfico toma así la forma de un artefacto que, mediante la puesta en marcha de un dispositivo textual une el presente con la trayectoria cronológica. ${ }^{14}$ En La escritura de la historia, De Certeau considera que la práctica historiográfica moderna es fruto de una operación de interrelación entre tres elementos: la particularidad del lugar social desde el que se escribe, vinculado a un espacio de "producción socioeconómica, política y cultural"; el conjunto de prácticas científicas y procedimientos de análisis empleados; y la construcción de un texto histórico que es el resultado de una práctica social. ${ }^{15}$ Este proceso de elaboración de la obra historiográfica es lo que nos permite cuestionar por lo tanto, el criterio seguido a la hora de seleccionar y manipular los conocimientos históricos con los que se construye la trama del pasado. De Certeau advierte, además, que el procedimiento de confección del producto historiográfico se encuentra respaldado por el poder institucional, de tal forma que los criterios de investigación responden a

\footnotetext{
13 Dario VILLANUEVA: "Historia, realidad y ficción en el discurso narrativo", en El polen de ideas, Barcelona, PPU, 1991, pp. 115-130 (118).

${ }^{14}$ Michel DE CERTEAU: "La operación historiográfica”, en ÍD., La escritura de la historia, México, Universidad Iberoamericana, 1993, pp. 67-118 (104-106).

${ }^{15}$ Ibid., pp. 68-69.
} 
necesidades y órdenes de grupos políticos, eruditos y eclesiásticos que se especializan de manera recíproca. Poco a poco se va estableciendo así un saber vinculado a lo institucional.

Al referenciar a De Certeau, a la operación historiográfica y a la institucionalización de la historia no pretendemos criticar ni a la historiografía actual, ni a su reflexión teórica, ni mucho menos poner en duda su cientificidad, como tampoco queremos entrar en áridos debates sobre la realidad y la ficción en la escritura de la historia. Lo que se persigue es más bien, contextualizar el nacimiento de la historiografía moderna dentro de un marco que relaciones el paradigma temporal con un modo muy concreto de exposición que se limita a reproducir las lógicas del patrón propio del tiempo. En otras palabras, evidenciar que el paradigma de la temporalidad no es solamente una cuestión de teleología, sino también de narración y que al existir una correlación directa entre lo epistémico y su voluntad de representación, el relato histórico que surge tiene que ver con la conceptualización que lo respalda. Por otro lado, queremos destacar que los relatos historiográficos de la modernidad no han sido pensados para representar la realidad histórica de la mejor manera posible, sino más bien para ratificar los ideales que sostienen una determinada concepción epistemológica previa.

¿Hay alternativas a este tipo de relación que se da entre tiempo y espacio? ¿Puede una mirada espacial generar relatos que se hagan cargo de la realidad histórica con mayor acierto? ¿De qué modo puede esto ayudar a superar la crisis paradigmática? Con el objeto de lograr una mayor comprensión de las posibilidades que ofrece la inclusión de la dimensión espacial en la narrativa histórica debemos realizar una indagación a través de la herencia del pensamiento espacial.

\section{Del giro espacial a la narrativa de la simultaneidad}

Reinhart Koselleck advirtió en una ocasión que todavía hoy en día "falta una historia conceptual del concepto espacio". ${ }^{16} \mathrm{Si}$ bien ese lamento no deja de ser cierto también hay que precisar que a pesar de las muchas carencias no partimos de cero. El pensamiento espacial cuenta con una larga tradición que se remonta más allá del siglo XX y que es posible reseguir desde Heródoto. Sin ir más lejos, Karl Schlögel ha reconocido

\footnotetext{
${ }^{16}$ Reinhart KOSELLECK: "Espacio...”, p. 94.
} 
que sus referentes teóricos los conforman no sólo autores como David Harvey, Edward Soja o Doreen Massey, sino también figuras como Alexander von Humboldt, Carl Ritter, Friedrich Ratzel o Karl Lamprecht. Aunque para entender las posibilidades de la espacialización de la historia que pretendemos mostrar basta con que centremos nuestro análisis en la época contemporánea.

Así pues, ¿cuándo se empieza a producir ese interés por la dimensión espacial? ¿En qué sentido reivindicamos el papel del espacio? ¿Cuáles son los precedentes conceptuales que nos permiten hablar de una historia espacial? En definitiva, ¿de qué hablamos cuando hablamos de giro espacial y qué interés puede tener para la teoría de la historia?

La noción de giro geográfico o giro espacial, tal y como lo ha definido Jo Guldi, “implica retrospección, un proceso de detenerse en la carretera y mirar hacia atrás en el camino por el cual uno ha venido". ${ }^{17} \mathrm{El}$ impulso que ejerce este giro epistemológico proviene del esfuerzo intelectual de diferentes disciplinas - por parte de la arquitectura, la geografía, la sociología, la economía o la filosofía antes que de la historiografía- que desde finales del siglo XIX comenzaron a acuñar una terminología y un lenguaje propios para poder describir y referirse a la experiencia espacial que estaba teniendo lugar. De esta manera, entre el palimpsesto y el panoptismo, el pasaje benjaminiano y el paisajismo, la simultaneidad y la yuxtaposición, encontramos toda una genealogía conceptual referida a o geográfico que ha ido asentando las bases de nuestra cultura espacial.

Es sabido que el siglo XX concentró una gran cantidad de críticas contra la tendencia historicista que se erigía alrededor de una fe ciega en el progreso y de una historia conceptualmente teleológica y evolutiva. Las dos guerras mundiales, los procesos de descolonización y en última instancia, también, la caída del muro de Berlín, fueron configurando paulatinamente un nuevo marco de interacción con la realidad donde como hemos observado, las relaciones entre tiempo y espacio que habían prevalecido durante la modernidad empezaron a extinguirse. De hecho, es a partir de los conflictos bélicos mundiales que las críticas hacia la idea de progreso se intensificaron y que el concepto aristotélico de espacio se antepuso frente a la idea moderna de espacio que había imperado

\footnotetext{
${ }^{17}$ Traducido del inglés: "to turn implies retrospection, a process of stopping in the road and glancing backwards at the way by which one has come". Jo GULDI: "What is the Spatial Turn?", University of Virginia, 2011, http://spatial.scholarslab.org/spatial-turn/what-is-the-spatial-turn/ [consulta abril 2017].
} 
hasta entonces. ${ }^{18}$ A partir de los años cincuenta nos encontramos con que el espacio va recuperando peso en el imaginario social y va reformulándose en los terrenos intelectual y epistemológico.

La nueva conciencia espacial emergente se materializó, en primer lugar, en el ámbito arquitectónico, con la necesidad de reconstruir el espacio social y urbano que se habían perdido a raíz de la Segunda Guerra mundial, los flujos migratorios y el proceso de descolonización. En el ámbito teórico, esta nueva percepción de la realidad se fue materializando en distintas esferas vinculadas al desarrollo económico de las ciudades: las crónicas urbanas estadounidenses pertenecientes a la Escuela de Chicago, la sociología urbana de Georg Simmel, la utilización de la figura decimonónica del flanêur por parte de Walter Benjamin, la innovadora historia de las ciudades y el urbanismo de Lewis Mumford o los análisis sobre la ciudad realizados por el filósofo Henri Lefebvre. ${ }^{19}$ A partir de entonces, el pensamiento espacial se fue propagando con interés e intensidad por el conjunto de las ciencias sociales y las humanidades. El contacto y la simbiosis que se produjo entre la arquitectura, las ciencias sociales y la filosofía generaron debates muy prósperos para la normalización de la noción espacial, hasta el punto que hoy en día podemos asegurar que el impulso del "giro espacial ha disipado la frontera entre las disciplinas que se ocupan del espacio". ${ }^{20}$

Uno de los casos más significativos de este intercambio entre arquitectura y pensamiento lo protagonizó Michel Foucault. El 14 de Marzo de 1967 el pensador francés fue invitado a participar como conferenciante en una de las sesiones del Cercle d'Études Architectuales de París. ${ }^{21}$ Su intervención, a pesar de estar insertada dentro del campo del urbanismo y la teoría arquitectónica, mantuvo un fuerte interés historiográfico y marcó

\footnotetext{
${ }^{18}$ Fernando QUESADA: "El giro espacial. Conquista y fetiche", Revista Europea de Investigación en Arquitectura, 2016, pp. 162-163, http://www.reia.es/Numero05.html [consulta abril 2017].

${ }^{19}$ Las crónicas y los reportajes periodísticos de Robert PARK sirven como ejemplo del papel que desempeñó la Escuela de Chicago en los años 1920-1930; Simmel dispone de diversos ensayos sobre el desarrollo social y capitalista del período; Benjamin exploró los procesos de urbanización del XIX en su famoso Libro de los pasajes (editado póstumamente en 1983); para Mumford véase La ciudad en la historia. Sus orígenes, transformaciones y perspectivas (1961); respecto a Lefebvre, su obra principal continúa siendo La producción del espacio (1974).

${ }^{20}$ Fernando QUESADA: "El giro espacial...", p. 169.

${ }^{21} \mathrm{La}$ conferencia a la que aludimos se basaba en una intervención radiofónica previa, pronunciada en France-Culture el 7 de diciembre de 1966, bajo el título: "Les Hérérotopies". Sin embargo, la publicación de ambas conferencias no fue autorizada hasta el año 1984: "Des espaces autres", Architecture, Mouvement, Continuité, 5 (octubre 1984), pp. 46-49.
} 
un punto de inflexión conceptual que invitaba, entre otras cosas, a realizar una relectura del entorno urbano en unos términos que se adecuaban más a unas necesidades contemporáneas. Se trata, tal y como lo expone el autor al comienzo del texto, de un cambio de percepción paradigmático a favor de la dimensión espacial:

\begin{abstract}
La gran obsesión que atravesó el siglo XIX, como se sabe, fue la historia: temas del desarrollo y de la detención, temas de la crisis y del ciclo, temas de la acumulación del pasado, gran sobrecarga de muertos, enfriamiento amenazador del mundo. El siglo XIX encontró en el segundo principio de la termodinámica lo esencial de sus recursos mitológicos. La época actual sería más bien la época del espacio. Nos hallamos en la época de lo simultáneo, nos hallamos en la época de la yuxtaposición, en la época de lo cercano y lo lejano, del lado a lado, de lo disperso. Nos hallamos en un momento en el que el mundo se experimenta, creo, no tanto como una gran vida que se desarrollaría a través del tiempo sino como una red que relaciona puntos y que entrecruza su madeja. ${ }^{22}$
\end{abstract}

Tal declaración contiene un tono fundacional. Primero porque se reconoce a la disciplina histórica como "la gran obsesión" propiamente decimonónica. En ese sentido, Foucault identifica claramente una forma de concebir la historia que se encuentra arraigada en un pensamiento lineal y en un sistema de enunciación estrictamente cronológico y que, por lo tanto, se olvida de todo lo que es "simultáneo". En segundo término, el autor hace hincapié en "el espacio" como categoría que debe hacerse cargo del estudio de "la época actual". Se trata de una contraposición teórica entre dos modelos de conceptualización y despliegue de los relatos históricos. Dicho en otras palabras, Foucault considera la obsolescencia de lo temporal, instrumento que anteriormente habría permitido exponer lo histórico y llama la atención sobre el espacio como nuevo valor de exploración.

A partir de la década de los setenta las publicaciones y las alusiones hacia el reconocimiento del espacio se van multiplicando sustancialmente. Guldi ha insistido que el pensamiento francés (French Theory) de estos años destacó por la proliferación de publicaciones. Además de Foucault, quien durante esta década centra sus estudios en los espacios del poder -a través del panoptismo de los centros penitenciarios y psiquiátricos, hubo otros autores que destacaron en la teorización de la dimensión espacial, entre los que destacan Henri Lefebvre, Paul Virilio o Michel de Certeau. Fernando Cabo se ha

\footnotetext{
${ }^{22}$ Michel FOUCAULT: El cuerpo utópico. Las heterotopías, Buenos Aires, Ediciones Nueva Visión, 2010, pp. 63-64.
} 
fijado también que tan sólo entre los años 1973 y 1974 salieron a la luz tres ensayos de gran repercusión y de distinta procedencia: Especies de espacios de Georges Perec, El campo y la ciudad de Raymond Williams y La producción del espacio de Lefebvre. ${ }^{23}$

Todo este cuadro conceptual que hemos ido desgranando e ilustrando sucintamente, conduce a un momento fundamental para el giro espacial. El tránsito de los años ochenta a los noventa está dominado por la actividad académica de geógrafos como Edward Soja, David Harvey o Doreen Massey, quienes incitan un debate crítico dentro y fuera de su disciplina. Soja por su parte, desarrolla sus tesis del tercer espacio y sus estudios sobre la postmetrópolis partiendo de la figura de Lefebvre, tratando de dar respuesta a la neutralidad o pasividad teórica y social del espacio: “¿por qué al tiempo se le considera dialéctico, en movimiento, en proceso, en cambio... y por el contrario al espacio se le trata como fijo, muerto, con un trasfondo inmóvil?". ${ }^{24}$ El énfasis de Harvey se centra en la realización de una lectura político-económica que describa las lógicas sociales en las ciudades. Massey por su parte, insiste en la necesidad de repensar la relación de oposición en la que conviven las categorías de espacio y tiempo desde la modernidad y en el problema de la narración geográfica. ${ }^{25} \mathrm{La}$ lectura de estos tres geógrafos nos anima a estudiar los procesos y las transformaciones de las urbes de los siglos XX y XXI desde el convencimiento de que se tratan de espacios socialmente dinámicos. Su gran aportación reside en saber ensalzar lo fragmentario y analizarlo desde una hermenéutica de lo simultáneo.

Estas breves pinceladas sobre las principales contribuciones del giro espacial nos sirven, entre otras cosas, para subrayar la poca atención que comparativamente, la historiografía le ha dedicado al tema espacial. La historia como disciplina, se ha mantenido al margen de la resignificación de los espacios y cuenta en efecto, con muchos menos ejemplos que permitan ilustrar el interés por el pensamiento topológico.

Uno de los campos en el que se puede trazar un interés historiográfico más

\footnotetext{
${ }^{23}$ Fernando CABO: "El giro espacial en la historia literaria", Actas de Congreso Literatura e historia, Fundación Caballero Bonald, 2004, pp. 63-74 (70).

${ }^{24}$ Núria BENACH y Abel ALBET: Edward W. Soja. La perspectiva postmoderna de un geógrafo radical, Barcelona, Icaria, 2010, p. 60.

${ }^{25}$ Adrián VELÁZQUEZ RAMÍREZ: "Espacio de lucha política: teoría política y el giro espacial". México, Argumentos, 26 (2013), http://www.scielo.org.mx/scielo.php?script=sci_arttext\&pid=S0187-579520130 00300010 [consulta abril 2017].
} 
continuado hacia el espacio es en la esfera geopolítica. En esta línea, uno de los ejemplos históricos más destacados lo encarna la figura de Karl von Clausewitz, como precursor de una mirada política, estratégica y militar del espacio y del territorio: "el sentido del lugar al que hacía referencia Clausewitz en el siglo XIX, resulta igualmente importante para la práctica política al interior de la sociedad contemporánea, como para su análisis. Todo antagonismo social supone una dimensión espacial". ${ }^{26}$ Esta perspectiva se basa en una interacción entre la guerra y el espacio que forma parte del orden del día, pero su exégesis teórica se reduce a la historiografía política y militar contemporánea.

Otro caso más reseñable, desde un punto de vista estrictamente geohistórico, proviene de la segunda generación de la escuela de los Annales y se trata de un trabajo de referencia que fue publicado por primera vez en el año 1949: El Mediterráneo y el mundo mediterráneo en la época de Felipe II. En esta investigación, Ferdinand Braudel presentó las tesis sobre la duración de los tiempos históricos en un espacio geográfico considerable. A pesar de que su principal objetivo fue el de demostrar que los tiempos históricos se mueven a distintas velocidades, en el prólogo de la obra reconoció que el espacio escogido -el de ese gran personaje que resulta ser el Mediterráneo- le había permitido "destacar con mayor fuerza los nexos permanentes que unen la historia al espacio". ${ }^{27}$ Habría que añadir además, a pesar de que no es un aspecto de su obra que se haya destacado especialmente, que la propuesta de la diversidad de los tiempos le permitió presentar un desarrollo histórico menos lineal de lo que era habitual. Al fin y al cabo, un enfoque que incluye más de una línea temporal impide la posibilidad de presentar una narración teleológica con una única meta. ${ }^{28}$

En cualquier caso, se acentúa que el carácter total de la obra de Braudel ha ejercido una influencia notable no sólo en la historiografía del momento, sino también en los actuales empeños por consolidar una historia global. El despegue de esta visión globalizada es, a fin de cuentas, una de las señales más flagrantes de que nos encontramos ante una nueva conciencia histórica y pese a que no hay todavía una definición unísona de lo que debe abarcar la historia global, es de suponer que tender puentes con la

\footnotetext{
26 Ibid.

${ }^{27}$ Fernand BRAUDEL: El Mediterraneo y el mundo mediterráneo en la época de Felipe II, Tomo I, México, FCE, 1987, p. 12.

${ }^{28}$ Manuel DE LANDA, en Mil años de historia no lineal, ha insinuado esta idea a la cual más tarde volveremos.
} 
dimensión geográfica debe ser una de sus prioridades. ${ }^{29}$ En este sentido y teniendo en cuenta el enfoque del presente trabajo creemos muy conveniente citar el siguiente fragmento de Collot: "Una historia mundial (World History, Global History) debe renunciar a un modelo lineal y unitario de los procesos históricos: tiene que actualizar las múltiples temporalidades superpuestas en el espacio-tiempo, y debe tener muy en cuenta los factores geográficos". ${ }^{30}$

En lo que llevamos de siglo han surgido numerosas obras que se autodefinen como historia global. Ejemplos de peso son el El nacimiento del mundo moderno, 1780-1914 de C.A. Bayly (2004) o La transformación del mundo de Jürgen Osterhammel (2013). Historias monumentales que con una vasta cronología y una amplia base geográfica se proponen el reto de mantener vivo y renovado el espíritu de la historia total. Es indudable que la historia global, con su vocación y su herencia braudelianas, se está mostrando cada vez más sensible con la cuestión espacial. Sin embargo, no podemos evitar comparar los planteamientos espaciales contenidos en las historias globales con las tesis que Karl Schlögel dedica en su obra En el espacio leemos el tiempo. Al hacerlo nos damos cuenta de que las diferencias son todavía importantes y de que el espacio no se ha interiorizado del todo en el pensamiento histórico.

Se observa que si bien por una parte la historia global está resultando ser una vía muy útil para canalizar preocupaciones que tienen que ver con problemas históricos propios de la dimensión espacial: los procesos de globalización, la geopolítica o el cambio climático. Gracias a ello, la teoría historiográfica actual ha empezado a dar muestras de una incipiente conciencia hacia lo espacial, aunque se echan en falta planteamientos que integren, asimilen o aprendan de los debates que han ido surgiendo en las disciplinas que se han dedicado al asunto, tal y como hemos podido observar a través del recorrido efectuado por el impulso del giro espacial. En este sentido los logros son modestos y los desafíos marcados no van más allá de "ir variando entre las diversas escalas de análisis y

\footnotetext{
${ }^{29}$ Otros acercamientos historiográficos que han manifestado su afinidad con el eje espacial son los lieux du mémoire de Pierre NORA o la historia medioambiental, corriente que cada vez está demostrando un mayor interés y compromiso con la espacializción de la historia. Véase como ejemplo JOHN R. MCNEILL, Algo nuevo bajo el sol. Historia medioambiental del mundo en el siglo XX (2001).

${ }^{30}$ Traducido del francés: "Une histoire mondiale (World History, Global History) doit renoncer à un modèle linéaire et unitaire des processus historiques: elle met au jour des temporalités multiples superposées dans l'espace-temps, et doit tenir le plus grand compte des facteurs géographiques". Michel COLLOT: "Le tournant spatial”, en ÍD., Pour une géographie littéraire, Paris, Éditions Corti, 2014, pp. 17-18.
} 
lograr articularlas, antes que aferrarse a territorios determinados". ${ }^{31}$ Por otro lado, sin embargo, la historiografía ha llegado a criticar a la idea de progreso, pero lo ha hecho sin llegar a poner en duda la construcción del propio relato en forma de progreso.

En este sentido, la obra de Schlögel se plantea como una excepción dentro de la teoría historiográfica, puesto que parte de un profundo conocimiento sobre el pensamiento espacial y encara el doble desafío de recuperar el peso del espacio como categoría histórica y de elaborar una narrativa de la simultaneidad que logre hacerse cargo de la experiencia y la representación espaciales. A lo largo del presente ensayo hemos descrito la situación en la que se encuentra el pensamiento espacial dentro de la teoría de la historia y a la vez hemos problematizado algunas cuestiones que tienen que ver con la elaboración del relato historiográfico teniendo en cuenta la dependencia con una lógica temporal. De esta manera, queda claro que la narración histórica se mueve cómodamente a través de la cronología, pero falta por aclarar de qué modo puede llegar a ser representado el espacio teniendo en cuenta que juega en el terreno de la simultaneidad, la yuxtaposición y la multiplicidad. No es un problema menor:

\footnotetext{
La narrativa histórica sigue el orden del tiempo. Su prototipo es la crónica [...] Describir un lugar ha de corresponderse por fuerza con lo yuxtapuesto, no con lo sucesivo. Uno lo hace por escrito y sucesivamente, cierto, porque también pensamos y formulamos sucesivamente, pero alfa y omega de ese suceder vuelve a ser siempre la simultaneidad de apariencia sobre el terreno. ${ }^{32}$
}

En efecto, se podrá alegar que la mejor forma de presentar una narración histórica es mediante la exposición cronológica a la que el propio orden del lenguaje obliga. Según esta idea, la subordinación del espacio al tiempo se produciría por razones obvias. Puesto que dos palabras no pueden ocupar un mismo lugar, la representación y concatenación lineal de los hechos parece ser, a priori, la forma más natural de exposición histórica. Pero hay que aclarar en este sentido que una concepción no lineal no tiene que ver con el estilo de presentación, pues puede darse una estrategia narrativa que presente el desarrollo de información ordenado cronológicamente y no obedecer por ello, a una concepción lineal.

Es el caso defendido por Manuel De Landa en Mil años de historia no lineal, donde

\footnotetext{
${ }^{31}$ Sebastian CONRAD: Historia global..., p. 109.

${ }^{32}$ Karl SCHLÖGEL: En el espacio leemos el tiempo. Sobre Historia de la civilización y Geopolítica, Madrid, Ediciones Siruela, 2007, pp. 52-53.
} 
elabora una reflexión histórica que tiene por objetivo "eliminar de la historia cualquier aspecto teleológico", de tal modo que "la conquista progresiva del pasado milenio por el Occidente" no sea vista como una meta forzosamente necesaria o inevitable. "La explicación de este desenlace tiene que ser hecha en términos contingentes: procesos que ocurrieron pero que pudieron no haber ocurrido". ${ }^{33}$ Para respaldar su tesis, el autor hace uso de representaciones y conceptos propios de la física, los cuales no presuponen necesariamente un ordenamiento dinámico lineal de los hechos, sino que incluyen acciones combinatorias que rompen inevitablemente con las lógicas progresivas y lineales. A pesar de tratarse de un ensayo articulado desde la filosofía de la historia, se encuentra perfectamente enmarcado dentro de los debates de la teoría historiográfica actual. Resulta interesante observar que la crítica que De Landa efectúa a la idea de progreso se fundamenta, principalmente, a partir de cuestiones tan arraigadas en la episteme del paradigma cronológico como son la termodinámica o el darwinismo evolutivo:

Tanto la termodinámica clásica como el darwinismo admitían sólo un resultado histórico posible, el alcance del equilibrio térmico o del diseño más apto. En ambos casos, una vez que este punto era alcanzado, los procesos históricos cesaban de contar. En cierto sentido, el diseño óptimo o la distribución óptima de energía representaban para estas teorías el fin de la historia. ${ }^{34}$

Del mismo modo, la narrativa de la simultaneidad responde a una lógica no lineal, pero su estrategia narrativa no surge exclusivamente como necesidad de ruptura respecto a una temporalidad preponderante, sino que se plantea ante la evidencia de que existe un vacío interpretativo y expositivo en la historiografía cronológica. La pregunta que Schlögel lanza es la siguiente: “¿qué pasa si se piensan conjuntamente historia y lugar? [...] ¿Qué ganamos en percepción y perspicacia histórica si nos tomaos en serio por fin (de nuevo) espacios y lugares?". ${ }^{35}$ No se trata pues de excluir o de substituir un paradigma por otro, sino de sintetizarlos, de incluir ambos modelos de lectura y combinarlos en función de las posibilidades y las necesidades.

A partir de aquí, la estrategia que sigue la narrativa de la simultaneidad se asemeja a un collage. La simultaneidad se fija en lo fragmentario, en lo múltiple, aprende del ojo

\footnotetext{
${ }^{33}$ Manuel DE LANDA: Mil años de historia no lineal, México, Gedisa, 2011, p. 18.

${ }^{34}$ Ibid., p. 10.

${ }^{35}$ Karl SCHLÖGEL, En el espacio..., p. 15.
} 
vago y dinámico del flanêur, se sirve de la literatura y el cine, recurre a una combinación heterogénea de imágenes, mapas, datos y técnicas de observación... Hasta lograr ofrecer finalmente, una panorámica espacial inigualable desde un desarrollo cronológico.

En última instancia, espacializar la narración histórica significa también, ser capaz de plantear un reto que es teórico y práctico a la vez. Se trata de forjar una nueva conciencia histórica que ponga la reflexión historiográfica y la autocrítica en primera línea de trabajo, pero también que se trata de ser coherentes con los problemas que el nuevo siglo plantea.

\section{Conclusiones}

Desde un comienzo, el presente trabajo se ha planteado como un ejercicio de reflexión historiográfica buscando un diagnóstico para el estado de la disciplina en relación con los desafíos que el siglo XXI nos depara. Hemos insistido en la importancia de incluir una perspectiva espacial dentro de los estudios historiográficos y en este sentido hemos valorado positivamente tanto el papel del giro espacial como las tesis desarrolladas por Karl Schlögel.

Consideramos que la percepción de la realidad social e histórica tiene que ver con la fragmentación anárquica de eventos aislados, múltiples y simultáneos, más que con una disposición cronológica, segmentada y ordenada de la realidad. Analizada desde esta perspectiva, la historia puede ser explicada desde ópticas que escapan a la exclusividad discursiva de un modelo lineal y evolutivo. Así, retomando el objetivo inicial, la espacialización de la historia y la estrategia discursiva de la simultaneidad se proponen como formas efectivas y diversas de abordar la disciplina rompiendo con la supremacía de la temporalidad, hecho que enriquece las miradas de nuestras interpretaciones y discursos historiográficos.

Consideramos que haber llevado a cabo una aproximación exclusivamente teórica puede suponer una limitación para el estudio. Es por ello que consideramos que las elucubraciones realizadas en esta disertación deberán concretarse en posteriores proyectos con el fin de operativizar esta propuesta de la espacialización de la historia. 


\title{
Seminario de Historia y Teoría de la Cultura. Una propuesta de generación de conocimiento colectivo*
}

\author{
The Seminar of History and Cultural Theory. A proposal for collective \\ knowledge generation.
}

Fernando García Naharro

Europa-Universität Flensburg

Carlos Navarro González

Universidad Complutense de Madrid

Federico Peñate Domínguez

Universidad Complutense de Madrid

José Emilio Pérez Martínez

Universidad Complutense de Madrid

\section{Resumen}

La presente comunicación detalla las experiencias del Seminario de Historia y Teoría de la Cultura, proyecto iniciado en el curso 2014-2015 y que actualmente va por su tercera edición. Comenzando por una breve exposición de los referentes internacionales de los que bebe la estructura del seminario, se describe el recorrido del mismo en sus tres ediciones. Éste consta de dos esferas diferenciadas, aunque permeables: el taller de lectura

\footnotetext{
* La presente comunicación se nutre de lo expuesto en las memorias anuales del Seminario y en Fernando GARCÍA NAHARRO y José Emilio PÉREZ MARTÍNEZ: "Problematizing the idea of subculture: a collective theoretical and practical approach", en Paula GUERRA and Tânia MOREIRA (eds.), Keep it Simple Make it Fast! An approach to underground music scenes, vol. 2, Oporto, Universidade do Oporto, 2016, pp. 157-165.
} 
y las actividades paralelas. Finalmente se hace un balance de los logros conseguidos, los problemas a solucionar y las previsiones de futuro del seminario.

\title{
Palabras clave
}

Conocimiento colectivo, estudios culturales, seminario académico, medios de comunicación, taller de lecturas.

\begin{abstract}
The present communication details the experience of the Seminar of History and Cultural Theory, a project born in the academic year 2014-2015 that is currently in its third edition. We will start with a brief exposition of the international references that influenced the seminar's structure, continued by its three-year trajectory. The structure is separated into two spheres: on the one hand, a reading workshop, on the other hand, parallel activities. To sum up, we will make a balance of the achieved goals, the issues to be solved and the seminar's projected future.
\end{abstract}

\section{Palabras clave}

Collective knowledge, cultural studies, academic seminar, media, reading workshop.

\section{Introducción. Influencias británicas}

El Seminario de Historia y Teoría de la Cultura nace, como todo proyecto, de una mélange de ilusiones y referentes individuales y responde a una constelación de problemáticas percibidas como partes de un todo. ¿Por qué cultura? Porque es en el ámbito cultural e ideológico donde percibimos más sensibles los nuevos rumbos tanto académicos como sociales; porque la dimensión cultural no nos parece secundaria, sino constitutiva de la sociedad y del marco académico; y porque el lenguaje del discurso cultural nos parece fundamentalmente necesario para cualquier lenguaje al que el estudio de la Historia y la lectura de la sociedad puedan reescribir. Con estas premisas, unidas a un buen puñado de filias y referentes personales, desde el SHYTC nos vimos en (casi) la 
obligación de tomar como referente a la Escuela de Birmingham, a los estudios culturales, incluso a las estructuras de las que nacieron estos modelos de estudio e, inevitablemente, a Stuart Hall y el círculo de intelectuales británicos de la época.

El éxito del modelo Birmingham Centre for Contemporary Culture Studies (BCCCS) se conecta con la década de los 1950 y el cambio social y político de la época a través de Stuart Hall y el círculo de la de la Universities and Left Review (la revista cuya fusión con The New Reasoner daría lugar a la New Left Review en 1960). En 1956 Stuart Hall, Raphael Samuel, Chuck Taylor y Gabriel Pearson fundaron desde el ámbito académico (algunos como estudiantes) la Universities and Left Review, un proyecto cultural y político dedicado a relacionar en calidad de sinergia tanto a cultura, como a política como a acontecimientos sociales de la época. El sistema comunicativo en el que estaban enmarcados en la época respondía a la lógica binaria de emisor - receptor del tema a tratar que fuera, unidireccional y autorreproductor de sí mismo. Ellos utilizaron la publicación cuatrimestral como aparato conector de otras muchas actividades que respondieran al mismo modelo comunicativo-participativo, de distintas maneras. En esencia, se trataba de dibujar una constelación interconectada de diversos elementos con entidad propia que diera sentido a un todo comunicativo, participativo y horizontal.

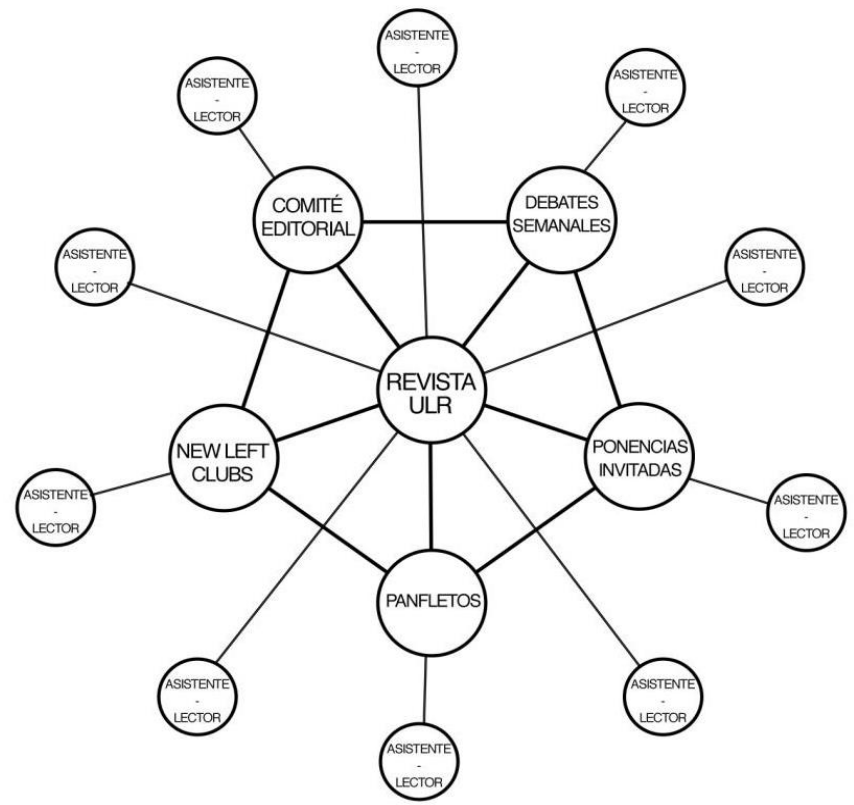

Figura 1: Modelo Universities and Left Review aplicado al sistema comunicativo horizontal 
En este sentido, el sistema propuesto por la ULR no atendía solamente a una publicación propia, ni tampoco a una serie de charlas, sino que mediante la interconexión de todas las facetas discursivas del movimiento (adscrito a lo que políticamente se llamaría la New Left) tejía una red de actividades con un propósito común. Esta red tuvo éxito como "sector" cultural en un sentido en que nunca pudo haber ocurrido en término territoriales sin más. Se debió a que sus circunscripciones, su público tenía una demografía muy concreta: la universidad y profesiones relacionadas.

En este grupo inicial estaba vigente el paradigma del "Long Revolution” de Raymond Williams y el concepto de comunidad de aprendizaje o la idea de que la gente a largo plazo gana acceso a los poderes culturales, esto es, empoderamiento cultural. Desde esta perspectiva, nosotros tomamos este referente para crear de la misma manera una comunidad de aprendizaje en la que estén presentes no solamente los textos a leer o los debates posteriores sino reproducir formalmente este paradigma de Raymond Williams ya seguido con éxito por la primera New Left con la $U L R$ y sus círculos inmediatos. A través de las charlas y los debates generar esta agrupación, comunidad, incluso identitariamente se crecía culturalmente y a nivel sistémico para la $U L R$; con los panfletos y el activismo político dejaban clara su ideología y con la publicación cuatrimestral fundamentaban ciertas líneas de su pensamiento (incluso con artículos cruzados en respuesta, con crítica interna pública).

Para que el funcionamiento de este sistema funcionara tenían que reforzar continuamente cada uno de los axiomas de participación (algunos requerían de financiación, que acabaría siendo verdugo). El modelo ULR no era el único en aplicar un sistema parecido ya que a raíz de su inicial éxito (sobre todo en los debates organizados en su sede, el Partisan Club en Londres) el público objetivo se hacía cada vez mayor, ampliando sus círculos de influencia e incluso reproduciéndolos en otras ciudades de manera independiente y funcional. Cuando hablamos de este éxito nos vemos reflejados en los inicios precarios y en la motivación cultural y académica de universitarios con un proyecto en marcha, con la misma fijación en generar una comunidad cultural que si bien estaba centrada fácticamente en el ámbito universitario, hubo una intención inicial de no estar necesariamente atados al mismo.

Las derivas iniciales de este movimiento llevaron a Stuart Hall y compañeros a su 
propio naufragio, al colapso absoluto de estos clubes interconectados por falta de financiación y por la precariedad de la comunicación entre los mismos. En este sentido cabe decir que la participación activa de los asistentes, lectores, activistas y demás dejó de tener su fuerza de núcleo inicial cuando el sector de influencia se agrandó y expandió las fronteras más allá del ámbito universitario-académico-juvenil. La comunidad cultural no podía dar un feedback a otro tipo de público que no fuera el que la había diseñado, creado y puesto en marcha. No obstante, si bien supuso un tropiezo, también sirvió de caldo de cultivo para movimientos posteriores, comunidades de debate y publicaciones que llegan hasta los años 1980 y 1990 con la misma estructura y modelo, como la celebérrima Escuela de Birmingham (BCCCS).

Esta continuación del modelo se vio definida sobre todo por dos factores: uno, ineludible, es la continuación del mismo equipo de autores en la Escuela de Birmingham, liderados por Stuart Hall tal y como lo hicieran en las etapas anteriores. El otro factor venía condicionado desde la última etapa de escisión de estos autores de la New Left Review y los proyectos que, o bien fracasaron o bien fueron descartados para dicho proyecto. La Escuela de Birmingham continuó con proyectos de ación más directa. En este sentido, el Seminario quiere continuar con un procedimiento no sólo de pura generación teórica de textos sino también en consideración con la vigencia y/o utilidad de los mismos. Las propuestas de textos en las distintas ediciones del Seminario obedecen pues a estas premisas, siempre con la elección (inevitablemente) subjetiva y horizontal del grupo organizador.

\section{Generando inteligencia colectiva: taller de lecturas:}

Así, el Seminario de Historia y Teoría de la Cultura surgió como esa propuesta que buscaba promover el debate y la reflexión en torno al concepto de cultura y generar un espacio donde abordar, desde una perspectiva crítica, el análisis de experiencias y productos culturales contemporáneos. Para ello decidimos apostar por el formato que, en nuestra opinión, era el más adecuado para desarrollar esta actividad: un modelo de "taller de lectura" que, si bien había sido poco habitual en nuestra trayectoria académica, sí 
habíamos tenido oportunidad de testar durante nuestras estancias de investigación. ${ }^{1}$ Así, nuestra idea fue que, a partir de la lectura de una serie de textos propuestos (desde textos canónicos hasta textos recientes en nuestro campo) se generara un debate en profundidad en torno a los temas, conceptos clave y las pautas teórico-metodológicas que estas lecturas proponían; todo ello para alcanzar un aprendizaje colectivo a través de la puesta en común de los distintos puntos de vista y análisis compartidos.

Lecturas que, en un primer momento, fueron seleccionadas por los coordinadores del Seminario de Historia y Teoría de la Cultura (Fernando García Naharro y José Emilio Pérez Martínez) quienes también se encargaron de dirigir las primeras sesiones. Estas pronto se enriquecieron con propuestas de lecturas de los asistentes, algunos de los cuales se ofrecieron a coordinarlas, incidiendo así en el aspecto participativo del proyecto. Si bien la necesidad de contar uno o varios representantes ligados contractualmente a la institución obligaba a que en éstos recayera la coordinación del Seminario, creemos importante subrayar la voluntad introducir una dinámica horizontal no sólo de trabajo sino también de organización. No obstante, tanto la idea original del proyecto como la puesta en marcha del mismo surgieron de los coordinadores originales. En esta primera edición el contenido de los textos fue variado y se fue desde autores clásicos como Raymond Williams o Roger Chartier, a autores algo más recientes como Henry Jenkins y su trabajo sobre las culturas de fans-, pasando por textos de la Escuela de Birmingham -lo que nos permitió introducirnos en los estudios subculturales.

Es en este primer curso cuando se decide también, que la última sesión del Seminario se dedique a hacer un ejercicio de evaluación y autocrítica colectiva. Visibilizar de forma horizontal los problemas detectados por cada uno de los asistentes e intentar buscar soluciones colectivas a los mismos. Este balance individual quedó reflejado en la memoria final, redactada en forma de opiniones y comentarios críticos. Algo que, debe ser reconocido, no siempre llegó a buen puerto. Del mismo modo se decidió que podría ser una herramienta útil para la reflexión pausada y para dejar constancia de la actividad del Seminario de Historia y Teoría de la Cultura el grabar en audio las sesiones. Una

\footnotetext{
1 Es el caso del Philosophy of Science Reading Group (University of Leeds, UK, 2014), enlace: http://www.leeds.ac.uk/arts/info/40006/centre_for_history_and_philosophy_of_science/1931/reading_gro ups/5 [consulta 20 de agosto de 2019].
} 
iniciativa que, como podremos comprobar más adelante, no tuvo ni éxito ni continuidad. Sí debemos apuntar como positiva la realización de memorias de actividad anuales que, al finalizar el curso, se remiten a la dirección del Departamento y se cuelgan en la página web del mismo. ${ }^{2}$ Un paso hacia la transparencia y la claridad que creemos debe caracterizar un modelo de universidad más democrática.

Por otro lado, la sesión final de balance sirvió para medir las fuerzas reales con las que el Seminario contaba en su primer año de vida. Los límites de estas quedaron de manifiesto en dos ambiciosas propuestas de actividad que no llegaron a ver la luz. En primer lugar, se propuso realizar una serie de sesiones extraordinarias, al margen del taller de lecturas, en las que se trabajarían previamente y de forma conjunta cada una de las temáticas a tratar en las primeras.

\section{Programa Primer Cuatrimestre Sesión 1 - Martes 14/10/2014}

WILLIAMS, Raymond: "La cultura como algo ordinario" en Alicia GARCÍA RUIZ (ed.): Raymond Williams. Historia y cultura común, Madrid, La Catarata, 2008, pp. 37-62.

\section{Lectura complementaria:}

ADORNO, Theodor y HORKHEIMER, Max: "La industria cultural. Ilustración como engaño de masas" en Theodor ADORNO y Max HORKHEIMER: Dialéctica de la ilustración. Fragmentos filosóficos, Madrid, Editorial Trotta, 1998, pp. 165-212.

\section{Sesión 2 - Martes 11/11/2014}

CHARTIER, Roger: "Cultura popular, retorno a un concepto historiográfico", Manuscrits: Revista d'historia moderna, 12 (1994), pp. 43-62.

\section{Lectura complementaria:}

GINZBURG, Carlo: "Prefacio" en Carlo GINZBURG: El queso y los gusanos. El cosmos según un molinero del siglo XVI, Barcelona, Ediciones Península,

\footnotetext{
${ }^{2}$ El sitio web del Departamento de Historia Contemporánea de la Universidad Complutense de Madrid cuenta con una página dedicada a la actividad del Seminario de Historia y Teoría de la Cultura en la que, además de las mencionadas memorias, pueden consultarse otras actividades, descargarse el programa de lecturas en curso y obtener la ficha de inscripción: https://www.ucm.es/hcontemporanea/Seminariohistoria-y-teoria-de-la-cultura [consulta 20 de agosto 2019].
} 
2001, pp. 9-28.

\section{Sesión 3 - Martes 9/12/2014}

CLARKE, John; HALL, Stuart; JEFFERSON, Tony y ROBERTS, Brian: "Subculturas, culturas y clase" en Stuart HALL y Tony JEFFERSON (eds.): Rituales de resistencia. Subculturas juveniles en la Gran Bretaña de posguerra, Madrid, Traficantes de Sueños, 2014, pp. 61-142.

\section{Lectura complementaria:}

CLARKE, John: “Estilo" en Stuart HALL y Tony JEFFERSON (eds.): Rituales de resistencia. Subculturas juveniles en la Gran Bretaña de posguerra, Madrid, Traficantes de Sueños, 2014, pp. 271-291.

\section{Sesión 4 - Martes 13/01/2015}

JENKINS, Henry: "Photoshop para la democracia: la nueva relación entre política y cultura popular" en Henry JENKINS: Convergence culture. La cultura de la convergencia de los medios de comunicación, Barcelona, Paidós, 2008, 209- 238.

\section{Lectura complementaria:}

DORFMAN, Ariel y MATTELART, Armand: “La máquina de las ideas” en Ariel DORFMAN y Armand MATTELART: Para leer al pato Donald. Comunicación de masas y colonialismo, Buenos Aires, Siglo XXI, 2012, pp. 115- 137.

\section{Sesión 5 - Lunes 09/02/2015}

GOFFMAN, Erving: "La ritualización de la feminidad (1976)" en Erving GOFFMAN: Los momentos y sus hombres, Barcelona, Paidós, 1991, pp. 135169.

\section{Lectura complementaria:}

HALL, Stuart: "The spectacle of the other" en Stuart HALL (ed.): Representations. Cultural Representations and Signifying Practices, London, Sage and The Open University, pp. 223-279.

\section{Sesión 6 - Martes 10/03/2015}

RINCÓN, Aintzane: "Introducción: Cine, Género y Poder" y "Conclusión” en Representaciones de género en el cine español (1939-1982). Figuras y Fisuras, Madrid, Centro de Estudios Políticos y Constitucionales, 2014, pp. 15-27 y pp. 337-349. 


\section{Lectura complementaria:}

ABRIL CURTO, Gonzalo "Cultura visual y espacio público-político" en Cuadernos de Información y Comunicación, 15 (2010), pp. 21-36.

\section{Sesión 7 - Martes 14/04/2015}

MORLEY, David: "Populismo, revisionismo y los "nuevos" estudios de audiencia" en VV. AA: Estudios culturales y comunicación. Análisis, producción y consumo cultural de las políticas de identidad y el posmodernismo, Barcelona, Paidós, 1998, pp. 417-437.

\section{Lecturas complementarias:}

CURRAN, James: "El nuevo revisionismo en los estudios de comunicación: una revaluación" en VV. AA: Estudios culturales y comunicación. Análisis, producción y consumo cultural de las políticas de identidad y el posmodernismo, Barcelona, Paidós, 1998, pp. 383-415.

CURRAN, James: "Debate mediático: una réplica" en VV. AA: Estudios culturales y comunicación. Análisis, producción y consumo cultural de las políticas de identidad y el posmodernismo, Barcelona, Paidós, 1998, pp. 439454.

\section{Sesión 8 - Martes 12/05/2015}

CRABTREE, Gareth: "Modding as digital reenactment: A case study of the battlefield series" en VV. AA: Playing with the Past: Digital Games and the Simulation of History, London, Bloomsbury, 2013.

\section{Lectura complementaria:}

JUUL, Jesper: "Video games and the classic game model" en Jesper JUUL: Halfreal: video games between rules and fictional worlds, Cambridge (Massachusetts), MIT Press, 2005.

Figura 2: Listado de sesiones y lecturas del curso 2014/2015

La implicación de personas como Pablo Sánchez López, Patricia Gil Salgado o Federico Peñate Domínguez, hizo que, en colectivo, se decidiera que de cara a la segunda edición del taller de lectura la temática girara en torno a un tema concreto: Medios de comunicación de masas y relaciones poder. Una cuestión lo suficientemente amplia y transversal que nos permitiría desarrollar un programa de lecturas acorde con el que 
atenderíamos a multitud de medios de comunicación (prensa, radio, televisión, fotografía, etc.) y a las diversas formas en las que éstos median y generan distintas relaciones de poder (género, etnia, clase, etc.). Así fuimos desde textos clásicos de Foucault y Althusser, que nos sirvieron de contextualización teórica, a estudios de caso concretos sobre cómo se articulan las diferencias de poder de género en medios como la radio o los videojuegos, o el tratamiento que se le dan a las cuestiones raciales en la prensa escrita.

La coordinación de las sesiones en esta segunda edición se confirma como actividad colectiva. La persona que ha propuesto las lecturas pasa a moderar la sesión, pues entendemos que los textos y su temática están relacionados de alguna manera con su investigación, y son, de alguna manera, “especialistas". Del mismo modo se abandonan las grabaciones en audio de los debates y se sustituyen por "actas" escritas que luego habrían de remitirse a los participantes. Esta labor se instaura como algo rotativo, de forma que todos los miembros del espacio colaboren en el correcto desarrollo del mismo.

Cabe destacar de esta segunda edición el esfuerzo por abrir el Seminario de Historia y Teoría de la Cultura a otras facultades y a alumnos de grado. Se consiguió conectar con ambos colectivos, si bien es cierto que paulatinamente fueron perdiendo el interés y dejando de asistir. La horizontalidad y la tendencia a la participación abierta trajo consigo la incorporación de nuevas personas a lo que podría considerarse "grupo motor", como Fernando Jiménez Herrera o Erika Tiburcio. De esta manera se consiguió consolidar un modelo de gestión colectiva en el que, si bien es cierto que dos personas, por su relación con la universidad, ejercían de "cara visible" las decisiones intentaron tomarse siempre que fue posible con la participación de todos los participantes.

Así, tras el ejercicio de evaluación correspondiente, se tomaron tres decisiones de cara a la tercera edición del taller de lectura:

1. Que las personas que seleccionaran los textos de cada sesión no las coordinaran. Con esta decisión intentamos evitar la posición de autoridad que detectamos se generaba durante la segunda edición, y pensamos que al hacer que otra persona se implicara más con la temática el debate se enriquecería.

2. Mantener el sistema de toma de actas, como reflejo de la actividad del Seminario.

3. Dedicar el taller del curso 2016/17 a la relación entre historia de las emociones y medios de comunicación de masas. 


\section{Sesión 1 - Control, delimitación y mediación del discurso (JUEVES 15/10/2015)}

Lecturas obligatorias:

FOUCAULT, Michel, El orden del discurso, Buenos Aires, Tusquets Editores, 1992.

ALTHUSSER, Louis, "Ideología y aparatos ideológicos del Estado" en La filosofía como arma de la revolución, México, Siglo XXI, 1989, pp. 183-206.

Sesión 2 - La construcción social del mensaje (JUEVES 12/11/2015) Lecturas obligatorias:

HALL, Stuart, et al., "The Social Production of News" en Policing the crisis. Mugging, the state and law and order, London, McMillan, 1982, pp. 53-80.

LAKOFF, George, "Metáforas del Terror” en No pienses en un elefante, lenguaje $y$ debate político, Madrid, UCM, 2007, pp. 83-105.

\section{Sesión 3 - Género y recepción (JUEVES 10/12/2015)}

\section{Lecturas obligatorias:}

VAN ZOONEN, Liesbet: "Gender and Media Reception" en Liesbet Van Zoonen: Feminist Media Studies, Londres, SAGE, 1994.

MORLEY, David: "The gendered framework of Family viewing” en Television, audiences and Cultural Studies, Londres, Rougledge, 1992, pp. 131-150.

\section{Sesión 4 - Género y Videojuegos (JUEVES 14/01/2016)}

Lecturas obligatorias:

GRIMES, Sara M., "You shoot like a girl!: The female protagonist in actionadventure videogames", en Proceedings of the 2003 DIGRA International Conference: Level Up, vol. 2, 2014.

YEE, N. (2008). Maps of Digital Desires: Exploring the Topography of Gender and Play in Online Games. In Kafai, Y., Heeter, C., Denner, J., \& Sun, J. (Eds.), Beyond Barbie and Mortal Kombat: New Perspectives on Gender and Gaming (pp. 83-96). Cambridge, MA: MIT Press, 2008.

YEE, N.; DUCHENHEAU, N.; YAO, M.; NELSON, L., "Do Men Heal More When in Drag? Conflicting Identity Cues Between User and Avatar" en 
Proceedings of CHI '11 Conference on Human Factors in Computing Systems, AMC New York, New York, 2011.

\section{Sesión 5 - Recepción: teleactante y derecho de mirada (JUEVES} 18/02/2016)

Lecturas obligatorias:

CHARAUDEAU, Patrick: “¿Nos manipulan los medios?” CIC: Cuadernos de información y comunicación, ISSN 1135-7991, No 10, 2005 (Ejemplar dedicado a: Información, cognición, memoria), págs. 319-330.

LARA, Ángel Luis: "Del televidente al teleactante: carácter productivo y explotación de los públicos mediáticos" Sociología del trabajo, ISSN 02108364, No 81, 2014 (Ejemplar dedicado a: El paro hace daño), págs. 90-111.

\section{Sesión 6 - Radio y género (JUEVES 10/03/2016)}

Lecturas obligatorias:

BARNARD, Stephen: “Mother's little helper: programmes, personalities and the working day" en Caroline MITCHELL (ed.): Women and radio. Airing differences, Londres, Routledge, 2000, pp. 126-136.

ANDREWS, Maggie: "Early domestic goddesses: competing discourses of domestic expertise2 en Maggie ANDREWS: Domesticating the airwaves. Broadcasting, domesticity and femininity, Londres, Continuum, 2012, pp. 3054.

\section{Sesión 7 - ¿Cultura de masas o culturalmente desclasados?} (JUEVES 07/04/2016)

Lecturas obligatorias:

HOGGART, Richard: La cultura obrera en la sociedad de masas, Barcelona, Siglo Veintiuno, 2013. (Capítulo 7 + Conclusión)

HOGGART, Richard; WILLIAMS, Raymond: "Working Class Attitudes" en New Left Review I/1, January-February 1960.

\section{Sesión 8 (JUEVES 12/05/2016) - Suspendida}

Sesión 9 - Los medios de comunicación de masas y las relaciones de poder. Sesión de clausura (JUEVES 16/06/2016) Algunas conclusiones.

Figura 3: Listado de sesiones y lecturas del curso 2015/2016 
Con todo esto en mente comenzaba la tercera edición del Seminario de Historia y Teoría de la Cultura con el título de "La cultura sentida a través de los medios de comunicación: un acercamiento a las emociones en la Historia". En esta última edición la decisión de dividir la responsabilidad de cada sesión en dos: quien propone los textos y quien modera y agilice el debate son distintas para crear así una mayor implicación y horizontalidad en el proceso de debate y preparación. Al encontrarse, en el momento de escribir estas líneas en curso, nos limitamos a dejar el programa de lecturas que estamos desarrollando, pues creemos que puede acercar a cómo se concibió el mismo:

\section{Sesión 1. Introducción: ¿Historia de las emociones o emociones en la Historia? (MARTES 11/10/2016) \\ Lecturas obligatorias}

FREIRE DÍAZ, José Javier, "Presentación: Emociones e historia" en Ayer, 98 (2015), pp. 13-20.

SCHEER, Monique, "Are emotions a kind of practice (and is that what makes them have a History)? A Bourdieu approach to understand emotion", en History and Theory, 51 (2012), pp. 193-220.

\section{Lectura complementaria}

ROSENWEIN, Barbara H., "Worrying About Emotions in History, Review Essay” en American Historical Review, 107 (2002), pp. 821-845.

Sesión 2. Traduciendo emociones: literatura infantil y cultura popular (MARTES 8/11/2016)

\section{Lecturas obligatorias}

DOUGLAS, Mary, "Los usos de la vulgaridad: una lectura francesa de Caperucita Roja” en Estilos de Pensar, Barcelona, Gedisa, 1998.

PERNAU, Margrit, "Translating books, translating emotions" en VV.AA., Learning how to feel. Children's literature and emotional socialization 18701970, Oxford, Oxford University Press, 2014.

Sesión 3. Punctum: La fotografía como detonadora de emociones (MARTES 13/12/2016)

\section{Lecturas obligatorias}

BARTHES, Roland, La cámara lúcida. Notas sobre la fotografía, Barcelona, Paidós, 2011, pp. 30- 36, 42-47, 60-65, 79-85, 111-112, 125-127. 
MITCHELL, W.J.T., Teoría de la imagen, Madrid, Akal, 2009, pp. 245-252, 267270.

Sesión 4. Enamorado de Pikachu: videojuegos, entorno digital y emociones (MARTES 10/1/2017)

Lecturas obligatorias

DORMANN, Claire; WHITSON, Jennifer R. y NEUVAINS, Max, "Once More With Feeling: Game Design Patterns for Learning in the Affective Domain”, en Games and Culture, 8 (4, 2013), pp. 215-237.

SMETHUST, Toby y CRAPS, Stef, "Playing with Trauma, Intereactivity, Empathy and Complicity in The Walking Dead Video Game”, en Games and Culture, 10 (3, 2014), pp. 269-290.

Sesión 5. El terror como emoción fílmica y estética (MARTES 14/2/2017)

Lecturas obligatorias

BRIEFEL, Aviva, "Monster Pains: Masochism, Menstruation, and Identification in the Horror Film" en Film Quarterly, vol. 58, 3 (Spring 2005), pp. 16-27.

CARROLL, Nöel, "Metaphysics and Horror, or Relating to Fictions" en The philosophy of Horror, or Paradoxes of Heart, Londres, Routledge, 1999, pp. 5996.

Sesión 6. Miedo y pasión en la lucha: emociones, medios y conflictos bélicos (MARTES 14/3/2017)

\section{Lecturas obligatorias}

DELUMEAU, Jean, El miedo en occidente, Madrid, Taurus, 2012, pp. 13-45. BOURKE, Joanna, Sed de sangre. Historia íntima del combate cuerpo a cuerpo en las guerras del siglo XX, Barcelona, Crítica, 2008, pp. 21-49.

\section{Lectura complementaria}

MOSCOSO, Javier: Historia cultural del dolor, Madrid, Taurus, 2011, pp. 1322.

Sesión 7. Sinceridad, amistad y feminidad en el medio radiofónico (MARTES 11/4/2017)

Lecturas obligatorias

LACEY, Kate, "Finding a voice" en Kate LACEY, Feminine Frequencies. 
Gender, German Radio, and the Public Sphere (1923-1945), Ann Arbor, The University of Michigan Press, 1996, pp. 193- 220.

SCANNELL, Paddy, "Sincerity" en Paddy SCANNEL: Radio, Television and Modern Life, Oxford/Cambridge, Blackwell, 1996, pp. 58-74.

Sesión 8. El aprendizaje emocional de la nación (MARTES 9/5/2017)

Lecturas obligatorias

GONZÁLEZ MANSO, Ana Isabel, "Héroes nacionales como vehículos emocionales de conceptos políticos" en Historiografias, 10 (Julio-Diciembre 2015), pp.12-30.

OLSEN, Stephanie, “< $<$ Happy home $>$ and $<$ happy land $>$ : Informal emotional education in british bands of hope, 1880-1914, en Historia y Memoria de la Educación, 2 (2015), pp. 195-218.

\section{Sesión 9. Sentido(s) y sensibilidad(es): Evaluación y consideraciones sobre el curso (MARTES 9/5/2017)}

Sesión de evaluación y puesta en común. Valoraciones sobre el desarrollo del taller de lectura

Figura 4: Listado de sesiones y lecturas del curso 2016/2017

\section{Actividades paralelas}

Desde un primer momento se pensó el Seminario de Historia y Teoría de la Cultura como un espacio que no quedara constreñido por los muros de lo estrictamente académico, con lo que siempre ha existido la voluntad de organizar actividades que corrieran en paralelo al taller de lecturas. Por lo tanto, durante el primero año de vida se organizaron la asistencia a presentaciones de libros y exposiciones, e incluso la presentación del libro Rituales de Resistencia, editado por Traficantes de Sueños (traducción del clásico de la Escuela de Brimingham: Resistance through Rituals). Realizado el martes 16 de diciembre 2015 a las 11:30h en la Facultad de Geografía e Historia (UCM), en el aula 21 de la $10^{\mathrm{a}}$ planta y organizado como actividad respaldada por el Dpto. de Historia Contemporánea, su puesta en práctica nos confrontó con la realidad de la Academia: la falta de público (motivada en parte por ser una fecha coincidente con el periodo de exámenes) hizo que se decidiera, de mutuo acuerdo con los 
miembros de la editorial, la suspensión de la presentación.

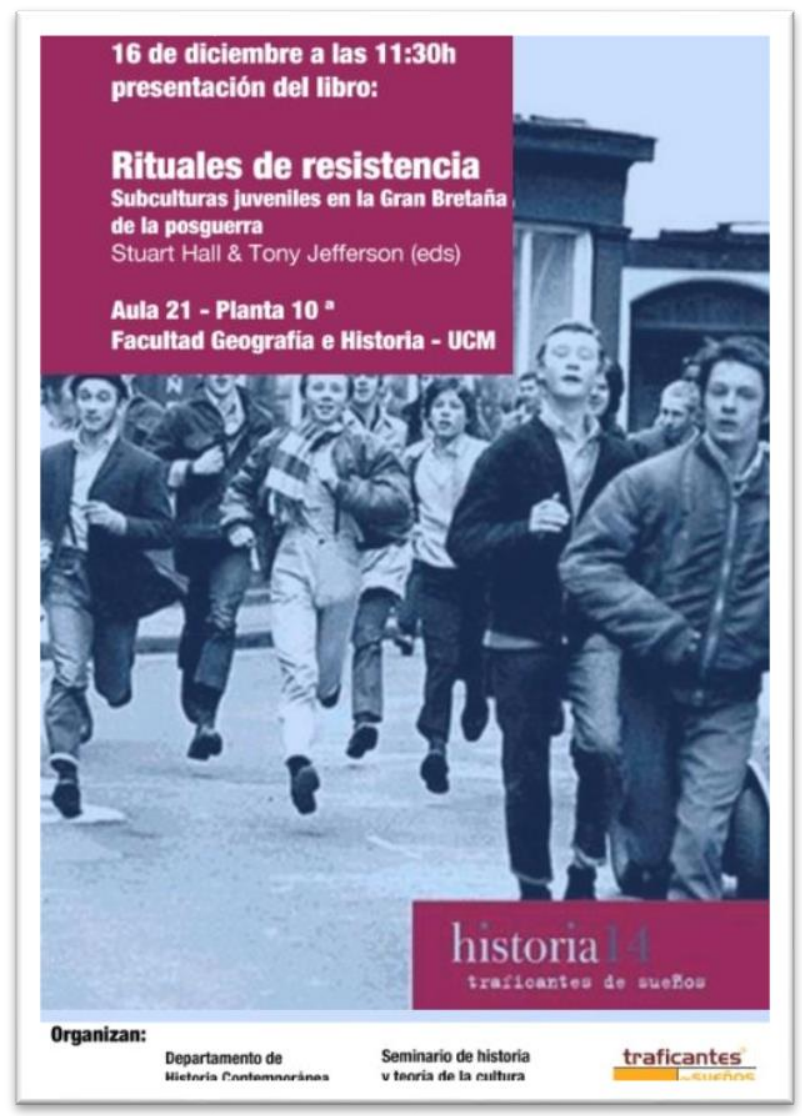

Imagen 1: Cartel de la presentación de Rituales de resistencia. Subculturas juveniles en la Gran Bretaña de la posguerra.
Por el contrario, y como compensación al fracaso de la presentación en el seno de la facultad, los miembros del Seminario acudieron a la celebrada con posterioridad en la Librería Traficantes de Sueños el jueves 22 de enero de 2015. Ésta se realizó como parte de un seminario titulado “Culturas Juveniles de Hoy”, al que acudió de invitado Carles Feixa, catedrático de antropología social de la Universidad de Lleida, quien aprovechó la ocasión para presentar su libro "De la Generación@a la \#Generación”. La actividad de los integrantes del Seminario de Historia y Teoría de la Cultura en dicho evento fue significativa, no sólo mediante la realización de preguntas y participación en el debate, sino también por la moderación del mismo por José Emilio Pérez Martínez ante la ausencia de la moderadora oficial. Consideramos que la experiencia contribuyó a poner en práctica la inserción del Seminario en el debate público externo a la academia, además de servir de prueba de las habilidades de discusión crítica adquiridas por los miembros durante los talleres de lectura de textos, principal actividad del Seminario. 
Merece la pena mencionar la visita a la exposición "Mapas de Acción”, presentada en el espacio de arte Serendipia el jueves 12 de febrero de 2015. Su autora, Yolanda Domínguez, dirigió una visita guiada en la que explicó a los visitantes el proceso creativo de las diferentes acciones desarrolladas durante años: desde las referencias que encienden la mecha hasta el impacto y alcance de las que han llegado a convertirse en pequeñas revoluciones sociales, situando al espectador como pieza clave de activación y al espacio público como campo de batalla. Consideramos la iniciativa de acudir como otro ejemplo del interés y la voluntad de tender puentes entre la academia y otras actividades culturales externas a la universidad, rompiendo así el aislamiento que tiende a caracterizar a la institución en España.

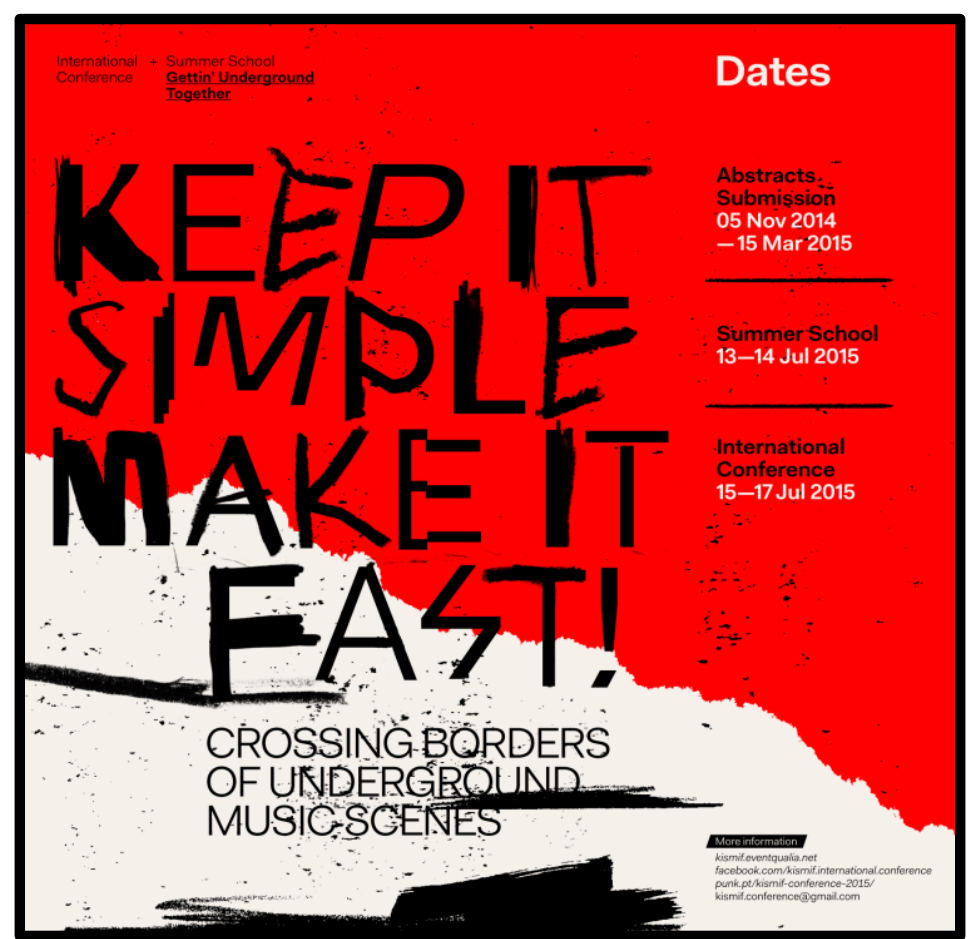

Imagen 2: Cartel de Keep It Simple Make It Fast.

Crossing Borders of Underground Music Scenes

(Oporto, 2015).

En aras de una internacionalización y visibilización del Seminario, en julio de 2015 los coordinadores presentaron tanto el proyecto como las reflexiones de los participantes del Seminario en torno a las subculturas juveniles en el Congreso Internacional Keep It Simple, Make It Fast (KISMIF), Crossing Borders of Underground Music Scenes, celebrado en Oporto entre los días 15 y el 17 de julio. Sin duda fue una buena plataforma para dar a conocer el trabajo del Seminario, teniendo la oportunidad de poner en común, 
con investigadores pertenecientes a otros centros, los resultados de nuestro esfuerzo colectivo. $^{3}$

En la edición del curso académico 2015/2016 se propuso entre las actividades paralelas unas jornadas dedicadas a la historia de las mujeres, los estudios de género y la cultura, pues vendrían a visibilizar unos intereses que tal vez queden un poco eclipsados por la ingente cantidad de actividades relacionadas con la historia política más clásica o la de las relaciones internacionales. Entre las charlas principales salieron como posibilidades figuran "Mujeres, militancia y culturas políticas", "Mujeres y género en las letras y mujeres y género en lo audiovisual”. El espíritu de esta jornada respondería al modelo original del Seminario y está entre la batería de posibilidades futuras a realizar que tiene el Seminario.

El tercer curso se han organizado actividades paralelas adicionales: en el mes de enero, Miguel César presentó un modelo de análisis del medio videolúdico como objeto cultural, extraída del estado de su tesis doctoral. Poco después tuvo lugar una sesión extraordinaria titulada "Cultura popular, música, capitalismo y conflicto. País Vasco (1960-2016)" en la que participaron tres ponentes de dicha región: Arkaitz Letamendia con "Capitalismo, aceleración, ruido (¡arritmia!)”, Ion Andoni del Amo con "Jóvenes, escenas, músicas y conflictos en EH. 1960-2016” y Jason Diaux González con "Radio libre Halabedi, acción colectiva MMSS resistencia, entre el medio y el mensaje, 19832016”. Finalmente, el acto de esta naturaleza más reciente que el Seminario ha organizado ha sido la charla de Víctor Notarfrancesco (Universidad de Salta, Argentina) titulada "Memorias, fotografías y dictaduras", en la que se hizo un repaso de los principales fotógrafos que, mediante su obra, reivindican la memoria de las víctimas de la dictadura cívico-militar argentina (1976-1983). Estos talleres tuvieron un gran éxito, a juzgar por la capacidad de convocatoria que tuvo: asistentes tanto del Seminario como del doctorado, del máster, alumnos de grado, ex-alumnos de la carrera de Historia y gente ajena a la universidad. Achacamos a este éxito de asistencia a la excepcionalidad temática (dentro del marco académico en el que el Seminario se ve inserto), así como la potencialidad de

\footnotetext{
${ }^{3}$ Fernando GARCÍA NAHARRO y José Emilio PÉREZ MARTÍNEZ: “Keep it Simple, Make it Fast International Conference: Crossing Borders of Underground Music Scenes + Gettin' Underground Together Summer School”, en Cuadernos de historia contemporánea, 37 (2015), pp. 305-309.
} 
aplicación social que tienen los medios libres.

Asimismo, consideramos que el gran hito de este tercer curso es la participación del Seminario en las tareas de organización un encuentro académico. Se trata de la coordinación de una mesa titulada "De los medios a las mediaciones: repensando la comunicación de masas en la España post-franquista" en el marco del Congreso "La España Actual: Cuarenta Años de Historia (1976-2016)" proyectado por la Asociación de Historiadores del Presente (AHP) y la Asociación de Historia Actual (AHA). La respuesta inicial a la propuesta ha sido relativamente favorable, pues contará con la participación de diez ponentes y ocho ponencias. Sin embargo, en el momento de escribir estas líneas el Congreso aún no se ha celebrado, por lo que nos resulta imposible adelantar el balance de la actividad. Confiamos en que la experiencia resulte enriquecedora y nos motive a lanzar propuestas similares en futuros encuentros científicos ya sea dentro de la disciplina de la Historia como en otras resonantes con nuestra actividad, esto es, Comunicación Social, Estudios Culturales, etcétera.

Como último hito de las actividades paralelas proyectadas por el Seminario destaca la I Jornada de Estudios del Videojuego Histórico contando, como siempre, con el respaldo del Departamento de Historia Contemporánea. El evento se presenta como un encuentro de jóvenes investigadores procedentes de todo el territorio estatal que toman como objeto de estudio el videojuego ambientado en el pasado. Los historical game studies, línea de investigación situada en la intersección entre los media studies, los game studies, la historia y los estudios culturales, cuenta ya con una notable producción extranjera. ${ }^{4}$ Los antecedentes españoles son escasos, ${ }^{5}$ por lo que el Seminario de Historia

\footnotetext{
${ }^{4}$ Algunos ejemplos notables son Adam CHAPMAN: Digital Games as History. How Videogames Represent the Past and Offer Access to Historical Practice, London/New York, Routledge, 2016; Andrew B. R. ELLIOTT \& Matthew Wilhelm KAPELL: Playing with the Past. Digital Games and the Simulation of History, London, Bloomsbury, 2013; Tobias WINNERLING \& Florian KERSCHBAUMER: Early Modernity and Video Games, Newcastle upon Thyne, Cambridge Scholars Publishing, 2014. Para un estado de la cuestión sobre la subdisciplina, véase Adam CHAPMAN, Anna FOKA \& Jonathan WESTIN: "Introduction: what is historical game studies?", en Rethinking History: The Journal of Theory and Practice (special issue Challenge the Past), 2016, pp. 1-14.

${ }^{5}$ El más notable es el I Congreso Internacional Historia y Videojuegos, celebrado en la Universidad de Murcia el 26 y 27 de noviembre de 2017. Esta actividad se enmarcaba dentro del proyecto de investigación "Historia y Videojuegos: el impacto de los nuevos medios de ocio sobre el conocimiento del pasado medieval" (HAR2011-25548), proyecto que ha sido renovado bajo el nombre de "Historia y Videojuegos II: Conocimiento, aprendizaje y proyección del pasado en la sociedad digital" (HAR2016-78147-P). A pesar de su loable intención, los contenidos del Congreso no versaron específicamente sobre los historical
} 
y Teoría de la Cultura busca, con la organización de las jornadas, sentar un precedente y convertirse en altavoz de aquellos historiadores preocupados por entender los discursos emanados de los productos de entretenimiento digital de corte histórico.

\section{Grandes esperanzas, humildes consecuciones:}

Desde un primer momento pensamos que esta forma de reflexión colectiva nos llevaría a profundizar en formas de aprendizaje y trabajo colectivo dentro del Seminario. Y la realidad con la que nos hemos topado es que la puesta en marcha de este tipo de proyectos horizontales, abiertos y "desde abajo" presentan toda una serie de problemas con los que nos hemos ido encontrando sesión tras sesión, intentando solucionarlo edición tras edición

\section{Problemas:}

A diferencia del primer año, en nuestra segunda edición y a petición de los asistentes, la sesión mensual se realizó los segundos jueves de cada mes, si bien es verdad que, por problemas de agenda, dos de las sesiones tuvieron que aplazarse o suspenderse. Un hecho que se convirtió en un inconveniente para el normal funcionamiento del Seminario: quizá motivado por ese cambio de día de realización, se vio una merma en cuanto a la afluencia de público y a la correcta preparación de las lecturas por parte de los asistentes. Algo que nos ha llevado a reflexionar en torno a por qué un Seminario que funcionó tan bien como en su primera edición ( $\sin$ trayectoria previa ni soporte promocional alguno) en su segunda edición, contando ya con una entrada propia en la página web del Departamento de Historia Contemporánea y con el soporte promocional (carteles y documentos informativos distribuidos tanto en la Facultad de Geografía e Historia y redes sociales como en otros Centros de la Universidad Complutense de Madrid) funcionó peor que la edición anterior.

Al moverlo de martes a jueves estábamos complicando la posible asistencia de los alumnos del Máster Interuniversitario en Historia Contemporánea, por tener clases ese día. Del mismo modo, en diversas ocasiones la sesión del Seminario se ha solapado con otras actividades científicas -congresos o Seminarios- pues éstas suelen comenzar este

game studies entendidos como disciplina, sino sobre distintos enfoques del videojuego inserto en la sociedad. 
día de la semana. En segundo lugar, a lo largo del primer cuatrimestre bajó la asistencia de los alumnos de grado. Creemos que este hecho pudo deberse al propio desarrollo de su actividad académica, que se iría complicando progresivamente según se fueran acercando los exámenes, y, probablemente, a una paulatina pérdida de interés. Finalmente creemos que también pudo influir de manera importante una atención discontinua por parte del grupo motor del Seminario y el hecho de que los textos propuestos por la coordinación del Seminario quizá sean algo complicados de abordar por los estudiantes de grado, la mayoría de los cuales aún no posee el bagaje y compromiso intelectual para sacar partido crítico de ellos.

Ligado a esto, problema del debate "de bar", de la preeminencia de la experiencia desconectada de la base teórica. En algunas sesiones, el debate en torno a los textos propuestos acababa por agotarse prematuramente y daba paso a una serie de intercambios experienciales entre los participantes. Experiencias que, si bien merecen la pena ser enunciadas y conocidas, de poca utilidad resultan para los objetivos del Seminario al no estar acompañadas de una reflexión sobre su inserción en dinámicas generales y entramados teóricos. Sin este último esfuerzo, los testimonios de las vivencias de los participantes con respecto a los medios de comunicación que el Seminario pretende problematizar se vuelven anecdóticos. Uno de los objetivos inmediatos de la organización es superar estas deficiencias mediante la ¿formación continua y participativa? Una de las vías que se ha propuesto es el nombramiento de un coordinador de debate distinto a la persona encargada de la selección de textos para la sesión. En este sistema, la coordinadora se encarga de preparar los textos en profundidad para extraer una serie de líneas por las que cree que el debate podría desarrollarse. Además, durante la sesión es su responsabilidad velar por que los turnos de palabra sean respetados, por la participación equitativa de los integrantes $y$, en especial, por lanzar nuevas preguntas directoras de la discusión cuando ésta de muestras de agotamiento o redirigir el debate en caso de 'irse por la tangente'. De esta manera se cuenta con dos participantes que han profundizado en el objeto de debate (quien propuso los textos y quien se encarga de la coordinación), con lo que aumentan las posibilidades de que la sesión sea satisfactoria.

Los intentos de hacer más participativa y horizontal la organización del Seminario se han visto comprometidos con un grado desigual de compromiso que, en la práctica, ha dado al traste con algunas sesiones. Consideramos que el fracaso parcial de esta iniciativa 
se debe a la falta de costumbre, en el contexto universitario, de participación activa del alumnado en tareas de organización. La construcción de una verdadera universidad horizontal pasa por la adquisición de dichas responsabilidades, de las que creemos el Seminario de Historia y Teoría de la Cultura es aliciente y campo de entrenamiento. El único escollo al que esta horizontalidad se ve obligada a enfrentar es la determinación institucional que diferencia entre contratados y no contratados dentro del propio Seminario (tanto el Seminario de Historia y Teoría de la Cultura como todos los demás que están insertos en el Departamento de Historia Contemporánea) ya que la capacidad representativa de cara a la proposición y defensa de proyectos difiere en gran medida dependiendo del estatus legal al que los investigadores/organizadores se encuentren en el momento de llevar a cabo las tareas de organización y proposición de nuevas ediciones del Seminario. Así pues, y con todo lo mencionado, consideramos que, pese a que los objetivos de trabajo colectivo y democrático no se han alcanzado en el grado esperado, el modelo no ha de abandonarse.

\section{Los humildes logros}

Si bien es cierto que dentro del Seminario de Historia y Teoría de la Cultura se intentan maximizar los efectos de la autocrítica -que casi podríamos tildar de leninista-, creemos humildemente que pueden señalarse una serie de logros en estos tres años de andadura.

En primer lugar, creemos que hay que valorar positivamente la creación de un espacio de debate con las características del taller de lectura del Seminario de Historia y Teoría de la Cultura, tan ajenas en forma y espíritu a las dinámicas que rigen el campo académico. El intento de escapar de la jerarquización y lo magistral, para ahondar en la participación y lo colectivo -con sus problemas-, parece que está arrojando saldos positivos.

Como segundo logro querríamos señalar el haber conseguido mantener el componente interfacultativo e interdisciplinar ya que han participado, a lo largo de las tres ediciones, personas provenientes de Sociología, Comunicación Audiovisual/Publicidad, Historia del Arte, etc. En esta misma línea hemos conseguido incorporar a nuestra actividad, de forma intermitente, a investigadores visitantes tanto de nuestro departamento como de otras facultades. Una experiencia que ha sido 
extremadamente positiva y nos ha permitido, a través de los debates, conocer perspectivas $\mathrm{y}$ tradiciones intelectuales ajenas a la nuestra propia.

La apuesta por la transparencia y la claridad, a través de las memorias anuales, es otro punto fuerte del ethos del Seminario de Historia y Teoría de la Cultura. Al tratarse de una iniciativa construida desde abajo siempre hemos creído que dejar constancia de nuestra actividad y de los debates que se generan en el espacio -tanto intelectuales como de autocrítica- constituye una fuente de legitimidad, sobre todo en un ámbito como el académico que, por desgracia, está cruzado por una serie de intereses que hacen que, en ocasiones, se produzcan dinámicas poco altruistas para con el común de los investigadores universitarios.

El último punto positivo en el que debemos incidir es que como seminario ponemos en valor determinadas temáticas y medios que, de no ser por nuestra labor pasarían desapercibidos en el departamento. En SHyTC trabajamos principalmente sobre textos como método de difusión de conocimientos y debates, pero dentro de ellos tratamos de conservar una heterodoxia que amplíe a muchos otros medios la oportunidad de manifestar la scopia propia de cada uno de ellos. Entre estos medios destacan la radio (sobre todo como medio libre) la propia fotografía, con sesiones enteras para tratarlo, como en la tercera edición del seminario; de la misma manera los videojuegos serán objeto de estudio (en la fecha de emisión de este paper) y como tarea de rescate, incluso la propia lectura y narración. Como consecuencia directa de la ampliación de tratamiento de todos los medios mencionados más arriba, los campos temáticos tratados son mucho más amplios que los que se vienen dando dentro del propio departamento y de la universidad (a modo local, el ámbito que conocemos más de primera mano). Superando temáticas más tradicionales como la política, las relaciones internacionales, los estudios urbanísticos etc. aplicamos paradigmas y herramientas de estudio en principio ajenos a la propia historiografía y nos nutrimos de ellos para alcanzar una mayor riqueza en los debates y las conclusiones sacadas de los mismos.

\section{Mirando hacia el futuro... ¿Alguien tiene alguna idea?}

El Seminario de Historia y Teoría de la Cultura, como proyecto, tiene vocación de continuidad. Desde la firme convicción de la utilidad y necesidad de espacios como este dentro del ámbito académico, el proyecto se prepara para afrontar una serie de cambios 
en su cuarta edición. El primero de estos es lo que podríamos considerar un cambio generacional. Por las dinámicas vitales y los azares de las carreras investigadoras, muchos de los asistentes durante estos primeros tres años de actividad -incluidos los coordinadores han tenido que verse desplazados a otros lugares. Debido a estos acontecimientos tenemos que plantear nuevas líneas de debate que sean capaces de atraer a nuevo público. En esta misma dirección, hemos de aprovechar y afrontar la coyuntura de una tendencia a la baja de asistentes al seminario y proponer temáticas más resonantes con las inquietudes intelectuales de los potenciales nuevos miembros. En concreto se baraja la posibilidad de centrar los debates en torno a los feminist media studies.

En consonancia y al respecto, las decisiones inmediatamente futuras del seminario están orientadas al pensamiento colaborativo, entre talleres y seminarios de la propia facultad o fuera de la misma. De esta manera, mantendríamos el espíritu generador primero del seminario y renovaríamos las temáticas y procedimientos del mismo, adaptándonos a la situación requerida tras estas primeras experiencias. El proceso logístico de este proyecto se desarrolla en un concepto de tender puentes entre todos los seminarios, talleres y actividades enriquecedores, no sólo para el Seminario de Historia y Teoría de la Cultura sino también para los asistentes y el grupo de organizadores a nivel individual. Por otra parte, los aspectos que creemos que funcionan y por los que hemos decidido seguir apostando son: la horizontalidad en los debates, hacer propias de cada participante las funciones organizativas fundamentales del seminario (propuestas de textos y autores, cuestiones en torno al funcionamiento del taller de lecturas, proposición de otras actividades...); el propio taller de lectura y la continuación con la organización de actividades más allá del mismo, entre las que se incluyen la participación activa en otros acontecimientos tanto académicos como que trasciendan los límites de la universidad. 


\title{
La espiral dialéctica de la historiografía: pasado y presente de los marxistas británicos
}

\author{
The Dialectical Spiral of Historiography: Past and Present of Britain \\ Marxists
}

\section{Rafael Buhigas Jiménez}

Universidad Complutense de Madrid

\section{Resumen}

Más allá de la última crisis epistemológica, la tensión sobre cómo investigar se remonta a la propia historia de la historiografía. El Grupo de Historiadores del Partido Comunista de Gran Bretaña, en uso del marxismo como una tradición, realizaron importantes aportes al método histórico. No solamente porque constituyeron un legado, sino porque llevaron la discusión a otros niveles. Si bien, estos mismos debates se siguen reproduciendo hoy en el nuevo siglo que se despliega ante el oficio del historiador. La crítica a las limitaciones de los marxistas británicos y a los que los interpretaron supone un nuevo punto de partida.

\section{Palabras clave}

Marxismo, británicos, materialismo, historiografía, conciencia.

\begin{abstract}
Beyond the last epistemological crisis, the tension on how to investigate can be traced back to the history of historiography itself. The Communist Party Historians Group, in use of marxism as a tradition, made important contributions to the historical method. Not only because they constituted a legacy, but because they led the discussion to other levels. Although these same debates continue to be reproduced currently in the new century that
\end{abstract}


unfolds before the profession of the historian. The criticism of the limitations of the British Marxists and those who interpreted them is a new starting point.

\section{Palabras clave}

Marxism, British, materialism, historiography, consciousness.

\section{Un punto de partida tras el cierre de un siglo}

Durante el corto siglo XX, tuvo lugar una ola revolucionaria que podríamos acuñar como Ciclo de Octubre (1917-1989). Cuando aquella rompió contra la costa de un siglo casi expirado, trajo consigo la derrota política del comunismo, también constatada ideológicamente. Los comunistas perdieron su horizonte revolucionario abriendo paso al revisionismo, por lo que si se emprende una lectura detenida de los clásicos marxistas es simple deducir que cualquier movimiento desde entonces solo ha podido ser en falso. Por tanto, parece lógica que la tarea de aquellos sea alcanzar de nuevo lo que perdieron. Para emprender dicha empresa, siguiendo las bases del marxismo, se torna como necesario acometer un balance del Ciclo de Octubre con el que extraer lo acertado de las experiencias acumuladas en aquel y eliminar todo lo que constituyó un fallo.

Esta es la manera que tiene el marxismo -y lo que le diferencia del resto- de garantizar su independencia ideológica y política. Se presenta, pues, la genuina tarea de reconstituir aquello que muchos han sentenciado como un fracaso incapaz de volver a recuperarse tras los golpes que recibió. Esta misma tesis tiene su equivalente en el debate historiográfico -ya que el ejercicio intelectual no es ajeno al posicionamiento ideológico. Sobre aquel debe trazarse un análisis crítico que evidencie el antagonismo en la construcción teórica de la historia. E.P. Thompson dijo en algún momento que no había ninguna razón deshonrosa para considerarse heredero de la tradición marxista y yo creo firmemente lo mismo, aunque con el ligero matiz de no considerarlo una costumbre sino una cosmovisión. 


\section{El paradigma marxista británico y su legado}

\section{Una vuelta sobre la identidad intelectual de los historiadores}

Más allá del consabido legado que el Grupo de Historiadores del Partido Comunista de Gran Bretaña ha dejado (GHPC), el detonante de este escrito es que apenas o ni siquiera hay historiadores marxistas desde que el sector británico cesó en sus tareas. De esta afirmación se pueden obtener dos cuestiones. En primer lugar, el acierto que la acompaña. Esto se debe a que, desde finales del siglo pasado, el revisionismo entendido en cualquiera de las claves en que se quiera formular -en este caso como tradición teórica anclada en el seno de la Academia- ha sido el hilo conductor de la producción intelectual. Lo que impide, por ello, hablar de marxismo, en tanto que en aquel se incuba una desviación que acaba por emanciparse perdiendo su componente revolucionario. En segundo lugar, este hecho de que hoy no existen historiadores marxistas podría ser objeto de exaltación y, por tanto, considerarse un error. Ante esto último cabrían también dos posibilidades dibujadas antagónicamente. Por un lado, la reclamación convencida que apela a la existencia de historiadores marxistas o potencialmente marxistas, hecha por aquello que ha sido presentado en el capítulo anterior como revisionismo. Y, por otro lado, frente a este último, la ofensiva de los revolucionarios, alegando que dicha declaración se basa en un entendimiento impreciso y equivocado del marxismo. Aconteciendo así a la histórica tensión entre reforma y revolución.

Esta última se traduce en la distinción entre quienes trabajan operando en términos de universalidad y quienes toman el marxismo como una herramienta recurrente con la que destilar un objeto de estudio que acaba por ser observado de manera teoricista. A la Academia le ha costado un largo trayecto asumir la necesidad de trabajar interdisciplinariamente. En el caso historiográfico hubo de debatirse sobre la viabilidad de mantener un diálogo con la sociología y la filosofía. Empero, esto es algo que los padres fundadores del marxismo y sus continuadores, como Edward H. Carr, ya comprendieron ideando la fórmula totalizadora que supone el materialismo dialéctico. ${ }^{1}$

Quien percibe dicha reflexión como un catecismo es porque no ha leído a Marx y Engels -explicándose así su imprecisión- o porque simplemente es un embustero, cuyo

\footnotetext{
1 "Cuanto más sociológica se haga la historia y más histórica se haga la sociología, tanto mejor para ambas". Edward Hallett CARR: ¿Qué es la historia?, Barcelona, Planeta-Agostini, 1993, p. 89.
} 
interés por propagar calumnias solo conoce él. No obstante, esto último es algo que debatió el propio Engels en uno de esos debates mantenidos por correspondencia epistolar que se olvidan, casualmente, haciendo creer que jamás se trataron ciertos temas. En una de esas cartas, el filósofo alemán decía a su compatriota Werner Sombart que "toda la concepción de Marx no es una doctrina sino un método, que no ofrece dogmas hechos sino puntos de partida para la ulterior investigación y el método para dicha investigación". 2 Esto es algo que comprendieron especialmente Hobsbawm y Thompson, siendo el vademécum del GHPC para inmunizarse frente a las posturas intelectuales antimarxistas de su época. Por lo que creo oportuno considerar a esta generación, no solamente brillante en calidad de aportes históricos y metodológicos, sino una auténtica vanguardia intelectual en el desarrollo del concepto de la historia de Marx. ${ }^{3}$

Otro axioma fundamental pasa por la pregunta de si se puede idear sin ideología. Para algunos está bastante claro que si y critican a quien se posiciona en esos términos. Dándose la casualidad de que son ellos los primeros, como norma general, los que más rápido "invalidan" el marxismo como ideología. Ahora bien, adivinen cómo lo hacen, ¡desde ideología! ¿Acaso no es una contradicción? Lo que pretende apuntarse con esto es que, por idílico que parezca, la objetividad si se puede alcanzar en tanto que, potencialmente, una subjetividad científica, universal y radicalmente crítica se acerca más a aquella que otra enterrada en un lodazal teórico, como puede ser la metafísica. Esto es algo que los marxistas británicos intentaron señalar con la promulgación de sus investigaciones y el debate con sus contemporáneos. Por todo lo expuesto, se presenta la necesidad de arrojar una nueva mirada sobre el GHPC. En aras de preguntarnos cuánto de verdad hay en el pretendido marxismo que se les ha atribuido o que ellos mismos reivindicaron para sí. Así pues, empecemos por esta última parte.

Las opiniones vertidas sobre los perfiles biográficos y militantes de los miembros del GHPC pueden organizarse en varios apartados que intentan explicar sus identidades intelectuales. Estas, arguyen diversos autores, pueden ser resultado del clima posbélico

\footnotetext{
${ }^{2}$ Friedrich ENGELS: "Carta a Werner Sombart", en Karl MARX Y Friedrich ENGELS: Obras escogidas, 3 vols., Moscú, Editorial Progreso, 1974.

${ }^{3}$ Entendiendo el concepto de "vanguardia intelectual" dentro de una coyuntura ideológica limitada, en que los marxistas británicos representaban entonces el ala izquierda de un intelectualismo monopolizado por los liberales.
} 
de la Primera Guerra Mundial, de una continuación de la "tradición” inaugurada por Marx o de un sentimiento consistente en la adhesión generacional al comunismo que se explicaría, atendiendo a cada caso particular, como la vía más factible en torno al repertorio ideológico de una Europa marcadamente dividida y radicalizada. Las tres posibilidades juegan un papel clave de manera interrelacionada, pero, independientemente del mayor peso de una u otra, lo más importante es que todos ellos están forjados por las condiciones materiales de su tiempo. De forma que a las eventualidades citadas se les debe sumar también el elenco de limitaciones del ya mencionado Ciclo de Octubre.

Asimismo, los integrantes del GHPC estaban profesionalmente enmarcados dentro de la Academia y no situados contra ella como sujetos ideológicamente independientes proposición obligatoria para negar su condición institucional al servicio de la clase apoderada-, siendo esta una de las principales razones de su limitación como marxistas. Sin embargo, al mismo tiempo, esa adhesión constituye una variable explicativa de su éxito al suponer, aún como actores restringidos, una discordancia en el seno del órgano reproductor de la ideología dominante. No obstante, pese a este último apunte, la ausencia o pérdida de un referente revolucionario es buena muestra de cómo una línea equivocada o ligeramente errónea acaba por prosperar. Desembocando, como sabemos, en el abandono del PCGB por algunos de sus historiadores, los cuales desterraron la ya de por sí malograda independencia ideológica y abrazaron firmemente su condición como profesionales del sistema. Lo que, a su vez, explica la deriva de muchos de ellos hacia nuevas corrientes que ascendieron con la derrota del marxismo, entre las que destacaría el estructuralismo en el campo epistemológico y el atractivo hacia cualquiera de las vocaciones políticas anunciadas por unas masas cada vez más fragmentadas tras los sucesos en el Mayo de 1968. Siendo en ese preciso instante cuando, paralelamente, las reivindicaciones se parcializaron de forma brusca desechando el análisis de la lucha de clases, aparentemente inservible, en favor de un empirismo que "como es sabido, no es más que una desacreditada manifestación de la ideología burguesa". ${ }^{4}$ Esa que tanto les gustó a algunos renegados como Althusser y Foucault, de los que hoy muchos beben.

A grandes rasgos, podría resumirse que el GHPC es producto de la oposición al

\footnotetext{
${ }^{4}$ Edward Palmer THOMPSON: La miseria de la teoría, Barcelona, Crítica, 1981, p. 11.
} 
fascismo y a la depresión económica de un corto siglo XX atravesado por las limitaciones propias de un horizonte socialista que se convertía, pese a todo, en la opción más factible para esta vanguardia intelectual. Algo que, desde 1990, como creo adecuado señalar, sucede respecto al revisionismo y a la crisis sempiterna del sistema capitalista. Abriendo así las puertas a una nueva generación de historiadores que está por llegar con el marxismo por pluma y bandera.

\section{El problema del modelo base-superestructura}

A continuación, trataré la problematización de los que considero, a grandes rasgos, los dos polos de discusión más controvertidos en el paradigma del marxismo británico y que son las cuestiones del modelo base-superestructura y de la falsa conciencia. La opinión general sobre la dicotomía estructural propuesta por Marx es que sus continuadores británicos consiguieron "trascender la estricta noción económica de clase, llegando a solucionar el problema de la base-superestructura que ha dominado al marxismo desde sus comienzos". 5 Si bien, esta afirmación resulta imprecisa y trataré de demostrar por qué. Al contrario de lo que se ha querido interpretar, principalmente de los aportes de Thompson, no estamos aconteciendo a un dominio absoluto de una estructura por la otra, dando la vuelta a la relación dicotómica "inicial”. Pero tampoco acontecemos, como señala Harvey o el propio Christopher Hill, a la superación de un economicismo inherentemente atribuido a Marx o a gran parte de su obra. El choque no es solo económico pero la lucha antagónica de clases sigue siendo un componente fundamental en la creación de las culturas. Esto es así por la dialéctica, por la pugna entre contrarios. Ante esto, el reconocimiento que se debe hacer a los marxistas británicos es el logro de llevar este pensamiento a la Academia y desarrollarlo con una producción teórica sobre hechos concretos como la formación de la clase trabajadora en Inglaterra, la Revolución inglesa, entre otros ejemplos históricos factuales. Ahora bien, parafraseando a cualquiera de aquellos, pese a que la base otorga un tímido reflejo sobre una superestructura determinada sólo unidireccionalmente en el momento embrionario de su nacimiento, esta evidencia es algo que ya señalaron los propios Marx y Engels. A su vez, esa misma certeza fue mostrada por quienes recogieron su filosofía, principal pero no exclusivamente en la Unión Soviética y China.

\footnotetext{
${ }^{5}$ Harvey J. KAYE: Los historiadores marxistas británicos, Zaragoza, Universidad de Zaragoza, 1989.
} 
Con la intención de demostrar, al menos brevemente, que no hay nada nuevo bajo el sol, incorporo algunos ejemplos esclarecedores.

\begin{abstract}
La situación económica es la base pero los diversos factores de la superestructura que sobre ella se levanta $[\ldots]$ ejercen también su influencia sobre el curso de las luchas históricas y determinan, predominantemente en muchos casos, su forma. ${ }^{6}$

Pero las superestructuras, determinadas directa o indirectamente por la base económica, no son, como piensan los economistas vulgares, un resultado pasivo de la economía, ni esta constituye la única fuerza activa en la evolución de la sociedad. Las superestructuras ejercen una influencia sobre la base, aceleran o frenan el desarrollo de la sociedad. ${ }^{7}$
\end{abstract}

Estos escritos y otros tantos que pueden rastrearse fácilmente -aunque a algunos les cueste por su tradición comtiana de higiene lectora- preceden a los marxistas británicos e, incluso, se publican durante su época de actividad. Estos ejemplos demuestran la equivocación de atribuir un economicismo intencionado o natural al marxismo. Ahora bien, volvemos al mismo punto, si Marx hubiera mostrado -como puede interpretarse- análisis más apegados a una faceta determinista, tampoco sería una razón de crítica en tanto que lo suyo no es una piedra filosofal o un repertorio de leyes fijas sino un método que se niega a sí mismo buscando superar constantemente lo viejo para alcanzar lo nuevo. No obstante, son "pocos" los autores que han dialogado críticamente con esa faceta del ideólogo alemán. El problema fundamental procede de la "retaguardia que pretendía ser más marxista que Marx", ${ }^{8}$ y que acabó, paradójicamente, doblegándose a un análisis incorrecto de su teoría. Por ello, las principales críticas se dirigen hacia economicistas que en ningún caso eran marxistas o que, como ya se expuso, tenían una limitación propia y contextual del desarrollo ideológico. ${ }^{9}$ Aun así, frente a los considerados economicistas de la sección británica, como puede ser Maurice Dobb, contrariamente hay otros como Christopher Hill que acabaron emigrando al culturalismo.

\footnotetext{
${ }^{6}$ Friedrich ENGELS: “Carta a Jose Bloch”, en Karl MARX y Friedrich ENGELS: Obras...

${ }^{7}$ Mark Moisevich ROSENTAL y Pavel Fedorovich IUDIN: Diccionario filosófico marxista, Uruguay, Ediciones Pueblos Unidos, 1946, pp. 24-25.

${ }^{8}$ Edward Palmer THOMPSON: La miseria ..., p. 10.

${ }^{9}$ Tal es el caso de la crítica realizada por Robert BRENNER a Maurice DOBB. El primero demuestra que la renuncia al análisis de la lucha de clases es lo que provoca caer en errores de tipo economicista. Por ello, Brenner señaló acertadamente que Dobb dejó de aplicarse a sí mismo lo que tanto defendía. Manifestando así que el marxismo no es pretendidamente economicista, sino que, como toda materia viva, es sujeto de desviación. Para tener un conocimiento más detallado se recomienda leer Robert BRENNER: "Maurice Dobb and the Transition from Feudalism to Capitalism", Cambridge Journal of Economics, 2 (1978), pp.121-140.
} 
Algo de lo que también se acusó a Thompson. ${ }^{10}$

Todo esto es sumamente interesante porque permite establecer una correlación entre dicha discusión teórica acaecida en la Academia durante la segunda mitad del siglo XX y el debate también teórico que tuvo lugar décadas antes durante la creación del POSDR(b) pero ante una praxis ya en marcha -que enfrentó a unos embrionarios mencheviques para entonces marcadamente economicistas y a los revolucionarios guiados por Lenin-. Una correlación que, de nuevo, evidencia esencialmente el mismo antagonismo que hemos venido presentando entre reformistas y revolucionarios, extensible a encuentros intelectuales como al que se dirige esta defensa.

Para algunos tránsfugos a las antípodas del marxismo como Eugene Genovese, quien acabó sus días en las filas del conservadurismo tradicional, la superestructura mantiene un papel activo. Ya hemos visto que esto es correcto e innegable, siempre y cuando no se defienda una separación total de la base. Asumiendo que hasta aquí el lector ha podido comprender la relación dialéctica o que ha abandonado directamente la lectura en un acto de despecho, sí que podemos asegurar sin miedo a ser tergiversados que la superestructura cobra delantera, en tanto que los sujetos sociales se recrean en ella y sus cambios pueden moldear la base, incluso hasta la quiebra. En mis años de carrera siempre me invitaron sin demasiado éxito a no leer a Lenin por una supuesta falta de rigor en el tratamiento bibliográfico. Lo que es seguro es que a los estudiantes del siglo pasado les dijeron lo mismo sobre Marx. Por ello, nuevamente, me veo obligado a insistir en que el carácter proactivo de la superestructura ya fue señalado por el dirigente bolchevique en la construcción de la estrategia comunista para la conquista del poder. Como sistema capacitado para reunir un aparato ideológico en su seno, la superestructura es el lugar en que se encarna el paso de la clase en sí a la clase para sí. Teniendo como culmen de aquello a la formación del Partido Comunista, encargado de impulsar la bancarrota de un sistema objetivamente agotado frente a cualquier tipo de contingencia espontánea de las masas. Esta última estrategia derivada de las tesis de Lenin, que hace referencia a la incorporación de la conciencia desde fuera del movimiento obrero espontáneo, es valorada por Harvey como estructuralista -muy probablemente por un humanismo que le

\footnotetext{
${ }^{10}$ Si bien, la crítica más certera que podría hacérsele es haber asumido el marxismo como una tradición en detrimento de su objetivo universal. Aunque, aun así, no tengo tan claro que esta afirmación se corresponda del todo con lo expuesto por el propio historiador.
} 
impide comprender que, por mucho que les duela a ciertos negacionistas, la falsa conciencia existe-

Esto vuelve a poner sobre la mesa la idea de que el marxismo no es un corpus cerrado y, a pesar de reconocer lo que otros autores no han hecho en la lectura del GHPC, el profesor americano no habla en toda su obra sobre los aportes teóricos del leninismo y del maoísmo. Hecho por el que se ve constreñido al no conocer, por ejemplo, los argumentos de Lenin en su Estado y revolución, en aquello que respecta a la línea de masas o al sistema de contradicciones en el proceso de construcción comunista.

Rescatando uno de los argumentos anteriores, no deja de llamar la atención como los miembros del GHPC que son más susceptibles de crítica acaban por ser los más ensalzados frente a quienes, como Hobsbawm, fueron atacados siguiendo la idea de que aquel se apegaba demasiado al modelo base-superestructura y a la militancia política como si abandonar esta última fuese un requisito para librarse de cualquier prisión ideológica-. Lo que no entienden los críticos es que el deseo de nuestros protagonistas no era mitigar la teoría de la lucha de clases o destruir el modelo binario estructural, sino que lo que estaban haciendo era aplicarlo lo más ajustadamente posible a la historiografía. De forma que el distanciamiento de este modelo no puede ser interpretado como una superación del mismo -lo que llevaría al marxismo a un nuevo estadio- sino como una desviación teleológica al entender la superestructura de manera estática, tal y como haría el althusserianismo. En conclusión, existe una tendencia generalizada a intentar desacreditar la teoría marxista más que a comprenderla. Algo que, si se quisiera, puede explicarse en el siglo pasado a causa del dilema provocado por una Europa segmentada en trincheras y una Guerra Fría de por medio. Si bien, hoy resulta difícil de asumir, en tanto que el trabajo intelectual está custodiado por un escenario democrático que, supuestamente, poco tiene que ver con el totalitarismo y las dictaduras. De forma que la investigación universitaria no debería tener miedo a la purga ni a la obligación de convertirse en un férreo militante. Aunque, a mi parecer, esto constituye un ejemplo más de como la intelectualización y la erudición sirven también a un propósito político.

No siendo casualidad que, dentro del cuerpo docente universitario, incluso entre los más propensos a valorar el marxismo británico, existe una clara vocación antimarxista ya sea por condenarlo o por usarlo como atajo ideológico en favor de terceras vías, cuya 
única hermandad con el marxismo es su oposición a él-. Hasta ahora he tratado de demostrar que no existe una superación del modelo base- superestructura, sino que, al contrario, lo que encontramos es una defensa del mismo y de la manera correcta de aplicarlo. Llegado a este punto, pretendo esbozar el ejemplo histórico con el que trabajaré durante mi exposición, pero primero he de remitirme al contexto investigativo que ocupó al GHPC y que no es otro que la propia Inglaterra.

Christopher Bayly, uno de los historiadores más reconocidos en el trabajo de la historia global y de la Gran Bretaña imperial, refiriéndose al origen de la historia y los paradigmas hobsbawmsianos comenta que su libro El nacimiento del mundo moderno (1780-1914) "no está diseñado para debatir temas de causalidad profunda, lo que si propone es que una historia mundial debe postular una interacción más compleja entre la organización política, las ideas políticas y la actividad económica". ${ }^{11}$ A mi juicio, Bayly presenta un error fatídico, puesto que para dar con todo lo que propone no hay interacción más compleja que el cuestionamiento del concepto de la historia y de la creación de la sociedad. En este sentido, observamos como nunca se acaba por querer responder con perspectiva histórica a la cuestión última fundamental y que no es otra que la transformación del mundo en vez de su mera contemplación. Teniendo como objeto de estudio el mismo escenario, los marxistas británicos no se quedaron en una descripción más o menos compleja- sino que arremetieron en sus presentaciones contra las bases mismas del entendimiento. Pero para ser alguien que no escribe una obra en aras de discutir temas de causalidad profunda, Bayly tiene tiempo de señalar lo equivocado que estaba Hobsbawm, citando nada más y nada menos que a uno de los mayores escapistas del marxismo, Perry Anderson. De este último se cita, con la pretensión de enmendar a Hobsbawm, que "los grandes avances intelectuales y políticos del XIX no siempre siguen una cronografía que refleje el crecimiento del poder del capital industrial". ${ }^{2}$

Este es uno de los numerosos ejemplos que manifiestan el intento de "innovar" el marxismo y su modelo. Siendo este el contexto en que, al igual que Thompson anteriormente, Charles Bettelheim recuerda que gente como Perry Anderson quiere hacer marxismo en detrimento del mismo. El economista francés acierta rotundamente, puesto

\footnotetext{
${ }^{11}$ Christopher BAYLY: El nacimiento del mundo moderno (1780-1914), Madrid, Siglo XXI, 2010, p. XXIX.

${ }^{12}$ Ibid., p. XXVIII.
} 
que el propio Hobsbawm responde a la crítica de su contemporáneo en algo que no reparó aquel. Y es que en uno de sus ensayos sobre el estudio del capitalismo industrializado, comenta que "los negocios capitalistas pueden adaptarse a operar dentro de un marco en general feudal, aceptar sus limitaciones y la peculiar demanda de sus servicios, convirtiéndose, en cierto sentido, en parasitarios de este". ${ }^{13}$ Con esto demuestra que un análisis dialéctico de la sociedad constata que un producto no se define exclusivamente en torno a un sólo aspecto -como en este caso se pretende sugerir de la clase respecto a la economía-. Algo que ya indicó muchos antes, como se ha venido repitiendo desde el principio, el propio Marx y que sucede de la misma forma con la superestructura. De facto, sí esto no fuera así, hubiera sido imposible que el ideólogo alemán concibiera una teoría revolucionaria veinte tres años antes de la Comuna de París.

Por continuar con Perry Anderson, este afirma que el feudalismo y el paso al capitalismo no es resultado de la contradicción existente en el primero porque en ese caso hubiera sucedido así en otros lugares al margen de Occidente. ${ }^{14}$ Es decir, niega que el paso de un sistema a otro sea la caducidad histórica atravesada por factores que van de lo social a lo político, pasando por supuesto por lo económico. Aunque, posiblemente recreándose en el mismo fallo que sus predecesores, aquel solo entendía el planteamiento en clave económica y de ahí su negación. Si bien, al igual que Hobsbawm, el resto de sus socios británicos trabajaron desde la perspectiva que entiende el feudalismo como un modo de producción del que se desprenden las relaciones sociales mantenidas entre los individuos, moldeadas al fuego lento de un aparato ideológico, político y cultural.

A Perry Anderson y sus aliados les gusta enredar teóricamente una situación tan simple como la que resolvieron los británicos conceptualizando la "historia desde abajo". Sea el motivo que sea, en el fondo de la explicación siempre se hallará un antagonismo entre dos grupos irreconciliables por las condiciones mismas de su existencia sobre un

\footnotetext{
${ }^{13}$ Eric HOBSBAWM: En torno a los orígenes de la revolución industrial, México, Siglo XXI, 1975, p. 20. ${ }^{14}$ Originalmente Perry ANDERSON hace referencia a la Europa oriental y a Japón, aunque también puede extrapolarse a China y Latinoamérica. Una vez más, podríamos afirmar que de haber estudiado las propuestas teóricas de marxistas como Mao -véase la Nueva Democracia y la división interna del campesinado- no cabría decir algo así. Si bien, en este caso, en uno de los artículos anónimos publicados en la New Left Review, editada por Perry Anderson, se afirma que "el maoísmo, en ciertos aspectos, superaba a Lenin". Georgy ELLIOT: Perry Anderson. El laboratorio implacable de la historia, Valencia, Universitat de València, 2004, p. 119.

Aunque esto, quizás, nunca tuvo mayor importancia para un marxismo occidental que reducía el maoísmo a las células izquierdistas francesas y británicas.
} 
modo de producción que no aloja la posibilidad de diluir su diferencia. Es decir, la lucha de clases, que en el caso del feudalismo está protagonizada por señores y campesinos. ${ }^{15}$ La renuncia a fijarse en las relaciones entre individuos es lo que lleva a hablar de cuestiones abstractas en que no se tiene en cuenta su papel como sujetos activos. Rodney Hilton es el más claro al respecto cuando discute la postura de historiadores como Georges Duby, a quien critica no considerar el campesinado como un elemento activo sino como un sujeto pasivo políticamente que solo estalla en tiempos de crisis. ${ }^{16}$ Este mismo hecho se encuentra hoy en el análisis del lumpenproletariado residente en reductos marginales de las ciudades industriales, siendo este el objeto de estudio al que quería llegar y que usaré en el próximo apartado.

En cualquier caso, la reacción ante una crisis que amenaza la supervivencia familiar o la necesidad de adoptar formas de trabajo modernas para adecuarse, directa o indirectamente, a una flamante realidad como puede ser la industrial, evidencia el surgimiento de unas condiciones que, ineludiblemente, hacen necesaria la construcción de nuevos actores. Por ello, aunque Anderson no quiera verlo en términos de caducidad y reposición de un producto nuevo, en términos de progreso sucede exactamente lo mismo. Ya que todo avance contiene forzosamente la experiencia de un pasado que ha dejado de funcionar. Máxima sólo incomprendida por aquellos que, por el motivo que sea, renuncian al materialismo histórico y dialéctico.

\section{El problema de la "falsa conciencia"}

Una vez resuelto el problema del modelo base-superestructura, se derivan otros muchos que he querido reflejar en el que atañe a la falsa conciencia. Asumiendo que, efectivamente, la superestructura es el tablero en que los individuos pueden adoptar una conciencia u otra, en este apartado voy a reclamar la validez de la falsa conciencia como producto de la alienación. Siendo estos términos acuñados por Marx, otro de los grandes campos usados para oprobiarlo ideológicamente. Aunque en el fondo de esta misma cuestión, así como en la tratada hace un momento, reside la crítica a si es correcto afirmar

\footnotetext{
15 Para los que en este punto se pregunten cómo es posible hablar de clases en el feudalismo es recomendable, entre otras, la lectura de Edward THOMPSON: La formación de clase obrera en Inglaterra, Madrid, Capitan Swing, 2012.

${ }^{16}$ Esto sería tratado más tarde por Eric WOLF: Los campesinos, Barcelona, Labor, 1982, e ÍD., Las luchas campesinas en el siglo XX, México, Siglo XXI, 1972.
} 
la existencia de la explotación explicada en la teoría del plusvalor.

Nuevamente, Harvey pondera que uno de los triunfos del marxismo británico, concretamente de Maurice Dobb, es negar la falsa conciencia que se ha atribuido a la clase obrera desde la teoría marxista. Esta negación es ampliamente aceptada en la Academia y también en el imaginario colectivo de una sociedad convencida de que ostenta un libre albedrío pleno -entre otras cosas, gracias a la conquista de la “democracia" y al sentimiento de un pasado bélico ya fulminado, aunque esto no fuera así como testimonia la Guerra de Yugoslavia-. Sin embargo, aplicando marxismo al propio marxismo, encontramos que esto no puede ser un logro, ni una verdad comprobada. Para explicarlo, he considerado oportuno rescatar a uno de los viejos contertulios de la discusión generada en la historiografía y la sociología del siglo pasado, Immanuel Wallerstein. Este científico social estadounidense es uno de los mejores representantes del determinismo económico funcionalista. Su propuesta estrella, el concepto de sistema-mundo, bebe intelectualmente de Marx y Braudel, algo que denota ya su eclecticismo. No obstante, no me interesa rescatar al Wallerstein de aquella época basada en los debates sobre la transición del feudalismo al capitalismo -lo que le llevó, como supondrán, a medirse con el GHPC-. Quisiera traer al Wallerstein que ha opinado en los últimos meses sobre la "inesperada" elección presidencial del empresario republicano Donald Trump en los Estados Unidos de América, especialmente con su artículo sobre La falsedad de la falsa conciencia. En este último, Wallerstein expone un análisis correcto de por qué los más perjudicados por una personalidad como la que encarna Trump son aquellos que le han votado.

Resumiéndose dicho análisis en que los "deplorables" -por usar el término empleado por Hillary Clinton, la opositora del republicano- simplemente dirigieron su voto a lo que consideraban una alternativa al establishment, resultando la paradoja de que el presidente electo es quien mejor lo encarna. Pero la cuestión aquí no es debatir sobre el mecanismo político estadounidense y la legitimidad de sus actores, sino mostrar que el análisis de Wallerstein acaba por pervertirse en el momento en que saca a relucir su concepción funcionalista del mundo. Y dice el sociólogo americano, "el lenguaje de la falsa conciencia es una forma de ocultarnos a nosotros mismos que todo el mundo 
persigue su propio interés, incluso los deplorables". ${ }^{17}$ En su artículo acaba llamando a entender y no simplemente a esputar improperios contra los votantes. Aunque estoy totalmente de acuerdo, lo que debería entender Wallerstein es que la falsa conciencia, cómo el mismo puede deducir de sus palabras, también reproduce la persecución de intereses. Ahora bien, de unos intereses subjetivos que no responden a la posición objetiva de los individuos en sociedad. Por lo que, a efectos conceptuales, no viene a demostrar la falsedad de nada. Siguiendo la defensa anterior del modelo base-superestructura, puede plantearse que la falsa conciencia, como producto de la alienación, no deja de tener un grado de autonomía respecto al papel asumido como mano de obra-al desarrollarse como consecuencia de las relaciones sociales existentes en el aparato cultural-. De esta forma, la falsa conciencia no sólo es un hecho, sino que, además, permite entender cómo los dominados objetivan para sí los intereses de una clase que los ostenta, como tal, gracias a la explotación que ejercen sobre quienes aspiran a poseer lo que ella. Llegados a este punto merece la pena hacer un breve inciso.

Apostillado frente a la validez de la falsa conciencia y de la alienación, gran parte del negacionismo se construye desde posiciones morales fundadas, a grandes rasgos, en la religión o en el humanismo de los marxistas renegados como Sartre. De este tipo de rechazo a la falsa conciencia se desprenden ataques al marxismo versados en el argumento de que si la trasmisión de la ideología se hace desde fuera y con autonomía del movimiento obrero es porque "un partido, una secta o teóricos particulares" consideran que aquel es necio e incapaz. ${ }^{18}$

No siendo casualidad que en las diatribas de estos predicadores se acabe asegurando que, además, cómo va a ser posible que los trabajadores comprendan las palabras de esos pedantes sectarios que se hacen llamar comunistas. Ante lo que yo me pregunto, ¿quién está menospreciando entonces a los obreros ${ }^{19}$ Empero, los marxistas británicos

\footnotetext{
17 Immanuel WALLERSTEIN: "The Falsity of False Consciousness", Immanuel Wallerstein, 2017, http://iwallerstein.com/the-falsity-of-false-consciousness/ [consulta 15 de abril 2017].

${ }^{18}$ Harvey J. KAYE: Los historiadores..., p. 218.

${ }^{19}$ En la mayor parte de los debates, estos pretendidos defensores del obrero que niegan su condición de alienado, también acaban por negar su explotación - por la negación comentada de la teoría del plusvalor. Empero, para reafirmarse en ello, deben trazar argumentos económicos que, paradójicamente, les hacen sucumbir ante el economicismo que tanto "detestan". Frente a lo que Thompson legó también una crítica brillante cuando "muestra que la explotación, incluso en el sentido estricto de las relaciones económicas, supone causas tanto subjetivas como objetivas. De esta forma deja bien claro que la explotación no es un mero concepto inventado por marxistas preocupados por la política y la economía con intenciones
} 
comprendieron que "el historiador debe saber qué papel ha desempeñado la conciencia social y política de las diversas clases a la hora de acelerar o retardar el ritmo del desarrollo capitalista. Puesto que esa conciencia no es un reflejo directo de la actividad económica de esas clases, el historiador tiene que preocuparse del derecho, de la política y de la religión. La sociedad y su actividad han de ser examinadas en su totalidad". ${ }^{20}$ Por ello, una de las variables por las que el capitalismo salió fortalecido fue, tras el fin del belicismo frío que asoló el globo, la estrategia neoliberal de blindar la falsa conciencia impulsando el individualismo, aumentando el consumismo y aprovechando la disgregación política de una izquierda que había resultado desprestigiada.

Quizá una de las razones por las que no se asume la falsa conciencia es por la perspectiva tomada sobre el sujeto que se observa. Aunque, incluso, sería más apropiado decir sobre el sujeto que no se tiene en cuenta. La creación de la historia desde abajo es, sin duda, a efectos metodológicos, el más importante de los aportes realizados por el GHPC, precisamente por abolir la prisión del olvido en que se encontraban muchos sectores de la sociedad. Aplicando el análisis de la lucha de clases - que no el análisis de clases, grupos o estamentos- se puso a voz quienes, por su condición de inferioridad en el sistema, vieron como un imposible la constatación de su experiencia. A pesar de que hubieran sido parte fundamental de la historia misma.

Con Hobsbawm a la cabeza, se inaugura un afán por explicar la clase obrera en su conjunto y todos aquellos mecanismos en los que se viera envuelta. Lógicamente, aquello no era tarea de una sola generación y algunos nos consideramos herederos de tal preocupación ante el nuevo siglo en que nos vemos insertos. Si bien, manteniendo el mismo espíritu con que se criticaba a Marx no haber tratado algunas cuestiones, algunas personas criticaron al GHPC no haber abordado el tema de la aristocracia obrera o, al menos, no haberlo hecho con el suficiente tesón.

Aunque sus postulantes fueron un alemán y un ruso, Engels y Lenin, el concepto de aristocracia obrera se deriva fundamentalmente de la historia británica, en la que Hobsbawm también encontró razones para dialogar con los aludidos y llevar el debate

moralizantes, sino que fue claramente sentida por quienes realmente la experimentaron". Harvey J. KAYE: Los historiadores..., p. 170.

${ }^{20}$ Rodney HILTON: “Capitalism: What's in a name?”, Past and Present, 1 (1952), p. 157. 
sobre la aristocracia obrera a un nuevo estadio en que no solamente alabó los análisis del dirigente bolchevique, sino que también aprovechó para corregir alguna de sus limitaciones. ${ }^{21}$ Justo este año hace un siglo que Lenin señaló, viendo la llegada del imperialismo y de la revolución proletaria, que en los países imperialistas la clase obrera se escindió en dos alas. Por una parte, la masa inferior y honda, en donde se destaca el lumpenproletariado. Y, por otra parte, la superior, es decir, la aristocracia obrera, quien ostenta mayor privilegio económico por el escalón que ocupan sus Estados en la cadena imperialista. Algunos apuntaron que la conformación de la aristocracia obrera es producto de la distinta posición de autoridad en el proceso de producción y no de la brecha salarial dentro de la clase obrera. En cualquier caso, la evidencia es que se produce un divorcio entre esta última y el nuevo sector enriquecido. Estas explicaciones vuelven a ser aprovechadas por algunos interesados, como Robert Gray, para acusar de economicistas a Lenin y Hobsbawm. Algo que vuelve a desmontarse atendiendo a la forma correcta de entender el modelo base-superestructura. Pues, al tiempo que la aristocracia obrera es un producto del sistema económico, su perdurabilidad se debe a la gestación de una conciencia sindical -he aquí un ejemplo de falsa conciencia- que bloquea el desarrollo revolucionario de la clase obrera a favor de un papel acomodaticio y negociador.

Algo que se puede comprobar, simplemente, leyendo a los repetidamente acusados. Para lo que vuelvo a tomarme el lujo de dejar que ellos hablen por mí.

Sobre la indicada base económica, las instituciones políticas del capitalismo moderno prensa, parlamento, sindicatos, congresos, entre otros- han creado privilegios políticos, correspondientes a los económicos, para los empleados y obreros respetuosos, mansos, reformistas y patrioteros. La burguesía imperialista atrae y premia a los representantes y partidarios de los 'partidos obreros burgueses' con lucrativos y tranquilos cargos en el gobierno o en el comité de industrias de guerra, en el parlamento y en diversas comisiones, en las redacciones de periódicos legales 'serios' o en la dirección de sindicatos obreros no menos serios y obedientes a la burguesía. ${ }^{22}$

Podemos considerar a la aristocracia obrera como un caso especial de este modelo general. Surge cuando las circunstancias del capitalismo permiten garantizar unas concesiones significativas al proletariado. Algunos de cuyos estratos logran por su escasez,

\footnotetext{
${ }^{21}$ Sobre ello pueden consultar Eric HOBSBAWM: "Lenin and the Aristocracy of labor", Monthly Review, 21 (1970), s. n.

22 LENIN: "El imperialismo y la escisión del socialismo", Marxists Internet Archive, 1916, https://www.marxists.org/espanol/lenin/obras/1910s/10-1916.htm [consulta 16 de abril de 2017].
} 
cualificación, posición estratégica o fuerza organizativa, establecer para ellos unas condiciones notablemente mejores que las del resto. Por tanto, hay situaciones históricas, como a finales del siglo XIX en Inglaterra, en las que la aristocracia obrera puede casi identificarse con el movimiento sindical, como a veces Lenin prácticamente sugería. ${ }^{23}$

Asimismo, al carácter superestructural estrictamente político que se refleja en las citas anteriores, también pueden sumársele atributos culturales en que las propuestas de ocio o educación contratadas por la clase dominante se convierten en el deseo de las clases dominadas. Donde este último anhelo se convierte en el techo, hasta cierto punto utópico, de unos desposeídos a quien sólo les queda la actitud de resistir como única herramienta para defender aquello que tienen. Una resistencia legítima pero inútilmente espontánea desde el punto de vista revolucionario y "previsiblemente" organizada en tanto que única ofensiva radicalizada para los reformistas. Por eso Thompson señaló con gran acierto que la espontaneidad no es sino una cultura del comportamiento que responde al sentido común de quien se ve amenazado. Siendo la transmutación de este "sentimiento" en conciencia de clase lo que evidencia la lucha entre ellas. Pero antes de acabar y a razón de estas últimas reflexiones, quisiera ilustrar lo planteado con un ejemplo de caso.

Prestar atención al sistema cultural en que los sucesos de vida y la memoria empírica de los individuos ayudan al historiador a comprender su esquemática social es un hecho sumamente importante presentado por la historia desde abajo -como también podría plantearse hacer con una historia desde arriba-. Ahora bien, yendo esta vez contra el propio Thompson o, mejor dicho, contra lo que han hecho de él los thompsonianos, considero un error interpretar la "experiencia" como un tercer brazo en la dicotomía propuesta por el modelo base (objetividad)-superestructura (subjetividad), así como en la concepción de una conciencia falsa o cierta.

Sería un absurdo en tanto que toda experiencia desarrollada como parte de la superestructura es una plasmación subjetiva del individuo. Esa interpretación ha dado lugar al pensamiento de que un obrero puede ser consciente de su opresión y no hacer nada para solucionarlo. Pero de ser así no estaríamos hablando de lo que significa verdaderamente el concepto de "conciencia de clase". Ahora bien, para entender una opinión tan extendida como la de que los obreros son conscientes de su opresión y no

\footnotetext{
${ }^{23}$ Eric HOBSBAWM: "Lenin and the Aristocracy of labor", Monthly Review, 21 (1970), s. n.
} 
abrazan el comunismo porque aquel fracasó estrepitosamente, podemos plantearnos dos premisas. La primera es que posiblemente estemos en una etapa donde prima una "alienación de nuevo tipo" reforzada por mecanismos culturales más férreos como consecuencia del auge neoliberal, tal y como se apuntó con anterioridad. La segunda es que la situación en que se da hoy la formación de la conciencia de clase difiere totalmente respecto a la relatada por Thompson para el caso británico. De ahí la necesidad, por encima de todo como decía Hobsbawm, de asumir una perspectiva histórica. Por obvio que parezca, debe insistirse en que el perfil de un obrero industrial del siglo XIX es totalmente diferente al de un trabajador inserto hoy en una sociedad en que la ideología revolucionaria no está desplegada y su única adhesión puede traducirse en el seguimiento de una aristocracia obrera codificada en sindicatos acostados bajo la nube de un tiempo "revolucionario" que ya pasó para ellos.

Asimismo, a esto último se le sumaría la importancia de definir la historia personal, desde abajo, de cada sujeto o colectivo. Puesto que no es lo mismo una familia del reducto marginal madrileño conocido como Cañada Real Galiana, dedicada a la pintura de carrocería y cuyos hijos abandonan la escuela de manera temprana, que una familia obrera afincada en un piso de IVIMA situado en un barrio acomodado, respaldada por trabajos temporales en el sector servicios, con subsidios de algún tipo y cuyos hijos prosperan educativamente. Normalmente se asume que, gracias a la educación, los hijos del segundo núcleo familiar tendrán capacidad de maniobra para generar conciencia política y los hijos del primero no. Si bien, esto no es tan simple porque el problema en la conformación de la clase, de su conciencia y de la lucha que puede seguirla, no se limita al determinismo que muchos han querido atribuir al marxismo.

Si en algo tuvo razón Chayanov y los que le siguieron es en que los campesinos diferían por completo de los capitalistas. La distancia entre el campo y la ciudad que señalaba Christopher Hill en su ejercicio sociológico de la cultura, precisamente, se codificaba en que los campesinos ansiaban asegurar aquello que tenían en forma de alimento y de posesión terrenal para, en el mejor de los casos, poder sacar un tímido beneficio que les permitiera seguir subsistiendo en términos productivos. Frente a ellos, los capitalistas se caracterizaban por competir por la obtención de beneficios con que aumentar su reserva monetaria. Como vemos, esto último es lo que se ha planteado en términos más abstractos párrafos atrás y que cobra sentido cuando se desciende al análisis 
histórico. Esto mismo sucedería hoy con el lumpenproletariado y, en general, con la clase obrera más alejada de sus hermanos aristócratas.

Podemos decir que el lumpenproletariado -en el que nos es casualidad que se integren mayormente minorías y colectivos históricamente oprimidos- es la sección de la clase obrera excluida del proceso productivo y a la que se margina socialmente. En el caso español y europeo, uno de los grupos más reconocibles que integra ese sector es el gitano. Aunque extensible al paradigma ibérico en general, desde que los gitanos entraron en España por primera vez en 1425, hubieron de esperar hasta bien entrado el siglo XIX para ver reconocidas como legales aquellas prácticas oficiosas que practicaban, entre las que destaca por encima de todo el mercado de caballerías. Este hecho, inevitablemente, acompañado por otras variables como las guerras o las epidemias, arrastraba a muchos gitanos -así como a otros elementos socialmente marginados- a la delincuencia que conocemos desde el presente, fundamentada principalmente en el robo.

Esto último, manifiesta una constante histórica en la que los desposeídos adoptan mecanismos de supervivencia social que suponen una resistencia al sistema normativo. Esta situación se radicaliza con el surgimiento del capitalismo, el cual fomenta la miseria de una población que crece constantemente por los impulsos demográficos de un nuevo contexto industrial incapaz de enfrentar el fuerte éxodo a las ciudades. Las crisis del capitalismo también se traducen culturalmente puesto que los propios discursos de la clase obrera arrojan una visión en que prima un aparente mundo sin esperanza posible. Las personas que asumen esa visión pierden cualquier objetivo de transformación a largo plazo para, como es lógico, sobrevivir diariamente ante unas condiciones angustiosas.

Ahora bien, este último peldaño de la pirámide social tiene un papel económico importante y no se puede desdeñar. Como el campesinado rebelde definido por los marxistas británicos, las personas en situación de miseria absoluta que integran el lumpenproletariado juegan un papel activo en el proceso de su propia conformación. Es decir, son lo que son porque deben existir y que deban existir implica que, sin ellos, el sistema carecería de fortaleza productiva y, por ende, de legitimidad política. Como señalaban Joseph Stiglitz y otros neokeynesianistas, paradójicamente, el análisis de las políticas keynesianas muestra como las ayudas a los más desfavorecidos tienden a desaparecer en época de crisis, justo cuando son más necesarias. 
Con el derrumbe de los Estados de bienestar y el auge del neoliberalismo, la vulnerabilidad del lumpenproletariado es lo que edifica una suerte de purgatorio de la conciencia en que el vacío existente permite la entrada a cualquier elemento que traiga, por pequeño que sea, un margen de mejora a la situación de miseria. De ahí que el lumpenproletariado haya sido tradicionalmente reconocido por el marxismo como un agente potencialmente reaccionario, ya que una cama caliente es igual en un hospicio comunista o en uno capitalista. Por ello, los "marginados" no son inadaptados como se ha tendido a pensar. Al contrario, se caracterizan por conocer mejor que nadie el juego del sistema. De ahí que la conciencia de clase sea una clave, puesto que la maximización de la alienación lleva, en estos casos, a una privación de la conciencia que acaba por resolverse en falsa. Sirviendo de manera decisiva al capitalismo como chivo expiatorio al que cargar con la culpa de alguna situación que se quiera justificar.

\section{Una defensa del materialismo histórico en vista al nuevo siglo}

Con todo lo que hemos visto hasta ahora, queda bastante claro que la conceptualización de Eugene Genovese al referirse al materialismo histórico como la "teoría del determinismo de clase" no es para nada precisa. La reivindicación del análisis de la lucha de clases con perspectiva histórica viene a superar el viejo debate en torno al planteamiento que los idealistas hacen de la "idea". Incapaces de contemplar que el individuo, como ser social, desarrolla su esquema ideológico a partir de la materia que percibe en un ejercicio cognoscitivo guiado por la razón. Sin embargo, después de varios siglos, este principio elemental de la filosofía no es asumido por muchos de los detractores del materialismo en general. Ahora bien, no es casualidad que, en el oficio de la historiografía esos mismos seguidores del idealismo y de la metafísica se vean obligados a depender del análisis materialista.

De lo contrario estarían anquilosados en la misma narración de tipo historicista que las crónicas, teniendo a las fuentes como única materia prima. Viéndose mucho más perjudicados ante la crítica del relativismo, puesto que "las ideas dominantes en una época han sido siempre las ideas propias de la clase imperante". ${ }^{24}$ De ahí la enorme importancia de una historia desde abajo o desde arriba pero realizada críticamente. Por ello, en

\footnotetext{
24 Karl MARX y Friedrich ENGELS: "Manifiesto comunista", Marxists Internet Archive, 1848, https://www.marxists.org/espanol/m-e/1840s/48-manif.htm [consulta 16 de abril 2017].
} 
términos de materialidad, la historia sigue un curso inevitable como producto de las contradicciones que se originan en el seno de las sociedades. Si proféticamente el marxismo hubiera defendido esto último con la intención de mostrar que nos enfrentamos a una imparable historia determinada, el capitalismo ya hubiera dado paso a la etapa socialista sin ningún esfuerzo humano. Sin embargo, esto no ha sido así debido al margen subjetivo de actuación que los individuos guardan respecto a las relaciones productivas. Por eso Marx, al reconocer el curso de la historia como inevitable, concedía mayor importancia a los individuos en la gestión de dicho discurrir. Aquellos que asumen como agotada la tesis del fin del capitalismo a causa de la obstaculización en el desarrollo de sus fuerzas productivas es porque, paradójicamente, vuelven a refugiarse en el economicismo que tanto atribuyeron a la teoría marxista. Al mismo tiempo que, en el plano de la construcción ideológica y de la conciencia, son incapaces de comprender que por la filosofía misma del marxismo no cabe pensar en una derrota sino en un repliegue estratégico desde el que emprender una nueva ofensiva. Que esto sea difícil de concebir se debe al pensamiento de que las ideas son inmutables y que, cuando caducan, lo hacen para siempre. Esta es la razón por la que las corrientes ajenas al marxismo han engendrado y engendrarán sin control toda una prole de nuevas formas teóricas, esencialmente idénticas en su fracaso, pero distintas en sus propuestas.

El marxismo, en cambio, no necesita de "versiones mejoradas" en su maquinaria ideológica. Esto se debe a que -hasta que se demuestre lo contrario-el marxismo fue y seguirá siendo la ideología más avanzada. En tanto que aquel, por su forma de comprender el mundo, forja sus propias mejoras siendo capaz de asimilar otras que se hayan podido desarrollar fuera de sí. ${ }^{25}$

De esta forma, por su propia condición, el marxismo tiene las herramientas necesarias para desarrollarse y no necesita transmutar a otra conciencia ideológica en una incansable búsqueda de lo aparentemente irresoluble. De ahí que el marxismo siga siendo marxismo, con toda su plenitud revolucionaria -aunque se encuentre en un periodo de latencia-. La solución a este cónclave de cuestiones "irresolubles" tiene una salida muy sencilla, el debate. Entonces, ¿cuál es el problema? Pues bien, los abanderados por las

\footnotetext{
${ }^{25}$ Es el caso de la revalorización del sistema cultural en la definición de las identidades. Frente a ello, la posición marxista no es otra que asumirlo y sintetizarlo críticamente.
} 
diferentes corrientes empeñadas en el fracaso no quieren entrar en una lucha entre dos líneas en el que el marxismo siempre triunfa. La imposibilidad de vencer al marxismo en la carrera hacia la objetividad epistemológica ha derivado en el también simple argumento, por no decir patoso, de que el marxismo se agotó en el pasado siglo -quien no lo vaticinó antes, como algún Böhm Bawerk-. Las conclusiones de esta breve reflexión son las siguientes. Por un lado, no toda evolución empírica acumulativa de teorías contempla una superación de limitaciones. Frente a lo que la lucha entre contrarios, es decir, el materialismo dialéctico, si propone una síntesis consciente en el sistema de contradicciones que permite su autosuperación. Por otro, cuando el marxismo deja de aplicarse a sí mismo la teoría revolucionaria, ya no es marxismo -aunque nuestros más excelentes revisionistas, en cualquier de los campos, quieran hacerlo ver así, acompañando al término de otros conceptos que no hacen sino, una vez más, mostrar su pasión por la trama de lo "irresoluble" desde cualquiera que sea la corriente teórica que esté en boga- .

A razón de todo ello, aunque igualmente importante, muchos de los debates se han reducido a discusiones terminológicas. En su momento los estudiosos que no eran marxistas y siguieron con mayor devoción a Weber o Durkheim, pusieron en duda algunos conceptos usados en el debate sobre el paso del feudalismo al capitalismo. Hoy esas mismas dudas se reproducen con el cuestionamiento de si se puede hablar de "clase", "conciencia de clase" o "lucha de clases". Entendiendo el primero como base de los que le siguen. Ahora bien, teniendo claro que el oficio del historiador no es lo que deseó Ranke y el positivismo en general, cabe preguntarse si aquellos que defienden el agotamiento terminológico de conceptos como "burguesía" o "proletariado" lo hacen por contribuir científicamente a la historiografía o por evitar una potencial acción política.

Esto es algo que llamó la atención a Raymond Williams en el siglo pasado y que he considerado menester destacar, puesto que el reto para los historiadores que se centran en el presente es tener en cuenta la significación tanto ideológica como política de sus escritos y no solo la perspectiva histórica. De manera ambiciosa, cuando diseñé la redacción de este documento, tuve la pretensión de incluir un apartado dedicado al dilema de la "clase". Si bien, acabé por darme cuenta de que aquello puede extenderse -como les sucedió a los marxistas británicos- por varios tomos, foros y discusiones de todo 
calado. ${ }^{26}$ Aunque la principal razón de no haberme adentrado en dicho debate es que he creído identificar en aquel, justamente, el punto de partida desde donde afrontar la discusión en el nuevo siglo que se inauguró hace diecisiete años.

Aunque sin entenderse en el sentido industrial, la idea de que las clases siguen siendo grupos con conciencia de sí mismas que emprenden luchas -en tanto que se definen respecto a un contrario y no solamente respecto a sí mismas- fue un pilar en la identidad intelectual del GHPC. Sin embargo, la nueva situación a la que nos ha traído la historia, especialmente tras la caída del muro de Berlín, sienta las bases para enfrentarnos a un replanteamiento. No únicamente para que se propongan nuevas vías con que intentar negar la clase, sino también para contrarrestar esa negación desde el marxismo. Pues este último se encuentra, como se expuso al principio, en un estadio superior donde su derrota empieza a ser un eco respecto a las voces revolucionarias que han impulsado su reconstitución frente a toda forma de revisionismos. Y justo aquí estaría el salto respecto al viejo baluarte del marxismo británico. No se trata de usar o recuperar una esencia, como aquellos insinuaron no pocas veces, sino que se trata de reconstituir sometiendo a balance y eliminando aquellos elementos materialmente caducos - por no corresponderse con la realidad-que imposibilitan el progreso de la propia teoría.

${ }^{26}$ La estela de esta polémica se ha seguido contemplando en los últimos años con encuentros. 


\title{
SCRIPTORIA III
}

\section{MEMORIAS E IDENTIDADES. SOBRE POSICIONAMIENTOS COMPROMETIDOS EN INVESTIGACIÓN CON FUENTES ORALES PARA LA (RE)ELABORACIÓN DE LA HISTORIA RECIENTE}

\author{
Vicent Bellver i Loizaga (Universitat de València) \\ Soraya Gahete Muñoz (Universidad Complutense de Madrid) \\ Sara Martín Gutiérrez (Universidad Complutense de Madrid) \\ Pau López-Clavel (Universitat de València)
}

Qué raro que seas tú

quien me acompañe, soledad,

a mí, que nunca supe bien

cómo estar solo

"Soledad", Jorge Drexler 


\section{Introducción}

Hacer ciencia es un trabajo solitario. Dicen que todxs morimos solxs al final, así que eso tampoco sería tan grave, dentro de la lenta agonía que muchxs de nosotrxs vivimos al realizar un proceso de investigación largo dentro del mundo académico. Bromas aparte, no es lo mismo trabajar solo/x que estar a solas, y en investigación histórica suele producirse una sensación de soledad añadida, debido al hecho de nuestro trabajo en los archivos, o sobre cosas ausentes, que ya no son o están. Sin embargo, la metodología de las fuentes orales nos ha permitido entrar en contacto con una nueva dimensión a la hora de hacer y pensar la Historia. Nos ha posibilitado salir de la soledad en la que trabajamos, casi aisladxs, en nuestros departamentos, con nuestros papers, sólo roto por algunos encuentros con colegas en seminarios o congresos. Ello, sin embargo, también ha reforzado las consecuencias del hecho de trabajar desconectadxs de otras personas, al hacer emerger grandes conflictos, emociones, sentimientos y problemáticas. Las cuatro personas que aceptamos fusionar nuestras propuestas iniciales y presentar un scriptoria conjunto para este VI Encuentro en Zaragoza lo hicimos teniendo en mente la suerte que habíamos tenido de conocernos en Madrid y en València a la hora de salir de nuestro aislamiento, de poder trabajar en solitario, pero no en soledad, y la necesidad de crear espacios más grandes para compartir nuestras experiencias y crear una red de apoyo.

Este texto pretende recoger el espíritu de apoyo de ese encuentro que se produjo en Zaragoza y que fue muy bien recibido, y apreciado, a juzgar por las impresiones que compartimos sobre el mismo, con posterioridad. Por ello, a lo largo de estas páginas, las personas que coordinamos este scriptoria nos limitaremos a plasmar, de la forma más honesta posible, algunas reflexiones críticas que pusimos en común a través de nuestras propias investigaciones, pero, sobre todo, que se debatieron y compartieron entre todas las personas que participamos. Queremos que estas páginas, escritas conscientemente de forma sencilla y sin un gran armazón teórico concreto, sirvan como una continuación del diálogo que se inició en septiembre de 2017, de manera que podamos seguir reflexionando colectivamente sobre quiénes y cómo trabajamos, y también compartiendo experiencias de trabajo y, en definitiva, de vida, especialmente cuando la Historia se vive a través del prisma de la implicación política activa y consciente.

\section{Sobre este scriptoria}

Partiendo de dos proyectos de fuentes orales - Compromiso y militancia femenina en la Transición en España y Trayectorias e historias de vida desde los movimientos sociales valencianos - y tras la propuesta de fusión por parte de la organización del VI Encuentro, lxs coordinadorxs de este taller pretendimos articular un espacio de debate centrado en las fuentes orales y el uso de las mismas en los relatos históricos, partiendo de la premisa de su utilidad no 
sólo para llenar huecos existentes en otro tipo de fuentes, sino por sus potencialidades intrínsecas. El scriptoria que presentamos pretendió abordar las implicaciones - éticas, políticas, metodológicas - de la recuperación de las distintas experiencias del pasado reciente a través de la historia oral. Para ello propusimos un formato de mesa taller que favoreciese el debate y confluencia en torno a diferentes cuestiones.

En primer lugar, la reflexión sobre el uso, utilidad y formas de difusión de las entrevistas: ¿Cómo utilizar las entrevistas? ¿Como un simple material para las investigaciones en curso, o también teniendo en cuenta la intención de muchxs narradorxs que, de forma recurrente, tiene implícita la voluntad de sacar a la luz sus experiencias y de reivindicar su memoria? ¿Qué implicaciones éticas tiene la elaboración, por nuestra parte, de historias de vida, más aún cuando existe una empatía hacia nuestrxs narradorxs, ya sea por su identidad de género, sexual o política? ¿Cómo podemos visibilizar y reivindicar las luchas y experiencias de lxs informantes más allá de nuestros trabajos académicos?

En este sentido, el primero de los ejes de trabajo planteó algunas de las cuestiones que deberíamos incorporar como investigadorxs en nuestros análisis e interpretaciones de fuentes, entre las que destacan el conocimiento profundo del período histórico que abarca la narración personal, y el establecimiento de una diferenciación que valore cuál hubiera sido el relato narrado en el momento histórico por el que se pregunta, y cuáles han sido las modificaciones del relato que a lo largo de los años la persona entrevistada ha podido (re)construir.

En segundo lugar, articulamos también una red de colaboración, posterior al Encuentro, para continuar debates, intercambiar preguntas y caminos, y explorar posibilidades de generación de materiales que permitieran dar forma física a estas fuentes históricas derivadas de las emociones. Para ello se impulsó un grupo de Facebook donde los compañeros fueron intercambiando algunas impresiones y metodologías sobre las memorias e identidades. Una propuesta que, sin embargo, no ha llegado a consolidarse, aunque esperamos que en futuros encuentros pueda recuperarse de alguna forma, quizás a otra escala.

Teniendo esto en cuenta, propusimos los meses previos al evento que lxs compañerxs que lo deseasen, y/o aquellxs que estuvieran elaborando relatos basados en fuentes orales, se animasen a participar de este espacio de reflexión en torno a la pertinencia de las fuentes orales, la historia de las emociones y las cuestiones éticas en cuanto a la articulación relatos sobre aquellxs que fueron silenciados.

Finalmente, además de generar un espacio de debate y análisis en metodologías y contenidos, y siempre con el objetivo de favorecer el impulso de una red de investigadoxs que 
trabajasen sobre dichas temáticas, nos interesó particularmente presentar un pequeño adelanto de este trabajo conjunto. Es decir, se adelantó una pequeña muestra documental sobre cómo la historia se puede difundir más allá de la Academia en otros formatos alternativos, por ejemplo, el multimedia, y puede adquirir otras dimensiones para la construcción de la historia del presente y conectar con la calle a través de las experiencias con memorias orales de Compromiso y militancia femenina en la Transición en España, elaborada por Soraya Gahete Muñoz y Sara Martín Gutiérrez, de la Universidad Complutense de Madrid y Trayectorias e historias de vida desde los movimientos sociales valencianos, una iniciativa más informal de de Vicent Bellver y Pau LópezClavel, de la Universitat de València.

\section{Aportes y dificultades para las fuentes orales}

La metodología de las fuentes orales resulta idónea, junto a otro tipo de fuentes menos exploradas en Historia como podrían ser las audiovisuales, y desde la apuesta por la transdisciplinariedad metodológica, para dar algunas respuestas a las preguntas que plantea, por ejemplo, la participación de aquellos sujetos individuales y colectivos más invisibilizados en el ámbito público, especialmente si sus acciones no quedaron registradas de manera escrita o no se desarrollaron en los mismos términos que el pretendido sujeto político neutro - generalmente masculino y occidental - , así como las formas de hacer historia que de él, y sobre él, se derivan. Sin embargo, plantea una serie de dificultades en su desarrollo, de las que podríamos destacar como principales, y comunes a todo tipo de fuente oral, la localización, la toma de contacto o relación inicial con los sujetos a entrevistar, o qué criterios de selección seguir a la hora de elegir nuestras fuentes. Uno de los conceptos que se trabajaron en el taller como dificultad en la elaboración de fuentes orales fue el definido por Penny Summerfield como composure, traducido al castellano como compostura o autocontrol, es decir, el proceso dual basado en la composición de la narración por parte del entrevistado sostenido en el equilibrio psíquico que mantiene el narrador en la entrevista por la influencia de su audiencia.

Otro de los ejes de debate del taller giró en torno a las distintas modalidades para la realización de entrevistas y su transformación en fuentes orales con diferentes objetivos e inspiraciones, entre las que destacaron la pertinencia de búsqueda de un lugar cómodo y silencioso, sobre todo si pretende realizarse una grabación de sonido o vídeo, tomar la precaución de que el entrevistado/a acuda sola/o a la entrevista, para que no se sienta cohibido/a en su narración. Otras de las discusiones circularon en torno a la pertinencia del uso del cuestionario, el tipo de preguntas que se formularían según los objetivos de la entrevista y la inclusión de los datos personales de los entrevistados/as en una ficha que ayudará al investigador/x en la catalogación y posteriores búsquedas de material de elaboración propia. Ante las nuevas 
regulaciones estatales sobre los derechos de imagen, intimidad y honor, se debatió la necesidad de solicitar diferentes autorizaciones a lxs entrevistadxs.

Finalmente se abordaron distintas formas de trabajar con fuentes orales a través del tratamiento de la información registrada. En este caso se destacó la necesidad de realizar transcripciones y también la puesta en común de distintas entrevistas realizadas, es decir, de los distintos relatos que integran una misma serie de entrevistas, ya sea por tema o por espacio cronológico. En el debate se detallaron los dos aspectos que podían incluirse en dicho análisis: por un lado, la valoración de aspectos cuantitativos: análisis de las conclusiones en torno a las experiencias colectivas. Gracias a este trabajo se reafirman o desechan las hipótesis; por otro, la estimación de aspectos cualitativos: análisis de trayectorias particulares y diferencias en las experiencias de los relatos colectivos. Enriquecen y pluralizan los relatos históricos, lo que supone un elemento indispensable de la narración.

\section{Un aporte para la memoria de sujetos colectivos invisibilizados}

La historia de las mujeres ha utilizado diversas metodologías y perspectivas para la elaboración de una her-story ${ }^{l}$, una trayectoria que no discurre al margen de la historia universal. Una de ellas es precisamente la posibilidad abierta a través de la historia oral. Gracias al impulso de los historiadores sociales que buscaron una nueva orientación de la disciplina histórica con el objetivo de dar voz a los sin voz a partir de los setenta, bajo el camino abierto por Paul Thompson ${ }^{2}$, se empezaría a reconocer, en medio de numerosos debates, un nuevo método basado en las fuentes orales que pretendía recobrar aspectos perdidos de la historia y cubrir los vacíos historiográficos existentes $^{3}$. Desde el scriptoria Memorias e identidades, sobre posicionamientos comprometidos en investigación con fuentes orales para la (re)elaboración de la historia reciente se propuso, que uno de los ejes proporcionase herramientas para la utilización de las fuentes orales precisamente, como espacio para el debate, la proyección y la visibilización de las mujeres.

Como ha señala Penny Summerfield, la historia oral es en realidad un diálogo entre el entrevistado y el investigador, que insta al primero a componer sus memorias. Gracias a este diálogo los sujetos exploran recuerdos y silencios, teniendo en cuenta también las diferencias de

\footnotetext{
1 Joan W. SCOTT: Only Paradoxes to Offer: French Feminists and the Rights of Man, Cambdrige (Massachusetts), Harvard University Press, 1996.

${ }^{2}$ Paul THOMPSON: La voz del pasado: la historia oral, València, Alfons el Magnànim, 1988.

${ }^{3}$ Penny SUMMERFIELD: "Oral History as an Autobiographical Practice”, Miranda, Multidisciplinary peer-reviewed journal on the English-speaking world, 12 (2016), p. 2; y "Culture and Composure: Creating narratives of gendered self in oral history interviews", Cultural and Social History, 1/1 (2004), p.66. Véase también Ana AGUADO (coord.): "Historia de las mujeres y fuentes orales", Arenal, 4/2 (1997), pp. 177254.
} 
género y sus tensiones, y de esta forma construyen una subjetividad basada en el lenguaje, la relación con la cultura de la memoria y las dinámicas propias de la entrevista ${ }^{4}$. El género se entrecruza con la cultura y la memoria en la historia oral e influye de la misma forma en la construcción del discurso y de la identidad ${ }^{5}$. Además, a medida que cambian los discursos también se modifican y reconstruyen los relatos lo que dificulta para aquellos que trabajan con fuentes orales la identificación del pasado y su reconstrucción en la narración ${ }^{6}$. Por otro lado, los silencios son también un aspecto importante en el análisis histórico y el trabajo con fuentes orales. Estos silencios se encuentran relacionados con la ausencia en la bibliografía y la historia del relato de las mujeres en los discursos populares, lo que predispone a las audiencias -familiares o personas del círculo cercano de las mujeres- a no conceder credibilidad a los testimonios y recuerdos que las mujeres construyen en torno a su pasado, especialmente cuando transgreden las normas de género determinadas para una época y espacio. Por lo tanto, una de las cuestiones sobre las que se reflexionó en el scriptoria fue ¿Qué es lo que influye o incide en cada sujeto a la hora de narrar su testimonio? ¿Qué oculta o destaca de la reconstrucción de sus experiencias vitales?

\section{Empatía necesaria y política consciente}

En la segunda parte de la exposición teórica del taller, llevado a cabo por lxs participantes del segundo de los proyectos, decidimos compartir con el resto de compañerxs algunas de las dudas y problemáticas que habíamos tenido en el curso de nuestras investigaciones. Para ello, debemos aclarar, primeramente, que en ambas tesis doctorales existe una implicación política explícita por nuestra parte, ya que participamos en el presente del movimiento por la diversidad sexual y de género, y del movimiento anarquista de nuestra ciudad, València. Esto, pese a los recelos o reservas que a priori puede suponer entre ciertxs compañerxs, no quiere decir contribuir a elaborar un relato redentor o victimista de ciertas derrotas, sino todo lo contrario, complejizar un pasado que, en ambos casos, se ha visto utilizado como fuego cruzado dentro de los propios movimientos, desestabilizando también nuestra propia posicionalidad en los mismos, puesto que este pasado también nos pone contra las cuerdas de nuestra propia identidad, y de nuestro entorno activista. Más aún, teniendo en cuenta las críticas desarrolladas a la propia noción de identidad realizadas desde los feminismos y el postestructuralismo, que han apuntado, entre otras cosas, la

\footnotetext{
${ }^{4}$ Penny SUMMERFIELD: "Oral History as an Autobiographical..., p. 4. Sobre la interpretación de las fuentes para una historia de las mujeres a través de la subjetividad, la intersubjetividad y la memoria como herramientas conceptuales véase Luisa PASSERINI: "La memoria como subjetividad e intersubjetividad en las narraciones de memoria de las mujeres", en Pilar PÉREZ-FUENTES HERNÁNDEZ (coord.): Subjetividad, cultura material y género: Diálogos con la historiografía italiana, Barcelona, Icaria, 2010, pp. 115-131.

${ }^{5}$ Penny SUMMERFIELD: "Culture and Composure: Creating Narratives of Gendered Self in Oral History..., pp. 70-77.

${ }^{6}$ Ibid., p. 74.
} 
complejidad de las diversas intersecciones entre éstas ${ }^{7} \mathrm{o}$ el hecho de que la identidad funciona como un eco de la fantasía, borrando las diferencias históricas entre sujetos y, en cambio, creando y subrayando las - sólo - aparentes continuidades ${ }^{8}$.

Hoy en día se ha convertido casi en un mantra señalar en este tipo de espacios, los congresos de jóvenes investigadorxs en historia contemporánea, que el presente guía nuestras formas de mirar el pasado o que toda historia es situada, pero muchas veces queda en vagas afirmaciones que pensamos cabe teorizar, construir y poner en común. No nos han enseñado a ello y se trata de un camino que nos toca intuir. Más aún cuando, como es nuestro caso, no se trata sólo de un acercamiento discursivo, sino que supone una amplia e intensa tarea de construcción intersubjetiva - con una cincuentena de entrevistas abiertas en ambas investigaciones -. Como ha puesto de relieve Miren Llona, la historia oral supone un entre-verse, conocerse, escucharse, un dejarse tocar, incluso, podríamos añadir ${ }^{9}$ ¿QQué implicaciones personales y políticas han tenido y tienen- nuestros propios procesos de investigación? ¿Dónde están los límites de la simpatía (o antipatía)? ¿Cómo trabajar desde la empatía, pero también desde la honestidad? ¿Podemos escribir historias polifónicas? ¿Qué violencias ejercemos como historiadorxs sobre nuestrxs entrevistadxs? ¿Habría una ética profesional por encima de la personal? ¿Qué resultados podemos ofrecer a las personas que se han abierto a nosotrxs más allá de las tesis? Aspectos sobre los que volveremos brevemente en este texto, cuando abordemos, a continuación, cómo fue la puesta en común entre todxs lxs participantes en el scriptoria.

\section{En común}

La tercera parte del scriptoria, y sin duda la más interesante, fue la puesta en común de las experiencias de todas las personas participantes en el mismo, en su trabajo con las fuentes orales. Alrededor de una treintena de jóvenes investigadorxs nos arremolinamos finalmente en una de las aulas de la Universidad de Zaragoza, superando ampliamente todas nuestras expectativas.

El debate fue muy rico, entre otras cosas, dada la multiplicidad de temáticas y perspectivas desde las que se estaban abordando las investigaciones, en su mayoría tesis doctorales en curso, pero también Trabajos de Final de Máster e incluso personas simplemente interesadas en la

\footnotetext{
${ }^{7}$ Kimberlé CRENSHAW: "Demarginalizing the Intersection of Race and Sex: a Black Feminist Critique of Antidiscrimination Doctrine, Feminist Theory and Antiracist Politics", University of Chicago Legal Forum, 1989/1 (1989), pp. 139- 167.

${ }^{8}$ Joan W. SCOTT: "El eco de la fantasía: la historia y la construcción de la identidad", Ayer, 62 (2006), pp. $111-138$

${ }^{9}$ Miren LLONA: "Historia oral: la exploración de las identidades a través de la historia de vida", en Miren LLONA (coord.): Entreverse: teoría y metodología práctica de las fuentes orales, Bilbo, Euskal Herriko Unibertsitatea, 2012, pp. 15-60.
} 
investigación, más allá de la vinculación académica. Algunos temas, por ejemplo, tenían que ver con las experiencias de subjetividad en la construcción transfronteriza europea, el trabajo con identidades nacionales y de género en el África Subsahariana - Senegal, Guinea Ecuatorial... - o la represión franquista. El punto en común entre todas las personas que estábamos era el uso de la metodología de la historia oral, y más allá de nuestras adscripciones explícitas o no a nivel ideológico, reconociendo lo que Carolyn Dinshaw ha establecido como el vínculo afectivo que establecemos con el pasado, desde el presente ${ }^{10}$.

Esta tercera parte del taller se convirtió, de hecho, en una suerte de catarsis, de terapia colectiva, dada la precariedad de redes colectivas en las que trabajamos quienes hacemos un uso preferente o no jerarquizado de la metodología de la historia oral. En el scriptoria se puso de manifiesto la extraordinaria complejidad de trabajar frente a frente con el testimonio vivo y memoria de otras personas, auténticas protagonistas de nuestros trabajos, y el impacto psicológico y emocional que ello tenía en nosotrxs, como investigadorxs. Desde aspectos en principio tan sencillos como el primer contacto con la persona informante - por vía telefónica, correo electrónico o redes sociales - al momento de la entrevista, pero también sobre cómo escribir y utilizar el testimonio cedido. En este punto, afloraron diversos conflictos éticos, referidos, por ejemplo, a la retribución hacia la persona que cede desinteresadamente su testimonio, e incluso se llegó a plantear la posibilidad de que hubiera una retribución monetaria, en contextos particularmente empobrecidos y marginalizados. Este aspecto, por ejemplo, causó un gran impacto al ser planteado, pero también nos dio que pensar a muchxs sobre hasta qué punto nuestro trabajo pertenece a un mundo cerrado, abstracto y en parte autocomplaciente, a veces disociado respecto a las realidades que nos envuelven.

En este sentido, se trató en profundidad la cuestión de la devolución: ¿para quién o qué escribimos? ¿Cómo dar salida y visibilizar el carácter político y su utilidad más allá del mundo académico? Afloraron diferentes propuestas, pero, en todo caso, más allá de si realizábamos investigaciones militantes o no, y dejando de lado el debate sobre la subjetividad e intencionalidad política evidenciada o no de nuestros trabajos, quedó claro que, por compromiso ético con nuestras informantes, tenemos que buscar fórmulas para que el conocimiento generado a partir de la interpretación histórica de las experiencias humanas traspasara los muros de las universidades.

En relación a esto, sin embargo, surgió un debate también muy interesante en torno al tratamiento ético del contenido de las entrevistas, y los límites de las mismas en los usos públicos. ¿Hasta qué punto podemos difundir determinados temas, tengamos o no la autorización expresa

${ }^{10}$ Carolyn DINSHAW et al.: "Theorizing Queer Temporalities: A Roundtable Discussion”, GLQ, 13/2-3 (2007), pp. 177-195. 
de lxs informantes? ¿Qué hacer, por ejemplo, con aquellos aspectos más complejos de gestionar, como los silencios o las violencias? ¿Qué hacer con la información obtenida fuera de lo que se registra estrictamente, o cuando la persona informante nos pide que detengamos temporalmente la grabación?

Más allá de estos interrogantes, también reflexionamos colectivamente sobre cómo dar cuenta de la complejidad, riqueza y diversidad de la información obtenida a través de entrevistas. En este sentido, una aproximación sensible a las problemáticas de nuestras investigaciones, curiosamente - o no - compartidas de forma transhistórica con nuestrxs informantes, necesariamente requiere de una escritura empática, poliédrica, crítica y comprometida con la multiplicidad de verdades que afloran en el cruce entre fuentes diversas, interpretación personal, e impresiones de la entrevista.

Finalmente, también abordamos algunas temáticas más clásicas dentro del debate sobre el uso de fuentes en la historia. Por ejemplo, la idoneidad y diseño del cuestionario/entrevista, optando generalmente por entrevistas abiertas semiestructuradas en el caso de historias de vida, y también respecto a la selección y representatividad de la muestra, concluyendo que, al final, lo realmente significativo era la saturación de la información, más que un número concreto. Sí afloraron cuestiones interesantes como, por ejemplo, cuestiones generacionales, de género, sobre sujetos racializados, y otras variables a tener en cuenta más allá de lo estrictamente referido a la obtención genérica de información en sí.

\section{Recepción del scriptoria, y propuestas y redes para el futuro}

La propuesta planteada de los scriptoria, novedad de este VI Encuentro, en tanto que supone un trabajo anterior y posterior a la celebración de la jornada, nos suponía un reto al que no sabíamos bien cómo enfrentarnos. No tanto por el trabajo previo de preparación, algo que se sobreentiende en este tipo de actividades, pero sí al cómo continuarlo. ¿Cómo dar continuidad a un trabajo del que no sabíamos qué recepción tendría?

Desde los primeros momentos teníamos muy claro, como se ha explicado en la introducción, que nos preocupaban nuestra soledad y nuestra falta de redes. También que nuestras puestas en común, desde Madrid y València, habían sido un importante punto de anclaje en nuestras trayectorias investigadoras, sanadoras incluso. Pero no siempre coincides con alguien que se encuentre con tus mismas inquietudes o, peor aún, no siempre somos capaces de expresarlas, de hablar desde la duda o la vulnerabilidad. Más aún, en espacios como los congresos de la disciplina, muchas veces muy masculinizados y con un marcado ethos de sabiduría entre muchos de los participantes (la marca del masculino no es casual). Además, el contexto de 
desconexión entre gran parte de universidades y entre las diferentes áreas y departamentos, al menos en nuestro ámbito de doctorandxs, tampoco supone un intercambio fluido de experiencias en las que mirarse. Por eso mismo, quisimos, desde bien pronto, poder plantear un espacio donde conocernos y reconocernos, no sabiendo bien entre quiénes y cómo, pero sí al menos facilitar la posibilidad de encuentro. Y darle importancia a tal espacio, tanto en el tiempo dentro del scriptoria como en la forma.

Fue entonces, durante el desarrollo del propio taller cuando surgió, de manera espontánea, la posibilidad de crear un grupo de Facebook en el que mantenernos en contacto. Este grupo, Memorias e identidades (Zaragoza, 2017) ${ }^{11}$, se encuentra abierto aún y es posible unirse. Sabemos que Facebook supone ciertas limitaciones - y entonces aún no había saltado el escándalo sobre la venta de datos -, que su utilización con asiduidad no está generalizada del todo, pero también consideramos que las nuevas posibilidades tecnológicas abiertas, y en concreto las redes sociales, tienen, a su vez, una enorme potencialidad, más aún en contextos de diáspora como es el nuestro. Sin embargo, la posibilidad de consolidar la red a través del grupo, fruto también de la euforia del momento, fue languideciendo con el paso de los meses, hasta el punto de haber quedado en algo prácticamente testimonial.

Otra opción que planteamos, pero no ha llegado a ser posible por el fracaso de esta experiencia en Facebook y la imposibilidad de su dinamización por parte de quienes redactamos estas líneas, es que la construcción de este texto fuera colectiva y polifónica, recogiendo un poco el transfondo que quisimos imprimirle al scriptoria. Sabemos de nuestros contextos precarizados y de la dificultad de romper dinámicas bien establecidas, como el currículum o la autoría. Pero también sabemos que vamos despacio porque vamos lejos.

A meses vista, las personas que coordinamos este scriptoria tenemos una certeza, y es que la capital de Aragón posibilitó que pusiéramos en común multitud de inquietudes intelectuales, pero también de emociones, respecto a nuestro trabajo. Aunque la continuidad de los objetivos del scriptoria, como ya hemos dicho, no ha sido posible - también por nuestros propios procesos personales que nos han impedido dinamizar propuestas tras el Congreso - ello fue suficiente como para dejar de movernos en el aislamiento y saber que, de una forma u otra, lo que sufrimos en nuestra cotidianidad es algo ampliamente compartido. Esto lo hemos vivido de forma positiva, ya que nos ha alentado a seguir trabajando desde nuestras perspectivas reflexivas, y ha puesto de manifiesto la posibilidad de que, en el futuro, cuando los tiempos y energías acompañen, puedan

${ }^{11}$ Para acceder al grupo, visítese el siguiente enlace: https://www.facebook.com/groups/831020967 060802. 
florecer determinadas iniciativas para el trabajo empático y reflexivo con la historia oral, posiblemente de carácter local.

Consideramos que este scriptoria nos ha permitido contactar con personas que trabajan desde marcos epistemológicos, teóricos, metodológicos y axiológicos diversos, pero fuertemente comprometidas con la transformación social en clave anti-violencias. Algo muy interesante ha sido poder colocar en el centro del debate cómo trabajamos, más que - o en relación a - qué trabajamos, y rompiendo con el esquema clásico de la comunicación, que suele dejar poco espacio para el debate y establece también jerarquías poco propicias al debate horizontal y democrático. Algo que consideramos fundamental, sobre todo para visibilizar la menor toma de la palabra por parte de las mujeres historiadoras, en particular. En definitiva, el scriptoria nos permitió no sólo compartir nuestras experiencias, largamente discutidas en la intimidad de nuestros departamentos en Madrid y València, con otrxs colegas, sino descentrar la propia exposición para que nuestra intervención fuera simplemente la excusa que precipitara un foro de debate y expresión realmente apasionante.

\section{Cierre}

A modo de conclusión, si es que podemos hacer eso para un taller como éste, participativo y que sigue en construcción, simplemente queríamos señalar como coordinadorxs una serie de cuestiones. Primeramente, pese a la diversidad de orígenes del taller, creemos que este se desarrolló desde una complementariedad de diversas preocupaciones y ámbitos - el técnico, el ético y emocional - que le dieron una complejidad y profundización de la que nos encontramos bastante contentxs. De hecho, estamos orgullosxs de la existencia de esta enorme constelación de investigaciones que pretenden contribuir al cambio social. En ese mismo sentido, la vocación didáctica y experiencial de lo que hablamos, partiendo siempre desde nuestras investigaciones, con nuestras dudas, aciertos y errores, creemos que también fue positivo para involucrar a lxs asistentes, pues huímos de sentar cátedra y buscábamos, más bien, el poder proyectar juntxs. Lo que consideramos que creó un interesante feedback. No en vano, como ya señalábamos arriba, pensamos que el principal potencial del scriptoria fue la confluencia de personas, dudas e intereses, que hicieron que nos sintiéramos todxs mucho más acompañdxs. Un único, pero a apuntar, quizás, ha sido la dificultad de seguir manteniendo esa red que se inició en el Congreso de Zaragoza, una red necesariamente precaria como son también nuestras experiencias investigadoras. 


\section{EPÍLOGO}

\section{el Caudal Que nos Arrastra}

\section{Gustavo Alares López*}

Universidad de Zaragoza

La actual universidad española sobrevive en gran medida sobre los rescoldos e inercias establecidos en la década de los ochenta. Fue en aquella favorable coyuntura cuando, en un contexto de masificación universitaria, de incremento presupuestario y de relevo generacional -de aquellos viejos catedráticos de posguerra-, se produjo -tal y como ha señalado Miquel Marín- un proceso de refundación de la profesión que, entre otras manifestaciones, se sustanció en el acceso a la Universidad de un importante número de historiadores. ${ }^{1}$ Precisamente aquéllos que en años sucesivos establecerían los fundamentos de la historiografía democrática y que en la actualidad se encuentran a las puertas de la jubilación o de acceder a la condición de eméritos. Esa ventana de

\footnotetext{
* El autor es integrante del proyecto HAR2012-31926 "Representaciones de la historia en la España contemporánea: políticas del pasado y narrativas de la nación (1808-2012)", del Ministerio de Economía, Industria y Competitividad, dirigido por Ignacio Peiró Martín, y el proyecto HAR2016-75002-P "La nación en escena: símbolos, conmemoraciones y exposiciones, entre España y América Latina (1890-2010)", Ministerio de Economía, Industria y Competitividad, bajo la dirección de Javier Moreno Luzón y Marcela García Sebastiani.

${ }^{1}$ Miquel Marín, "La historiografía democrática en España, 1965-1989" en Ignacio Peiró, Carmen Frías (eds.), Políticas del pasado y narrativas de la nación, Zaragoza, Prensas de la Universidad de Zaragoza, 2015, pp. 357-442.
} 
oportunidades profesionales se cerró definitivamente a comienzos del siglo XXI y, de manera dramática, tras la última crisis económica.

La crisis económica ha supuesto la introducción de una serie de nuevos paradigmas en el ámbito económico, político y cultural, que han repercutido en el ámbito universitario. La lastimosa situación de la universidad española constituye uno más de los efectos de una clara devaluación de lo público y su progresiva privatización que, entre otras consecuencias, está hurtando a importantes sectores de la población las posibilidades de acceso a una educación superior. A este respecto, el descenso de la inversión del estado en las universidades públicas se ha traducido en el incremento de las tasas, el descenso de las becas y las cada vez más reducidas expectativas de inserción en el mercado laboral o, en su defecto, de continuar una carrera investigadora (con la drástica reducción de los programas de becas pre y post doctorales y la desarticulación de la carrera investigadora). Todo lo anterior ha generado una progresiva elitización del alumnado y el consiguiente debilitamiento del ya de por sí tibio y nebuloso criterio de «igualdad de oportunidades». De manera paralela, al contemplar al alumnado como cliente, en definitiva, como sustento económico de un entramado académico que debe de ser «eficiente», se ha iniciado lo que diversos autores califican como la secundarización de las universidades, con la consiguiente conversión de los centros de educación superior en empresas de capacitación y de los docentes en meros burócratas gestores de títulaciones. $^{2}$ Y todo ello en un contexto de financiación insuficiente y de abusiva precarización laboral. El informe de 2016 del Observatori del Sistema Universitari de Cataluña sobre las plantillas docentes de las universidades catalanas (por otro lado en gran medida extrapolable al resto), señalaba un preocupante envejecimiento y reducción de los cuerpos docentes, acompañado de manera paralela de una creciente precarización ejemplificada en la temporalidad de los contratos, el brusco descenso de la plantilla funcionaria y un aumento de la dedicación a tiempo parcial. ${ }^{3}$ En esta restrictiva coyuntura el actual entramado universitario se revela como rácano y egoísta, ya que al mismo tiempo que multiplica el nivel y rango de exigencias, ofrece a los aspirantes unas menguantes oportunidades de inserción. El fenómeno se ha traducido en una precarización reflejada en la creciente complejidad de las figuras docentes e investigadoras (asociados y "falsos

\footnotetext{
${ }^{2}$ Ver al respecto Nuccio Ordine, La utilidad de lo inútil, Barcelona, Acantilado, 2013, pp. 77-82.

${ }^{3} \mathrm{http} / /$ www.observatoriuniversitari.org/es/2016/09/el-profesorado-universitario-en-cataluna/
} 
asociados", profesores visitantes de dudosa justificación, ayudantes doctores, contratos de profesores doctores e interinidades de variada estirpe) que, lejos de ofrecer unas mayores posibilidades de inserción profesional, han generado arbitrariedades, falta de transparecia e inestabilidad. Bajo estas nuevas denominaciones, parecen tomar nueva vida aquéllos ayudantes y adjuntos que pupulaban por las universidades españolas de los años cincuenta y sesenta y que con gracejo diseccionó Alejandro Nieto: envejeciendo a la sombra del consabido catedrático, ocupando lentamente pequeñas esferas de poder siempre delegado, «soltero, puesto que nadie pude permitirse el lujo matrimonial»y, sólo tras un arduo rumiar entre las estructuras universitarias, triunfante con la victoria en un concurso de oposición siempre bajo sospecha. ${ }^{4}$ Esta precarización debilita la posición personal, social y profesional de los aspirantes a historiadores e historiadoras, pero también su independencia intelectual y las posibilidades de trazar itinerarios intelectuales heterodoxos.

Parapetados tras los criterios de eficiencia del mercado, los gestores institucionales están alterando los tradicionales valores de la profesión (y de la universidad), sometiendo con guante de seda al conjunto de la comunidad científica. Como señalaba Anthony Grafton, bajo estos principios, profesores excéntricos -por no participar de la norma- o investigaciones de largo recorrido, quedarían marginadas por entrar en conflicto con los aludidos criterios de mercado. ${ }^{5} \mathrm{Y}$ es que en ese contexto productivista en el que hasta las palabras se capitalizan, las humanidades vuelven a resentirse de su carácter supuestamente inútil. Mucho más si cabe en el caso de la historia, en donde las urgencias de la opinión -siempre tendente hacia la simplificación binaria-, colisionan con el carácter complejo de los razonamientos históricos y los propios tiempos de la investigación y la reflexión historiográfica.

Este cúmulo de circunstancias provocan una serie de efectos y consecuencias que trascienden lo estrictamente socio-laboral, para incidir de manera directa en el campo historiográfico y en la propia construcción actual del historiador e historiadora, llegando incluso a alterar el tradicional conjunto de virtudes epistémicas asociadas a la profesión. ${ }^{6}$ De hecho, cualquier aspirante «eficiente» a universitario debería afanarse en diseñar una

\footnotetext{
${ }^{4}$ Alejandro Nieto, La tribu universitaria, Madrid, Tecnos, 1984, pp. $62-67$.

${ }^{5}$ Anthony Grafton, "The nutty professors. The history of academic charisma", New Yorker, 23, October, 2006, pp. 82-87.

${ }^{6}$ Herman Paul, "What is a scholarly persona? Ten theses on virtues, skills, and desires", History and Theory, 53, 2014, pp. 348-371.
} 
estrategia curricular más sujeta a cumplimentar los inputs requeridos que al interés estrictamente historiográfico. Centrarse así en la búsqueda de la consagración via artículo-en-revista-relevante frente a la laboriosidad de la monografía; consolidar la hiperactividad como norma -pese a los efectos sobre una calidad que se resiente-; plegarse siempre a las modas historiográficas y culturales; vincularse a los más activos nichos de mercado (editorial, de consumo político); frecuentar el ámbito internacional -aunque las estancias realizadas no siempre tengan sentido científico-; procurarse alguna incursión en el ámbito mediático bajo la figura del experto; ejercer de precoces maestros olvidando que siempre somos aprendices y, obviamente, renunciar -salvo para espíritus suicidas, ingenuos o románticos-, a proyectos de investigación de medio o largo plazo. Esto son los criterios de eficiencia bajo los que muchos jóvenes investigadores e investigadoras han crecido, como si aquéllos fueran los nuevos presupuestos básicos de la profesión.

Este ecosistema, y bajo un criterio de falsa excelencia, tiende a favorecer el predominio de lo cuantitativo sobre lo cualitativo, amparando un modelo de fast science destinada a ser capitalizada y rápidamente cuantificada. Al mismo tiempo, la asfixiante presión productivista, la ineficiencia de los mecanismos de control (pese a la abrumadora burocracia), las solidaridades bochornosas, y la falta de escrúpulos, favorece que ciertos académicos se vean inclinados a devaluar su investigación y, en el caso extremo, optar por el plagio y el fraude, con el ejemplos por todos conocidos, algunos de alcance mediático como el de Fernando Suárez, el rector plagiario de la Universidad Juan Carlos I. ${ }^{7}$ Carreras académicas que, como fruto conjunto de la ambición, la vanidad y la falta de rigor profesional, se desmontan estrepitosamente como naipes en cascada. Aunque para descrédito de todos, más allá de la censura de una ciudadanía desencantada y de parte de los colegas, las prácticas piratas de estos universitarios raramente acaban traduciéndose en un cambio en sus respectivas situaciones adminitrativas o profesionales. ${ }^{8}$

¿Es posible desembarazarse de la intromisión de estos elementos? ¿En qué medida este entramado institucional va a determinar las futuras prácticas de los historiadores?

\footnotetext{
${ }^{7}$ Una respuesta ante el plagio por parte de la comunidad de historiadores representada por la Asociación de Historia Contemporánea en «Comunicado de la Junta Directiva de la AHC sobre el plagio», https://www.ahistcon.org/PDF/doc/Plagio.pdf

${ }^{8}$ Miguel Ángel González, "Notas para la historiografía jurídica española. Una plaza desierta de catedrático de Historia del Derecho en la Universidad de Zaragoza (1998-2017)", Cuadernos de Historia del Derecho, vol. 25, 2018, pp. 235-317.
} 
¿Qué conocimiento histórico generaremos bajos estas premisas? ¿Qué utilidad tendrá al margen de estadillos, ránkings y formularios standarizados de evaluación? ¿Qué capacidad tienen los profesionales de la historia a la hora de gestionar su propia disciplina?

Mientras se despejan dudas y confirman presagios, quizás sólo nos quede, como animaba Francisco Giner de los Ríos, «trabajar como si todo tuviera sentido». 

Actas del VI Encuentro de Jóvenes Investigadores e Investigadoras en Historia Contemporánea

COMITÉ ORGANIZADOR

Alfonso Bermúdez Mombiela

Carlos Adán Gil

Cristina Alquézar Villarroya

Cristina Sánchez Martínez

Daniel Aquillué Domínguez

María Pilar Rodrigo Catalán

Pablo Aguirre Herráinz

Sandra Blasco Lisa

Sergio Murillo Gracia

ZARAGOZA, 2017 


\section{La colección Jóvenes por la Historia nace del trabajo}

realizado durante los años 2016 y 2017 , en el transcurso

de la preparación y desarrollo del VI Encuentro de Jóvenes Investigadores e Investigadoras en Historia Contemporánea, celebrado en Zaragoza durante los dias 6,7 y 8 de septiembre de 2017.
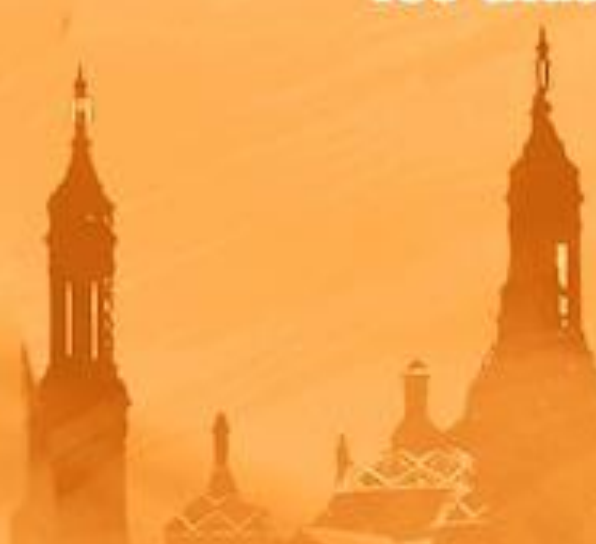

Dentro de esta Colección se encontrarán tres volúmenes organizados temáticamente: Naciones en conflicto, centrado en los procesos de formación ideológica, contestación social e interrelación política de los Estados-nación contemporáneos; Identidades en transición, donde se aborda

lo dinámico; los procesos que generan cambios en las identidades y la organización social, y Experiencias en común, que gira en torno a nuestra profesión y a la importancia de las fuentes orales y los testimonios en primera persona.
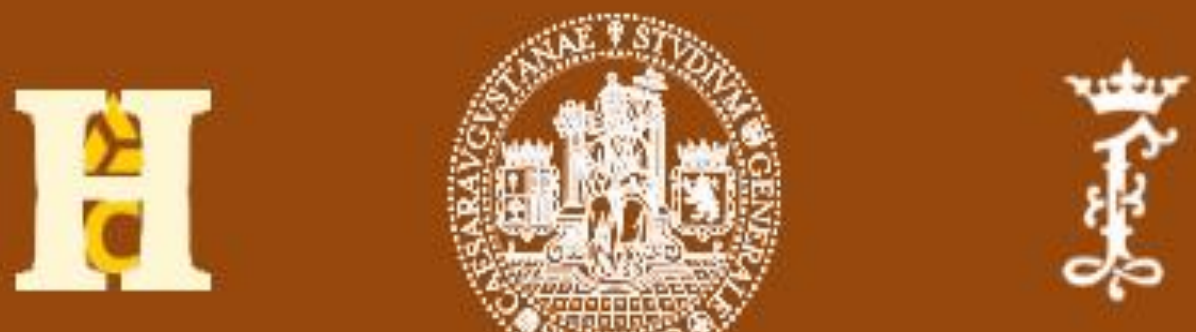